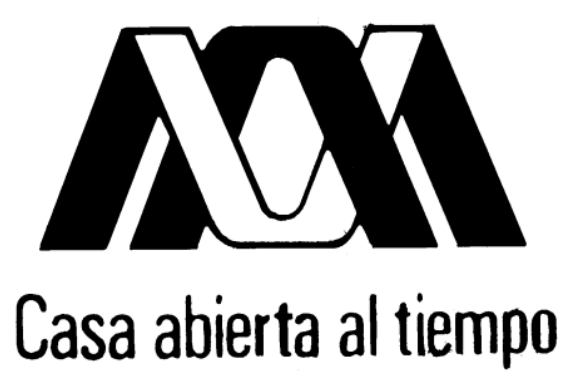

UNIVERSIDAD AUTÓNOMA METROPOLITANA

UNIDAD IZTAPALAPA

DIVISIÓN DE CIENCIAS SOCIALES Y HUMANIDADES

POSGRADO EN CIENCIAS ANTROPOLÓGICAS

\title{
DESEOGRAFÍAS \\ ANTROPOLOGÍA DEL DESEO Y PRÁCTICAS DE LA DIFERENCIA \\ (El Club Gay Amazonas)
}

Rodrigo PaRrini Roses

Tesis de Doctorado en Ciencias Antropológicas

Director: Dr. Rodrigo Díaz Cruz

Asesores: Dra. Marta Lamas Encabo

Dr. Federico Besserer Alatorre

México, D.F.

Abril, 2015 
A Palmira, en su ausencia Al Club, en su alegría y dignidad A las Tres Joyas, en su infinita compasión 
“(...) y no fue en las grandes ciudades donde la conciencia se hizo otra -o yo lo sabría”

Yves Bonnefoy, El territorio interior, 2013:48 


\section{Índice}

I. Deseografías: hacia una antropología del deseo............................. 8

II. Quantas de libertad. El Club Gay Amazonas................................ 28

III. Epistemes locales. Sexualidad, formaciones discursivas y redes de significación........ 81

IV. El Círculo Interior. Homoprácticas y (psico)topologías de la homosociabilidad......... 129

V. Oscuras máquinas del devenir: Diferencia, deseo y corporalidad.................... 185

VI. El Estado y La Bestia. Flujos, globalización y deseo........................... 240

VII. El abandono y su aura. Nuda vida e inmunidad.............................. 293

VIII. La escritura y su sombra. Etnografía, deseo y subjetividad....................... 335

IX. Archivos del futuro. Posiciones de deseo y prácticas de la diferencia............... 367

X. Bibliografía......................................................... 384 


\section{Agradecimientos}

A veces uno tiene la fortuna de conocer y relacionarse con personas justas, sensibles y dignas. Ha sido mi caso durante el largo periodo de trabajo que desemboca en este texto. Personas justas porque te piden verdad e intensidad y no se dejan convencer por argumentos que no sean sólidos y profundos. Sensibles porque pueden experimentar y leer un mundo desde su corazón y su inteligencia y comprenden el devenir insondable de la vida, sin renunciar a la razón y la verdad. Dignas porque su presencia y su acción producen un mundo encomiable y amable, infinitamente necesario. He tenido la suerte, como dije, de encontrarme y relacionarme con muchas de estas personas. Ellas son el sustento final de este escrito, su horizonte ético ineludible y un sostén amoroso y bondadoso. Mi agradecimiento es infinito y mi deuda impagable. Ambos son la forma de una conciencia y de una vida.

Con Ana Amuchástegui compartí años de reflexión e investigación que han alimentado este texto. Su confianza y ayuda hicieron posible gran parte del trabajo de campo que sustenta el estudio. Siento que para ella investigar es un viaje hasta sí misma y los otros, impredecible y muchas veces doloroso. Me enseñó que el corazón vivo también es inteligencia despierta. Su ejemplo, su compañía, su ayuda y su paciencia han sido inestimables y fundamentales.

Nattie Golubov es mi mejor amiga. La conocí recién llegado a México y mi vida en este país ha estado profundamente marcada por su presencia, su amistad y compañía. En momentos muy difíciles y dolorosos, Nattie fue mi salvación. Creo que, en parte, este trabajo es una extensión de muchas conversaciones en las que me ha iluminado, ha comprendido con cabalidad y me ha exigido con elegancia. Como en un mito hindú o en una parábola budista, siento que con Nattie hemos conversado durante muchas de vidas de múltiples temas. Por eso, en ésta nos entendemos con singular alegría y fecundidad. Ella me cuidó muchas veces cuando me enfermaba al regresar de Tenosique, me prestó dinero, me acompañó. Conoció a algunos integrantes del Club cuando visitaron mi casa. Fue conmigo a recoger a Fray Tomás González cuando visitó la UAM-X y lo llevó de regreso al finalizar su charla. Alguien dirá que son pequeñas cosas, pero juntas son el único sustento con el que contamos, al menos el que yo he tenido, y lo agradezco infinitamente.

Eva Alcántara ha escuchado muchas de mis ideas, muchos de mis problemas. Posee una sensibilidad admirable y una mirada bondadosa que hace brillante cualquier vida. Mucha veces 
en la prudencia del silencio o de la compañía, Eva ha sido como un espíritu tutelar que guía y protege. Su investigación sobre personas intersexuales, única en su tipo en México, es un viaje a la dignidad y la sensibilidad, la escucha atenta y la reflexión profunda. Las conversaciones en las que Eva me contó de esas personas y sus vidas, han sido caminos para mis reflexiones. Lo que nunca conseguiré es la bondad con la que ella ha mirado ese mundo, la dulzura con la que lo ha interpretado.

A Edith Flores la conocí en unos de los primeros seminarios que impartí en el Programa Universitario de Estudios de Género de la UNAM. Nos hicimos amigos y trabajó con Ana y conmigo en diversas investigaciones. Durante la Semana Santa de 2014 me acompañó a Tenosique, quería realizar algunos grupos de discusión con personas de la comunidad sobre la migración que cruza por sus lindes. Confiaba en que ella sería la mejor moderadora y no me equivoqué: entró en ese mundo con fluidez y sensibilidad. Llevábamos algunos días en la ciudad y ya la saludaban en la calle, aunque fuera su primer viaje. Quien crea que cuento nimiedades, se equivoca: la verdad de una persona es su forma de existir en el mundo. Edith lo hace con generosidad y empatía, con una dulzura silenciosa, pero profunda. Todo eso sólo lo puedo agradecer. Otro infinito se agrega a mis palabras.

Daniel González Marín fue el primero en escuchar mis ideas iniciales sobre el deseo. Nos conocimos en un evento muy extraño, que intentaba transmitirse vía internet, en el que le hablamos a un auditorio vacío. Como en las prácticas del budismo zen, el vacío es el inicio de la verdad. Al menos en mi caso fue el principio de una amistad entrañable. Daniel ha leído casi todo este texto, lo ha corregido, ha hecho preguntas, ha dudado. Pero, fundamentalmente, me ha transmitido una confianza dulce y profunda que ha sido un sostén en momentos de azoro y duda. Su gran cultura literaria ha sido una fuente de muchas inspiraciones. Peter Sloterdijk, que había leído de soslayo, regresó de su mano a mi trabajo. Daniel me regaló la esfera, la más bella de las formas y la más misteriosa. Ante alguien que es capaz de hacer un regalo así sólo caben la gratitud y el silencio.

Alan Contreras aparecerá una y otra vez en estas páginas. Es el espíritu tutelar de casi toda la investigación. Lo quise desde que lo conocí y quedé, literalmente, fascinado. Mi admiración no ha sabido sino crecer. Sin él nada de lo que escribo habría sido posible: Alan creó un mundo en el que muchos han cabido. No descansa, tampoco alardea. Puede alimentar a su mamá enferma, atender a una persona que necesita ayuda, cocinar, reír, escuchar. Es como un dios hindú que tuviera muchos brazos, pero también muchos corazones: Alan es querido y 
amado. Siempre está rodeado de personas, de conversaciones y risas. Para alguien solitario como yo, verlo es experimentar una nostalgia por lo que nunca seré; pero él me ha dado un espacio en su vida que agradezco. No sólo eso, Alan me ha ofrecido su verdad casi sin impedimentos. Yo he tomado, para comprender su mundo, mucho de lo que me dio. Mi deuda es realmente incalculable y mi agradecimiento igual de infinito.

Mis amigos de Tenosique son joviales y explosivos. Con ellos he reído, conversado, bebido, llorado y caminado; con algunos he discutido, me he dejado de hablar y luego he vuelto a ser su amigo. Me han invitado a sus casas, me han dado de sus comidas, he escuchado sus vidas. Hablo de una generosidad desmesurada. Mi corazón es otro luego de conocerlos. Sin duda he sido tributario de una fecundidad luminosa que atraviesa mi cuerpo y mi consciencia. Hernán, Licho, Pablo, Miguel, Juanito, Javier, Gerardo, Luisa Fernanda, Franklin, Manuel, Raúl, Andrés, Juan Virgilio, Daniel, Edgard, Trino, Erick, Rubí, Lucio, Ulises, Óscar, Guillermo, Tutti, Tomás, José, Berenice, Juan Daniel, Don Chema y Mamá Gegé, Carlitos, Gaviota., Alondra, Quebradita, Hugo, Nandier, César, Natán, Romeo, Javier........

Rodrigo Díaz fue como un Virgilio que me orientó en el Paraíso de la antropología. Sus palabras fueron un mapa que me mostraba si había perdido el camino o no. Son pocas las personas que cobijan una gran cultura y una erudición profunda; afortunadamente es el caso. Pero su lectura, entonces, implica un desafío, porque nos deja frente a la inmensidad de lo que no conocemos. Para mí ese sería el único camino válido para entrar a cualquier paraíso: las puertas de la ignorancia y la duda.

Antes de terminar este texto, murió mi madre. Ella había sido mi cómplice en todas las aventuras, que le relataba por teléfono. Leyó algunos capítulos, pero sobre todo, estuvo siempre sorprendida y maravillada. Cuando visitó México confirmó esa sensación. Seguí trabajando en medio de la bruma de la muerte, porque sentía que a través de la escritura heredaba su mirada. No sé si se puede hablar con los muertos, pero sí que se puede escribir con ellos. Palmira, mi madre, reposa también en estas palabras. Perder también es una forma de conocer; escribir, un ritual que hace un homenaje a los que ya han partido, a nuestros corazones adoloridos ante el destino y el misterio. 


\section{I}

\section{Deseografías}

\section{Hacia una antropología del deseo}

Al final de Las palabras y las cosas, Foucault se pregunta: “¿Acaso no es el deseo lo que permanece siempre impensado en el corazón del pensamiento?” (Foucault, 2008[1968]: 364). Si el deseo yace impensado en el corazón del pensamiento mismo, ¿cómo acercarnos a ese corazón para engendrar, aunque fuera de manera tentativa, un pensamiento sobre el deseo? Ese corazón impensado nos llevaría, en palabras del mismo Foucault, a una región

(...) en la que la representación permanece en suspenso, al borde de sí misma, abierta en cierta forma sobre la cerradura de la finitud, dibujándose las tres figuras por las que la vida, con sus funciones y sus normas, viene a fundarse en la repetición muda de la Muerte, los conflictos y las reglas en la apertura desatada del Deseo, las significaciones y los sistemas en un lenguaje que es al mismo tiempo, Ley (ibid::363).

Esta investigación es un intento por aproximarse a esa región limítrofe o a ese corazón del pensamiento y explorar eso impensado que sería el deseo mismo; no sólo del pensamiento, sino también de las prácticas y las relaciones sociales más cotidianas, las instituciones, las normas, el poder; incluso, del cuerpo mismo. Mi itinerario es un intento por abrir estas cerraduras y acceder a un pensamiento antropológico sobre el deseo, que no lo busque ante todo en las configuraciones psíquicas, sino en el orden social y sus relaciones. Una antropología del deseo interroga esa región en la que la representación (el pensamiento) permanece en suspenso y explora esa "apertura desatada del Deseo", que Foucault refiere. Si el deseo fuera, a la vez, lo que ha permanecido impensado y una apertura desatada: ¿cómo se puede pensar desde la antropología algo que yace, en alguna medida, oculto en sus propias formas de pensar pero que, a su vez, atraviesa sus reflexiones y también los mundos que explora?

Foucault formula la pregunta que mencionamos cuando escribe sobre el lugar del psicoanálisis y la etnología en las ciencias humanas. Dice que el psicoanálisis ha recorrido un camino inverso al de las ciencias humanas "que sólo van hacia el inconsciente en la medida en que le vuelven la espalda", hacia aquello "que está allí y que se hurta, que existe con la misma solidez muda de una cosa, de un texto cerrado sobre sí mismo o de una laguna blanca en un texto visible" (ibíd.). De la etnología dirá que en vez de "relacionar contenidos empíricos (...) con la positividad histórica del sujeto que los percibe", colocará "las formas singulares de cada 
cultura, las diferencias que la oponen a las otras, los límites por los que se define y se encierra en su propia coherencia, en la dimensión en que se anudan sus relaciones con cada una de las tres grandes positividades (la vida, la necesidad y el trabajo, el lenguaje)" (ibíd:: 366). El autor agregará que "el problema general de toda etnología no es otro que el de las relaciones (de continuidad o discontinuidad) entre la naturaleza y la cultura" (ibid.). Ciencias a contrapelo de las otras, encontrarán su originalidad en esa mirada descentrada, ya sea del sujeto o la sociedad. La muerte, el deseo y la ley inquietan a ambas disciplinas, aunque de formas diversas, preocupadas por "la región que hace posible un saber sobre el hombre" (ibíd:: 367; énfasis mío) y que escapa a su consciencia. Ciencias de la diferencia, podríamos decir.

Si bien mi reflexión no es psicoanalítica, el inconsciente será un concepto, pero también una dimensión, ineludible para su despliegue. Estudiar el deseo es ir a contrapelo, por así decirlo, hacia aquello "que está allí y que se hurta, que existe con la misma solidez muda de una cosa", como ha escrito Foucault sobre la dirección del psicoanálisis con respecto a las otras ciencias humanas. Pero también esta investigación ha sido un itinerario a través de las formas singulares de una sociedad y una cultura, sus diferencias, los límites que la definen y las coherencias que produce. Es una etnología de lo contemporáneo y lo moderno (Rabinow et al., 2008), pero también de lo heterogéneo y diferente, si se me permite la imagen.

El deseo, no obstante, fue un hallazgo antes que una premisa. Me encontré con él luego de varios años de trabajo de campo y escribir muchas páginas. Como lo relataré luego, fue un sueño el que me permitió hallar ese "texto cerrado sobre sí mismo", que comencé a descifrar cautelosamente. Fue una irrupción del inconsciente la que me puso ante esa "apertura desatada del Deseo", como la llama Foucault. Estas circunstancias me obligaron a pensar el proceso mismo de investigación y no sólo sus resultados. Por eso lo he llamado deseografía, porque la exploración del deseo ha sido una de la escritura o de su escritura. No me refiero sólo al proceso de poner en palabras; la escritura también es una inscripción en el campo, en los sujetos con los que me encontré y en mí mismo. Esos anudamientos han sido fundamentales para mi reflexión; sin embargo, ella no me condujo hasta el deseo, fue el deseo el que me llevó hasta su "apertura desatada" y me mostró un panorama vasto y complejo que he tratado de describir y entender.

En algún sentido, creo que la escritura siempre es tardía y constituye un gesto frente un abismo, tanto social como personal. "Escribir, dirán Deleuze y Guattari, no tiene nada que ver con significar, sino con deslindar, cartografiar, incluso futuros paisajes” (2010[1980]: 11). En 
cierta forma, la escritura que las deseografías producen es una cartografía y un deslinde. No se trata de escribir en el azoro del deseo, sino de registrar sus vibraciones y luego transcribirlas. Por eso esta escritura es tardía, porque no puede cerrarse sobre el deseo con premura y debe encontrar su tempo. El deseo puede ser escrito sólo si reconocemos que hay algo imposible de serlo, tal vez esa apertura desatada que no logra atarse al texto; incluso si la escritura no tuviera nada que ver con significar o cartografiar y fuera una exploración por esos terrenos desatados del deseo. Las deseografías serán deslindes, entonces, grafías para esa apertura desatada. En otro momento, las ataduras y las cuerdas tomarán un sentido más dramático y enfático; pero siempre estaremos en ese juego entre lo que atamos y lo que desatamos, entre lo que puede ser anudado y lo que no.

Deleuze y Guattari ofrecerán las pistas fundamentales para intentar una antropología del deseo, cuando nuevamente discutan los aportes del psicoanálisis y la etnología, pero desde una perspectiva (radicalmente) crítica. Yo no me he hecho cargo de la polémica y he preferido leer los textos que escribieron juntos, y los que cada uno escribió por su cuenta, como una cartografía de un terreno apenas visto. Alguien dirá que ya El Banquete de Platón interrogaba al deseo, y sin duda lo hace. Tal vez gran parte de la literatura lo ha hecho, basta ver la influencia de autores como Henry Miller o Antonin Artaud en el pensamiento de Deleuze y Guattari. El deseo, tan antiguo y tan citado. Nada de eso negamos. Sólo teníamos que resolver un obstáculo empírico, antes que teórico: ¿cómo entender la fuerza que produce los mundos (de vida) y las subjetividades?, ¿cómo elaborar una lectura antropológica que se detuviera en la producción simbólica, pero también en las prácticas sociales; que atravesara los cuerpos y las hablas; que se paseara por las instituciones, pero también por los afectos; que merodeara las fantasías así como los objetos?, ¿una antropología del aquí y el ahora, pero también del allá y del entonces?

Deleuze y Guattari dirán que "la producción social es tan sólo la propia producción deseante en condiciones determinadas" y que "el campo social está inmediatamente recorrido por el deseo, que es su producto históricamente determinado (...) Sólo hay deseo y lo social, y nada más" (Deleuze y Guattari, 1985[1972]: 36). ¿Se puede pensar una investigación donde sólo hay deseo y lo social, y nada más?, ¿sólo, nada más? Sería una forma de investigar las condiciones determinadas de la producción deseante y las formas en las que el deseo recorre un campo social, como "su producto históricamente determinado". En eso se ha centrado este estudio. 


\section{Escribir el deseo}

Durante 8 años he realizado una etnografía en Tenosique, una ciudad de la frontera de México con Guatemala, en el estado de Tabasco. En esa ciudad he investigado a un grupo de personas gay, que tienen una organización social y política: el Club Gay Amazonas. Durante todo ese tiempo he pasado largas temporadas en la ciudad y he seguido casi todas las actividades relevantes tanto del Club como de la localidad misma. La pregunta inicial, que orientó la investigación, fue cómo el Club se constituía en un sujeto político y cómo transformaba ciertas relaciones sociales que excluían o subordinaban a sus integrantes. No obstante, el trabajo de campo ha sido, fundamentalmente, la exploración de un mundo de vida muy denso, lleno de matices y ambiguo. Los lugares donde he estado no han sido las instituciones públicas, principalmente, sino la casa de las personas que he conocido allá, las cantinas, las fiestas y las calles. He participado en actos y momentos especiales, pero sobre todo me he involucrado en la vida cotidiana, esa vida con pocas excepciones y muchas rutinas en la que se producen y reproducen las relaciones y los significados cruciales que sostienen, pero también transforman, un orden social.

Si bien el tema central fue, en un principio, lo que podría llamar sexualidad, siguiendo a Foucault, hoy avizoro una interpretación quizás más compleja de los materiales reunidos. Primero, pensé que podría diferenciar entre sexualidad y erotismo. Si leía el campo desde ciertos desarrollos conceptuales sobre la sexualidad, siguiendo al pensamiento posestructuralista, feminista e incluso queer, que enfatizan algunos puntos como las relaciones de poder, las formas en las que se engrana con otras relaciones sociales, los modos en los que diversas instituciones y formaciones discursivas la constituyen, quedaba fuera, por decirlo así, un amplio espectro de observaciones. Finalmente elaboraré una postura más radical sobre estos asuntos, porque creo que debemos salir de la sexualidad para pensar el deseo, al menos desde la antropología. La sexualidad opera como un universal que impide pensar las diferencias y las heterogeneidades, pero también como un dispositivo que cerca el deseo e intenta producirlo técnicamente. Las prácticas de la diferencia y las posiciones de deseo, que elaboraré en las conclusiones de este texto, son rutas para salir de la sexualidad, romper con los universales y entrar en el denso campo de las diferencias y las pluralidades sociales y subjetivas.

El erotismo sería una especie de frontera sitiada entre el deseo y la sexualidad; entre la potencialidad de los cuerpos y las constricciones de los diversos órdenes sociales y culturales y 
todas sus expresiones normativas o coercitivas. Están los grandes anclajes de la sexualidad: las identidades, los flujos subjetivos nominados y rutinizados, los significados, las normas y los valores; todo el sistema de conexiones múltiples entre la sexualidad y las otras instituciones y formaciones discursivas: el parentesco y la familia, el Estado y el mercado, la medicina y la pedagogía. Tenemos, por otra parte, ese campo de fuerzas que organiza el deseo y las intensidades que produce. El erotismo no tiene ni la inscripción institucional de la sexualidad, ni la densidad social y colectiva del deseo. En alguna medida, sólo es un sesgo. Un interludio que atraviesa un momento social, una relación que cruza a uno o muchos sujetos, que los vincula o los desvincula de determinado modo, que permite ciertas prácticas sociales y que se diluye con rapidez, sin más rastros que los cobijados por la imaginación y la fantasía. Pero creo que el erotismo es, también, una alteración profunda del orden institucional: se alimenta de sus definiciones y sus diferencias, las intensifica mediante investimentos específicos, pero también las turba, las desencaja.

Al registro de este campo también lo he llamado deseografías. Con este concepto quisiera pensar, por una parte, la posibilidad de convertir al deseo en un objeto de estudio etnográfico; por otra, como antes lo dije, la forma en que se puede escribir sobre el deseo, cómo construir una grafía posible de él.

Existe una larga tradición de estudio de la subjetividad por parte de la antropología, aunque no haya sido su tema preferido ni central (Biehl et al., 2007; Lutz, 1998; Obeyesekere, 1981; Ortner, 2005). Preguntas sobre la persona, el carácter, la personalidad, los sueños, las emociones y los afectos, las formas de individualidad, entre otras tantas, atraviesan etnografías y ensayos. Parece que, en general, la subjetividad se convierte en un objeto de estudio semejante a otros como el parentesco, los mitos, las formaciones religiosas, los sistemas económicos y las formas de gobierno, por mencionar sólo algunos. Cuando se trata de la subjetividad, creo que la antropología la piensa como cualquier otro objeto posible, aunque difícil de formalizar. Hablo de objeto sólo como una distinción conceptual y empírica de cierto campo de la vida social y cultural. Me parece que al convertir al deseo en un objeto etnográfico, el estudio de la subjetividad por parte de la antropología puede dar un giro interesante. A mi entender, el deseo es íntegramente un fenómeno social. Si bien no discutiré su importancia en la configuración psíquica de los sujetos, lo que quiero destacar es que se lo puede estudiar a través de una aproximación etnográfica y sin que necesitemos, de manera ineludible, usar conceptos psicológicos. 
A partir de mi trabajo de campo en Tenosique, con la sexualidad y el erotismo, he constatado que el deseo se encuentra entre los sujetos antes que en ellos mismos; en las densas tramas de relaciones sociales y simbólicas, formas de corporalidad y prácticas sociales. Cuando algún sujeto hablaba de su deseo siempre remitía a otro, ya sea intersubjetivo o simbólico. En esas observaciones y pláticas ha sido muy difícil distinguir la parte del uno de la parte del otro. La intimidad ha aparecido siempre como una forma de extimidad, en términos lacanianos.

Félix Guattari escribe que "el deseo atraviesa el campo social, tanto en prácticas inmediatas como en proyectos más ambiciosos” (Guattari, 2005: 318). Franco Berardi, por su parte, también define al deseo como un campo, “(...) en el cual se desarrolla una densísima lucha o, mejor dicho, un espeso entrecruzamiento de fuerzas diferentes, conflictivas" (Berardi, 2010: 20). Si bien estas definiciones despsicologizan el deseo, creo aún son vagas para poder realizar un trabajo etnográfico o una investigación antropológica. Lo ubican en un campo eminentemente social, siguiendo una línea que podemos trazar, al menos, hasta los freudomarxistas. Pero campos sociales hay muchos, luchas también. Fuerzas conflictivas se cuentan por cientos o miles. En ese panorama, ¿cómo comprender el deseo y cómo distinguirlo en términos observacionales y metodológicos?

Creo que debemos pensar el deseo como una intensidad que desmiente la distinción entre intimidad y exterioridad, entre dentro y fuera, entre sujeto y colectivo, entre orden psíquico y orden social; es decir, que cuestiona las topologías con las que, habitualmente, se piensa la subjetividad. Desmiente esa topología, sin negar su existencia, para poder discutir su estatuto. Esas distinciones, que muchas veces son utilizadas como evidencias indiscutibles, se tornan más porosas, más tenues e inestables. El deseo es una intensidad que cruza los discursos, en sus axiomas o sus valoraciones, en las emociones que convocan, en sus rechazos y aversiones. También las prácticas estarán marcadas por él, en su concreción espacio-temporal o en su despliegue consecutivo, en las corporalidades que comprometan o requieran.

Podemos, por ejemplo, pensar qué deseo está en juego cuando un paciente con VIH, homosexual, llega a un centro de salud para que lo atiendan de emergencia, con un cuadro de deshidratación aguda, producto de varios días consecutivos de diarreas. En esa trama que se inaugura al momento de arribar al hospital, ser recibido (si corre con suerte), hablar con los médicos, que ellos conozcan su diagnóstico, que lo internen, ¿qué deseo estaría en juego en el trato que le darán, en las miradas, en las formas que visibilizarán su diagnóstico, en lo que supondrán sobre él? Pero, también, ¿qué deseo se jugará en el mismo sujeto, en la relación con 
la institución médica y su personal, con la enfermedad y con la muerte? Esta es una escena que no parece demasiado adecuada para pensar el deseo, pero ha sido parte de mi trabajo de campo. Rosi Braidotti escribe que el deseo “(...) es como un estrato de afinidad y simpatía entre diferentes sujetos encarnados, forma parte precisamente de este proceso de composición y reunión de fuerzas" (Braidotti, 2009: 261). Pero habría que preguntarse si no cruza, retomando a Berardi, fuerzas conflictivas, relaciones de poder, antagonismos diversos.

Quisiera pensar que el deseo de vivir de la persona internada de urgencia forma parte de los recursos subjetivos con los que cuenta para enfrentar su situación. Los deseos de sus amigos y familiares, de sus vecinos de que se recupere, expresados en visitas, en oraciones, en chismes, en toda una intensidad preocupada, concernida por su situación. Guattari define al deseo como “(...) todas las formas de voluntad o ganas de vivir, de crear, de amar; a la voluntad o ganas de inventar otra sociedad, otra percepción del mundo, otros sistemas de valores” (Guattari, 2005: 318). ¿Desea vivir esta persona?, ¿desean atenderlo los médicos?, ¿cuáles otros deseos se despliegan en esta escena?, ¿podemos identificar algunos contra-deseos, por llamarlos de alguna manera? Justamente las formas de muerte, de destruir, de repetir, de impedir que lo nuevo o lo distinto emerja. Esas afecciones del deseo, como las denomina Deleuze (2007a: 124), también están en juego en este episodio. El rumor de las enfermeras, la camilla ubicada en un pasillo con un cartel bastante visible en el que está escrito con un plumón azul el diagnóstico: "VIH". El desprecio que muchos sienten por los homosexuales. Todo eso está presente, como una fuerza también que se interpone frente a los deseos de vivir y de sanar.

Esta escueta descripción puede entenderse como una actualización de relaciones biopolíticas, que no sólo son simbólicas (enfermedad y muerte, normalidad y anormalidad) y materiales (edificios, diagnósticos, camillas, agujas), sino también deseantes. Debemos encontrar debajo o encima, o a través, del tono cansino de las burocracias y las instituciones manifestaciones espurias de deseo, o contra-deseos y sus afecciones. La pulcra claridad de un hospital, su distribución geométrica, los espacios vedados y los permitidos: ¿no son expresiones de un deseo colectivo de regulación, de normalidad y limpieza? Frente a ese deseo, nunca evidente, pero perceptible, la sexualidad de esta persona enferma produce ciertos efectos, abre algunas lecturas, modifica determinadas intensidades sociales e institucionales. El sida se ha relacionado con la muerte de manera tan sistemática no sólo por la evidencia científica (que permitiría establecer la misma relación en muchas otras enfermedades), sino porque condensa una afección del deseo que espera la muerte de los enfermos. 
En la escena que describo, preguntar por los deseos que se movilizan en ella, que cruzan su conformación, es preguntarse por algo que, a mi entender, no puede ser interrogado de manera directa; sólo podemos observar con esmero, atender a los cuerpos, a sus rictus y sus gestos, sentir los olores, reconocer las voces y sus tonos, distinguir los comportamientos, escuchar, también, las palabras. El deseo será más un remanente que una evidencia. Como cuando entramos a una fiesta aburrida; no hay certeza del aburrimiento, la falta de deseo es una especie de sedimento de los estados emocionales y corporales de los presentes, de sus vínculos y de sus expectativas. ¿Podemos leer las intensidades de esa fiesta descolorida? Sí, claro que podemos, pero debemos saber reconocer las energías que la recorren.

Por otra parte, el deseo conectará de manera consistente antropología y subjetividad en un trabajo de campo. Tal vez la mayor dificultad que experimenté para pensar todo lo que he planteado es que parte de la etnografía había pasado, por así decirlo, por mi propio deseo. Quiero decir, si no hubiese conectado mi deseo con el de los otros, si no hubiera trabajado desde mi deseo, en el diálogo y la observación permanente que supone una etnografía, no habría podido estudiarlo. Tampoco podría pensar una antropología del deseo, que explore las formaciones colectivas, o los planos como los llama Deleuze, por las que fluye el deseo o las organizaciones e instituciones que lo estancan. No se trata, por supuesto, de que la etnografía sea una autobiografía. Sostengo que el lugar que nos permite investigar el deseo, colectiva y subjetivamente, es nuestro propio deseo; no como una configuración cerrada, sino más bien como un punto de conexión de nuestros cuerpos con otras corporalidades, de nuestras intensidades con otras (humanas y no humanas, conscientes e inconscientes, espirituales y corporales, materiales e imaginarias), con la de los otros.

¿Puedo observar desde el deseo un hospital y sus formas, sus utensilios y modos, su personal y sus rutinas?, ¿podría acompañar desde mi deseo a una persona enferma, en su pathos, en sus temores, en la incertidumbre que la persigue?, ¿atender a los tratos, las palabras, las posiciones de los cuerpos?, ¿debería conectarme con el deseo de vida de esa persona y con las afecciones de quienes lo atienden?; del significante escrito en un cartel con color azul: ¿puedo dilucidar sus vínculos con los procesos colectivos que el deseo anuda o desata?, ¿determinar qué deseo se cuaja en las tres letras del VIH y qué afecciones se arremolinan en torno a ellas?

Si se estudia una forma de organizar el parentesco o la economía, o las creencias religiosas o los usos del derecho, tal vez la propia subjetividad no sea indispensable. Pero si investigo otras subjetividades y, aún más, si pretendo investigar el deseo, es imposible que lo haga sin mi 
propia subjetividad y mi deseo. Y no digo sólo el mío, hablo del deseo del antropólogo. ¿Cómo puedo utilizar mi subjetividad en un campo de estudio como una herramienta de investigación? No es necesario, por supuesto, cosificarla. No es una encuesta. Más bien, creo que su participación, querida o no, requiere de cierta lectura de uno mismo: ¿cómo se vincula mi deseo con el de los otros?, ¿qué reverbera en mi deseo y en mi subjetividad a partir del trabajo de campo, durante y después de él?

Sueños y persecuciones: los campos oníricos

El sueño, “dios de los salvajes”, como decían los antiguos misioneros, se ha deslizado siempre entre mis dedos como un mercurio sutil. ¿Dónde me ha dejado algunas partículas brillantes? Claude Lévi-Strauss, Tristes Trópicos, 2011[1955]: 50

Esa relación opaca entre deseo y etnografía me fue revelada por un sueño. En él aparecía mi principal informante en Tenosique, por quien tengo gran cariño y una profunda admiración. Al despertar, le envié un mensaje por celular diciéndole que había soñado con él; me respondió enseguida contándome que su hermano estaba muy enfermo y que pronto moriría. Mi amigo interpretó el sueño como si yo hubiese sabido, de una forma misteriosa, lo que estaba sucediendo. Era una conexión entre los dos que superaba el trabajo de campo in situ, aunque después de mis viajes pasara mucho tiempo recordando lo que había sucedido. ¿Es mi deseo lo que motiva todos esos gestos subjetivos, esas preocupaciones, esos recuerdos? Y si así fuera: ¿podría decir que la etnografía se extiende a mis sueños y mis iluminaciones cotidianas, que permanece en ese soterrado rumor de la mente y del corazón que nos acompaña diariamente?, ¿podría leer todo esto como una escritura emocional y corporal que el trabajo de campo va plasmando sobre nosotros mismos? Si el deseo tuviera una escritura tendría que ser lateral e imperceptible, sutil y continua, inesperada y reveladora. Sería una forma de experimentar ese "estrato de afinidad y simpatía", del que habla Braidotti, entre sujetos encarnados; pero también de producir "una composición y reunión de fuerzas": soñar con alguien y vincularse con sus procesos vitales; ir con otro al hospital y quedarse a su lado. El deseo es la trama que se teje entre gestos y palabras, entre discursos y prácticas, entre instituciones y sujetos.

Creo que este trabajo de campo onírico, que se cuela en las capas profundas de la subjetividad y que produce otros relatos y otros actos -partículas brillantes, como las llama Lévi- 
Strauss-, es fundamental para encontrar el deseo. La versión nocturna y onírica de una etnografía nos conduce a lugares y momentos heterogéneos: una de las puertas hacia el deseo, uno de sus umbrales. Si bien me sorprendió que un sueño sostuviera una tesis, luego constaté que era la ruta adecuada. En el silencio emerge esta sombra que había acompañado el trabajo de campo; en su reverso la etnografía devela un rostro secreto. El brillo de estas partículas ilumina la opacidad diurna y el dios del inconsciente, que atañía a Lévi-Strauss, dispone su oráculo sobre nuestras subjetividades. Por eso el deseo fue al encuentro de la etnografía cuando quiso hacerlo. En algún sentido, como antes dije, la escritura siempre es una espera, una velada, que aguarda al pensamiento, pero también lo vela y hace un responso en su honor. Es la ritualidad secreta del inconsciente la que nos devela nuestra mirada más profunda y densa.

Pero, por otra parte, el sueño se conectaba, por así decirlo, con algunas preocupaciones que había suscitado el trabajo de campo en los meses anteriores a su ocurrencia. Durante el año 2011 observé, con azoro, cómo la modificación de las políticas de seguridad, implementadas por el primer alcalde de un partido de izquierda en el municipio, transformó notoriamente la vida social y, primordialmente, nocturna de la ciudad. Un remedo de las políticas de tolerancia cero que se habían aplicado en la capital del país, también gobernada por la izquierda, supuso el acoso policial hacia sujetos homosexuales de la localidad, en especial hacia los afeminados o que vistieran de mujer. En las cantinas, por ejemplo, la policía los revisaba y les pedía las "tarjetas sanitarias" que se requieren para ejercer el trabajo sexual en la localidad, aunque la mayoría no se dedicara a él. Si no contaban con ella, los acusaban de ejercer la prostitución sin permiso de las autoridades locales y los detenían. Muchas de las personas que conocía dejaron de frecuentar bares y cantinas, donde desplegaban una parte de su sociabilidad, por temor a la policía.

El lado nocturno del deseo se vinculaba con este otro, institucional y normativo. La tolerancia cero que el Director de Seguridad Pública intentaba aplicar suponía, a mi entender, una intervención profunda en la producción social del deseo homoerótico en esta localidad. No sólo eran perseguidos los homosexuales, también lo fueron las trabajadoras sexuales y los hombres jóvenes de clases populares, especialmente si tenían aspecto o vestimenta de "pandilleros". Era otra manifestación de las afecciones del deseo de las que hablaba Deleuze. Si bien yo les propuse a algunos amigos que fueron detenidos de manera arbitraria que 
interpusieran una queja ante la Comisión Estatal de Derechos Humanos, ninguno quiso hacerlo; en estas circunstancias, no parecía factible una ruta jurídica.

Si bien sentía una honda molestia por las actitudes de la Policía Municipal de las que había sido testigo, no lograba entender muy bien mi desazón. Cuando tuve el sueño y comprendí que estaba investigando el deseo, también entendí ese azoro. El trabajo de campo diurno se articulaba con uno onírico; el inconsciente con la reflexión; los itinerarios etnográficos con otros subjetivos y emocionales. No fue el sueño lo que resolvió la tensión, fue el mismo deseo. Deleuze, en un texto en el que discute sus diferencias con Foucault, escribe que los agenciamientos de deseo (o dispositivos) "nunca pueden describirse en términos de poder"; el deseo circula en esos agenciamientos "de lo heterogéneo" y no se distingue de ellos, formando lo que llama un "co-funcionamiento" (Deleuze, 2007a:123). Si hubiese leído las razias policiales sólo como relaciones de poder, que sin duda lo son, no habría encontrado el deseo. Si leyera el sueño como un simple acontecimiento azaroso de mi propia subjetividad y Alan, mi informante, no lo hubiese ligado con la enfermedad de su hermano, no habría encontrado el deseo. Si no pensara los vínculos entre hechos tan disímiles, también se me escaparía. Deleuze anota que es necesario distinguir, en los dispositivos o agenciamientos de deseo, entre "los estados de cosas y las enunciaciones" y "las territorialidades o reterritorializaciones y los movimientos de desterritorialización" (ibid.). La reconfiguración de las políticas locales de seguridad pública era una reterritorialización que producía "un dispositivo de poder", en palabras de Deleuze; el sueño una desterritorialización, literal, de la etnografía, que originaría nuevos "agenciamientos de deseo".

¿Cómo vincular el sueño que relaté con la persecución que describo?, ¿son dos campos disjuntos: uno irreal e imaginario, el otro real?, ¿qué proporcionaría un cruce entre ambos momentos y ambas dimensiones sin someter unos a los otros?, ¿qué realidad empieza en los sueños?, ¿qué sueños empiezan en la realidad? Guattari escribe que "el contenido de un mensaje onírico puede transformarse, maquillarse, mutilarse, pero no su dimensión afectiva, su componente tímico" (Guattari, 2000: 229; énfasis mío); el afecto es transitivo, agrega, "una categoría pre-personal, que se instaura 'antes' de la circunscripción de las identidades, y que se manifiesta a través de transferencias ilocalizables” (ibíd.). ¿Es el afecto la verdad del sueño? Guattari escribe que “(...) el afecto permanece vago, atmosférico y sin embargo perfectamente aprehensible en la medida en que se caracteriza por la existencia de umbrales de pasaje y transformaciones polares" (ibid:: 230). El sueño era una puerta a la realidad del afecto, eso que 
se había gestado durante tantos años de conversaciones y amistad. Un umbral de transformación que conducía a nuevas reflexiones. Es como si ese corąón impensado que Foucault menciona tuviera que latir para significar. Lo impensado del deseo se devela por un sendero afectivo, pero que no se aleja del mundo y de la realidad, sino que se acerca a ellos a través de esas transferencias ilocalizables, que Guattari insinúa.

Yael Navaro-Yashin se pregunta si el afecto emerge del yo (self) o del ambiente (environment), de la subjetividad o de los objetos (Navaro-Yashin, 2009: 5). Guattari responderá que no surge de ninguno de ellos, pero que constituye "su motor"; el afecto, dirá, no es un estado pasivamente sufrido, "se trata de una territorialidad subjetiva compleja de protoenunciación, sede de un trabajo, de una praxis potencial" (Guattari, 2000: 239). Si el afecto atraviesa tanto al sujeto como a los mundos sociales, las subjetividades y las materialidades, lo hace en un registro distinto al discurso, porque no se funda “(...) en sistemas de oposiciones distintivas que se declinan siguiendo secuencias de inteligibilidad lineal y que se capitalizan en memorias informáticas compatibles entre sî” (ibíd.: 230). Sin embargo, escribirá Guattari, esa inscripción no discursiva, o proto-discursiva, no reduce la complejidad del afecto e incluso la incrementa. El afecto sería "la instancia de engendramiento de lo complejo", que interroga la disposición de la enunciación: "el afecto me habla, o por lo menos habla a través de mí”" (ibid:: 232).

Navaro-Yashin sostiene que los afectos no están circunscritos por una teoría del sujeto, “e ilustran que la afectividad puede ser estudiada en lugares y espacios más allá del alcance del 'sujeto humano', su 'subjetividad' o 'psiquis”' (Navaro-Yashin, 2009:15, la traducción es mía). Ese más allá es el lugar donde se podrían conectar, etnográficamente, un sueño y una razia policial, pero también a los sujetos, las instituciones y las prácticas sociales. El sueño parece confirmar una relación afectiva y se localiza en un espacio distante (en términos geográficos, pero también topológicos) de aquellos donde la policía detiene a quienes no cumplen con las reglamentaciones locales o que resultan sospechosos. El Estado vigila la producción social del deseo, tratando de coartar sus 'energías', el motor del que habla Guattari; pero también el sueño conecta mundos a través de esos relatos oníricos que guardan la realidad del afecto, que inquietaba a Freud. El afecto habla a través de nosotros y la dificultad radica en reconocer su lengua, su idioma, si tuviera alguno; el discurso es un rumor lejano que no permite traducciones (afectivas). El deseo es el itinerario y la trama que conecta los afectos y sus afecciones. Por eso, el sueño y las razias necesitan que nos detengamos, que escuchemos detrás 
de las palabras el eco de otras dimensiones, esa "procesualidad en estado naciente", de la que habla Guattari.

En la aplicación de nuevas políticas de seguridad pública en Tenosique estaban en juego controles inéditos sobre los deseos y su espacialidad. Era el deseo de los otros lo que emergía en mis preocupaciones, esa tensión difícil de resolver entre el fuero íntimo y las normas públicas, entre las prácticas institucionales y las eróticas, entre el Estado y el sujeto. El Estado, que se interponía entre el deseo y su anclaje espacial y vincular, ordenaba cierto tipo de comportamientos y exigía permisos a quienes parecían transgredirlos. El castigo era la cárcel y la humillación pública del arresto. Se esbozaban, así, intentos de disciplinar el deseo. Pero en el sueño era mi propio deseo lo que estaba en juego, como una ampliación del trabajo de campo a territorios oníricos. Lo que se restaba socialmente proliferaba subjetivamente. Las noches turbadas por las razias o intensificadas por los sueños otorgaron un tiempo a este diagrama deseante que intento develar o entender.

Si el afecto permite, según Guattari, la “proliferación de devenires” (Guattari, 2000: 232), la subjetividad del etnógrafo sirve como una superficie de elaboración del trabajo de campo donde líneas diversas se entrecruzan y suscitan nuevas asociaciones entre hechos muy distintos. Sin embargo, su investigación no se agota ahí, sólo es un inicio. Las persecuciones que relato se deben entender a la luz de muchos otros fenómenos y relaciones sociales. También el sueño. Y eso es lo que haré detalladamente a lo largo de los capítulos que componen este trabajo. Si el deseo, como lo sostendrá Deleuze, está “primero” (Deleuze, 2007a: 124), también deberá surgir al último, por así decirlo, luego de una reconstrucción paciente y minuciosa de relaciones y prácticas sociales, de subjetividades y corporalidades, de procesos históricos y políticos, de materialidades y discursos. En otro texto, Deleuze se preguntará: “¿No es el deseo el interior en general, o más bien el vínculo móvil del interior con las otras dos instancias, el afuera y los estratos?” (Deleuze, 2007b: 235). Ahí, en esos vínculos entre el “interior general”-los pliegues-, el afuera y los estratos -las formaciones históricas-, es donde debemos explorar para engendrar la antropología del deseo que nos interesa. "Los estratos -dirá Deleuze- son formaciones históricas, positividades o empiricidades. Están hechos de cosas y de palabras, de ver y hablar, de lo visible y lo decible, de regiones de visibilidad y de campos de legibilidad, de contenidos y expresiones" (ibid:: 224). Será justamente ese espacio entre los pliegues y las formaciones históricas el que importe a esta etnografía. Buscaremos, por tanto, empiricidades que sostengan sus indagaciones. 


\section{Maravillas y conjeturas}

Cuando llegué por primera vez a Tenosique, en junio de 2006, visité la cárcel local para conocer las actividades de prevención del VIH que el Club Gay Amazonas realizaba entre los internos ahí recluidos. Era una cárcel rural, con cincuenta internos, si mal no recuerdo, muchos de ellos habitantes de la localidad, acusados de diversos delitos. A esa visita me acompañó Alan Contreras, el presidente del Club, y el principal activista contra el sida del municipio. Los funcionarios del organismo estatal dedicado a prevenir y controlar la epidemia me hablaron de él con mucho entusiasmo. Había estado en prisiones bastante más grandes y sobrepobladas y ésta parecía una casa de campo ubicada entre las malezas y el bosque. Los internos descansaban debajo de los árboles y algunos tejían hamacas. Antes de ingresar al recinto nos revisaron unos guardias; cuando le tocó su turno, Alan levantó los brazos y jugueteó con un guardia muy alto y serio. Todos rieron efusivamente con sus intentos de seducción y luego entramos. Era una escena que me parecía inédita: ingresar a una prisión en medio de la algarabía del doble sentido, del erotismo y el humor.

Desde ese momento noté que había tocado un mundo insospechado y que se abría un tesoro etnográfico. Todo lo que sucedió en adelante confirmó mi intuición. Alan me presentó con los otros integrantes del Club, muchos de ellos vestidos de mujeres o intensamente afeminados, que se nombraban con apodos femeninos; otros, parcos funcionarios del Ayuntamiento o de los partidos políticos locales. La risa y el juego eran prácticas constantes: en las calles y las cantinas, en las casas y los comercios. A su paso se producían escenas de seducción, de humor y de amistad casi sin pausa. Sentados a la mesa de una cantina, que en ese tiempo tenía muchos parroquianos, los amigos de Alan se transformaban en el corazón de la fiesta, rodeados de soldados, campesinos, pescadores, cañeros y hombres, en general, acostumbrados a los trabajos rudos. Las masculinidades más enfáticas se cruzaban con unas feminidades oscilantes y producían un mundo intensamente ambiguo. Bailes, cervezas, risas.

Ese fue el principio de una larga exploración del deseo y también su término. La pregunta inicial fue qué hacía posible una organización de ese tipo, un Club Gay en una ciudad de rancheros y un mundo en el que los estereotipos más acendrados bailaban y se contorsionaban sin descanso. El binarismo, que había dado origen a una incesante producción teórica, dejaba acá sus togas y se convertía, en algún sentido, en el guión de un mundo de travestismos y 
oscilaciones constantes. Me sentía como Alicia, en este país de las maravillas, fronterizo y rural, porque todo estaba al revés, al menos con respecto a mis criterios clasificatorios y conocimientos conceptuales. Las combinaciones inusitadas, las prácticas imprevistas, las estéticas insospechadas fueron el espejo que atravesé hacia ese país que llamaré deseo. Luego me percaté de que el problema no era ese mundo sino el mío. Por eso, al finalizar mi exploración, al menos en términos formales, lo que se había reconfigurado era mi deseo; los mundos que investigaba habían cambiado, sin duda, pero en lo fundamental seguían siendo los mismos que conocí al principio. Pero esa reconfiguración implicó una transformación profunda en mi mirada. La etnografía y los capítulos de este texto son un viaje hacia un punto de vista que explore el deseo sin objetivarlo; es decir, un deseo vivo, activo, incesante y no piezas mudas y secas de un pensamiento que llega a destiempo.

Guattari, otro viajero en los lindes del deseo, lo pone en las siguientes palabras: "El estudio de un objeto de deseo implica que no se pierda en el camino la singularidad del modo de enunciación. En estas condiciones, la propia enunciación del estudio no podría permanecer independiente de los modos de enunciación relativos a su 'objeto"' (Guattari, 2013: 63). ¿Cómo enunciar este 'objeto’ sin perder sus modos de enunciación?, ¿cuáles serían dichos modos?, ¿qué hacer con ese material proto-discursivo que pulula en los afectos? Ya he dado algunas pistas y he tanteado respuestas provisionales. El modo de enunciación del deseo, si tuviera alguno, es heterogéneo con respecto a otros modos (los del parentesco, la sexualidad, la ley, la economía), pero los atraviesa a todos, produciendo grietas afectivas en sus superficies. El modo de enunciación del deseo es una polifonía y una heteroglosia, que habla el lenguaje cifrado de los sueños y el mascullante de la ley y el poder, entre otros muchos. Habla a través de nosotros y nos habla, a la vez. Por eso, como el mismo Guattari lo anota, el lenguaje neutro de las ciencias humanas "solo podrá perder la economía colectiva del deseo, sus resortes más esenciales”. Dirá que “solo el deseo puede leer el deseo”, el postulado metodológico más importante de su pensamiento, a nuestro entender. No obstante, agrega que "el hecho de renunciar al carácter de generalidad del objeto científico, a su función de ejemplaridad, no implica de ningún modo el abandono del método de investigación científica." No responde, claro está, cómo el deseo puede estudiar al deseo, pero acota el efecto de ese enunciado, al salvar el método ante un deseo que se auto-investigaría.

Las ciencias del deseo, si las hubiese, serían conjeturales, caracterizadas por "la singularidad del deseo, las mutaciones históricas, el acontecimiento que 'viene del afuera', la emergencia de 
nuevas ramificaciones maquínicas, el surgimiento de lo que llamaremos máquinas concretas” (Guattari, 2013: 63).

Para estudiar el deseo, añade Guattari, es necesario que el "sujeto productor de un estudio" realice una “cierta transferencia de enunciación”, que le permita “estar 'en contacto', de una forma u otra, con el modo de enunciación concernido por el estudio" (ibíd.). En una "epistemología objetivista", como la denomina Viveiros da Castro, "los sujetos, igual que los objetos, son vistos como resultados de procesos de objetivación: el sujeto se constituye o se reconoce a sí mismo en los objetos que produce, y se conoce objetivamente cuando logra verse 'desde el exterior' como un 'eso"' (Viveiros de Castro, 2010: 40). Ese juego epistemológico se llamaría objetivación: "lo que no ha sido objetivado permanece irreal y abstracto. La forma del Otro es la cosa" (ibid.).

¿Qué sucedería si la 'forma del Otro’ fuera el deseo y no la cosa? Creo que, al menos en este campo, implicaría un proceso de subjetivación. Deleuze escribe que "el adentro es un resultado del afuera, una subjetivación (...) el adentro también es una relación, la relación convertida en sujeto" (Deleuze, 2007b: 233). Agrega que "si es cierto que el interior se constituye por un pliegue del exterior, hay entre ambos una relación topológica, la relación consigo mismo es homóloga de la relación con el afuera, y todo el contenido del adentro está en relación con el afuera" (ibid: 235). Por eso, la exploración del 'interior' es una forma de conocer el 'exterior'. Ese espacio que se produce mediante un pliegue Deleuze lo llama subjetivación. Esta topología evita, a mi entender, que el deseo sea sólo un concepto o una dimensión psicológica. El deseo es también un afuera plegado sobre el sujeto, o un pliegue convertido en sujeto. Sin embargo, el filósofo sostendrá que la relación consigo mismo es “irreductible a la relación con el exterior y se realiza en un eje específico" (ibid:: 233). El deseo, dirá, no es "un dato natural", "es un proceso, no una estructura ni una génesis; es afecto, no sentimiento; es 'hecceidad' (...), no subjetividad; es acontecimiento, no cosa ni persona” (Deleuze, 2007a: 127). Estamos, considero, ante lo que Guattari denomina "procesos complejos de producción de subjetividad", que permiten "cartografiar los diversos componentes de subjetivación en su profunda heterogeneidad” (Guattari, 2000: 231).

¿Qué significaría alinear una investigación en torno a un proceso, el afecto, la 'hecceidad' y el acontecimiento?, ¿evitaríamos, así, que la forma del Otro fuera la cosa? Creo que el deseo ha sido un conector, en esta investigación, de las heterogeneidades subjetivas y las exterioridades plegadas. Entre las maravillas y las conjeturas, una antropología del deseo investigará las 
formaciones sociales y su subjetivación, pero también los pliegues y su heterogeneidad. El etnógrafo es parte del campo, no sólo su observador; participa de los procesos deseantes y no sólo los describe. La antropología del deseo es una antropología de los pliegues, que explora las formas en las que el 'exterior' ha producido un 'interior', pero también las manifestaciones de su irreductibilidad y singularidad.

Archivos del futuro: Tenosique/Nueva York

Al inicio del trabajo de campo, le pregunté a un político local qué particularidades tendría la ciudad para que existiera una organización como el Club; él me contestó, casi de inmediato, que "Tenosique era como Nueva York". La comparación me sorprendió, en un primer momento, pero luego inquirí porqué consideraba que una ciudad se parecía a la otra y el político me respondió que ambas eran "ciudades liberales". Tenosique es uno de los 17 municipios del estado de Tabasco; colinda al este y al sur con la República de Guatemala y al oeste con el estado de Chiapas. El 2010 contaba con 58,960 habitantes, repartidos en más de 130 localidades, muchas de ellas con menos de 500 habitantes. En la ciudad de Tenosique habitan 32,579 personas. Según datos de la Secretaría de Desarrollo Social, un 69.7\% de la población presentaba algún nivel de pobreza; un 14.4\% vivía en pobreza extrema y un 9.5\% no tenía acceso a la alimentación (SEDESOL, 2013: s/p). Un 10.3\% de la población mayor de 15 años era analfabeta y un 46.5\% no había completado la educación primaria. De su población económicamente activa, gran parte trabajaba en el sector primario (agricultura y ganadería) o en el terciario (servicios y actividades de gobierno).

En ese municipio, el 13 de septiembre de 1995 se fundó el Club Gay Amazonas. Su presidente relata que se reunieron en el local de la Asociación Ganadera y anunciaron que eran “43 personas decididas a pelear por el orgullo gay”. La fecha de fundación es un dato relativo, porque he escuchado otras, pero también porque el Club hereda formas previas de sociabilidad. Como lo veremos a lo largo de los capítulos, es una organización muy flexible; algunos de sus integrantes participan de manera constante, pero muchos otros sólo lo hacen de modo esporádico, especialmente cuando hay fiestas o eventos. El Club agrupa fundamentalmente a hombres gay, algunos de ellos viven como 'mujeres' casi toda su vida, pero no se definen ni como transexuales, travestis o trans. Si bien también han participado 
mujeres lesbianas, su inclusión es relativa y ocasional; su mundo no lo pude explorar desde el Club. La organización no cuenta con registro legal, ni estatutos; tampoco tiene una sede.

Cuando comencé mi investigación, el Club era ampliamente conocido en la ciudad. Había participado en varios carnavales con sus propios carros alegóricos, organizaba fiestas de todo tipo durante el año y se encargaba de la prevención del VIH en la ciudad (mediante pláticas, distribución de preservativos y ayuda a personas enfermas). En 2009 todos los candidatos a alcaldes y diputados se reunieron con sus integrantes, tendencia que se confirmó en las elecciones siguientes. Esta organización estaba incluida en los mapas políticos locales, aunque no fuera su objetivo. El Club pasó por diversas etapas e incluso se disolvió durante varios años después de 2010. Las relaciones que lo sostenían eran, fundamentalmente, amistosas y cuando ellas se enturbiaron, por múltiples razones, el Club desapareció; cuando las divergencias se resolvieron, al menos en parte, volvió a constituirse. Pero esta organización fue una ruta para explorar y conocer un mundo de vida muy denso, que lo superaba ampliamente. Vidas de muchos sujetos con los que he tenido contacto y de otros tantos que sólo conocí mediante relatos de terceros; vidas, muchas, que terminaron durante el trabajo de campo, producto de la enfermedad o la violencia. Pero no sólo vidas, también relaciones y espacios, desde la intimidad de las casas hasta las mesas de una cantina; las calles y las cocinas; los dormitorios y los edificios públicos. Seguí muchos itinerarios, dentro y fuera de la ciudad. Los integrantes del Club me llevaron hacia muchas otras personas que conformaban un mundo plural. No podría recapitular todo lo vivido y visto, todo lo escuchado.

Cuando tuve el sueño que relaté antes y comencé a seguir la pista del deseo, me percaté que podía dar cuenta de algo que intuía casi desde el principio. En mi etnografía había sido testigo, por así decirlo, de la creación de un mundo y de su transformación. Testigo de las memorias sociales a través de las cuales pude adentrarme en la historia del Club y en las biografías de sus integrantes, pero también de los procesos de cambio que estaban en marcha cuando llegué a la ciudad y los que surgieron en el camino. El deseo, en la lectura de Deleuze y Guattari, es una fuerza creadora. Serán los dispositivos de deseo, escribirá Deleuze, los que distribuirán las formaciones de poder. De este modo, si el poder constituye una afección del deseo, entonces “el deseo es primero" (Deleuze, 2007a: 124). El poder cruza esta investigación de diversas maneras, pero de un modo derivado con respecto al deseo. Hemos tomado al pie de la letra estas sentencias deleuzianas: el deseo es primero y el poder su afección. 
En otras lecturas antropológicas de los trabajos de Deleuze, especialmente, pero también de Guattari, el énfasis se pone en otros aspectos. Viveiros de Castro (2010) se interesa por el pensamiento múltiple que se despliega en los dos tomos de Capitalismo y esquizofrenia (Deleuze y Guattari, 1985[1972] y 2010[1980]); Navaro-Yashin (2009) en el potencial de los afectos para pensar los espacios sociales, algunos procesos políticos y el vínculo de los sujetos con los objetos y los paisajes. Por su parte, si bien Biehl y Locke (2010) reconocen que la ruta deleuziana evita muchos de los obstáculos foucaultianos, se centran en los devenires abiertos por este pensamiento. El deseo ronda todas estas lecturas, pero no fundamenta ninguna de ellas. Es extraño, porque parece ser el concepto central de ambos autores, al menos desde la escritura del Anti-Edipo. Las dificultades que hemos relatado tanto para llegar a este campo de estudio como para realizarlo explican, en parte, esa ausencia. Hay una tarea metodológica pendiente que debería aclarar cómo estudiar el deseo desde una perspectiva antropológica.

Cuando el político que cité arriba me dijo que Tenosique era como Nueva York intuí que hablaba de un deseo colectivo de modernidad, cuya manifestación más nítida era el Club mismo. Ambas ciudades sólo podían conectarse a través de un paisaje global de aspiraciones y representaciones, que vinculaba la modernidad con la liberalidad sexual y política. Nueva York, inscrita como la ciudad global en los discursos mediáticos, la polis de la libertad personal y corporal; Tenosique, tan distante y diferente, que cobijaba los deseos de un grupo de homosexuales que podían organizase y producir un denso mundo de relaciones, afectos y discursos. Liberales a su modo, tratando de encontrar un espacio entre las significaciones más estereotipadas sobre el deseo homoerótico y unas prácticas sociales desarraigadas, muchas veces, de los discursos normativos.

Pero de todos modos, la comparación siempre me pareció antojadiza e inusitada. Sin embargo, la historia diría otra cosa. Siete años después de esa entrevista, el 4 de junio de 2014, el periódico The New York Times publicó en la portada de su edición impresa la foto de tres pequeñas migrantes hondureñas, con un pie de foto que informaba que las niñas estaban en Tenosique, Tabasco, alojadas en la Casa del Migrante local. Tenosique y Nueva York estaban, sorpresivamente, juntos. Al ver esa foto y leer el texto me di cuenta de que la etnografía había terminado, en alguna medida. Ya estaba investigando los procesos migratorios que transitan por la ciudad y los vínculos que sus habitantes establecen con los migrantes, pero en cierta forma había salido de un campo cuya forma era una curva, extensa en el tiempo, pero acotada en el espacio, que se trazaba entre la visita a una cárcel, el ingreso a los mundos de mis 
informantes y esa salida metafórica que era como el cumplimiento de un deseo colectivo: Tenosique es como Nueva York. Por eso, el deseo estuvo al principio, pero también al final. Fue la apertura y el cierre de esta investigación.

Lo que presento en los distintos capítulos representa todo lo que está entremedio de un momento y otro. En ese sentido, es un relato detallado o una descripción densa; pero también es una exploración acuciosa, o al menos así lo espero, que recurre a muchos autores y que abreva en muchos conceptos. He leído a las autoras feministas como pioneras en la dilucidación del deseo; he tomado de muchos antropólogos sus problemas y soluciones; he leído con palabras de filósofos diversos hechos que trato de describir. He regresado siempre al principio para mantener cierta fidelidad a mis ideas, pero la escritura se desliza hacia otros lugares con mayor rapidez de la que puedo reconocer. He escrito esta etnografía con la ayuda de muchas personas, cuyas voces atraviesan los textos. Las conclusiones, el lector lo verá, son como un reinicio de este camino. En cierto sentido la imagen de la esfera, que me ha fascinado profundamente y que he utilizado con prontitud en algunos capítulos, se encarnó en este documento. El principio es también un final; el término un inicio. Nunca nos abandonará el deseo: de investigar, escribir, entender o de leer.

Quisiera pensar que este escrito es, en última instancia, resultado del proceso que empezó un día se septiembre en la Asociación Ganadera de Tenosique, cuando 43 personas se dijeron dispuestas a "luchar por el orgullo gay". Si el texto fuera un fruto de ese deseo colectivo, mi escritura sería una forma de honrar a quienes han sentido orgullo de sí mismos en un contexto adverso. El orgullo podría ser una manifestación del deseo, una afirmación arriesgada del cuerpo y del alma, una fuerza inédita que anuncia otros mundos y otras subjetividades. Por eso, este texto puede leerse como el archivo de un deseo futuro. 


\title{
II \\ Quantas de libertad \\ El Club Gay Amazonas
}

\begin{abstract}
(...) no hay más historia que la historia de la emoción.
Derek Walcott, La voz del crepúsculo, 2000: 15

Después de todo, lo que nosotras entendemos por 'política' no es más que una acción relacional, capaz de desarrollar en lo real las consecuencias de una posibilidad impredecible, la libertad femenina, desautorizada por el orden social y simbólico. Ida Dominijanni, El estrabismo de Venus..., 2012: 60
\end{abstract}

En la ciudad de Tenosique, frontera de México con Guatemala en el estado de Tabasco, se creó hace 20 años un grupo social y político de hombres y mujeres homosexuales, que hoy asociaríamos con el rótulo de diversidad sexual. El Club Gay Amazonas empezó como un colectivo que procuraba actividades y distracción para sus integrantes. Además, realizaba una labor preventiva en el campo del VIH/sida. Luego se preocupó por la salud y la sobrevivencia de las personas que vivían con el virus, cuyos tratamientos comenzaron a conocerse desde los años noventa en la ciudad. Al mismo tiempo, participaba con carros alegóricos en los carnavales (sin duda la festividad más importante del lugar), organizaba eventos 'gay' como elecciones de diversos tipos de "misses" y "señoritas" y espectáculos de transformismo.

El Club era ampliamente conocido, en la ciudad, cuando me acerqué a él en 2006. En las últimas elecciones municipales (2009 y 2012), sus integrantes se reunieron una o más veces con los candidatos a alcaldes de todos los partidos políticos en competencia. Las autoridades estatales de salud y de derechos humanos los reconocían, y especialmente a su presidente, Alan Contreras, como interlocutores destacados. Buena parte de las actividades de promoción de derechos humanos y de prevención del VIH (como pruebas rápidas, entrega de condones, charlas informativas) se hacían en conjunto con ellos. Sus eventos causaban expectación colectiva y aseguraban, siempre, una asistencia masiva de ciudadanos que deseaban ver a algunos de sus integrantes imitando a sus cantantes favoritas (Yuri, Amanda Miguel, Laura León, Marisela), mientras otros desfilaban transformados en mujeres por una noche.

A finales de 2009 y durante 2010, el Club experimentó una crisis que si bien no lo disolvió, le restó presencia y capacidad de convocatoria. Hoy es una organización distinta a la que 
conocí a finales de la década pasada. En algún momento consideré que mi 'objeto' de estudio había desaparecido y, con él, mi investigación se transformaba en una especie de arqueología. Después constaté que el Club siempre tuvo una forma sui generis que no había entendido con claridad y hacía difusa su creación y disolución aparentes. El colectivo es resultado y expresión de un proceso social complejo con muchas aristas. Estudiarlo me permitirá reconstruir una serie de trayectorias históricas, sociales, políticas y subjetivas. Muchas de ellas atraviesan, por así decirlo, el Club, pero no se restringen a él; permiten su existencia, pero no lo explican. Es difícil sostener una mirada que explore tanto los procesos sociales como las singularidades, pero sólo desde esa tensión el Club es comprensible.

En este capítulo abordaré la organización desde dos ángulos: a través del discurso y la mirada de sus integrantes y los sujetos gay de la ciudad, y por medio de lo que actores opinan desde 'fuera'. Creo importante mantener esta perspectiva doble porque, habitualmente, los estudios en este campo privilegian la versión de los sujetos directamente involucrados, por ejemplo, en ciertas formas de erotismo o articulados en torno a una identidad específica. He intentado explorar la dinámica que se produce entre las voces de un grupo de sujetos gay y las de autoridades políticas y sociales, con una densa paleta de voces colectivas e individuales de diversos actores locales. Entiendo que la mirada que los integrantes del Club elaboran sobre sí mismos y su agrupación está delimitada por esas otras perspectivas que los valoran y evalúan, los comparan y juzgan, aunque no se restrinja a ellas y de muchas maneras las reformule y desplace.

Lo que analizo es, ante todo, una red intrincada de prácticas y discursos sociales. El proceso que intento reconstruir en este capítulo implica la conformación de un espacio social y simbólico para un colectivo que he analizado desde diversos ángulos en distintos capítulos, pero es central para entender las otras reflexiones y el resto de los análisis. Si bien el Club ha sido un objeto difuso, pues se ha disuelto y reconstituido en este tiempo, la brecha que desde su fundación abrió en los discursos sociales de la localidad obligó a muchos actores a posicionarse frente a ellos y produjo un habla sobre la homosexualidad muy compleja. La ruptura de un silencio o una indiferencia, el uso de lenguajes distintos a los peyorativos, la interpelación de diversas instituciones; además, la producción de una argumentación racional y afectiva, estética y moral en torno a la sexualidad, el deseo, el cuerpo, la política, la enfermedad, entre otros temas, implicó una transformación significativa de esos discursos, aunque fuera en forma de rechazo y condena. 
En un primer momento quise entender cómo el Club se había constituido en un sujeto político. Ese proceso permitía esclarecer algunas de las coordenadas socioculturales e históricas que lo posibilitaban y vincular la expansión global, mediática y política de la identidad gay, su producción cultural, estilos de vida y modos de organización, con los procesos locales de apropiación y resignificación de esos imaginarios y esas formas de vida. Hay evidencias históricas y sociológicas consistentes sobre la veracidad de dicho proceso, pero falta la antropológica (al menos para México) que ayude a entender cómo es leído en contextos locales; cómo determinadas comunidades ‘traducen' lo gay dentro de sus propias coordenadas identitarias, en el orden de género y sexual que practican y reproducen; y cómo esas apropiaciones, resignificaciones y traducciones, transforman y desplazan el orden que las precede en términos históricos y culturales. Pero también me interesaba estudiar cómo esta identidad se 'acomodaba' al orden sexual y de género, dado que ni lo gay será igual a su versión globalizada, occidental, blanca y educada, ni dicho orden sexual y de género subsistirá indemne a nuevas definiciones y otros horizontes de inteligibilidad y legitimidad identitaria y sexual.

De este modo, para conocer las coordenadas que permitieron la formación del Club, debí apuntar a procesos colectivos que excedían a sus integrantes y al grupo mismo. Si fuera correcto argumentar que el orden sexual y genérico es transformado por el surgimiento de la identidad gay, y de un colectivo que se identifica de ese modo, debía saber cuál es ese orden, qué características tiene o ha tenido, dónde empezó su transformación, si es que la hubiera. El desafío era mantener el foco en el objeto y las preguntas de estudio que había formulado, ampliándolo lo suficiente para que se hiciera comprensible y restringiéndolo lo necesario para producir una etnografía.

La pregunta de fondo de mi investigación y la que he tratado de seguir durante todos estos años de estudio es cómo se forma un sujeto en el campo de la sexualidad. Sólo ahora, luego de muchas reflexiones, logro articular una respuesta con cierto grado de coherencia, inteligibilidad y sustento. Lo hago para el contexto que estudié y con los materiales que ese campo arrojó, pero ha sido una exploración más amplia la que me ha permitido elaborar un análisis que se adentre en esa pregunta. Durante mucho tiempo, la interrogante y sus respuestas permanecieron desarticuladas de los procesos que consideraba centrales para formularlas. En el caso de esta investigación, el vínculo entre la conformación de un sujeto político y otro 'psíquico', entre procesos sociopolíticos locales, nacionales y globales, entre instituciones y 
discursos diversos en el campo de la sexualidad, pero también en el de la ciudadanía y los derechos humanos.

La trama de procesos, instituciones y discursos es muy densa, pero lo más difícil ha sido entender cómo ella se ha articulado, en sus diversos niveles de abstracción y generalidad, para producir, de una forma no estrictamente causal ni lineal, una organización política y social de sujetos homosexuales y ciertos procesos de subjetivación que han modificado en los últimos 30 años tanto sus identidades, el vínculo con los colectivos y comunidades más inmediatos, así como la relación que mantienen consigo mismos.

\section{Del silencio a las hormonas}

Durante una conversación telefónica con Alan le comenté que me gustaría preguntarles a los integrantes del Club cuándo comenzaron a denominarse o identificarse a sí mismos como gays. Él me contestó de inmediato: “antes no éramos gay, éramos putos”. Mi intuición me indicaba que entre ellos podría encontrar un momento de emergencia de esa identidad o forma de identificación. Entre ambas denominaciones -lo puto y lo gay- se jugaría, a nuestro entender, un proceso de politización de las identidades, del deseo y de un orden sexual, y la constitución de un sujeto político por parte de los integrantes del Club.

Juanito es uno de los miembros más longevos del Club. Llegó en 1965 a Tenosique para trabajar en el ingenio azucarero. Se quedó, me dice, porque le gustó el trato con los muchachos. Nació en Mérida, en el seno de una familia católica muy estricta, que no aceptaría a un homosexual entre los suyos. Recuerda que su padre casi no tenía educación. En la ciudad de México, durante los años cincuenta, conoció el 'ambiente'. Tenosique era una ciudad pequeña cuando llegó, me cuenta. Apenas existían las colonias del centro; toda la gente se conocía y no se podía hacer escándalo. Recuerda que los 'putos' se contaban con los dedos de la mano, que todo el mundo sabía quiénes eran, pero nunca se exhibían abiertamente. El más osado usaba un copete en el pelo. Los otros, vestían normal.

No se vieron 'hombres vestidos de mujer', relata Juanito, sino hasta los años noventa. Eso no habría sido posible cuando él arribó. La gente era conservadora y las costumbres se respetaban. Él trabajó un año en el ingenio azucarero y luego instaló la primera peluquería de la

\footnotetext{
1 Ambiente es la denominación de los espacios de sociabilidad homosexual en México antes de que se utilizara la palabra gay.
} 
ciudad que fue atendida por un hombre. El local, ubicado sobre la calle principal de la ciudad, a unos metros de la iglesia, lleva ahí cuarenta años. Fue la peluquería más importante. En ella se atendían las señoras de 'sociedad' más conocidas. El estilista recuerda que era tan extraño ver a un hombre dedicado a esto, que la gente se apostaba en las puertas del local a observar su trabajo. Hoy, desde fuera, casi no se distingue el tipo de local que fue, aunque ocupe toda una esquina.

Juanito está enfermo y ve con sospecha el ambiente gay de la ciudad. Dice que él no va a fiestas ni le gusta traer hombres a su casa. Siente que el Club, en muchos sentidos, distorsionó la vida de los gay en Tenosique, porque les dio demasiada visibilidad; ahora hacen escándalo, se visten de mujer, van a las cantinas. Antes, recuerda, sólo se juntaban para participar en el carnaval, pero no como grupo, sólo como individuos, para divertirse.

Cuando estuve en el carnaval de 2008, recuerdo que Juanito llegó vestido de pochovera ${ }^{2}$, se subió al carro del Club y se sentó en una silla. Así hizo todo el recorrido, saludando a la gente. Sólo él iba arriba del carro, mientras el resto de los participantes viajaba atrás como comparsa. En 2010 repitió su participación.

“Antes sólo éramos putos", me dijo Alan cuando le hice la pregunta por teléfono. Conoció el mundo gay cuando se fue de la ciudad para seguir sus estudios de preparatoria. Estuvo en Villahermosa, luego en el Distrito Federal, después en Mérida, donde vivió muchos años. Recuerda que desde pequeño sintió atracción hacia otros hombres, que iba con algunos amigos o los trabajadores de la tortillería de su padre a un lugar cerrado que quedaba detrás de su casa para tener sexo. Desde niño sus padres sabían de sus gustos, me cuenta, y fue una de las razones para que lo mandaran a estudiar fuera de la ciudad. Alan regresó a Tenosique cuando tenía 36 años y fundó el Club. Han pasado muchos años desde sus aventuras de adolescente, ha visto muchas cosas y vivido otras tantas. Cuando volvió a la ciudad ya se identificaba a sí mismo como gay.

Ese 'antes' es menos tajante que una simple distribución temporal de los hechos, pero es verídico. De eso habla Alan cuando lo enuncia. Es un 'antes' que implica temporalidades diversas: el tiempo lento y pesado del orden simbólico, central para la organización de la sexualidad y el género en esta comunidad; el tiempo rápido y crispado de la política o el tiempo cansino de la vida cotidiana; el tiempo de los afectos y de la memoria; el tiempo de un coito o

\footnotetext{
${ }^{2}$ Es uno de los personajes que participa en una danza tradicional de la ciudad llamada del Pochó (Rubio, 2008).
} 
el de un insulto o una reflexión sobre sí mismo. En todas esas temporalidades, el 'antes' tiene efectos diversos. Pero el 'antes’ que Alan delinea tiene un referente muy claro: el Club Gay Amazonas. Cuando dice que 'antes los putos...' se refiere al periodo anterior a la creación del Club. ¿Qué hizo el Club para Alan lo considera como una cesura en la historia de la ciudad y de los gay? En primera instancia, el hecho mismo de existir y tener un nombre fue toda una novedad. Lo crearon en 1994, luego de algunos intentos de organización más bien festiva, bajo el mote de Reinas de la Noche. Era el punto de reunión de hombres gay que deseaban organizar fiestas y shows travestis. El Club tenía, también, fines festivos y los sigue teniendo en abundancia, pero no se limitaba a eso. También propiciaba la visibilidad pública de los gay de la ciudad como colectivo, se preocupaba de la expansión de la epidemia del sida en la ciudad, ayudaba a las personas que vivían con VIH, buscaba dialogar con las autoridades sobre temas que les interesaban a sus integrantes.

Samuel cuenta que desde niño sintió atracción por otros hombres, que le gustaba jugar con mujeres y era afeminado. Nació a fines de los años ochenta, cuando ya existía un movimiento político homosexual, arreciaba la epidemia del sida, y comenzaban a gestarse profundos cambios políticos y culturales en el país. Sus primeras experiencias sexuales con hombres las tuvo en la preparatoria. Cuando era alumno ya existía el Club Gay y ahora es uno de sus integrantes. La familia de su padre no le habla desde que sabe que es 'puto'. A veces lo insultan en la calle por su modo de caminar y de hablar, pero hace caso omiso o responde abiertamente a los desafíos. Sostiene que nada cambiará su deseo, ni la atracción que siente por los hombres, ni sus modos, tampoco sus gestos. El rechazo se dirige a lo que está consumado y es inmodificable. Él dice que lo sabe desde su infancia, que así nació y así seguirá siendo. Su madre lo aceptó luego de una discusión en la que se lo dijo abiertamente: "acaso no sabes, no te has dado cuenta de que soy puto". Su hermano, dos años mayor, no le habla y le dice que es una vergüenza para su familia. Sus hermanas lo aceptan. Él mismo dice que ha aprendido poco a poco a aceptarse, a sentirse mejor y menos agraviado.

A Juanito y Samuel los separan casi 50 años. Medio siglo de cambios profundos. Ambos son homosexuales, para ambos la homosexualidad ha sido conflictiva, ha supuesto silencios, evitaciones y rechazos diversos. En ese medio siglo emergió en México la identidad gay y comunidades organizadas en torno a ella. Surgió un movimiento político, se comenzó a hablar de estos temas en los medios de comunicación, se difundieron los imaginarios sexológicos y terapéuticos, se expandió la educación y la televisión. Tenosique, durante ese período, continuó 
siendo una ciudad lejana, a la orilla de un río y de una frontera por delimitar. En ese lapso, Juanito comenzó a nombrarse gay, ya de adulto, cuando la palabra llegó hasta sus oídos, cobró sentido y pudo utilizarla. Samuel ya la tenía a su disposición para denominar su gusto y su afeminamiento, para construir un lugar seguro frente a los insultos y los rechazos. De cierta manera, una identidad siempre es un corte en la incertidumbre, una forma de poner coto a oscilaciones y ambigüedades, un registro certero para la angustia o el desconcierto. Juanito se queja porque antes todo era más discreto, sobrentendido y silencioso. Nunca haría escándalo en la calle, ni se vestiría de mujer, pero por eso mismo los hombres se le acercaban, porque el sexo empezaba en el silencio y en la prudencia. Ahora, dice, todo se ve y todo se grita, los 'putos' andan vestidos de mujer, van a las cantinas; ya se perdió el recato, que era una forma de ocultamiento así como una garantía para los vínculos eróticos.

A Juanito su padre lo educó de manera estricta, para que no se desviara. Él tomó su camino y migró. Sólo en otra ciudad pudo vivir como quería y sentir lo que deseaba sentir. A Samuel, muchos años después, todavía quisieron 'curarlo' y lo llevaron a Mérida con un médico que le daba hormonas masculinas, como si el deseo, la identidad, el cuerpo y el género se pudieran 'hormonizar', según los valores y las normas de una sociedad que se transforma lenta, pero profundamente, aunque no quiera enterarse de sus propios cambios. Hormonas para que Samuel fuera quien debía ser: un hombre hecho y derecho, de caminar pesado, de formas rudas, de modos imperativos. Hormonas para que dejara atrás las cadencias, las oscilaciones, los quiebres; esa vOz fina y con inflexiones agudas; esos modos femeninos, suspensivos y risibles. Hormonas para que su familia recuperara el honor y se disipara la vergüenza de tener un joto entre sus integrantes, una loca. Vergüenza tan profunda que impide cualquier trato entre él y su hermano y lo obliga al ostracismo ante la familia de su padre ya muerto. Las hormonas, como una forma de migración, también, pero en el mismo cuerpo, y a través de él, para restituir la norma y terminar con cualquier desviación y desfase y ponerlo todo en su lugar: la hombría en los pasos, en la voz y en los gestos; en todas las formas de presentación de una identidad y un devenir adecuado.

Si no fueron las hormonas, entonces los psicólogos, que harían lo suyo mediante las terapias: restituir una masculinidad dañada, devolver al muchacho a las trayectorias de vida esperadas y normales. Eso hizo la familia de Ismael, lo llevó al psicólogo cuando lo suyo se comenzó a notar demasiado. Tanto juego con las niñas, esas formas de aproximarse a sus compañeros, el gusto por la ropa extravagante y apretada, una voz aguda. Un padre macho, me 
dice Ismael, quiere un hijo macho, que se case, tenga hijos y se comporte como hombre. Un padre macho no quiere un hijo 'puto', por supuesto, que lo denigre y avergüence. Un padre macho, pasados estos cincuenta años a los que nos hemos referido, recurre a los golpes y los insultos, como se hacía antes, pero también a los métodos modernos de 'curación' y de enderezamiento de los críos fallidos: hormonas, terapias. Se empieza con el cuerpo y se termina en la 'mente'. Se golpea sólo para constatar que estas desviaciones son inmunes a los golpes; se insulta para saber que no hay ofensa que pueda rectificar un deseo; luego se inyectan hormonas para constatar que lo macho no se puede inocular. Por último, se terapeutiza para concluir que hay algo resistente a cualquier convencimiento, a todo logos; algo sin solución, en último término.

Para Juanito, el escándalo está en las ropas llamativas, en los gritos, en los gestos. Esa exhibición indecorosa de los gustos, esa escenificación inapropiada del cuerpo que realizan algunos gay en la ciudad. Maquillados, vestidos, enfáticos en sus amaneramientos. Ese es el escándalo. Así como para las familias de Samuel e Ismael lo son esas actitudes impropias de sus hijos, esa gestualidad suave, tímida y traviesa que confunde, que causa risa y ofende. El escándalo siempre está en quien se desvía, en el que no asume los mandatos de manera consistente, en el que desvirtúa su destino y descarrila su vida.

Sería difícil saber qué ha cambiado y qué ha permanecido durante ese medio siglo en Tenosique. Sabemos que muchas cosas en el ámbito de la sexualidad se transformaron, pero, al mismo tiempo, constatamos la persistencia de ciertas representaciones y prácticas en ese campo y en las relaciones de género. Juanito se refugió en la prudencia, afirma que nunca tuvo problemas con nadie, que siempre fue respetuoso y supo darse su lugar. Samuel no se mete con nadie, pero de todos modos lo insultan; no entiende el rechazo de su hermano ni el de la familia de su padre, pero dado que "ellos no lo mantienen", pueden decir lo que quieran, él seguirá siendo el mismo. "Antes los putos, comenta Alan, eran considerados de lo peor: borrachos, promiscuos, flojos, ladrones”, sólo útiles para el sexo y la diversión, pero incapaces de cualquier moralidad, incompetentes para construir vidas provechosas. Pareciera que sucedió algo que permite distinguir ese 'antes', aunque sea de manera relativa y precaria. 'Antes' que es un modo de narrar una historia, acontecimientos que supusieron un cambio, transformaciones paulatinas, pero sistemáticas, en la vida de estos sujetos. Juanito, en alguna medida, vivió en un presente continuo; sus sucesores, en cambio, experimentaron tiempos disjuntos que les dieron 
una biografía sinuosa. Para Juanito, la diferencia fue el horizonte que nunca pudo modificar; para los otros informantes, constituyó una herramienta para producirse a sí mismos.

\section{Los límites: orden moral y gubernamentalidad}

Nadie está solo y nada es sólido:

el cambio se resuelve en fijezas que son acuerdos momentáneos

Octavio Paz, El mono gramático, 1998: 16

En este contexto surge el 'antes' del que habla Alan: que todo cambie para que siga igual. Pero sólo en parte. Muchas de las transformaciones que describiremos superan la voluntad de permanencia o de cambio de cualquier sujeto o colectividad. Luego analizaremos los procesos de globalización de las identidades sexuales y los imaginarios relacionados con ellas: porque suscitan dinámicas de transformación que invalidan muchos intentos de control o de reversión. Las mutaciones acaecidas en México en el plano político y cultural han sido fundamentales. La instalación paulatina y relativa, pero consistente, del discurso de los derechos humanos; la formación de organizaciones civiles y no gubernamentales dedicadas a temas de sexualidad, derechos y salud; la implementación de políticas públicas en ese terreno; así como los cambios que gatilló la epidemia del sida en las instituciones de salud.

Pero estos horizontes discursivos se entrelazarán de forma intrincada con un orden moral, que ya avizoramos. Es difícil entender la forma en que se articula un discurso público sobre el Club y sus integrantes, y sobre los homosexuales en general, sin atisbar cuáles son los valores que están en juego y cómo se vinculan con ciertas prácticas sociales. Ese orden aparecerá de modo sistemático en los discursos de los políticos y otros líderes locales: si bien conocen a los gays del Club, y dicen que los aprecian y respetan, los relacionan, sistemáticamente, con la prostitución, la enfermedad y la anormalidad. Las referencias a ellos están cargadas de un orden moral que produce una localización particular: son cercanos porque acá nacieron; son nuestros amigos, pero son ajenos porque su deseo es extraño.

Un diputado local lo expresa de manera clara. Dice sentir a los integrantes del Club como hermanos y considera a la comunidad gay como un grupo vulnerable. Una invocación a la igualdad permite avalar el vínculo que tiene con ellos: "nuestra relación siempre ha sido para todos igual y yo creo que es lo que falta, tratarnos de igual a igual como hermanos y como 
seres humanos que somos, eso es lo que ha faltado en nuestro país, no tiene por qué haber distinción de ninguna especie." La cercanía personal y la humanidad compartida serán dos argumentos que escucharemos repetidamente en bocas de ex alcaldes, dirigentes políticos, médicos, líderes sociales y otros actores. La esposa de un ex alcalde, directora del DIF (Desarrollo Integral para la Familia) local durante la administración de su cónyuge, indica que decidieron apoyar a los integrantes del Club "porque creemos que son gente, son seres humanos y no nos importa la preferencia sexual, son seres humanos y hay que ayudarlos, son gente muy trabajadora, muy capaz y muy metida a lo que están haciendo, muy comprometidos." La humanidad y la subjetividad ('son gente', decide la funcionaria) de los homosexuales dependen de una creencia y la aceptación salta lo que esta informante llama la preferencia sexual' y cae en ese terreno de la humanidad compartida, leída como una creencia. Las virtudes que otros informantes mencionarán ya resuenan en esta conversación: los homosexuales son trabajadores, capaces, comprometidos. Estas cualidades que permitirán, en última instancia, dar el salto sobre el deseo ('la preferencia sexual'), son también los límites de lo que se puede aceptar o rechazar, integrar o expulsar. Siempre y cuando los homosexuales cumplan con esas virtudes y las encarnen, entonces se podrá creer que son humanos y se les considerará personas. Los problemas empezarán cuando no las cumplan o no lo hagan como se esperaba.

Por otra parte, parece que el deseo, sobre el que hay que saltar, es justamente lo que se debe eludir para arribar a ese espacio compartido. Esta será tal vez la característica central de los discursos sociales sobre la homosexualidad y los homosexuales en la ciudad: lo que se resta para que se puedan considerar sujetos, ciudadanos o personas es justamente el deseo. Se esboza una lógica del excremento, que en este caso se vinculará con los usos del cuerpo y de los órganos, con la presencia fantasmal de los excrementos corporales en las prácticas homosexuales masculinas, con la función erótica del ano. Sólo el lenguaje cotidiano menos controlado dará espacio a estas significaciones, de modo indirecto muchas veces. Es decir, este nudo colectivo e inconsciente, que será la verdadera roca de los procesos de significación y el límite más profundo de las prácticas sociales, será perceptible sólo mediante el insulto, el doble sentido, la broma o las palabras más soeces (excrementicias, en muchos sentidos). Los excrementos que merodean cualquier percepción de los homosexuales y apenas se pueden nombrar, articularán, en cierta forma, esta lógica excrementicia y conformarán un lenguaje, una capa de palabras apenas formuladas, pero muy poderosas, que se colarán en las pláticas 
informales, en los chistes, en los rumores. Así escucharemos decir, por ejemplo, de un homosexual que "le gusta que le empujen los frijoles": la comida que sale se trenzará con el deseo que entra. El ano defecador se conectará y traslapará con el ano erótico. Los orificios que expulsan también recibirán. La mierda resonará en el deseo. Incluso se hará una mención explícita al encuentro desafortunado, quizás, entre falo y ano, entre pene y mierda: alguien dirá, por ejemplo, que un "puto le cagó la verga"; es decir, que en las relaciones anales penetrativas el falo fue cubierto no sólo de deseo o de erotismo, también de excremento. Esa lógica, que empieza en alguna medida en el cuerpo mismo, en esta intercoporalidad deseante que exploramos, debe eludir el excremento que cubre los órganos para saltar sobre el deseo que los acopla. Un pene cubierto de excremento es un falo 'cagado'.

\section{Bares fantasmales}

La política habría tenido un papel de vanguardia en este campo, porque debilitó y traspasó las resistencias locales para constituir a los homosexuales en interlocutores válidos. Un ex alcalde del PRI, que los integrantes del Club recordaban como cercano y disponible, señala:

Bueno, de inicio, como todo, siempre somos criticados, porque siempre es un poco delicado tratar con homosexuales, porque aquí la gente somos también cabrones, disculpa la palabra, pero somos cabrones y entonces siempre había como un rechazo por parte de la sociedad, pero nosotros venimos de una familia de comerciantes y habíamos tenido muchos tipos de relaciones con ese tipo de gentes en el aspecto pues de trabajo y entonces es gente muy creativa, son gentes muy trabajadoras y que la verdad a nosotros nos apoyaron mucho, y cuando nosotros los invitamos a ellos a participar, participan directamente en la campaña que también eso fue muy curioso porque era muy raro que los homosexuales participaran en una campaña política, que era así como que... !!huy!!, que invitaron a los homosexuales como si ya andaban pensando en andar haciendo lo mismo, pero no era eso sino era una buena relación que tenemos con ellos, de conocimiento más que nada.

El alcalde, con una historia de trato comercial con homosexuales, los invita a participar en su campaña electoral. Esto sucede en los años noventa. Pese a las resistencias que esa participación genera, el político reconoce sus cualidades (creativos, trabajadores) y asegura que, luego, muchos otros siguieron su camino. Esa dinámica entre cercanía y extrañeza, conocimiento y distancia, se reformula de diversas maneras. Al parecer, el vínculo tiene un 
carácter potencialmente contagioso - "andaban pensando en andar haciendo lo mismo"-, por eso hay que remarcar las diferencias y las distancias. ¿Qué se podría contagiar: el deseo, la identidad, el desprestigio? Ese carácter invasivo de la homosexualidad, especialmente la masculina, será una constante en muchas conversaciones. Se la entenderá como algo innato o adquirido, pero nunca se resolverá del todo su capacidad viral, por así llamarla. Estar cerca de los homosexuales implica algún riesgo; los chismes y los rumores son las formas expeditas de esas contaminaciones simbólicas. Si bien parece que un orden moral diferencia de manera tajante un tipo de sujeto de otro, en las prácticas cotidianas el carácter fluido y también difuso del deseo supone riesgos que se extienden más allá de cualquier identidad.

El alcalde elabora una temporalidad social con respecto a este colectivo. Cuando lo entrevisté, en 2007, consideraba que sólo durante los últimos seis o nueve años "habían comenzado a liberarse un poco". Es decir, aproximadamente desde fines de los años 90, y luego de un lustro de existencia del Club. Como presidente municipal, él participó de esa liberación homosexual local: les otorga permiso para organizar eventos públicos y habilita vigilancia policial. Pero rápidamente surgen los límites morales y políticos de los que hemos hablado y, en ese sentido, relata que:

cuando subió la administración pública la bronca que teníamos nosotros con la sociedad es que se quejaba mucho la sociedad de los homosexuales, o sea, de los travestis que andaban en la calle, porque aquí hay una sola tolerancia, aquí nada más a la vuelta los veía pasar, entonces les provocaba mucho escozor a la gente, mucho coraje porque también habían acciones que no eran adecuadas

Ese escozor y coraje colectivos permiten tomar algunas medidas gubernamentales, que se articulan claramente sobre el rechazo social y la tensión de los límites morales y valóricos dominantes: se establece un bar donde los homosexuales podían ir a expresarse, así como quienes quisieran convivir con ellos. Nunca tuve noticia de tal lugar, pero creo se refería a La Caña Brava, que tenía un table dance en la planta baja y un caguamero ${ }^{3}$ en la segunda. Jamás escuché a alguien considerarlo un bar gay, aunque llegaban, en algún momento, muchos homosexuales, particularmente al caguamero. Pero había todo tipo de gente, desde soldados hasta cañeros y pescadores. Creo que el bar gay del que habla el alcalde sólo existió en su

\footnotetext{
${ }^{3}$ Caguama es un término coloquial para referirse a la cerveza, especialmente la que se vende en envases de más de un litro. Caguamero es un lugar donde se vende y se bebe cerveza.
} 
discurso administrativo. En ese tiempo, como ahora, los otros bares y cantinas también recibían homosexuales, travestis y trans. El alcalde recuerda que,

entonces eso nos permitió a nosotros en la administración pública platicar con gente que trabajan, que tienen bares, por eso se estableció un lugar que no sé si todavía lo conservan, que está allá arriba en la parte donde estaba la Flor de la Caña, donde era un bar gay, y cabrón que quería ir con los gay pues ahí estaba y no había ningún problema, ni se les perseguía ni nada.

De todos modos, es revelador el esfuerzo gubernamental por delimitar un área para la libertad personal y social de este colectivo. Luego veremos cómo un candidato a la alcaldía les preguntará a los integrantes del Club si consideran correcto implantar una zona de tolerancia, tal como lo exigían algunas “dueñas de casas y madres de familia”, según comentó en esa ocasión. La intención era similar: darle un lugar al sexo y cercar las desviaciones, ya sea la homosexualidad o el trabajo sexual. Una vez que exista una zona o un bar, el resto de la ciudad se limpiará de esas presencias que producen escozor o coraje. El citado alcalde recuerda que una vez establecido ese bar gay fantasmal, ya no se permitiría que los homosexuales anduvieran "chingando" en la calle "vestidos de mujer". Eso, considera el informante, "era mucho, era demasiada libertad”. ¿Cuál es la medida de la libertad para estos sujetos y colectivos?, ¿cómo se puede establecer que un grupo goza de demasiada libertad?, ¿cuál es el patrón que determina la medida y sus desbordes consecuentes?

llegamos a unos acuerdos con ellos también, que no se iba a permitir eso de andar chingando en la calle como estar vestidos de mujer, porque esto ya era mucho, o sea, ya era demasiada libertad que tenían, entonces, ya se empezó a tener los lugares adecuados para que ellos pudieran, pero la participación que tienen en los carnavales, entonces...

Si los homosexuales tienen sus espacios, aunque sólo sea un bar, y un tiempo, aunque sólo sea la noche, entonces se encuentra un acomodo administrativo entre las demandas de la sociedad, signifique lo que signifique, y estos grupos vulnerables, como los denominó el entonces diputado local. Desde el primer momento tenemos una escena afectiva: grupos y sujetos que desean tener una presencia pública y un espacio social a su modo, por un lado; y esa entelequia llamada sociedad que invoca una autoridad y, según su testimonio, siente molestia, coraje o escozor cuando el paisaje corporal y moral habitual es interrumpido por esas figuras marginales e inquietantes. 


\section{Zonas de tolerancia}

En agosto de 2009 el diputado era candidato a alcalde por el PRD (Partido de la Revolución Democrática); se enfrentaba a un médico priista muy conocido en la ciudad. Había cierta esperanza de un cambio en las formas de gobernar, luego de décadas de mandato priista, marcado en muchos sentidos por la corrupción y la ineficacia. En una de sus actividades de campaña hizo una especie de cena para los integrantes del Club, a la que asistieron aproximadamente 25 personas. Entre emparedados y refrescos el candidato les recordó que siempre ha tenido la puerta abierta para los gay, que ha ayudado al Club y a los enfermos de sida de la ciudad y que deseaba integrarlos a su gestión en el Ayuntamiento, pues realizaban una labor fundamental en la prevención del sida y de otras enfermedades de transmisión sexual. Destacó el lugar prominente que tienen muchos gay en la ciudad, por todos conocidos, la creatividad que los caracteriza y su participación siempre central en las fiestas de la ciudad, incluido el carnaval.

Luego de su intervención se abrió un diálogo con los asistentes. Uno de ellos le contó que cuando iban vestidos de mujer a las cantinas o con ropas 'afeminadas' la policía les pedía la autorización para ejercer trabajo sexual y si no la tenían los llevaban detenidos, aunque ellos no estuvieran ejerciendo la prostitución y nunca lo hicieran. Lo que deseaban era divertirse 'hechizando' a los hombres con sus ropas, maquillajes y accesorios. El candidato le respondió que había recibido muchos reclamos, especialmente de amas de casa y madres de familia, en torno a las cantinas de la ciudad donde se ejerce el trabajo sexual. Las mujeres se quejaban que sus maridos o parejas iban a esos lugares, habiendo cobrado su semana o quincena, y gastaban parte importante de su dinero en alcohol y mujeres. Luego, ellas dicen, no tienen para darle de comer a sus hijos.

El candidato le preguntó a la asamblea presente qué pensaba del proyecto de crear una zona de tolerancia en la ciudad, en la que se controlara el trabajo sexual y la venta de alcohol. Mi experiencia etnográfica me indicaba que los lugares donde se realiza trabajo sexual eran muchos, desde las cantinas más conocidas de la ciudad, pasando por los table dance, hasta una larga lista de casas de citas no legalizadas. Para beber alcohol no existe ninguna limitación, ni de lugares, ni de provisión, ni de horarios. Si no se consigue alcohol en una cantina o en uno de los múltiples dispendios de cerveza que hay en la ciudad, se puede comprar en alguno de los clandestinos que atienden todo del día. La tolerancia, en este aspecto, está distribuida de 
manera generosa por toda la ciudad. Su intervención fue, en primer lugar, una elusión, porque no respondió al reclamo que se le había planteado en un tema que es de competencia directa de los ayuntamientos en todo el país que, a través de los bandos de buen gobierno, regulan el trabajo sexual y las ofensas a la moral. Los invitados consideraron que una zona de tolerancia no funcionaría, en un contexto de proliferación del trabajo sexual y la venta de alcohol.

Los integrantes del Club le reclamaron al candidato las restricciones que algunos gay experimentaban en el uso de sus cuerpos y en sus estéticas por la asociación con el trabajo sexual que realizaba la Policía Municipal cuando los veía. Putos y putas son dos colectivos contiguos en muchos aspectos. Este candidato, en la parte más importante de su discurso, remite a los gay al sexo y su cuerpo al trabajo sexual, el placer y las cantinas. No les habló de sus propuestas en educación, salud o infraestructura; sólo les platicó de sexo, efectuando una reducción de sus campos de visibilidad y legitimidad. Replica, de ese modo, una operación de larga data: reducir a los homosexuales a su sexo. Esa reducción es una forma de transformarlos sólo en cuerpos parlantes, en términos de Rancière (1996), o cuerpos sexuados. La voz se reduce al sexo y como sujetos de habla sólo se pueden referir a aquello que les sería propio y característico: su sexualidad y su deseo. Al responder de esta forma, el candidato impone un silencio. No contesta con sus facultades potenciales (el cambio de los bandos municipales que ordenan ciertas costumbres y usos del cuerpo, por ejemplo), sino con un proyecto de acorralamiento del sexo, en respuesta a las demandas crecientes de las madres de familia. Al responderles de este modo, el candidato supone que los gay tienen algún vínculo con esos hombres descarriados. Y polariza la escena: madres demandantes y putos/putas gozantes y vividores. La familia versus el sexo, los hijos versus el placer, el hogar versus la cantina. Topologías de un orden moral que empieza en el hogar, al lado de la madre y sus retoños y se encabalga en esos recorridos descarriados y disipados que siguen los hombres. Putos y putas como sirenas que llaman a la 'perdición' de los jefes de familia, machos en celos que no saben gastar el dinero si no en alcohol y placeres.

Si los gay tienen una voz es la del gemido del sexo. Voz del placer, pero sin articulación, sin ley, sin espacio público, previa a cualquier posibilidad política. Los emparedados se acabaron y quedaban pocos refrescos. La política abre el apetito y da sed. El candidato se despide llamando a votar por él que ha tenido un compromiso con los gay de la ciudad y con los enfermos de sida, que se parecen pero no son lo mismo. Alan le reclama una sede para el Club, pero no recibe respuesta. Voz en el desierto. Habrá, quizás, zona de tolerancia, 
prostíbulos ordenados y vigilados, putas censadas y examinadas, madres de familia tranquilas. La tolerancia necesitará una zona en la que pueda expresarse, mientras el resto de la ciudad le pertenece a las madres y sus hijos, a las esposas benevolentes y sus maridos controlados, al orden familiar que ampara las angustias maternas y que se enfrenta con la disipación de esos sujetos nocturnos y acechantes que no sólo desean a los hombres sino que también se quedan con su dinero. Tenemos, así, un primer esbozo de lo que luego llamaremos una economía libidinal.

\section{Ambivalencia y clasificación}

Denise Riley escribe: "No estoy adentro de nada. Tampoco estoy afuera de nada. Pero la distinción público/privado, cuyos efectos desembocan en realidades tan sólidas, tiende por su conceptualización topográfica a subrayar la metaforicidad afectiva de dentro y afuera" (Riley, 2006: 10). El espacio se fragmenta transido de afectos que producen y sostienen esas realidades tan sólidas, de las que habla la autora. Pero como no es claro que alguna vez ese espacio social fuera homogéneo, como suponen esas imágenes de un antes unívoco y un después oscilante, tampoco sabemos qué sería lo público y lo privado en estos deslindes: ¿ivestirse de mujer es privado y andar por la calle es público?, ¿no son los afectos mismos una forma de cercar los cuerpos y sus posibilidades, los deseos y las apariencias?

Nancy y Lacoue-Labarthe escriben que el afecto sólo es eso: “(...) la afectación de un dentro por un afuera, de allí la división de ambos y su penetración recíproca” (citados en Riley, 2006: 8n12). Pero parece que, en este caso, la afectación viene primero desde ese dentro corporal, identitario y deseante y toca un fuera social, moral y gubernamental. Es ese dentro el que producirá escozor en el afuera. Luego veremos que los afectos se esconden o se enmascaran y su develación supone que aquellos descubiertos/desenmascarados cesen de perturbar el afuera social con su dentro subjetivo. Pero al crear esos adentros administrativos (bares, zonas de tolerancia), los gobiernos buscaban salvar ese afuera social en el que tanto insisten. Una vez delimitado ese dentro, quienes quepan en él serán identificables (han salido de su escondite y se han quitado las máscaras), pero el afuera que se intenta proteger ya está agujereado por esas pertenencias ambiguas y esos lugares semi-privados.

"La ambivalencia es el afecto mismo", añaden los dos filósofos (ibíd.). Si traslapamos los argumentos, podremos ver que esa ambivalencia ha sido creada por la intervención 
gubernamental: en su afán por sacar del espacio público lo que supone privado, fragmenta ese espacio y desdibuja la distinción que intenta proteger. Lacoue-Labarthe y Nancy hablan de una "extirpación" productora de un sujeto. Al intentar sacar a esos homosexuales vestidos de mujeres de las calles, al extirparlos del espacio público y confinarlos en esos tugurios nocturnos y exclusivos, terminan produciendo un sujeto: en los fantasmales espacios de un bar gay inexistente o detrás de las máscaras de un carnaval, como luego veremos. "El afecto, o en otras palabras la ambivalencia, escribirá Riley, nos coloca en el corazón de la sociabilidad” (Riley, 2006: 10n16).

De este modo, la escena familiar que antes analizamos, trastornada por esas subjetividades ambiguas y esos cuerpos oscilantes, se articula con esta otra de mayor amplitud en la que la perturbación es generalizada y amerita la intervención gubernamental. Pero lo que ambas conservan es una intención rectificante y la voluntad de modificar el curso de los hechos: castigar y hormonizar, terapeutizar y controlar, separar y restringir, respectivamente.

En otro capítulo veremos un momento más dramático de estas intenciones gubernamentales, pero creo que es importante destacar que la voluntad de control y de cercamiento atraviesa las administraciones y se expresa de modos diversos, algunas veces de maneras laterales y opacas, otras de formas muy visibles. En torno a la homosexualidad, la apariencia de los cuerpos, las distinciones de un orden de género y moral, se condensan temores y rechazos colectivos muy profundos. Si bien los discursos democráticos, de derechos humanos y, más recientemente, los de la tolerancia y no discriminación, implican poderosos controles sobre la acción gubernamental, no logran disolver ese núcleo de miedo y aversión. Si se lograra capitalizar políticamente, entonces podría ser un motor de gubernamentalidad muy eficaz. Mientras estos colectivos, específicamente los homosexuales, estén cercados y su libertad y capacidad de acción individual y social tengan medidas sometidas a un orden social y moral que los desprecia y sospecha de su estatuto como ciudadanos dignos, entonces su lugar será incierto y frágil. Podrían, en algunas circunstancias, condensar temores y conflictos sociales para transformarse en chivos expiatorios, como diría Girard (2006), de la violencia colectiva. Serían los vectores de la constitución de otra topología del adentro y el afuera.

Esta voluntad clasificatoria se intercepta con otra identificatoria. Lo vimos ya: es importante saber quiénes son los homosexuales, y lo veremos nuevamente, porque es una forma de protección ante los peligros que implican o que traen (el sida, por ejemplo). La ruptura histórica que intentamos explorar supuso que muchos estuvieran "escondidos", como 
dice un integrante del Club Rotario de la ciudad. Veinticinco años atrás “era raro ver a un gay”, agrega. Pero ahora, muchos ya se han "quitado el tabú” y lo muestran abiertamente. Coincide con otros informantes en considerar que la homosexualidad se ha expandido, aunque no es claro si resulta de su nueva visibilidad o de cambios culturales propicios. Pero el lenguaje guarda un tono epidemiológico: la homosexualidad (¿qué de ella?) se expande como lo hacen las enfermedades, como lo hará el sida, específicamente.

Por lo mismo, ya hay una información, cuando tengo 65 años, a los 40 años, ver a un gay, era raro, todos estaban escondidos, he tenido la facilidad y la ventaja de tener muchos amigos dentro de los cuales hay gays, a los cuales trato de la misma forma, amigos muy fuertes y ellos me han hecho el favor de platicarme muchas cosas, entonces ellos mismos me han dado información de cómo se ha ido quitando el tabú de atender a un gay, entonces a la medida de que eso se ha ido expandiendo, la facilidad para que todos puedan vivir en la forma que mejor les guste. (Integrante del Club Rotario)

Este mismo informante considera que no es necesario que los homosexuales se muestren sólo durante el carnaval y lo dice de un modo que me parece relevante: "no es necesario que haya un carnaval para que un gay se tenga que mostrar disfrazado”. Este juego entre escondite y disfraz, entre verdad y simulación, aparecerá reiteradamente en muchos otros diálogos y conversaciones. El rotario opone este disfraz a una identidad que permanece a lo largo del tiempo, ese gay que sólo se puede mostrar disfrazado en una fiesta podría hacerlo constantemente: "se puede mostrar siempre gay durante todo el tiempo". A las rupturas que introduciría el disfraz, se opone esta persistencia identitaria, que supone certezas. Una temporalidad perenne en vez de un disfraz ocasional.

El gay surge como un personaje visible, consistente, que ha roto los tabúes, pero que también se ha apegado, de otro modo, a las normas (morales, corporales, sociales). En ese desocultamiento, pero también en el desnudamiento subjetivo y corporal, el gay emerge con un rostro identificable. Quienes no han hecho este tipo de operación generarán una intensa ansiedad colectiva. Aquellos a los que "no se les nota", por ejemplo, estarán rodeados de rumores, de incitaciones, de llamamientos e imprecaciones. Es como si el disfraz nunca terminara de quitarse completamente y algo subsistiera, en el rostro y en el cuerpo, que serviría de escondite. Quizás la demanda colectiva sea que mediante la identificación clara de quiénes son homosexuales, también se produzca una diferenciación tajante con respecto a quienes no lo son. 
Si bien el modelo gay, como lo veremos más adelante, supuso una reorganización de los parámetros corporales, identitarios y afectivos con los que se evaluaba a los sujetos, también introdujo confusión en las claridades reclamadas: si el gay puede ser completamente masculino, entonces no es posible identificar tajantemente a quiénes lo son y, en consecuencia, podría serlo cualquiera. El efecto es paradójico porque en ese escondite del que habló el rotario sólo había ciertos sujetos, en este espacio público hay muchos otros; si el disfraz comprometía a algunos, una vez que se lo quitan, esa rostridad pública dificulta las diferenciaciones.

La directora del DIF propone otra solución: salir de las apariencias para radicar en los genes el deseo. En ese lugar sin disfraces y sin escondites, la homosexualidad es definitiva. Si ellos “son así”, entonces no se les puede exigir que cambien y lo único que queda es aceptarlos, así "como les gusta", según dice la funcionaria. Los gays, en este sentido, quedarían ubicados por este gusto genéticamente desviado en ese vasto mundo de los defectuosos y los anormales: discapacitados, mujeres sin hombres, ancianos, etc. Retorna el argumento de la humanidad compartida como el horizonte último de la sociabilidad. Los genes fallidos no impedirían reconocer una humanidad común.

Bueno como en todas partes creo de que hay algunas personas que aún no lo ven bien y pues habemos otras personas que apoyamos al grupo gay pues, porque ellos así son y no podemos cambiar los genes que traen y así es cómo les gusta, pero es todo parte de nosotros, parte del pueblo que las personas que queremos apoyar deberíamos apoyarlos a todos, así como apoyamos a un anciano, a una persona con discapacidades, así como apoyamos a madres solteras, a madres maltratadas, por qué no apoyar a los gays pues es un ser humano como todos nosotros.

¿Por qué el deseo puede ubicarse tanto en los genes como en las máscaras?, ¿qué tipos de hermenéuticas sociales originan estas localizaciones?, ¿cómo se articulan las identidades cuando se ven compelidas hacia un sustrato biológico inmodificable o una mascarada transitoria? Al parecer, colectivamente es necesario proponer un origen suigeneris para estos deseos desviantes. Necesitan algo particular que permita, más allá de esa humanidad compartida, diferenciar a los sujetos, devolverlos a sus escondites genéticos, enmascararlos con sus propias singularidades.

Corrupciones degenerativas. El sida, el sexo, las poblaciones

Pero no fue sólo esa irrupción en el espacio público, que modificó las coordenadas identitarias, pero también eróticas, habituales de Tenosique, lo que incentivó la intervención 
gubernamental. El sida fue, sin duda, una de las razones más importantes. Sin embargo, adquirió un estatus ambiguo: era un peligro que parecía venir directamente de los cuerpos de los homosexuales, de sus mundos y sus comportamientos, a la vez que una ruta de politización, de visibilidad pública y de justificación social. Otro alcalde recuerda que:

dentro de las funciones que también nos corresponden a los políticos, es también tratar con la gente del pueblo en sus diferentes aspectos sociales y también como mandatario del municipio, como primer regidor, como presidente municipal, tuvimos también la oportunidad de conocer los programas y proyectos de salud y dentro de ellos estaban precisamente la de atender el sector gay que no podemos negarlo, en Tenosique y bueno, en muchos lugares en Tabasco y en México, se ha venido incrementando día a día, y sin estar en contra de ellos tampoco fomentándolo, pero sí de alguna forma interviniéndolo para regular enfermedades venéreas o transmisibles como puede ser el sida o puede ser otro tipo de enfermedades.

El lenguaje gubernamental es aún más claro en este informante. Acepta atender a un sector que parece "incrementarse" en la ciudad, el estado y el país; pero esa aceptación es la vía para que pueda ser intervenido y regulado. Nuevamente surge este lenguaje de medidas y cantidades, antes fue la libertad, ahora es la población; asimismo, se repite el dilema: controlar sin fomentar, contener sin esparcir. El asunto son las enfermedades que no sólo amenazan a dicho "sector" sino a la población en general y, especialmente, a los más jóvenes. El alcalde recuerda que por esos motivos apoyaron la labor del Club para la prevención del sida.

por esa razón tuvimos la atención emanada de una amistad primeramente o de una relación inclusive social, y luego viendo el objetivo social también que perseguía este grupo Amazonas, es como decidimos brindarle apoyos a través del DIF municipal, a través de actividades para darle a ellos estímulos, darle apoyos para que no se fomente esto pero tampoco podemos cerrar los ojos ante una realidad y era evitar más que nada contagios y problemas de carácter serio transmisibles a la juventud y bueno a toda la gente que tenga que ver con los gays, ese fue el objetivo.

Si el sida es el peligro, también es la ruta del reconocimiento y la participación de ese sector en las tareas del gobierno. Defender la juventud y a toda la gente "que tiene que ver con los gays" amerita considerarlos e incluirlos parcial y localizadamente en tareas de prevención y cuidado de la salud. Si bien se insiste en que no se desea fomentar la homosexualidad, tampoco se "puede cerrar los ojos" ante ella. Nuevamente, la visibilidad representa un problema para la acción del gobierno. Primero, mediante esa regulación fallida del uso del espacio público de los 
homosexuales que se vestían de mujer; luego, a través de esta apertura controlada que se interpone a una ceguera colectiva: ver sin fomentar. El objetivo central, que era "evitar contagios", obliga a mirar al otro, aunque se le desprecie; pero la mirada que se conforma es parcial y localizada, como el bar gay o la zona de tolerancia, en el sexo y en el peligro.

Si controlar tiene como antecedente la paradoja de reconocer, visibilizar implica dirigir la mirada sobre un aspecto del otro y no sobre su totalidad. En este sentido, si bien la identidad homosexual parece invasiva y sistemática y el deseo homosexual es potencialmente contagioso, su visibilidad social y gubernamental es, ante todo, metonímica: la parte remitirá a un todo que nunca se constituye plenamente. La parte del sexo, de la apariencia o la enfermedad. El gobierno trabaja con síntomas o problemas, con riesgos, pero no con deseos.

Esta tensión entre una enfermedad que parece afectar sólo a un grupo (los homosexuales) y la propaganda epidemiológica que insiste en que cualquiera puede enfermar, se resuelve de un modo que ya hemos atisbado. Si bien, como dice el miembro del Club Rotario, hoy no se puede culpar de contagio, como antes, "a los gay", sí se los puede apoyar para que eviten "que se propague el sida". La exigencia es semejante a otra que analizamos antes: si los gay pueden circular libremente y sin máscaras, si han salido de sus escondites, entonces no hay razón para que nadie se oculte. Su deseo tampoco se propagará, asunto que preocupa a todos estos informantes, porque estarán circunscritos. La operación que se les exige hacer con su deseo también se les pide con respecto al sida: conténgalo, eviten su propagación.

Primero, desde que salió la propaganda de sida donde solamente se culpaba a los gays del contagio, pensé que estaba en un error, que el sida se propagaba por relaciones sexuales por fuera sin importar el sexo que lo realizaba. Cuando se presenta Alan y me dice su programa y además conociéndolo a él en el entusiasmo que siempre ha puesto en todas las cosas que ha emprendido, no hay más, era cuestión de apoyarlo y por esa cuestión fue, la decisión, la disciplina que tiene Alan, el servicio que le ha dado a la comunidad y además convencido yo que hay que apoyar para que no se propague el sida. (Presidente Club Rotario)

El alcalde antes citado menciona que si bien los homosexuales locales han mostrado respeto hacia la comunidad, en otros lugares representan un serio problema: donde se dedican "al comercio carnal", donde actúan "burda o groseramente". Esa actitud de respecto del Club y sus integrantes evitará que se transformen en un "problema social para el gobierno".

Pues por lo menos y sí lo puedo afirmar, no ha sido tan degenerativa, no ha ido a lo burdo, no ha ido a lo vulgar. Sabemos que existen gays, bueno como en todos los 
sectores del mundo, como en toda la población mundial, pero en Tenosique no se ve el comercio carnal que se puede ver en otras ciudades, no se ve tampoco el acosamiento de los gays hacia los jóvenes, no se ve burdamente en las calles o de una forma grosera actuar a ellos. Ellos tienen su grupo, hacen sus reuniones, pero de una manera muy respetuosa. Yo así la veo y por eso hemos en ese momento pues aprobado y darles el apoyo adecuado para que dentro de sus actividades que realizan sin meterse a que salga un problema social al gobierno, ellos actúan y trabajan.

Cuando enuncia esto le pregunto cómo podrían generar un problema social, a lo que responde: Bueno, pues precisamente a través del ejercicio del comercio carnal, de la venta de su cuerpo, de prostituir inclusive a los mismos jóvenes, de caer, de inducir al vicio no solamente a la labor sexual sino a otro tipo de actividades que pudieran repercutir más fuerte todavía en nuestra sociedad. Yo a eso era a lo que me enfocaba para decir que han sido respetuosos y que no han inducido al sector juvenil, particularmente, a los niños, a los jóvenes a actuaciones quizás negativas en sus vidas como puede ser la drogadicción, no nada más el sexo, porque bueno con la facilidad del sexo se pueden lograr otras cosas, el vicio del alcohol, el vicio de la droga.

Sólo el respeto ha evitado que en Tenosique suceda lo que en otras partes, donde el sexo conduce a la drogadicción y la homosexualidad a la prostitución. Parece que los homosexuales tienen las llaves de un infierno colectivo de sexo, drogas y desorden, pero han evitado usarlas. Sólo la comparación permitirá conocer los méritos de los gays locales. El alcalde señala que:

afortunadamente yo puedo decirlo. No ha habido esa promiscuidad que pueda haber en otros lugares y no en la vida de Tenosique, y bueno, no negamos que hayan las relaciones sexuales entre jóvenes y gays pero tampoco podemos afirmar que haya habido depravaciones o hayan habido actos inmorales en las calles como puede ser la venta del cuerpo de ellos, como puede ser la venta de drogas, como puede ser como dicen los jóvenes un degenere o una degradación de la sociedad, a eso me refiero.

Nuevamente, se reconoce para negar de inmediato. Sí ha habido sexo entre "los jóvenes y los gays", pero no las "depravaciones o actos inmorales" que se ven en otros lugares. La degradación de la sociedad, a las puertas de Tenosique, ha sido contenida por la actitud respetuosa de sus potenciales responsables: los homosexuales locales. Ellos son, nuevamente, la amenaza y la contención, de forma simultánea. Traen el sida, pero también lo previenen; corrompen a los jóvenes, pero también los respetan y los cuidan. En otro momento veremos cómo esa línea atraviesa a los mismos homosexuales, y algunos serán catalogados como decentes y otros como indecorosos. A unos se los podrá detener en las cantinas si no portan 
una tarjeta sanitaria, aunque no ejerzan el trabajo sexual. A los otros, nadie los molestará. Pero, en última instancia, el peligro ha permanecido: pueden contagiar y corromper, pueden prostituirse o drogarse.

El Club, en este sentido, distingue a los homosexuales. Alan lo ha dicho: antes éramos de lo peor. Pero ese antes es provisional. No es un salto que diferencie un momento de otro, sino una oscilación que admite discursos diversos y prácticas sociales específicas. Es un antes que se encuentra imbricado con tiempos sociales múltiples y que tiene expresiones particulares en ciertos momentos. Por ejemplo, durante el carnaval el relajamiento de los controles es generalizado. Pero cuando los asuntos sean de salud o de educación, entonces los temores se intensificarán.

Para que los homosexuales tuvieran un lugar en este lenguaje administrativo, pero también en las prácticas gubernamentales, fueron situados en esa zona de tolerancia metafórica que son los grupos vulnerables. Un alcalde dice que así como la sociedad avanza, los "sentires” y los derechos también lo hacen. Eso produciría una apertura de las autoridades hacia "sectores de la población" que antes no eran considerados. En ese momento, cuando menciona esta apertura reciente, que coincide con el avance de las tecnologías, el alcalde relaciona los gays con la "prostitución femenina". Los "sectores gays" son atendidos tal como se hace con los "sectores femenil". A las prostitutas se les practican exámenes médicos para evitar "contaminaciones" entre sus clientes y se "estrecha el círculo" de vigilancia médica y control administrativo.

Yo creo que hemos coincidido quizás en estos últimos años en que la población, la sociedad misma, va avanzando en muchas cosas. Así como la tecnología avanza también, ya los derechos humanos avanzan, también los sentires humanos se llegan a ver de otra manera. La autoridad es un poco más abierta hacia los sectores de la población y en ese caso hacia los sectores de los gays, pero también tenemos la prostitución femenina que acá en Tenosique es un caso muy especial porque somos zona fronteriza con Guatemala y entonces vienen muchos muchachos también y se estrecha mucho el círculo para evitar también contaminaciones, problemas degenerativos, y se les da también una atención particularmente a ese sector femenil que es cuidada por el sector salud, que es atenderlas, hacerles revisiones médicas, etc., pero también cuidando de que no rebasen lo que son las autorizaciones de gobierno (Ex alcalde) 
Si lo que escribe Guattari fuera correcto, estaríamos ante una batalla en torno a una economía libidinal, que "no cesa de desplazar sus intensidades sobre un continuum cuya existencia recusa por adelantado los sistemas de opción cristalizados según una lógica de objetos totalizados, de personas responsabilizadas, de conjuntos cerrados" (Guattari, 2013: 135). El discurso del político recién citado trata, claramente, de constituir objetos cristalizados (el sexo, la prostitución, el sida), personas responsabilizadas (los homosexuales, las prostitutas) y conjuntos cerrados (esos sectores de los que habla el alcalde: gay y femenil). Pero como estamos ante una economía libidinal que "no cesa de desplazar sus intensidades" y que recusa los sistemas de opción solidificados, entonces las prácticas de control se intensificarán. Lo vimos con la creación del bar gay, o con el rechazo a que los hombres anden vestidos de mujeres.

Ahora con los controles sanitarios y las medidas policiales. El alcalde lo explica:

Ha habido un respeto tanto del gobierno hacia los sectores mencionados como de ellos hacia el gobierno y eso ha permitido que camináramos bien y yo comento con mi esposa, que nos tocó platicar lo que era la prostitución, la prostitución femenina y lo que era también la prostitución masculina, los gays y las prostitutas, tuvimos mucho cuidado de no ofender, no lastimar a ninguno de ellos, ni con palabras ni con hechos, entonces cuidarlos mucho esto y sin caer en el extralímite de libertinaje, sí conseguimos apoyos para que él pudiera organizarse, pudieran hacer labores sociales, en el caso de los gays, ahí está el caso del grupo Amazonas, en las mujeres lamentablemente no ha habido todavía organización, pero fundamentalmente uno como parte de la sociedad debe ser organizado y con respeto hacia el pueblo particularmente.

El respeto es la medida que se toma para que estos "sectores" no caigan en el libertinaje. Los homosexuales deben organizarse para evitar males mayores, aunque no lo consiguen en el caso de las prostitutas. El gobierno ha caminado bien, según sus palabras, en la dirección correcta que supone ese cuidado de las acciones para no lastimar y la firmeza en las medidas para contener. La economía libidinal descarriada que amenaza al "pueblo" debe ser rectificada, hay que cristalizar administrativamente sus intensidades. El horizonte siempre peligroso del libertinaje amenaza la convivencia social y la integridad colectiva. Las burocracias detectan esa intensificación de la libertad, a la que otro alcalde se refería también, y aplican contenciones que detengan su avance. Sobre esas intensidades los integrantes del Club y los sujetos homosexuales de la ciudad trabajarán ciertas prácticas de sí que luego analizaremos, pero será justamente esa intensificación de la libertad una de las fuerzas más importantes que susciten la 
conformación de un colectivo y la emergencia de la singularidad deseante. Las medidas que hemos mencionado indican que el Estado detectó el peligro y operó en consecuencia.

A este funcionario y político le pregunté, en su momento, por qué comparaba a las trabajadoras sexuales (según mi terminología) con los gays. Reproduzco el diálogo completo:

¿Qué similitud ve usted entre las mujeres trabajadoras sexuales y los gays?

Bueno pues el ejercicio de la venta de la carne, la venta del cuerpo y es ahí donde se ve una gran similitud y que a través de esa actividad pues ellos tiene mucho que ver con la sociedad para que esta sea... o bien, para que esta avance positiva o negativamente a través de enfermedades y a través de corrupciones degenerativas o excesos, yo veo mucha similitud.

Con degeneraciones degenerativas ¿a qué se refiere?

Pues perversión hacia los jóvenes, perversión hacia la misma sociedad por inducir o motivar más, que hubieran más prostitutas o más gays, o sea, estar fomentando más eso y aquí afortunadamente no lo ha habido, este grupo son de gente muy dedicadas y en el caso de los gays pues de manera organizada ya saben quiénes son ellos y cómo actúan y es cierto que muchos de ellos en sus reuniones se visten de mujeres, pero ya los han identificado quienes son aquí en Tenosique.

Es interesante, primero, que la coincidencia enunciada por el alcalde esté en la carne que se vende, es decir, en una economía libidinal aún más literal. Luego, ambos son portadores de enfermedades y corrupciones y el registro sanitario se transforma, casi de inmediato, en otro moral. Sin embargo, sólo un grupo pequeño de homosexuales, muchos de ellos travestidos o que se consideran trans, realiza trabajo sexual en la ciudad. Pero en ese discurso, lo son todos: ¿por qué? Cuando le pregunto a qué se refiere con "corrupciones degenerativas" me responde que se trata de la perversión hacia los jóvenes, una acción que busque incrementar el número de prostitutas o de gays; es decir, que busque intensificar el libertinaje y que destruya o sobrepase las medidas (como cantidad y procedimiento) socialmente aceptadas para la sexualidad, el deseo o el cuerpo. Por eso, el funcionario indica que es importante identificarlos, saber quiénes son: la economía libidinal tiene actores que la orientan en un sentido u otro, hacia la perversión o el respeto, hacia el libertinaje o la regulación estatal.

Paso seguido, le pregunto si es importante identificar a los gays de la ciudad. El ex alcalde responde, enfático:

Desde luego que sí, pues para que no se caiga o se preste a que pudiera haber en algún momento determinado una forma de corromper a los jóvenes o de pervertirlos más o 
de caer inclusive en actividades más graves, de delitos como pueden ser inclusive asesinatos, como pueden ser robos, como pueden ser muchas cosas más, hasta violaciones quizás.

Los temores se multiplican: si no se les conoce no sólo corromperán a los jóvenes, también propiciarán delitos más graves como asesinatos, robos o violaciones. En mi experiencia etnográfica, generalmente los responsables de esos delitos no son homosexuales y en el caso de los asesinatos, específicamente, ellos han sido víctimas antes que victimarios. Pero no se trata de la verdad sociológica sino de la lectura política y moral de los hechos. Guattari escribe que “antes de ser tomada por la policía, el ejército o la administración, la sociedad encuentra su consistencia, su inercia, sus líneas de estratificación, en esa suerte de auto-intoxicación que constituye la puesta en circulación de formaciones imaginarias reaccionarias (...)" (Guattari, 2013: 131). Frente a una economía libidinal que se está desplazando y creando nuevas consistencias, el discurso de los políticos produce estas líneas de estratificación que ponen en circulación formaciones imaginarias reaccionarias como las antes descritas. Formaciones que crean similitudes entre grupos que no necesariamente son equivalentes, que se inquietan por amenazas inexistentes, que acusan a ciertos sujetos de delitos no cometidos. Sí, antes de ser tomada por la policía y la administración, pero también después de que esto ocurra: la gubernamentalidad de la economía libidinal se conectará con esas formaciones imaginarias reaccionarias.

Si regresamos a las máscaras que nos preocuparon en otro momento, los modos en que se interpretan las subjetividades y las exigencias de identificación se articulan en determinado nivel. Por eso, cuando se le atribuye una carga genética a la homosexualidad, o se estima que corresponde con una biografía específica, se dota de interpretaciones socialmente válidas a los diversos aparatos estatales. Veremos en el siguiente capítulo que la medicina nutre al gobierno. La ex directora del DIF que antes citamos considera que los gays tienen "doble personalidad": tienen la personalidad del hombre que es fuerte y la de la mujer que es luchona.

Yo sí platico con mis amigos gays y decimos que tienen doble personalidad, que los hace doblemente fuertes, porque tienen la personalidad del hombre que es fuerte de por sí, que te domina, y aparte la personalidad de la mujer que es luchona, que le gusta los cambios y ellos tienen esta doble personalidad, bueno yo así lo considero que tienen esa doble personalidad, que la mujer es organizada y el hombre es carácter fuerte, entonces ellos con esa doble personalidad, esa visión que tienen, son muy 
trabajadores, se organizan mejor, por lo mismo, bueno, yo así lo siento. (ex-directora DIF)

La identificación está en problemas porque la máscara que analizamos ahora se subjetiviza y crea esta doble personalidad. Los gays son sujetos ambivalentes: son mujeres y hombres a la vez y alternadamente. No se sabe claramente quiénes son y disponen de varias formas de ser o de una pluralidad de subjetividades y posiciones de sujetos. Denise Riley sugiere que "si hay una verdad de la ambivalencia, entonces hay inestabilidades mutuas de lo interno y lo externo, un éxtasis inocente del lenguaje, una propulsión del inconsciente desde fuera y una mutabilidad irregular de lo público y lo privado" (Riley, 2006:8). La inestabilidad de lo interno y lo externo se complejiza con esa duplicación psicológica, que incrementa la ambivalencia y dificulta la identificación. Es decir, dada esa mutabilidad irregular de lo público y lo privado, los dobleces, esas mascaras interiorizadas, se produce un tipo de éxtasis inocente del lenguaje, que se traducirá en una intensa ambivalencia gramatical en muchos gays, que transitan de formas femeninas para referirse a sí mismos(as) y a los otros(as) a unas masculinas y viceversa. Ellos, que no saltan sobre su deseo, sí lo hacen sobre las convenciones del habla y despliegan una táctica contraidentificatoria que multiplica las voces, en una especie de polifonía festiva y placentera que impide que el lenguaje cristalice la subjetividad.

Tal vez lo que Riley llama "una propulsión del inconsciente desde fuera” equivalga a esa imagen del habla coloquial que sostiene que a los homosexuales les gusta "que les empujen los frijoles". Esa intersección no resuelta entre comida y excremento, entre pene, boca y ano, podría leerse como una manifestación de una propulsión del inconsciente desde fuera, que trata de acotar la ambivalencia y atribuirla al homosexual. El inconsciente propulsado desde fuera sobre el homosexual es una estrategia que impide los contagios que arriesga el deseo y es una forma de interiorización semejante a las máscaras y los genes. Nuevamente, si no se 'propulsa' el inconsciente, así como se 'empujan los frijoles', el riesgo es que se esparza sobre todos, así como el excremento cubría el falo erecto.

Recordemos lo que Nancy y Lacoue-Labarthe escriben sobre los afectos: “(...) la afectación de un dentro por un afuera, de allí la división de ambos y su penetración recíproca” (citado en Riley, 2006: 8n12). Si los homosexuales son dos o más personas ${ }^{4}$ a la vez, entonces

\footnotetext{
${ }^{4}$ Etimológicamente persona significa máscara (Mauss, 1979[1938]: 323). Por lo tanto, no es imposible pensar en muchas personas, como se podrían imaginar muchas máscaras. El cierre moderno del individuo sobre su cuerpo (Bajtín, 1990; Cohen, 2008; Harvey, 2000) ha dificultado pensar una multiplicidad subjetiva. Las posturas del
} 
crean una topología de lo interior y lo exterior singular, que se afecta de modos específicos. Dentro y fuera se pueden dividir y penetrar recíprocamente. Si el interior está dividido, a su vez, en dos interioridades distintas, al menos, entonces el exterior también se multiplica. La vOz femenina se relaciona de una forma particular con el exterior y la masculina de otra: la mujer organiza, el hombre trabaja, dice la funcionaria. Uno y otro se afectan mutuamente. Nadie sabe a ciencia cierta quiénes son estos sujetos. La policía los busca para identificarlos, pero el deseo ya los ha enmascarado.

\section{Desórdenes centelleantes}

Guattari plantea una hermosa pregunta: “¿Cómo comprender que los desviados, que algunos grupos-sujetos puedan inventar palabras, romper una sintaxis, cambiar significaciones, producir connotaciones nuevas, palabras de acción, palabras de orden político, engendrar revoluciones tanto en la sociedad como en la lengua?" (Guattari, 2013: 161-2). ¿Cómo comprender que otro lenguaje emerja en este desorden aparente, en esta desmesura inusitada y en el libertinaje sexual y corporal de un colectivo? El que los desviados, como los llama Guattari, puedan inventar palabras, cambiar las significaciones, romper las sintaxis nos muestra la profundidad de la conmoción y la extensión de nuevas libertades y singularidades.

Foucault escribe, en la introducción de Las palabras y las cosas, que:

(...) hay un desorden peor que el de lo incongruente y el acercamiento de lo que no se conviene; sería el desorden que hace centellear los fragmentos de un gran número de posibles órdenes en la dimensión, sin ley ni geometría, de lo beteróclito; y es necesario entender este término lo más cerca posible de su etimología: las cosas están ahí "acostadas", "puestas", "dispuestas" en sitios a tal punto diferentes que es imposible encontrarles un lugar comín. (Foucault, (2008 [1968]: 3).

El discurso gubernamental y sus prácticas buscan crear ese lugar común que evite el desorden centelleante, del que habla Foucault, y resuelva de cierta forma esa pluralidad de órdenes que inauguraría lo que él llama heteróclito. Si las utopías consuelan, agrega el autor en ese mismo párrafo, las heterotopías inquietan, “(...) porque minan secretamente el lenguaje, porque impiden nombrar esto y aquello, porque rompen los nombres comunes o los enmarañan,

perspectivismo han abierto, en la antropología, otros horizontes interpretativos en este campo (Descola, 2012; Viveiros de Castro, 2010). 
porque arruinan de antemano la 'sintaxis' y no sólo la que construye las frases -aquella menos evidente que hace "mantenerse juntas"' (unas al otro lado o frente de otras) a las palabras y las cosas" (ibid.). La pregunta de Guattari obtiene una respuesta provisional: los desviados han deshecho algunas tramas culturales y significantes que mantenían juntas las palabras y las cosas. No hay afán más intenso en una práctica gubernamental o en un discurso que mantenerlas unidas; es la garantía del gobierno y de la administración. Por eso nuestros informantes, que participan plenamente de esas lógicas y esos haceres, se inquietan cuando ven que otros sujetos resquebrajan esas junturas. Una vez que las cosas y las palabras guardan distancia, aunque no sea muy notoria, entonces los lugares comunes a los que apela el gobierno también se difuminan. Entramos al terreno de lo heteróclito y lo heterotópico. Otras formas de yacer y de disponer y otras ubicaciones y localizaciones.

Las heterotopías, continúa Foucault “(...) secan el propósito, detienen las palabras en sí mismas, desafían, desde su raíz, toda posibilidad gramática; desatan los mitos y envuelven en esterilidad el lirismo de las frases" (ibíd.). Secar mitos y esterilizar el lirismo de las frases, desafiar la gramática, arruinar la sintaxis. Estamos ante la conmoción profunda de un orden social y cultural; no sólo se disputan los contenidos, sino que se debaten las formas. Por eso creo que nos encontramos ante ese espacio intermedio que Foucault vislumbra en ese mismo texto, “(...) más confuso, más oscuro y, sin duda, menos fácil de analizar”, dirá. En ese momento, una cultura,

(...) librándose insensiblemente de los órdenes empíricos que le prescriben sus códigos primarios, instaura una primera distancia con relación a ellos, les hace perder su transparencia inicial, cesa de dejarse atravesar pasivamente por ellos, se desprende de sus poderes inmediatos e invisibles, se libera lo suficiente para darse cuenta de que estos órdenes no son los únicos posibles ni los mejores (ibid:: 6).

Una cultura, entonces, se encontraría ante el hecho en bruto del orden: “(...) librándose por una parte de sus rejas lingüísticas, perceptivas, prácticas, les aplicará una segunda reja que las neutraliza, que, al duplicarlas, les hace aparecer a la vez que las excluye, encontrándose así ante el ser en bruto del orden" (ibid.). No podemos sostener que esta trama discursiva y las prácticas que hemos descrito permitan pensar la cultura como una totalidad que se revela a sí misma mediante sus hechos brutos y su orden mudo. Pero sí que ha producido una distancia con respecto a los códigos primarios de la sexualidad y el género, el deseo y la corporalidad. Podríamos pensar, incluso, que la cultura no es sino ese entramado de distancias y junturas, de 
pliegues y superficies, de heteroclotías y heterotopías en disputa. El hecho bruto del orden revela su arbitrariedad necesaria así como una historicidad en movimiento.

Sin embargo, no se trata sólo de develar un orden sino de liberar las posibilidades que ha clausurado. Por eso, lo más disruptivo, me parece, es la emergencia de otras formas de subjetividad y corporalidad y de otros deseos. Es como si el orden se deshiciera justo en los lugares que debieran garantizarlo: el sujeto, el cuerpo, el deseo. Guattari lo expresa de otra manera, en el oscuro lenguaje conceptual que ha elaborado:

Las líneas de fuga maquínicas, del lado de las multiplicidades intensivas, tienden a desterritorializar los procesos semióticos, a abrirlos, a conectarlos con otras materias de expresión, mientras que las codificaciones estratificadas, del lado del orden las "cosas", del lado de las mundanidades dominantes, tienden a sintactizarlos y a cortarlos de todo asidero sobre lo real intensivo. (Guattari, 2013: 166)

La desterritorialización de los procesos semióticos, de la que hemos atisbado algunos ejemplos, intensificará una perturbación de las clasificaciones y de las identidades, que las técnicas gubernamentales pretenderán detener o cercar mediante esas codificaciones estratificadas de las que habla Guattari, reforzando lo que Foucault llama el orden de las cosas. Las similitudes, por ejemplo, que los políticos elaboran entre homosexuales y prostitutas codifican el deseo en los estratos de una economía libidinal heterosexual y monetaria. El deseo homosexual, si algo así existiera, sólo se puede sintactizar a partir de la venta del cuerpo (la carne), el enmascaramiento subjetivo y el libertinaje corporal.

Las corrupciones degenerativas que antes analizamos son justamente esas líneas de fuga, esas multiplicidades intensivas que desterritorializan los procesos semióticos. El deseo, "perpetuamente en estado naciente", como escribe Guattari, "sigue su propia línea sin respeto de las estratificaciones semiológicas" (ibíd.). Ahí donde el Estado ha llegado con sus clasificaciones para tratar de identificar con claridad a los homosexuales (sea mediante sus gestos, genes, biografía o inclinaciones), el deseo se fuga eludiendo esas estratificaciones semiológicas. Por eso, si retomamos algunas palabras de Foucault escritas antes, el peor desorden es el que "hace centellear los fragmentos de un gran número de posibles órdenes en la dimensión, sin ley ni geometría, de lo heteróclito". Para el deseo no hay lugar común, por lo tanto tampoco gobierno. Pero como no es individual, tampoco tiene un lugar común de carácter subjetivo. Si se fuga del orden social también lo hace del sujeto. Será, sin duda, territorializado permanentemente en identidades, espacios, leyes, reglamentos, instituciones e, 
incluso, derechos. Pero no tardará en fugarse. Por eso los políticos estarán atribulados por las medidas y los desajustes, intentando moderar el deseo y regularlo (energéticamente, como se regula una flama, y normativamente, como se lo hace con un comportamiento).

Una forma de producir lo que Guattari llama una "subjetivación individuada y conciencial" será mediante "la amenaza de la pérdida de identidad en el doble, por la oposición del sujeto y el otro y, más allá, por todos los sistemas de valores bipolares (masculino-femenino en torno del falo, singular plural en torno del objeto, verdadero-falso, bien-mal, etc.)" (ibíd: 169). En este sentido, no es extraño entonces que se piense la subjetividad homosexual como doble, porque es la única manera de entenderla y localizarla. Hay que duplicar la identidad en torno a la diferencia sexual para que esta subjetividad quede anclada en esas grillas de inteligibilidad, de las que habla Foucault. Si bien se capta la diferencia que esa subjetividad articula y produce, se la traduce al lenguaje homotópico y homoclótico de las identidades ya conocidas. Homotópico porque lo masculino y lo femenino se vinculan mediante la sintaxis comprensible de la duplicidad subjetiva y corporal, como mostró la directora del DIF: los homosexuales tienen una doble personalidad "que los hace doblemente fuertes". Pero también homoclótico porque el doble se constituye en el lugar común en el que yacen un hombre (fuerte) y una mujer (luchona). Tenemos los dos valores bipolares y sus sintaxis conocidas, aunque el resultado sea anormal. Por eso el desorden centelleante de los fragmentos es peor que la juntura anormal de las partes (el doble en vez de lo múltiple), porque multiplica las formas de subjetividad, las líneas de fuga del deseo y los usos del cuerpo.

Las imágenes de dobles y duplicidades intentan resolver las tensiones que advertimos entre interior y exterior y entre lo público y lo privado, traslapando los conflictos por el espacio social con una disputa interior entre un plano femenino y otro masculino. Si el homosexual no es uno en el uso del espacio público, tampoco lo es en su relación consigo mismo. Pero el lenguaje de los dobles sincroniza un plano con el otro. La trayectoria social que nos condujo desde los escondites y las máscaras hasta los dobles intenta mantener la univocidad del espacio público y evitar sus transformaciones. Pero no se trata, a mi entender, sólo de un tema administrativo, ni siquiera moral; lo que inquieta es el lugar de los cuerpos en ese espacio y su correlación con las formas de gobierno. En ese punto se juegan las medidas de las que hemos hablado: mucha libertad, exceso de perversiones, ausencia de valores, etc. Los hombres vestidos de mujeres que inquietaban a algún alcalde o los que comerciaban con su carne y molestaban a otro funcionario, son líneas de fuga de los modos de estratificación de los cuerpos: un cuerpo que 
deviene otro, uno que vende lo que no se comercia, etc. Quizás formas de ese desorden centelleante pero creativo que muestra el hecho bruto del orden social y que instaura una distancia con respecto a él. Si esos cuerpos "desatan los mitos y envuelven en esterilidad el lirismo de las frases", entonces desmienten, de cierto modo, el campo mismo en el que se produce una retórica gubernamental y política: los mitos de la sociedad y el consenso, el lirismo de los derechos y la tolerancia.

Pero no sólo será una retórica gubernamental la que esté en cuestión, es toda una producción cultural que insiste en duplicar al homosexual para entenderlo, en parcializarlo en partes reconocibles (femenino y masculino) para circunscribirlo en esas homotopías imaginarias y reaccionarias. Un mensaje que me envió por celular un amigo gay de Tenosique, conmemorando el Día Internacional de la Mujer, decía:

Para ti que naciste diferente y estás atrapada en ese horrible cuerpo de hombre, pero que llevas una flor dentro... Tu mente sabe que eres mujer... Muchas felicidades hoy también es tu día, ser gay también es una opción, esa risa loca y esas miradas tiernas, los senos planos y la cola juguetona también te hace parte de ese grupo hermoso y especial... Feliz día de la mujer!!!!

Un curioso pliegue superpone el rechazo al cuerpo masculino, más característico de la transexualidad, con una reivindicación de la "opción gay". La mente sabe, así como los genes, que "eres mujer", pero el cuerpo, como obstáculo, impide que ese saber se plasme. Ante este fracaso de la mente y la persistencia del cuerpo no queda sino la risa loca (no podía faltar), las miradas tiernas y la cola juguetona. En este espacio, el gay sólo se puede expresar mediante la locura (de la risa) o la ternura (de las miradas); su cuerpo no será sino plano (los senos) y juguetón (la cola). Domado por sus contradicciones, el deseo será como una tarjeta postal o un muñeco de peluche. La flor que los gay llevan dentro es lo que les permitiría sobrevivir a la diferencia y la discordancia, a la locura y la ternura.

\section{Fármacos}

Habría que pensar los intentos por curar a los homosexuales, ya sea individual o colectivamente, como la búsqueda de un fármaco social que rectifique sus tendencias y sus desajustes. Lo vimos en la reconstrucción de algunas historias de vida: la homosexualidad debe ser curada, aunque no pueda serlo. El deber excede los resultados y más bien ratifica el lugar 
social de quienes realizan el intento. En vez de aliarse con la desviación, intentan corregirla. Si no lo logran, el fracaso corresponderá al sujeto enfermo. La profundidad de la inscripción del desvío, sea en el cuerpo o en la psiquis, mostrará la dificultad para borrarla o modificarla. Si la homosexualidad no tiene cura, en última instancia, entonces hay que crear una serie de remedios que la mitiguen o la controlen. Hemos visto que una terapéutica individual se entrelaza con otra social y gubernamental. Quizás la novedad es que ambos intentos reconocen un problema e intentan resolverlo. El orden bruto se ha distanciado lo suficiente de sí mismo como para reconocer otras grillas subjetivas y sociales. Esto no escudará la voluntad de resolver esos desajustes.

Pero entre las historias de vida y los discursos gubernamentales hay una diferencia importante. En el caso de los sujetos homosexuales, sus familias intentan curar su enfermedad mediante intervenciones médicas o terapéuticas fracasadas. La distancia histórica entre Juanito y Samuel e Ismael expone una lectura colectiva compleja sobre la homosexualidad, que no intenta resolverse/curarse sólo mediante golpes, oraciones o expulsiones, sino que añade un componente técnico, de tipo médico-terapéutico. Se recurre a sustancias como las hormonas, que debieran rectificar el cuerpo afeminado y el deseo homoerótico. Dosis de hombría, prescritas por los médicos, que podrían disolver esa doble personalidad que se avizora en los gestos y en los gustos. El pecado, que era la lectura de la familia de Juanito y por la cual prefirió irse lejos, es una dimensión muy distinta a la enfermedad, por la cual Samuel e Ismael recibieron tratamientos. Si bien el pecado se expresa en el cuerpo, es un lenguaje que remite, primero, al alma. En cambio, las intervenciones médicas suponen que el cuerpo es el sustrato fundamental del desvío. Incluso si la homosexualidad fuera una enfermedad psicológica, aun así permanece dentro del registro médico antes que del religioso. En estricto sentido, estas configuraciones culturales no son cerradas y el pecado infiltra la medicina así como ésta alimenta nuevos discursos religiosos. Lo que está en juego en este caso es la búsqueda colectiva que se inicia cuando se actúa según el pecado o la enfermedad. Una vez que los padres llegan con un médico, comienzan a tender el cerco gubernamental que luego no dejará de intensificarse en torno a un homosexual.

No obstante, cuando revisamos las estrategias gubernamentales atisbamos una paradoja: se le pide al enfermo contener su enfermedad. Esta ruta fue una de las formas de legitimación social que los integrantes del Club encontraron para tener un lugar en su ciudad. De algún modo, ellos se encargarían de resolver los problemas que traían. Quizás el sida fue, en este 
sentido, la confirmación y la cúspide de dicha dinámica: enfermedad de homosexuales que fue enfrentada por ellos mismos. Las víctimas potenciales debieron también encontrar herramientas para contener el virus. La interioridad del sida con respecto a la homosexualidad es equivalente a la que hemos analizado en la producción de un sujeto: la homosexualidad es interior al sujeto, así como el sida es interior al colectivo homosexual. Dicha interioridad enferma se enfrentará de modos diversos, como lo vimos, pero la tensión entonces será doble, otra vez: una subjetividad desviada y una sexualidad contagiosa. El sujeto quedará atrapado por esa doble tensión: lo que viene de dentro perturba el orden social y lo que viene de fuera, cuyo lugar privilegiado será al cuerpo, también produce desorden y, potencialmente, la muerte.

La prevención del sida que el Club realiza en su comunidad será el fármaco que ofrezca para contener la enfermedad que sus integrantes potencialmente traen. Algún médico local proponía, durante los años noventa, quemar a los homosexuales para detener el sida, porque éstos lo traían en el culo, como una cepa maligna que se extendía a través del deseo. Como no se podían levantar esas piras epidemiológicas ni hacer esos sacrificios tardíos de los enfermos, sólo quedaba que ellos se hicieran cargo de sus actos y los contuvieran. Alan ha destacado muchas veces que uno de los mayores logros del Club es que ninguno de sus integrantes ha resultado positivo a la prueba del VIH. Es decir, el Club fue un método profiláctico eficaz. Pero, por eso mismo, la responsabilidad social que debieron asumir fue mayor; ya no sólo evitar la enfermedad, sino también prevenirla entre los otros: los jóvenes, las trabajadoras sexuales, los migrantes, los militares, los policías, las amas de casa, los hombres, etc. El Club mismo era el fármaco que evitaba la enfermedad, una especie de remedio colectivo ante males sociales. Esa virtud le dio un lugar muy sólido en los imaginarios locales que los actores entrevistados no cesaban de alabar y destacar.

Pero esa labor preventiva replica, de algún modo, la extraña cercanía que elaboraban los políticos y funcionarios locales en relación con el Club y los homosexuales: los conocemos, son de nuestra comunidad, pero también les damos una medida para sus desajustes y desbordes. El Club despliega sus tareas de cuidado colectivo distanciándose de sus propios temores y amenazas; también crea una forma de extraña cercanía con respecto a sí mismo. Por eso, tal vez, ninguna persona que vive con VIH participa activamente en las actividades del Club. Para un hombre gay, el sida supone un ostracismo, primero, en relación a los otros gay de su comunidad. Si no logra mantener el secreto, lo que será muy difícil, entonces se alejará de la sociabilidad gay. El Club es fármaco para quienes no están enfermos. 
Pero, en cambio, no hay fármaco para el deseo o la subjetividad. Quienes se asumen como homosexuales no dejarán de serlo y no parece existir terapéutica que transforme su deseo. Uno de los remedios, que funciona sólo como un paliativo, es la duplicación que ya analizamos. Ser dos personas es una forma de ser alguien reconocible.

Quizás otra paradoja es que los intentos fracasados por modificar el cuerpo y la subjetividad ofrecen una forma de conocimiento de sí mismo, en alguna medida. Vimos antes cómo algunos de los integrantes del Club debieron lidiar con los esfuerzos de sus familias por cambiarlos: tomaron hormonas, fueron a terapia, los golpearon, los aconsejaron. Todas esas prácticas les brindaron, de cierto modo, una lectura de sí mismos que se entrelaza con las percepciones de sus propios deseos y sus comportamientos. La identidad es una bruma que parece aclararse poco a poco y se asienta sobre experiencias y expectativas.

Derrida escribe, a propósito del fármacon griego: “A diferencia de la 'droga' e incluso de la 'medicina', remedio explicita la racionalidad transparente de la lengua, de la técnica y de la causalidad terapéutica, excluyendo así del texto la apelación a la virtud mágica de una fuerza cuyos efectos se dominan mal (...)" (Derrida, 2007[1968]:144). Si los esfuerzos de los padres de los gays muestran esa racionalidad transparente de la lengua, de la técnica y de la causalidad terapéutica, entonces constituyen la homosexualidad como un objeto que puede ser abordado racional y transparentemente. Le restan esas fuerzas mágicas de las que habla Derrida y que, en estos casos, están cerca del lenguaje religioso y la imaginería cristiana. Samuel e Ismael nacieron en un contexto donde los fármacos eran preparados por unas terapéuticas sociales complejas, arraigadas en aparatos y discursos científicos, correlativas a explicaciones que provienen de la genética, la psicología o la endocrinología. Juanito, en el albor de una época, estaba rodeado de explicaciones religiosas y de terapéuticas mágicas. Los otros informantes también lo están, sin duda, pero cuentan con otras aproximaciones. Juanito eligió el silencio para resolver las tensiones y paradojas que experimentó, antes de que la homosexualidad saliera a la calle y produjera escándalo, antes de que las piezas de ese silencio se desajustaran y la polifonía de discursos, interpretaciones y narraciones turbara el paisaje opaco de la discreción y el secreto.

Que los fármacos sean ambivalentes no debiera sorprendernos. Derrida señala que el fármaco cobija en sí mismo una "complicidad de valores contrarios" y que, antes de cualquier definición, es “(...) lo que, dándose como remedio, puede corromper(se) en veneno, o lo que dándose como veneno puede resultar ser remedio, puede aparecer después de administrado en su verdad de remedio” (ibid:: 189). Es el medio, agrega Derrida, “(...) en que se produce la 
diferenciación en general". Esta descripción resuena con la forma en que hemos avizorado al deseo: ambivalente y móvil. ¿No debe ser el fármaco símil a la enfermedad? En los casos que hemos analizado, el remedio no cura, porque lo que se pretende aliviar es incurable, pero inocula el deseo mismo mediante sus contrarios, por así llamarlo. Los esfuerzos por extirparlo sólo lo incrementan; las sustancias ratifican el deseo en vez de modificarlo. El fármaco (en sus diversas manifestaciones) que debiera curar, se transforma en el veneno corruptor.

¿No es el sida, por ejemplo, lo que "dándose como veneno puede resultar ser remedio"? Sin duda que es 'veneno', pero también fue la forma en que se produjo en un campo social, la inteligibilidad de ciertos sujetos y algunas corporalidades. No es la ideal, sin duda, y ha habido otras. Pero en el caso que estudiamos es paradigmático.

\section{Quantas de libertad}

¿Qué fármaco transformó a los putos en gays? Guattari escribe que "lo posible antes de su manifestación en estructuras semióticas o en estratificaciones sociales materiales, no existe como pura materia lógica; tampoco parte de nada, sino que es organizado bajo una forma de quanta de libertad (...)” (Guattari, 2013: 197). El quanta de libertad es el fármaco que vincula el deseo con el lenguaje, en el ámbito estudiado, y dicha articulación empezó a modificar un campo social complejo. El lenguaje fue atravesado por intensidades y prácticas de libertad que terminaron transformándolo. Antes de su manifestación en estructuras semióticas o en estratificaciones sociales materiales, como todas las formas de gubernamentalidad que investigamos, lo posible se manifestó en esas libertades que pronto se midieron y se quisieron controlar. En este caso, pienso en una libertad corporal creciente, pero también en una libertad semiótica que deshizo las convenciones más preciadas del lenguaje mismo: la diferencia sexual, por ejemplo. El lenguaje sería el campo donde otros sentidos posibles (y experiencias y prácticas) pueden articularse o vislumbrarse. La intensidad de los cuerpos, su desacomodo radical con respecto al orden social, fue el primer remedio/veneno que se introdujo en ese orden. Pero sólo cuando la libertad que ya tensaba los cuerpos, escandalizando a muchos, consiguió algunas palabras, se produjo la transformación de los putos en gays. De hecho, el significante maestro de este proceso, es lo gay mismo. Lo exploraremos más adelante.

De todos modos, las líneas de fuga, si existieran, son capturadas por otras líneas. Tal vez la misma terminología esconde otra paradoja: ¿de qué y desde dónde se fuga una línea?, ¿con 
respecto a qué cautividades puede decirse que una línea se fuga? Creo que es importante apreciar los límites del deseo y avizorar que no basta para impulsar los procesos que estudiamos. El deseo homoerótico, por ejemplo, tiene muchas versiones y acomodos: desde sujetos que tienen sexo esporádico o que deseando nunca lo han tenido, ni eventual ni constante; hasta otros para quienes es central y, quizás, definitivo en la configuración de su subjetividad.

Arriba trazamos algunos contornos del orden moral que regula, en cierta forma, la sexualidad en la ciudad y cristaliza en aparatos discursivos y prácticos. Los hombres, específicamente, pueden presentar una trayectoria sexual sinuosa y variable, pero permanecerán adheridos a una trayectoria vital consistente: tener mujer e hijos. Habría que preguntarse si el deseo mismo es una línea de fuga de los sistemas normativos y de las prácticas sociales hegemónicas. En algún sentido, la heterosexualidad, fantasma que merodea cualquier política sexual disidente, no es un continente plano y sólido, sino una trayectoria estriada que tiene ciertos ejes o fuerzas gravitacionales, por así llamarlos. Uno es la familia, otro es la reproducción. Será la tensión entre esas líneas que operan como una fuerza gravitacional y las otras fugitivas las que dirimirán el destino político del deseo.

En la historia de Juanito vemos un sujeto que si bien se fuga, literalmente, de esas fuerzas, sólo puede articular un deseo, una subjetividad y un discurso en los meandros que abre o deja esa economía libidinal conflictiva y un orden social cerrado. No hay otro espacio que no sea el intersticio. Las líneas de fuga a las que trenza su deseo no son lo suficientemente potentes para producir una trayectoria legítima y visible. Tampoco lo deseaba, según nos ha dicho. Cuando en los años noventa las fugas se intensifican, alimentadas por procesos políticos y culturales de diversa potencia y amplitud, sus derroteros se hacen más consistentes. Existe todo un espacio, por ejemplo, de sociabilidad gay en la ciudad, así como personas que se identifican de ese modo y parejas del mismo sexo. Si bien las tensiones son muchas, la potencia de la trayectoria se incrementa. El Club se nutre de ese proceso y también lo intensifica.

Un hombre bisexual ${ }^{5}$ puede experimentar su deseo homoerótico de modos diversos, pero no se fuga con él o a través de él. Tampoco quiere hacerlo, en la mayoría de los casos. No

\footnotetext{
${ }^{5}$ Utilizaré bisexual, por ahora, sólo como una categoría descriptiva. En Tenosique no constituye una identidad todavía, aunque se use comúnmente. Exploro sus significaciones y usos locales más adelante. En términos etnográficos, un hombre bisexual será conocido como mayate. El mayate, según algunas exploraciones antropológicas (Almaguer, 1995), es el escarabajo que arrastra los excrementos y por extensión nombra a los
} 
quisiera decir que la homosexualidad se vive en un clóset y seguir esa pista. Creo que esa ruta entrega respuestas antes de hacer las preguntas. Lo que me interesa remarcar, en este contexto, es que la heterosexualidad masculina permite un rango amplio de exploración, mayor que la femenina, pero que es contenida mediante esas fuerzas gravitacionales. El sujeto, al menos en este campo, experimentará una tensión permanente entre líneas de fuga y fuerzas gravitacionales. En este sentido, Guattari señala que "es cierto que las fugas del deseo (...) son sistemáticamente apresadas por las codificaciones de la familia, de la escuela, de la medicina, del deporte, del ejército, y de todas las reglamentaciones y las leyes que se supone rigen el comportamiento 'normal' del individuo" (Guattari, 2013: 192-3). En algunos casos, esa captura a la que se refiere Guattari es completa; en otros relativa.

Los fármacos que exploramos son remedios para esa tensión y debieran intensificar las fuerzas gravitacionales. Si se inocula masculinidad es para que los desviados regresen a las trayectorias esperadas y a las semióticas debidas: que tengan novias, se comporten virilmente, vistan y hablen como hombres, tengan hijos. Es un proceso reciente el que los sujetos puedan sostener e insistir en sus fugas. La identidad, en este sentido, es sólo una forma de fugarse antes que un punto de llegada; la sociabilidad sería otra.

Los discursos de los políticos son formas de contener la fuga que intentamos seguir. Es claro que evalúan cualquier deseo o vida con esos parámetros gravitacionales familiares y reproductivos. Reconocen la enfermedad y también que ya es tarde para extirparla. Aplican una bomeopatía gubernamental que busca remediar los males mediante sus propias sustancias. Duplican a los sujetos para contener la ambivalencia que producen. En ese momento, como dice Riley, estamos “en el corazón de la sociabilidad” (Riley, 2006: 10n16). ¿Qué corazón es éste? Los discursos gubernamentales tratan de reducir la intensidad de las fugas y su potencial multiplicación mediante las homotopías (los bares, las zonas de tolerancia) y las homoclotías (las máscaras, los dobles). El Club, en cierto modo, es una de las formas que restan poder a las fugas, pero que también las ha producido. Cuando se introducen distinciones, por ejemplo, entre homosexuales decentes y los que no lo son, las fuerzas gravitacionales del orden moral

hombres activos en una penetración anal con otros hombres. Sin embargo, es necesario considerar que en algunas relaciones el mayate estima que se vincula con una mujer o con un puto. Es decir, su pareja no es identificada como otro hombre o si lo es, muchas veces se desestima su masculinidad mediante formas de feminización, por ejemplo, hablándole en femenino. Por su parte, muchos gay locales sienten y desean que se los trate como una mujer en el sexo y aunque reconocen las homologías genéricas, privilegian las diferencias identificatorias. 
obstaculizan micro-fugas como vestirse de mujer, jotear, conquistar hombres en las cantinas, alternar los géneros gramaticales. La ambivalencia cruza al Club mismo, que nunca dirime si está dentro de esos discursos o fuera de ellos, si excluye o no a ciertos sujetos, si traza otro parámetro de normalidad o no lo hace. Si bien nunca resuelve todo esto, y no creo que lo haga, experimenta la tensión afectiva que implica esa ambivalencia.

La única experiencia que podría nombrar como excluyente es el sida. Antes lo mencionamos: si bien el Club es uno de los fármacos que la comunidad se ha dado para protegerse del sida, y eso le ha otorgado una gran legitimidad social, también es la frontera final, quizás, entre quienes poseen algún lugar y quienes no. Cuando un hombre gay, pero no sólo, resulta seropositivo, entonces el fármaco ha fracasado y es abandonado a su suerte. Él mismo se aleja, me parece, de la burla, del escarnio, del temor que suscita. ¿Qué otras fugas, orgánicas y corporales, morales y afectivas, empiezan en este punto?, ¿qué potencia podrían adquirir en un futuro?, ¿qué otras formas de politización emergerán en ese abandono? Eso no lo sabemos aún.

Los quantas de libertad, dijimos, fueron el fármaco que permitió que los putos se transformaran en gays. Constituyeron, por tanto, la fuerza de las múltiples fugas que horadaron el espacio y el orden social hasta que cierta diferencia emergiera y estriara su aparente homogeneidad. Esos quantas se desactivaron, a mi entender, ante el sida. La muerte, que es la amenaza que pesa sobre la enfermedad incluso hoy, tuvo el poder de transmutar la libertad en miedo, de hacer rotar la ambivalencia (los afectos) en contra de las fugas. Creó una nueva fuerza gravitacional que se alimentaba no sólo del temor sino del abandono, de la humillación y del desprecio. Los enfermos de sida fueron (y en muchos sentidos aún lo son) los enfermos definitivos, para quienes nunca habrá un fármaco que permita integrarlos, duplicarlos o enmascararlos. La enfermedad desviste al sujeto y suspende estos procesos semióticos de fuga y estratificación. La falta de cura, sea material o simbólica, los excluye radicalmente de la ambivalencia misma, es decir, de los afectos. Ahondaré en este tema en otro capítulo, pero quisiera señalar que algunos que conocí y de quienes testifiqué su deterioro paulatino pero definitivo, me parecieron verdaderos muertos en vida. El sida es el afuera del afuera. Si representa una parálisis de la ambivalencia, por lo tanto de los afectos, impide el funcionamiento de cualquier fármaco. El sida es la enfermedad pura, sin cura alguna. Los afectados evitan la sociabilidad porque están ausentes, de muchas maneras, de las intensidades afectivas que atraviesan la vida social. En este sentido, la muerte social corresponde con una 
parálisis afectiva, no sólo personal sino colectiva. La soledad es un afecto no farmacológico, a mi entender, porque dificulta la ambivalencia y resalta el veneno antes que el remedio. Estar solo, en este contexto, es estar enfermo y, en algún sentido, también muerto. Las sombras que analizaremos en otro capítulo conforman acá un paisaje social; la soledad es el afecto sombrío, que atravesado por cierta luminosidad sólo puede dar cuenta de una oscuridad personal y corporal, de la visita temprana de la muerte, que toca pero no arranca, que merodea sin hospedarse.

¿Qué otras fugas, qué agenciamientos habría que crear para evitar esos destinos?, ¿qué deseos tendrían que ponerse en movimiento para que de la enfermedad y del abandono surgieran nuevos quantas de libertad transformadora?, ¿qué formas de luminosidad habría que crear para suspender la sombría quietud de la enfermedad y de la muerte?

\section{Don, gubernamentalidad y deseo}

En su introducción a Los hombres infames, Foucault escribe que en las transformaciones que se pueden explorar en los diminutos textos que ha compilado, anotaciones de esas vidas mínimas, como las llama, se establece “(...) -un- tipo muy diferente de relación entre el poder, el discurso y lo cotidiano, una manera muy distinta de regir lo cotidiano y regularlo. Nace una nueva puesta en escena de la vida cotidiana" (Foucault, 2010e: 685). A mi entender, creo que estamos, nuevamente, ante la conformación de una relación inédita entre poder, discurso y vida cotidiana. Ha surgido, como lo hemos visto, de un largo proceso, pero su expresión más clara sólo comienza a delinearse en las últimas décadas. Foucault llamará a esa nueva relación "gubernamentalidad”, entendida como “(...) el conjunto constituido por las instituciones, los procedimientos, análisis y reflexiones, los cálculos y las tácticas que permite ejercer esta forma tan específica, tan compleja, de poder (...)” (Foucault, 2010b: 854). La gubernamentalidad sería un conjunto de prácticas múltiples de gobierno que se articulan en campos y espacios diversos. En este sentido, y éste es quizás el giro más importante que introduce Foucault en el análisis de poder, la gubernamentalidad no se limita al Estado ni coincide con él. Es probable, escribe Foucault, que:

(...) si el Estado existe tal como existe ahora, sea precisamente gracias a esa gubernamentalidad que es, a la vez, interior y exterior al Estado, puesto que las tácticas de gobierno son las que permiten definir en cada momento lo que le debe y lo que no 
le debe concernir, lo que es público y lo que es privado, lo que es estatal y lo que no lo es (Foucault, 2010b: 855)

Si bien el horizonte del análisis foucaultiano excede el contexto que nos interesa en este capítulo, creo que la noción de gubernamentalidad, y las perspectivas que abre, permiten comprender una serie de características de las prácticas gubernamentales locales. Primero, muchas de ellas se llevan a cabo sin estar estrictamente normadas. Por ejemplo, cuando un alcalde destina, supuestamente, un lugar de la ciudad para que los gays se junten y no anden vestidos de mujeres por las calles. Segundo, suceden en un registro que es institucional, pero también lo excede; por ejemplo, cuando la amistad en algunos políticos y los integrantes del Club les permite realizar actividades conjuntas o solicitar favores. Tercero, operan utilizando rutas que les ofrece la vida cotidiana y otras formas de vinculación independientes a las leyes y normas que regirían el ejercicio gubernamental; por ejemplo, cuando algún funcionario identifica a personas que viven con VIH, el diagnóstico no proviene de las instituciones médicas (lo que sería ilegal), sino de una serie de contactos cotidianos en los que algunos integrantes del Club solicitan ayuda a las autoridades para cierta persona convaleciente. El rumor de pronto se articula con procedimientos administrativos y el diagnóstico es conocido públicamente.

Por otra parte, para entender el funcionamiento de estos poderes y estas prácticas no debemos centrarnos en lo que dicen explícitamente sino en lo que hacen efectivamente. Lo he visto repetidas veces y lo he escuchado: los políticos y los funcionarios elaboran ciertas narrativas, por ejemplo, sobre la igualdad de todos los ciudadanos ante la ley o la salud como una de sus prioridades. Pero, luego, estos enunciados son desmentidos por prácticas gubernamentales que no sólo los contradicen, sino toman el camino inverso; por ejemplo, enfatizar el derecho a la salud de todas las personas y negarle la atención médica a alguien que vive con VIH. Esa disyunción entre los enunciados y las prácticas es central para comprender las formas de gubernamentalidad locales, aunque no correspondan quizás con las características que el mismo Foucault y otros autores que han profundizado su pensamiento atribuyen a la gubernamentalidad (Burchell, 1993; Murray, 2007; Rose, 2001; Weider, 2009). No creo que dicha dislocación corresponda a una racionalidad específica, como la que algunos identifican con las formas de gubernamentalidad, aunque esté inscrita en lo que Rose y sus colaboradores llaman un mapa de las racionalidades y técnicas gubernamentales (Rose, O’Malley y Valverde, 2006: 99). Al menos no en este contexto. 
Creo que, en este caso, la disyunción se relaciona ante todo con la forma en que se organiza el poder: siempre es un intertanto entre relaciones institucionales y otras personales; entre intereses públicos y otros privados; entre marcos normativos y posibilidades prácticas. Los discursos gubernamentales no están orientados, en primera instancia, a generar un consenso narrativo o un marco común de comprensión e interpretación, sino a sostener una serie de prácticas que los pueden desmentir y contradecir abiertamente, como quedó de manifiesto en algunas descripciones que hemos hecho (y lo quedará también en muchas de las que siguen). Se habla, por ejemplo, de derechos humanos con mucha facilidad, pero no se los respeta con la misma premura. Para entender, entonces, el funcionamiento del Estado en su concreción local, ${ }^{6}$ se deben observar dos direcciones: lo que se dice y lo que se hace; aunque no siempre se presente dicha disyunción. Que la gubernamentalidad sea un conjunto de prácticas múltiples no sometidas necesariamente ni a un plan ni a una sola racionalidad la hace útil para pensar estos contextos. Es una matriz histórica, en palabras de Rose y Miller (1992: 273), que articula esquemas, estrategias y maniobras que buscan que los gobernados actúen de determinadas maneras y en ciertas direcciones; pero que no necesariamente asegura que lo hagan.

Según Castro-Gómez (2010) no sólo se gobiernan las conductas, también se administran los deseos. Lo que hemos explorado en parte de este capítulo son, precisamente, diversos

${ }^{6}$ Das y Poole (2008) sostienen, en la introducción de una antología dedicada a estudiar los márgenes del Estado desde la antropología, que la etnografía es un método privilegiado para conocer los ámbitos del Estado que se resisten a una formalización sociológica, pero que constituyen experiencias relevantes para los sujetos y colectivos. Creo, de todos modos, que la noción de gubernamentalidad discute la de margen. Aunque las autoras critican a los antropólogos que dan por sentada la forma Estado, incluso como un fantasma que se debe evitar (es el caso de Clastres), permanecen atadas a ella mediante la exploración de sus márgenes.

"El Estado, escribe Foucault, no es un universal, no es en sí mismo una fuente autónoma de poder. El Estado no es otra cosa que el efecto, el perfil, el recorte móvil de una perpetua estatización (...) En síntesis, el Estado no tiene entrañas, es bien sabido, no solo en cuanto carece de sentimientos, buenos o malos, sino que no las tiene en el sentido de que no tiene interior. El Estado no es más que el efecto móvil de un régimen de gubernamentalidades múltiples” (Foucault, 2007: 96).

¿Cómo podría investigar la antropología ese efecto de perpetuas estatizaciones?, ¿cómo se puede explorar esa ausencia de entrañas y de interior que caracterizaría al Estado?, ¿efectivamente carece de sentimientos, como dice Foucault?, ¿qué implicaría estudiar ese 'régimen de gubernamentalidades múltiples'? También cabría preguntarse si esa ausencia de interior es correlativa con una falta de márgenes. Algo permanece de la topología que Foucault discute en la noción de márgenes o en la presencia fantasmal de un centro o de muchos; la intensidad de las distancias; la hipótesis de los desplazamientos. 
intentos por gobernarlos. Tentativa, como lo hemos visto, llena de paradojas. Sostuve que el Club participa, pero también desplaza, las formas de gubernamentalización del deseo homosexual. Esta ambigüedad estará inscrita, a mi entender, en su forma misma.

$\mathrm{Al}$ reconocer que el Club tenía una forma extraña, difusa en muchos sentidos, pensaba primero en el tipo de organización que representaría. Después de explorar su carácter farmacológico, creo que su forma se relaciona con las posibilidades de existir en el contexto donde surgió y se desarrolló antes que con una característica organizacional específica. El Club no tiene registro legal, ni sede, ni representante, tampoco estatutos. Sólo cuenta con una organización bastante flexible y, en última instancia, no muy relevante de puestos. Alan es el presidente; había un tesorero, un secretario y algunos encargados de ciertas áreas como los eventos o la salud. En términos prácticos, creo que sólo Alan concentraba una gran capacidad de gestión y convocatoria, mientras el resto de los integrantes actuaba en absoluta igualdad. Para el gobierno y el Estado, el Club no existe legalmente. No ha recibido fondos gubernamentales para ninguna de sus actividades, aunque era considerado en todos los eventos vinculados con diversidad sexual y prevención del VIH en el municipio y el estado.

El Club existe como una asociación de personas con ciertos intereses comunes, vinculadas fundamentalmente por la amistad. Su estatus, como se ve, es ambiguo: existe en un plano y en otro no; está inscrito en los discursos sociales, pero no en los registros institucionales; tiene una forma provisional, pero ninguna norma que lo regule; hace muchas cosas, pero no recibe ningún dinero. Puede ser convocado por los políticos para pedirles el voto a sus integrantes, pero no tiene ninguna directriz ideológica y navega en el mapa político local con bastante libertad. Diré que sigue y, a la vez, evita la lógica gubernamental.

Por otra parte, las opiniones locales sobre el Club valoran de manera consistente que su trabajo sea gratuito y le dé algo a la comunidad. La gratuidad y el don ${ }^{7}$ son, quizás, los dos pilares del aprecio colectivo que suscita esa organización. Si los observamos, son dos atributos distantes de las formas de gobierno, acusadas colectivamente por el interés y la corrupción. En ese sentido, el Club se ubica en las antípodas del gobierno, aunque esté cerca de él.

De este modo, surge una tensión entre las formas de gubernamentalidad que hemos explorado y en las que el Club participaría de alguna manera, su autonomía efectiva y el carácter gratuito de su trabajo, leído colectivamente como un don. Si el Club ha participado de

\footnotetext{
${ }^{7}$ Hago propio lo que Marcel Mauss escribió en su Ensayo: "los términos que hemos empleado -presente, regalo, don- no son del todo exactos, pero no hemos encontrado otros” (Mauss, 2012 [1925]: 241-2).
} 
ciertas prácticas gubernamentales, lo ha hecho sin sumirse nunca en las estructuras estatales ni siquiera en las legales. Se mantiene en una bruma organizacional que, a mi entender, ha sido la clave de su existencia y sobrevivencia. A contrapelo de las formas de activismo que se han impuesto en los últimos veinte años en México, el Club no pide nada al Estado ni al gobierno. Si tiene una forma es la de la amistad y la improvisación, si cuenta con una norma es la que sus integrantes se dan a sí mismos de manera contingente. Lo que resulta misterioso, entonces, es que se pueda participar de formas de gubernamentalidad de un modo tan sui generis.

Incluso su nombre es tributario de esa tensión que intento explorar. Por una parte, es un Club, es decir, una asociación de personas vinculadas por intereses comunes; luego es gay, lo que especifica la identidad de sus integrantes. Quizás lo más particular sea Amazonas. Cuando le pregunté a Alan por qué se habían puesto ese nombre, me dijo que sus integrantes eran como las mujeres míticas: guerreras y luchadoras. Nuevamente, la sintaxis es sometida a una ambigüedad intensa. Un club de hombres gay que son guerreras amazónicas. Si bien la noción de club remite a un tipo de organización tradicional, más bien conservadora y que no causa problemas, la referencia a las Amazonas muestra un mundo autónomo en el que las mujeres, sometidas a los poderes patriarcales, se liberan y forman su propia sociedad. El Club está dentro de un orden y fuera de él, se integra y lo excede.

Leo como una intuición política genial esa forma de organización. El Club es, ante todo, un modo para que un colectivo se relacione con las formas de gubernamentalidad antes que con el Estado. Aunque diversas personas le han planteado a Alan y otros integrantes legalizar el Club, hasta ahora nunca lo ha hecho. Mi sensación es que no lo desean e intuyen que la cercanía con el Estado destruiría a la organización rápidamente. El Club se disolvió en la práctica, aunque no en los discursos, cuando se encontró con dos obstáculos: el reparto de un dinero que habían ganado en un Carnaval y la participación de su presidente en la administración del primer alcalde perredista de Tenosique.

Durante los tres años en los que Alan fue funcionario del DIF local, luego de haber trabajado en la campaña del alcalde electo, el Club dejó de existir. Muchos integrantes sentían y expresaban un malestar por el resultado de lo que consideraban fue un compromiso colectivo y no sólo individual. Por lo que he alcanzado a ver, durante las campañas locales mucha gente participa con la promesa de conseguir algún cargo si gana el candidato que apoya. Alan no fue el único gay que tuvo un puesto durante ese gobierno, pero su presencia fue muy criticada. El dinero y los compromisos políticos disolvieron el Club, organizado en torno a la gratuidad y la 
amistad. En la última elección, una candidata a diputada organizó un grupo gay que tardó unos pocos meses en desaparecer, aunque congregó a destacados integrantes del Club. El interés político no bastaba para sostener una organización de este tipo y su objetivo, al contrario, era claramente gubernamental.

Si fuera cierto que se puede gobernar el deseo o que el deseo puede ser un objeto de prácticas gubernamentales, el Club encontró una forma adecuada para evitar, en parte, dicha gubernamentalización participando de ella, en alguna medida. A la homeopatía gubernamental, que antes hemos analizado, el Club responde con una exterioridad implacable que no se puede integrar en las formas de gubernamentalidad. ¿Es dicha exterioridad el deseo mismo?

Si regresamos a dos puntos expuestos anteriormente, tal vez podemos resolver el intríngulis al que nos condujo este capítulo. Por una parte, el Club es un fármaco, remedio y veneno a la vez, que así como elude las prácticas de gobierno, las concita. Por otra, el Club dona su propia acción a la comunidad y es reconocido por la gratuidad de su trabajo. Pero, junto con esto, se constituye en el límite entre la comunidad y las personas con sida. Al proteger(se) de la epidemia crea un afuera del afuera, como lo describimos en algún momento. Pero dicha protección es justamente la que permite un vínculo, al menos en un primer momento, con las instituciones y la comunidad. Si relacionamos la lógica del don con la de la gubernamentalidad, veremos que el Club da aquello que, justamente, lo vincula con las prácticas gubernamentales, sin integrarse a ellas. Al mantenerse en el plano de la donación, el Club evita su institucionalización y nunca queda inscrito ni escrito en el Estado. ${ }^{8}$

Me interesa remarcar que en el contexto de relaciones institucionales regidas por leyes y normas, se introduce la lógica del don. Por ejemplo, cuando algunos integrantes del Club han solicitado permisos para realizar eventos e incluso locales administrados por el Ayuntamiento, recurren a la amistad con determinados funcionarios para conseguir la autorización. De este modo, si bien operan en el marco formal e incluso cumplen con los trámites exigidos, la decisión será tomada considerando las relaciones personales antes que los requisitos

\footnotetext{
${ }^{8}$ Con respecto a la escritura, Foucault considera que "para que la disciplina sea siempre ese control, esa captura permanente y global del individuo, creo que está necesariamente obligada a utilizar un instrumento que es la escritura (...) La visibilidad del cuerpo y la permanencia de la escritura van a la par y producen, desde luego, lo que podríamos llamar individualización esquemática y centralizada” (Foucault, 2005: 69). Habría que preguntarse si esa resistencia a la escritura que caracteriza al Club es un modo de evitar las disciplinas y las formas de individualización centralizadas.
} 
institucionales. ${ }^{9}$ Creo que en esos aspectos, la lógica del don se articula con estrategias gubernamentales que crean formas mixtas o híbridas de administración de la vida colectiva: no son estrictamente institucionales ni están regidas sólo por marcos legales o normativos, pero tampoco son puramente personales. Me parece que Foucault no se detiene en este aspecto y tampoco les interesa a los sociólogos de la gubernamentalidad, pero su valor etnográfico es inocultable, en la medida que las prácticas develan lógicas cruzadas y mixturas productoras de nuevas formas de gobierno.

El Club funciona, fundamentalmente, bajo la lógica del don. Pero eso no le impide adentrarse en otras, como las burocráticas o las legales. Al menos, en el nivel local que estamos trabajando. Por eso, cito un caso, no puede solicitar fondos federales destinados a la prevención del VIH. Pero, por otra parte, esa inscripción tan profunda en la organización de las relaciones informales de la localidad, y su participación en una dinámica de intercambio densa y permanente, le otorga un lugar social seguro y estable. Si bien los rechazos y los prejuicios pueden ser muy intensos e incluso violentos, cualquier persona de la ciudad pensaría antes de atacar o agredir a los integrantes del Club, porque la respuesta podría ser contundente. Lo que yo he observado durante estos años de investigación es una trama amplia y compleja de relaciones personales que se está moviendo constantemente. Los favores son solicitados y devueltos; una cosa se intercambia por otra; lo que se recibe luego se regresa, aunque sea en otras maneras. El favor es una práctica social altamente valorada y ser egoísta o tacaño son dos rasgos personales y morales enérgicamente condenados. ${ }^{10}$

Debo decir que una vez que descubrí esa lógica también participé de ella: hoy en día, muchas de las relaciones más sólidas que tengo con personas de la ciudad se han organizado en torno a favores mutuos. Dar es central en la constitución del vínculo social y afectivo. Pero, y

${ }^{9}$ Cuando se produjo la ruptura dentro del Club, algunos de sus integrantes simpatizantes del PRI local, acusaban a Alan de bloquear las autorizaciones para utilizar los espacios públicos por parte de la nueva administración perredista. En este plano, las relaciones personales podrían ocuparse en varias direcciones, al menos en beneficiarse de ellas o entorpecer a otros sujetos mediante su concurso.

${ }^{10} \mathrm{Al}$ contrario, la generosidad y la dádiva son cualidades altamente valoradas. En las fiestas y los rituales, la gente dispensará comida y bebida a los invitados. En un funeral o un rezo, por ejemplo, se dará de comer abundantemente. Lo mismo sucederá en una fiesta de quince años, a la que se invitará a una gran cantidad de gente. Me parece que estos valores y prácticas apuntan al corazón de la sociabilidad local; incluso personas con poco dinero harán un gran esfuerzo para que sus fiestas (especialmente los quince años y las bodas) sean abundantes y los invitados queden contentos y satisfechos. 
esto es quizás uno de los rasgos que más me ha sorprendido, el don es ajeno al cálculo; es decir, si el favor se hace sólo pensando en la devolución potencial o estimando la deuda que se contrae, no será plenamente un favor, sino sólo un préstamo. El favor necesita de una actitud desinteresada, aunque sea aparente. Por ejemplo, me he dado cuenta que prestar dinero sin que te lo devuelvan no conduce necesariamente a un conflicto; puede ser también una confirmación de la amistad, que se aleja del cálculo y se adentra en otro terreno que llamaría afectivo, pero también en una solidaridad profunda con las dificultades de una persona que, quizás, no puede regresar el préstamo.

Una expresión de esta lógica, si es que fuera una, transpone los términos en un préstamo monetario. La gente, habitualmente, dice que el deudor le prestó dinero a su acreedor. El préstamo está del lado del que entrega el dinero, no del que lo recibe. No existe confusión sobre quién debe regresar el dinero, pero se transpone una lectura que acentúa el acto de prestar antes que el de pedir y lo dispone en el lugar del que recibe y no del que dona. Si bien no he estudiado las prácticas económicas de esta localidad, ni siquiera de los integrantes del Club, pienso que esto muestra una valoración social del acto de prestar que reside en la generosidad antes que en la deuda o la devolución. Es como si el dinero prestado, en el sentido que delineé, fuera una confirmación del vínculo social y personal y no una amenaza.

No obstante, parece que en el don es difícil distinguir entre gratuidad e interés. Marcel Mauss, en su famoso Ensayo sobre este tema, anota que uno de los rasgos más profundos del don es “(...) su carácter voluntario, por así decirlo, en apariencia libre y gratuito y, sin embargo, forzado e interesado de esas prestaciones", y añade que "éstas casi siempre han adoptado la forma del presente, del regalo que se brinda con generosidad, incluso cuando en ese gesto que acompaña la transacción sólo hay ficción, formalismo y mentira social y cuando, en el fondo, detrás de él hay obligación e interés económico” (Mauss, 2012 [1925]: 253-4). Por eso, Godelier considera que "el don es, en su misma esencia, una práctica ambivalente que une o puede unir pasiones y fuerzas contrarias" (Godelier, 1998: 23).

La ambivalencia regresa a nuestros argumentos, ahora de la mano del don. No obstante, el mismo Mauss sostendrá, en las conclusiones de su Ensayo, que "gran parte de nuestra moral y de nuestra propia vida permanece en esa misma atmósfera donde se mezclan el don, la obligación y la libertad” (Mauss, 2012 [1925]: 229). Al iniciar este capítulo tratamos de esbozar una moral sexual que pudiera conectarse con otra que se delineaba en los discursos gubernamentales. Nuestro interés era entender el contexto cultural en el que había surgido el 
Club y en el que se desarrolló. La trabajosa formalización de su estructura dificulta comprender su lugar en la densa trama de relaciones de poder y de gubernamentalidad que hemos esbozado, porque es ambivalente, pues los afectos que suscita lo son, así como su relación con el Estado y las formas de gobierno.

Que el Club encuentre un lugar social mediante una práctica del don se vincula, como lo hemos visto, con algunas de sus características sociológicas. La gratuidad era una, pero otra, destacada por Godelier, es que el don se halla presente "en todos los dominios de la vida social en los que las relaciones personales continúan desempeñando un papel dominante" (Godelier, 1998: 27). Sin duda, Tenosique es un caso de ese predominio. Al Club le ha permitido inscribirse en esas relaciones, porque el acto de donar “( (..) parece instituir simultáneamente una doble relación entre el que dona y el que recibe" (ibid:: 23). La clave, me parece, es que el don permita instituir una relación, aunque sea ambivalente o conflictiva. Una vez establecida, entonces el otro tiene existencia y obtiene un lugar, aunque sea precario. Godelier agrega que esa relación puede ser de solidaridad - “el donante comparte lo que tiene o lo que es con aquel al que dona”- y de superioridad - “ya que el que recibe el don y lo acepta contrae una deuda con aquel que se lo ha donado"-. No estoy seguro que esto se cumpla cabalmente en el caso del Club por lo arriba mencionado, pero al menos es innegable la relación de solidaridad que ha establecido con diversos grupos y personas.

Quisiera regresar a la gubernamentalidad y, nuevamente, a unas palabras de Foucault:

En la medida en que el gobierno de los hombres es una práctica que no es impuesta por quienes gobiernan a quienes son gobernados, sino una práctica que fija la definición y la posición respectiva de los gobernados y los gobernantes entre sí y con referencia a los otros, 'regulación interna' querrá decir que esa limitación no es impuesta exactamente ni por un lado ni por otro, o en todo caso no se la impone global, definitiva y totalmente por, yo diría, una transacción, en un sentido muy lato de 'transacción', vale decir, 'acción entre', mediante toda una serie de conflictos, acuerdos, discusiones, concesiones recíprocas. (Foucault, 2007: 29)

Para que se establezca esa "acción entre" es necesario, al menos, distinguir los términos o los actores que actúan entre sí en esa "regulación interna". Entiendo que el Club ha sido capaz de fijar una definición y una posición respectiva frente a los gobernantes, pero también frente a la sociedad a la que pertenece. A su vez, ha podido participar de una serie de relaciones en las que se dirime dicha regulación y, en muchos sentidos, ha operado en favor de los sujetos homosexuales de la comunidad. Hemos visto las discusiones, los conflictos y los acuerdos que 
atraviesan ese proceso y lo siguen impulsando. Mauss sugiere una hermosa definición de contrato e intercambio: una mezcla de vidas y personas, de almas y cosas, en la que cada término sale de su esfera para mezclarse con los otros (Mauss, 2012 [1925]: 109). ¿De qué modo se han mezclado los términos en este contrato e intercambio que tratamos de describir?, ¿de qué esferas han salido para suscitar esa mezcla?, ¿qué ha permanecido ajeno a cualquier mezcla posible?

En la economía libidinal que tratamos de reconstruir y entender, los términos se han desplazado, nuevas regulaciones intentan normar al deseo y a los sujetos, y nuevos desplazamientos transforman las relaciones que dicha economía articularía. El Club es un actor de dicha economía y participa de ella de un modo ambiguo y ambivalente, como ya lo dijimos. El don se contrapone al gobierno, pero también se entrelaza con él. Las relaciones personales cruzan las instituciones. El Club participa de esas mezclas que supondrían los intercambios y los contratos. Frente a las formas difusas de la gubernamentalidad se ha creado una organización igualmente imprecisa y cambiante.

Recordemos la cita de Guattari, una economía libidinal "no cesa de desplazar sus intensidades sobre un continuum cuya existencia recusa por adelantado los sistemas de opción cristalizados según una lógica de objetos totalizados, de personas responsabilizadas, de conjuntos cerrados" (Guattari, 2013: 135). Me parece que es justamente ese entrecruzamiento de una lógica y una práctica del don con las estrategias gubernamentales lo que permite a dicha economía recusar los sistemas de opción cristalizados, cuyas expresiones exploramos en Tenosique, los objetos totalizados y las personas responsabilizadas. Si una persona es ubicada de determinado modo en las estrategias gubernamentales, puede desplazarse mediante las prácticas del don en las que participe. Si el homosexual está inscrito en esos diagramas gubernamentales y en los del don, el doblez que se le atribuía a su personalidad adquiere ahora otro sentido: doble participación en las lógicas sociales, inscripción relativa en las prácticas gubernamentales e inscripción profunda en las del don.

El deseo, si fuera esa exterioridad que antes esbozamos, no quedará inscrito en ninguna de las relaciones ni lógicas exploradas. Será, a mi entender, la intensidad que desplaza todas las cristalizaciones, gubernamentales o no. "Pensar la minoridad en el orden del deseo, escribe Guattari, presupone (...) la fabricación de nuevas líneas de realidades” (Guattari, 2013: 136). ¿Hemos pensado esta minoridad en el orden del deseo a lo largo de este capítulo?, ¿qué nuevas líneas de realidades hemos encontrado en ese trayecto? Si el Club fuera un tipo de 
agenciamiento, como los que interesan a Guattari, cumpliría con uno de sus propósitos: hacer "trabajar los signos 'directamente' en las cosas, los cuerpos y los flujos de toda naturaleza." (ibid.). Directamente quiere decir también que no representa nada, no habla en nombre de otros y no es vocero de nadie. Directamente como esas torsiones de la gramática o esas oscilaciones del cuerpo, que tanto atormentaban a algunas familias. Si fuera el caso que los agenciamientos no correspondieran a personas individuadas, sino a "constelaciones de órganos, de funciones orgánicas, de flujos materiales, de flujos semióticos” (ibíd.), el Club correspondería a las constelaciones y funciones que parecen alteradas por la homosexualidad: el ano, la boca; comer, defecar.

Así, el carácter farmacológico del Club se vincula con la producción de la diferencia. En su análisis, Derrida indica que el fármacon es "el movimiento, el lugar y el juego (la producción de) la diferencia. Es la diferencia de la diferencia.” (Derrida, 2007[1968]:191). El Club es el lugar y el juego de la producción de la diferencia. Por eso puede navegar en las aguas de Estado, de la gubernamentalidad y del don, porque no sólo se produce a sí mismo como diferencia, sino que conmina a los otros a producirla. Hemos visto que el solo hecho de hablar sobre el Club, la homosexualidad o el homoerotismo, implica esa producción, aunque se lea como distancia, extrañeza o ajenitud. El Club ha roto la densa certidumbre de un orden sexual, o participado de su dispersión, haciendo aparecer lo heterogéneo, esos desórdenes centelleantes que inquietaron a los políticos y los hicieron tomar medidas. Si somos fieles al análisis que hemos realizado, agregaría que la diferencia de la diferencia que Derrida menciona, está del lado de las personas que viven con VIH o con sida. Eso lo exploraremos luego.

\section{El significante maestro: desidentificaciones y desclasificaciones}

Como lo vimos a lo largo de este capítulo, una parte importante de la acción del Club ha contado con el soporte simbólico e imaginario (en términos sociales y no psíquicos) de la identidad gay. Dijimos que ésta operaba como el significante maestro de un proceso complejo, que ha desplazado algunas representaciones sociales que vinculan la homosexualidad con el sexo y la fiesta o con la marginalidad y la enfermedad. En el mejor de los casos, los homosexuales son como personajes circenses, divertidos pero vacíos e ineptos para producir algo serio, significativo o duradero. No sólo son políticamente insignificantes, sino simbólicamente improductivos, incapaces de crear algo que les concierna a todos o que 
involucre el orden social. El Club ha rebatido, en la práctica y en sus pronunciamientos públicos (en pláticas con funcionarios, en talleres en las escuelas, en cursos con personal de salud, en charlas con padres y madres, en intervenciones en actos públicos, en entrevistas en las radios locales o en los periódicos, entre otros), esas concepciones y ha mostrado que esos personajes oscuros y cómicos pueden intervenir creativamente en la construcción de los sentidos colectivos y en la transformación de las relaciones sociales.

La identidad gay, como significante maestro, anuncia características y destinos distintos a los que tradicionalmente se le asignaban a estos sujetos. Esta identidad es la que ha establecido con mayor fuerza y sistematicidad una interlocución política con las instituciones estatales, con los medios de comunicación y con la sociedad civil. En este campo, es la identidad sexual con un carácter político más intenso o marcado. El Estado no dialoga con 'putos', sino con gays; las organizaciones civiles o no gubernamentales en este ámbito reivindican nociones como diversidad sexual o disidencia sexual, y rechazan, en general, los términos peyorativos. El sostén político y simbólico de la identidad gay involucra organismos internacionales, instituciones académicas, producción cultural diversa, organizaciones políticas, sociales y culturales de distinto alcance, debates legislativos y jurídicos, grandes marchas en ciudades importantes, entre otros muchos procesos, intervenciones y artefactos sociales.

Sin embargo, los movimientos sociales y organizaciones políticas aglutinadas en torno a la identidad gay o a la diversidad sexual, han convertido al Estado en el interlocutor principal de las políticas sexuales y han privilegiado la ley como el instrumento fundamental para el cambio social y la consecución de la igualdad. En este punto, la acción del Club es claramente diferente y, diría, disidente. Una política que enfatiza la ley por sobre otras dimensiones de lo social estaría ubicada, en términos de Rancière, en el campo de la policía, entendida como las formas estatales de gobierno (Rancière, 1996: 44).

La vida cotidiana, en nuestra mirada, excede al orden policial y estatal y permite la construcción de un conjunto de relaciones sociales en alguna medida autónomas. En términos de Michel de Certeau, la vida cotidiana aloja una multitud de tácticas que modifican el funcionamiento de las "estructuras tecnocráticas" (la policía, en palabras de Rancière), mediante "una creatividad dispersa, táctica y artesanal de grupos o individuos atrapados en lo sucesivo dentro de las redes de la "vigilancia"' (2007: XLV). Los nombres, clasificaciones e identidades de la policía - de las estructuras tecnocráticas del Estado y el mercado- no coinciden necesariamente con los nombres, las clasificaciones y las identidades de la vida cotidiana. Y en 
ese intervalo, donde se localiza la acción del Club, se producen los procesos de subjetivación política que aquí nos interesan. El lugar del sujeto político, escribe Rancière, “(...) es un intervalo o una falla: un estar-juntos como estar-entre: entre los nombres, las identidades o las culturas" (Rancière, 2006: 24). Ese estar-entre impide una identidad definitiva y sustancial y a la vez permite la impugnación de cualquier identidad impuesta y de cualquier clasificación. El mismo Rancière indica que "una lógica de la subjetivación política es una heterología, una lógica del otro" (ibid.: 23).

¿Cuál es el otro al que se remite el Club?, ¿cuál sería su heterología política? El otro, y hemos insistido en esto, es uno cotidiano y cercano, que participa en las relaciones personales más directas e inmediatas. No es el otro constituido por la policía, ni del Estado, ni de la ley; aunque también hable y dialogue con él. Frente a ese otro, los sujetos homosexuales desplazan las identidades estigmatizadas que se les han asignado y a partir de las cuales los insultan o los desprecian.

En este caso, creo que la identificación imposible de la que habla Rancière, es decir lo "(...) que no puede encarnarse en aquellos o aquellas que la enuncian" (ibid.: 22), es, paradójicamente, la misma identidad gay. En algún sentido, según las coordenadas semióticas, estéticas, económicas y culturales de esta identidad, los integrantes del Club nunca la podrán habitar completamente y su identificación será siempre fallida. Tal vez vistos con la mirada de individuos de clase media, con mayor educación, sintonizados con los gustos culturales hegemónicos, quizás globalizados, los integrantes del Club no aparecerán como gays y más bien ocupen el lugar de los homosexuales populares de las grandes ciudades que nunca estarán plenamente integrados a una identidad sexual que es, en muchos modos, una identidad de clase.

En esa medida, la acción político-cultural del Club puede leerse a la luz de lo que Rancière entiende como un proceso de subjetivación política: “(...) un proceso de desidentificación o de desclasificación" (ibid:: 21). No sólo se desidentifica de las formas locales de identificación, también lo hace de sus versiones políticas o comunitarias globales y hegemónicas. Lo gay como significante maestro es una máscara, en muchos sentidos, que permite movimientos puntuales en un orden social, pero que también admite retruécanos y desplazamientos. Las prácticas de libertad que mencionamos en otro momento desclasifican estos cercos identitarios y saltan sobre ellos, para trazar otros territorios desde el deseo. 
De Certeau llamará táctica “(...) a un cálculo que no puede contar con un lugar propio, ni por tanto con una frontera que distinga al otro como una totalidad visible. La táctica no tiene más lugar que el del otro” (De Certeau, 2007: L). Si la táctica no tiene más lugar que el del otro, el Club despliega su acción política desde ahí. Por eso, a contrapelo de las políticas identitarias centrales en las luchas contemporáneas en este campo, el Club tiende a construir una diferencia como un lugar de interlocución con los otros antes que como un sitio de distinciones y distancias. Rancière arguye que "(...) el lugar de manifestación de la diferencia no es lo "propio" de un grupo o su cultura. Es el topos de un argumento" (Rancière, 2006: 24). El Club sería un lugar de argumentación, no de separación, en el que se construye y despliega una identidad para poder dialogar con las distintas alteridades e identidades de la localidad. Una identidad imposible, como antes dijimos. De este modo, la diferencia atraviesa el campo de las identificaciones políticas potenciales; si lo gay sirve como significante maestro es porque enmascara las diferencias que lo atraviesan, porque elude la beterología al borrar su propia alteridad en la reivindicación de una identidad reconocible y aceptable (policial, en términos de Rancière; tecnocrática, en los de De Certeau). 


\section{III \\ Epistemes locales. \\ Sexualidad, formaciones discursivas y redes de significación}

Por muy agradecidos que podamos estar en acoger el espíritu objetivo -
quien no se ha hartado de toda subjetividad y su ambigua forma de ver las
cosas—-, en última instancia, no obstante, debemos ser prudentes, incluso
en relación con nuestra propia gratitud.

F. Nietzsche, Más allá del bien y del mal, citado en W.H. Auden, Iconografía romántica del mar, 1996: 47

Desde que inicié mi trabajo de campo en Tenosique escuché diversos argumentos en torno a la homosexualidad, explicaciones con distintos grados de complejidad, pero que coincidían en un intento por esclarecer sus causas, sus motivos y sus orígenes. Estas argumentaciones, que se inscribían en un campo más general de reflexiones en torno a la sexualidad, los cuerpos y los géneros, conforman, a mi entender, un modo de pensar. Si bien, es un modo de pensar tributario de diversos discursos e instituciones, también constituye una formulación local. He querido llamar epistemes locales a las formas en las que una comunidad o localidad específica piensa la sexualidad, las identidades y el deseo. Ellas surgen, como veremos, de la intersección histórica, pero local, de redes de significación y formaciones discursivas y producen desplazamientos importantes en los modos de pensar los tres campos mencionados. Son sedimentaciones históricas de dichos modos, pero también terrenos de disputas ideológicas y políticas, que permiten su transformación. Dado que, al menos en el momento que estudié, tributan tanto de las redes locales, resignificándolas, como de las formaciones discursivas, interpretándolas, pero también localizándolas, no son estrictamente ni las unas ni las otras. Por esto, para los fines de mi estudio, las epistemes locales son un locus que permite estudiar el cambio cultural, expresado en este caso, en las formas de clasificar, explicar y significar.

Veremos, más adelante, que esas epistemes se traducen en prácticas sociales específicas que se forman en los sistemas expertos, que crean una densa red de discursos en torno a la sexualidad, y articulan una serie de espacios y de prácticas institucionales que intentan regularla y producirla, como en las interacciones cotidianas, cara a cara, organizadas en torno a una también densa red de relaciones sociales (de género, de clase y generacionales, fundamentalmente). 
La historicidad de estas epistemes permitirá distinguir formas de pensar la sexualidad de larga duración, por ejemplo, aquellas que se articulan en torno al binarismo de sexo-género; y otras novedosas, como las que distinguen identidades sexuales diversas. Pero no será una historicidad lineal, en la que un avance modernizador repliegue las viejas formulaciones y fortalezca las nuevas. Más bien, creo que es necesario pensarla como una sedimentación de redes y de formaciones discursivas que han sido leídas de maneras específicas en el lugar que investigo. Así, los discursos psiquiátricos sobre la homosexualidad, que comenzaron a formularse y expandirse en México durante el siglo XX convivirán, si se me permite la palabra, con los discursos más recientes sobre las identidades sexuales que han elaborado, en este campo, la sexología y los movimientos políticos. Y ambos estarán atravesados por formas de clasificar que son quizás mucho más antiguas, como las denominaciones populares de ciertos deseos, corporalidades y comportamientos. Una episteme local, que no está sometida a los mismos rigores que las científicas, puede articular estos tres planos temporales y elaborar clasificaciones y significaciones particulares, que desplazan formas antiguas, pero que no las eliminan por completo. De esta forma, por ejemplo, el gay convive con el homosexual y con el puto. Pero no en un plano horizontal, sino que en una trama de significaciones desniveladas, si se me permite la imagen. Lo que tienen en común estas tres denominaciones es una intención de clasificar. Pero sus orígenes y sus resultados son muy diversos entre sí. Me interesa develar este punto, porque las denominaciones permitirán subjetivaciones diferenciales. A mi entender, sólo la identidad gay sostendrá un proceso de politización y será el artefacto de cambios culturales relevantes. Pero, en cambio, la homosexualidad constituirá un ancla para las relaciones entre las instituciones, especialmente las médicas y pedagógicas, con los grupos sexualmente minoritarios. El puto será la denominación central en el habla cotidiana y, aunque implica mayor estigma, también será la forma en que los sujetos homosexuales participen de ciertas relaciones sociales: aquellas vinculadas con la diversión y la risa y las del ligue y el deseo.

Los discursos científicos y las instituciones que los sustentan y los llevan a la vida cotidiana atraviesan las redes de significación. En el campo de la sexualidad, las redes de significación en Tenosique están todas marcadas por algún tipo de discurso, concepto o concepción de tipo científico. Son saberes científicos sedimentados en la vida cotidiana, pero que se utilizan articulados, algunos de ellos, con las instituciones que son su sostén principal o su referente; y no sólo sirven para explicar ciertos fenómenos, sino para relacionarse con ellas. Al menos hay tres instituciones que utilizan discursos o conceptos científicos y que son sus principales 
fuentes, aunque operan de modo y en registros distintos. Primero, la institución médica, que tiene un formidable poder interpretativo y goza de una gran legitimidad social como fuente de saberes verídicos y fidedignos sobre la enfermedad, el cuerpo, la sexualidad y la subjetividad. Luego, la institución pedagógica, que enseña esos discursos como las fuentes de un conocimiento social válido y legítimo. Por último, pero de un modo muy distinto, los medios de comunicación, que son poderosos socializadores de esos discursos y sus racionalidades, mediante una serie de intervenciones, diversas entre sí, pero que se legitiman en el saber científico, médico y terapéutico.

Las epistemes locales resignifican y rearticulan esos conocimientos y esos saberes de un modo que llamaré paracientífico. En antropología hay una larga discusión sobre la clasificación de los saberes y los conocimientos de sociedades diferentes (Durkheim y Mauss, 1969 [1903]; Goody, 2008; Lévi-Strauss, 2009[1962]). Dicho debate tuvo como parámetro el pensamiento científico occidental, que permitía comparar otras formas de pensamiento, ya sean míticas o tradicionales. Esa discusión se ve complementada por otra, también muy compleja, sobre la extensión y los efectos de la modernidad en las sociedades que fueron colonizadas por los países occidentales. Creo que la noción de paracientífico permite, por una parte, reconocer la importancia que adquieren los discursos científicos en la construcción de significaciones colectivas, pero también atender a los desplazamientos que muchos de los conceptos y concepciones que esos discursos utilizan -y también promueven-, experimentan en un contexto local. Entonces la oposición, si la hubiera, no es entre científico y mítico, ni entre tradicional o moderno, sino más bien entre formas de uso de los conocimientos científicos, sus inscripciones institucionales y las legitimidades que promueven y disputan. Lo trabajaré con mayor detalle más adelante, pero por ejemplo, ante los discursos religiosos que condenan la homosexualidad, los integrantes del Club recurren, fundamentalmente, a este tipo de saberes que les permiten, de algún modo, enfrentar el poder simbólico de las iglesias.

Si bien algunas de las tensiones que todos esos debates registraban no son pertinentes para mi argumento ni para el colectivo que estudio, creo que es importante reflexionar sobre la intensidad con la que los discursos científicos, que no sólo son un conjunto de narrativas, explicaciones y legitimidades, sino formas específicas de pensar, han permeado las redes locales de significación que, de algún modo, existían antes de que esos discursos adquirieran la importancia que hoy tienen. Mi investigación tiene una perspectiva histórica de corto alcance, por lo que desconozco cuáles eran las redes que existían con antelación a la llegada de los 
discursos científicos y, también, los militantes o identitarios. Las redes con las que puedo trabajar están atravesadas todas, de una u otra manera, por esos discursos y saberes. ${ }^{11}$ Por esa razón, no creo que sea pertinente distinguirlas entre tradicionales o modernas, como lo han hecho otras investigaciones en este campo (Amuchástegui, 2001; Carrillo, 2002). El relativo aislamiento de Tenosique permitiría hipotetizar que esos discursos llegaron recientemente y que las redes conservaron su gramática hasta hace poco tiempo. La investigación social en México permite sostener, no obstante, que los cambios que sucedieron en esas redes de significación fueron producidas, fundamentalmente, por los discursos científicos, por un lado, y por los identitarios, por otro (Argüello, 2013 y 2014; de la Dehesa, 2010; Díez, 2011; Guerrero, 2014; Núñez, 2000, 2007 y 2009; Salinas, 2008; Parrini, 2011 y 2012; McMannus, 2013).

En este sentido, esta investigación logra reconstruir la ruptura de las redes previas de significación y su reconfiguración. Algunos de mis informantes nacieron y se educaron en un contexto en el que no existía, por ejemplo, la identidad gay y apenas estaba socializada la noción de homosexual. La única identidad, si fuera una, de la que disponían era la de puto y sus sentidos y términos colindantes. Socializaron en este espacio difuso, pero bastante extendido, que se conoció como el ambiente (González Mateos, 2005; Laguarda, 1997 y 2009; Monsiváis, 1997, 1998 y 2010; Rodriguez, 2012; Vargas, 2011). En cambio, otros nacieron en un momento histórico en el que la identidad gay ocupaba una parte importante de los sentidos que se vinculaban con el homoerotismo, existía como una identidad pública ampliamente conocida y era reivindicada por colectivos y sujetos.

La pregunta es qué lugar ocupan estos saberes paracientíficos en la ruptura relativa de esas redes, pero más importante aún, en su reconfiguración. Creo que tendremos una respuesta si consideramos el doble movimiento que sucede entre formaciones discursivas y redes de significación. Por una parte, las formaciones discursivas -científicas o legales- transforman las

\footnotetext{
${ }^{11}$ Dado que no he podido tener acceso a materiales que me permitan saber cómo eran esas redes de significación el corte temporal que propongo es ficcional, en alguna medida. Si bien las historias de vida de los integrantes del Club muestran transformaciones desde la década de los setenta del siglo XX hasta ahora, no son suficientes para reconstruir las redes de significación previas a la irrupción de los discursos científicos y los identitarios. Si bien no hay redes de significación locales que no hayan sido modificadas, de alguna forma, por las instituciones y los discursos científicos (sean médicos o pedagógicos) y los discursos identitarios, dado que ambos son históricos y 'arribaron' a la localidad en cierto momento, podemos suponer que las redes de significación previas a ellos eran distintas.
} 
redes de significación y las obligan a desplazarse hacia un campo semántico nuevo. Por ejemplo, hoy en día un funcionario público o un médico no podrían referirse públicamente a los homosexuales como maricones, aunque en privado lo hagan sin restricciones. El lenguaje institucional los obliga al uso de ciertos términos, estén o no de acuerdo con ellos. Las formaciones discursivas, en este sentido, son también constricciones a las prácticas discursivas cotidianas o institucionales. Pero, por otra parte, las redes de significación se apropian de los términos y discursos científicos, desplazándolos a su vez. El uso cotidiano de esos términos y denominaciones no responde, necesariamente, a las exigencias argumentales de la ciencia. Creo que esto es válido para otras formaciones discursivas, como las jurídicas y las militantes.

\section{Condiciones de posibilidad y epistemes}

Quisiera retener una noción de episteme que Foucault plantea en la introducción de Las palabras y las cosas, y que luego desarrolla a lo largo de su obra. ${ }^{12}$ En esas páginas la define como un "campo epistemológico" en el que “(...) los conocimientos, considerados fuera de cualquier criterio que se refiera a su valor racional o a sus formas objetivas, hunden su positividad y manifiestan así una historia que no es la de su perfección creciente, sino la de sus condiciones de posibilidad" (Foucault, 2008[1968]: 7). Son justamente esas condiciones de posibilidad las que el concepto de episteme local permitirá dilucidar en un contexto específico como el que investigo. Sin duda que hay, también, formas de racionalidad, modos de comprender la relación entre conocimiento, sociedad y naturaleza, diversas filtraciones de patrones morales y éticos. Pero, sobre todo, lo que esa episteme produce, como plataforma de transformaciones sociales y simbólicas, son nuevas condiciones de posibilidad para ciertos enunciados y discursos. A su vez, determinadas condiciones de posibilidad (de distinta índole y amplitud) permiten la constitución de nuevas epistemes y sus mutaciones. Este proceso no sólo corresponde a la

\footnotetext{
${ }^{12}$ El uso que hago de la noción de episteme no es literal ni estricto, respecto de la obra de Foucault. En La arqueología del saber la define como “(...) el conjunto de las relaciones que pueden unir, en una época determinada, las prácticas discursivas que dan lugar a unas figuras epistemológicas, a unas ciencias, eventualmente a unos sistemas formalizados”, y también como “(...) el conjunto de relaciones entre unas ciencias, unas figuras epistemológicas, una positividades y unas prácticas discursivas" (Foucault, 2010a[1969]): 249 y 250). El uso que hago de este concepto se vincula, sin duda, con las figuras epistemológicas, las ciencias y unas prácticas discursivas, pero no se limita a ellas. Pero en ese mismo libro, Foucault ya visualizaba arqueologías distintas a las que él realizaba. Eso lo retomaré más adelante.
} 
construcción de otros conocimientos, enunciados y posiciones de sujeto, como luego lo veremos, sino a un campo en el que se expresan y se juegan dinámicas políticas de diferente envergadura, pero que forman parte de esas condiciones de posibilidad.

Aunque esas dinámicas no sean centrales en el análisis de Foucault, sí lo son en el que intento realizar. Debemos enfatizar que los procesos políticos son productores de nuevos conocimientos y que, en el caso de las políticas sexuales, esa producción es capital. ${ }^{13}$ Tanto el feminismo como los movimientos de las minorías sexuales (en sus diversas expresiones) han sido corrientes epistémicas, que han discutido una forma de conocer y clasificar la sexualidad, el cuerpo, los deseos y las relaciones sociales en general (Haraway, 1995; Hartsock, 1983; Braidotti, 2009). Foucault, en algún momento de Las palabras y las cosas, escribe que "[E]s necesario reconstituir el sistema general del pensamiento, cuya red, en su positividad, hace posible un juego de opiniones simultáneas y aparentemente contradictorias. Es esta red la que define las condiciones de posibilidad de un debate o de un problema y ella es la que porta la historicidad del saber" (Foucault, 2008[1968]: 81). Si bien no es mi objetivo reconstruir esa red en su gigantesca extensión y diversidad, al menos la que constituye un saber sobre la sexualidad y la homosexualidad, creo que debemos contemplarla como horizonte histórico. Lo interesante del análisis foucaultiano es que admite que dos o más discursos aparentemente contradictorios formen parte de la misma red y que, por tanto, resulten de las mismas condiciones de posibilidad. Lo que cabe preguntarse es qué sucede si esas condiciones se modifican. Creo que las epistemes locales permiten identificar esos momentos, por así llamarlos, en los que dichas condiciones comienzan a transformarse, aunque no dejen de formar parte de un sistema general de pensamiento ni inauguren otro.

No obstante, debemos destacar que las condiciones de posibilidad de enunciados como puto, homosexual y gay son distintas y que las epistemes locales, al articular formaciones discursivas con redes de significación, permiten resolver parte de las contradicciones y tensiones que dichas diferencias producen. Al ser fundamentalmente modos prácticos de pensar, no requieren de una certificación lógica ni deben respetar, necesariamente, las

\footnotetext{
${ }^{13}$ La investigación más reciente en México ha mostrado que la configuración de un campo de saber se vincula con la constitución de una/s identidad/es. El vínculo entre discursos científicos y políticos comienza a esclarecerse paulatinamente. Véase por ejemplo, Argüello (2013 y 2014) y Guerrero (2014), también McMannus (2013). Creo que hay pocos datos, no obstante, sobre el uso de la ciencia y de los saberes científicos por parte de movimientos políticos y sociales en el ámbito de la diversidad sexual.
} 
convenciones que ciertas formaciones discursivas exigen para mantener su integridad (un médico, por ejemplo, no debería dar explicaciones mágicas). Foucault escribe, al preguntarse cómo se constituye cierto orden, que “(...) nada hay más vacilante, nada más empírico (cuando menos en apariencia) que la instauración de un orden de las cosas; nada exige una mirada más alerta, un lenguaje más fiel y mejor modulado; nada exige con mayor insistencia que no nos dejemos llevar por la proliferación de cualidades y de formas" (Foucault, 2008[1968]: 5). Si pensamos, en consonancia, cómo se disipa un orden, las advertencias foucaultianas pueden ser tan pertinentes que si investigáramos cómo se constituye. Nada hay más vacilante, diríamos también, que la transformación de un orden o su desplazamiento. Pero cabe preguntarse qué significa no dejarse llevar "por la proliferación de cualidades y de formas". Si bien los enunciados que pertenecen a órdenes diversos, conviven temporalmente (como, por otra parte, ha sucedido muchas otras veces), la proliferación de las cualidades y las formas puede leerse, a mi entender, como una advertencia para evitar localizar la transformación en el campo de las identidades (que sin duda, también la hay). Debemos retroceder a un nivel previo, quizás más imperceptible, de ahí la insistencia de Foucault en la mirada alerta y el lenguaje fiel, a un nivel en el que los contenidos concretos comienzan a diferenciarse y a producir efectos de sentido distintos. Creo que en ese registro encontraremos formas distintas de pensar que conviven, como pueden cohabitar las contradicciones en la vida social, pero que no dejan de producir una honda modificación de los modos de comprensión e interpretación. En este sentido, y para regresar al ejemplo que antes di, enunciados como puto, homosexual y gay, representan o suponen modos de comprensión distintos. Cabe determinar cuáles son las consecuencias de esa diferencia.

Foucault prosigue sosteniendo que: “[E]l orden es, a la vez, lo que se da en las cosas como su ley interior, la red secreta según la cual se miran en cierta forma unas a otras, y lo que no existe a no ser a través de la reja de una mirada, de una atención, de un lenguaje" (Foucault, 2008[1968]: 5). Creo que dicha reja es lo que se está modificando, pero esta vez en la mirada que los sujetos y los grupos se dirigen a ellos mismos. Por eso son tan relevantes los desplazamientos someros del lenguaje, que a veces resultan imperceptibles justamente por la capacidad social de decir cosas contradictorias sin que se produzcan mayores conflictos. Es decir, el lenguaje sigue operando como si no hubiese modificaciones y sólo en un determinado momento registra esas tensiones y sufre un cambio de mayor calado. Pero no estamos aún en ese momento, en el que ciertas palabras desaparecen y se olvidan y otras surgen, en el que la 
mirada se reconfigura y se ven por lo tanto otras cosas y se pueden producir enunciados diferentes. Sólo presenciamos un momento previo en el que se intensifican las contradicciones y las tensiones. Estamos, quizás, en el momento en que se configura un "sistema de elementos”, según Foucault, “(...) el umbral por encima del cual habrá diferencia y por debajo del cual habrá similitud".

¿Cómo definen las epistemes locales esos umbrales que marcan relaciones de diferencia o similitud? Esto me parece fundamental, porque justamente la modificación de esa red que menciona Foucault tiene como vector principal la transformación de los umbrales de diferencias y similitudes. La figura del puto registra un umbral de similitud con respecto a la feminidad y las mujeres y otro de diferencia en relación a la masculinidad y los hombres. En cambio, la figura del gay realiza justamente la operación contraria: remarca la diferencia con lo femenino y acentúa la similitud con lo masculino. La figura del homosexual, al menos en sus usos científicos, tiene una historia más ambigua, a mi entender, porque mientras fue leída como una inversión, entonces se ubicaba en un lugar similar a la figura del puto. Pero cuando comenzó a formar parte de discursos psiquiátricos más progresistas o de los sexológicos, e incluso militantes, tuvo mayores parecidos con la del gay. Estos umbrales diferenciados serán capitales en la articulación de las redes de significación locales con las formaciones discursivas, que he sostenido forman una episteme local en el campo de la sexualidad.

\section{Textos borrosos, espíritus indemnes}

Si es cierto que un etnógrafo encara, como lo sostiene Geertz, “(...) una multiplicidad de estructuras conceptuales complejas, muchas de las cuales están superpuestas o enlazadas entre sí, estructuras que son al mismo tiempo extrañas, irregulares, no explícitas, y a las cuales el etnógrafo debe ingeniarse de alguna manera, para captarlas primero y explicarlas después" (Geertz, 2005[1973]: 24), entonces la noción de epistemes locales permitiría dirimir, en alguna medida, entre dichas estructuras conceptuales y entender sus superposiciones o enlazamientos. Sin duda que esas epistemes son "extrañas, irregulares, no explícitas", pero también tienen una forma y permiten pensar de cierto modo. Creo que la rareza no es una descripción suficiente, aunque sea necesaria, para esas epistemes. Si logramos identificar formaciones discursivas, por un lado, y redes de significación, por el otro, y podemos entender cómo se han entrelazado en este contexto y qué estructuras de significación han producido, entonces podremos reconstruir un 
proceso histórico en el que ciertas estructuras conceptuales complejas se han encontrado, han colisionado y se han transformado, deslizándose unas en otras. Podríamos decir, de este modo, que las epistemes locales son el resultado de ese proceso de conflicto y filtración entre estructuras de significación. Pero, como sostendré en otros capítulos, no se trata sólo de significaciones: ese proceso ha producido, en muchos sentidos, una forma de vida, en el sentido wittgenstaniano, y ha creado una serie de prácticas sociales novedosas. A mi entender, cuando hablamos de sujetos y de colectivos que apenas emergen en el campo histórico y que articulan una voz y un discurso de manera incipiente y novedosa, las nuevas significaciones que se disputan en las epistemes locales no sólo son formas de comprender un mundo, sino de vivirlo. ${ }^{14}$ Creo que esto es lo más relevante.

"Hacer etnografías, escribía Geertz, es como tratar de leer (en el sentido de interpretar un texto') un manuscrito extranjero, borroso, plagado de elipsis, de incoherencias, de sospechosas enmiendas y de comentarios tendenciosos y además escrito, no en las grafías convencionales de la representación sonora, sino en ejemplos volátiles de conducta modelada." (Geertz, 2005[1973]: 24). Si así lo fuera, habría que añadir que no basta con leer ese texto borroso, plagado de elipsis y de incoherencias — rasgos paralelos a la extrañeza y la irregularidad no explícitas de las estructuras conceptuales-, también es necesario poder entenderlo en su dimensión práctica. ¿Qué hacen los sujetos, los grupos, los colectivos y las comunidades con ese texto borroso?, ¿'es igualmente elíptico e incoherente para todos los que participan en una cultura?, ¿quién puede enmendar el texto y quién no?, ¿son todos los comentarios igualmente válidos y posibles? Quizás las epistemes sean una forma de entender cómo determinados textos, por ejemplo, los de la sexualidad y el deseo, se tornan borrosos o transparentes, se hacen más o menos incoherentes o son enmendados, pero no por los mismos actores ni de las mismas maneras.

Ese trajín textual es lo que, finalmente, tenemos en una etnografía, aunque Geertz enfatice demasiado, a mi entender, el resultado sobre el proceso de crear, reproducir, y cuestionar los textos. Geertz discute la pertinencia de distinguir la cultura como una "conducta estructurada o una estructura de la mente", en tanto entenderá la conducta como acción simbólica. Lo que me interesa remarcar cuando utilizo la noción de epistemes locales es que ella permite identificar el

\footnotetext{
${ }^{14}$ Si bien no será la ruta que tome en este capítulo, creo que las epistemes locales podrían leerse, también, como juegos de lenguaje, que Wittgenstein define como "el conjunto consistente en el lenguaje y en las acciones en las que él está entretejido" (citado en Laclau y Mouffe, 2006: 147).
} 
umbral en el que una conducta se transforma en acción simbólica. Si retomo un ejemplo que di previamente, cuando algunos de los integrantes del Club inscriben sus deseos y sus experiencias en la estructura conceptual gay u homosexual, lo que hacen también es inscribir sus conductas en un campo simbólico legible e interpretable. Lo que no daría por sentado es que las conductas sean, necesariamente, acciones simbólicas, ni que puedan ser interpretadas. Me parece que la historia de ese anciano que nace en un mundo con códigos específicos para su deseo que se desvanecen, a lo largo de su vida, y que encuentra otros paulatinamente, muchas veces a su pesar, es también la historia de una vida que no podría ser interpretada cabalmente, si es que alguna lo fuera. Él mismo se queja, luego, de que la irrupción de la identidad gay y el uso que hacen de ella algunas personas en la ciudad significó una modificación de sus propias coordenadas de vinculación erótica: al simbolizar, si se me permite la palabra, los deseos mediante una identificación, lo que se rompe es un pacto de silencio, totalmente implícito, que le permitía tener contactos con hombres diversos de manera continua, pero soterrada. Digamos que él es obligado, ya en su adultez tardía, a interpretar de un modo nuevo sus conductas y a simbolizarlas de otra forma. ${ }^{15}$ Pero quizás esa aparente ausencia de sentido, al menos de uno que tuviera un soporte colectivo o público, finalmente las sustentaba. Cuando fueron conductas públicas, y además formas de identificación, comenzaron a perder la inscripción que antes tuvieron: el silencio y el sobreentendido.

Geertz sostiene que si entendemos la conducta como acción simbólica, aquello por lo que hay que preguntarse “(...) es por su sentido y su valor” (Geertz, 2005[1973]: 24). Pero

15 Es importante considerar que este informante es un ferviente católico que supo convivir con su homosexualidad y sus creencias. Su argumentación moral es religiosa y se contrapone o se aleja, en muchos puntos, de los discursos sobre la diversidad sexual, la tolerancia y los derechos humanos. Fue católico a la vez que homosexual y las tensiones que podrían surgir de ambas experiencias las solucionó íntimamente, si es que las hubiese experimentado, no las transformó en recursos para una posición política o ética. Cuando en un debate radial un pastor evangélico le dice a Alan Contreras que Dios ha ordenado que sólo una mujer y un hombre yazgan en el mismo lecho, él le responde que no se preocupe, porque entonces "sólo lo harán parado". Esa respuesta irónica habría sido impensable para el otro informante, que tenía una actitud de profundo respeto hacia la religión y sus representantes. En esa medida, lo que llamaremos el discurso de la diversidad sexual no sólo lo obligaba a repensar su identidad y lo reposicionaba en las tramas eróticas locales, sino también cuestionaba la relación entre su sexualidad y sus creencias y prácticas religiosas. No quiero decir, por supuesto, que ambos sean dicotómicos (porque en términos cotidianos no lo son), pero cuando emerge una voz minoritaria en el terreno sexual, entonces se producen debates inéditos entre actores que antes no dialogaban. 
retengamos la idea de que podemos describir conductas que no tienen necesariamente sentidos sociales (que son los que nos interesan) y que carecen de valor. Esto evitaría que limitáramos nuestra investigación a “( ...) descubrir las estructuras conceptuales que informan los actos de nuestros sujetos, lo 'dicho' del discurso social” (ibid.: 37). Si bien estamos tratando de descubrir cómo esta comunidad piensa la sexualidad y el deseo, específicamente en el campo del homoerotismo, creo que no podemos trabajar sólo con lo "dicho" del discurso social. Debemos extender el análisis tanto a lo que no puede ser dicho como a lo que comienza a serlo, que ya aludimos cuando mencionamos las condiciones de posibilidad de una episteme. Incluso si seguimos la sugerencia de analizar las formas simbólicas estrechamente ligadas “(...) a los hechos sociales concretos, al mundo público de la vida en común” (ibíd:: 39), necesitamos preguntarnos cómo analizar la formación de nuevos hechos sociales y estudiar el campo de lo que no puede categorizarse como tal y lo que aún no ingresa (ni tampoco cabe) en el mundo público. La vida en común sería también un espacio de imposibilidades, de evitaciones, de experiencias que no pueden articularse colectivamente, de actos y vínculos que no se transforman en hechos sociales. Justamente, las epistemes, atentas a las condiciones históricas de posibilidad y a los umbrales, permiten identificar aquellos puntos en los que comienza a constituirse un hecho social, a la sombra de las experiencias y los silencios, y el mundo común comienza a reconocer e integrar, de modos diversos, conductas antes inusitadas.

Si volvemos sobre un párrafo de Foucault, creo que cabe preguntarse si podemos investigar aquello que aún no ha sido incorporado a “(...) la reja de una mirada, de una atención, de un lenguaje.” (Foucault, 2008[1968]: 5) ¿Dónde está aquello que aún no forma parte de un orden, pero que de manera silenciosa lo está modificando?, ¿qué estatus tiene todo ese material cultural, experiencial y subjetivo que aún no tiene una inscripción precisa, pero que perturba el orden (simbólico y social)?, ¿qué puede hacer la antropología con todo lo que no logra analizar de manera precisa, con esas borrosidades e incoherencias, pero aún más, con esos rastros casi imperceptibles y difíciles de formalizar, que son, según mi propuesta, las evidencias tenues de la transformación de las estructuras conceptuales, de las formas de vida y de los textos? Junto con lo que Foucault llama "la red secreta" que permite un orden, habrá que pensar otra red, quizás igual de secreta, que está formada por todo aquello que aún no cabe en un orden determinado, que lo excede y también lo orada.

Convengamos con Geertz que la cultura no es una 'entidad', a la que se le podrían atribuir “(...) de manera causal acontecimientos sociales, modos de conducta, instituciones o procesos 
sociales", sino un contexto, "dentro del cual pueden describirse todos esos fenómenos de manera inteligible, es decir, densa” (Geertz, 2005[1973]: 27). Aceptemos, también, que la cultura es pública, "porque la significación lo es” (ibid:: 26). Pero ahora pensemos qué implican ambas proposiciones para estudiar lo que aún no es público o lo es de una manera específica, o lo que está fuera del contexto, en sus deslindes o más allá de él. Deberíamos entonces matizar ambas ideas, planteando que el carácter público de una significación es un rasgo conflictivo, que aloja disputas en torno a lo que es o no público, lo que podría serlo y lo que aún no lo es. Para el estudio de la homosexualidad esto será de capital importancia, porque justamente discute los límites de lo público y también de lo común, como lo vimos en el capítulo anterior. Pero, por otra parte, discute el contexto en el que comienza a emerger como asunto y práctica pública. Carlos Monsiváis (1998) plantea a propósito del escándalo del Baile de los $41^{16}$, que la homosexualidad antes de ese evento fue impensable. Creo que esta idea hay que entenderla de manera precisa, que fuera impensable no significa que no existiera y, de hecho, hay registros de ella, como práctica sexual delimitada, durante toda la Colonia y el siglo XIX (Gruzinski, 1988; Macías-González, 2004; Molina, 2010; Reséndiz, 2014). El asunto no es su facticidad sino, más bien, su representabilidad. Cuando aparece como motivo de escarnio y escándalo en la esfera pública finisecular, se convierte en una significación pública de la que se puede hablar (lo dicho del discurso social, en términos de Geertz). Esa aparición modifica el contexto. Pero no es una especie de creación ex nibilo, más bien representa, a mi entender, la culminación de un proceso de infiltración en el orden existente, que lo fue modificando paulatinamente. Si describir de manera densa implica establecer cierta inteligibilidad me parece que debemos pensar cómo hacerlo en los bordes de los contextos (públicos) en los que nuevas inteligibilidades pugnan por producirse. ¿Cuál es la densidad de dichos bordes?, ¿cuáles son las inteligibilidades que podemos observar en ellos cuando los reconocemos e intentamos comprenderlos?, ¿qué

\footnotetext{
${ }^{16}$ El 17 de noviembre del año 1901, la policía hizo una redada en una fiesta privada, que se llevaba a cabo en una lujosa casa del centro de la ciudad de México. Detuvo a los 41 invitados. La mitad de ellos, según las crónicas de la época, estaban vestidos de mujer y hacían de parejas de la otra mitad, de apariencia masculina. La mitología urbana dice que el invitado número 42 era el yerno del presidente Porfirio Díaz y que por sus influencias escapó y no fue incluido en el escándalo y el escarmiento posteriores. Varios de los detenidos travestidos fueron desterrados a Yucatán, junto con una compañía militar. (Irwin et al., 2003).
} 
transformaciones se juegan ahí?, ¿qué modificaciones del orden están pendientes en esos deslindes?

Foucault define la discontinuidad como “(...) el hecho de que en unos años quizá una cultura deje de pensar como lo había hecho hasta entonces y se ponga a pensar en otra cosa y de manera diferente" (Foucault, 2008[1968]: 57). Si estuviéramos, como luego argumentaré, ante una discontinuidad semejante, es decir, ante el hecho de que una cultura deja de pensar de un modo y comienza a hacerlo de otro, las epistemes locales permitirían identificar, pero también describir, los pormenores de ese momento. La discontinuidad, dirá Foucault, plantea el problema de las relaciones entre el pensamiento y la cultura: “¿cómo es posible que el pensamiento tenga un lugar en el espacio del mundo, que tenga algo así como un origen y que no deje, aquí y allá, de empezar siempre de nuevo?” (ibid.).

Geertz señala que los sistemas culturales deben poseer un mínimo grado de coherencia, para que se los pueda llamar sistemas. Sin embargo, advierte que dicha coherencia no podría ser "la principal prueba de validez de una descripción cultural" (Geertz, 2005[1973]: 30). ¿Qué sucede con esa coherencia, la de los sistemas, pero también la de las interpretaciones, cuando una cultura comienza a pensar de un modo diferente y se enfrenta a la discontinuidad de sus discursos y sus estructuras conceptuales? Creo que las epistemes locales permitirán entender, al menos en parte, cómo se resuelve este dilema. Al formarse con unos materiales que provienen de formaciones discursivas como la medicina o la pedagogía y otros de las redes de significación locales, esas epistemes intentan producir algún tipo de coherencia, aunque sea tambaleante y provisional. Gran parte de las colisiones interpretativas que analizaré más adelante, muestran cómo se intentan crear esas coherencias y cómo son constantemente desafiadas por formas de discontinuidad que no logran incorporarse. Por esto, las epistemes no son campos de quietud conceptual o discursiva, sino al contrario, de batallas interpretativas. Una episteme local no está sometida, y es importante resaltarlo, a las mismas exigencias de coherencia que muchas formaciones discursivas, como las que ya citamos. Es decir, admite un grado bastante amplio de incoherencias, contradicciones, superposiciones, porque la única demanda que la condiciona es que sea capaz de generar sentidos y de producir interpretaciones socialmente válidas, aunque sean argumentativamente contradictorias.

Citaré una conversación que tuve con una funcionaria pública de Tenosique en la que ella me comentó que los gays eran personas que tenían un alma de mujer en un cuerpo de hombre, pero que su espíritu, no obstante, era masculino. Le pregunté qué significaba eso y ella me 
comentó que como el espíritu era la conexión con Dios, no podía haber engaño en ese plano. Pero el alma, que era el vínculo con el mundo, a través de un cuerpo, podía admitir confusiones, como las que ellos experimentaban: tener en su cuerpo un alma equivocada. ¿Ésta es una interpretación religiosa? Tiene trazos de discursos religiosos, pero no alcanzan a contenerla ni explicarla. ¿Qué tipo de discurso permite proponer una discontinuidad entre el alma y el cuerpo y entre ambos y el espíritu?, ¿se han filtrado saberes más esotéricos o algunos psicoterapéuticos, que tributan de lecturas de la identidad, pero las trastocan mediante interpretaciones de carácter religioso? Habría que preguntarse, primero, qué le permite comprender a esta funcionaria una interpretación semejante: elaborar una respuesta frente a un campo de grandes complejidades, como las del cuerpo y las identidades, el deseo y la transcendencia. Ella admite, en una lectura tributaria de las redes locales de significación, que el deseo homoerótico implica una transposición de los cuerpos y las identidades: si un hombre desea a otro hombre sólo puede hacerlo en tanto "mujer" y desde un lugar femenino. Entonces el deseo es indicativo de una alteración del vínculo entre cuerpo y alma (que sería extensiva a la psicología y la personalidad individuales). En este aspecto no hace sino reproducir discursos sociales sólidamente inscritos en la ciudad. La novedad que ella introduce es diferenciar entre alma y espíritu y restringir la inversión de la homosexualidad al primero, dejando incólume al segundo. No sé cuáles son las estructuras conceptuales que le permiten hacer esto, pero me parece que no es ninguna en particular y, más bien, se trata de una lectura un tanto sui generis, pero sustentada en ciertos discursos. No obstante, lo que ella hace es impedir que la trascendencia (Dios) se vea afectada por las inversiones del deseo. Es decir, si bien en el mundo humano al parecer todo se puede alterar, invertir y traslapar (incluso el cuerpo y el alma), a Dios no se le puede engañar y Él rechaza esos desplazamientos. El espíritu, creación suya que permite que los humanos mantengan una conexión con lo divino, no puede ser modificado en su naturaleza fundamental.

Entonces, el binarismo masculino y femenino (soporte de los discursos sociales en torno a la diferencia sexual), que forma parte de una estructura conceptual de larga data y una gran fortaleza cultural, sirve para realizar dos operaciones reflexivas: entender el desorden que supone la homosexualidad y conservar el mandato y la potestad divinos que garantizan el orden sexual del mundo, de tipo binario. Los homosexuales tienen almas invertidas, pero espíritus inalterados. Sólo en el mundo puede haber homosexualidad, porque en un plano trascendente no la hay. Es interesante que esa distinción y la defensa que esta mujer realiza del espíritu, 
permitan suavizar los efectos que la historia y los procesos sociales tienen sobre la sexualidad y la diferencia. Ella habla en un contexto donde los sujetos homosexuales son interlocutores de estos discursos sociales y podrían impugnarlos, cuando la inversión ya tiene un espacio social y público bastante notorio. Su interpretación debe convivir con otras, tal vez disímiles u opuestas. Pero su estrategia (que no es sólo personal o idiosincrática), permite proteger la coherencia del mundo y de cierto tipo de interpretaciones. Dios se transforma en el cobijo de dicha coherencia y en la figura narrativa que permite darle una transcendencia que la protege de los avatares de la historia y de la corrosión que producen ciertos discursos.

Foucault, en La arqueología del saber, indica que las relaciones discursivas no son interiores al discurso ni exteriores a él. Se hallan, escribe, "en el límite del discurso: le ofrecen los objetos de que pueden hablar, o más bien (...) determinan el haz de relaciones que el discurso debe efectuar para poder hablar de tales y cuales objetos, para poder tratarlos, nombrarlos, analizarlos, clasificarlos, explicarlos, etc.” (Foucault, 2010a[1969]: 64-65). ¿Qué relaciones discursivas se despliegan en la interpretación de esta mujer?, ¿en qué límites se hallan esas relaciones?, ¿de qué objetos pueden hablar? Nos faltan antecedentes para entender todo el "haz de relaciones" que involucraría su interpretación. Pero pudimos identificar algunas de ellas: discursos religiosos y psicológicos, profanos y sagrados, sobre la sexualidad pero también sobre la trascendencia. Sus tres objetos —el alma, el cuerpo y el espíritu- mantienen relaciones insospechadas entre sí, pero con cierto grado de coherencia. Al menos, permiten producir sentidos y valores, regresando a Geertz.

Si las relaciones discursivas se ubican en el límite del discurso, en este caso, dicho límite atraviesa varios espacios conceptuales, pero de una manera en la que no podemos distinguir claramente unos de otros sin desarmar la interpretación misma. Si las epistemes locales se sitúan en el cruce histórico, pero contingente, entre formaciones discursivas y redes de significación, entonces ellas mismas son un límite. Geertz plantea que la naturaleza microscópica de la etnografía debe resolverse "comprendiendo que las acciones sociales son comentarios sobre algo más que ellas mismas, y que la procedencia de una interpretación no determina hacia dónde va a ser luego impulsada", y agrega que "pequeños hechos hablan de grandes cuestiones, guiños hablan de epistemología o correrías contra ovejas hablan de revolución, porque están hechos para hacerlo así" (Geertz, 2005[1973]: 34-35).

Tal vez aquí apuntamos a un aspecto central de esas epistemes, vistas a través de Foucault y de Geertz, y puestas en práctica por la funcionaria citada. Justamente, una episteme local se 
podría entender como el campo en el que pequeños discursos y narrativas "hablan" de y con otros mayores, pero comentándolos a través de redes locales de significación. Si dichas epistemes se conciben como nodos por los que cruzan relaciones discursivas, pero que también las transforman y desplazan, entonces caracterizan al discurso no como lenguaje o como contexto, sino ante todo como práctica (Foucault, 2010a[1969]: 65). Las epistemes locales son las superficies conceptuales que impulsan una interpretación, como dice Geertz, hacia lugares insospechados o impredecibles, pero contextuales y específicos, mediante ciertas prácticas interpretativas y discursivas. Impulsan, por ejemplo, el alma hacia el cuerpo, desasiéndolos, y el espíritu hacia Dios, conectándolos. De este modo, ellas permiten comprender la forma cómo ciertas comunidades, los grupos y los sujetos piensan “(...) en el mismo lugar —el mundo social— en que hacen todo lo demás" (Geertz, 2005[1973]: 33). Pero, a su vez, permiten conocer esa zona intermedia que Foucault identifica, justamente, como propia de la episteme, y que se ubica entre "los códigos fundamentales de una cultura — los que rigen su lenguaje, sus esquemas perceptivos, sus cambios, sus técnicas, sus valores, la jerarquía de sus prácticas" (Foucault, 2008[1968]: 7) y las explicaciones que los filósofos y los científicos elaboran sobre dicho orden. Ese espacio, presente en las epistemes locales, le permitiría a una cultura liberarse "(...) de las rejas lingüísticas, perceptivas, prácticas" y neutralizarlas para encontrarse "ante el ser en bruto del orden” (ibid.). Esa distancia es crítica y el hecho en bruto del orden es también su historicidad. A diferencia de las estructuras conceptuales propuestas por Geertz, las epistemes permiten dilucidar y entender tanto el orden del pensamiento como las distancias que lo transforman y las impugnaciones que lo socavan, en el mundo de los sujetos y los colectivos que investigamos. Esa distancia crítica, donde una cultura “(..) se desprende de sus poderes inmediatos e invisibles, se libera lo suficiente para darse cuenta de que estos órdenes no son los únicos posibles ni los mejores" (ibíd.), es el espacio de constitución de las políticas locales, que son justamente formas críticas, en primera instancia, de pensar el orden dado. Si bien se discuten sus contenidos, ante todo, se impugna la transparencia "de sus poderes inmediatos y visibles". En esa distancia, regresando a otra cita de Foucault, podríamos encontrar el trabajo de la discontinuidad, que permite que "una cultura deje de pensar como lo había hecho hasta entonces y se ponga a pensar en otra cosa y de manera diferente” (Foucault, 2008[1968]: 57).

Quizás la interpretación de nuestra informante intente resolver esa discontinuidad, que no sabrá sino intensificarse, al pretender atar con las viejas amarras de la religión los nuevos corderos de la medicina y la psicología. Me parece que el gesto de distinguir dos planos y 
localizar en uno el des-orden y en otro el orden más profundo y definitivo, es una forma de combatir esa discontinuidad y de regresarle cierta transparencia y coherencia. Si el mundo es confuso, porque traslapa esquemas conceptuales diversos, la trascendencia es clara, porque restaura el orden que se ha perdido y purifica su lectura. La continuidad, en este caso, es trascendente y sólo puede ser asegurada por Dios, que opera como una metonimia de la cultura.

\section{Nuevas arqueologías}

Antes argumenté que en las epistemes locales que investigamos se articulaban tres formas de identificación de los sujetos homosexuales que, utilizadas sincrónicamente, parecían describir a un mismo tipo de sujeto y de una manera semejante. La noción de discontinuidad que introdujimos abre una sospecha acerca de esa similitud. Si bien en Tenosique hay un conjunto de enunciados para aludir a un sujeto homosexual, desde los más cotidianos y burlescos hasta los más técnicos, consideramos que no guardan relaciones de continuidad y que, en muchos sentidos, no son sinónimos. Esos enunciados no corresponden a una misma "disposición de la episteme", en palabras de Foucault (2008[1968]: 48). Creo que para profundizar este punto es necesario intentar una arqueología de esas epistemes locales, distinta a la realizada por Foucault, pero que será tributaria de sus conceptos e intuiciones. Ya hacia el final de La arqueología del saber, Foucault se pregunta si podrían concebirse unas arqueologías que no fueran la de las ciencias y responde que no le costaría trabajo imaginar otras que siguieran "direcciones diferentes" (Foucault, 2010a[1969]: 250). El ejemplo que él cita es justamente el tipo de arqueología que intentamos hacer. Habla de una "descripción arqueológica de la sexualidad" y se pregunta si en las conductas y representaciones discernibles en este campo podemos encontrar una práctica discursiva que no se reduzca a un discurso científico, y que permita pensarla como:

(...) un conjunto de objetos del que se puede hablar (o del que está vedado hablar), un campo de enunciaciones posibles (ya se trate de expresiones líricas o de prescripciones jurídicas), un conjunto de conceptos (que puede presentarse, sin duda, en la forma elemental de nociones o de temas), un juego de elecciones (que puede aparecer en la coherencia de las conductas o en unos sistemas de prescripción) (ibíd: 251).

Me parece que la serie de identidades que intento comprender corresponden a ese campo de enunciaciones posibles. Para hacer esta arqueología local de la sexualidad es necesario entender 
con qué estamos trabajando. Perentoriamente, diré que con enunciados, pero unos muy específicos: puto, homosexual y gay. Creo que si nos centramos en ellos podremos comprender cómo forman parte de estructuras conceptuales diversas y cómo son resignificados en este espacio local. No son enunciados locales, eso es claro, y uno de los aspectos que podremos revisar es cómo llegaron a Tenosique, si fuera el caso. Pero, por ahora, me centraré en los procesos mediante los cuales unos enunciados son incorporados a las estructuras locales de significación y cómo dichas estructuras son transformadas por ellos. Si bien en la arqueología foucaultiana los enunciados son parte de formaciones discursivas, creo que para el estudio de estas epistemes es necesario empezar por los primeros. En el registro cotidiano encontramos enunciados y no, necesariamente, formaciones discursivas, porque el material con el que trabajamos es fundamentalmente oral y no está sometido a las mismas reglas que dichas formaciones. ${ }^{17}$ Asimismo, en ese registro de la producción discursiva lo que tendremos es un cruce local, como lo vimos, de formaciones discursivas y otros tipos de discursos. Por lo tanto, si empezáramos por ellas, requeriríamos un nivel de coherencia y sistematicidad relativas que en nuestra investigación nunca encontramos. Dado que las epistemes locales emergen de la intersección de redes locales de significación y formaciones discursivas, lo que tenemos como evidencia de ese mutuo atravesamiento son los enunciados que circulan en los discursos cotidianos de la ciudad. Quisiera añadir que en ese nivel cotidiano los enunciados sirven como enlaces con formaciones discursivas u otra clase de discursos, pero también como artefactos de identificación. Es decir, que en su dimensión práctica los enunciados se transforman en identificaciones e identidades. Esto será relevante en nuestros análisis porque el intervalo entre el enunciado y la identificación lo entenderemos como un espacio de subjetivación.

\footnotetext{
17 Aunque no debemos entender que una formación discursiva incluye sólo materiales escritos y un enunciado otros orales. Esta distinción no sería correcta. Más bien, quiero destacar que el tipo de materiales con los que he trabajado en esta etnografía es fundamentalmente oral. Foucault define un enunciado como el átomo de un discurso y quizás podríamos reconstruir un discurso siguiendo esa ruta atómica. Si tenemos átomos -puto, homosexual, gay — lo que no sabemos con certeza es cómo se conectarán con otros niveles discursivos; los enlaces son inciertos, pero no arbitrarios. Por ejemplo, al decir que alguien es homosexual, este enunciado no necesariamente nos conectará con formaciones discursivas como la medicina, la psiquiatría o la sexología, y podría conducirnos a un discurso religioso o a otro de ciudadanía. Que una formación discursiva 'cree' enunciados no garantiza su uso. Y mi mirada está puesta, sobre todo, en el uso de esos enunciados.
} 
¿Por qué trabajar con enunciados y, específicamente, con los que distinguí? Creo que esos enunciados son la materia mínima, por así decirlo, para pensar la homosexualidad en Tenosique. No se pueden desarticular en partes más pequeñas, del tipo que sea. El enunciado surge como un elemento último, escribe Foucault, “(...) que no se puede descomponer, susceptible de ser aislado por sí mismo y capaz de entrar en un juego de relaciones con otros elementos semejantes a él (...) Grano que aparece en la superficie de un tejido del cual es el elemento constituyente" (Foucault, 2010a[1969]: 106). Si bien tiene este carácter indescomponible, también es más tenue y menos estructurado que una frase, una proposición o un acto de habla (ibíd: 111). ¿Cómo podemos pensar este carácter atómico y no descomponible, junto con esa tenuidad? Tal vez los tres enunciados que me interesan sean un límite para cualquier pensamiento sobre la homosexualidad, tal como dijimos que eran su componente mínimo. Lo interesante es que hoy son enunciados que se vinculan con formaciones discursivas y otros discursos, que se contraponen entre sí en muchos sentidos y que suponen historicidades diversas. En el denso tejido conceptual que develan las epistemes locales, estos tres enunciados son granos que surgen en sus superficies y que permiten explorar algunas de sus fibras y de sus conexiones.

Pero creo que antes de realizar una arqueología local de estos enunciados hay que trazar algunas características de su historicidad nacional e incluso global. El más antiguo, sin duda, es el enunciado 'puto'. Según Corominas es una derivación de la palabra puta y está en uso en el español desde el siglo XV, al menos en textos literarios. "Sodomita, esp. el pasivo", anota Corominas en sus etimologías (1980: 701). Hace referencia a la primera obra en español que usa esa palabra entre sus términos, Las coplas del provincial, "A ti Fray Diego de Llanos, /puto mal quisto de gente, /de linage de villanos/de sangrelluvia doliente:/di à tu hermano por mi amor/que castigue su trasero/de tanto puto palmero/que trae al rededor" (¿Fernández de Palencia?, s/f: estrofas 75-76). En la etimología y en este escrito del siglo XV la palabra puto tiene ya el uso que encontramos en Tenosique: un hombre pasivo en el sexo. En tres diccionarios de la lengua española, los de Palencia (1490), Nebrija (1495) y Covarrubias (1611), hay una entrada para esta palabra y es definida en un sentido más o menos semejante al que hoy está en uso: inversión, afeminamiento, pasividad (Molina, 2010: 45-46). Hay diversos indicios de su uso en México (Gruzinsky, 1986; Molina, 2010). No es mi objetivo reconstruir esta historia, sólo me interesa remarcar la persistencia de este enunciado con sentidos muy parecidos a los contemporáneos. Tal vez se puede discernir en esta aparente continuidad una 
disposición cultural hacia el deseo y las prácticas homoeróticas de larga duración. Es interesante notar, también, que el término puto fue de uso popular, cotidiano y burlesco, en muchos casos. No era parte del lenguaje formal de las instituciones, de las leyes ni del Estado. Los términos fueron otros, como sodomita en la colonia (Gruzinsky, 1986), afeminado e invertido en el siglo XIX (Buffington, 2001; Chávez, 2005; Macías-González, 2004) y homosexual en el siglo XX (Domínguez, 2007; Guerrero, 2014; McMannus, 2013; Monsiváis, 1998; Rodriguez, 2012). Esta informalidad cotidiana podría explicar, quizás, su pervivencia en México.

En el caso del otro enunciado que nos interesa, homosexual, su registro es más reciente. Llega a México como parte de la expansión de los discursos científicos europeos durante el siglo XIX, pero es utilizado de manera habitual durante el siglo XX. Fue una clasificación psiquiátrica y también criminológica (Buffington, 1998 y 2001) que se integró a los discursos científicos, estatales y políticos hasta conformar la categoría central en el lenguaje de las instituciones. Incluso, cuando emergieron los primeros movimientos políticos de minorías sexuales en México, la palabra homosexual fue su seña (Argüello, 2013 y 2014; De la Dehesa, 2010; Díez, 2011; Parrini, 2011 y 2012; Rodriguez, 2012; Salinas, 2008). Me parece que es un término que mantiene un cariz científico y que si bien se utiliza, ampliamente, en las instituciones y los medios de comunicación, nunca tuvo en Tenosique la impronta cotidiana de la palabra puto. Esto produce una escisión importante en el campo de las denominaciones y los lenguajes, porque permite usar términos diversos en contextos distintos. El enunciado homosexual es fundamentalmente producido por las instituciones y permite su inscripción, primero mediante la desviación y luego a través de la diversidad, en sus esquemas conceptuales. Esa diferenciación semántica, pero también contextual, genera una complejidad conceptual creciente que será pivote de los procesos de politización que luego estudiaremos.

Creo que el proceso más importante en este campo fue la aparición del sida y las intervenciones estatales subsecuentes para intentar detener la epidemia, que durante años no tuvo casi tratamiento alguno. La medicina será la encargada de llevar el enunciado homosexual hasta los lugares más remotos del país y comprometerlo en el funcionamiento del sistema de salud nacional. Sin duda que ya había llegado a Tenosique, porque cuando surge el sida es un término que tiene cerca de cincuenta años ininterrumpidos de uso en la ciencia, en los medios de comunicación, en la política, en las discusiones morales. Pero el sida obliga a incorporar el término a las acciones de salud del Estado, si bien muchas veces en un tono discriminador y estigmatizante. La que fue la primera institucionalidad dedicada al tema incluyó de manera 
temprana a personas homosexuales en su trabajo y sus órganos de decisión (García et al., 2010). Pero esa carga médica marcará profundamente al término, de modo que no será integrado a las redes de significación locales como lo fue puto o gay, y supondrá una aproximación técnica, pero también lejana, al deseo y a las identidades. No obstante, proveerá de un lenguaje aséptico, teñido del prestigio normalizante de la medicina, pero que permite elaborar discursos públicos e institucionales. El término puto era demasiado ofensivo y coloquial como para ser usado en ese sentido. En esa brecha discursiva se colará el potencial político de estos enunciados, cuando los términos y sus registros institucionales otorguen una plataforma conceptual a los sujetos que sólo habían sido nombrados.

Si seguimos a Laguarda (2009) el término gay recién comenzó a ser utilizado en México a fines de los años sesenta y principios de los setenta. Fue una creación de las comunidades homosexuales estadounidenses y europeas y luego fue incorporado a las de otros países. En México primero fueron hombres y mujeres educados, de clase media, que viajaron a distintas ciudades de Occidente, quienes comenzaron a usar ese término. El ambiente descrito en algunos textos por Monsiváis (1997 y 1998) comenzó a transformarse en comunidades adscritas a cierta identidad, que no sólo les otorgaba un sentido común a su deseo y sus prácticas, sino que las conectaba con otras en diversas partes del mundo (Altman, 1996). El efecto de la identidad gay fue enorme, porque abrió no sólo un campo de significaciones distintas de las que se podían articular hasta ese momento, también otorgó una superficie discursiva que permitió un proceso de politización que continúa hasta el día de hoy. El enunciado gay, que reemplazó al término homosexual en las denominaciones políticas de las minorías sexuales, se extendió en la cultura popular, dotó de significaciones positivas a las identidades y a las relaciones homoeróticas (de hombres y mujeres), pero se ancló con rapidez en el habla cotidiana. Si la noción de puto tuvo un contendiente en este plano fue este término anglosajón. En contraste, puto se vinculó con un habla denigratoria e insultante. Los orgullos que lo gay trajo consigo fueron formas de enfrentar, resistir y desplazar el potencial humillante de ese término. Antídotos de buen gusto, de farándula, de cosmopolitismo y de glamour que abrieron otra brecha discursiva, pero también identificatoria, entre el habla cotidiana y el lenguaje de la política, entre las denominaciones deseadas y las que resultan de la intervención de los otros. Este brecha no opera sólo en referencia con el puto, también lo hace en relación con el homosexual. El término gay crea un campo social y simbólico que permite contrarrestar y enfrentar la acción del Estado y de las instituciones. Este antagonismo tendrá una gran capacidad para crear procesos de 
politización, de autoconciencia y autonomía y será una fuerza importante para la creación cultural, discursiva y estética de los colectivos y los sujetos que se vean sometidos a sus tensiones.

Leyes de posibilidad, reglas de existencia

Hecho este breve recuento, creo que podemos regresar al análisis de los enunciados. Hay cuatro rasgos que Foucault distingue en ellos y que nosotros deberíamos encontrar en esta arqueología local:

- Un enunciado está ligado a un referencial constituido "por leyes de posibilidad, reglas de existencia para los objetos que en él se encuentran nombrados" (Foucault, 2010a[1969]: 120). Ese referencial constituye el lugar, el campo de emergencia, "la instancia de diferenciación de los individuos o de los objetos, de los estados de cosas y de las relaciones puestas en juego por el enunciado mismo" (ibid.).

- Un enunciado mantiene con un sujeto, escribe Foucault, "una relación determinada" (ibíd: 121). El sujeto del enunciado es una "función" que puede ser desempeñada por individuos diversos y, a la inversa, un mismo individuo puede ocupar distintas posiciones en una serie de enunciados (ibid:: 123). Se debe determinar “(...) cuál es la posición que puede y debe ocupar todo individuo para ser su sujeto" (ibid:: 126).

- Un enunciado implica un dominio asociado y un campo enunciativo "en el que tiene un lugar y un estatuto, que dispone para él unas relaciones posibles con el pasado y que le abre un porvenir eventual” (ibid:: 130). La pertenencia a ese campo implica que todo enunciado mantenga relaciones con otros en las que se dirimen “(...) unos efectos de serie y de sucesión, una distribución de funciones y de papeles” (ibid:: 131).

- Un enunciado supone un 'espesor material' en el que está inscrito y que forma parte de sus "caracteres intrínsecos" (ibid: 132). Esa materialidad permite distinguir tipos de enunciados, ya que una frase, por ejemplo, no sería la misma "articulada por alguien en el curso de una conversación, o impresa en una novela" (ibíd.)

El análisis de estos cuatros puntos, que leeré como rutas de interpretación etnográfica, permitirá dilucidar el "régimen general al que está sometido el estatuto de estos enunciados" y 
también la manera como son “(...) institucionalizados, recibidos, empleados, reutilizados, combinados entre sí” (Foucault, 2010a[1969]:195). Ese estatuto, visto desde las prácticas cotidianas de uso de los enunciados, permitirá reconocer las articulaciones entre ellos y sus discontinuidades. Será la forma, a mi entender, de investigar las modificaciones en la interpretación social de los enunciados y sus efectos en el campo de las subjetivaciones y las formas de politización de la sexualidad.

¿Cuáles son las leyes de posibilidad y las reglas de existencia de estos tres enunciados? Podemos distinguir las unas de las otras, porque las leyes que hacen posible un enunciado, no necesariamente corresponden con las reglas que lo hacen existir. Podríamos pensar enunciados posibles, pero no existentes; u otros, aún más insólitos, que fueran existentes, pero no posibles. No es un juego retórico. Esta diferencia me parece importante para entender cuál es la historicidad de estos enunciados y cómo se articulan unos con otros, si es que eso sucediera. Si bien, como he mencionado, hoy día en Tenosique los tres enunciados son utilizados en el habla cotidiana de manera muchas veces indistintas, su legitimidad social varía o ha sido conseguida muy trabajosamente. Pero hace 30 años, por definir un periodo, no todos eran posibles. Estos enunciados han sido un campo de batallas simbólicas e identitarias, muchas veces tributarias de las que han ocurrido nacional e internacionalmente, pero específicas en su inscripción local. El enunciado gay comenzó a ser de uso corriente en los años noventa en la ciudad y supuso una especie de ‘transfusión' semántica que trasladó parte de los rasgos del puto y del homosexual a esta otra denominación. Luego veremos cómo modificó la posición de sujeto de los homosexuales en la ciudad, pero desde su inicio fue una categoría distinta, aunque híbrida en relación con las otras existentes.

Si retomamos las condiciones de posibilidad de las que antes hablé, creo que en el caso del enunciado gay fue durante mucho tiempo existente pero imposible. Sólo cuando introdujo una posición de sujeto específica, entonces su existencia se transformó en posibilidad. El Club Gay Amazonas se fundó en 1994, luego de un largo proceso de construcción de ciertos espacios políticos y ciudadanos para los sujetos homosexuales en México, que en ese momento no conseguían lo que serían sus mayores logros, como el matrimonio igualitario o las leyes antidiscriminación. Recién se había fundado la institucionalidad que debía resguardar los derechos humanos en el país y no se había roto la hegemonía del Partido Revolucionario Institucional (PRI) en el gobierno federal. Pero el organismo que debía evitar la propagación de la epidemia del sida en México se había creado 6 años antes y constituyó, como lo 
mencioné, el primer lugar de interlocución entre el Estado y las minorías o diversidades sexuales. Tenosique, en muchos sentidos, era un lugar lejano a todos esos procesos, pero la transformación de lo existente en lo posible se expresó en la creación de ese Club, que utiliza el enunciado gay como un referente identificatorio que permite crear un espacio de sociabilidad y acción colectiva a partir de un deseo homoerótico. Si bien era un enunciado que había llegado al país desde hace más de 25 años, recién en esas fechas pudo sustentar la creación de una organización local de sujetos homosexuales.

Pero, a la inversa, el enunciado homosexual ha sido uno posible, pero casi inexistente. Quiero decir que en Tenosique ha sido utilizado por ciertas instituciones como un término técnico, que si bien se conoce colectivamente no se utiliza cotidianamente. Lo gay ocupó su campo de manera drástica y bastante intensa y ha sido el motor de los procesos identificatorios. Pero este enunciado vinculó a la ciencia con el deseo homoerótico. Foucault (1981) dice que creó un personaje, al menos en la Europa del siglo XIX. También podría decirse que inauguró una relación que todavía perdura entre el Estado y los sujetos que eran clasificados como homosexuales. Pero, también, la homosexualidad fue una forma de darle cierta densidad biográfica a esos sujetos.

Finalmente, puto es un enunciado existente, pero imposible en ciertos contextos. Dijimos que es ampliamente utilizado en la vida cotidiana, pero que supone mayor violencia que el término gay. Mientras que éste transita desde la cotidianidad hogareña o callejera hasta la vida institucional y política, el puto no puede traspasar ciertas barreras o lo hace con efectos que tal vez no se esperaban. Durante mi trabajo de campo asistí a dos elecciones municipales. En ambas contiendas todos los candidatos se reunieron al menos una vez con los integrantes del Club y con otras personas homosexuales, hombres y mujeres. En la elección del año 2009, uno de esos mítines fue organizado por el equipo de campaña del candidato del PRI a la alcaldía, un conocido médico de la ciudad. Varios de los asistentes me comentaron luego la molestia que les causó la forma en la que este político se había dirigido a ellos. El motivo del enojo era coincidente en las diversas versiones que escuché: el candidato les había dicho, hacia el final de la reunión, que convencieran a todos sus mayates para que votaran por él. Mayate es una forma coloquial para referirse a las parejas masculinas de los hombres gays de la ciudad. Si bien forma parte del habla cotidiana, se puede utilizar en diversos sentidos y con intenciones distintas: un gay puede decir, por ejemplo, que tal muchacho es mayate, es decir, que está dispuesto a tener sexo con 'hombres'. Pero también puede ser usado como insulto, por ejemplo, en una disputa 
entre hombres heterosexuales y que guardan las características esperadas de la masculinidad, uno puede acusar a otro de 'ser mayate' como una forma de humillarlo u ofenderlo. En resumidas cuentas, no es un término correcto en el lenguaje público o institucional y su uso puede producir reacciones violentas o adversas. No es lo mismo que nombren a alguien de ese modo en una cantina, en medio de una borrachera, que frente a su familia o en el trabajo. En el discurso de un político que realizaba proselitismo y que se había reunido expresamente con un grupo de personas homosexuales, su uso se leyó como una vulgaridad que los descalificaba. Si bien este político no pronunció la palabra puto, que hablara de los mayates de sus contertulios, ubicaba su discurso en su mismo campo semántico, pero también ético: figuras risibles y poco serias, que tienen como parejas a hombres denigrables. Es curioso que si bien se refirió a los mayates no mencionara a los putos, como probablemente habría sucedido en una conversación informal. El exabrupto no pasó ese límite, lo que habría sido mucho más grave, según entiendo. Este es un ejemplo de un enunciado existente, pero no posible. Es decir, no era posible que en ese contexto específico el político en campaña, que deseaba el voto de las minorías sexuales de su comunidad, usara el enunciado puto para referirse a esos ciudadanos. Pero sí pudo nombrar coloquialmente a sus parejas como mayates. Pero la reacción del colectivo fue de enojo, no expresado directamente durante la reunión, y de distanciamiento con el político, que parecía el seguro ganador de unas elecciones que perdió estrepitosamente. ${ }^{18}$

Si regresamos al texto foucaultiano vemos que esas leyes y reglas constituyen un referencial, que es "la instancia de diferenciación de los individuos o de los objetos, de los estados de cosas y de las relaciones puestas en juego por el enunciado mismo" (Foucault, 2010a[1969]: 120). Estos tres enunciados que he tratado de distinguir - puto, homosexual o gayimplican diferenciaciones específicas de los individuos y de las relaciones. Los dos primeros enunciados suponen una diferenciación externa, heterónoma y clasificatoria, sea mediante la burla o el escarnio o mediante la sintomatología y la normalización. El enunciado gay, al contrario, ha sido autoconstruido, en muchos sentidos, y tiene algún grado de autonomía conceptual y política. Que el Club lo haya elegido como su significante maestro no es casual. Esa elección surge de las leyes de posibilidad y las reglas de existencia de los enunciados y muestra el

\footnotetext{
18 A fines de 2013 algunos amigos que estuvieron presente en ese evento recordaron las palabras del candidato y la molestia que les produjo. Me sorprendió que aún se acordaran del hecho, pero creo que eso revela su importancia y el impacto que tuvo en ellos.
} 
potencial de una arqueología de los discursos para entender los procesos de subjetivación y politización.

Esto nos conduce a la segunda de las características que anotamos antes. Foucault indica que el sujeto del enunciado es una función "que puede ser desempeñada por individuos diversos y, a la inversa, un mismo individuo puede ocupar distintas posiciones en una serie de enunciados" (Foucault, 2010a[1969]: 123). Los análisis que hemos realizado confirman este rasgo de los enunciados, al menos desde una perspectiva arqueológica y local. Si bien hemos sostenido que los tres elegidos son distintos entre sí y tienen relaciones de discontinuidad, pero también de articulación contingente, no habíamos planteado que son disjuntos en relación con los individuos que los sostienen o que son descritos por ellos. Lo que a mi entender será particular de la función enunciativa en este caso es que estará superpuesta desde el punto de vista de los individuos, que pueden ser múltiples o uno solo, pero diferenciada en sus efectos. Es decir, diversos individuos pueden ser nombrados, en diferentes contextos y situaciones, como putos, homosexuales o gays, o uno sólo puede serlo de las tres maneras, incluso simultáneamente. Pero, si un individuo desempeña esa función y utiliza algunos de esos tres enunciados, sus efectos serán centrales en su inscripción social, política y simbólica (que son las que nos interesan en este caso). Cuando realicé las primeras entrevistas con integrantes del Club, una de las argumentaciones centrales de mis informantes fue que ser gay marcaba una diferencia significativa con ser sólo puto. El Club surgió de lo que podríamos llamar una modificación en la función enunciativa en el campo del homoerotismo en la ciudad; pero también la fomentó. El enunciado puto tiene como sujeto de la enunciación a quien lo profiere, no a quien se dirige ni a quien es aparentemente descrito o señalado por él. Es, ante todo, un enunciado heterónomo. En cambio, el enunciado gay permite que el sujeto del enunciado y el enunciado mismo, su contenido si me permite llamarlo así, coincidan de algún modo.

Foucault escribe, refiriéndose a esta función enunciativa, que se debe determinar “(...) cuál es la posición que puede y debe ocupar todo individuo para ser su sujeto” (2010a[1969]: 126). ¿Cuál es la posición que deben ocupar los individuos no heterosexuales para ser sujetos de una función enunciativa? Cuando se utiliza el enunciado homosexual ya se produce un desplazamiento entre un enunciado sin sujeto como sería el de puto y otro con sujeto que correspondería al gay. El homosexual, si bien es objeto de descripciones, calificaciones y valoraciones por parte de diversas instituciones, puede recuperar, de alguna manera, todo ese material discursivo para describirse, calificarse y valorarse a sí mismo, sosteniéndose en las 
legitimidades de los discursos científicos, que fueron a mi entender unos de los primeros pivotes de autoconocimiento y autorreconocimiento para estos individuos. El puto no tiene sujeto de la enunciación que se articule con uno o muchos individuos, su soporte es una tradición cultural y voces colectivas que rotulan, tal vez se ríen, quizás denigran, también desean, pero nunca preguntan. Pero será el enunciado gay, ese grano en las superficies discursivas de la sexualidad y el homoerotismo, el que permita que los individuos antes descritos, clasificados y valorados, se transformen en sujetos de una función enunciativa, que además comenzarán a crear y a transformar. El trayecto histórico que permitirá esta emergencia será clave para los procesos de politización y organización colectiva que nos interesan.

Quizás podríamos pensar, retomando la definición de enunciado que propusimos más arriba, que el verdadero átomo de las superficies discursivas en torno a la sexualidad y el homoerotismo es el enunciado puto. Me parece que no hay nada debajo de él y que es completamente indescomponible. Homosexual puede ser historizado y se puede reconstruir su trama discursiva institucional que, tal vez, permita encontrar enunciados aún menores, como invertido o afeminado, que se articulen luego en este otro. Lo mismo podría pasar con el enunciado gay, que responde a una trayectoria cultural de escala global y que va siendo resignificado paulatinamente en contextos locales, y cruza discursos mediáticos con otros políticos y estéticos. Pero más allá del puto no hay nada en este campo. A mi entender, es el grado cero del homoerotismo. Por eso, tal vez, no hay individuo que pueda desempeñar la función enunciativa. En este sentido, es un enunciado flotante, del que ningún individuo se apropia, pero que cualquiera puede emitir. Su perseverancia cultural, su enorme fuerza descriptiva, su capacidad paralizante y a la vez jocosa, la ambigüedad que produce y la liminaridad que permite tendrán una explicación en esa flotación enunciativa, que aún no encuentra un sujeto que la contenga y la desempeñe.

Foucault nuevamente nos da una pista cuando escribe que "la constancia del enunciado, la conservación de su identidad a través de los acontecimientos singulares de las enunciaciones, sus desdoblamientos a través de la identidad de las formas, todo esto es función del campo de utilización en que se encuentra inserto" (Foucault, 2010a[1969]: 137). ¿Cómo el enunciado puto ha logrado esa constancia, esa conservación de su identidad (enunciativa), a través de los acontecimientos singulares de las enunciaciones? Creo que mediante la preservación de su campo de utilización. Si bien informal y cotidiano, éste ha sido el campo donde ha sobrevivido 
más de cinco siglos. Difícil de inscribir en los discursos institucionales, pero inextirpable de los usos diarios y personales. Si el enunciado homosexual, tal como lo hemos analizado en su uso en Tenosique, tiene una adherencia institucional muy clara y precisa, el enunciado gay la tiene en una dimensión identitaria, reivindicativa y también comunitaria, que facilita cierta acción colectiva. Pero, por eso mismo, es más circunscrito y menos ambiguo. En cambio, puto es un enunciado que permite reproducir cierta organización social de la diferencia, sin desarticular el deseo. En la vida cotidiana, las mismas personas que se declararían gays públicamente, en determinados contextos, se autodenominan como putos o nombran a otros como tales. Si gay es un enunciado para la identidad, puto lo es para el deseo. Pero lo es porque, a mi parecer, no requiere de un sujeto que lo enuncie. Basta con lanzar la palabra al ruedo de las relaciones y las prácticas para que tenga efectos en las vidas y en los cuerpos. Si esos individuos que mencioné se nombran como putos, lo harán jocosamente, irónicamente, abriendo un campo de ambigüedades y de sobrentendidos. Si nombran a otros, aunque no deseen esa denominación, lo harán burlonamente, disfrutando del poder que otorgan ciertos saberes. Pero se acabará ahí, en ese nivel carnavalesco y erótico. No habrá formaciones colectivas que surjan del enunciado, como las que hay a partir de lo gay. No habrá acción política ni institucional. Por supuesto, jamás habría derechos, porque el deseo no los requiere. Se articula, en cambio, contra las normas o a pesar de ellas.

Sometidos a las persecuciones y presiones sociales de las que han sido objeto, los individuos que utilizan el enunciado puto crean un campo de utilización estratégico que les permite participar de manera soslayada, como dice Monsiváis (1998), en un mundo de relaciones y afectos. Como el ambiente de los años previos a la emergencia de la identidad gay es un mundo informe, ambiguo, difícil de cercar y con límites difusos. Pero por eso mismo posible. Cuando las condiciones de posibilidad se modifican sustantivamente entonces surgen comunidades, identidades, propuestas políticas, movimientos sociales, argumentos intelectuales. El mundo soterrado del anciano que antes mencionamos, es un espacio de sobrevivencia pero también de deseo. Es un intersticio, sin duda, pero en él se puede experimentar un erotismo y vivir un deseo, al costo de no producir una subjetividad que se declare públicamente. ${ }^{19}$

\footnotetext{
19 A mi entender, no hay enunciado más cercano al término queer que puto. En torno a esa palabra cotidiana y, primero, insultante, se ha generado un pensamiento crítico tanto de las políticas de identidad como de las formas de pensar (y actuar) del feminismo y el movimiento gay en los Estados Unidos. Sobre ese término, Judith Butler se pregunta: "How is it that a term that signaled degradation has been turned (...) to signify a new and affirmative
} 
Si regresamos a los cuatro puntos que caracterizarían a un enunciado podremos abordar lo que Foucault nombra como "un dominio asociado y un campo enunciativo". La pertenencia a ese campo implica que todo enunciado mantenga relaciones con otros, en las que se dirimen “(...) unos efectos de serie y de sucesión, una distribución de funciones y de papeles" (Foucault, 2010a[1969]: 131). Creo que hemos analizado algunas de esas relaciones en las páginas anteriores. Pero son, como vimos, relaciones complejas, muchas veces desiguales y desarticuladas. Sostuve que no podíamos pensar estos enunciados como sinónimos, es decir, como si tres palabras correspondieran a un solo enunciado. Eso no nos permitiría reconocer las discontinuidades que existen entre unos y otros. Pero los tres que distinguimos tienen efectos mutuos que se encadenan en una sucesión. Es decir, que sean discontinuos epistemológicamente no implica que sean ajenos los unos a los otros culturalmente. Su uso abre efectos diferenciados, en tanto emergen de superficies discursivas disímiles. Tienen límites que impiden que un enunciado se superponga con el otro. Como escribe Foucault, no hay un enunciado general, “(...) enunciado libre, neutro e independiente, sino siempre un enunciado que forma parte de una serie o de un conjunto, que desempeña un papel en medio de los demás, que se apoya en ellos y se distingue de ellos: se incorpora siempre a un juego enunciativo, en el que tiene su parte, por ligera e ínfima que sea” (ibid: 130). Quizás en este caso tenemos tres series o tres conjuntos que se interceptan y que se confrontan. La serie cotidiana del puto, la institucional del homosexual y la identitaria y comunitaria del gay. Una vez que utilizamos

set of meanings?” (Butler, 1993: 223). Con puto no ha sucedido lo mismo, hasta ahora. Su potencial político aún no ha sido explorado y persiste en los espacios de la vergüenza o la burla. Sin embargo, cuando queer fue resignificado y reutilizado, inauguró una nueva capacidad de pensar el insulto y el rechazo, pero también las identidades y las posiciones de sujeto. Si alguna vez sucediera que, en los desplazamientos socio-conceptuales que estamos investigando, puto fuera resignificado de una manera semejante a como lo fue queer, su politización radicaría, justamente, en ese grado cero difícil de descomponer culturalmente. El enunciado puto está fuera de las instituciones, tal como lo estuvo queer hasta que comenzó a adquirir otros sentidos y estatus. Pero, tal vez por eso, tiene una capacidad política inexplorada. En este sentido, Butler escribe:

For an occupation or reterritorialization of a term that has been used to abject a population can become the site of resistance, the possibility of an enabling social and political resignification. And this has happened to a certain extent with the notion of 'queer.' The contemporary redeployment enacts a prohibition and a degradation against itself, spawning a different order of values, a political affirmation from and through the very term which in a prior usage had as it final aim the eradication of precisely such an affirmation. (ibid.: 231) 
alguno de esos enunciados, entonces se inaugura una serie o se forma un conjunto. Entre ellos habrá un juego enunciativo, que he tratado de dilucidar.

Esas series podrían apoyarse unas en otras o distinguirse. Sucede, por ejemplo, cuando el enunciado gay abre una serie enunciativa que se apoya, en alguna medida, en la del enunciado homosexual. Esta serie, que se produce fundamentalmente en las instituciones públicas y en los medios de comunicación, le otorga legitimidad social a la serie enunciativa gay. En el caso del Club, el uso del lenguaje médico ha sido constante. Dado que se transformaron en un referente en la prevención del VIH en la ciudad, ellos se vinculan con las instituciones médicas, pero también las desplazan. Con los médicos o los psicólogos se podría hablar el lenguaje de la homosexualidad, que correspondería a las series enunciativas institucionales en este campo. El sida ha sido el ámbito donde dos series de enunciados se han articulado tensamente: la homosexual con la gay. Pero los integrantes de Club y, específicamente, Alan Contreras, su presidente, realizan un trastrocamiento de la prevención cuando utilizan un lenguaje muy coloquial para hablar de sexo y prevención. Hablan "sin pelos en la lengua", como dice Alan. De alguna manera, esta forma más directa, pero también más vulgar, produce escozor y molestia en algunos y risa en otros. Pero él reivindica este lenguaje, que rompe con las series más académicas y formales, y argumenta que la gente no entiende las palabras técnicas y que la prevención debe tocar la vida diaria de las personas. Yo asistí a varias de sus intervenciones preventivas en escuelas públicas de la ciudad, en las que promovía el sexo seguro y repartía preservativos entre los alumnos. En una de ellas, Alan le habló a un grupo de casi 40 adolescentes de ambos sexos sobre sexualidad y prevención del VIH. En un tono jocoso, les platicaba con las palabras cotidianas que se usan para hablar de sexo. Muchos se reían, otros se sonrojaban, pero ninguno dejaba de prestar atención. Si bien él es considerado, colectivamente, un experto y el principal actor comunitario en la prevención del VIH, su lenguaje no es institucional, aunque las instituciones locales avalen sus intervenciones. Pero también puede realizar una presentación en un evento académico o en uno institucional usando otro lenguaje. Esta posición, que luego leeremos como una posición de sujeto, es posible dado el apoyo entre series discursivas: las institucionales de la homosexualidad y las comunitarias de lo gay. Alan no improvisa una intervención, su acción enunciativa es posible sólo porque existe un contexto social e institucional que la permite. No podría entrar a las escuelas a hablar de sexualidad, por ejemplo, de motu propio, sin contar con esos avales colectivos. En el campo enunciativo que hemos analizado, hay un papel o una función para alguien como Alan y para un grupo como el 
Club. Pero sólo pueden cumplirlos articulando la serie de lo gay o de lo homosexual. Como putos no podrían hacerlo, no tendrían lugar institucional ni legitimidad social para realizar el tipo de intervenciones descritas.

Ese mismo campo, escribe Foucault, dispone para los enunciados “(..) unas relaciones posibles con el pasado y (...) un porvenir eventual” (Foucault, 2010a[1969]: 130). La prevención del VIH es una acción vinculada con el porvenir y, en esa medida, permite que los integrantes del Club participen de la definición de un futuro colectivo de diversas maneras y con distintos grupos, pero especialmente entre quienes son considerados el porvenir de la ciudad: los jóvenes. Si el enunciado homosexual conlleva la temporalidad de las instituciones y de los discursos científicos, que hurgan el pasado para garantizar el futuro, y en esa medida son productores de una forma biográfica para los sujetos (la densidad de un personaje, en palabras de Foucault) y, por lo tanto, de una memoria personal; el enunciado gay permite una reescritura de ese pasado y otra narración del futuro. Ambos enunciados son intensamente temporales. El tiempo social que llamamos historia los constituye y los determina. En cambio, el enunciado puto, en su pervivencia y su larga duración, parece fuera del tiempo, aunque por supuesto no lo esté. Pero como enunciado no permite una relación con el pasado ni un porvenir eventual. Sólo admite el presente. En muchos sentidos el puto no tiene historia, o no la puede articular discursivamente. Su memoria es una memoria secreta o acallada. Pero tampoco tiene futuro, que sólo se puede articular mediante pactos institucionales, tramas biográficas y formas de reproducción social. Se podría decir que bubo putos en la ciudad y que los sigue babiendo. A pesar de que distaran cincuenta años, el enunciado los haría contemporáneos. Dada la desafección temporal de este enunciado, que será claramente su imposibilidad política, no servirá de soporte para la reconstrucción del pasado ni para la figuración del futuro. Las instituciones que son, entre otras cosas, formas de organizar el tiempo colectivo e individual, requieren de series de enunciados que se articulen con él y que lo produzcan. En el caso que hemos analizado, la serie enunciativa de lo gay permite que se genere una temporalidad sanitaria en una versión preventiva: se habilita a los individuos con información y/o medios para que tomen decisiones que garanticen su salud en el futuro. Y en Tenosique eso no sólo lo hacen los funcionarios del sistema de salud, también lo realiza un colectivo de personas gays. Sin duda, ya han entrado a la historia y se les ha otorgado un trozo de tiempo social para que lo administren. 
Cabe entender por qué Alan utiliza ese lenguaje cotidiano en la prevención y se distancia del técnico o institucional. A sus interlocutores no les habla intelectualmente, lo hace de manera afectiva. No se dirige a sus conocimientos sino a sus disposiciones emocionales. En ese sentido, su lenguaje es un habla del deseo, no de la identidad, tampoco de la conducta. Pero si quiere articular esa habla, que es significativa no sólo en términos conceptuales sino también en otros corporales y afectivos, debe recurrir a la serie enunciativa del puto. Es un habla sin tiempo, pero jocosa, encarnada, afectuosa, seductora. El lenguaje de las instituciones no bastaría, es un idioma seco y áspero, en muchos sentidos ajeno e incomprensible. No obstante, varios de los rasgos del habla del puto podrían encontrarse en la del gay; Alan se desinviste de su identidad y juega con las atribuciones que los otros hacen de él. Es un gay que hace prevención hablando, en algún sentido, como un puto. Y es ése el lenguaje cercano y reconocible para la mayoría de los habitantes de Tenosique. Podría ser esa aparente transparencia de los sentidos, esa comunicabilidad de los enunciados, lo que explicaría su persistencia cultural. Veremos luego que esas series enunciativas tendrán efectos diversos sobre el deseo. Pero quisiera adelantar que la serie de lo gay abre una discontinuidad en los esquemas conceptuales locales que sirven para interpretar el deseo y clasificarlo. Al conectar redes de significación con formaciones discursivas, esta ruta de enlace que constituye la serie enunciativa gay, reconfigura esos esquemas y transforma la episteme local sobre la sexualidad. Alan reconoce que los frutos de esa reconfiguración están aún inmaduros y que se debe hablar en los dos idiomas que la episteme local permite: el del puto y el del gay. Por eso salta los lenguajes institucionales para entrar en los cotidianos y cumple una función de traductor de series enunciativas. Crea mediaciones jocosas, pero significativas, entre el lenguaje técnico de la prevención y el lenguaje cotidiano, afectivo y corporal del sexo.

Alguna vez me tocó cumplir con ese rol de traductor, al intentar explicarle a una mujer de más de 50 años, analfabeta, que administraba una casa de citas y que vivía con VIH desde hace varios años, cuál era la importancia de que tomara puntualmente su tratamiento antirretroviral. El efecto de los medicamentos sobre el virus es completamente abstracto en términos conceptuales, pero intensamente real en otros vitales y corporales. Yo le dije que imaginara que su cuerpo era como un castillo que defendían muchos soldados y que el virus estaba acabando con todos y que los medicamentos, tomados estrictamente, eran un refuerzo que permitía defender ese castillo y derrotar al virus. No era una 'traducción' en el campo del deseo, pero sí en el de la salud. Esa mujer no lograba comprender los efectos de los medicamentos ni los de 
su forma de tomarlos. ¿Cómo se pueden cruzar series enunciativas para transformar a ciertos individuos en sujetos de enunciación de conocimientos cruciales para sus vidas? Esta pregunta supera el campo de la estricta arqueología, para adentrarse en el de la biopolítica. Ese camino lo recorreremos luego.

Por último, otra de las características de un enunciado es que supone un "espesor material" en el que está inscrito y que forma parte de sus "caracteres intrínsecos". Esa materialidad permite distinguir tipos de enunciados, ya que una frase, por ejemplo, no sería la misma "articulada por alguien en el curso de una conversación, o impresa en una novela" (Foucault, 2010[1969]: 132). Vimos cómo los enunciados se distinguen cuando son dichos en contextos diversos. No es la misma prevención, para seguir con ese ejemplo, la articulada por un médico en una charla o una consulta que aquella que el Club realiza. No es el mismo enunciado preventivo escrito en un folleto que pronunciado en una charla informativa. Pero si regresamos a los tres enunciados con los que hemos trabajado, veremos que sólo homosexual y gay que pueden ser impresos, escritos y logran articularse con las formas institucionales y sociales de escritura. Sólo ellos tienen esa forma de materialidad. No es que no se pueda escribir "puto", pero su inscripción será fundamentalmente oral, no escrita.

Si consideramos la relevancia que la escritura tiene para la acción del Estado y la política (Giddens, 2011; Chartier, 2005), entenderemos la importancia de ese registro para los enunciados que estudiamos. Goody lo plantea en los siguientes términos: si la cultura puede entenderse como una serie de actos comunicativos, entonces son tan relevantes las diferencias en los modos de comunicación como en los modos de producción. En este sentido, indica que la escritura "(...) hace posible escrutar el discurso con un tipo de modalidad diferente" (Goody, 2008: 48), al darle a la oralidad una forma semipermanente. Esta inscripción estaría vinculada, según Goody, con el incremento de los conocimientos sociales y las capacidades críticas, porque "deja al discurso delante de los ojos" (ibíd.). Asimismo, la escritura transformaría los medios de comunicación al superar los encuentros cara a cara como condición del discurso, ampliar el número de interlocutores potenciales y aumentar las posibilidades de almacenamiento de la información. Si bien podemos destacar la importancia antropológica de la escritura, luego haremos tributaria a esta visión de la crítica que Derrida (2003[1967]) dirige a la serie oralidad-escritura y al privilegio de la primera sobre la segunda. Pero rescataremos de esos planteamientos la diferencia crítica que permite el uso de escritura 
en la producción de enunciados. No solamente son dos formas de inscripción, son dos tecnologías sociales distintas que permiten relaciones sociales diferentes. ${ }^{20}$

Nuevamente, lo que encontramos son límites y umbrales de diferencia y semejanza entre los tres enunciados. Puto podría ser escrito como insulto o como broma, pero de manera informal. No puede ser utilizado, al menos en el contexto que investigo, como un enunciado de textos institucionales. Sólo, como lo indiqué, los enunciados homosexual y gay pueden serlo. Si homosexual fue la forma en la que la ciencia escribió sobre los sujetos "desviados", generando una colosal narrativa de anormalidades, inversiones, identidades y otros artefactos, gay ha sido el modo en el que esos colectivos e individuos han podido escribir sobre sí mismos. No es una división tajante, por supuesto, porque ambos enunciados han sido utilizados alternadamente $\mathrm{y}$, de hecho, algunos homosexuales utilizaron ese enunciado para hablar de sí mismos, en una larga tradición de introspección y autoconocimiento (Rodriguez, 2012). Escribir es una forma de intervenir en el espacio público y en la producción social de los discursos, por eso estará vinculado de manera tan intensa con la formación de un sujeto político. De hecho, uno de los primeros actos de las organizaciones políticas de hombres y mujeres homosexuales fue elaborar una escritura (Argüello, 2013 y 2014; Parrini, 2012). Se despliega así una historia de manifiestos, folletos, revistas, afiches, periódicos, cartas, pronunciamientos, entre otros materiales, que han formado una escritura de la homosexualidad paralela, en muchos sentidos, a la que elaboró la ciencia y el Estado. Pero la escritura gay es una creación autónoma y que rompe, de alguna manera, con la heteronomía de las escrituras institucionales.

Pero lo importante en esta secuencia de materialidades e inscripciones es que los límites y umbrales de los enunciados corresponden con los de las instituciones. Si bien técnicamente todo se puede escribir, socialmente sólo algunos enunciados pueden serlo. De este modo, la relación entre escritura e institución confirma el régimen de materialidad que Foucault distingue para los enunciados, que sería “(...) del orden de la institución más que de la localización espacio-temporal: define posibilidades de reinscripción y transcripción (pero también de

\footnotetext{
${ }^{20}$ La escritura se relacionará, según Foucault, con la configuración de un nuevo tipo de poder en las postrimerías de la modernidad europea, que inaugurará una "relación directa y continua de la escritura con el cuerpo" (Foucault, 2005: 69). La resistencia del Club a la escritura, en cualquiera de sus formas, es tal vez una manera de enfrentar o evitar las disciplinas; por eso también evita los registros estatales, como lo vimos en el capítulo anterior.
} 
umbrales y límites) más que individualidades limitadas y perecederas" (Foucault, 2010a[1969]: 135). ¿Qué implica para los enunciados producidos localmente que ese régimen de materialidad dependa más del orden de la institución que de la localización espacio-temporal? Creo que tiene varias consecuencias. Entre ellas, que la materialidad de los enunciados no está adscrita, institucionalmente, a la vida social y política local. Hay regímenes de materialidad mayores, si se me permite la imagen, que determinan esa reinscripción y transcripción local. Por ejemplo, la institución médica y el aparato de salud constituyen un orden institucional que permite, obliga y fomenta cierta forma materialización de los enunciados, mediante una densa red de procedimientos, formatos y escrituras institucionales. Lo mismo sucede con las instituciones políticas o educativas. Las instituciones locales deben enmarcarse en ese régimen de materialidad. Antes dijimos que un funcionario público, en ejercicio de sus labores, no podría utilizar el enunciado puto, pero sí homosexual o gay. Los límites que enfrenta una cultura para pensar son límites materiales: qué se puede decir, qué se puede escribir, qué se puede ver. Y en los últimos cuarenta años en México (como en muchas otras partes) ese régimen de materialidad se ha transformado de manera profunda, desde la asunción de la identidad gay hasta el matrimonio igualitario, pasando por las leyes contra la discriminación (que se podrían leer como garantes de una materialidad democrática) y las aperturas mediáticas y culturales. ${ }^{21}$

No obstante, el orden de las instituciones, tal como lo hemos entendido aquí, no coincide necesariamente con el de la vida social cotidiana, y la materialidad oral de esa vida no está sometida a las mismas restricciones. Como ya hemos indicado, el enunciado puto pervive porque se ubica debajo de ese orden institucional. No puede ser pronunciado en ciertas circunstancias, pero tampoco ha sido eliminado del habla local. Me parece que las intervenciones políticas, legales y culturales en este campo han acentuado esa escisión, entre una materialidad enunciativa institucional y otra cotidiana. Lo que se puede decir en la casa, en la calle, en las pláticas informales, no se puede replicar en las instituciones, al menos en sus lenguajes formales. Esto puede leerse como el avance relativo de un régimen de materialidad en el campo de la sexualidad y las relaciones de género, eficaz en conseguir una restricción enunciativa. Es claro que el objetivo de las leyes antidiscriminatorias es éste: consolidar un régimen material para los enunciados públicos que se oriente según valores democráticos y eluda la discriminación y la estigmatización. Lo que hemos indicado para el juego institucional

21 Análisis y descripciones de estos procesos se pueden encontrar en Argüello 2013 y 2014; Díez, 2011; de la Dehesa, 2010. 
de los tres enunciados analizados se podría extender a otros, como los enunciados de género, que también han experimentado reinscripciones y transcripciones nuevas en el país y en la ciudad, bajo la égida de la equidad. Sería difícil, también, que un funcionario público sostuviera en el ejercicio de su cargo que las mujeres son inferiores a los hombres o menos inteligentes. Pero, sin duda, el lenguaje misógino persiste.

En el caso del Club los enunciados que produce tienen, fundamentalmente, una materialidad oral. Es muy poco el material impreso o gráfico que ha generado directamente. Creo que sus enunciados se conectan con las escrituras gay y homosexual para legitimarse, aunque correspondan a materialidades distintas. Podríamos pensar que la gigantesca escritura que ambos enunciados han producido se transforma, en alguna medida, en un soporte para las otras materialidades, especialmente las orales. Otra materialidad privilegiada para los enunciados del Club es la visual, pero la analizaré en otro momento. De nueva cuenta nos encontramos con una mediación entre materialidades diversas. El Club habla el lenguaje cotidiano y también el institucional y realiza traducciones tácticas entre ambos. Y se ubica en un lugar especial de reinscripción y transcripción de enunciados, al poder lidiar con las dos materialidades y con los diversos órdenes que se ponen en juego, específicamente el institucional y el cotidiano. El Club produce enunciados mixtos, de alguna manera, que logran inscribirse en un orden y en el otro, que reinscriben enunciados y que los transcriben.

¿Qué lugar ocupa el Club en este juego entre órdenes y materialidades?, ¿cómo resolver las discontinuidades conceptuales y epistemológicas de la vida cotidiana?, ¿qué hace el Club con ellas? Me parece que crea formas provisionales de continuidad que permiten mantener vínculos entre las formaciones discursivas y las redes locales de significación. ¿Qué tipo de continuidad es ésta?, ¿se sostiene en alguna forma de reinscripción y transcripción de los enunciados? Quisiera recordar que Foucault entiende la discontinuidad como el término, por parte de una cultura, de una forma de pensar y el inicio de otra. Si las epistemes locales son un arreglo transitorio y práctico, contingente e histórico, en ellas podríamos encontrar tanto lo que se está dejando de pensar como lo que está empezando a pensarse. La episteme local, que tiene una función eminentemente práctica, no exige que se resuelva esa tensión, sino que la administra, de alguna manera. Pero eso no significa que no existan discontinuidades. Es necesario que nos preguntemos, entonces, qué artefactos permiten morigerar la transformación y la ruptura. Antes mostré cómo el Club realiza una tarea de traducción, entendida como reinscripción y transcripción de enunciados, que podría ser uno de esos artefactos. Si, por otra parte, 
volvemos a la comprensión de la cultura como un contexto, siguiendo a Geertz, habría que pensar cómo las discontinuidades lo transforman. Esos cambios no afectarán sólo los modos en los que una cultura piensa, también la forma como actúa. Y los artefactos que nos interesan son, precisamente, modos de ajustar los esquemas conceptuales a los prácticos, cuando se ha producido o está sucediendo un proceso de cambio de las formas de pensar muy profundo y radical. Creo que esos artefactos evitan la parálisis, por un lado, y moderan los conflictos, por otro. Luego veremos cómo el Club representa el conflicto mediante ciertas representaciones y desplaza el antagonismo (que leeremos, justamente, como grieta en los consensos conceptuales y prácticos) a través de formas paródicas de interpretar la realidad social y la diferencia sexual.

Al utilizar artefactos como algunos enunciados, trozos de discursos institucionales, materiales visuales, entre muchos otros, el Club se convierte en un bricoleur, que utiliza medios y razonamientos técnicos e incluso científicos con fines prácticos. "El bricoleur, escribe LéviStrauss, es capaz de ejecutar un gran número de tareas diversificadas”, pero su regla es "siempre arreglárselas con 'lo que uno tenga', es decir, un conjunto, a cada instante finito, de instrumentos y materiales heteróclitos" (Lévi-Strauss, 2009[1962]: 36). Si bien Lévi-Strauss contrapone esta figura a la del científico o el ingeniero, creo que se puede extender su significación y aplicarla a quienes utilizan conceptos técnicos y resuelven problemas conceptuales sin ajustarse a un marco conceptual estricto, como la ciencia, sino a los requerimientos cotidianos. Así, el bricoleur elabora "conjuntos estructurados, no directamente con otros conjuntos estructurados, sino utilizando residuos y restos de acontecimientos (...) sobras y trozos" (ibid: 42). Tenemos que saber frente a qué tipo de residuos y restos nos encontramos y de dónde provienen. Pero antes debemos destacar, más bien, que el Club como bricoleur trabaja efectivamente con materiales heteróclitos, que proceden de "conjuntos estructurados", en palabras de Lévi-Strauss, o de "esquemas conceptuales", en las de Geertz, diferentes. Lo hemos visto, utilizan los materiales de discursos científicos, políticos, mediáticos distintos, además de los cotidianos. Tal vez en su definición más estricta, el bricoleur usa trozos y residuos para construir algo, pero en la que nos interesa sólo podríamos clasificar de ese modo sus materiales si suponemos que provienen de unas fuentes no residuales ni fragmentadas. Pero también sería plausible que ocuparan trozos de trozos y desechos de desechos, por así decirlo. Lo que me parece más importante no es el carácter de los materiales simbólicos y discursivos con los que trabaja el bricoleur, sino su estatuto: Lévi-Strauss sostiene que trabaja con signos y no con conceptos, y que mientras estos últimos desean ser 
transparentes a la realidad, aquellos aceptan que "un determinado rasgo de humanidad esté incorporado a esta realidad" (ibid.: 40). Precisamente, ese rasgo de bumanidad le permite al Club conectar redes de significación con formaciones discursivas, buscando una comprensión local de ciertos discursos y conceptos. El traductor bricoleur hace significativo un concepto en términos afectivos y emocionales, al dotarlo de ese rasgo de humanidad del que tal vez carece en su uso institucional o técnico.

En este sentido, etnográficamente lo que nos interesa son los enunciados utilizados en la vida cotidiana y en el mundo inmediato del grupo y las personas que estudiamos. Creo que la arqueología realizada en este registro se encuentra ante una dificultad: no podemos conocer claramente el origen de los enunciados que investigamos, que podrían proceder de formaciones discursivas o de esquemas conceptuales muy diversos o de varios a la vez. Tenemos fragmentos y trozos, pero no las totalidades de las que provendrían.

\section{Subjetividades parlantes: epistemes locales y posiciones de sujeto}

El primero de diciembre de 2011 se celebró en la plaza principal de Tenosique, frente al Ayuntamiento de la ciudad, el Día mundial de lucha contra el sida. El evento fue organizado por Alan Contreras, funcionario, en ese entonces, de la Dirección de Infancia y Familia del gobierno municipal y presidente del Club Gay Amazonas. Una nota periodística publicada en una página web local que difunde información sobre la ciudad, describe el evento de la siguiente manera ${ }^{22}$ :

Tras reconocer que el VIH Sida esta ganando terreno entre la población local, Alan Contreras López dirigente del grupo Gay Amazonas en Tenosique, dijo que en 30 años de intensa lucha, muy poco se ha logrado para frenar el grave virus que mantiene en jaque a hombres y mujeres de todo el mundo.

Al celebrarse esta mañana en Tenosique el día mundial de respuesta al Sida, Contreras López quien encabezó la actividad que se realizó en la plaza principal de la fronteriza ciudad, aseguró que en este municipio el número de personas infectadas se ha incrementado en los últimos años y aunque aclaró que no es alarmante esta situación, si preocupa a las autoridades y de manera directa a las familias donde hay un miembro viviendo con el Sida.

\footnotetext{
${ }^{22}$ He mantenido la redacción y ortografía del texto original.
} 
Alan Contreras López, dijo que se han reforzado las campañas de información en instituciones educativas, en áreas de trabajo, en parques, y a través de los diversos medios de información, sin embargo hay que ser realista en este municipio cada día aumenta el número de personas con el VIH Sida.

El presidente del grupo Gay Amazonas de Tenosique, informó que en 20 años que lleva al frente de su organización, se ha trabajado intensamente para apoyar a la población con amplia información sobre el Sida a fin de evitar el contagio, cada año se realizan las pruebas rápidas en las que participan personas de todas las edades hombres y mujeres quienes se unen a la lucha contra el Sida.

La mayor parte de los pacientes con el VIH detectados en Tenosique son ambulatorios, aclaró el dirigente del grupo Gay Amazonas quien ha logrado el apoyo de las autoridades para continuar su ardua labor contra el virus maligno que cada día esta ganando terreno entre la población, agregó Contreras López que las campañas de información también han alcanzado a los militares y elementos de diversas corporaciones policiacas (Tenosique.com, 1 de diciembre de 2011).

Cuando los medios de la ciudad desean consultar a un grupo o una persona sobre el sida, recurren al Club y a su presidente. Si bien en la ciudad hay un Centro Ambulatorio para la Prevención y Atención del VIH/SIDA y de las Infecciones de Transmisión Sexual (CAPASITS), que es dirigido por un médico, los interlocutores relevantes son otros. La arqueología también busca determinar las posiciones de sujeto que un discurso genera. Foucault habla de una "propiedad del discurso", entendida como “(...) derecho de hablar, competencia para comprender, acceso lícito e inmediato al corpus de los enunciados formulados ya, capacidad, finalmente, para hacer entrar este discurso en decisiones, instituciones o prácticas", sólo pertenece "a un grupo determinado de individuos" (Foucault, 2010a[1969]: 91). Esa propiedad y el grupo de individuos que serán sus titulares forman parte de las epistemes locales, que al interceptar redes de significación locales con formaciones discursivas, suponen también una redistribución de las facultades discursivas y las capacidades para usar los discursos en campos institucionales y cotidianos. Estas epistemes no sólo son reconfiguraciones de modos de pensar, también lo son de formas de actuar y de relaciones de poder. Cuando las epistemes comienzan a desplazar formas de pensar, desarticulan también relaciones institucionales. Por ejemplo, y lo hemos visto a través de los análisis, el paso del enunciado puto a homosexual y gay implica una rearticulación de ciertas relaciones de poder institucionales, simbólicas y cotidianas. ¿A qué tipo de posición de sujeto corresponde el 
enunciado puto? Lo hemos dicho: a ninguna. Las formaciones discursivas no pueden hablar de él y los discursos cotidianos lo constituyen en un enunciado sin sujeto: puede ser cualquiera, no es nadie. El puto no habla, es hablado.

Si bien Foucault indica que las reglas de formación de un discurso se imponen “(...) según una especie de anonimato uniforme, a todos los individuos que se disponen a hablar en ese campo discursivo" (ibid:: 84-85), el anonimato de las reglas no es equivalente al de los usos. Es decir, un médico habla anónimamente las reglas del discurso de la medicina, pero ocupa un lugar identificable dentro de la institución. El médico $x$ que diagnostica, prescribe y ordena debe obedecer a esas reglas anónimas, no las inventa ni son idiosincráticas, pero una vez que estampa su firma, decide un tratamiento u ordena un procedimiento entonces, en ese anonimato, singulariza su acción dentro de la institución. Las reglas anónimas se transforman en procedimientos con nombre. Si un sujeto o un colectivo utilizan, a su vez, estas reglas sin estar ubicados en la posición de sujeto que ocupa un médico, entonces se produce un desplazamiento de las instancias productoras y reguladoras del discurso. Creo que eso sucede cuando individuos ajenos a la institución médica, por citar alguna, se apropian del derecho a hablar y de la capacidad de comprender, siguiendo de alguna manera las reglas discursivas de una formación determinada, en este caso la medicina. Eso es lo que permiten los enunciados homosexual y gay, pero de maneras diversas. El homosexual resulta del discurso médico (en su vertiente psiquiátrica y sexológica) y ha sido producido por las reglas de ese discurso. Es su producto anónimo, también, pero con mayor capacidad de habla. El gay, en cambio, es exterior a dicho discurso y sus reglas, pero se puede apropiar de ambos de alguna manera. En torno al sida se despliega un proceso histórico complejo en el que colectivos que no tenían prerrogativas discursivas ni institucionales, por así llamarlas, se apropiaron de ellos mediante diversas intervenciones en distintos niveles.

De este modo, las modificaciones de las epistemes son también transformaciones en las posiciones de sujeto. En la nota que citamos, quien realiza el diagnóstico de la epidemia es Alan, no los médicos encargados del tema, pero habla su lenguaje. El presidente del Club, se escribe, “aseguró que en este municipio el número de personas infectadas se ha incrementado en los últimos años y aunque aclaró que no es alarmante esta situación, sí preocupa a las autoridades y de manera directa a las familias donde hay un miembro viviendo con el Sida". ¿Cómo sabe Alan que el número de personas que viven con VIH se ha incrementado? Su narración es epidemiológica, eso mismo lo podría explicar un médico. Es decir, ambos utilizan 
las mismas reglas de formación de un discurso. Él mismo se encarga de tranquilizar a los lectores: "no es alarmante la situación”, dice. ¿Cómo lo sabe?, ¿qué parámetros utiliza para establecer el nivel de alarma de un cuadro epidémico? Luego, añade, con una mirada de salud pública, que la situación preocupa a las autoridades y a las familias afectadas. Habla, de este modo, en nombre de las instituciones locales y menciona su preocupación frente al sida. ¿Por qué puede decir algo semejante y representar a esas autoridades? En ese momento trabajaba como funcionario del Ayuntamiento local, pero eso no basta para que ocupe una posición de experto. Y es un experto como funcionario y como presidente del Club. De este modo, en la nota se relata que:

El presidente del grupo Gay Amazonas de Tenosique, informó que en 20 años que lleva al frente de su organización, se ha trabajado intensamente para apoyar a la población con amplia información sobre el Sida a fin de evitar el contagio, cada año se realizan las pruebas rápidas en las que participan personas de todas las edades hombres y mujeres quienes se unen a la lucha contra el Sida.

Al mismo tiempo que habla de la preocupación oficial, menciona las actividades del Club y sus efectos. Si las autoridades se preocupan, el Club actúa. Las administraciones duran 3 años, el Club ha trabajado durante 20, según la nota. Ellos llevan la información para evitar el contagio, pero también realizan pruebas rápidas. Es decir, suplen por parte doble a la institución médica. $\mathrm{Y}$ eso convierte al presidente en el interlocutor mejor informado sobre el tema. Las reglas no son tan distintas, pero las posiciones sí. El Club surge en un contexto en el que las prerrogativas discursivas e institucionales se están discutiendo. Las certezas ya no son tan sólidas. Y esto permite que irrumpan otros actores en el campo de la salud, al menos, con capacidades discursivas específicas.

Foucault sostiene que el análisis de los enunciados no se realiza con referencia a un cogito, sino al "(...) conjunto de las cosas dichas, las relaciones, las regularidades y las transformaciones que pueden observarse en ellos, y es el dominio del que ciertas figuras, del que ciertos entrecruzamientos indican el lugar singular de un sujeto parlante" (Foucault, 2010a[1969]: 161). En las epistemes locales, ¿cuál es el conjunto de cosas dichas que hoy en día está transformándose?, ¿qué figuras, qué entrecruzamientos, indican ese lugar de "un sujeto parlante"? La especificación de un sujeto parlante es capital para entender los procesos de politización, pero por ahora tenemos esta brecha que permite que otros sujetos parlantes intervengan en el campo de las regularidades, relaciones y transformaciones discursivas. Esa 
brecha modifica lo que Foucault llama la economía de la constelación discursiva (ibid.: 89), es decir, permite que juegos inéditos se realicen, y que "compatibilidades y arquitecturas" que no habían emergido, lo hagan. Arquitecturas tales como un grupo de sujetos homosexuales que se apropian de algunos rasgos del discurso médico, lo replican y lo desplazan para realizar intervenciones en el campo de la salud de su localidad, que se legitiman por la posición que ocupan y los discursos que enarbolan.

La pregunta que resta es qué tipo de posición de sujeto es la del Club y sus integrantes. Creo que nuevamente debemos pensar en un bricoleur. Las posiciones de las epistemes locales no son equivalentes a las de las formaciones discursivas que interesan a Foucault. En nuestro caso, tenemos algunas posiciones en las epistemes locales que se superponen a las de ciertas formaciones discursivas, pero que también se distinguen de ellas. Creo que el Club tiene esa posición bricoleur porque comparte algunas prerrogativas discursivas de ciertas posiciones discursivas y también las capacidades traductoras de algunas posiciones locales. No existe una forma única de resolver las propiedades del discurso y los derechos que otorga. Hay varias. Y una de ellas es aceptar una posición mixta, en términos locales, que autoriza un discurso en las instituciones y otro en la vida cotidiana. Es claro, por ejemplo, que los integrantes del Club no hablan como médicos y de hecho hay un conflicto con las instituciones médicas a partir de su labor, pero también es notorio que hablan desde la formación discursiva médica. Pero, asimismo, ellos hablan como parte de una comunidad, que los reconoce como sus integrantes, y que les otorga una facultad discursiva. Si esa prerrogativa está sostenida, de alguna manera, en la legitimidad social del discurso médico, también lo está en la capacidad discursiva de generar sentidos compartidos y de resolver contingentemente las facturas y brechas que abren las epistemes locales.

\section{Redes y formaciones: bisexuales, violaciones e inversiones}

Quisiera terminar este capítulo abordando dos interpretaciones de la sexualidad que permitirán comprender con mayor precisión la noción de epistemes locales y su funcionamiento en este contexto. Creo que en ellas se condensa y se expresa intensamente el cruce formaciones discursivas con redes de significación y la creación, subsecuente, de formas locales de comprensión de la sexualidad. 
Cuando inicié esta arqueología local de la sexualidad, indiqué que abordaría primero los enunciados y después las formaciones discursivas. Luego, a lo largo de los análisis me di cuenta de que sólo existen trazos de esas formaciones en las epistemes locales y que el papel del bricoleur es utilizar trozos discursivos para producir interpretaciones localmente significativas. Del largo proceso histórico en el que las formaciones discursivas han filtrado las redes de significación, sólo conocemos los esquemas conceptuales que se han producido. No sé si será posible determinar con exactitud dónde empieza una formación discursiva y dónde lo hace una red local de significación, porque, como sostuve, los materiales con los que contamos ya resultan de su infiltración mutua. Pero, de todos modos, aunque tengamos sólo rastros de una formación discursiva es importante entender qué han producido en los esquemas conceptuales relativos a la sexualidad, porque su presencia indica un cambio histórico, profundo y definitivo, de esos esquemas locales. Creo que, en términos arqueológicos, estamos ante una práctica discursiva que conocemos a través de su trasiego cotidiano, pero distinta de la que Foucault analiza. Si para él la práctica discursiva es “(...) un conjunto de reglas anónimas, históricas, siempre determinadas en el tiempo y el espacio, que han definido en una época dada, y para un área social, económica, geográfica o lingüística dada, las condiciones de ejercicio de la función enunciativa" (ibíd:: 154), para nosotros esa práctica estará marcada por la intercepción histórica y local de las reglas anónimas de las formaciones discursivas con las de las redes locales de significación. Esto implica que también la función enunciativa está en disputa y no se resuelve bajo el modelo de ninguna de las dos. La historicidad que nos interesa es justamente la de una interrupción mutua, que cuaja en una forma provisional de pensamiento, que no sabrá sino cambiar en lo venidero.

Hace unos años noté un desplazamiento interesante del concepto de bisexualidad en el habla cotidiana de la ciudad. Si bien es un término poco utilizado, comencé a escucharlo con mayor frecuencia. En Tenosique se utiliza de dos maneras. Primero, en consonancia con los discursos médicos y terapéuticos, se entiende la bisexualidad como una atracción por personas de uno y otro sexo. Yo he escuchado a hombres definirse a sí mismos como bisexuales, dado que sienten deseo tanto por mujeres como por hombres. Estas autodefiniciones han ocurrido en conversaciones íntimas o ante poca gente. No son, en este sentido, públicas, pero son posibles. Pero, por otro lado, se entiende como bisexual al hombre que en una relación con otro quiere penetrar y ser penetrado. El primer sentido corresponde con el que elaboran algunas formaciones discursivas, como lo dijimos, y es ante todo una lectura del deseo. El 
segundo, es una interpretación local y un desplazamiento de su significado, pero como una lectura de la conducta homoerótica.

Que un hombre que no se defina a sí mismo como gay ni como homosexual, y menos como puto, desee ser penetrado por su partenaire, abre muchas discusiones entre las personas de la ciudad, especialmente entre los gays. Primero, porque la penetración es el acto por excelencia del deseo homoerótico y su petición es una forma de aceptar un deseo por hombres, no por putos. Cuando un hombre desea de esa manera, el conflicto no atraviesa sólo su deseo, sino también su identidad. Esto no lo abordaremos con detalle aquí, porque es motivo de otro capítulo, pero la penetración anal es un límite de la masculinidad, al menos representacionalmente. A un homosexual se le nota, dice la gente, que desea ser penetrado porque se comporta como una mujer, es afeminado, amanerado, más fino, más suave, entre otros rasgos que lo delatan. Pero un hombre al que no se le nota, pero que desea igual que un puto, produce una serie de conflictos en los esquemas conceptuales locales. En ellos, como lo mencionamos antes, los putos están en un lugar equivalente al de las mujeres: desearían el falo y son penetrados. Pero ese deseo se trasluce en sus comportamientos, cuerpos, modos de vestir y gestualidad. Putos y mujeres serían equivalentes no sólo por un deseo parecido, sino por su presentación corporal y conductual. Sin duda que el modelo gay alteró notoriamente ese esquema, abriendo la posibilidad de que el deseo no se trasluciera en los comportamientos ni en los gestos. Esto supone, como vemos, una dificultad clasificatoria que desordena los esquemas conceptuales locales.

Ambas nociones de bisexualidad son problemáticas entonces. Pero lo es más aquella que insinúa que un hombre desee a otro sin cuestionar su masculinidad, así como desea a una mujer. Esta forma de deseo discute ese lugar equivalente que se le otorga a putos y mujeres. Cuando un hombre tiene sexo con un puto es como si lo tuviera con el sustituto de una mujer. Si se pregunta a los individuos involucrados en este tipo de relaciones qué diferencia habría entre tener sexo con una mujer o con un puto (nótese que no sería lo mismo decir "otro hombre"), muchas veces la respuesta es ninguna, en términos inmediatos, porque un puto "es como una mujer". Sin duda que las diferencias estimables son muchas, pero lo que me interesa resaltar es la similitud que se construye colectivamente en torno a la práctica sexual misma. Otra respuesta que dan los informantes es que hay pocas diferencias porque "hace lo mismo que una mujer". Esa equivalencia será uno de las formas en las que se expliquen esas 
relaciones, sin que se cuestione ni la virilidad ni el deseo heterosexual de los hombres involucrados.

El problema inicia cuando un hombre desea a otro sin ocupar ese lugar de equivalencia o desplazarse a él. La bisexualidad es un término parco, porque sólo indica una inclinación del deseo, no necesariamente una identidad. Pero aun así cuestiona los esquemas referidos. Las epistemes locales resuelven tensiones conceptuales entre formaciones discursivas y redes locales de significación. En este caso, creo que lo hacen mediante un desplazamiento de los términos: incorporan el concepto de bisexualidad, pero modifican su significado. Localmente el bisexual es, también, un hombre que quiere penetrar y ser penetrado. Su deseo se ocluye en este uso, porque ya no implica que desee a hombres y mujeres, y se restringe al campo del homoerotismo. Mencioné que este gusto es polémico, porque para muchos gays de la ciudad que un hombre quiera ser penetrado lo convierte en puto y deja de ser una pareja atractiva. Hay, no obstante, diversos acomodos prácticos. Mi reconstrucción implica, ante todo, las representaciones y las clasificaciones y no intento agotar las variaciones cotidianas, personales y cara a cara que suceden en este ámbito. Lo interesante de una clasificación o de un esquema conceptual es que si bien permite pensar, no necesariamente resuelve la práctica ni la determina cabalmente. Ésta admite, según he observado en Tenosique, una gama mucho más amplia de variaciones que las que permite una clasificación o un esquema. Pero, de momento, sólo nos ocupan las formas de pensar, no las de actuar. Habrá que entender, luego, cómo se vinculan posibilidades conceptuales limitadas con prácticas más diversificadas. Cuando alguien transgrede estos esquemas y sus prácticas son difíciles de clasificar se dirá que es raro. La rareza, a mi entender, es un locus de transformaciones conceptuales.

El concepto de formación discursiva atraviesa toda la investigación arqueológica, y Foucault vuelve sobre él una y otra vez a lo largo de La arqueología del saber, como si no pudiera definirlo cabalmente. Una de las características que lo distinguen es su regularidad en la dispersión para vincular enunciados, conceptos y objetos. Cuando dicha regularidad puede ser descrita, entonces, sugiere Foucault, diremos "por convención", que se trata de una formación discursiva (Foucault, 2010a[1969]: 55). Dirá también que esa formación, al determinar una regularidad, “(...) plantea el principio de articulación entre una serie de acontecimientos discursivos y otras series de acontecimientos; de transformaciones, de mutaciones y de procesos", y que eso construirá un "esquema de correspondencia entre varias series temporales" (ibíd: 100). Así también, subraya que una formación discursiva no es un "texto ideal, continuo y sin 
asperezas", que resolviera o reflejara las contradicciones, sino más bien "un espacio de disensiones múltiples, es un conjunto de oposiciones diferentes cuyos niveles y cometidos es preciso describir" (ibid:: 203). Si la primera definición de bisexualidad tuviera su origen en una formación discursiva, entonces podemos establecer sus relaciones de regularidad con otros enunciados: homosexual y heterosexual, en primera instancia. No es simplemente un término, es un modo de pensar largamente elaborado por diversas disciplinas y que se ha extendido a través de los medios de comunicación, la educación y la medicina. Si bien fue primero un concepto técnico, hoy es una voz popular. Pero, de todos modos, es una noción que llega a Tenosique con relativa novedad y que se enfrenta a los esquemas conceptuales locales. En las formaciones discursivas donde emergió no ha tenido, si atendemos a sus características, un lugar continuo y sin asperezas y quizás, en algún momento, reconfiguró otros enunciados. Pero una vez posicionado en otros campos, como lo son los esquemas locales, permite otras transformaciones y otras disensiones. En este intertanto comienza a formarse una episteme local, como lo hemos visto.

Una inversión semejante de los conceptos sucede con una explicación que se repite localmente para entender la homosexualidad. Dada su recurrencia en las conversaciones que he mantenido con diversos informantes en distintos momentos y contextos, creo que es pertinente reconstruirla. Cuando alguien se pregunta por qué un individuo es homosexual, una de las respuestas que se sugiere es que tal vez fue violado cuando niño "y le quedó gustando". Nuevamente, explicaciones médicas o psiquiátricas, o que guardan alguna relación con esos discursos, son interpretadas localmente. Existe una larga discusión sobre las causas de la homosexualidad, que no reconstruiremos aquí, pero que mencionamos para entender su implantación. Como una excepción al comportamiento sexual o como una especificidad del deseo sexual o erótico, la homosexualidad debe explicarse de algún modo. Y esas explicaciones circulan en libros, manuales, artículos, programas televisivos, consultas médicas o psicológicas y conversaciones cotidianas, entre los muchos registros que podrían nombrarse. Quizás una de las más insistentes ha sido vincular el deseo con el desarrollo infantil de los sujetos, como esa vulgata freudiana que sostenía que una madre fuerte y un padre débil favorecían la homosexualidad de sus hijos. Yo nunca la escuché en Tenosique, pero creo que la violación forma parte de una serie de explicaciones de tipo psicológico que aluden al trauma como el motivo para la desviación. La violación es un acto violento y sexual. Por lo tanto, intercepta deseo con poder. En la explicación mencionada, la violación sería la causa de un gusto, es decir, 
de un deseo. En ese niño hipotético, que fue violado por otro hombre, si bien se reconoce la violencia que supuso el acto, sobresalen sus consecuencias: el gusto. Si una interpretación que citamos antes intentaba resguardar el espíritu de los hombres gays de la transposición de su alma en un cuerpo equivocado (alma de mujeres en cuerpos de hombres), la que ahora mencionamos localiza en el cuerpo la transposición del deseo. Es la violación lo que permuta el deseo. Un niño que ha sido violado por un hombre deseaba, suponemos, a las mujeres antes del acto; luego, desea a los hombres, como si quisiera que la violación se repitiera. El acto sexual transpone el deseo y lo invierte. El alma estaba en el cuerpo correcto hasta que sucedió la violación. En ese momento, el cuerpo comienza a ser recipiente de un deseo invertido, como si de alguna manera se deseara a sí mismo. El tema aquí no es la trascendencia. Es el desacomodo de una psicología mediante un acto traumático. El orden natural de los deseos es tan consistente que si la víctima de una violación fuera una mujer, los efectos no serían los mismos. Dado que el violador es un hombre, aunque se reconozca la violencia del acto e incluso se le condene, sus resultados diferirán, porque después de una violación la mujer seguirá deseando a otros hombres. Sólo en el caso de un hombre se puede producir una inversión de ese orden.

Si atendemos al razonamiento que intentamos descifrar podemos aventurar una interpretación, que será coincidente con las anteriores. Si un niño es violado su posición es la de una mujer. Y una vez ubicado en esa posición, entonces se inaugura su deseo invertido. Creo que esto resguarda dos concepciones de los esquemas locales. Primero, que el orden sexual es heterosexual, viene desde el nacimiento y corresponde a las características naturales de los humanos. Cualquier alteración se deberá buscar en la biografía, no en la naturaleza. Segundo, que si un hombre es penetrado analmente, entonces su posición es femenina y se le ubica próximo a las mujeres. Un hombre no puede ser penetrado sin que su posición en el orden sexual y de género se vea alterada. Incluso si sucede contra su voluntad, como entendemos que lo es en el caso de una violación. El ano es una frontera definitiva para ese orden. Sea que se desee o sea que se obligue, en un hombre su uso sexual supondrá consecuencias en su deseo y en su identidad. En otro capítulo veremos que será el falo el vector de los cambios y el que invierte los deseos. Lo que quisiera añadir es que en estos desplazamientos semánticos y conceptuales nuevamente tenemos formaciones discursivas que dotan de explicaciones o clasificaciones y que son desplazadas localmente para que coincidan o 
se articulen con las redes locales de significación. Esto a mi entender es una episteme local en el campo de la sexualidad. 


\title{
IV
}

\section{E1 Círculo Interior:}

\section{Homoprácticas y (psico)topologías de la homosociabilidad}

\author{
Ágil y turbulento, un círculo de hombres/ \\ cantará entre la orgía de una mañana de verano/ \\ su borrascosa devoción al sol
}

Wallace Stevens, Las auroras de otoño y otros poemas, 2012:73

El primer colectivo de hombres homosexuales que existió en Tenosique se llamó El círculo interior. Ese nombre lo tomaron de un libro, que sus integrantes habían leído, de Xaviera Hollander (1983), sexóloga y ex prostituta que se hizo famosa relatando su vida. Cuando esos individuos, en los años ochenta, mientras se socializaba de manera masiva la identidad gay en diversos lugares del país, tuvieron una primera forma de organización, ante todo de camaradería y festiva, lo que hicieron fue trazar un círculo en torno a sí mismos para poder diferenciarse y resguardarse. Como un acto mágico, que esboza una circunferencia para crear un territorio mítico, ellos extendieron ese círculo no sólo para delinear una frontera social, sino también para instituir una interioridad. Ese momento fundante inaugura un largo proceso de subjetivación que culminará con la creación del Club Gay Amazonas. Desde El círculo interior hasta el Club podemos reconocer la producción de un sujeto. Los integrantes de ese Círculo eran hombres de clase media de la ciudad, que tenían más educación y una mayor experiencia del mundo, más allá de Tenosique, y podían trazar un círculo que les diera un espacio de convivencia e identidad. Pero, en el camino, el sida los diezmó a casi todos. El Círculo fue barrido, como las cenizas, por el viento gélido de la muerte.

Supe de la existencia de ese Círculo recién el 2012. Alan me habló de él y mencionó el libro de Hollander, que tampoco conocía. El nombre me hizo recordar algunas lecturas de la filosofía de Peter Sloterdijk en las que exploraba la noción de esfera. Me sorprendió la coincidencia, porque El círculo interior era un dato etnográfico y las esferas, una propuesta teórica. Habían ensamblado, por así decirlo, un hecho y una forma de leerlo. Confieso mi predilección por las formas curvas para pensar, en vez de líneas o rectángulos, incluso de redes y nodos. Un círculo es un misterio estético y también conceptual. 
Un pensamiento sobre las esferas y la dilucidación de un Círculo será una forma de describir e interpretar la formación de un sujeto en el campo de la sexualidad, desde un ángulo distinto al que exploramos en otros capítulos. En éste me interesa, fundamentalmente, entender cómo emerge una nueva forma de subjetividad que a ciertos sujetos les permitirá relacionarse de otro modo consigo mismos y con los otros. Si bien es un proceso que se vincula con la formación del Club, también es distinto; como si para crear formas colectivas, fuera necesario producir dimensiones interiores. En este sentido, el Club surge del cruce de un proceso social, que hemos explorado, y otro personal. No hay antelación, sino mutua constitución. La ruta de las esferas será un modo de superar o atemperar la distinción entre lo colectivo y lo individual. Lo íntimo, escribe Sloterdijk,

se refiere exclusivamente a espacios interiores divididos, compartidos, consubjetivos e inter-inteligentes, en los que participan grupos diádicos o multipolares y que sólo puede haber en la medida en que individuos humanos, por estrecha cercanía mutua, por incorporaciones, invasiones, cruzamientos, repliegues de uno en otro y resonancias -psicoanalíticamente también: por identificaciones-, crean esas peculiares formas de espacio como receptáculos autógenos. (Sloterdijk, 2003a:97-98.)

Desde esta perspectiva, la relación de un sujeto consigo mismo es esférica e incluye otros vínculos y otros seres (de diverso tipo y de distintas maneras). Tal vez el Club mismo podría considerarse una de esas "peculiares formas de espacio como receptáculos autógenos", de las que habla Sloterdijk. Si fuera el caso, constituyó un cobijo para algunos procesos subjetivos y les dio una forma colectiva. Si bien muchos de sus integrantes iniciaron esos procesos antes, y también fuera del Club, éste los dotó de un receptáculo que, a mi entender, los potenció. En otro capítulo, esto lo leeremos como la creación de una inmunidad grupal que protege las inmunidades subjetivas e, incluso, las corporales. Quedan por identificar, sin duda, las “incorporaciones, invasiones", así como los "cruzamientos, repliegues de uno en otro" y las "resonancias e identificaciones". A eso dedicaremos este capítulo.

Pero si la creación de esferas resultara un camino adecuado para pensar la mutua implicación de individuos y grupos, de subjetividades y colectividades, la formación de un sujeto la leeremos, también, como una forma de experimentación. En los albores de la modernidad europea, experiencia y experimento fueron sinónimos (Williams, 2003: 137-8), por lo que podremos explorar tanto un modo de experimentación subjetiva, corporal y deseante como la conformación de un nuevo campo de experiencia. Experimentar, en este sentido, es 
probar e investigar posibilidades subjetivas, afectivas y corporales novedosas e incluso inéditas, pero también inaugurar experiencias personales y colectivas, es decir, formas de habitar el mundo y relacionarse consigo mismo.

Las esferas y las experimentaciones dieron pie a la formación de singularidades, o procesos de singularización. Guattari sostiene que un proceso de singularización sería automodelador, porque construye "sus propios tipos de referencias prácticas y teóricas", a partir de los cuales "los grupos adquieren esa libertad de vivir sus propios procesos -y- pasan a tener capacidad para leer su propia situación” y adquieren un "mínimo de posibilidad de creación” (Guattari, 2005: 65).

Hemos visto en los otros capítulos que el grupo y sus integrantes construyeron algunas “referencias prácticas y teóricas", que les dieron, primero, un lugar y, luego, una autonomía relativa. Lo que me interesa remarcar, en este punto, es la capacidad de creación de la que habla Guattari. Volveremos sobre eso, pero las esferas, la inmunidad, la experimentación y la singularidad, vinculados de modos diversos y no lineales, permitirán a este colectivo y sus integrantes explorar nuevas formas de vida, de afectividad, usos del cuerpo y del lenguaje, modos de afectividad. En muchos sentidos, ellos serán inventores de un mundo propio.

\section{Modernidades tardías}

Si los integrantes del Club fueran realmente experimentadores, en el sentido que deseo plantearlo, también serían modernos, por tanto. Sloterdijk, en una conversación que mantiene con un filósofo español sobre su obra, define individuo como "un sujeto involucrado en la aventura de su propia autoconservación, un sujeto que quiere determinar en términos experimentales qué tipo de vida es la mejor para él" (Sloterdijk, 2003b: 34). Involucrarse en la “aventura de su propia autoconservación” será, quizás, una de las principales tareas del Club, incluso cuando autoconservación adquiera un tono literal ante el sida y la violencia. Pero, me parece que lo más importante fue la posibilidad, largamente buscada, costosa y relativamente conseguida, de "determinar en términos experimentales qué tipo de vida es la mejor", para cada uno y para todos. La fuerza creadora del deseo, en la que nos hemos centrado y a la que nos abocaremos durante todo esta investigación, ha sido uno de los caminos, pero también de los impulsos, para alcanzar esa libertad experimental. Y ese logro no se restringe sólo a la experiencia sexual, también corresponde a la posibilidad de crear y vivir una forma de vida 
autónoma, aunque no aislada. Ese individuo “(...) se arroga el derecho de experimentar en su propia vida sin límite alguno. Ésta es la forma en la que hoy en día los individuos ponen en práctica su Modernidad" (ibíd.). Practicantes de una modernidad tardía y relativa, los integrantes del Club harán de sus propias experimentaciones corporales, emotivas, estéticas, lingüísticas y políticas un soporte para esferas y círculos que los vinculen, les den un espacio, pero también los cobijen. En muchos sentidos, la autoconservación en el contexto que estudiamos es siempre un desafío colectivo. Los sujetos se conservan a sí mismos con la ayuda de otros. Esa colaboración experimental es también sustento para las exploraciones subjetivas y grupales. En un proceso social inédito, estos sujetos se convirtieron en "autores de sus propias descripciones" y reclamaron "derechos de autor respecto a sus propias historias y opiniones" (ibid.: 32). En esa medida serían modernos, según Sloterdijk.

El libro de Hollander es, quizás, una demostración de la modernidad que esperaba a los sujetos en los albores de los años ochenta del siglo pasado. Parece que la emancipación sexual ha sido parte de algunos proyectos modernos significativos, pero en el caso del Círculo Interior, también hay una práctica de la modernidad sexual vinculada intensamente con un estilo de vida y un tipo de sujeto. La autora es una mujer europea, guapa y emancipada, vive su sexualidad sin tapujos ni prejuicios y no conoce, al parecer, ni la culpa ni la monogamia. En su libro, desfilan todo tipo de personajes, realizando sus fantasías sexuales sin mayores dificultades. Cada cual tiene una identidad y ninguna restricción aparente. Sentada con una amiga en el lugar que le da nombre a la novela, conversa relajadamente sobre las virtudes del sitio:

¿Sabes una cosa, Xaviera? - me dijo Tania-, realmente amo este lugar. Tiene un ambiente... Y cuando estábamos ahí tocando, sentíamos a este gentío bueno y caliente. Quisiera tener un club como este en dónde vivir.

- A mí también me gusta mucho -respondí-. Es un lugar en donde me puedo relajar, ser yo misma, hacer lo que me plazca sin tener que molestarme en ser amable o gentil. No es elegante, pero tiene calor. En el Círculo Interior no es el lugar sino la gente la que cuenta. (Hollander, 1983: 23-24)

Hollander está a sus anchas en ese espacio. El Círculo que la acoge es una esfera en la que se puede sentir tranquila y "ser ella misma". Es decir, habitarlo ya es subjetivarlo. El ser empieza en ese estar relajado que ambas mujeres exaltan. La gente es lo importante, dicen, y el calor que emana esa multitud que acoge el Círculo, sujetos que buscan estar con otros para ser "ellos mismos", como si la autenticidad de la experiencia subjetiva dependiera de la compañía de otros individuos que, sin intervenir, dan fe que cada cual es quien desea ser, al menos en ese 
lugar. Si el Círculo está conformado, ante todo, por la gente que lo habita, entonces en muchos otros lugares se podría generar el mismo ambiente. Basta que haya personas dispuestas a producir ese calor y esa corriente de autenticidad individualista, donde cada uno es autor de sus propios placeres y reivindicará derechos sobre sus descripciones y su deseo.

Luego de una noche bohemia, Xaviera viaja a México para participar en un congreso de sexología. La modernidad subjetiva se enlazará con otra institucional. La sexología será una ruta de modernización sexual, si se me permite la expresión, que dará a cada conducta y deseo, a cualquier fantasía, pero también a los tabús, una pátina de objetividad que las sacará del campo religioso y las abrirá a las intervenciones de la medicina, la psicoterapia y la farmacología. ${ }^{23}$ Hollander viaja a través del país como una misionera de las nuevas modernidades sexuales, que deben reemplazar las vetustas eróticas provincianas, repletas de temores y de prohibiciones. Se dirige a un grupo de mujeres judías de Guadalajara, insatisfechas sexualmente, y les dice:

—Entonces, ¿por qué no superar ahora sus prejuicios?, es eso lo que están preguntando ¿no? -miré a mi alrededor. Tenía su atención: con los ojos abiertos, ansiosos, seguían mis palabras, aguardando la revelación que fuese a cambiar sus vidas-. No hay manera de que me lleve a mi casa a cada una de ustedes para hacerles un estudio de sus compañeros. Pero comiencen por ustedes mismas. Son delgadas o gordas, altas o bajas, ¿y qué? Aún tienen un cuerpo que pueden amar; por eso, comiencen por amarse a ustedes mismas. Siéntanse, hagan correr sus dedos por su cuerpo, acaríciense los pezones, saboreen la suavidad de su piel, aprendan a admirar las curvas incitantes de sus caderas, acaríciense el pelo del pubis. Una vez que hayan comenzado a amarse, estarán en condición mental como para amar a otro (ibid.: 79).

Ella traía otras "revelaciones" desde Europa; ya nos las religiosas que anunciaban al dios único, sino las sexuales que profetizaban una nueva sexualidad emancipada, el nuevo cuerpo sensible y experimental, la nueva esfera interior llamada "amor por uno mismo". La sexóloga holandesa, experta en un sexo intenso y sin prejuicios, les revela a esas mujeres mojigatas y temerosas el Evangelio de las caricias y las autoexploraciones corporales. Es como si les dijera a sus interlocutoras que tienen un cuerpo y que lo pueden tocar. Les muestra el deseo allende los prejuicios. En la modernidad, dirá Sloterdijk, “a lo antes oculto, desconocido, inconsciente,

\footnotetext{
${ }^{23}$ Para un análisis más detallado de la emergencia de la sexología en México, véase Alcántara y Szasz (2013). Otro análisis muy interesante, pero para el caso brasileño, se puede encontrar en Carrara y Russo (2002).
} 
nunca sabido, nunca observado, nunca observable se le obligó de repente a aparecer en el plano de la manifestación" (Sloterdijk, 2009a: 113). Lo antes oculto ha sido develado y se lo ha hecho aparecer en el plano de la manifestación. En el terreno que exploramos este proceso de manifestación de lo desconocido se llama sexualidad. Eso es lo que les trae Hollander a sus amigas judías y su misión profesional: es portadora de la sexualidad como una forma moderna de manifestación del deseo, el cuerpo y la subjetividad.

Pero los que recogerán el mensaje de esta misionera desenfrenada no serán esas mujeres ricas, sino unos homosexuales rurales de la frontera sur del país. Ellos entrarán en el Círculo interior de la sexóloga para no abandonarlo jamás. Para ellos, Hollander es portadora de una modernidad deseada, porque quieren tener un espacio en el que puedan explorar sus propios deseos y sus erotismos. Una vez que han creado un círculo, no dejarán de producir otros; aunque unos se desarmen, prepararán los siguientes. Degustadas las promesas modernas de individualidad y placer, no hay manera de renunciar a sus frutos. Expulsados del paraíso del sobrentendido y la oscuridad, en el que había vivido Juanito, por ejemplo, ellos no quisieron regresar jamás. Entonces inauguraron un largo proceso en el que incrementarían las dosis de experimentación y las posibilidades de exploración, que terminaría en el Club y lo que hoy conocemos. El viejo pacto de silencio y sexo no pudo reconstituirse. Ellos serán motores, pero también testigos, de una proliferación incesante de nuevos campos, discursos, imágenes, saberes y productos vinculados con la sexualidad. Sus descendientes nacerán ya en una cultura experta y técnica sobre la sexualidad, que ofrecerá todo tipo de aparatos y artefactos para suplementar el deseo, desde los textos escolares que abordan la reproducción humana, hasta los preservativos y las pastillas de anticoncepción de emergencia.

La modernidad que ellos reivindican esféricamente también la reclamará el país. El Círculo interior surgirá en los tiempos de la planificación familiar y de la creación de las instituciones que hoy conocemos en el campo de la sexualidad. Durante los años ochenta el Estado se hará cargo de la respuesta ante la epidemia de VIH (García et al., 2010). En los noventa surgirá una academia cada vez más abundante dedicada a temas de género y sexualidad, que coincidirá, también, con una nueva fase en el desarrollo del feminismo ${ }^{24}$ y de un movimiento político de la diversidad sexual. ${ }^{25}$

\footnotetext{
${ }^{24}$ Para una historia del feminismo en México, véase: Bartra, 1999; Bartra, Fernández y Lau, 2000; Cano, 1996.

${ }^{25}$ En el caso de los movimientos políticos de la diversidad sexual, véase Argüello, 2013 y 2014; de la Dehesa, 2010; Díez, 2011, Salinas, 2008.
} 
Sin embargo, estos sujetos optaron por una modernidad esférica en un contexto donde primaban las lineales o en forma de bloque. Es interesante que ellos optaran por crear un círculo y no un frente ${ }^{26}$, por ejemplo. Su intención no era política, ante todo, ni el contexto en el que surgieron permitía, en ese momento, una organización política de homosexuales. La esfera, en ese sentido, también fue como un vehículo blindado que los resguardó en su largo viaje hacia la visibilidad, la interlocución social y los derechos. El Círculo fue disuelto desde dentro, mediante un virus que atravesó todas las inmunidades y acabó con sus integrantes. El Club, que ya tiene una forma social más reconocible, actúo, en primera instancia, contra ese virus. Es decir, se dotó de una inmunidad colectiva y de un proyecto comunitario.

\section{Homoprácticas}

Me puse en manos de mí mismo F. Nietzsche, Ecce Homo, citado en Sloterdijk, 2012: 415

El sujeto, dice Foucault, "es una forma, y esta forma no es ni ante todo ni siempre idéntica a sí misma”. Es esa forma la que he tratado de estudiar en Tenosique, sea en su expresión contemporánea como en sus desplazamientos históricos: desde un pasado que se puede trazar y un futuro que es posible describir en algunos de sus rasgos. Si a Foucault le interesaba "la constitución histórica de estas diferentes formas de sujeto" (Foucault, 2010c: 1036), a nosotros nos concierne la constitución histórica de diversas formas de sujeto en el campo de la (homo)sexualidad. ${ }^{27}$

\footnotetext{
${ }^{26}$ Como el FHAR, Frente Homosexual de Acción Revolucionaria, creado en 1978 (Díez, 2011: 697).

${ }^{27}$ Creo que es necesario insistir en que estamos ante un campo que se ha transformado de manera intensa en los últimos 40 años en México. Esa transformación incluye la consolidación de las descripciones y clasificaciones psiquiátricas y sexológicas, condensadas en la noción de homosexualidad; la constitución de la identidad gay durante los años setenta, que fue 'importada' desde los Estados Unidos y Europa; la formación de un sujeto político a fines de los años setenta y su desplazamiento a partir de los años ochenta hacia formas específicas de ciudadanía y reivindicación de derechos; la creación de ciertos vínculos entre los sujetos y colectivos homosexuales con el Estado, específicamente a partir de la irrupción del sida en México, pero que hacia fines de los años noventa y durante la primera década de este siglo se ha traducido en una institucionalidad cada vez más compleja, leyes específicas y una demanda creciente de igualdad e inclusión.
} 
Foucault introduce un matiz que me parece fundamental para investigar esas formas de constitución de los sujetos desde la antropología. En la entrevista citada agrega que está interesado en las formas en las que el sujeto se constituye de manera activa, mediante lo que llamará "prácticas de sí”. Estas prácticas no son “algo que el individuo invente”, puntualiza, "se trata de esquemas que encuentra en su cultura y que le son propuestos, sugeridos, impuestos por dicha cultura, su sociedad y su grupo social" (Foucault, 2010c: 1037). En otro texto se pregunta: “¿Cómo la experiencia que se puede hacer de sí mismo y el saber que de ello se forma han sido organizados a través de ciertos esquemas? ¿Cómo se han definido, valorado, aconsejado o impuesto estos esquemas?" (Foucault, 2010d: 907). Por nuestra parte, las preguntas que planteamos son: ¿cuáles son los esquemas que se encuentran disponibles en Tenosique para que los sujetos homosexuales se constituyan como tales y se vinculen consigo mismos y con los otros mediante ciertas prácticas?, ¿con qué prácticas de sí cuentan estos sujetos para constituirse de determinada manera en el campo de la sexualidad y de la homosexualidad, específicamente?

Foucault escribirá que las prácticas de sí corresponden a:

los procedimientos, existentes sin duda en cualquier civilización, que son presupuestos o prescritos a los individuos para fijar su identidad, mantenerla o transformarla en función de cierto número de fines, y todo ello gracias a las relaciones de dominio sobre de sí sobre uno mismo o de conocimiento de uno por uno mismo (ibíd.).

En el caso que estudiamos, muchas de las prácticas de sí son procedimientos inventados o desviados de su uso común. Si bien formarían parte de la historia de las relaciones con uno mismo que Foucault quiso elaborar, lo serían de una manera particular. Las prácticas que hemos encontrado no son realizadas en los modos esperados ni con los fines prescritos. Son, en algún sentido, como si los hombres infames, a los que Foucault dedica una hermosa introducción, hubiesen elaborado una relación singular con ellos mismos y, en muchos sentidos, sui generis. Pero, al contrario de ellos, para existir nuestros sujetos no tuvieron que "cruzarse con el poder y despertar sus fuerzas" (Foucault, 2010e: 681). A la pregunta que Foucault planteó sobre esos individuos: “¿No constituye uno de los rasgos fundamentales de nuestra sociedad el hecho de que el destino adquiera la forma de la relación con el poder, de la lucha con o contra él?” (ibíd.), nosotros responderemos que, en este caso, el destino se ha desplegado mediante la creación de nuevas formas de vida y subjetividad y no está anclado en sus relaciones con el poder, únicamente. Al contrario, creo que "el punto más intenso de sus 
vidas, aquel en el que se concentra su energía" (ibíd.) se encuentra, hoy, en el deseo antes que en el poder.

Esa diferencia será fundamental, al menos por tres razones distintas. Primero, porque las prácticas de sí que nosotros encontramos no tienen la entereza, por así decirlo, de las que rastrea Foucault en un amplio espectro histórico y cultural. En muchos sentidos, diremos que sólo son ejercicios de sí o formas incipientes de prácticas posibles. Habría que contextualizar estos estudios con otros que delinearan las prácticas de sí vigentes en un país como México. Como no contamos con tales datos, sólo podremos esbozar lo que podría ser una mirada antropológica a dichas prácticas en contextos contemporáneos. Segundo, las prácticas que acá exploramos son, en muchos sentidos, marginales; es decir, son prácticas creadas o apropiadas por sujetos lejanos a sus formas institucionales, no sólo por su deseo o sus identidades, también por su ubicación en los mapas sociopolíticos y culturales del país. Como dije, no es claro cuáles son las prácticas de sí contemporáneas que permitan la producción de ciertos tipos de sujetos en México, pero habría que buscarlas en las instituciones pedagógicas, médicas y terapéuticas, así como en las religiosas y en las mediáticas. El mapa de prácticas de sí emergería, sin duda, fragmentado y, también, contradictorio. El Estado podría ser un prescriptor de ese tipo de prácticas, pero también el mercado o las diversas confesiones religiosas; los medios de comunicación podrían incitar algunas, pero desde ángulos diversos (desde el consumo, hasta la introspección moral). Tercero, son prácticas realizadas de manera heterogénea con respecto a los análisis foucaultianos ${ }^{28}$ : en vez de constreñir, esas prácticas abren un campo de indagación subjetiva, por eso prima la exploración sobre la introspección; no producen verdad, fundamentalmente, sino visibilidad, de modo que son prácticas que permiten crear cierta inteligibilidad subjetiva y códigos de lectura de sí y, por último, son prácticas afirmativas antes que negativas: no escudriñan los deseos para controlarlos, al contrario, buscan expandirlos y

\footnotetext{
${ }^{28}$ Foucault escribe:
}

Cuando comencé a estudiar las reglas, los deberes y las prohibiciones de la sexualidad y los procedimientos y las restricciones con las que se la asocia, mi interés no se centró simplemente en los actos que estaban permitidos y prohibidos, sino también en los sentimientos representados, los pensamientos y los deseos que se podían suscitar, la inclinación a escudriñar en sí mismo todo sentimiento oculto, todo movimiento del alma, todo deseo disfrazado bajo formas ilusorias. (Foucault, 2010f: 1069). 
expresarlos; no se remiten a una trascendencia que las justificaría, sino a una inmanencia que las facilita.

A estas prácticas las llamaremos homoprácticas: el conjunto de prácticas de sí que permiten la conformación de un sujeto homosexual y articulan formas específicas de subjetividad en torno a un deseo o partir de él. Esas prácticas agruparán un sinnúmero de experiencias de sí que estos sujetos han realizado a lo largo de sus vidas y que han creado colectivamente. Son prácticas que no requieren una identidad, en primera instancia, y se pueden rastrear en diversos momentos históricos. Se podría decir también que las homoprácticas son el grado mínimo de constitución tanto de un sujeto como de una sociabilidad. Por esto, aunque pueden presentar distintos grados de formalización o coherencia, donde se encuentren sus rastros se podrán hallar, también, formas de sociabilidad, modos de convivencia y la creación de un común homoerótico y homosocial. La identidad será, a mi entender, una especie de metapráctica que representará una articulación específica de las homoprácticas y permitirá la emergencia de un sujeto, es decir, de una "una forma -que- no es ni ante todo ni siempre idéntica a sí misma". Hoy, sin duda, lo gay es la metapráctica más densa y relevante. Pero no ha sido la única y, sin duda, experimentará transformaciones en lo venidero. El único común denominador de todas las homoprácticas será el deseo homerótico. En este sentido, el deseo será el antecedente de estas prácticas, como luego lo veremos, pero también un lugar mítico al que regresarán los relatos sobre sí que exploraremos. Dado que las homoprácticas deberán utilizar, pero también desplazar y transformar, los "esquemas" culturales y sociales disponibles para realizar una experiencia de sí y, en primer lugar, para que una experiencia en este campo sea posible, el deseo será un ancla subjetiva y narrativa, es decir, el principal esquema grupal y personal para producir prácticas de sí, utilizar las existentes o modificarlas.

Por último, creo que es importante pensar estas prácticas desde la perspectiva de una pluralidad de formas de ser o de subjetividades. Es una discusión a la que retornaremos luego, pero es fundamental evitar cualquier relato lineal sobre el desarrollo de formas de subjetividad. Muchos datos permitirán sostener, al contrario, que existe una pluralidad subjetiva que implica temporalidades diversas. No agotaré el argumento en este capítulo, pero será fundamental para reflexionar, al cierre de la investigación, sobre las prácticas de la diferencia que postularemos. Quisiera apuntar, por ahora, que esa pluralidad subjetiva emergerá cuando evitemos pensar la identidad como una consumación socio-histórica, o como un proceso de desarrollo que supera etapas mediante la creación de nuevos referentes. 
Esta perspectiva permitirá visualizar sujetos o formas de subjetividad que despliegan homoprácticas muy diversas, con distintas sedimentaciones históricas. Si retomamos los argumentos expuestos en el capítulo sobre las epistemes locales, cada posición de sujeto (puto, homosexual y gay) implicará ciertas homoprácticas. Pero, en cualquier sujeto existente, algunas o todas ellas podrían estar presentes, incluso si alguna metapráctica, leída también como una posición de sujeto, fuera dominante, por ejemplo la gay.

\section{Darse un nombre}

Juan ha sido uno de mis informantes más importantes. Es muy inteligente y reflexivo y, como Alan, desempeña una labor etnográfica en su propia comunidad. Es estilista y tiene un salón de belleza en su casa, junto con una pequeña tienda. A veces realiza lo que llama shows travestis, en los que dobla a Yuri, principalmente. Él se define como un gay afeminado: "yo soy afeminado porque me gusta la ropa afeminada, o sea, mi característica como gay es afeminada". Es muy conocido en la ciudad y entre las personas gay del lugar. Ha sido muy generoso conmigo y ha compartido parte importante de sus experiencias y reflexiones. Una de las primeras que platicamos fue su demanda de que lo llamaran por su nombre y no con insultos o apodos. Para Juan tener un nombre significaba poseer un lugar social digno y reconocido, resguardar su intimidad y exigir respeto por su forma de vida y su apariencia. Juan exige respeto y un nombre como resultado de la relación que ha construido consigo mismo a lo largo de los años: "antes en la calle te gritaban maricón, joto, puto y las veinte mil maneras de llamar a una loca, ¿no?, entonces ahora por lo menos ya te llaman por tu nombre, eso es un logro.” Recuerda que antes de participar en el Club era muy reprimido,

yo antes era muy reprimido, yo era de los que siempre iba viendo para abajo para ver si me encontraba algo, era yo muy reprimido, muy penoso, a mí me costó en lo personal aceptarme yo, me costó mucho, era homofóbico sin saberlo, hasta ahora que ya entiendo la palabrita, ya sabía que era yo homofóbico, de hecho yo odiaba a los gays, me caían mal porque yo llevaba esa represión, entonces me ha servido para aceptarme tal cual soy, para proyectarme tal y cual soy y pues me siento bien, ha servido de mucho la verdad. (Juan)

En este proceso, Juan levanta su mirada para observar el mundo, pero sobre todo para verse a sí mismo. Identifica la represión y la pena (vergüenza) como una dinámica subjetiva previa a su aceptación. Él mismo era un dique para su propio deseo que, a su vez, le causaba vergüenza. El 
odio, que él lee ahora con un término técnico como homofobia, era el afecto que marcaba la relación con los otros, así como consigo mismo. Si el afecto "se refiere al paso de un estado a otro en el cuerpo afectado, el aumento o la disminución de su capacidad de actuar" (Lloyd, citada en Braidotti, 2009: 224), el odio claramente limitaba la capacidad de actuar de Juan y restringía sus vínculos. Por eso, la dinámica que él experimenta está anclada entre dos coordenadas: por una parte, la restricción de su deseo, que es, fundamentalmente, una restricción corporal y subjetiva intensa; por otro, la apertura que encuentra en un colectivo de personas gay.

Yo pienso que lo importante es que te superas, superas esa parte de restricción propia que tienes de que muchas veces ese humorcito gay de casita, de closet y de que no quiero que mi familia, entonces te vas juntando con un grupo que es más abierto, con ideas más abiertas y rompes ese vínculo y dices “jah! Mis amigos son más abiertos, yo ¿por qué no?” y te ayuda, es una experiencia padre, bonita. (Juan)

¿Cómo consiguió levantar su mirada, este informante?, ¿cómo pudo establecer otra relación consigo mismo? Realiza pequeños ejercicios que, en algún momento, producen otra configuración subjetiva, al menos en relación con su deseo. Sloterdijk llama ejercicio a "cualquier operación mediante la cual se obtiene o se mejora la cualificación del que actúa para la siguiente ejecución de la misma operación, independientemente de que se declare o no se declare a ésta como un ejercicio" (Sloterdijk, 2012: 17). Parece una definición técnica, y lo es, pero permite pensar esos pequeños momentos en los que se actúa sobre uno mismo con miras a una transformación posible. Juan no levanta su mirada, de ese suelo vergonzoso en el que posaba sus ojos, de una vez y para siempre. El proceso es paulatino: poco a poco aprende a mirar y a mirarse de otra manera; poco a poco, también, comienza a sentirse a sí mismo de otras formas y a sentir a los otros. Los afectos, en este sentido, no son estados absolutos y definitivos, sino relativos y provisionales. En su caso, el tránsito dificultoso desde el "odio" a la “aceptación” es un proceso que le toma años. Es interesante observar que la disminución del odio, que él sentía por los otros gay, implica un incremento de la aceptación hacia sí mismo. En esas circunstancias, la aceptación puede leerse como una operación que "mejora la cualificación del que actúa para la siguiente ejecución de la misma operación”. Según odia con menor intensidad, puede aceptarse con mayor plenitud. La restricción subjetiva que es derrotada por la apertura grupal es consecutiva a esa dinámica de incremento/disminución entre aceptación y odio. 
En ese proceso complejo y duradero, Juan puede renunciar a las caretas y a los pesos que carga. Cuando le pregunto cómo se sintió en esos momentos, responde que libre:

como que te quitas un pesito de encima y dices "ay ya, basta", como que te quitas una careta, porque parece mentira como que tratas de aparentar y engañar a mucha gente que aún no se ha dado cuenta entonces ya dices: “jay! Yo ya quiero ser asî” y con el pie derecho empiezas y te quitas la careta y que me acepten tal y cual soy. (Juan)

Las caretas que algunos informantes atribuían a los gay, en un capítulo anterior, han caído en el caso de Juan. La apariencia que engaña da paso a un deseo que no lo hace. En ese momento, la aceptación personal se transforma en otra social. Sólo sin caretas se puede exigir que los otros te acepten.

Efraín habla de un modo semejante, dice es importante "reconocerse a uno mismo" y que es "difícil vivir una dualidad, vivir dos vidas" o aparentar una que no es cierta:

Pues es importante reconocerse a uno mismo, es muy difícil vivir una dualidad, vivir dos vidas, o aparentar una vida que no la es como hay gente que la lleva y que la ha llevado, mal que bien, la ha llevado, pero el shock emocional y psicológico va a tener costos muy grandes a la larga, imagínate a un padre que tienes hijos y que tiene muy cerrada su homosexualidad y de repente se le descubre así por azar, y va a ser un shock psicológico para la familia para sus hijos, entonces eso desde mi punto de vista es feo ¿no? Porque te estás mintiendo como a ti mismo, es más fácil que tú te aceptes para que sepas cómo te vas a conducir. (Efraín)

El reconocimiento de uno mismo evita la mentira y el engaño, que duplican las vidas. Parece que ante el deseo no hay ardid posible. En este relato, parecido al que veremos en el siguiente capítulo, el deseo pospuesto es una amenaza. Ni los hijos, ni la familia pueden contener la homosexualidad y si ésta surge, a pesar de los intentos por negarla, produce un "shock emocional". La mentira es una forma de evitar el reconocimiento del deseo, por lo tanto, impide la aceptación. Pero podemos ver cómo la mentira constituye una relación distorsionada con uno mismo. En ese sentido, la aceptación y el reconocimiento son rutas para crear un sujeto integrado. La dualidad o las caretas, las mentiras y las apariencias confunden, evitan y ocultan; en cambio, la aceptación, la integración y la verdad producirían una relación distendida y más amable con uno mismo.

Juan relata que cuando inició este proceso temía que los otros se dieran cuenta de que era gay y, consecuentemente, a sus reacciones. Usaba bigote y trataba de tener una apariencia masculina, dentro de lo posible. Pero "el cuerpo y la vida" le exigían quitarse la careta. Y en ese 
esfuerzo se encuentra con otros y fundan el Club. Juan relata que fue un proceso que vivió junto con otros gay de su misma edad.

Cuando yo me quito la careta empiezo a tener todas a mis amistades gay a escondidas, porque yo estaba en proceso de aceptación ¿me entiendes?, ya para esto tenía 18 años, ya sentía yo que la vida y el cuerpo me exigían quitarme yo la careta entonces la vinculación surge porque como teníamos amistades, fulanito me dice "va a haber una reunión de una fiesta de un cumpleaños de un amigo...", o sea, de la misma comunidad gay, "vamos te invito" "ay no, es que van a ir puras locas, puras vestidas y guácala y no sé qué" entonces "ay no, es que nadie te va a obligar, y mira y esto", aunque yo la inquietud la traía y ahí nace el vínculo con las demás, con las que ahora formamos el grupo y que somos varias, ahí nace el vínculo.

Juan intensifica su propio poder de interactuar con los demás y parece que ese incremento se traduce en un sentido más nítido y afable de sí mismo. El cuerpo se lo demandaba: interactuar con otros, vincularse. Lo que parece una necesidad corporal se transforma también en una ganancia psíquica. Braidotti escribe que "el sentido del sí mismo de sujeto corporizado depende de no estar aislado del ambiente, por cuanto este sujeto se define por la capacidad del cuerpo de impedir o intensificar su propio poder de interactuar con los demás" (Braidotti, 2009: 207). El aislamiento, que él lee como restricción, careta, apariencia y mentira, se rompe mediante la apertura y la aceptación. Juan en este sentido es más verdadero luego de ese proceso, porque su apariencia coincide con su autoimagen; porque su deseo conviene, en alguna medida, con su mundo; porque su cuerpo, en última instancia, concuerda con su subjetividad. Pero es una verdad particular, porque no la gatillan los esquemas institucionales, sino una urgencia corporal.

En el contexto en el que vivía, Juan debió mantenerse oculto. Su verdad era disruptiva y no era deseada colectivamente. Según me relata, su padre no le volvió a hablar cuando se enteró de su homosexualidad. Cuando su progenitor a agonizaba, Juan fue a verlo; llevaban más de 20 años sin hablarse, pese a que vivían en la misma ciudad. En una conversación que tuve con él por esas fechas me contó que se había dado cuenta de que su padre siempre lo había querido, pero que "el orgullo de ambos había sido más poderoso que el amor". En este caso, los vínculos se disolvieron, éste fue el precio que Juan debió pagar por ser quien deseaba. Quitarse las caretas, al menos cuando él lo hizo, tuvo costos muy altos, pero también los tenía seguir cargándolas, por eso Juan dice que "se sacó un peso de encima". La imagen es intensamente corporal: se saca el peso de la mirada y los juicios de los otros, pero también del 
odio y el rechazo que siente hacia sí mismo y los otros. La nueva ligereza le ayudará a vincularse con otros que viven el mismo proceso y será la fuerza que le permita alzar su mirada de ese piso confuso y aflictivo. En alguna medida, el sí mismo que vemos emerger es el espacio psíquico y narrativo que se forma entre los pesos que se quitan, la mirada que se levanta y las caretas que caen. Es un espaciamiento y un develamiento, porque lo que se resta deja espacio y lo que se quita muestra algo que ya estaba. En alguna medida, las prácticas de sí son una forma de exploración antes que de creación. Juan se encuentra con quien es, por eso necesita despejar su mirada y su cuerpo, para poder contemplarse. El deseo, como lo dijimos, será el ancla mítica de un viaje hacia sí mismo. Lo importante es que se disponga de un lugar al que regresar, de un rostro que descubrir o cuerpo que liberar. Lo que estuvo antes de su enmascaramiento fue su deseo, lo que encuentra después de su desocultación es su deseo. El deseo, lo veremos luego, podría pensarse como una esfera que permite ese trayecto de un sujeto desde sí mismo hasta sí mismo. No es forzoso que Juan descubra algo sustancial, sólo que existan coordenadas en un itinerario interior que lo conducen hasta un lugar en sí mismo que parece previo a cualquier socialización, anterior a las restricciones y los temores. Ese lugar es mítico, pero indispensable. Si el futuro está obturado por el rechazo (interior y exterior), entonces el viaje es un regreso que propulsa, como si para encontrar un lugar en el mundo se necesitara, primero, hallar un espacio en sí mismo. La práctica de sí es el trayecto de ese desplazamiento hacia el pasado (la biografía) y el futuro (el cuerpo).

\section{Respeto}

Si nos preguntáramos cuáles son los esquemas, como los llama Foucault, que organizan esta experiencia de sí mismo, creo que Juan y otros gay de la ciudad encontrarán uno en el respeto. Lo hemos visto a lo largo de los capítulos: el respeto es exigido y demandado, dado o pedido. Es un valor y una práctica central en la constitución de lo común y de los vínculos interpersonales. Es, en este sentido, un esquema primero de las relaciones sociales y luego de las relaciones con uno mismo. Pero los gay de Tenosique lo transforman en un esquema mediante el cual la relación consigo mismo puede sincronizarse con los vínculos con los demás. Juan lo dice con claridad:

porque ahí empieza el respeto por uno mismo, yo me quiero, yo me respeto, yo te aprecio, tú me respetas y si no me respetas o te desecho o te hago que me respetes de 
alguna manera ¿me entiendes?, entonces yo voy luchando por eso, yo estoy empezando con el respeto conmigo mismo, no te digo que ya lo llevo ganado porque todavía hay dos que tres ignorantes, pero sí la mayoría de la comunidad y de la gente, o sea, con la gente no hay tanto problema porque para la mayoría de la gente soy Juanito, es entre la misma comunidad (gay) la que te hace.

El respeto está siempre marcado por la presencia de los otros, que lo confirman o desmienten. Pero, en el proceso de constitución de sí mismo se ha producido una inversión de esas relaciones: si previamente la careta ocultaba lo que se era ante los otros, ahora el respeto es una forma de exigirles que acepten lo que se es. La práctica de sí ha sido un modo de modificar las relaciones de poder y las formas de producir subjetividades. Juan se transforma: se quita pesos de encima y caretas de su deseo y luego exige respeto. Una vez consolidado el proceso interior (vivido colectivamente) entonces los otros deben acomodarse a él: "o te desecho o hago que me respetes", dice Juan. La apertura, el desenmascaramiento, cierta coherencia entre cuerpo y deseo, se convierten en una demanda para que los otros limiten sus acciones.

Cada uno puede reconstruir una larga historia personal y colectiva en la que no se les respetó. Narración de las humillaciones y los malos tratos que experimentaron por ser homosexuales. Efraín recuerda que:

Lo he visto en el transcurso de mi vida que ha habido gente que es afeminada y en una secundaria lo empiezan a vacilar, a quitarles las cosas, le rompen sus cosas, pero como maldad que se le puede volver no nada más a un niño afeminado, a un niño tímido, o sea, en las escuelas hay veces que los grupos que se vuelven hacia las personas más débiles (Efraín)

No haré ahora un recuento de estas experiencias, pero deseo mostrar que el respeto es leído como un logro y no como un antecedente de sus relaciones con los otros y con el mundo. El mismo Efraín narra que en ciertas ocasiones "le han faltado el respeto", pero no de manera “oprobiosa”. Piensa que tal vez él mismo provocó esas acciones, pero que en general lo han tratado bien, aunque amigos suyos hayan experimentado agresiones más graves.

A mí no, nada, oprobioso que yo me sienta mal, no, o sea, no tengo factores así que diga que me sentí ofendido, no, sí ha habido en épocas de mi vida que jay!, pero a palabras necias oídos sordos, y yo he utilizado esa... esa... y casi por lo regular no he tenido, ha sido muy raro, y si ha habido faltas de respeto es porque hay veces uno mismo lo ha provocado y te das cuenta, y no es porque la sociedad esté en tu contra pero también se debe quizás a que yo soy open mind, ¿me entiendes?, por eso no he 
tenido ese tipo de circunstancias, pero sí he tenido compañeros que han tenido agresiones, verbales y físicas por esas cuestiones

Este informante evalúa su relación con "la sociedad" según el grado de apertura que muestra: él se siente open mind en un mundo que parece cerrado. La relación entre apertura y aceptación que vimos en la historia de Juan se repite en este caso, pero de un modo distinto. Efraín se parapeta detrás de sus oídos sordos para no escuchar los insultos y elude la confrontación directa con sus agresores. A otros les ha ido peor. El respeto es una relación frágil y no se sabe cuándo se romperá, pero una vez rota las consecuencias son claras: insultos, burlas, "agresiones verbales y físicas". Él mismo delinea una estrategia ante esta situación: en el caso de las personas afeminadas se "alían con las mujeres" y tratan de ganarse a los ofensores. Dice, claramente, que el homosexual solitario "las lleva de perder" y que encontrará protección "unido a un grupo". La simiente de la sociabilidad sería una defensa frente a los ataques de los otros: es una manifestación de las formas de producción de las inmunidades que exploraremos luego. Pero, en esta dinámica entre respeto y agresión, el homosexual necesitará de cobijos colectivos para sobrevivir a la hostilidad generalizada; por eso formará Círculos o Clubes que lo protejan. Esferas de inmunidad.

¿Qué hace la persona homosexual? Se alía, el homosexual afeminado se alía con las mujeres y ya forma parte del grupo de las mujeres aunque no es mujer y ya ellas lo defienden, o sea, no es tonto, el homosexual no es tonto, sabe que solo la lleva de perder pero que unido a un grupo que les caiga bien y hay formas que yo he visto que se los ganan, que les regalan cosas a los chamacos para... o sea es una forma de sobrevivencia que se ve en muchos ámbitos no nada más en el aspecto sexual (Efraín)

Los informantes consideran que el respeto es una relación mutua: si se lo pide, también se lo debe brindar. El respeto sería el fundamento de los vínculos con la gente de la ciudad. Enrique, que se dedica a confeccionar adornos para fiestas de XV años y ha sido un integrante muy importante del Club desde su fundación, dice que el respeto se traduce en la valoración social del grupo y el cariño que la gente siente por sus miembros. "Creo que nunca les faltamos al respeto, dice, nos damos a valorar, somos lo que somos, valemos lo que somos, queremos mucho a la gente, la gente nos apoya mucho”. Así se abriría una secuencia de relaciones positivas entre los integrantes del Club y los habitantes de la ciudad: respeto, valoración, cariño. Juan considera básico respetar para poder exigir, a su vez, el respeto de los otros -“yo siempre he dicho algo, que no podemos ir por la vida exigiendo respeto si nosotros no respetamos"- y en ese vínculo también reclama que se le dé un nombre: 
Para mí no es un lujo que me llamen loca, jota, yo tengo mi nombre entonces sí, sí es importante para mí que me llamen por mi nombre, que yo sienta el respeto por el que yo estoy luchando, porque sí lo siento, siento que sí, me ha costado, en lo personal he tenido que jalarle las orejas a alguna de mis compañeras también, me ha costado, pero lo he logrado que por lo menos me respeten porque eso es muy importante, que la gente se dé cuenta que nosotros no sólo servimos para jotear, o sea, tenemos que demostrar que somos capaces y que merecemos respeto y aquí lo estamos logrando, poco a poco lo estamos logrando. (Juan)

"Yo tengo mi nombre", dice este informante y exige que se llame por él. Pero la voz de los otros no está garantizada y conseguir una coherencia entre el deseo y la conducta ha requerido mucho trabajo, incluso con otros gay de la comunidad. Si el respeto es una condición básica, el nombre es su resultado principal. El respeto se traduciría en otra develación, consecutiva a quitarse las caretas o evitar las duplicidades, que mostraría que estas personas no sólo "sirven para jotear", tienen capacidades para hacer otras cosas y desarrollar otras potencialidades. Juan es muy enfático en este punto; dice que él "no es un perro, un gato, algo a lo que le puedas adjudicar un adjetivo". El respeto y el nombre son condiciones para que sea considerado como persona y evitan su deshumanización y su cosificación. El nombre es una palabra solitaria, en el discurso de Juan que no necesita adjetivos; se basta a sí mismo. En alguna medida, el nombre es una palabra absoluta y no relativa. Sustenta la relación con los otros y consigo mismo y no puede ser negociado; es una garantía de la existencia en el mundo y el pivote de cualquier reconocimiento.

- ¿Qué es el respeto para ti?, ¿que respeten tu nombre?

- ¡Cómo no! que me digan mi nombre, es que yo no soy perro, no soy gato, yo no soy algo que tú puedas venir a adjudicar como un adjetivo, no, si tú como persona me conoces y desde el momento en que nos presentan, yo te voy a decir "Hola, mi nombre es Juan" porque tú vas a decir “!Ay! ahí viene la Juana o ahí va la Juana”, no, si yo nunca te dije "Mi nombre es Juana". Entonces eso es muy importante, lo peleo y lo voy a pelear, cueste lo que me cueste lo voy a pelear, así me quede con tres o cuatro amigos yo lo voy a pelear. (Juan)

Practicar su propio nombre, usarlo, repetirlo, incitar e incluso obligar a los otros que lo usen. La práctica de sí que se organiza en torno al respeto y el nombre utiliza dos esquemas que permiten una experiencia de sí mismo: nombrarse y ser nombrado, respetarse y ser respetado. La relación con uno mismo está marcada por la relación con los otros. El diálogo interior es 
consecutivo, aunque sea paralelo, al diálogo intersubjetivo. Si esto también fuera un ejercicio sobre sí mismo, coincidiría con la definición que leímos de Sloterdijk: “cualquier operación mediante la cual se obtiene o se mejora la cualificación del que actúa para la siguiente ejecución de la misma operación” (Sloterdijk, 2012: 17). Luego de ser nombrado con el nombre propio se está mejor cualificado para serlo nuevamente; una vez que se consigue respeto, éste puede aumentar.

En Juan este ejercicio constante produce un efecto paradójico. Con respecto a Tenosique dice que "este pueblo antes era muy etiquetado, nos etiquetaban mucho". Pero esa larga trayectoria, que lo ha dotado de un nombre y de cierto respeto, lo conduce a esperar que no sea su identidad (gay) la que prime en la relación con los otros.

Ese, que me vean como ser humano, que no me vean como bicho raro, trato de comportarme de una manera en la que tú como persona no sientas que estás hablando con un gay ¿me entiendes?, yo he intentado que cuando conozco gente o con mis propias amistades de alguna manera proyectarles que lo último en que tú te fijes es en mi sexualidad, o sea, eso es lo que inconsciente, consciente o psicológicamente, como le quieras llamar, intento que la persona me trate de acuerdo a mi forma de ser, o sea, trato de intentar que tú no te des cuenta que estás hablando con un gay, estás hablando con un ser humano, ¿sí me explico?, aunque uno sea amanerado, tenga su forma de vestirse y todo, yo trato psicológicamente que tú no te des cuenta de eso, de cómo yo ande, sino de con quién estás tratando. (Juan)

Es como si detrás de las caretas de las que Juan se ha deshecho y de los pesos que se ha quitado surgiera alguien intensamente singular que no puede ser clasificado bajo ninguna etiqueta. No importa si ciertos comportamientos o vestimentas develan al sujeto, Juan busca que las personas se relacionen con un ser bumano antes que con un gay. Pura subjetividad que elude los adjetivos. Las caretas no fueron quitadas para mostrar algo que estuviera oculto, lo han sido para que emergiera un sujeto inclasificable, una singularidad intensa, un cuerpo que no puede ser etiquetado.

Ser humano, escribe Sloterdijk, "significará considerarse a sí mismo como el taller de la autorrealización” (Sloterdijk, 2012: 415). Si al sacarse las caretas, Juan se hace visible para sí mismo y los otros, también busca una "ceguera" colectiva que no vea su sexualidad o su deseo; es como si emergiera un interior aún más íntimo que debiera primar en cualquier relación. De hecho, cuando realizamos esta entrevista alguien que estaba en la sala donde platicábamos comentó, en tono de burla, "habría que ser ciego", ante la demanda de Juan de que la gente no 
notara su afeminamiento o no se fijara en su aspecto - "lo último en que tú te fijes es en mi sexualidad"-. ¿Qué significaría esa ceguera frente a lo que es leído como evidente e ineludible?, ¿por qué lo humano se mostraría una vez suspendida la mirada social que clasifica y juzga?, ¿qué sujeto surge de esa mirada pasmada y esa ceguera provisional que pide Juan? Es paradójico que la claridad interior corresponda, incluso exija, una ceguera exterior. Las caretas que caen del rostro propio son traspuestas al de los demás y la humanidad compartida se guarece detrás de la vista, casi fuera del mundo, en una interioridad luminosa, pero que se desea invisible. ${ }^{29}$

El trayecto vital de Juan es una curva, que va desde la aceptación dificultosa hasta una invisibilidad deseada. En ese recorrido, Juan se produce a sí mismo, es orfebre de un interior que se erige paulatinamente, pero también creador de nuevas coordenadas de reconocimiento y visibilidad. Su gesto, tal vez de los más radicales que conocí en el campo, es afirmarse en una singularidad luminosa, íntima, propia, pero también incatalogable. Juan resiste a una cultura y un orden social que insiste en clasificarlo y en nombrarlo en contra de una autonomía fundamental, que él reclama. La humanidad compartida, que inquietaba a alguna funcionaria, se transforma en este caso en el sostén de una originalidad radical. Lo humano es lo mínimo y

\footnotetext{
${ }^{29}$ Cuando en un capítulo posterior exploremos el aura que produce el abandono entre ciertos sujetos y colectivos, constataremos que ella surge, en alguna medida, de la mirada de los otros, especialmente de las instituciones. El aura de los abandonados no corresponderá a esta luminosidad interior que cegaría la mirada social, en el caso de Juan, sino al brillo exterior de relaciones sociales de abandono. Diremos que el aura de los abandonados es el brillo de la nuda vida y la biopolítica. Pero en esta ceguera colectiva que Juan exige, y que se sustenta en un resplandor singular más intenso que cualquier identidad o apariencia, leeremos un aura inmune que protege a los sujetos del abandono. Lo que puede ser visto o lo que no admite clasificaciones, tampoco puede ser intervenido. El poder, quizás, termina donde empieza una singularidad radical, que desconoce cualquier identidad, pero también toda etiqueta. Al contrario del aura de los abandonados, el aura de la inmunidad interrumpe la mirada estatal, al confundir sus procedimientos clasificatorios mediante singularidades resplandecientes. La luz, que será una propiedad de los dispositivos, según Deleuze, puede operar como una superficie material de develamiento (abandono) o de enceguecimiento (inmunidad). Una estrategia de los colectivos amenazados por el abandono sería incrementar el brillo de sus auras inmunes. Tal vez fue lo que hizo el Club al participar en el carnaval de la ciudad o al realizar eventos festivos de manera constante. La fiesta, en alguna medida, sería una estrategia de intensificación de la luminosidad para generar cegueras colectivas y para producir auras inmunes.
} 
lo común, lo subjetivo es lo singular y lo intenso. Juan es un practicante de las libertades venideras. $^{30}$

\section{Conocerse a si mismo}

El deseo constituye una de las primeras experiencias de sí que relatan los gay de la ciudad. Esta experiencia es previa a la formación de cualquier identidad en este campo, al menos cuando los informantes eran niños ${ }^{31}$. Josué recuerda

Como a eso de los seis años, entre cinco y seis, porque me acuerdo perfectamente que yo iba en el kínder, entonces yo sentía, no sé, algo, algo... a mí me gustaba que mis mismos compañeritos, los varoncitos, o sea, que me tocaran o no sé, o sea, yo sentía bonito que me tocaran a mí, alguna parte de mi cuerpo, la mano, yo qué sé; lógicamente tal vez ellos no se daban cuenta que pues a lo mejor yo iba a ser homosexual o no sé, pero yo sí, la verdad, desde esa edad ya me sentía yo atraído por los hombres, la verdad, ya sentía que me gustaban, mis compañeritos pues. (Josué)

Un saber sobre el deseo es un saber sobre uno mismo. Josué reconoce su diferencia y su gusto, recuerda la atracción y las sensaciones que le producían sus compañeros. Su cuerpo, en muchos sentidos, guardó un recuerdo de esos deseos tempranos. Él aprendió sobre sí mismo a través de esas experiencias corporales y sensitivas. En tanto experiencia de sí, el deseo es como una onda que atraviesa la propia intimidad y se conecta con los demás; en ese sentido, la atracción es un conocimiento de los otros. Es como si el cuerpo calibrara su propia intensidad y regulara los deseos que se producen en él. Josué tiene una conciencia temprana de su deseo porque recuerda las sensaciones que tenía al sentir a sus compañeros o tocarlos. Un deseo que

\footnotetext{
30 Alguna vez Juan me comentó que su madre lo increpaba porque no sentaba cabeza. Él le preguntó si tenía un hijo que hubiese sido más feliz que él, que había hecho lo que quería, que había viajado, que se vestía como gustaba. Esa respuesta me sorprendió, también me conmovió, porque la justificación de su propia vida la hallaba en la felicidad que había experimentado: ¿existe un motivo más poderoso que la felicidad para sentir que una vida ha valido la pena?, ¿dónde, sino ahí, podríamos sostener una ética que asegurara el buen vivir, colectivo e individual?

31 Según Alain Badiou, a la (hermosa) pregunta de Rousseau “¿Qué es la infancia?”, Freud habría contestado que "la infancia es el escenario de la constitución del sujeto en y por el deseo, en y por el ejercicio del placer ligado a representaciones de objeto. La infancia fija el marco sexual dentro del cual, en lo sucesivo, todo nuestro pensamiento debe mantenerse, por sublimadas que sean sus operaciones” (Badiou, 2005: 102).
} 
es previo a cualquier práctica sexual específica y que es, ante todo, un conocimiento de sí. "Los cuerpos, escribe Braidotti, no son entidades pasivas sino que contienen sus propias fuerzas y tratan de conectarse con ellas. La sincronización con estas fuerzas es la fuente de la conciencia y, por lo tanto, de un conocimiento de uno mismo" (Braidotti, 2009: 207). ¿Ha nacido una conciencia en esas sensaciones sincronizadas por la memoria?, ¿ellas son fuentes de un conocimiento de uno mismo?, ¿es el deseo la fuente de una conciencia que, en algún sentido, sólo es un eco de las fuerzas que atraviesan el cuerpo?

Jesús lo vivió más tardíamente, a los 10 años dice que "presentía que -le-gustaban los chicos" y que ese gusto se fue intensificando hasta que tuvo su primera relación sexual. Sabe que nunca le "llamaron la atención las mujeres", pero su deseo por los hombres fue algo que descubrió paulatinamente. Él se educó en una familia muy religiosa y temía tanto a la reacción de sus padres como a la de Dios frente a su deseo.

Bueno, a la edad de los diez años ya presentía de que me gustaban los chicos, o sea, me gustaban los niños y ya después de ahí, terminé mi primaria, entré a la secundaria y entonces ya era un poquito más fuerte, o sea, vi más chavos en mi salón que, jay!, buenísimos, o sea, nunca me llamaron la atención las mujeres, nunca, entonces ya de ahí empecé a sentir más atracción por los chamacos y mi primera vez que tuve mi relación sexual fue con un amigo y ahora sí que él fue el que me quitó mi virginidad. (Jesús)

El deseo es una experiencia solitaria y una de las primeras evidencias de una diferencia con respecto al orden sexual dominante. La experiencia de sí, por tanto, es muchas veces conflictiva, pero es fundamental para que se conforme un sujeto, que emergerá en esa relación entre las sensaciones corporales, una lectura subjetiva y las reacciones del mundo y de los otros. Al menos en el ámbito que nos interesa, el sí mismo surgirá de esa experiencia del deseo que es, en muchos sentidos, desconcertante y también muda.

El sexo puede ser temprano, un informante recuerda que a los siete u ocho años "le hacía sexo oral a mi primo mayor". La distancia entre el deseo y la práctica sexual puede variar. Pero hoy, cuando este informante recuerda, traza una línea desde esas primeras experiencias hasta el presente. El deseo es un arco para el acto de recordar, que otorga una coherencia y organiza una trayectoria.

Alan experimenta un deseo homoerótico desde niño, pero recuerda con claridad una experiencia con un compañero de salón cinco años mayor que él. Califica esa experiencia como 
“inolvidable" y dice que aún es "vívida". En el salón, durante la clase, se tocaban sin que nadie se diera cuenta.

una experiencia que se me hace inolvidable, que la tengo aquí vívida, no se me olvida, cuando estaba yo en quinto año de primaria, yo estudié la primaria aquí, en José María Pino Suarez, aquí adelante, y en ese tiempo habían unos bancos así, inclinados que tenían sus cajones abajo y entonces un compañero de clase, que yo estaba enamorado de él ya, se llamaba Juan José y me excitaba, me enamoraba y me acuerdo que en el salón de clase él se aconchaba así y se paraba y ya era más grande que yo, era más grande que yo, yo tenía, en quinto año yo creo que tenía como diez años, diez u once años y Juan José ya tenía quince años, entonces Juan José ya tenía la verga grande y bonita y entonces él, en plena hora de clase, en horario de clase se metía así, en el mesa banco y ahí se paraba la verga, se la sacaba y yo se la estaba jugando y la maestra estaba dando clase enfrente y los compañeros de clase a lado y todo, y nadie se daba cuenta de él.

Recordemos que Foucault denomina técnicas de sí a "los procedimientos (...) que son presupuestos o prescritos a los individuos para fijar su identidad, mantenerla o transformarla en función de cierto número de fines" (Foucault, 2010d: 907). En nuestro campo no encontramos algo tan elaborado, al menos en términos institucionales. El conocimiento de sí que hemos analizado no es sistemático ni obedece a prácticas establecidas de relación con uno mismo. El descubrimiento del deseo y las formas de conocimiento de sí mismo que genera no fijan una identidad ni la transforman; la identidad es el resultado posterior de una larga travesía por el propio deseo, marcada por la presencia de los otros y por los contextos en los que se despliega. Frente a su deseo, podríamos decir que el homosexual es una figura tardía, que puede revisar en retrospectiva su biografía y crearla. En estas trayectorias, cuando entrevistamos a nuestros informantes, presenciamos la creación de ciertas prácticas de sí, que son fundamentalmente lecturas de su pasado y de sus vidas. Una mnemotécnica del deseo que puede hallar, entre múltiples hechos y vínculos, ese primer momento, quizás mítico, donde se lo descubre, pero que también lo inaugura. Estamos en los albores de lo que denominamos homoprácticas.

Alan recuerda esas aventuras escolares, entre compañeros y pupitres, en las que encuentra el cuerpo del otro dispuesto para su deseo. "No se me olvida", dice, "lo tengo bien presente en mi mente". Tal vez ese muchacho fue su primer amor y aún percibe las sensaciones que le producía. Alan merodea por su memoria para recorrer, también, su cuerpo; habla de su deseo 
para acercarse a sus afectos. Una práctica de sí para su deseo, que no necesitaba de ninguna identidad que fijara ese sí. No había nada que asentar, en primera instancia, porque todo debía ser creado, entre sensaciones, ideas, temores y experiencias.

esa experiencia de manosearle la verga ahí, bajo el banco, no se me olvida nunca, la tengo pero bien presente en mi mente, cada vez que me acuerdo parece que estoy en el momento en que yo... es más, siento a veces, porque creo que fue mi primer amor sin darme cuenta, a veces yo he pensado eso que tal vez fue mi primer amor, porque hasta la fecha no me olvido de él, me acuerdo y todavía siento a veces, por ejemplo, ahorita pongo las manos aquí debajo de la mesa y siento así, la sensación de cómo le agarraba yo la verga....

¿Cómo se puede formar un sujeto en un contexto violento?, ¿cómo se puede experimentar un deseo que es despreciado por los otros? Alan también recuerda la época en la que era un adolescente. Eran otros tiempos, más hostiles que los actuales para un hombre homosexual, especialmente si era afeminado. A Mario su padre no lo aceptaba, a Luis lo corrieron de su casa y tuvo que forjar su vida solo. Fue de casa en casa buscando cobijo. No había lugar para su deseo en el mundo del que proviene.

Entonces, de los más afeminados en ese tiempo eran ellos: Margarito, Clavelito, Julio y Mario ya empezaba a afeminarse bastante, pero Mario estaba muy restringido por el papá, porque el papá había tenido tres hijas mujeres y él era el único varón y no aceptaba que fuera homosexual. Mario tuvo muchos problemas porque su papá no lo aceptaba como homosexual, a Luis Pérez lo corrieron de su casa, porque no lo aceptaban como homosexual, a veces, actualmente yo pienso que Luis Pérez exagera, por ser como es, pero yo a veces lo comprendo porque él ha llegado a ser lo que es y a tener lo que tiene él solo, él se hizo solo sin el apoyo de la familia, los demás compañeros no conocen el pasado de Luis Pérez, no saben cómo sufrió, no saben cómo anduvo de casa en casa, no saben cómo anduvo rolando en Campeche, en Villahermosa; (...) Ya fue más adelante, pero en ese tiempo tendríamos, cuando yo tenía doce o trece años, había que esconderse para ser gay, no podías hacer fiestas gay, no podías ir a las cantinas, tenías que ser muy puto para estar en las cantinas y sufrir el acoso de la gente en las cantinas.

Para ser gay, dice Alan, "había que esconderse”. Las caretas de las que habló Juan, que vivió su adolescencia y juventud diez años más tarde, eran cercos para estos sujetos en esos momentos. Los escondites fueron formas de sobrevivencia, entre expulsiones y recriminaciones. Así se formó un sujeto, teniendo una experiencia de sí ambivalente, entre las certezas que le daba el 
deseo y las incertidumbres del mundo. Alan recuerda que "las familias golpeaban a los hijos por ser gay, ¡Claro que sí! La mayor parte de las familias a veces golpeaba a los hijos por ser gay, la mayor parte de las familias e incluso a mí me pegaron. Cuando mi papá descubrió que me gustaban los hombres, me golpeó.” Frente al deseo, los golpes, esos intentos contiguos a otros que analizamos previamente para rectificar estas subjetividades torcidas. La violencia parecía ser la respuesta esperada frente a los desvíos del cuerpo. En algún sentido, era una forma de crear otra experiencia de sí mismo: en las antípodas de las excitaciones del deseo, la crudeza del dolor corporal.

Exequiel tenía 18 años cuando lo entrevisté. Es decir, estaba viviendo su adolescencia y lo separaban más de treinta años de las huidas de Luis, los escarceos de Alan y de la violencia del padre de Mario. Pero temía decirles a sus familiares que era gay; sentía que los defraudaría si se enteraban. Quería participar en un evento gay y salir "vestido de mujer", pero temía que su familia lo supiera: "que la gente se dé cuenta va y se lo dicen a tu familia o cualquier cosa, o te toman fotos y se lo dan a tu familia, y pues la verdad a mí no me gustaría pues defraudar a mi familia." Cuando le pregunté si su familia sabía que era gay me contestó que sí: "yo se los confesé”. La historia de golpes y huidas que nos relató Alan ha sido reemplazada por otra de confesiones y fraudes subjetivos. Exequiel no huye, pero sí se esconde, parcialmente. Él dice que le habría gustado ser mujer y habla de un proceso de conocimiento de sí mismo marcado más por el cuerpo que por el deseo: “¿Qué no me gusta de ser hombre? Ay pues de tener lo que ya tiene un hombre, órganos que son de hombres, eso es lo que no me gusta, el tener ropa así de hombre, no me gusta, no me atrae lo de un hombre." Quiere "ser mujer" porque le atrae todo lo femenino, admira a algunas cantantes y le gusta cómo se visten y algún día quisiera vestirse como ellas: “a mí sí me gustaría vestirme porque siento que tiene algo bonito, bueno, me imagino que es algo bonito vestirse bien, pintarse bien, todo eso me gustaría." Exequiel deseaba otro cuerpo y fue a través de esa desavenencia como pudo conocerse a sí mismo y trazar, de alguna forma, un futuro. En lo venidero quisiera ser otra persona, transformarse, mutar.

Hasta el día de hoy no lo ha hecho, salió a estudiar un tiempo fuera de Tenosique y regresó a trabajar a un salón de belleza que instaló su tía. Hoy se define como gay y no oculta su deseo. Es ambiguo en sus ropas y apariencia (según los parámetros locales) aunque sólo se trasviste para fiestas y eventos. Tomó cursos de belleza y de peinado en el municipio. En su trayectoria subjetiva, Exequiel se transformó, paulatinamente, en un gay y abandonó sus 
aspiraciones de convertirse en mujer e incluso en hacerlo quirúrgicamente. Las redes de identificación y sociabilidad locales le ofrecían dos caminos: ser un hombre gay afeminado o una "vestida". No conocía otras subjetividades ni otros cuerpos. Y eligió ese lugar que le permite explorar su deseo y su cuerpo: ser hombre, ser gay, vestirse, ser mujer, transformarse, regresar a ser un gay, dejar de ser hombre....

A Jesús este proceso le tomó varios años. Nació en una familia de protestantes devotos y participó en una iglesia que condenaba severamente la homosexualidad. Aunque a los 13 años tuvo su primera relación sexual con un hombre sólo comenzó a experimentar abiertamente su homosexualidad pasados los 25 años. Alan me hablaba de él cuando lo veíamos pasar cerca de nosotros. Decía que era "un putito de clóset" y que su familia era muy religiosa. Luego lo encontré en las actividades del grupo y había dado un giro importante a su apariencia y su lenguaje. Jesús piensa la homosexualidad como la definición de un sexo: "yo creo que para que tú puedas ser un homosexual tienes que definir tu sexo, si eres gay, si eres travesti, si eres transgénero, si eres bisexual o si eres... 'puto’ como le decimos acá.” La pregunta es quién eres y no, fundamentalmente, qué deseas. Las prácticas de sí rondan, intensamente, las identidades más que los deseos. "Mi vida en la homosexualidad, dice Jesús, he aprendido a vivirla día con día"; ser homosexual no significa que "seas una reina", agrega.

Alan actúa como un hermeneuta de su deseo cuando Jesús habla con él sobre su sexualidad: "Alan me decía: 'ay, entonces eres homosexual si ya tuviste tu primera relación sexual con un hombre, y si te gustó, pues entonces eres homosexual, fácil y sencillamente”. Fácily sencillamente, después de años de huir dentro de su casa de las voces de su familia y de las imprecaciones de los pastores; luego de eludir su deseo o posponerlo "por la palabra de Dios" que lo condenaba. El deseo, en la interpretación que Alan le brinda, será definitivo: "si ya tuviste tu primera relación sexual con un hombre, y si te gustó, pues entonces eres homosexual". Eres homosexual, le dice Alan y establece su identidad y los parámetros de una lectura de sí. La experiencia difusa del deseo, las condenas de su familia y de la iglesia, el gusto "por los chamacos" y los escarceos con ellos, todo eso es fijado en torno a una identidad y sellado a un cuerpo. Lo que parece abierto en su experiencia cotidiana con la homosexualidad, ese día con día del deseo, es sellado de manera perentoria por estas hermenéuticas personales de las prácticas y los géneros. El "putito de clóset" del que, en cierta forma, Alan se reía, ya ha definido su "sexo". Sabe quién es y se lo dice a los otros. Las diversas homoprácticas a las que recurrió Jesús, se transforman en esa metapráctica que es la identidad. Jesús relata su vida 
desde ese punto de aglutinación subjetiva, lo que estuvo disperso hoy está unido, lo que era fragmentario parece coherente. La apertura de ese día a día del devenir homosexual se convierte en la constancia del deseo y de sus descripciones.

Ahora él es un gay bastante conocido en la ciudad porque conduce un programa en la televisión local junto con Alan. Mucha gente lo saluda en la calle y le dicen "la Jesusa". Es muy sociable y llevadero. Los años en los que se "ocultaba" quedaron atrás, el temor a Dios y a su familia. Alguna vez me comentó que sus papás veían el programa en el que participaba y que le habían dicho que se sentían orgullosos de él. Su trayecto lo condujo a una mayor libertad personal.

\section{Las características positivas}

Para tener un lugar estos sujetos trazaron una trayectoria vital y, además, modificaron las descripciones que hacían de ellos mismos. Adquirir un conjunto de características positivas es un logro y supone un trabajo sobre sí y los otros. El desprecio nunca se acaba del todo, pero su poder se morigera con ciertos antídotos. A lo largo de la investigación he escuchado decir a los gay locales, innumerables veces, que ellos son trabajadores, creativos, alegres, especiales, solidarios o exitosos. Son características con las que coinciden otros informantes. No es relevante saber si esto es cierto o no; lo importante es reconocer el rango de afirmaciones que sustentan estas descripciones y las diferencias que suponen con respecto a las otras personas. Cuando los gay de la ciudad hablan de sí mismos destacan de manera particular esos rasgos que los caracterizarían. Pero, lo que me parece más significativo, es que se dotan de ciertos atributos singulares, que los distinguen del resto de la gente y producen modos de identificación colectivos.

Ángel, por ejemplo, destaca la diversidad de talentos y capacidades que tienen los gay.

Sí, yo creo que tratamos de abarcar más cosas porque en general una persona se dedica a una cosa específica, a su carrera por ejemplo el licenciado, el doctor, el maestro, qué sé yo, y un gay sabe guisar, o sea, yo soy estilista pero me gusta guisar, sé decorar, me gusta el baile y pongo vals, me gusta bordar y hago mis trajes para el carnaval, o sea, creo que tenemos más diversidad en nuestra vida. (Ángel)

Ángel dice que los gay son útiles, "gente que trabaja y productiva". En la misma línea, Juan afirma que ser gay no significa "que tu vida sea un carnaval, que tu vida sea una fiesta". Al 
enfatizar estas características positivas, también se produce un nuevo campo de identificaciones. Juan menciona que la gente debe darse cuenta de que los gay "tienen otras cualidades y pensamientos", distintos a la fiesta y la celebración.

nosotros no nada más nos vestimos de mujeres bonitas para estar recorriendo las calles, que tenemos otras cualidades, que tenemos otros pensamientos, otras formas de ser, entonces les demostramos que somos gentes capaces y que ante todas las cosas respetamos a esa gente para que esa gente nos dé el lugar que hoy tenemos, que nos respetan. (Juan)

La relevancia de estas afirmaciones será más clara al contrastarlas con los relatos de los propios gay sobre su lugar social y el trato que se les ha brindado. Cuando le pregunté a Alan cómo era el ambiente gay previo a la existencia del Club, respondió que era:

Muy reservado, los gays no podían salir a las calles con sus parejas, los gays no podían decir abiertamente que son gays, los que andaban vestidos de mujer tenían problemas, no, anoche nos gritó el doctor que los gays no podían salir a las calles vestidos de mujer, la policía los recogía si encontraban a los gays vestidos de mujer dentro de las cantinas, la policía los arrastraba y a golpes a las camionetas se los llevaban, todo eso era comúnmente.

Exequiel relata que muchas veces no se siente bien, "porque hay humillaciones que le hacen a las personas como a los gays, se burlan, porque a mí me, o sea, en la escuela, yo soy estudiante, hay personas que se burlan de mí, me humillan por ser gay”. Jesús dice, por su parte, que algunas personas creen que la homosexualidad "es parte de Satanás”. Alan agrega que ser gay significaba "ser de lo peor": "porque si eras gay, eras ratero, eras drogadicto, eras pervertidor de menores, lo único que puedes hacer como gay es barrer, trapear, cocinar y cortar pelo, enseñar vals".

No sólo se trataba de arbitrariedades, también era una forma de catalogar a las personas y de trazar su futuro. Son los parámetros para las prácticas de sí que elaboran estos sujetos. Deben construir otra imagen de sí mismos, otros discursos sobre sus subjetividades y sus vidas, otras representaciones de sus cuerpos y sus deseos para poder enfrentar y moderar esta carga de desprecio y las humillaciones que conlleva. Veremos cómo las formas esféricas del Club serán cruciales en ese proceso. "Entonces, dice Alan, la gente empezó a ver que somos un grupo gay y que tenemos la misma capacidad que los que no son gay". Pero nombrarse de otro modo, como lo vimos antes, y percibirse de una manera diferente demandan un largo 
proceso. Son, quizás, algunas de las experiencias de sí determinantes en la conformación de estos sujetos.

No basta, en este sentido, contar con descripciones y relaciones que no conduzcan al desprecio o a la humillación. Es necesario poder elaborar otro relato de sí, que nunca es completamente personal. Si no se gesta una forma colectiva de autodenominarse, otras formas de describirse y horizontes vinculares diferentes, los esfuerzos individuales tendrán un efecto menor. Pero, a la vez, es primordial que los sujetos puedan tener una experiencia de sí distinta. Y este proceso doble, por así llamarlo, produjo ciertas prácticas de sí, no muy estructuradas y que tal vez son los brotes de prácticas futuras más densas, pero también de modos colectivos de autoconocimiento y experimentación. En dicho proceso encontraremos una sedimentación histórica de apuestas personales y grupales y, también, una insistencia y perseverancia en el deseo y la singularidad. En algún sentido, estaríamos ante una de las características fundamentales de lo que Sloterdijk denomina antropotécnicas, a saber: "el efecto retroactivo de todas las acciones y de todos los movimientos sobre su propio autor". Sin actos que inauguraran una retroacción no se habrían producido estas prácticas de sí, "ninguna actividad, escribe Sloterdijk, escaparía al principio de la determinación retroactiva del operador, y lo que tiene un efecto retroactivo opera también de antemano. La acción generaría al autor, la reflexión a quien reflexiona, la emoción a quien la experimenta, el examen de conciencia a la propia conciencia.” (Sloterdijk, 2012: 408). Todas estas prácticas produjeron a ese autor difuso, pero real, que hemos descrito; autor de sus propias descripciones, experimentador de su vida, buscador de singularidades vitales que le ayuden a sobrevivir en un contexto adverso. Diremos que una serie de homoprácticas disjuntas suscitaron a ese autor, efecto de una retroactividad reflexiva que potenció la acción futura.

\section{Topologías de la homosociabilidad: ambientes, círculos y esferas}

Una historia de las homoprácticas es correlativa a otra de las esferas homoeróticas. Si bien un sujeto podría desplegar prácticas de sí de manera solitaria, nunca puede hacerlo aisladamente. Como ha dicho Foucault, las prácticas de sí no son inventos individuales y para existir requieren de esquemas culturales. En el caso que nos interesa, los esquemas disponibles no permitían, en primera instancia, producir una experiencia de sí; por lo tanto, dicha experiencia tuvo que ser inventada paulatinamente, pero no ex nibilo, sino a partir de los esquemas 
existentes. Como esa es una labor colectiva que, no obstante, cada sujeto realiza sobre sí mismo, hemos sostenido que donde encontremos homoprácticas deberíamos hallar homosociabilidades. Estas homosociabilidades las leeremos como esferas homoeróticas.

Ya en la historia de Juanito hay pistas de este tipo de espacios. Cuando él llega al Distrito Federal participa de lo que llama el "ambiente" de la ciudad. Es decir, esa red difusa de personas y lugares que coincidían en un deseo, aunque lo hacían de manera soslayada o clandestina. En nuestra lectura, el ambiente es el primer espacio de homosociabilidad entre los sujetos que investigamos. Es, así mismo, una manifestación esférica inicial, aunque no consiga plenamente su forma. El ambiente sería una primera atmósfera, en palabras de Sloterdijk, cuya explicación sería una característica de la Modernidad, que se ve obligada a tematizar "un-seren-el-aire" hasta entonces "incuestionablemente dado y despreocupadamente previsible" (Sloterdijk, 2009a: 103). En un fascinante y extraordinario capítulo dedicado a esas condiciones atmosféricas de una modernidad tóxica y ecológica, que surge entre las ráfagas de gases contaminantes y los informes meteorológicos, Sloterdijk indica que el ser-en-el-mundo contemporáneo ya no puede experimentar inocentemente el acto (reflejo) de respirar; en estas nuevas condiciones atmosféricas ha surgido una "tematización pormenorizada de las condiciones del aire y la atmósfera" (ibíd.). Se comienza a entender, escribe Sloterdijk, que "el ser humano no es sólo lo que es, sino lo que respira y aquello en que se sumerge. Las culturas son estados colectivos de inmersión en aire sonoro y sistemas de signos" (ibid:: 134). Es una hermosa definición de cultura: inmersión en un aire sonoro y un sistema de signos. Si bien no podemos profundizar en esta discusión, de suyo apasionante, creo que el ambiente al que se refiere Juanito sólo podría emerger como una forma de esa "inmersión en el aire sonoro y un- sistema de signos".

La explicación de atmósferas que caracterizaría a la Modernidad, tendrá en estos aires locales, saturados de deseos y corporalidades, pero frágiles ante la violencia o la persecución, un capítulo singular. Si el ser humano es también lo que respira, esos sujetos necesitaron crear un ambiente donde pudieran hacerlo con cierta libertad. La exclusión social y los estigmas eran gases que les impedían tener una vida llevadera en cualquier otro sitio. Pero, creo que así como se perdió en las trincheras de la Primera Guerra Mundial cualquier inocencia sobre el ser-en-elaire o en-lo-respirable, según Sloterdijk, con las guerras químicas que envenenaron, justamente, ese aire, una vez creado el ambiente el deseo será sometido a procesos de explicación radicales. Y no dejará de serlo hasta hoy. El ambiente es también la pérdida de cualquier inocencia erótica y 
el inicio de las atmósferas identitarias, que serán como escafandras colectivas para nadar en los densos aires de las modernidades en curso.

Sloterdijk define una atmósfera como "una totalidad estructural teñida de sentimiento" (Sloterdijk, 2011: 129). Por eso, lo más relevante de la existencia de un ambiente es que crea un espacio de sociabilidad y afectividad. El ambiente es, sobre todo, una formación anímica que facilita modos de proximidad entre quienes participan en él. Las atmósferas, dirá Sloterdijk, son "compartidas entre varios, o muchos, que disponen y tonalizan unos para otros el espacio de proximidad" (ibid.).

Por otra parte, el ambiente fue, fundamentalmente, un lugar. Y, además, inauguró una topología del homoerotismo, vigente hasta el día de hoy. Un lugar, escribe Sloterdijk,

Es una porción de aire cercada y acondicionada, un local de atmósfera transmitida y actualizada, un nudo de relaciones de hospedaje, un cruce en una red de flujos de datos, una dirección para iniciativas empresariales, un nicho para auto-relaciones, un campamento de base para expediciones al entorno de trabajo y vivencias, un emplazamiento para negocios, una zona regenerativa, un garante de la noche subjetiva. (Sloterdijk, 2009a: 385)

Se podría aplicar literalmente esta definición al ambiente del que habla Juanito. Pero todavía era algo difuso, con fronteras porosas y demasiados riesgos. No era un lugar propicio para crear una experiencia de sí. Por eso, luego de varias décadas de experimentación con formas de habitabilidad y atmósferas diversas, los gays de Tenosique crearon un Círculo. Inicia, así, la historia de las esferas en este campo. El círculo, dirá Sloterdijk, "hace resaltar un interior del exterior"; en la medida en que los grupos humanos "son magnitudes autocobijantes”, formarán “círculos’ en torno a sí, y desde sí mismos” (Sloterdijk, 2011: 186-187). Este primer intento de darse una magnitud autocobijante permitió resaltar un interior frente al exterior, como las homoprácticas habrían producido una cierta interioridad en la exterioridad de las experiencias de sí, estipuladas por determinados esquemas culturales. Sin duda el ambiente fue un lugar de experimentaciones subjetivas, pero su atmósfera era urbana y anónima, dos características ausentes en Tenosique de los años ochenta: rural y pequeña. Visto desde una topología de las homosociabilidades, el Círculo fue una forma adecuada, en ese contexto.

Que las atmósferas puedan convertirse en esferas es algo que Sloterdijk considera en su propia interpretación. En ese sentido, entiende las esferas como “(...) mundos interiores de 
relación fuerte, en los que 'viven, penden y son’ quienes están aliados mutuamente en una atmósfera autógena o en una relación vibrante que los supera” (ibíd:: 129-130).

Cuando le pregunté a Alan por qué su organización era un club, me respondió:

Porque no somos asociación, iniciamos como un club donde todos participábamos haciendo fiestas, reuniones, celebrando los cumpleaños de cada quien y como club que éramos nos reuníamos a leer una poesía, platicar sobre un libro o platicar los chismes de la homosexualidad en club ¿no? y todo eso lo manejábamos a manera de club y por eso ahí se crea el club de homosexuales.

La camaradería era el fundamento del Club: un grupo de hombres homosexuales que se juntan a platicar y divertirse, "aliados mutuamente en una atmósfera autógena o en una relación vibrante que los supera". En esas motivaciones se cumplen, a mi parecer, los rasgos esenciales de una esfera. Sloterdijk anota que "las esferas son espacios de simpatía, espacios de afinación, espacios de participación"; sin presuponer su existencia, sostiene el filósofo, "no podríamos compartir palabra alguna con el otro, y tan pronto las damos por presupuestas, también las dotamos de una nueva intensidad" (Sloterdijk 2003b: 93).

El Club es una esfera informal, de diversión y encuentro, en el que confluyen personas diversas sin tener una tarea determinada ni un mandato. La simpatía, la afinación y la participación se antepondrán a cualquier deber o jerarquía. En otro capítulo vimos cómo el Club había eludido su formalización legal y no tenía cargos que supusieran jerarquía alguna.

Cuando, seguido, le pregunté a Alan por qué se llamaban Amazonas me respondió que: en Italia hay una isla que se llama "Lesbos" donde vivían las amazonas según la mitología griega, y las amazonas eran grandes guerreras, las amazonas usaban caballos y siempre andaban montadas a caballos, entonces nosotros somos amazonas porque somos grandes guerreras en la actualidad y además cuando nosotras no nos montamos a caballo nos montan y por eso somos el Club Gay Amazonas.

Si bien las referencias no serían correctas en términos académicos, son muy efectivas en otros identificatorios. Son amazonas como las grandes guerreras; es decir, sus figuras de identificación son femeninas, en primera instancia. Somos grandes guerreras, dice Alan, que si no montan a caballo son montadas. Sloterdijk sostiene que "hasta la interacción más banal implica nuestra participación en la constitución de esferas (...) somos como radios vivientes, que podemos sintonizarnos a través de ondas comunes" (ibid.). Las ondas que las radios vivientes transmiten y facilitan las sintonizaciones se expanden hasta la mitología y la Grecia antigua: ahí estos hombres encuentran unas guerreras que habrían vivido en la isla que le da nombre al 
homoerotismo femenino: Lesbos. Sloterdijk dedicará muchas páginas a las islas y otras representaciones semejantes, pero lo interesante es que, en este caso, las formas mitológicas del homoerotismo ya suponían esferas que separaban, mar mediante, el interior del exterior y creaban un espacio propio y relativamente autónomo. El Club encuentra en una isla, habitada por mujeres guerreras, un nombre que lo distinga y lo singularice.

Alan menciona un acto inaugural que no coincidirá, cronológicamente, con la celebración de los XV años del Club, en la que nos detendremos en el siguiente capítulo. Relata que el 13 de septiembre de 1995 realizan una conferencia de prensa, en el local de la asociación ganadera, en la que "43 personas decididas a pelear por el orgullo gay" hacen "público, ante periodistas y gente de la ciudad, que hemos integrado un grupo que se llama Club Gay Amazonas y que a partir de eso vamos a participar en todo como grupo".

En ese momento, dice Alan, todo comenzó a cambiar: "yo creo que empezó a ser todo positivo, empezó a ser todo positivo porque empezamos a demostrarle a la gente que sí éramos gay". La esfera, como espacio de autocobijo y como delimitación de un interior frente a un exterior (muchas veces amenazante) surge, también, por medio de una proclama constituyente, un fiat de la diferencia. Ellos anuncian, primero, su existencia, luego su disposición a defender el orgullo gay; posteriormente, Alan "acepta públicamente" su homosexualidad a través de la radio. Si se me permite leer esto al pie de la letra, la interpretación de Sloterdijk que define a los humanos como radios vivientes -“que podemos sintonizarnos a través de ondas comunes"- se cumple cabalmente en este caso, cuando Alan utiliza una tecnología de sintonización a través de ondas como la radio: "yo hablo de mi preferencia sexual y le digo a la gente que hay un grupo en Tenosique donde estamos recibiendo a todos los que tienen el mismo problema que tengo yo." El orgullo es también un problema, pero ambos se pueden transmitir a través de las diversas atmósferas locales y sus climas.

Sloterdijk escribe que "lo que nosotros llamamos clima designa, en principio, una magnitud comunitaria y, sólo después, un hecho atmosférico” (Sloterdijk, 2011: 129-130). La magnitud comunitaria, que se ha producido mediante la creación de una esfera, atraviesa ahora otras magnitudes compuestas, también, por radios vivientes que pueden sintonizarse a través de ondas comunes. La magnitud precede al hecho atmosférico, tal como la formación del Club antecede a su anuncio.

Alan transmite un mensaje, pero ahora en un sentido inverso a la lectura que hicieron de las enseñanzas de Hollander. Ese mensaje de liberación sexual y emancipación subjetiva fue 
leído como una interpelación personal e hizo que algunos hombres gay formaran un círculo que los dotara de un interior común. Ahora, Alan emite un mensaje de la buena nueva del Club a toda la comunidad: existimos y esto somos. La interioridad ya está formada, por eso no necesitan círculos. El asunto ahora es producir un exterior que los respete. Alan continúa su relato:

a raíz de entonces empezamos a demostrarle a la gente que podemos, empezamos a organizarnos como grupo y se da a conocer el Club Gay Amazonas, y empezamos a decirle a la gente que el Club Gay Amazonas tiene cocineros, tiene meseros, tiene estilistas, tiene costureros, y que tenemos abogados, que teníamos psicólogo, que teníamos doctores, que teníamos licenciados, que teníamos arquitectos y que podíamos prestarle servicio a la comunidad de lo que quisiera

Efraín, por su parte, dice que:

la sociedad que ya poco a poco te va aceptando y sobretodo que nosotros queremos sobresalir, que nosotros queremos formar parte de esta sociedad, pero como una parte positiva no como un escoria, no que se nos tenga en un estatus muy bajo, de que somos lo feo, lo degenerado, lo depravado, lo morboso. Somos personas normales, que tenemos una sexualidad diferente a la heterosexual, pero que no deja de ser normal dentro de los límites de nosotros y que la misma naturaleza por lo que tú quieras, llamémosle Dios, naturaleza, vida, lo que sea pues la hizo, como dijo la China Martínez “Aquí nos tocó vivir" y "así tenemos que vivir", queramos o no queramos.

El proceso que antes leímos como una homopráctica de respeto se traduce, ahora, en la demanda colectiva de un reconocimiento distinto al otorgado por su comunidad. La opinión de los otros es muy importante y no basta con constituirse para que la interioridad que se cree sea la deseada. Las esferas, al menos el Club, son porosas. No son formas de aislamiento, son modos de cobijo y convivencia. Por eso, una vez que se autoconstituyen, pueden exigirles a los demás un trato distinto y otras representaciones. "No somos lo feo, lo degenerado, lo depravado, lo morboso", sostiene Efraín, “somos personas normales". La normalidad no apunta aquí a una renuncia de la singularidad, a mi entender, sino a una intensificación de la legitimidad de una forma de subjetividad, que existe tal como lo hacen otras ("la heterosexual", como dice Efraín). "Aquí nos tocó vivir", dice Efraín, "queramos o no", citando el lugar donde se desenvuelven y su relación problemática con un deseo de habitarlo. Al hablar de un espacio común aunque diverso, escribe Sloterdijk, "hay que contar con la interpelación y la anticipación de cosas y personas. Veo y escucho que formo parte de un espacio que produce puntos comunes entre yo y las cualidades que están afuera.” Alan dice que el Club puede 
prestarle "servicios a la comunidad", es decir, ofrecerle algo al conjunto. La diferencia, en este caso, no es sustantiva o, si lo es, no constituye un abismo.

Como esfera, el Club sería una "apariencia revestida de una existencia real”, que constituiría "nuestro espacio existencial más real” (Sloterdijk 2003b: 92). Por eso no necesitará, creemos, otras formas de existencia que lo asienten socialmente (las legales, por ejemplo). ¿No está toda la densidad de la esfera colocada en ese lugar del deseo que enuncia Efraín: "nosotros queremos sobresalir, que nosotros queremos formar parte de esta sociedad, pero como una parte positiva, no como un escoria”?, ¿no es la esfera un modo de desmentir el estatus de 'escoria' que parecen atribuirle los otros y protegerse de sus efectos negativos?

El interior es un modo de elaborar lo exterior; cuando un sujeto entra en sí mismo encuentra también un mundo. Sloterdijk sostiene que "sólo si se pone de relieve la tensión entre interior y exterior, como el motivo fundamental de toda topología cultural, se hace plenamente consciente, en su sorpresividad, el constante retorno del interior" (Sloterdijk, 2011: 137). Cualquiera participaría de múltiples esferas y replicaría esa percepción del entorno a través de una lectura de sí. Por eso aventuramos que las homoprácticas conducirían a homosociabilidades, para elaborar un ensayo de "topología cultural", siguiendo a Sloterdijk. El trabajo vibrante con uno mismo es un eco, también, de un mundo que resuena en quien realiza una experiencia de sí. Sloterdijk escribe que "cuando entro en mí mismo, percibo en mi interior una dimensión que al mismo tiempo está en torno a mí (...) La esfera, la bola abierta de la que soy parte, la mitad de mi "yo"” (Sloterdijk 2003b: 93). Si al entrar en mí mismo percibo una dimensión que me rodea, entonces el desafío ha consistido en producir un interior que divise un entorno menos hostil, pero también transformar ese entorno para facilitar el surgimiento de un interior. La "mitad de mi "yo" había que buscarla en un contexto que no la ofrecía: ¿cómo producir un en-torno menos hostil?, ¿cómo contar con una apertura que me reciba, pero no me clausure?, ¿dónde buscar esa mitad del 'yo' si esa mismidad está en cuestión?

El Club produce y participa de esferas. Su trabajo es conectivo, no disruptivo. Como dijimos, crea un espacio de convivencia, no de aislamiento. En algún sentido, sigue una ética de la vecindad que le permite exigir respeto a los otros, pero también preocuparse por ellos. Vimos cómo opera una lógica del don en su trabajo. Pero ahora también visualizamos la inscripción afectiva de esa lógica. "El ser humano es el genio de la vecindad", escribe Sloterdijk; "mundo", escribe a continuación, "significa para nosotros el contexto de las 
posibilidades de acceso" (Sloterdijk, 2009a: 16). Hemos visto cómo esas posibilidades de acceso se han expandido a través de las homoprácticas y las homoesferas. Pero son posibilidades abiertas en esas relaciones de vecindad, que se privilegian por sobre cualquier enemistad. La esfera del Club no se cierra para protegerse de los otros, aunque también lo haga en cierto modo; se abre para relacionarse con los otros de un modo más amable e intenso. Juan lo dice con claridad: "el Club Gay Amazonas ha abierto muchas puertas, muchas mentes, ha hecho muchos cambios."

\section{Vacunas contra la muerte}

Una esfera es un espacio de protección ante el exterior. Hemos mostrado, en éste y otros capítulos, que el Club sirve de cobijo frente a una realidad amenazante, en muchas de sus manifestaciones. El espacio humano, dirá Sloterdijk, surge "por la vacuna de la muerte" (Sloterdijk, 2011: 142). Se pregunta, en ese sentido:

$¿$ ¿No son innumerables los que han tenido que experimentar el mundo exterior como un conjunto de incidentes destructores de esferas? ¿No es el exterior perforante, arrollador, desguarneciente siempre más impasible y fuerte que cualquier construcción de mundo interior? La imagen-burbuja que antepusimos a nuestra teoría de las esferas de intimidad evoca la fragilidad de los espacios habitados por seres humanos. (Sloterdijk, 2011: 137)

Alan relata que el Club se organiza, también, para responder a las acusaciones que se hacían contra los gay de "traer el sida a Tenosique". Cuenta que:

el sida ya estaba entrando a Tenosique y estaban acusándonos a nosotros los gays que éramos los causantes de que el sida llegará a Tenosique y empezamos a agruparnos y demostramos a la gente que nosotros no éramos las personas que estábamos trayendo el sida a Tenosique y la prueba es, de que de 12 años, 13 años que tenemos de ser grupo, del grupo hasta ahora no se ha muerto nadie de sida, en 13 años que tenemos de ser el grupo no se ha muerto nadie con sida.

Una exterioridad se superpone a la otra: la del sida y la de la homosexualidad. Ellos eran acusados de traer el sida a la comunidad, desde un exterior indeterminado, pero que se asentaba en sus cuerpos. Nuevamente, una topología cultural representa las epidemias como catástrofes venidas de lejos y a sus portadores como individuos culpables y peligrosos. Ante las acusaciones, el Club responde con evidencias: "ninguno de nosotros ha muerto de sida". Ese 
exterior funesto será desplazado en otras direcciones: primero, hacia homosexuales que no formaban parte del Club. Alan dice que "se han muerto hombres gay, y se han muerto de sida, pero no hombres gay del grupo Amazonas, tú puedes preguntarle a cualquiera de Tenosique y te van a decir que no". Segundo, hacia extraños, como los migrantes o los soldados. Un integrante del Club dice que los soldados son "aventadísimos" y que:

la mayoría son de fuera y vienen ya casi enfermos, ya los sacan, hacen y deshacen y van para afuera, te enferman de gonorrea, sífilis, chancrillos, todos son muy aventados y a veces se agarran a mujeres que no se bañan, que no se cuidan, que no se asean, no usan condones y a dónde va a parar uno.

El peligro no viene sólo de un exterior ajeno, sino del interior enfermo. Pero esto estimula la creación de esferas y no las suspende. Sloterdijk distingue, en la capacidad de "arrojar el abrigo sobre sí y los suyos y retirarse al invernadero invisible de mutua pertenencia experimentada”, el estímulo creador de esferas, "originario e incesante, que, sobre todo después de crisis de grupos, ha de acreditarse en múltiples casos. (Sloterdijk, 2011: 137).

¿No es el Club un "abrigo" que los hombres gay han "arrojado sobre sí mismos”, para sobrevivir a la enfermedad y la muerte? La consistencia de la esfera se confirma por su efecto protector. "Nada es más frágil, dirá Sloterdijk, que la existencia en las cubiertas exhaladas de interioridad específicamente humana" (ibid:: 134); los mundos interiores pueden ser destruidos “por invasiones de fuera o conflictos endógenos". Fuera y dentro habrá peligro para estos espacios de cobijo autógenos.

La respuesta al peligro tiene que ser colectiva y será una respuesta esférica. Alan relata sus primeras acciones ante la epidemia

entonces ahí empezamos nosotros primero que nada a repartir información, hacíamos una hoja de tamaño oficio, y ahí poníamos qué es el sida, cómo se reproduce el sida, cómo se transmite, cuántas personas infectadas de sida hay y sacábamos el boletín cada quince días, cada quince días sacábamos una hoja así con información y poníamos infecciones de transmisión sexual, en ese tiempo la información nosotros la agarrábamos de una revista que se llamaba "Macho Tips" y "Del Otro Lado" eran revistas que usábamos nosotros para la información y ahí fue donde por primera vez en un carnaval salimos disfrazados de condones y de ahí sacamos una comparsa de aquel entonces...

La "inteligencia común”, sostiene Sloterdijk permitirá enfrentar las "catástrofes esféricas", mediante "reparaciones oportunas". De ese modo, "aquello que normalmente habría de 
conducir a la muerte de una esfera puede resultar efectivo como estímulo a su crecimiento" (Sloterdijk, 2011: 142). Si el Círulo Interior fue barrido por el sida, el Club existe gracias a él. La muerte también es una fuerza aglutinadora, aunque lo sea en la huida, una forma de crear espacios y mundos, un llamado urgente a producir respuestas adecuadas que ayuden a resguardar los cobijos y conservar las esferas. La simpatía que antes hemos mencionado es también un límite: no sólo se siente simpatía o sintonía por quienes nos protegen, también se la puede sentir por aquellos que sufren. Los integrantes del Club fueron de los pocos que se preocuparon, de algún modo, de las personas que vivían con VIH o que habían desarrollado el sida. Las formas han sido múltiples, y no me detendré en ellas ahora, pero una de las más comunes fue solicitar dinero para que pudieran viajar a Villahermosa a recibir atención médica o buscar medicamentos. Enrique cuenta que:

Vamos a pedir apoyo porque se van algunos enfermos a Villahermosa, pero no tienen más dinero y ya el DIF no te da más dinero ahora, te cerró todas las puertas y ya no hay presupuesto, ya van de salida y no hay dinero, tenemos aquí al señor Luis, Saúl, a don Santiago, la señora Mireya y a su nieta, al señor del ayuntamiento, al doctor de la farmacia y nos apoyan mucho "no que aquí hay $\$ 100$, no que hay $\$ 20$ o que hay $\$$ $30 "$, nos dan de $\$ 20$ para arriba, es rara la persona que nos da $\$ 10$, así cooperamos y le damos el dinero a la persona que va a Villahermosa, para su ida, para su regreso y para su comida y sí nos apoyan mucho. (Enrique)

El espacio que forman las esferas no es una distribución física de edificios y personas, es una dimensión de la convivencia. "En el espacio psico y socio-esférico"”, escribe Sloterdijk, "los reunidos (...) están ensamblados unos en otros y configuran un lugar psicosocial de tipo propio, a modos de cobijo mutuo y evocación recíproca" (Sloterdijk, 2009a: 235). En este sentido, no toda reunión de individuos conforma una esfera. El cobijo mutuo y la evocación recíproca serían sus propiedades definitorias. La participación en el Club no ha sido, por esto, una forma de exclusión. Creo que el Club sólo existe como "espacio psico y socio-esférico" y que, dada ciertas condiciones, cualquiera puede participar en él. Si bien está delimitado por una identidad, a sus reuniones y eventos asisten muchas personas que no son gay. Además, si articulamos lo que antes analizamos sobre la lógica del don con este carácter esferológico del Club, veremos que su impulso cobijante incluye a muchos otros. De este modo, siguiendo a Sloterdijk, contemplamos "la diferencia entre los simples receptáculos acogedores de la concepción física del espacio y los receptáculos autógenos, autoabombantes, de la esferología” (ibíd.). 
Enrique y Alan hablaron de la ayuda material a las personas que viven con VIH. Juan, por su parte, destaca el apoyo "psicológico" que les han dado,

pues la ayuda que tenemos para las personas que están enfermas, tratar de buscarles sus medicamentos, sus pasajes, darles pues ánimos para que también tengan otra calidad de vida porque pues la persona que tienen esa enfermedad el primer rechazo empieza en su casa, entonces buscan la ayuda de nosotros porque saben que nosotros somos buena onda y "ay, que dame un consejito ¿qué puedo hacer?" y de alguna manera la hacemos hasta de psicólogos, tratamos de darles buenos consejos para que no se dejen morir ellas solas, que tengan por lo menos otras ideas, otros tipos de cosas que hacer, otros ánimos. (Juan)

Hacerse cargo del otro significa también asumir su ánimo y ayudarlo a procesar y transformar, si se puede, su visión de la vida. Una esfera es, en ese sentido, "el campo de las cosubjetividades cruzadas" (Sloterdijk, 2003a: 419), pero también "un universo polisignificativo de la amplitud existencial" (ibid:: 311). De este modo, la entrada del otro en el espacio interior (colectivo) no es una amenaza que penda sobre las esferas; en cambio, ellas serán más densas cuanto mayor sea su capacidad para cobijar sin desarmarse e incrementar la intensidad de sus evocaciones recíprocas. El otro, en el pensamiento de Sloterdijk, enriquece la subjetividad, no la amenaza; el acceso a ella presupone "todo tipo de penetraciones dichosas, invasiones conformadoras y entregas interesadas a intrusos enriquecedores" (ibid.: 97). Los intrusos enriquecedores se filtran por los perímetros de la esfera o son incluidos en ella a través de puentes anímicos como la amistad o la compasión. De igual manera, los intrusos peligrosos, como los virus, también se filtran o invaden, pero son motivo de respuestas autocobijantes y autógenas.

\section{Deseo y esferas}

En el caso que hemos investigado, el deseo es un productor de esferas. El deseo es la intensidad que permite mantener la forma grupal y comunitaria a través del tiempo y de las vicisitudes de la vida. Como vimos, en las historias de los integrantes del Club y de muchas personas gay de la localidad, el deseo es el antecedente biográfico más antiguo. Previo a cualquier identidad, las narraciones se encuentran con él como la roca de todo un proceso de subjetivación, cuyas fuentes son los desacomodos, los desajustes, las dudas, los temores que produce el deseo homoerótico. El desafío, quizás de modo más dramático en estas historias 
que en otras, ha sido encontrar espacios donde compartir ese deseo y sus manifestaciones, donde acomodar los desajustes y encontrar formas de solidaridad y camaradería.

Guattari sostiene que "el deseo es siempre el modo de producción de algo, el deseo es siempre el modo de construcción de algo" (Guattari, 2005: 319). Quizás esta definición nos dé una pista sobre cómo encontrar el deseo o cómo explorarlo en una formación social, en una comunidad, un grupo o en un sujeto: preguntándonos qué han construido o producido. Las respuestas a esas interrogantes nos dirán, en cierta medida, qué han deseado. En el campo que investigamos, hemos visto que el deseo produce y construye múltiples relaciones, lenguajes, experiencias y estéticas, entre muchas otras cosas. Pero pienso que lo primero que suscita son turbulencias subjetivas, preguntas y exploraciones y, luego, esferas: amistades, complicidades, secretos, alianzas, afectos ambivalentes, sentidos provisionales. Sin ese sustrato íntimo y microsocial, el deseo no produciría nada.

Los integrantes del Club han deseado un lugar y un espacio; una forma de vida y un modo de vincularse. Ese deseo, tal vez antiguo y soslayado, comenzó a crear y a producir cuando encontró formas de producción y construcción específicas, a su vez históricas y políticas. En el largo trayecto que va del mundo de Juanito hasta los modos de vida contemporáneos de los gays locales, el deseo ha constituido el sustrato común y también el articulador de diferencias. Juanito, silencioso y prudente, encuentra y elabora una inscripción contextual para su deseo, que lo deje vivir y no lo destruya. Pero la historia, que es una vorágine, abre un campo nuevo de posibilidades que son exploradas, a mi entender, bajo las formas esféricas de los Círculos y los Clubes. El silencio y la prudencia de Juanito son reemplazados, en una generación, por el discurso y los atrevimientos de Alan, que discute con los sacerdotes, los médicos y los políticos y por las nuevas exploraciones de los más jóvenes (ya han pasado cuatro generaciones) que forman pareja entre ellos, que elaboran proyectos de vida y que así como construyen una intimidad habitable y formas esféricas diversas (desde parejas hasta comparsas y grupos de amigos), también habitan con mayor confianza el espacio público y las instituciones.

Las esferas serían, de este modo, espacios libidinales que conectan deseos y los sintonizan. Deleuze y Guattari llaman libido “al 'trabajo' conectivo de la producción deseante” (Deleuze y Guattari, 1985[1972]: 20-21). Si el deseo fuera una intensidad creadora de esferas, como propusimos, ellas serían los receptáculos de esos trabajos libidinales de conexión. Leyendo a Deleuze y Guattari a través de Sloterdijk, diríamos que la producción deseante, a pesar de que cruza múltiples espacios, se cobija en las esferas; en ellas, si aún no fuera el tiempo para un 
trabajo libidinal, el deseo puede aguardar mejores condiciones climáticas y guarecerse. Juanito, por ejemplo, hizo del silencio su propia esfera, que lo protegió de las inclemencias de las atmósferas despreciativas y discriminantes en las que le tocó vivir, pero también le permitió hacer un trabajo conectivo de baja intensidad con diversos sujetos. Otra esfera fue el Círculo Interior, que implicó una conectividad mucho mayor y reunió a algunos hombres gay que querían explorar sus propias vidas y sus deseos. Pero si leyéramos a Sloterdijk a través de Deleuze y Guattari, diremos que la producción deseante es la fuerza creadora de las esferas. ${ }^{32}$ Por eso, en el caso de Tenosique, cuando la conectividad alcanzó cierta intensidad personal, social e histórica, logró producir otras formas esféricas, como el Club.

Si el trabajo libidinal implica conectividad, también supondrá, y producirá, devenir. Los flujos del devenir, sostiene Braidotti, "marcan un proceso cualitativo de cambios estructurales en los parámetros y los límites de la subjetividad” (Braidotti, 2009: 207). Vimos cómo el incremento en los flujos estuvo determinado por esas modificaciones estructurales en los parámetros y límites de la subjetividad, que también produjeron. Desde la esfera tenue y silenciosa de Juanito, hasta el desparpajo del Club, lo que se ha transformado, a nuestro entender, son justamente esos parámetros y límites. Por eso sostuvimos que las homoprácticas nos conducirían a las homosociabilidades esféricas, y viceversa. Pero, a su vez, una mayor conectividad implica un incremento en el trabajo libidinal y también un fortalecimiento y expansión de las esferas, "en la medida en que transforma a los sujetos en entidades transversales que se conectan entre sí, definidos atendiendo a las inclinaciones comunes" (ibíd.). No hay otra "inclinación común”, en nuestro caso, que el deseo mismo. Los sujetos, sostiene Braidotti, "son materia inteligente, activada por la afectividad compartida" (ibíd.); vimos cómo en el caso del Club la intensificación de la conectividad y el fortalecimiento de las esferas suscitaron, también, un incremento en la inteligencia común, como la llama Sloterdijk, sostenida por una afectividad compartida que la misma esfera propiciaba.

\footnotetext{
32 Aunque Deleuze y Guattari no hablen de esferas, sí refieren círculos y huevos. El cuerpo sin órgano (CsO), dirán, es un huevo que se lleva "como su propio medio de experimentación" (2010[1980]: 166). El CsO es un concepto clave en la arquitectura de Capitalismo y esquizofrenia, y será leído como "un conjunto de prácticas" (ibíd.: 156), atravesado por intensidades. Ambos autores dirán que el CSO “es deseo, y gracias a él se desea” (ibíd:: 169). También que el esquizoanálisis "puede representarse por cuatro componentes circulares, pero que brotan y hacen rizoma" (ibid. 148); esa descripción la acompañan del dibujo de una esfera.
} 
El devenir, diremos, no podría suceder a campo travieso, en los espacios vacíos que pronto ocupan la muerte o la desolación. Necesita de esos recipientes autógenos que lo cobijen, pero que también lo engendren. Las esferas, propulsadas por el deseo, crearán nuevas formas de conectividad, no sólo entre sujetos, sino con otras formas esféricas. El trabajo conectivo hallará en estos receptáculos un espacio propicio para intensificar la producción deseante y modificar los parámetros y límites de las subjetividades. Esferas sin deseo serían formas secas; deseo sin esfera sería pura energía suelta. ${ }^{33}$

\section{Oscuridades y destellos: mapas psicotopológicos}

Mi conciencia tiene mil lenguas distintas

W. Shakespeare, Ricardo III, 2008 [1594]: 452

Se pueden distinguir, al menos, dos procesos que modificaron los parámetros y los límites de las subjetividades que investigamos. Uno, que acabamos de revisar, fue la creación o exploración de prácticas de sí, que denominamos homoprácticas. Otro, que abordaremos ahora, fue la explicitación del deseo, que abarcó no sólo a quienes formaron el Club sino a muchas otras personas. Nos aproximaremos a una dimensión distinta de la producción de las subjetividades: ya no la autoconstitución de un sujeto sino la determinación del deseo del otro. Una vez que los límites y parámetros se han conmovido, eso no afectará sólo a un grupo, sino que expandirá, a mi entender, su radio de acción y transformación a muchos otros individuos y colectivos. En este sentido, los integrantes del Club han cumplido un papel de explicitadores de los deseos de los otros.

Efraín piensa que en "cualquier lugar" se puede encontrar a un homosexual: "abierto o de clóset”. La apertura o la clausura del deseo pueden ser inspeccionadas mediante lo que este informante llama "comunicación telepática", que conocería a otra persona más allá de las palabras.

Lo que nos ha ayudado a nosotros como grupo gay es que en cualquier parte de la sociedad, en cualquier estrato social vas a encontrar a un homosexual, de cualquier

\footnotetext{
33 “El deseo, escriben Deleuze y Guattari, nunca es una energía pulsional indiferenciada, sino que es resultado de un montaje elaborado, de un engineering de altas interacciones" (2010[1980]: 219). Parte de este engineering de altas interacciones son las técnicas de sí y las antropotécnicas que exploramos.
} 
forma, bueno, regular o malo pero lo vas a encontrar, abierto, de clóset, gente que no está abierta, que nunca lo va a aceptar, pero porque la misma sociedad no se lo permite o a él no le conviene a sus intereses, yo pienso que eso es muy privativo de la persona el querer abrirse o no abrirse, pero nosotros tenemos como un sexto sentido, yo sin la necesidad de que una persona me diga que es gay yo me puedo dar cuenta que es gay, porque hay una comunicación telepática entre las dos personas en donde nos identificamos, la forma de ver, la forma de pensar, la forma de actuar, no sé, que hay un detonante de que hay algo, identificas como persona del mismo género, de la misma preferencia, género porque somos hombres, pero de la misma preferencia que tenemos algo a fin

Sloterdijk llama mapas psicotopológicos a las "tomas de rayos infrarrojos de estados internos en cuerpos huecos polivalentes" (Sloterdijk, 2009a: 231). ¿'Tomas de rayos infrarrojos de estados internos en cuerpos huecos polivalentes? Es casi una imagen de ciencia ficción. Pero también lo es la comunicación telepática que Efraín dice poseer, un sexto sentido que develaría el deseo del otro. Es una forma de ver esos "estados internos de los cuerpos", pero también de las subjetividades. La telepatía, esa comunicación entre mentes que no necesita del sonido y que, por lo tanto, es una forma subliminal, pero también oculta, de relacionarse con los otros, permitiría que dos personas supieran una de la otra sin que nadie se enterara. De algún modo, es una supracomunicación que elude cualquier dificultad del contexto en el que sucede. Efraín dice que abrirse con respecto a la "preferencia sexual" es algo privativo de cada quien; no obstante, esos poderes, como rayos infrarrojos virtuales, logran observar el "interior" de alguien, aunque intente esconderse.

Esos súperpoderes son herencias de la Modernidad, según Sloterdijk. En ese sentido, el filósofo escribe que "quien se aventura a explicitar realidades de trasfondo, que antes estaba suspendidas tácitamente en lo consabido pensado (...) reconoce una situación, en la que la escasez de lo presumible y callable ha avanzado y sigue progresando imparablemente. (Sloterdijk, 2009a: 57). Efraín explicita "realidades de trasfondo" y colabora con esa escasez de lo presumible y lo callable, de la que habla Sloterdijk. En este caso, una presencia generalizada de homosexuales sería el pivote para una explicitación posterior de sus deseos y le daría consistencia a la experiencia de cualquier homosexual. Efraín dice que "eso nos ha ayudado". ¿A qué? Si retomáramos algunos argumentos desarrollados antes, diríamos que los "poderes telepáticos" o la visión infrarroja "de los estados interiores" se aplicaron, primero, sobre uno mismo. Luego, se pueden desplegar en los otros. Encontrar sujetos similares en cualquier 
contexto es "una ayuda", dice Efraín, no importa si son "buenos, malos o regulares". De este modo, esa certeza del encuentro con individuos semejantes, aunque sólo la telepatía los detecte, es una forma de "hacer explícito lo implícito -que-constituye la forma cognitiva del destino" (Sloterdijk, 2012: 20). El destino adquiere una forma cognitiva, y telepática agregaríamos nosotros, cuando las subjetividades y los deseos pueden ser explicitados.

¿Qué significa que, en alguna medida, el deseo sea visible, que no haya 'escondite' alguno para él? Sloterdijk apunta que la Modernidad sería, también, "la era de explicación del trasfondo los seres humanos -quienes- se ven obligados a reconvertir sus orientaciones ancladas implícitamente en el trasfondo en apuestas explícitas” (ibid.:155). En ese sentido, los integrantes del Club cumplen un papel de reconvertidores de orientaciones implícitas en apuestas explícitas.

Danilo trabajaba en las oficinas locales de un partido político cuando lo entrevisté y tenía un puesto importante en su maquinaria electoral. Todo el mundo sabía que era gay, aunque eso a veces le traía problemas con algunos militantes o funcionarios. Él narra una visión de la política local desde dentro y cuenta que

vas conociendo, vas viendo, tú mismo te vas relacionando con la mismas personas que hay ahí dentro, entonces vas viendo y vas diciendo "Oye, mira a ésta o esto", bueno uno no lo dice pero lo vas checando "Puta, yo creía que este cabrón era así y mira, resulta que era asî” entonces es una amalgama lo que hay ahí adentro, el que no ha entrado es como el que no sabe, es como el que no ve, pero no, te digo que hay que entrar a la política para ver lo que hay ahí adentro y ya después que no te digan, que no te cuenten.

Una vez que se ha visto, entonces se conoce a los sujetos involucrados en ella:

ya sabes tú quiénes son, ya sabes tú cómo son y hasta quiénes jugamos, porque $x$ es un hombre chingón, así, es un hombre chingón en el cargo que tiene, pero afuera se revuelca con medio mundo, entonces es la verdad, hasta al director de tal parte lo ves ahí en la oficina que es un gran hombre, pero en la primera fiesta resulta que es un desmadre, drogas, sexo y alcohol.

Le pregunté si era importante tener esa información sobre sus colegas y me respondió que:

En algún momento dado como dice un compañero "ayúdame no seas cabrón, y todo por el mismo gremio", hay tipos que te echan la mano porque te la echan, entonces tú te ganas a ése, aunque sea con trapazos, pero ya te lo ganaste y cuando menos lo ves ya tienes a una persona importante dentro del grupo. 
El secreto que no se quiere develar es conocido, tal como lo dijo Efraín, y se usa como una pieza de cambio con el otro: se le muestra que es "del mismo gremio" y te lo ganas "aunque sea con trapazos". Saber del otro y explicitarlo de alguna manera es una forma de tener cierto poder sobre él. Pero esto sólo puede ser dicho por alguien que ya ha hecho explícito su propio deseo y que puede conseguir que otra persona sea "un integrante importante dentro del grupo (el Club)". Estar oculto fue un peligro durante mucho tiempo y dio pie a extorsiones y amenazas. Hoy es una forma de negociar con otros. Durante una entrevista, otro informante me pidió, en algún momento, que apagara la grabadora y, paso seguido, me contó que un político local muy importante los había ayudado mucho, entre otras razones, porque tenía amantes comunes con algunos integrantes del Club. Él lo sabía, aunque nunca lo platicaron abiertamente, pero como ya era algo explícito, a la vez que telepático, fue uno de sus motivos para apoyarlos. Sloterdijk escribe que las explicaciones "no sólo hacen explícitos los supuestos de trasfondo no expresados ('inconscientes', desconocidos, incomprendidos), sino que elevan a la existencia manifiesta 'realidades' hasta entonces plegadas en la latencia” (Sloterdijk, 2009a: 163). No es la primera vez en la que esas realidades plegadas en la latencia se manifiestan. Me interesa destacar que sean los integrantes del Club quienes realicen esas operaciones en otros sujetos.

En algún sentido, las homoprácticas, y los procesos de subjetivación que hemos investigado, son formas de desplegar una subjetividad. Sloterdijk anota que "el pliegue percibido alude a un interior plegado que aún no ha sido desplegado" (Sloterdijk, 2009a: 171); de modo que explicitar el deseo es una forma de desplegar un interior plegado, desenrollarlo para explicarlo. Vimos en otro capítulo, y lo veremos también en el siguiente, que hay una tensión colectiva en torno a los deseos homoeróticos ocultos. Las imágenes de caretas, máscaras y dobles han sido persistentes. Hay una exigencia de que todos hagan explícitos sus deseos e inscriban sus subjetividades en mapas psicotopológicos. Estar oculto o en un clóset, como han dicho los informantes citados, y muchos otros a lo largo del trabajo de campo, es un modo de guarecerse de los mandatos explicitadores y explicativos de un orden social que parece privilegiar lo evidente y sospechar de lo sobrentendido. Pero en sí mismo es un tipo de mapa, aunque quienes sean descritos por él no lo hayan buscado y ni siquiera se reconozcan en esa inscripción.

A mi entender, no hay explicitador más poderoso que la identidad. Si comparamos a Juanito, esférico en su silencio y en sus sobreentendidos, con los integrantes más jóvenes del 
Club, veremos que la identidad ha sido el soporte de un conocimiento de sí, una especie de hilo para adentrarse en los laberintos interiores, pero también para atrapar al otro y traerlo a la luz desde los espacios recónditos de su deseo. En la lectura de Sloterdijk, tener identidad(es) correspondería a ser moderno. En la Modernidad, escribe este autor, "se implanta el largo ciclo coyuntural de las llamadas "identidades"; que define como "prótesis de obviedad en terreno inseguro" (Sloterdijk, 2009a: 155). Una prótesis de obviedad que "ya no se deduce primariamente de la herencia cultural, sino que se convierte cada vez más en un asunto de invención nueva y de transformación continuada" (ibid.).

El capítulo final de la novela de Hollander se titula "Cerrando el círculo". Entre otros eventos, la escritora relata las experiencias de un exhibicionista que era conocido como El destellador: "para mí destellar era una necesidad psicológica, dice el personaje, para destellar necesito mucha gente" (Hollander, 1983: 359). Alguien dice que "hay un voyeur en cada uno de nosotros", a lo que Xaviera responde que todos tienen fantasías sexuales "y el ser voyeur es solamente una manera en que la gente trata de hacer reales tales fantasías"; en seguida le pregunta a una amiga si canaliza sus fantasías interiores "a través del voyerismo" (ibíd.: 360). El Círculo se cierra con una de esas "tomas de rayos infrarrojos de estados internos en cuerpos huecos polivalentes", como las llama Sloterdijk. El destello es una manera de hacer públicos los deseos, el voyerista dice que "sin público no sentiría nada". Pero también es una imagen de la luz que progresivamente cubre cualquier interioridad o toda oscuridad, otra "prótesis de obviedad en el terreno inseguro". La pregunta por las fantasías interiores, es una consumación de la explicitación; se ha des-plegado hasta lo más íntimo. Una característica de las relaciones de saber modernas, dice Sloterdijk, es que los sujetos operen sobre sí mismos “(...) y tengan planos ante sí de la oscuridad propia, en parte aclarada, que les señalen puntos de intervención potencial para la auto-intervención.” (Sloterdijk, 2009a: 61). La pregunta de Hollander es una invitación a la auto-intervención, como el voyeur que necesita de los otros para "canalizar sus fantasías". No es casual, tal vez, que le digan El destellador, porque constituye una figura de ese mandato moderno de aclarar las oscuridades propias, aunque en su caso lo haga mediante una exhibición pública de fantasías íntimas.

Los hombres homosexuales que crearon el Círculo Interior en los años ochenta respondieron de algún modo a estas preguntas: aclararon paulatinamente sus "planos de oscuridad" e interrogaron sus fantasías. Ellos crearon una prótesis (la identidad) para el terreno inseguro en el que vivían y, de este modo, se integraron al "ciclo coyuntural de las 
identidades". Pero, al hacerlo, también participaron en la producción de muchas otras prótesis identitarias e integraciones a ese ciclo coyuntural. El Club heredó ese afán luminoso. Vimos cómo sus integrantes se quitaron caretas y levantaron la vista, cómo operaron sobre regímenes y formas de visibilidad.

Una vez integrados a ese proceso explicitador (y la identidad sólo será una forma de explicitar), los miembros del Club se abocaron a enseñarles a otros cómo entender, explicar y mostrar sus deseos. Alan dice que mucha gente no tiene conocimientos "de la actual educación sexual"; lo homosexual, heterosexual y bisexual, agrega, "es parte de la nueva era de la educación sexual”. Muchas personas, sin embargo, aún no lo saben y no se han integrado al “ciclo coyuntural de las identidades", ni han creado las prótesis necesarias para operar sobre sí mismas. Alan anuncia y también trae esos nuevos mapas psicotopológicos en los que, tarde o temprano, todos participarán y tendrán sus "planos de oscuridad propia, en parte aclarada, que les señalen puntos de intervención potencial para la auto-intervención".

Nos falta mucho de tener conocimientos de lo que es la actual educación sexual, porque eso de lo de homosexual, heterosexual y bisexual es parte de la nueva era de la educación sexual, porque eso no existía antes, ¿no? ya ves que de un tiempo acá es que se ha venido pues hablando, de los años setenta es que empiezan a hablar de lo heterosexual, bisexual, homosexual. Entonces aquí en Tenosique hay mucha gente que no sabe todavía qué cosa es eso, no saben distinguir entre heterosexual, bisexual, homosexual, pero hay mucha gente que sí se define como bisexual, pero no públicamente, sino en privado.

Como Hollander, Alan inspecciona las fantasías y dice que en cada uno hay un sujeto sexual, aunque falte aclarar cuál es y darle un nombre. De este modo, igual que la novelista holandesa, cierra el Círculo, pero no sobre sí mismo sino en los otros. Predicador de una "nueva era sexual", anuncia este Evangelio de las identidades y de las crecientes claridades: donde hubo mucha gente que no sabía, habrá otra que lo sepa. Como en el libro de Hollander, cada cual encontrará su deseo, pero siempre bajo la condición de que devele su interior.

En esta tensión clarificante se producen síntomas "que median entre la obstinación y el éxtasis" y "el débil se obstina encerrándose en sí allí donde el fuerte se entrega" (Sloterdijk, 2003a: 93). ¿Quiénes son los débiles o los fuertes, en este contexto? Los integrantes del Club transitaron desde la oscuridad sobrentendida de Juanito hasta la claridad declarativa de Alan o Juan. Sloterdijk argumenta que el sujeto más fuerte sería "el metabolizador más exitoso", es decir, "el ser humano que menos hace un secreto de su oquedad, penetrabilidad y medialidad" (ibid:: 
95). Los integrantes del Club han sido esos metabolizadores locales, que no han hecho un secreto “de su oquedad, penetrabilidad y medialidad". Y han metabolizado no sólo sus deseos, sino lo de los otros, en esa máquina creadora de mapas psicotopológicos -heterosexual, homosexual, bisexual- que es la sexualidad misma.

En este campo, sin duda, un sujeto débil es el puto, incapaz de metabolizarse o metabolizar a los otros. El homosexual, en cambio, es un personaje al que se le atribuye una densidad biográfica de cierto tipo: una densidad médica, terapéutica, que guarda algo de desprecio, pero en el lenguaje cifrado del síntoma o de la explicación etiológica. Densidad que es resguardada y producida en los gabinetes médicos y en las consultas psicoterapéuticas. También en los sets de televisión, donde la homosexualidad se puede abordar ya sea como un problema, una enfermedad, una opción o como un resultado ineludible de la genética. El puto no tiene densidad biográfica, porque su descripción se agota en sus gestos y sus ademanes, en sus retruécanos de la feminidad, en la inversión de su deseo. Su cuerpo y sus gestos son su explicación; no necesita origen, porque es una actualidad siempre renovada en su lenguaje y en las apariencias. El puto no necesita explicación, en muchos sentidos, porque no representa un misterio ni articula causalidades. Resulta inquietante, contraviene las normas y los usos, implica una alteración de las corporalidades e identidades, es un traspié en la socialización y en el destino de los sujetos. Pero no tiene causas, ni las necesita; no tiene un origen, ni lo busca; no es denso, porque es casi pura representación.

En la homosexualidad la mirada encuentra un referente que, desprendido de los gestos, permite aglutinar las prácticas, las identidades y los deseos, sorteando, curiosamente, las evitaciones y los desvíos que los mismos sujetos pudieron elaborar o crear para despistar o desvanecerse. El homosexual es denso porque es comprensible, porque se lo puede explicar, pero también porque se pueden comprender sus laberintos, sus escarceos, la variación repentina de sus conductas, la aparente inexcrutabilidad de su deseo. El puto, en cambio, se presenta a sí mismo como su propia evidencia: no da pistas, devela el secreto de manera taxativa: los modos de su habla, sus ropas, ciertos gestos, la entonación de la voz, la forma de sentarse, la mirada, los accesorios. El todo o las partes muestran públicamente quién es; no lo oculta o no puede hacerlo. No hay clósets que puedan encerrarlo ni desmentirlo. Pero tampoco necesita de una biografía que lo justifique. De algún modo, se ha creado a sí mismo: por eso es festivo y risueño; por eso su desparpajo. Si bien el puto no será feliz, al menos no vivirá amargado ni oscurecido; será motivo de risas y las aprovechará para ubicarse al centro de 
la escena, trasponiendo el rechazo en complicidad, la ausencia de valor en la certeza de su presencia. El puto captura al mundo en su representación. El homosexual lo padece. El puto, en última instancia, no tiene aún un mapa psicotopológico, por eso es una reliquia identitaria y un presente continuo para el deseo.

\section{Inventar la vida: formas de vida y experimentaciones}

Ellos entran en escena, se inventan a sí mismos

F. Nietzsche, Así habló Zaratustra, en Sloterdijk, 2009b: 45

Si los integrantes del Club sólo hubiesen creado mapas identitarios para ubicarse en ellos y situar a los otros, no habría necesidad de explorar el deseo. Pero ellos hicieron algo distinto: utilizaron esos mapas psicotopológicos para constituir lo que denominamos esferas de homosociabilidad. Una vez que contaron con una interioridad, que investigamos desde la perspectiva de las homoprácticas, ellos pudieron crear una forma de vida y experimentar procesos de singularización constantes. Si bien la identidad, como la hemos leído, es una metapráctica necesaria, entre otras cosas porque dota de cierta inmunidad a sus suscriptores, también es un obstáculo para la experimentación y la singularización. La identidad se transforma, pronto, en habitus. Sin duda no habría innovación sin un territorio estable, pero las intensidades afectivas, subjetivas y estéticas que se articulan en torno al Club, no cesan de impulsar procesos de cambio desedimentizadores. A esto, Guattari lo llama "procesos de singularización", es decir "una manera de rechazar todos esos modos de codificación preestablecidos (...) para construir modos de sensibilidad, modos de relación con el otro, modos de producción, modos de creatividad que produzcan una subjetividad singular" (Guattari, 2005: 25).

Esa singularidad coincidiría con el deseo, según Guattari, y con "una voluntad de construir el mundo en el cual nos encontramos” (ibíd.). La identidad sería parte de las máquinas de producción de subjetividad, porque es un concepto "de circunscripción de la realidad a cuadros de referencia", que hace pasar "la singularidad de las diferentes maneras de existir por un solo y mismo cuadro de referencia identificable" (Guattari, 2005: 98; énfasis del autor). Si en nuestro caso lo importante sería salvaguardar esas diferentes maneras de existir, la pregunta es si las identidades pueden convivir con esa pluralidad subjetiva y existencial. 
Esta singularidad debe leerse, también, como una forma de propiciar la experimentación, entendida como la creación de los propios parámetros para vivir. Recordemos lo que propusimos al principio de este capítulo: si los gays de la localidad fueran modernos, lo serían por su capacidad de aventurarse en "su propia autoconservación" y "determinar en términos experimentales" qué tipo de vida es mejor para ellos (Sloterdijk, 2003b: 34). Los gays de la localidad inventaron formas de vida, modos de relacionarse, creando, en algún sentido, una interioridad y una sociabilidad, saltaron entre las identidades y se nombraron de modos diversos. Ellos hicieron todo eso porque era posible producir ciertos cambios. Pero también se toparon con aquello que no se podía transformar, lo que Paolo Virno llama "el sustrato de piedra", que según el autor, "subyace, por lo general oculto, bajo los cambiantes juegos lingüísticos que se suceden en el transcurso del tiempo" (Virno, 2011: 83). Ese momento, en el que una forma de vida se modifica, pero también devela sus regularidades más profundas, sería característico de su crisis. Virno escribe que:

Una forma de vida se contrae y decae cuando una misma norma es realizada de muchas maneras distintas, contrastantes entre sí. Ante la necesidad de suspender o desautorizar la norma en cuestión, es preciso remontarse, entonces, al 'modo de comportarse común a los hombres', o sea, a la regularidad de las actitudes y de las conductas específicas de la especie. Esta regularidad, antepuesta a todo sistema de reglas positivamente determinadas, es la vida humana a punto de (sólo a punto de) asumir una u otra forma. (Virno, 2011: 83)

No estoy seguro que la crisis, si fuera una, que investigamos corresponda sólo a la realización plural de una norma. Si recordamos que el surgimiento de un colectivo como el Club y de identidades como la gay obligó, en muchos sentidos, a que los otros (indefinidos y múltiples) se localizaran en los nuevos mapas sexuales, podremos avizorar un cambio semejante al que Virno trata de pensar desde sus manifestaciones normativas. Pero este cambio se extiende a las experiencias de sí mismo, la expresión de los afectos, las formas de vinculación, entre otros campos. Si el Club fuera un colectivo que sigue públicamente una regla "de modos bizarros e imprevistos", realizaría, según la lectura de Virno, "la praxis púbica que prevalece cuando una forma de vida implosiona o se desmorona" (Virno, 2011: 49). En ese momento, dirá el pensador italiano, "la aplicación de la norma vuelve a mostrar, y con la máxima franqueza, su intrínseca (esto es, originaria e ineliminable) problematicidad" (ibíd.).

De este modo, el Club sería tanto el síntoma como el propulsor de esa crisis, lo que reafirmaría la hipótesis de que es un fármaco: remedio y veneno, a la vez. Sería su carácter 
farmacológico lo que le permitiría inscribirse en las crisis de formas de vida y participar en ellas. En nuestra topología, sólo emerge una esfera pública homosocial y homoerótica cuando la crisis se ha profundizado o asentado. El Círculo Interior fue, entonces, una manifestación previa a la implosión de una forma de vida. El ambiente, sin duda, era un acomodo a una norma que no podía, al parecer, realizarse de otros modos. Desde los años ochenta se entra, en México al menos, en un momento antropológico en este campo que puede develar la regularidad, en palabras de Virno, de una forma de vida, pero también reconocer su problematicidad intrínseca. El Club, en ese sentido, es un aparato antropológico que crea topologías y problematizaciones particulares en torno a ellas.

Alan expresa las tensiones de este momento de manera muy clara: dice que a los gays de la ciudad "los aceptan, pero no los perdonan".

Exactamente sí nos acepta que seamos homosexuales, pero no te perdona que seamos homosexuales, porque si eres hombre, tienes que ser hombre y no dejan de recalcártelo a cada rato.

¿Y cómo se ve que no te perdonan?, ¿en qué se ve?

No puedes expresarte ni abrazarte con tu pareja delante de ellos, porque ya eres mal visto, entonces te están aceptando que seas homosexual, pero no te lo están perdonando, porque si te perdonaran que fueras homosexual te dejarían que te beses, que te abrases, que vayas a una fiesta, nosotros como gays, como putos, como homosexuales vamos a fiesta de sociedad, de la sociedad, de la gente rica de Tenosique, la gente rica de Tenosique nos invita a sus eventos sociales y podemos bailar entre nosotros como homosexuales en la fiesta de sociedad, más no bailar con mi pareja entonces ahí está implícito, te acepto como puto, como gay, como homosexual pero no te perdono, yo estoy de acuerdo que seas puto pero no te perdono que en mi fiesta te hayas abrazado, que te hayas besado con otro cabrón macho igual que tú, entonces te acepto pero no te perdono, el perdón que te lo conceda Dios.

Es interesante que la aceptación se siga de la ausencia de perdón. Aceptan, dice Alan, que seas "gay, homosexual o puto", pero no lo perdonan. A mi entender, ésta es una excelente descripción de la crisis que nos interesa. Por una parte, la gente de la ciudad tiene que aceptar a los homosexuales por diversos motivos, que ya exploramos; por otra, se percatan que su praxis pública altera sus formas de vida. ¿Qué es lo que no perdonan estas personas de las que habla Alan? Que él y su grupo, que los homosexuales en general, modifiquen "la gramática de su forma de vida", a decir de Virno, "el sustrato de todo mi buscar y todo mi aseverar", 
compuesta por “opiniones y creencias histórico-sociales”. Éstas constituirían certezas-éndoxa "que, en caso de crisis, vuelven al estado fluido, recobrando, pues, una tonalidad empírica" (Virno, 2011: 87). Si Alan bailara con "otro cabrón macho" como él, entonces discutiría esa gramática y las certezas-éndoxa que la sostienen; eso no se lo perdonarían -"que te hayas abrazado, besado con otro cabrón”- y sólo Dios, el sustrato de piedra más poderoso, podría hacerlo.

Una vez que esas gramáticas se han vuelto fluidas, se propagan muchas búsquedas y se gestan nuevas afirmaciones. Virno se pregunta, siguiendo a Wittgenstein, “¿qué ocurre si el fondo gramatical, del cual uno obtenía los criterios para juzgar y actuar, se empaña, si manifiesta una progresiva inestabilidad, si se hace añicos?” En este momento, responde, “el 'sustrato de todo mi buscar y de todo mi aseverar' deviene, entonces, el objeto de muchas búsquedas y de muchas afirmaciones" (ibid.: 89-90).

Pero eso no sucederá de manera fácil ni ligera. Ciertamente la crisis también es interior, no afecta sólo a quienes rechazan cualquier cambio en sus gramáticas, también a quienes los realizan o los empujan.

Yo creo que es como que algo natural del gay ser una persona que tenga facilidad de palabra, es raro que un gay no tenga facilidad para hablar y para expresarse, es como un don natural del homosexual, el gay con sólo hablar te opaca, el gay es muy sensual para hablar, no sé si te has fijado, los gay hablan "Ay, mira mi amor, cariño, preciosidad", denotan debilidad y tratan de ser sumisos a la hora que hablan, a la hora que expresan sus pensamientos, pero cuando se enojan te sale a relucir lo hombre, y entonces cuando les sale a relucir lo hombre son personas fuertes, llenas de vigor, llenas de energía, es cuando te dicen "lo macho lo traigo adelante y lo puto lo traigo atrás". (Alan)

Podríamos leer esto como una expresión más de las dualidades que aparecen constantemente. Pero también podemos interpretarlo como una modificación de las gramáticas subjetivas, que al hacerse fluidas, también se hacen cambiantes. Alan reivindica un poder especial de los gays con respecto al lenguaje. Una capacidad sensual, pero también un modo de resaltar ante los otros; destellos, pero esta vez en el habla. También advierte las transformaciones que pueden experimentar desde un habla aparentemente sumisa a una violencia explosiva. El cuerpo, nuevamente, se convierte en un mapa de modificaciones y de circulación de posiciones sociales diversas: "lo macho lo traigo adelante y lo puto lo traigo atrás". Un cuerpo oscilante, que 
expresa identificaciones de formas alternas, pero desvaneciendo cualquier certeza sobre su inscripción: macho-adelante, puto-atrás.

Deleuze y Guattari dirán que el problema del socius consiste en "codificar los flujos del deseo, inscribirlos, registrarlos, lograr que ningún flujo fluya si no está canalizado, taponado, regulado" (Deleuze y Guattari, (1985[1972]): 39). Las crisis gramaticales de las formas de vida y su fluidificación intensifican ese problema, porque los tapones que impedían los flujos se debilitan y los canales se modifican.

De este modo, a través de las experimentaciones con sus cuerpos, su deseo y sus subjetividades, los gay de Tenosique crearon, paulatinamente, una zona o mancha de indeterminación $n^{34}$ corporal y subjetiva. Si en el orden sexual de la localidad el afeminamiento y la homosexualidad los colocaban en un lugar femenino, organizado fundamentalmente en torno al falo, en las exploraciones de sus cuerpos algunos crearon una corporalidad deseada. Aquellos que fueron jóvenes a fines de los años ochenta y principios de los noventa del siglo pasado, rompieron con las molduras de la masculinidad y comenzaron a crear un cuerpo ambiguo, que no era ni el de una mujer ni el de un hombre. Un cuerpo oscilante que les permitía recorrer diversos caminos sociales y personales, mutar constantemente. Un cuerpo para múltiples prácticas y que no se ceñía de manera definitiva ni a los mandatos de la masculinidad ni a los de la feminidad. Un cuerpo indeterminado que permitía tanto una exploración como ciertas prácticas de libertad. En la cornisa del sistema de sexo-género local, estos sujetos se desplazaban de un lado a otro. Pero primero conquistaron tanto la posibilidad de transitar como la de transformarse. La eventualidad de transitar corporalmente entre unos espacios y otros fue consecutiva con la de moverse con libertad por la ciudad, "vestidos de mujeres". La

\footnotetext{
${ }^{34}$ En sus ensayos sobre La comprehensión de la obra de arte literaria, Roman Ingarden denomina lugar, punto, e incluso mancha, de indeterminación a "la parte o aspecto del objeto que no está específicamente determinado por el texto" (2005[1968]: 71). Al encontrarse con esas manchas de indeterminación, los lectores podrán reconocerlas y dejarlas como tales o llenarlas y completarlas "con determinaciones que no son justificadas por el texto" (ibíd:: 73). En nuestro caso, no hay forma de determinar si estamos ante "un macho o un puto", si el cuerpo actúa por “delante o atrás”. Esta mancha crea una indeterminación que obliga a los otros sujetos a decidir o determinar por cuenta propia el cuerpo y la subjetividad indeterminados. La experimentación se localiza justamente en esa posibilidad de crear manchas de indeterminación, que suscitarán respuestas sociales diversas, pero que eludirán cualquier determinación definitiva o única. Si una forma de vida fuera, también, un ensamblaje aparentemente resuelto, las manchas o zonas de indeterminación producirán un aflojamiento de las junturas y una intensificación de los flujos.
} 
conquista personal fue también social, el espacio subjetivo concernió otro colectivo. "Lo corporizado es aquello que quiere vivir", escribe Sloterdijk (2003c: 200); en este caso, lo corporizado fue, también, lo que permitió vivir y abrió una brecha en ese sustrato de piedra, una brecha por la que se filtraron otras formas de vida y nuevos modos de experimentación.

Si el sustrato de piedra fuera también una formación material, por ejemplo, la corporalidad o la reproducción sexual, entonces las estrategias de indeterminación requieren de un sustrato semejante, aunque disjunto. En el caso de los gays de Tenosique, el cuerpo fue esa roca material de experimentación, que no sólo soportó nuevas gramáticas, sino un trabajo libidinal, para retomar a Deleuze y Guattari, distinto o torcido. Contra cualquier giro discursivo, creemos que ese soporte material es fundamental para producir nuevas significaciones; en muchos sentidos, primero sustentó prácticas sociales incipientes y luego significados y discursos. En la oscuridad del cuerpo, que no es mudo, pero tampoco habla el lenguaje articulado del sujeto, emergió una ruptura de las gramáticas sociales y las normatividades.

Guattari escribe que "siempre deberíamos pasar por ese punto: la invención de la vida" (2005: 193). Este sería el único mandato, si hubiese alguno. La invención, dirá Lazzarato, por su parte, “es un proceso de creación de la diferencia que pone en juego, cada vez, al ser y a su individuación. Toda invención es ruptura de normas, de reglas, de hábitos que definen el individuo y la sociedad" (Lazzarato, 2010: 69). Crear diferencias es lo que han hecho los integrantes del Club y todos los sujetos que nos han ayudado a pensar estos temas. Y las han creado experimentando con ellos mismos, algunas veces con enormes costos.

Recuerdo una conversación con un amigo de Tenosique en la que me contó que alguna vez tuvo una plaza de profesor en una escuela del Estado, pero que había tenido que elegir entre "la putería" y el trabajo formal, al que no podía "ir de mujer". Eligió la putería y sus atuendos ambiguos; perdió el trabajo y la estabilidad laboral. Salió del socius laboral para quitarle los tapones a su deseo y su cuerpo. ¿Qué habría sido mejor: que conservara el trabajo o que eligiera la putería, como él la llama? No es fácil evaluar una vida, él tampoco lo hacía con la suya, sólo cavilaba sobre las consecuencias que todo eso tuvo. Virno escribe que la creatividad humana "se manifiesta únicamente en los caminos laterales e impropios que nos sorprende tener que inaugurar mientras nos esforzamos por atenernos a una norma determinada" (Virno, 2011: 25; énfasis mío). Este informante tomó ese camino lateral, que lo condujo del trabajo docente a la putería, pero también eludió un mandato insoportable para que cumpliera con un orden de 
género y se vistiera de manera correcta. La invención permite escapar a los hábitos establecidos y a "las alternativas binarias que imponen", dirá Lazzarato (2010: 70).

Con ese gesto libertario, mi amigo propicia la creatividad de la que habla Virno y abre un campo de experimentaciones al que luego llegarán otros sujetos, muchos de los cuales no tendrán que asumir consecuencias tan drásticas al tomar sus decisiones vitales.

Deseo y formas de vida

Parece una paradoja el que la acción del Club y las formas de vida de los gays, que horadan ese sustrato de piedra del que habla Virno, sean impulsadas y sostenidas por otro sustrato, quizás igual de sólido, constituido por el deseo. Así, el perdón que estos sujetos tendrían que pedir se relaciona, justamente, con esa develación incómoda del propio deseo y el de los otros. Pero, por otra parte, no habría forma de cambiar una vida si no se contara con un sustrato sólido que soporte muchas turbulencias. Tal vez el deseo, ese lugar anterior a cualquier reflexión, pero también ese punto de iluminación de una consciencia, no sea más que un mito. En una escueta definición de forma de vida, Wittgenstein escribe que "imaginar un lenguaje significa imaginar una forma de vida" (Wittgenstein, 2004[1958]: 31, \$19); luego añade que "bablar de lenguaje forma parte de una actividad o de una forma de vida” (ibid:: 39, \$23). Virno, seguidor de Wittgenstein, ha señalado que "una forma de vida se contrae y decae cuando una misma norma es realizada de muchas maneras distintas, contrastantes entre sí” (Virno, 2011: 83). ¿Podríamos pensar el deseo como la fuerza de imaginación de un lenguaje, que "significa imaginar una forma de vida"?, ¿será el deseo el sustrato de realización de una norma/forma de vida de maneras diversas? Un dictum de Guattari anunciaba que "sólo el deseo puede leer el deseo" (Guattari, 2013: 63). Si así fuera, el sustrato final de toda forma de vida, en crisis o no, nueva o antigua, sería el deseo mismo. Y el deseo sería el sustrato sin sustrato. Por eso, lo describimos como la roca de los procesos de subjetivación de los sujetos gay de Tenosique. No hay un más allá del deseo, ni siquiera mítico.

De este modo, cuando hablamos de la transformación de una forma de vida mediante el deseo no lo asignamos a unos sujetos o colectivos en vez de otros. Si lo leemos como el sustrato de todo sustrato, estas pugnas por las gramáticas de las formas de vida, y las normas que las regulan, serán conflictos entre deseos (o formas de desear consecutivas a cualquier forma de vida) y a través de ellos. Quizás podríamos entender ese misterio guattariano desde 
esta perspectiva: sólo el deseo puede leer el deseo, porque lo que está en juego son justamente las formas de deseo y las de vida, imbricadas unas con otras.

En el caso que hemos investigado, el sustrato de piedra que permite inaugurar otros flujos sociales y modificar las gramáticas vitales no ha sido la identidad. En cierta manera, sólo nos encontramos con ella cuando los flujos están en movimiento y han logrado alguna intensidad. Previamente, sólo hallaremos al deseo como la fuente de la innovación subjetiva y social. La identidad oculta, por así decirlo, que sólo es una forma de aglutinación de gramáticas y de nuevos y viejos usos. Por eso, es como un tragaluz por el que entraríamos a unas habitaciones más oscuras y distantes, a sótanos inaccesibles. Pero su efecto es encandilante y, a veces, obstaculiza la visión. El deseo, sustrato temprano, pero confuso, parece tributario de la identidad, pero debemos modificar ese enfoque y entender que ésta es una prótesis de aquél: extensión útil que permite ciertos gestos y operaciones en el mundo, pero que también impide otras. Sin embargo, el deseo, que tiene la capacidad de quitar todos los tapones (no sólo los eróticos, por supuesto), no restringe sus manifestaciones, ni sus modos, a la identidad. También produce irregularidades en el lenguaje, modificaciones en los cuerpos, saltos en las trayectorias de vida, inusitadas formas de amor y de afecto, contravenciones de las normas, aquiescencias estratégicas. Produce, y sobre esto regresaremos, formas de temporalidad diversas y subjetividades disjuntas. Si una forma de vida se enfrenta, de pronto, a muchas realizaciones posibles que la amenazan, en alguna medida, el deseo será el motor de la pluralidad práctica y de la multiplicidad de sus realizaciones. Pero como es otro sustrato, no será fácil de detectar ni de transformar. Es como si estuviera dentro y fuera de esas formas de vida, como tal vez lo está de la historia misma. Una zona de indeterminación casi estructural que impediría, radicalmente, cualquier cierre posible de lo social y de lo vital. 


\title{
V \\ Oscuras máquinas del devenir. Diferencia, deseo y corporalidad
}

\author{
A través del velo de las opiniones, imágenes y situaciones nunca capto \\ otra cosa que fragmentos y vistas parciales de la oscura máquina del devenir. \\ Peter Sloterdijk, Esferas III, 2011: 90 \\ Entre ellos cruje el mundo \\ Como la diferencia y la distancia \\ Paul Hoover, Poemas en español, 2012:11
}

Durante el trabajo de campo en Tenosique percibí una limitación para transitar desde los espacios sociales y vinculares en los que me movía a otros distintos. Dicha dificultad la leí, primero, como una incapacidad personal, pero luego constaté que develaba algunas características relevantes de la organización social de la sexualidad y del género en esa localidad. Dado que el grupo que estudio se ubica en el límite entre los sistemas de clasificación social aceptados y las prácticas sociales permitidas y desordena, en cierta forma, sus órdenes más significativos (el sexo, el género, el parentesco, la alianza), el tipo de investigación que realicé podría considerarse como una etnografía lateral.

La lateralidad es, ante todo, un modo de aproximarse a un campo marcado por su forma y constituyó una ruta para reconocer algunas características casi ‘estructurales' de la organización social del género y la sexualidad. Muchos datos y descripciones etnográficas tomaron sentido mirándolos desde esta perspectiva. Creo que esa lateralidad puede leerse como una "tecnología semiótica" que permite "enlazar los significados con los cuerpos" (Haraway, 1995: 330) y conseguir ' (...) versiones fidedignas de un mundo 'real', que pueda ser parcialmente compartido" (ibid:: 321; énfasis mío). Una exploración lateral como la que acá reconstruiremos, busca lugares paradójicos donde los cuerpos han sido enlazados con los significados, pero también otros donde han sido desatados (como el deseo). En vez de reproducir "el ojo ciclópeo y autosatisfecho del sujeto dominante", hemos elegido elaborar lo que Haraway llama una topología de la subjetividad multidimensional, que recupere las "multiplicidades heterogéneas que son simultáneamente necesarias e incapaces de ser apiñadas en niveles isomórficos de listas 
acumulativas" (ibid:: 331). La lateralidad es un punto de vista, en términos de Hartsock (1983: 285), y una posición que permite producir conocimientos situados (Haraway, 1995: 324).

De este modo, la lateralidad que nos interesa consiente dos operaciones. La primera, observar desde una perspectiva la diferencia sexual o el orden de sexo-género; la segunda, contemplar de modo específico la heterosexualidad y la organización de la sexualidad y el deseo. Si bien éstos son planos que se superponen en distintos momentos, nunca se pliegan completamente, al menos en nuestra etnografía. Mantendré esa tensión para atemperar una disputa entre los estudios de género y los de sexualidad. Si bien no intentaré resolver ese conflicto, creo que mirar las “conexiones parciales” (Strathern, 2004) del género y el deseo, la sexualidad y la diferencia sexual ha sido una aproximación productiva. En ese sentido, creo que he mirado desde el punto de vista de los gays de la ciudad, que no necesariamente se articula con el de las mujeres ni con el de los hombres. ${ }^{35} \mathrm{Si}$ bien aquéllos comparten subordinaciones con las mujeres, sus posiciones no son isomorfas; tampoco lo son respecto a los hombres, aunque disfruten algunas prerrogativas de su posición. No conforman, por supuesto, un tercer género. La posición en la que están es, ante todo, ambigua y oscilante. Por eso, su lateralidad es doble: vistos desde el género, comparten algunas características con las mujeres; pero desde el deseo, pugnan con ellas en un terreno conocido: el masculino.

Una visión caleidoscópica fue la única manera que encontramos para investigar esas "multiplicidades heterogéneas" que surgieron en el campo y que, en último término, no se pueden resolver de modo categórico. Es muy difícil, en este sentido, dar cuenta de un campo que no se ha suturado, cuando debemos pensar conceptualmente y describir con cierta precisión. Quisiera creer que nuestro ‘objeto’ siempre está más allá de sus descripciones, como si saltara cuando intentamos circunscribirlo.

Estas lateralidades podrían leerse como superficies etnográficas que intentan explorar algunos órdenes y relaciones sociales a través de sus manifestaciones en pequeña escala. Según Strathern (2004), el conocimiento antropológico enfrenta serias dificultades para trabajar con distintos niveles (escalas) de un fenómeno o una realidad: desde estructuras sociales hasta

\footnotetext{
35 En este capítulo mantendré una tensión identificatoria entre gays, hombres y mujeres, que está presente en el lenguaje cotidiano de la localidad. Joan Copjec escribe, en contra de cualquier solución taxativa en este campo, que "el sexo nombra lo no duradero, la no asimilabilidad entre las forma de una vida biológica y social, entre anatomía y convención, hombre y mujer; esto es, entre estas cosas que son inconmensurables y, por ende, no relacionables" (Copjec, 2011: 34).
} 
individuos. Cada nivel supondría distintos tipos de complejidad, pero también una cantidad de pérdidas analíticas o descriptivas. Lo que se gana en generalidad, se pierde en detalle; lo que se adquiere en complejidad, se dilapida en singularidad. En vez de suponer unos principios generales o un núcleo de características centrales, Strathern propone pensar en conexiones parciales. En este trabajo, una conexión parcial sería, específicamente, una de las superficies laterales que nos interesan, que permitiría captar, al mismo tiempo, el efecto relativizante de múltiples perspectivas (parcialidades) y atender a la recurrencia de proposiciones o bits de información (conexiones), en términos de la antropóloga inglesa (Strathern, 2004: XX). La lateralidad constituiría un recorte que busca mantener la complejidad a pesar de que no domina la amplitud del registro o los niveles en juego.

\section{Mapas}

Comprendí con mayor exactitud la dimensión estructural develada por la lateralidad de mi inscripción el campo al leer una reflexión de Slavoj Žižek sobre el antagonismo social, en la que cita un análisis de Lévi-Strauss sobre las percepciones del espacio entre los winnebago. Ellos representan de maneras distintas el plano de su aldea según al subgrupo al que pertenezcan. En esa percepción diferenciada, Žižek lee un antagonismo subyacente:

(...) la división misma en dos percepciones "relativas" implica una referencia oculta a una constante -no la disposición "real", objetiva de los edificios, sino un núcleo traumático, un antagonismo fundamental que los habitantes de la aldea son incapaces de simbolizar, de justificar, de "internalizar", de aceptar, un desequilibrio en las relaciones sociales que impedía que la comunidad se estabilizara como un todo armónico (Žižek, 2005:121).

Como mostraré en este capítulo, creo haber encontrado un tipo de antagonismo parecido al que Žižek propone. Mi análisis se centrará en dilucidar cómo dicho antagonismo se articula en torno a la diferencia sexual y el deseo. No espero que corresponda estrictamente con las lecturas de Žižek (1992 y 2005) de este tema ni con las de otros autores, como Laclau y Mouffe (2006). Seguiré, no obstante, sus reflexiones sobre la constitución de lo social, especialmente el acento que ponen en la imposibilidad de su cierre y la persistencia de un residuo no simbolizable que, sin embargo, incide en la organización de las representaciones y las relaciones sociales; aquello que Žižek llama un "núcleo traumático", ese "antagonismo 
fundamental que los habitantes de la aldea son incapaces de simbolizar". Aunque no sé si el antagonismo que exploro sea igual de fundamental o si corresponda a ese núcleo traumático, creo que permanece velado, por así decirlo, a las percepciones colectivas sobre el orden social del lugar que estudio, que tienden, por el contrario, a enfatizar un acomodo no problemático de los espacios y los sujetos. ${ }^{36}$

Por eso, la dificultad para cruzar dicho orden tenía que ver con su propia constitución. Resumiré mis hallazgos: en diferentes ocasiones y contextos, cuando estaba con personas gay de la ciudad, habitábamos un espacio social específico que, si bien no tenía fronteras físicas, poseía otras invisibles que separaban colectivos distintos. Esa espacialidad es producto tanto de una distribución singular de los lugares físicos como de un orden que se materializa en una serie de relaciones sociales. Una explicación para ello es que dicha materialidad también encarna, por así decirlo, la diferencia sexual. Es decir, dado el estatus problemático que los gays ocupan en el orden de sexo-género local, un modo de dirimir su lugar es ubicarlos en un espacio social particular, darles ciertas oportunidades de desplazamiento y contacto y limitar otras. Gráficamente, la división del espacio social podría representarse del siguiente modo:

\section{Diferencia sexual y división social del espacio}

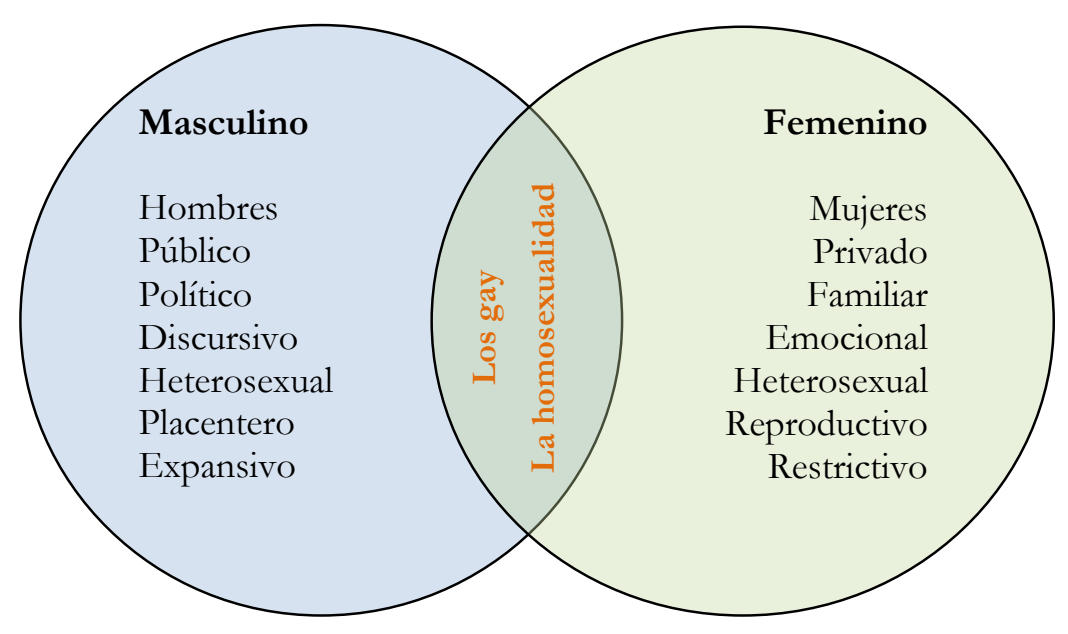

36 "El antagonismo, escriben Laclau y Mouffe, escapa a la posibilidad de ser aprehendido por el lenguaje, en la medida en que el lenguaje sólo existe como intento de fijar aquello que el antagonismo subvierte" (Laclau y Mouffe, 2006: 169). En este capítulo no profundizaré en este aspecto, pero creo que esa invisibilidad muestra el funcionamiento de la fantasía social, Žižek sostiene que la fantasía es “(...) una contrapartida necesaria del concepto de antagonismo: fantasía es juntamente el modo en que se disimula la figura antagónica" (Žižek, 1992: 173). 
La descripción no es exhaustiva y la división topológica implica, necesariamente, una simplificación y cierta inmovilidad. Pero, a rasgos generales, los gays ocupan una posición liminar entre el espacio social masculino y el femenino. El espacio masculino pertenece a los hombres, es público (o lo es más marcadamente), es político, discursivo, placentero en términos eróticos y expansivo visto desde los vínculos. En cambio, el espacio femenino agrupa a las mujeres, es privado, familiar, emocional, reproductivo y exclusivo. Ambos son espacios heterosexuales, percibidos desde la organización social del deseo y la sexualidad. El carácter ambiguo y ambivalente de los gay de la localidad, que ya hemos analizado, los ubica en un espacio híbrido que reúne características de los dos principales; en un umbral entre los espacios socialmente signados y reconocidos. La representación gráfica, en ese sentido, es equívoca porque no superpone ni tampoco conecta los espacios binarios del orden de sexo-género, sólo los entremezcla con resultados contingentes y específicos.

Laclau y Mouffe entienden el antagonismo como un exterior constitutivo que impide que una sociedad se cierre sobre sí misma y transforma lo social en una fractura irreparable que suscita esfuerzos constantes para su suturación. De este modo, lo social sólo existiría "como esfuerzo parcial para instituir la sociedad -esto es, un sistema objetivo y cerrado de diferencias" y el antagonismo, "como testigo de la imposibilidad de una sutura última", constituiría la ““experiencia’ del límite de lo social” (Laclau y Mouffe, 2006: 169).

Žižek considera que esta imposibilidad de representar consensualmente el espacio común, como en el ejemplo citado, es "exactamente igual" con respecto a la diferencia sexual; de manera que “(...) masculino y femenino son como las dos configuraciones de la aldea” (2005: 121).

En las divisiones del espacio que hemos referido, en sus límites invisibles, pero efectivos, ¿opera un antagonismo semejante al que postulan Laclau, Mouffe y Žižek? La oscilación identitaria, narrativa, estética y sexual que he atribuido a las personas gay de la ciudad supone una manifestación anómala de las simbolizaciones de la diferencia sexual. Ida Dominijanni sostiene que la diferencia sexual se ubica "en el umbral entre la naturaleza y la cultura, y entre lo psíquico y lo social, donde está expuesto al significado histórico y político"; no es un dato fijo, "sino un significante abierto, que es tanto un objeto como un agente de la interpretación y el significado" (Dominijanni, 2012: 69). En ese umbral histórico-político, los gays de la ciudad realizan dos operaciones intrusivas: primero, cuestionan la versión dominante de la diferencia 
sexual, al construir una versión anómala de ella; segundo, la parodian al escenificarla, representarla y, en muchos sentidos, desnaturalizarla, como lo veremos más adelante.

Una etnografía lateral se ocupará de los antagonismos. Por eso, mi propio lugar como investigador, que se suma al espacio de los integrantes del Club, participa de sus antagonismos. Éste no es un problema comunicativo que se reduzca a poder, o no, conversar con gente distinta y seguir sus vidas. El problema, en este caso, es estructural, porque cruzar la organización del espacio es atravesar el antagonismo que la estructura. Pero ese antagonismo es develado por -y desde- ese espacio liminal el que se ubican los gays y la homosexualidad.

Para investigar estos antagonismos he reconstruido una serie de 'superficies etnográficas', como antes las denominé. Quisiera retener ese concepto, porque cada una es como una viñeta, que describe en un registro microsocial algunos vínculos, acontecimientos y sujetos. Veremos que ellas, si bien corresponden a conexiones parciales, conforman una densa red de fenómenos que permiten visualizar un orden social desde la posición lateral que hemos elegido y el grupo con el que trabajamos. Esas superficies son diversas, incluyen a muchas personas en distintos momentos, y corresponden, fundamentalmente, al orden de género y sexual de la localidad, que he intentado concebir convocando muchas voces y describiendo espacios múltiples. He ido desde algunas fiestas organizadas por el Club hasta las experiencias de las trabajadoras sexuales; desde el ligue entre hombres en las cantinas, hasta la historia de una mujer golpeada por su pareja.

En ese sentido, salgo del lugar del Club y de los gays, para entrar en otros, como el de algunas mujeres en sus relaciones de pareja, de otras en su trabajo o de algunos hombres. Si bien, esto puede producir cierto desconcierto descriptivo, creo que sólo reconstruyendo muchas superficies etnográficas, es decir, instancias en las que los cuerpos se atan a ciertos significados o se desatan de ellos, podremos comprender las múltiples lateralidades que produce un orden social, incluso cuando nos encontramos con su versión hegemónica. Es difícil superar una visión de contraposiciones lisas, para entrar en estas lateralidades estriadas. Pero etnográficamente he encontrado, a partir de un interés puesto en la subjetividad, que no hay espacios lisos, ni sujetos completos o cerrados. Por eso, como lo veremos luego, nociones como la heterosexualidad normativa son problemáticas: efectivamente existe tal ordenamiento, pero casi nunca se cumple como se esperaba o se obligaba. Esta distancia entre la experiencia y la norma, entre los significados y las prácticas, entre los deseos y las identidades, que ha sido 
productiva en términos analíticos, es lo que permite, justamente, la lateralidad que me interesa y conforma esas superficies etnográficas estriadas.

Por otra parte, nociones como diferencia sexual o sistema de sexo-género condensan discusiones académicas y antropológicas de amplio aliento y enorme complejidad. He seguido algunas rutas conceptuales, pero podrían tomarse otras. De todos modos, la diferencia sexual o el sistema de sexo-género están inscritos en los órdenes sociales y culturales que he estudiado; es decir, trabajo con materiales atravesados por esas diferencias.

\section{Fiestas, velorios y encantos: topologías de la femineidad}

En diciembre de 2008 asistí al novenario del hermano recién fallecido de uno de los integrantes del Club. Apenas llegué a la ciudad me invitaron a ir "al rezo". Caminamos por la ciudad con un grupo de ocho o diez personas, todos amigos del hermano del difunto. Llegamos a su casa, que como muchas otras de la ciudad, da directamente a la calle. En el espacio que ocupan la sala y el comedor, y donde está la puerta de entrada, había varios cirios y jarrones con flores en el lugar donde estuvo el ataúd. Los rezos correspondían al novenario que se realiza con posterioridad al entierro de la persona. Dentro de la casa había un grupo de diez mujeres que se alistaban a iniciar las oraciones. Junto a la puerta, pero en la calle, habían colocado varias sillas de metal donde estaban sentados los integrantes del Club y otros gay de la ciudad que habían asistido a recordar al difunto y acompañar a su amigo. Minutos antes de que iniciara el rezo llegaron más mujeres y algunos hombres. Todos ellos permanecieron detrás de las sillas, a unos dos metros de distancia, apoyados en algunos carros o en las rejas de las casas vecinas.

De este modo se había dibujado ante mis ojos un mapa social de las identidades sexuales, que se actualizaba ante la muerte. Las mujeres, cabezas de todos estos rituales mortuorios, formaban el primer círculo en torno al espacio vacío que representaba al muerto: el lugar donde estuvo su cadáver. Luego, en un espacio intermedio estaban los gays y en un tercer círculo, lejos del muerto y a distancia de las mujeres y de los gay, estaban los hombres. Los hombres heterosexuales (o no identificados como gay) que acompañaban a los amigos del hermano del difunto se sentaron en las sillas de la última fila, es decir, cerca de los otros hombres, aunque próximos también a los gays con quienes venían. Cabe decir que nadie había distribuido a los invitados y que el orden emergió de manera espontánea. Antes del rezo 
comimos tamales y bebimos atole. La comida será otro elemento siempre presente en las celebraciones, especialmente las que se realizan en las casas.

\section{Mapas de un velorio}

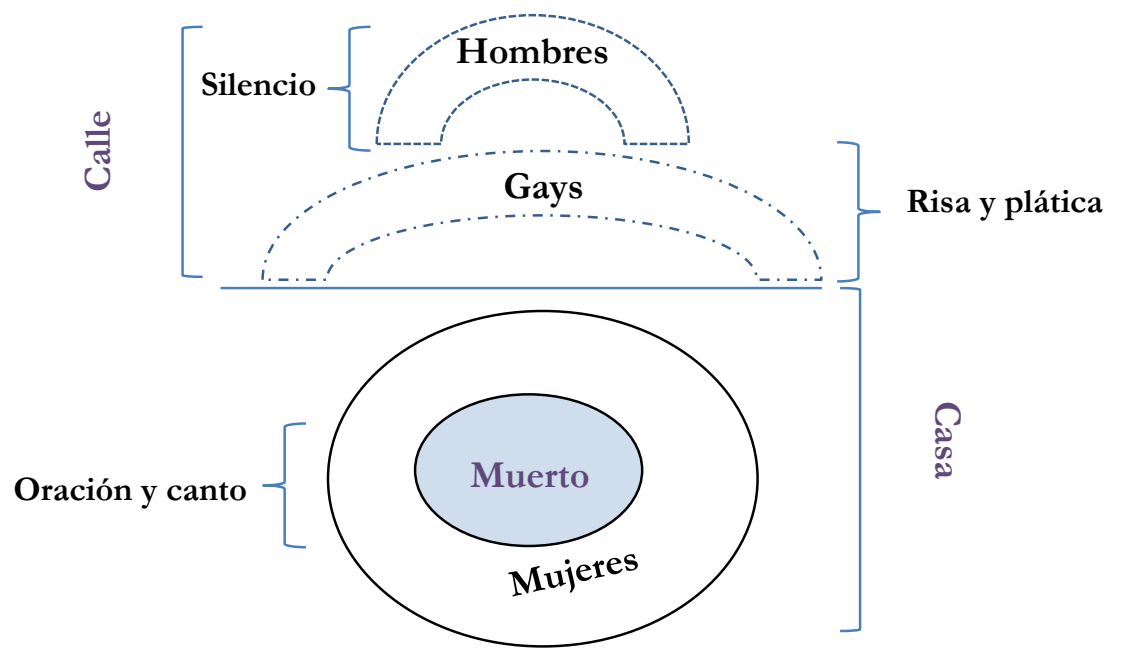

Había tres espacios dibujados con claridad: uno de mujeres, otro de homosexuales (de putos sería la forma más precisa de llamarlo) y un tercero de hombres. Cuando me percaté de eso pude visualizar, retrospectivamente, esa misma distribución en otros lugares y circunstancias. En las cantinas, las mujeres se sentarán juntas en alguna mesa, salvo que acompañen a un hombre, hasta que alguien las invite. En otras estarán los gay, hasta que lleguen los hombres a pedirles cerveza. La mayoría estará ocupada sólo por hombres. Los cruces son los menos y la separación es consistente. Sucederá lo mismo en las fiestas, aunque en este caso, mujeres y hombres compartirán los espacios, porque se organizan en torno a relaciones de parentesco y alianza o de amistad y camaradería.

Al percibir esta división invisible y tácita del espacio constaté, como dije, que había determinado mi propio trabajo etnográfico. Cuando seguía las redes y las pautas de sociabilidad y socialización de los integrantes del Club vivía en una parte de la ciudad, tomaba ciertas rutas, veía y conocía algunas personas. Al seguir la inercia del grupo, sus inclusiones y exclusiones, he aprendido a vivir con ellos en un lugar donde son aceptados parcialmente, donde entran y salen de relaciones que marcan ciertos límites y disponen de prohibiciones. Si he recorrido sus propios itinerarios entonces conozco la ciudad según ellos la experimentan. El mismo mapa para interpretaciones diversas, para legitimidades distintas. 
Este primer mapa, debemos notarlo, está organizado en torno a la muerte y un espacio vacío: donde estuvo el cadáver queda su sombra. Un espacio distribuido ritualmente, que se constituye en una especie de analogía de la ontología de lo social que describen los pensadores del antagonismo. Es como la representación de los winnebago, que interesaba a Žižek, en la que confluye tanto un orden social del espacio como otro de la diferencia sexual, organizados en torno a un antagonismo. Habría que pensar porqué la muerte ofreció la primera evidencia; quizás en ella, que supone la disolución de lo social, en alguna medida, y que está intensamente ritualizada, el orden social se muestra, también, de una manera liminar.

\section{Compartir la mirada: un festival fallido}

En agosto de 2009, organizamos junto con la gente del Club el Primer Festival de Cine por la Diversidad Sexual de Tenosique. Financiados por un proyecto sobre sexualidad y ciudadanía, pudimos comprar películas, imprimir trípticos y afiches, que pegamos por toda la ciudad. La Casa de la Cultura nos facilitó el auditorio, que tiene la forma de un cine de barrio, con asientos desvencijados, algo oscuro, y un suave declive hacia el escenario. El DIF de la ciudad nos prestó un equipo de proyección de películas de muy buena calidad. La sala, sumada al equipo, permitió crear un verdadero cine, con sonido bastante potente y una gran pantalla. La colección de películas era una suma de clásicos del cine gay: Priscilla, la reina del desierto, La jaula de las locas en su versión francesa, Mi vida en rosa, La mala educación, El lugar sin límites. Durante seis días pasamos doce películas, en dos horarios distintos. En la inauguración proyectamos Milk, la historia del primer político abiertamente gay de la historia estadunidense. Película de identidades sólidas y diferencias claras en una ciudad de identidades en claroscuros y diferencias oscilantes. Al cierre, La mala educación y su versión anticlerical del mundo católico. Clausura con show travesti: Paquita la del Barrio, Yuri y otras cantantes que deleitaron al público. Vendedores de dulces y de golosinas. 


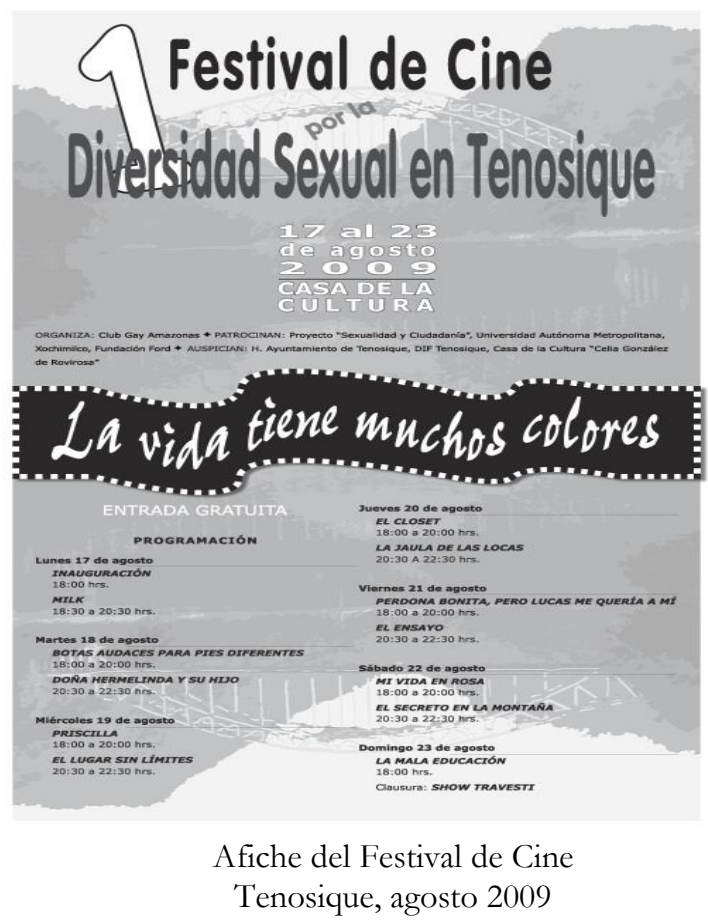

Si bien hicimos difusión del festival por toda la ciudad, incluso con perifoneo dos veces al día, llegaron mayoritariamente los gays de la ciudad y algunas mujeres. Muy pocos hombres. Entre 20 y 40 personas por día, no más. Era una cifra menor en una ciudad que no cuenta con una sala de cine hace más de una década y donde el evento era una novedad. Pero los límites que he mencionado son más poderosos que el aburrimiento. El error, según entendí, fue que la gente creyó que era cine "de putos". Entonces ir a verlo era, de alguna forma, asemejarse a ellos. El festival se estructuró sobre esta división social de las identidades y las pertenencias. Los menos interesados en cruzar las líneas eran los hombres, que no deseaban que los identificaran con los putos. Es como si las identidades representaran una amenaza y el cruce inoportuno de ciertos límites supusiera una transformación del infractor. El cruce indebido, en lugares inadecuados y momentos poco propicios, se traduce en sospecha y rumor. Las fronteras de las que hablamos son, sin duda, límites simbólicos y sus efectos son parlantes: comidillas, chismes, rumores, chistes. La identidad es puesta bajo sospecha, la masculinidad comienza a ser escrutada (siempre será objeto de observación y reafirmación). 


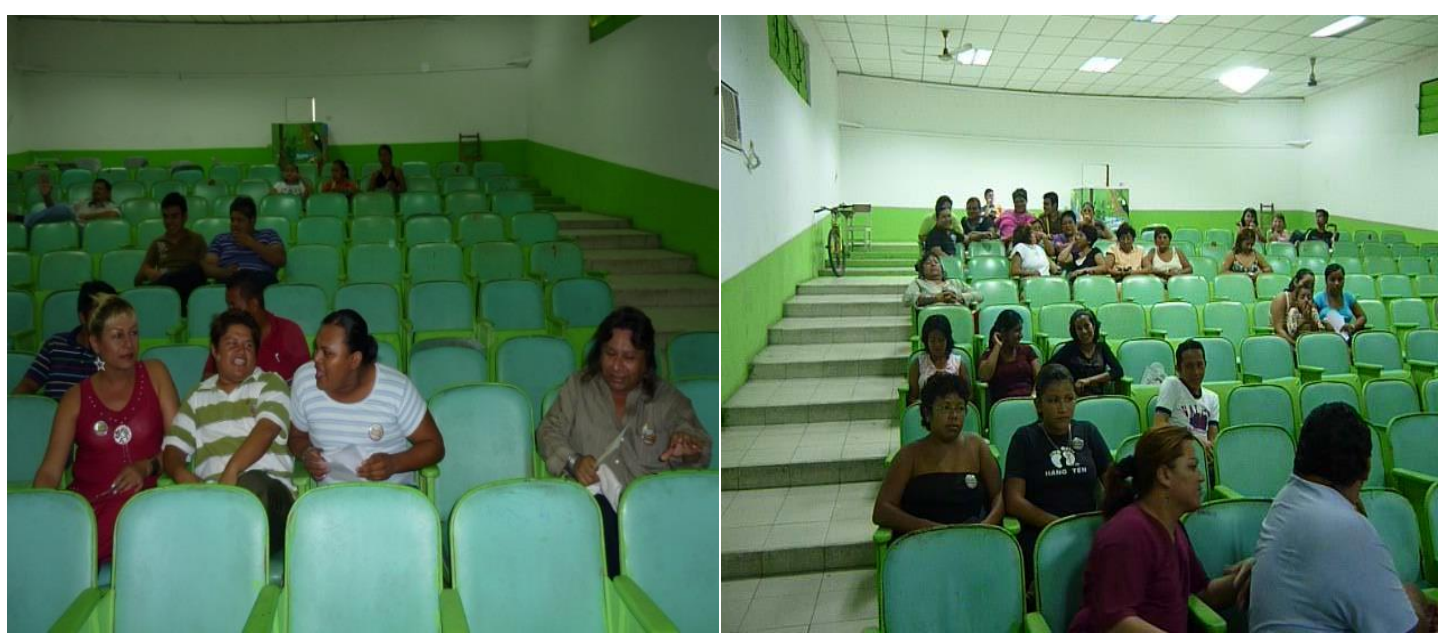

Funciones del Primer Festival de Cine de la Diversidad Sexual

Tenosique, agosto 2009

Los espectadores gay vieron las películas con gran interés. De algún modo, el cine permitía la proyección de sus propias vidas. Mi vida en rosa, la historia de un niño que desea vivir como una niña, y Kinky Boots, el relato de una trans británica de raza negra que logra ganarse un lugar en una fábrica de zapatos en el norte de Inglaterra, en un mundo conservador y prejuicioso, tuvieron una repercusión particular. La primera, porque muchos de los espectadores habían pasado por situaciones semejantes y habían tenido deseos parecidos. La segunda, porque era una historia de éxito ante la adversidad, que se enfrentaba con alegría y humor.

Si las películas dotaban de referentes identificatorios a los espectadores gay del Festival, no ofrecían lo mismo a quienes no lo eran. En ese punto se producía la ruptura. La mirada no se constituía en el espacio de confluencia que había imaginado, sino en una forma de articular los antagonismos en torno a la diferencia sexual y el deseo.

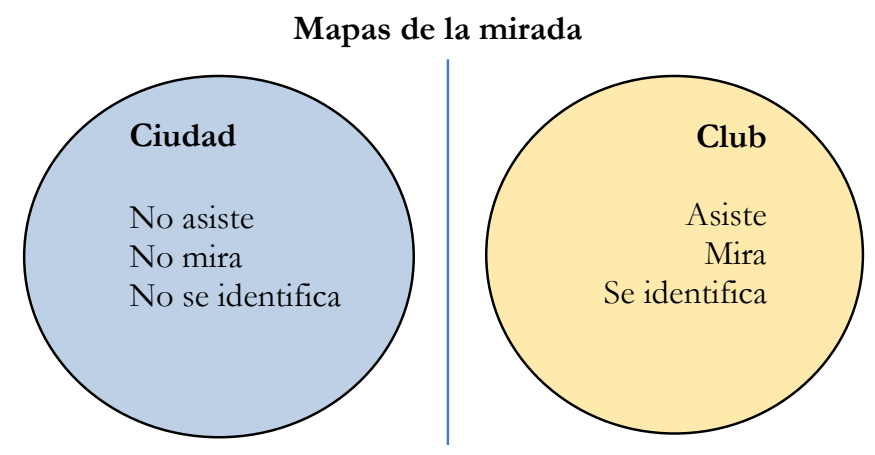

La mirada imposible 
¿Cómo atraviesan los antagonismos la mirada? En un video anónimo, que subieron a Youtube habitantes de Tenosique, aparece una filmación del carnaval del año 2013. La persona que sostiene la cámara está situada en una orilla de la calle por donde transitan los carros alegóricos y las comparsas y los ve venir. Otro individuo tiene un micrófono y comenta los carros y los disfraces. En un momento, se ve a lo lejos el carro y la comparsa de los gays de la ciudad. La cámara que ha filmado durante más de media hora tambalea y, cuando ese grupo pasa frente a ella, se produce un corte. El salto que hace la grabación es sintomática, a mi entender, porque materializa lo que he descrito en el caso del Festival de Cine. Quien filma no tuvo problema para grabar los otros carros y las otras comparsas y registrar la extravagancia colectiva que transitaba ante el lente. Pero cuando aparecen los homosexuales, entonces se desvía. La cámara, literalmente, cambia de dirección y ahora graba desde atrás el movimiento del desfile. Elude la mirada y oscurece la presencia de los gays. El antagonismo, si nuestra interpretación fuera correcta, impide que esos sujetos y esos colectivos sean filmados. La mirada se deshace, se perturba y cambia de sentido. ${ }^{37}$ ¿Qué puede ser visto y qué permanece velado o invisible?, ¿cómo se organiza el espacio social mediante miradas que cortan y que eluden?, ¿salta la mirada el deseo porque muestra, por así decirlo, el antagonismo que organiza el orden sexual local?, ¿no se puede 'ver' el antagonismo, como tampoco se lo puede pensar objetivamente?

\section{Todas íbamos a ser reinas}

Os impedirán experimentar en vuestro rincón. Deleuze y Guattari, Mil Mesetas, 2010[1980]: 156.

En noviembre de 2009 asistí a los XV años del Club. Por primera vez tuve una fecha de fundación clara: 11 de noviembre de 1994. Los XV años serían celebrados con una fiesta multitudinaria en el Centro de Convenciones de la ciudad. Éste era sin duda el cumpleaños más importante del grupo, porque vinculaba su historia con uno de los 'rituales de paso' de las mujeres. Llegué tres días antes y participé de su preparación. Este evento me parece crucial para comprender los procesos de identificación de los hombres gay de la ciudad, la construcción de identidades colectivas y el lugar de este grupo en el orden de sexo-género y en

\footnotetext{
${ }^{37}$ Bhabha escribe que "cada vez que tiene lugar el encuentro con la identidad, en el punto en que algo excede el marco de la imagen, elude el ojo, evacua el yo [self] como sitio de identidad y autonomía y, sobre todo, deja una huella resistente, un mancha del sujeto, un signo de resistencia” (Bhabha, 2002: 71).
} 
la producción social del deseo. En él, quince integrantes del Club se vistieron de quinceañeras y presentaron un espectáculo con chambelanes, pasteles y bailes, tal como se estila en una fiesta de ese tipo en la ciudad.

El evento me permitió conocer mejor los procesos de transformación en mujeres de algunos integrantes del Club, en este caso, en quinceañeras. Desde que comencé a investigar al grupo la oscilación de sus integrantes entre lo femenino y lo masculino me pareció relevante. Como lo hemos visto en capítulos anteriores, las clasificaciones del sistema de sexo-género que se utilizan en la ciudad ubican a los gays en el campo de lo femenino, pero de forma paradójica o incompleta: hombres con alma de mujeres, mujeres encerradas en cuerpos de hombres; nunca son cabalmente mujeres, sino aproximaciones fallidas. Tal vez la definición social de la identidad de los integrantes del Club y de los hombres homosexuales de la ciudad más insistente e importante era esa: un cruce entre los campos sexuados, una mixtura de identidades y corporalidades, cierta hibridez subjetiva y corporal. Un homosexual en este contexto es un hombre afeminado o al que se le nota 'algo'. Si bien lo trabajaré más adelante en relación con las construcciones de la masculinidad que se producen en la ciudad, quisiera añadir que estas clasificaciones están llenas de excepciones. De este modo, ni los hombres gay desean ser completamente mujeres, ni los habitantes de la ciudad consideran que lo sean. El hecho más relevante es que se admite, colectiva e individualmente, un espacio de oscilación identitaria, sexual, estética y corporal. De este modo, todo el campo de la homosexualidad queda ubicado en un 'entre'.

Vestirse de mujer es un acto serio y requiere de bastante trabajo y esfuerzo. Es una transformación, no sólo un travestismo, que opera sobre esos dispositivos simbólicos básicos de un orden social. Los integrantes del Club que se vistieron de quinceañeras lo tomaron con mucha seriedad y hubo una transición desde los ensayos, donde en general prevalecía cierto desorden, la risa y el juego hasta la noche del cumpleaños, cuando todo se hizo más grave y severo. Me pareció que el placer era anterior al acto de presentarse transformado.

En los ensayos los participantes aprendían una coreografía colectiva que representarían durante la celebración. En las fiestas de quinceañeras tradicionales también se ensaya: la festejada aprende los pasos, los chambelanes reconocen cuándo entrar, cómo tomarla. En este caso todo fue igual, pero eran quince en un mismo espacio. Por eso, todo tuvo algo de teatral: era un espectáculo. Cada una fue presentada con su nombre de fantasía. La identidad civil de los participantes se perdió en medio de la representación. Frente al público importaban las 
mujeres que deseaban ser. Cada familia, ordenada en torno a la mesas de plástico que una empresa cervecera había prestado, reconocería a su hijo. Pero el panorama general era el de actrices que representaban a quinceañeras dichosas por su cumpleaños. Tres temas musicales fueron acompañados de movimientos diferentes y cada una bajó de un pastel de cumpleaños hecho de madera y telas, que se enarbolaba arriba del escenario. Cada una encaramada en zapatos con tacón de aguja, maquillada prolijamente, vestida con los trajes de quinceañeras provincianas: brillantes y decimonónicos.

Juntas provocaban una sensación extraña, como si cada una estuviera poseída por su papel, en alguna forma sola, pero a su vez intercambiando pasos y movimientos con sus compañeras. Desde el inicio hubo una competencia sobre quién sería la más bella. Pero creo que fue menguando ante el efecto embriagante de las miradas, los aplausos y las luces. Cada una salía a compartir su propia imagen y transitaba, de alguna manera, desde su propia transformación hasta el asentimiento de los otros. Eran mujeres completamente fincadas en la mirada ajena, que calibraría con aplausos su belleza, la profundidad de la metamorfosis.

Me sorprendió el esfuerzo que se requería para conseguir la transformación, el tránsito dificultoso sobre el propio cuerpo para obtener uno distinto, imaginado y deseado. Los pelos, las barbas, las cinturas, los zapatos y las tallas. En todo había que hacer un ajuste, quitar allá o agregar acá. Como si el cuerpo se compusiera de sumas y restas destinadas a producir un efecto visual completo. Transformarse era crear una gestalt para los otros. Y debía ser convincente en todos sus detalles: uñas postizas, pestañas artificiales, maquillajes hiperbólicos, vestidos vaporosos y resplandecientes, bisutería, zapatos con tacones. No hay mujer por partes, pero sí partes de una mujer hipotética que se suman, se agrupan, se retroalimentan. Pelucas de cierto color que combinaran con la ropa, un determinado maquillaje que producirá tales efectos. Observé una artesanía corporal.

Mientras se acercaba la noche triunfal aumentaba la expectación. Habían ensayado durante diez días, pero antes de la presentación llegaron más candidatos para participar en el desfile. Disputas, enojos. Unos amenazaron con no salir si se aceptaba a los advenedizos; otros dijeron que ‘todas tenían derecho’. Discutieron entre sí: “todos somos gay”, “el Club es de todas”, “te avisamos y no quisiste venir". Los argumentos rodaron de un lado a otro. Finalmente no se aceptaron más quinceañeras. El rito se había cerrado y la cofradía dispuso su clausura. De todos modos, las que no pudieron participar también llegaron vestidas la noche de la fiesta. 
Previo al show una de ellas dobló a Thalía. Creo que todos tenían un espacio a fin de cuentas, si se sabían acomodar.

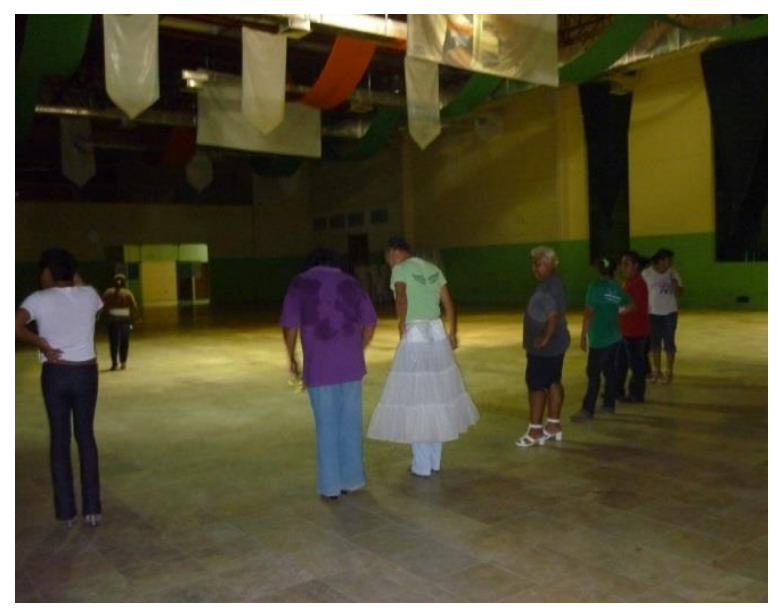

Ensayos previos

Tenosique, noviembre 2009

El truco forma parte de la transformación, por eso era una noche de acomodos y no de exclusiones. Cada uno debía acomodar su cuerpo para conseguir un efecto. Los efectos sumados coreográficamente serían representados ante el público, que también se acomodaría a ellos. Llegan unos muchachos a la puerta del Centro de Convenciones y me piden entradas para el evento. Les regalo dos que me dieron hace poco. "Venimos a ver a los putos", me comentan. "Los putos", pienso en silencio, "los putos que han hecho todo lo posible por ser mujeres.” ¿Cuál es el truco?, ¿es la fascinación un truco del orden simbólico?, ¿es el truco una invasión del imaginario sobre ese orden serio y parco?, ¿qué truco es uno que no engaña nadie?, ¿qué tipo de magia es ésta?

Una de las palabras que los gay utilizan para describir sus andanzas en las cantinas conquistando hombres es hechizar. Trucos, hechizos, todo del orden de lo artificial, sea del engaño o de la modificación. ¿Cómo se puede hechizar?, ¿son los hechizos signos despojados de su verdad? Quizás la transformación es algo más radical que el cambio de apariencia y avisa un uso del orden simbólico específico, que saca todas las certezas de sus lugares sin conmoverlas. Del cuerpo se hace una especie de clivaje de significantes que construyen un sintagma de lo que cada uno desea. 


\section{La función mitológica del transformismo}

El cumpleaños constituyó una representación de la división del espacio que nos preocupa; representación tanto de un antagonismo, organizado en torno a la diferencia sexual, como de su arreglo provisorio. En el Centro de Convenciones se replicaron los usos del espacio ya descritos. Las mesas se organizaron en círculos en torno a un óvalo central donde se desarrolló el espectáculo; tres filas de mesas, una detrás de la otra. En este caso, las mesas de la primera fila, la más cercana a la pista, fueron ocupadas en su mayoría por otros gays o por las familias de los participantes. Las quinceañeras estaban rodeadas de conocidos cuando daban la vuelta por la pista luciendo sus vestidos y sus arreglos. Frente al escenario, pero al final de la pista, estaba la mesa de honor, donde se sentaron algunos gays destacados de la ciudad y los invitados más importantes. Ellos encabezaron la ceremonia. Las otras filas, alejadas de la pista, estaban ocupadas por las personas que compraron entradas y mesas. Muchos eran amigos o conocidos de los integrantes del Club, pero otros tantos sólo iban a presenciar un espectáculo poco común en la ciudad. Si restamos las mesas que algunos gays ocupaban en la primera fila de mesas, todas las otras estaban ocupadas por familias. Digamos, el espectáculo era visto fundamentalmente por personas heterosexuales que iban con sus parientes. Si había un espacio heteronormativo era el del público. Quedaba un remanente de hombres jóvenes que paseaban en grupo y estaban interesados en ligar con los gay y/o en que les invitaran cerveza.

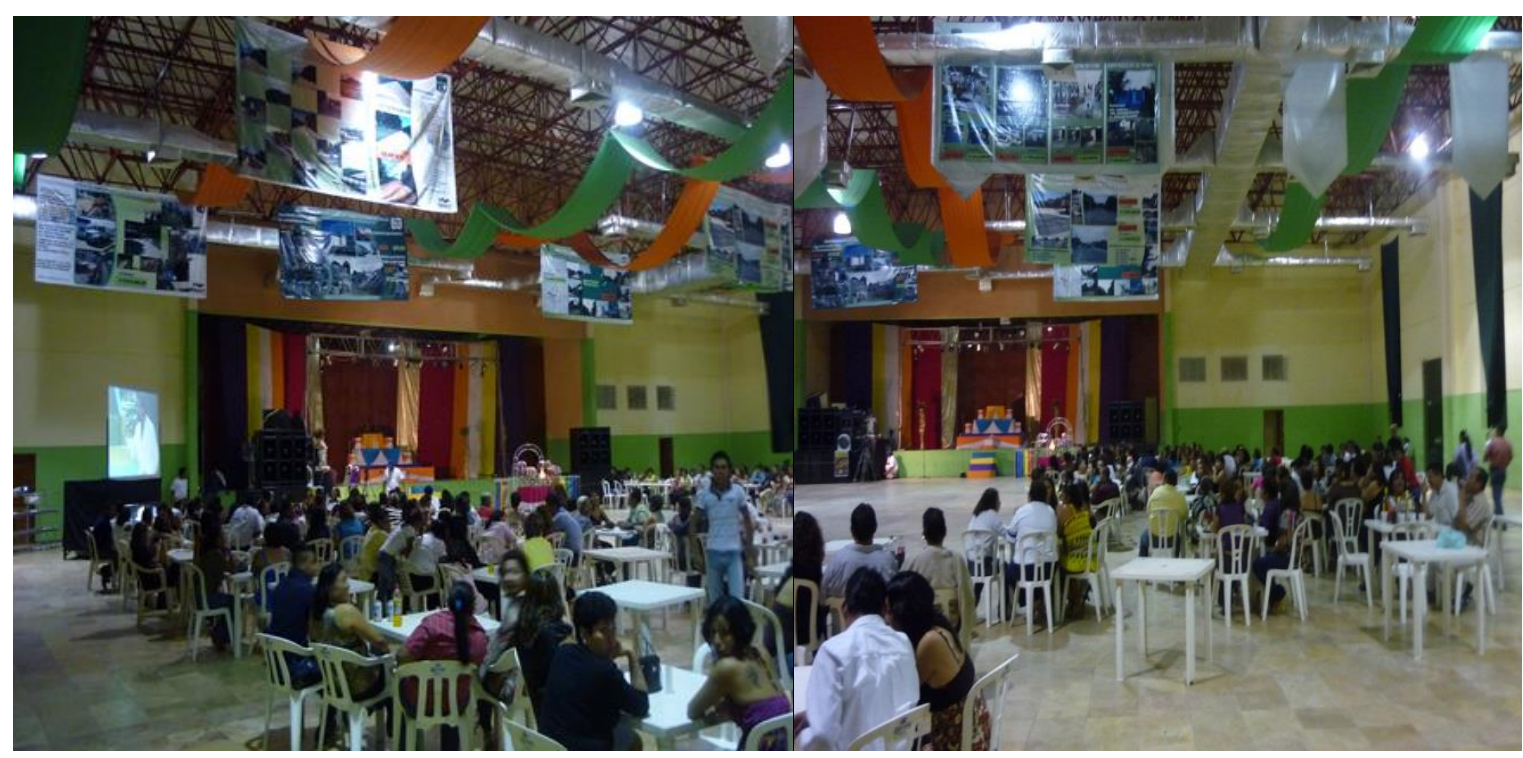

Distribución del espacio.

Centro de Convenciones de Tenosique, noviembre 2009 
Entonces, el espectáculo era la representación de una división social del espacio organizada en torno a un antagonismo no simbolizable. Si el antagonismo no puede ser enunciado, entonces, una estrategia para abordarlo sería la parodia. ${ }^{38}$ Hay que insistir en un punto: el antagonismo no es equivalente a la enemistad, entonces si bien produce clasificaciones específicas, divisiones del espacio y de las identidades, no necesariamente opera como un discurso político de la hostilidad. En esa línea, el espectáculo interpretaba y representaba la división social del espacio, que corresponde a una división del campo social; de algún modo, también la narraba. Por eso, el transformismo tiene, entre estos hombres gay de la ciudad, una función mitológica que les permite pensar su realidad social e intentar resolver su posición oscilante y ambigua.

De este modo, el espectáculo y la fiesta son formas de representar el entre en el que se encuentran. Al parodiar, de alguna manera, la diferencia sexual, destacan la provisionalidad de las divisiones sociales. Laclau y Mouffe señalan que "no hay principio subyacente único que fije -y así constituya- al conjunto del campo de las diferencias. La tensión irresoluble interioridad/exterioridad es la condición de toda práctica social” (Laclau y Mouffe, 2006: 151). El entre mencionado es producto de esa "tensión irresoluble" entre interioridad y exterioridad, en la que están situados los gay. Están fuera, en muchos sentidos, de las categorías y las prácticas sociales aceptadas: no se casan, no forman familias ni se reproducen. No son completamente hombres, tampoco son mujeres. Pero pertenecen a la comunidad, participan de su vida económica, social y cultural. Están dentro/fuera, son interiores y exteriores a su comunidad.

Laclau indica que el antagonismo no expresa la identidad “(...) sino la imposibilidad de constituirla; la fuerza que me antagoniza niega mi identidad en el sentido más estricto del

\footnotetext{
${ }^{38}$ Gerard Genette escribe, sobre la etimología de esta palabra griega, que: “ôda, es el canto; para: 'a lo que largo de’; parôdein, de ahí parôdia, sería (¿) el hecho de cantar al lado, cantar en falsete, o con otra voz, en contracanto contrapunto-, o incluso cantar en otro tono: deformar, pues, o transportar una melodía." (Genette, 1989[1962]:20). El mismo autor agrega que "el vocablo parodia es habitualmente el lugar de una confusión muy onerosa, porque se utiliza para designar tanto la deformación lúdica, como la transposición burlesca de un texto, o la imitación satírica de un estilo" (ibíd: 37). Si el transformismo que acá describo correspondiera efectivamente a un tipo de parodia, sería cercano a ese cantar con otra voz, en otro tono, que anuncia la etimología. Deforma, en este caso, un orden corporal y la diferencia sexual. Hay, sin duda, imitación, deformación y transposición, aunque no necesariamente tengan un tono burlesco ni satírico. Sólo la dimensión lúdica alimentaría, claramente, este tipo de parodia. No se trata de deformar para burlarse; se transpone para jugar. Veremos cómo esto se vincula con el mundo carnavalesco, central en las manifestaciones colectivas de la ciudad.
} 
término" (Laclau, 1993: 34). Si los gay parodian, en el sentido que delimitamos previamente, sus propias identidades y sus cuerpos, así como las divisiones sociales y sus categorías, entonces parodian todo el sistema que las sostiene; y sus destinatarios son, ante todo, los espectadores, especialmente las dos últimas filas de mesas. En este caso, la parodia mostraría la imposibilidad de constituir cualquier identidad y su provisionalidad (Butler, 2001).

En este sentido, podemos leer esta función mitológica del transformismo como una respuesta a los procesos de mitologización de lo social. Roland Barthes escribe que, en las sociedades modernas, el mito es un "habla despolitizada", en la que "(...) las cosas pierden el recuerdo de su construcción” (2002[1957]: 238); además, el mito al hablar de las cosas “(...) las purifica, las vuelve inocentes, las funda como naturaleza y eternidad” y, asimismo, “(...) organiza un mundo sin contradicciones puesto que no tiene profundidad, un mundo desplegado en la evidencia, funda una claridad feliz: las cosas parecen significar por sí mismas” (ibíd:: 239). Un mundo sin contradicciones sería, en el lenguaje que seguimos, uno sin antagonismos. En el transformismo, el mito se convierte en un habla politizada mediante la parodia, pues devuelve todo a su contingencia, remueve las evidencias, confunde la claridad de las cosas e interroga los significados.

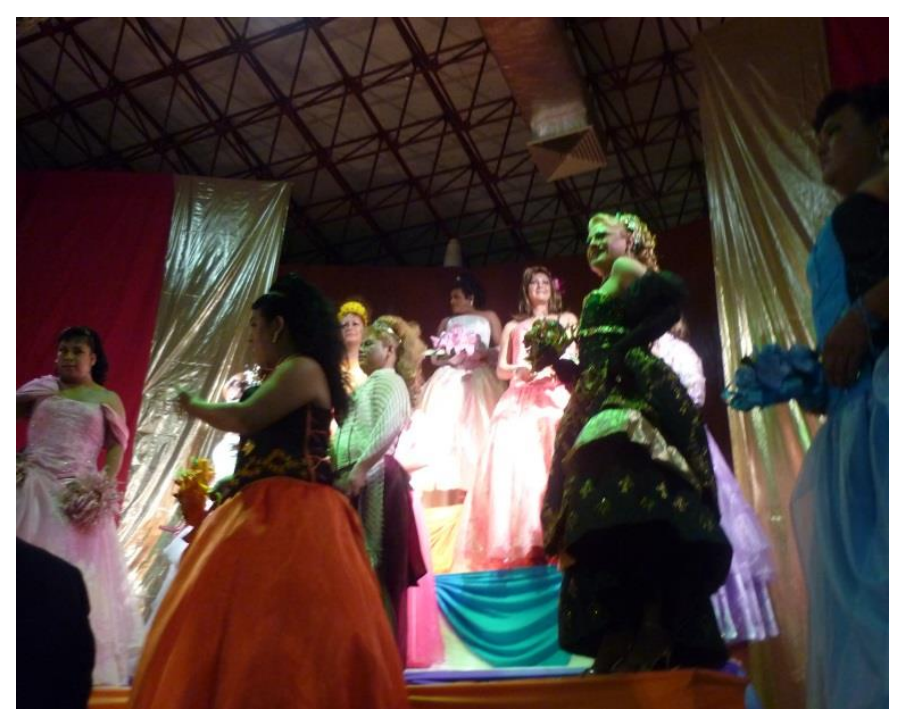

Las quinceañeras descienden del pastel

Tenosique, noviembre 2009

El transformismo podría leerse como un habla mítica, en el sentido de Barthes, que representa el antagonismo, pero también lo atempera, lo suaviza. Los gays organizan espectáculos 
permanentemente, shows y concursos, en especial para las fiestas importantes de la ciudad: Miss Independencia Gay, Señorita Gay, La Flor Gay más Bella, La Pochoverada Gay, además de carros alegóricos que concursan en el carnaval.

Cuando les pregunté a los integrantes del Club si la gente asistiría a sus eventos su respuesta fue: "claro, a la gente le encanta la putería". A la gente le encanta: ¿qué es lo que le encanta a la gente: la parodia, la representación, la ambigüedad, la oscilación?, ¿por qué le encanta eso y le disgusta que dos hombres se besen en una fiesta familiar, como ha dicho Alan?, ¿es el encanto homólogo al hechizo y también al truco? A la gente le encanta transformarse, podría ser una respuesta, pero miméticamente.

Michael Taussig refiere una 'facultad mimética', que se puede concebir "en dos niveles sobrepuestos: mimesis como proceso de copia o imitación y como conexión sensorial y tangible entre la percepción y el cuerpo mismo que percibe" (Taussig, 1993: 21; la traducción es mía). Me interesa destacar esa conexión sensorial entre el cuerpo que percibe y aquel que es percibido. Eso es lo que encanta, me parece: la imitación que los gay hacen de la realidad y la posibilidad de una conexión sensorial, mediante el espectáculo, con el cuerpo del que imita. El espectáculo aísla el antagonismo y lo cubre a través de la representación (lo mitologiza, en términos de Barthes). En ese espacio mítico -y productor de mitos- se aceptan conductas que habitualmente no se admiten. Entonces el transformismo y los shows son una forma de negociación estética y festiva que los gays realizan con la sociedad en la que viven. Les permiten crear ciertos lazos sociales basados en el encanto mimético y les dejan, a la vez, parodiar esos lazos. Posibilitan, en un mismo gesto, la crítica y el vínculo.

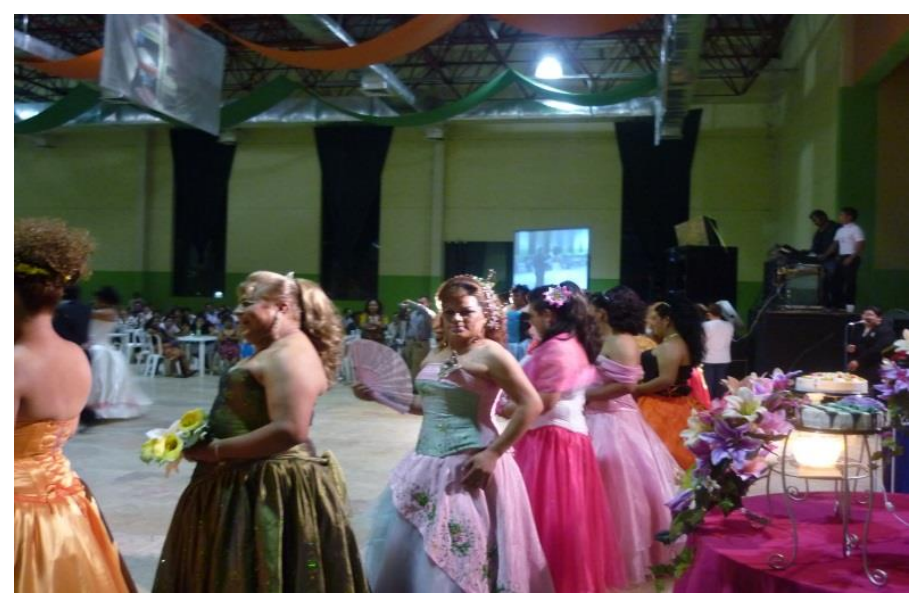

Presentación de las quinceañeras Tenosique, noviembre 2009 
Parodias y carnavales

Estas representaciones y espectáculos permiten establecer un lazo libidinal -“conexión sensorial y tangible entre la percepción y el cuerpo mismo que percibe"- entre los gays y los habitantes de la ciudad. El espectáculo calma, suaviza, libera y renueva, en alguna medida. En esta localidad, el carnaval tiene un lugar central en el calendario festivo y es un evento primordial en la vida colectiva. ${ }^{39}$ Bajtín señala que los ritos y espectáculos de la sociedad barroca, "organizados de manera cómica", ofrecían "una visión del mundo, del hombre y de las relaciones humanas totalmente diferente, deliberadamente no-oficial"; en ese espacio, al lado del mundo oficial, se construía "un segundo mundo y una segunda vida" y se creaba "una dualidad del mundo" (1990: 11). El carnaval, señala el mismo autor, "está situado en las fronteras entre el arte y la vida. En realidad es la vida misma, presentada con los elementos del juego" (ibid.: 12). La parodia carnavalesca estaría alejada de la parodia moderna, "puramente negativa y formal", porque la cultura popular evita "la negación pura y llana" (ibíd: 16). La parodia carnavalesca, en este sentido, "resucita y renueva a la vez", dice Bajtín. En la parodia carnavalesca del Club "la realidad social es presentada con los elementos del juego"; por eso, como el mismo carnaval, es incluyente, integra y no rechaza, vincula y no separa. Su efecto es el encantamiento, del mismo modo que en el plano erótico lo es el hechizo y en el corporal el truco. Son los "elementos del juego", puestos al servicio de la transformación política del estatuto de las personas homosexuales en esta comunidad. Como el antagonismo, en estricto sentido, no se puede representar o simbolizar, lo que resta es experimentarlo. Los espectáculos que el Club organiza son una forma de producir esa “"experiencia' del límite de lo social”, avizorada por Laclau y Mouffe.

Retomando a Bajtín, Kristeva escribe que "la estructura carnavalesca es como un rastro de una cosmogonía que no conoce la sustancia, la causa, la identidad fuera de las relaciones con el todo que no existe más que en y por la relación", por eso, sostiene la autora el carnaval es "esencialmente dialógico" y sus materiales serían "las distancias, relaciones, analogías, oposiciones no excluyentes" (Kristeva, 1981[1969]: 208-9). ¿'No establece este espectáculo un diálogo con sus invitados?, ¿no son la parafernalia, los actos, los trajes y las imitaciones formas de dialogar con los otros? En ese sentido, los quinceaños tendrían una forma carnavalesca que

\footnotetext{
${ }^{39}$ El estudio más acabado sobre el Carnaval de Tenosique y la Danza del Pochó es el de Rubio Jiménez (2008).
} 
"no existe más que en y por la relación". Comparado con el festival de cine, la fiesta fue un éxito, aunque también implicara distancias y oposiciones.

El encantamiento que nos ha intrigado tiene que ver, también, con los efectos que el espectáculo produce en sus espectadores. De este modo, no sólo los participantes, transformados en quinceañeras, se sumergen en un mundo distinto, también quienes van a verlos.

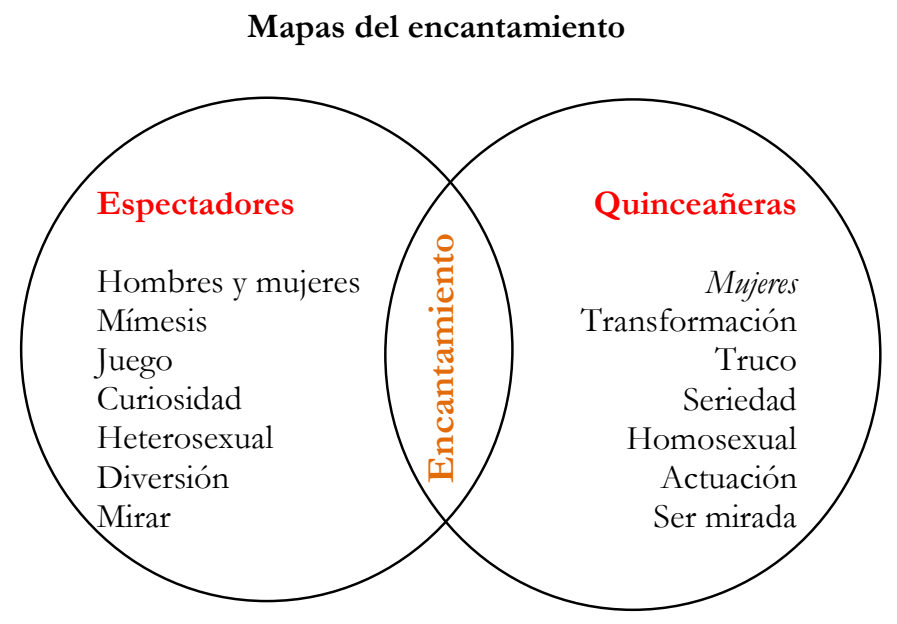

En ese sentido, si este espectáculo tuviera una estructura carnavalesca, también produciría otros de sus resultados. Kristeva añade que quien participa del carnaval es actor y espectador a la misma vez, "pierde su conciencia de persona para pasar por el cero de la actividad carnavalesca y desdoblarse en sujeto del espectáculo y objeto del juego"; así, "el sujeto resulta aniquilado" (ibid.). Creo que en este espectáculo la despersonalización no es tan radical como en un carnaval, según la descripción de la teórica francesa. Ese efecto es más claro en quienes se transforman, porque el proceso de transformación es una desubjetivación que se ancla en un vaciamiento corporal, como lo veremos luego. Pero, el encantamiento que los gay atribuyen a sus espectáculos, colindante con sus hechizos eróticos, es compartido, mediante el diálogo paródico, con los espectadores. La alteridad que emerge en la subjetividad del transformista se expande a las subjetividades de quienes lo acompañan. Sin mirada el transformismo es imposible. Cuando la mirada confirma, pero también acompaña, a quien se transforma: ¿se transforma miméticamente, como lo sugerimos?, ¿es en realidad una transformación dialógica que incluye al otro desde el principio, incluso cuando sólo son actos privados u ocultos?

Kristeva añade que el carnaval "saca a la luz inevitablemente el inconsciente que subyace a esa estructura: el sexo, la muerte" y entre ellos "se organiza un diálogo", que tiene como diadas 
estructurales "lo alto y lo bajo, el nacimiento y la agonía, el alimento y el excremento, la alabanza y la maldición, la risa y las lágrimas (ibid.: 209). En un capítulo anterior vimos que el inconsciente emerge ("sale a la luz") mediante un lenguaje soez o el doble sentido, sin que pueda articularse con algún discurso público. Citamos, por ejemplo, todo un pensamiento excrementicio que circula en las conversaciones cotidianas, en un tono burlesco, sobre la homosexualidad y los gays. El carnaval, si tiene esa estructura dialógica que Kristeva le atribuye, permite que "el alimento y el excremento" salgan a la luz. Reubica el excremento, pero también la alabanza y la maldición o la risa y las lágrimas en otro lugar, en el que se puede dialogar. El potencial político de estos espectáculos reside en una subversión del orden cotidiano, que ocurre en sus contornos. En ese sentido, Kristeva agrega que "impugnando las leyes del lenguaje que evoluciona en el intervalo 0-1, el carnaval impugna a Dios, autoridad y ley social; es rebelde en la medida en que es dialógico" (ibid.).

Pero esa impugnación localizada, atempera, momentáneamente, las amenazas que implican el cuestionamiento, pero también el desbaratamiento, de la autoridad y la ley social. En ese escenario, el "único espacio en el que el lenguaje escapa a la linearidad (a la ley)", dirá Kristeva, se "realizaría 'la infinidad potencial' (...) del discurso, en el que se manifestarían a la vez las prohibiciones (la representación, lo 'monológico') y su transgresión (el sueño, el cuerpo, lo “dialógico')" (ibíd:: 210). La parodia carnavalesca que realiza el Club, articulando mecanismos miméticos y libidinales, permite atemperar la exterioridad de la que son objeto los homosexuales. La linearidad de la ley, por lo tanto de la misma diferencia, es curvada por el espectáculo dialógico.

Kristeva sospecha de la noción de parodia, porque implica una "consolidación de la ley". En cambio, sostiene que "la risa del carnaval no es simplemente paródica; no es más cómica que trágica; es ambas cosas al tiempo, es, si se quiere, seria y sólo así su escenario no es ni el de la ley ni el de su parodia, sino su otro" (ibid.: 211). La seriedad que atribuimos a los actos de transformación regresa con la risa carnavalesca. ¿Qué será lo otro de la ley y de su parodia? Judith Butler propone la noción de prácticas de la parodia para pensar la constitución del género. Esas prácticas podrían servir para “implicar y consolidar la distinción misma entre una configuración de género privilegiada y naturalizada y otra que aparece como derivada, fantasmática y mimética: una copia fallida, por así decirlo” (Butler, 2001: 177); pero también muestran el "fracaso constitutivo de todas las prácticas de género". Agrega que, en sentido, "hay una risa subversiva en el efecto pastiche de las prácticas paródicas, en que lo original, lo auténtico y lo real también están constituidos como efectos" (ibid.). Butler agrega que "la 
pérdida de las normas de género tendría el efecto de hacer proliferar diversas configuraciones de género, desestabilizar la identidad sustantiva, y privar a las narraciones naturalizadoras de la heterosexualidad obligatoria de sus protagonistas centrales: 'hombre' y 'mujer”' (ibíd.).

La artificialidad de estas configuraciones de género ya estaba sugerida en esa triada de prácticas sociales: el hechizo, el encantamiento y el truco. En el lenguaje de Butler todo eso está del lado de lo fantasmático, produciendo lo que ella llama "los géneros marginales del territorio de lo natural y de lo real" (ibíd.). Sin embargo, no estoy seguro de que despojen a las narraciones de la heterosexualidad obligatoria de sus protagonistas centrales: el 'hombre' y la 'mujer'. Al contrario, si la parodia tiene un efecto político disruptor y no consolida la ley, como teme Kristeva, es porque enfatiza la literalidad de la representación de la diferencia sexual, o en los términos de Butler, de la configuración de género privilegiada, "la repetición paródica del género, escribe, también presenta la ilusión de la identidad de género como una profundidad inmanejable y una sustancia interior" (ibíd.). Curiosamente, en otro capítulo vimos que era la homosexualidad, como una especie de identidad de género confusa, la que mostraba una profundidad inmanejable y una sustancia interior misteriosa (genes, máscaras, dobles). Hay que preguntar si se puede parodiar el sexo y la muerte, si los pares que emergerían de su diálogo pueden morigerarse de alguna manera. De alguna forma, el lenguaje soez es paródico, pero reafirma el orden social y sus antagonismos. Se ríe del sexo y de la muerte de los otros, de esos que se ubican en el territorio marginal de "lo natural y lo real", en palabras de la Butler; se burla, también, de las copias fallidas, una definición casi literal de la homosexualidad en algunos discursos que exploramos. Esa risa está del lado de la configuración de género privilegiada. En esa medida, la parodia carnavalesca del Club sería la risa de esa risa o una risa de segundo orden.

\section{Truco sin órganos}

¿Qué parodian, entonces, estas quinceañeras?, ¿la diferencia sexual, las configuraciones de género hegemónicas?, ¿o parodian a los personajes centrales de la heterosexualidad obligatoria? Creo que, ante todo, se parodian a sí mismos y las representaciones y los discursos sociales que se elaboran en torno a ellos. Cuando los espectadores de esa celebración ven a esos 'hombres' vestidos de 'mujeres' no sienten el mismo temor y rechazo que cuando los ven en las calles, como algún político nos dijo. El espectáculo atempera; pero por eso mismo, dada su excepcionalidad, produce otros enunciados acerca del antagonismo clivado en la diferencia 
sexual. Por eso se despliegan estrategias que llamamos mimético-libidinales: el encanto y el hechizo. Si el carnaval crea relaciones dialógicas, impugna el intervalo 0-1 del lenguaje y la ley, también habita y produce ese espacio híbrido donde cabe la diferencia de la diferencia, como Derrida llamaba al fármaco.

Diremos, siguiendo esa intuición, que este espectáculo, leído como un carnaval miméticolibidinal, es también una terapéutica específica y contingente para el antagonismo. El asunto será, luego lo veremos, evitar sus expresiones violentas y destructivas, mediante este diálogo risueño y festivo. No logrará impedirlas cabalmente, pero al menos, las morigerará momentáneamente. El carnaval es un fármaco contra el odio y la agresividad, un fármaco producido por un colectivo que tiene una forma farmacológica. Si el antagonismo, como ha escrito Laclau, no puede ser reconducido a ninguna racionalidad subyacente (Laclau, 1993: 34), ¿qué se puede hacer entonces con él, al menos en este caso? Tal vez estamos ante las antípodas de las homoclotías y homotopías que analizamos antes. Ésas eran producidas por las prácticas gubernamentales, que intentaban generar un lugar común según sus propios parámetros, pero también cercar las fugas que implicaban el deseo y la subjetividad homosexual. Éstas, en cambio, son creadas por los mismos colectivos y sujetos cuyo lugar está en discusión. En esas homotopías pasajeras y esas homoclotías provisionales se pueden desplegar las prácticas paródico-carnavalescas: es un lugar común que permite cierta convivencia. Por eso se produce mímesis y se crean lazos libidinales. Las 'narraciones' que el Club crea no arrebatan a los espectadores los personajes centrales de sus propias historias, si fuera el caso. Sólo los desplazan y los transforman, pero de manera efímera. El carnaval muestra que hay un segundo mundo y otra vida o que hay muchos mundos y vidas diversas. Pero no necesita desbaratar las ajenas para inventar las propias. En este sentido, en vez de exponer la provisionalidad y artificialidad sólo de las otras narraciones, lo muestra también de las propias. El Club, de este modo, es un terapenta cuidadoso. Si fuera cierto, como ha escrito Kristeva, que el carnaval, o sus símiles, sacan a la luz el inconsciente, es decir, el sexo y la muerte, la operación debe ser escrupulosa, porque el potencial destructivo de esas oscuridades temporalmente iluminadas es enorme.

Si el sujeto fuera, como sostiene Braidotti, "un proceso de negociación entre las condiciones materiales y semióticas que afectan al propio yo encarnado y situado" (Braidotti, 2005: 99), creo que en estos espectáculos asistimos a una negociación (hecha de diálogos) entre condiciones materiales y semióticas, que permite expandir el espacio empírico, pero también el 
simbólico, de los colectivos homosexuales de la ciudad. De este modo, también se evita lo que la misma Braidotti describe como la captura "bajo la mirada paralizante del amo, odiando y envidiando, a la vez, su posición” (ibid.:109). En vez de eso, se abren las puertas al "deseo del cambio y de los flujos" y al dinamismo "de los múltiples deseos".

Abrirse al deseo, en mi opinión, implica que la heterosexualidad, por ejemplo, no sea entendida simplemente como obligatoria (lo que induciría su parodia negativa), sino como una de las múltiples posibilidades deseantes, que pueden ser negociadas en ese espacio carnavalesco. Eso no desmiente su hegemonía (o su obligatoriedad, en palabras de Butler), pero tampoco la reduce a ella. No estamos ante deseos resueltos y otros incipientes o unos estables y los otros cambiantes. En esa medida, como lo sugiere Bhabha, "sólo comprendiendo la ambivalencia y el antagonismo del deseo del Otro podemos evitar la adopción cada vez más fácil de la noción de otro homogeneizado, a cambio de una política celebratoria, oposicional, de los márgenes o minorías" (Bhabha, 2002: 74). El otro homogeneizado en su deseo requeriría de una política celebratoria. ¿Sería la parodia carnavalesca una expresión de esa política? Potencialmente, sí. Pero, en el caso del Club, al comprender la ambivalencia y el antagonismo del Otro', evita su homogeneización y permite que surja lo que Bhabha llama una "estructura de la heterogeneidad" (ibíd: 49). Si la heterosexualidad fuera obligatoria, eso no significa que sea homogénea; por eso, puede participar de esta creación carnavalesca de una estructura de la beterogeneidad. ${ }^{40}$

Así, estas estrategias paródicas, mimético-libidinales, capturan la mirada del otro y no la esquivan, tampoco la rechazan. En algún sentido, la recrean miméticamente. Si la racionalidad subyacente al festival de cine buscaba negociar las miradas y las identidades bajo el rótulo de la diversidad, que es el lenguaje contemporáneo para tratar con las diferencias y que, claramente, se deslinda de cualquier antagonismo inasimilable; la parodia carnavalesca se exime de las racionalizaciones y propone imágenes y actos hechos “(...) de distancias, relaciones, analogías,

\footnotetext{
40 Sólo una estructura de ese tipo permitiría trazar una topología de la subjetividad multidimensional, como propone Haraway (1995). La clave estaría en la comprensión de la ambivalencia y el antagonismo del deseo del Otro ¿Cómo podemos comprender el deseo del Otro?, ¿qué acceso tenemos a él?, ¿es la noción de obligatoriedad una forma adecuada para realizar tal exploración?, ¿cómo evitar la mirada paralizante del amo, que preocupa a Braidotti, y que requiere del odio y la envidia?, ¿son esos afectos formas propicias para investigar el deseo del Otro? La heterogeneidad debiera comprometer la exploración misma para poder elaborar esa topología de una subjetividad multidimensional, en vez de las cartografías unidimensionales de un otro homogeneizado, en términos de Bhabha.
} 
oposiciones no excluyentes", como ha dicho Kristeva. Busca, de este modo, producir una mirada que surja de un diálogo corporal y libidinal entre sujetos y colectivos diferentes.

Las homotopías y homoclotías carnavalescas nos dejan, nuevamente, ante la "“experiencia' del límite de lo social”, esbozada por Laclau y Mouffe. ¿Por qué se llega a esa “"experiencia’ del límite de lo social", mediante la transformación, el truco, el encantamiento, el hechizo? Es como si hubiese claridad sobre la artificialidad de esa aproximación, que en un último término es imposible. ¿No representan estos espectáculos el límite, que ya esbozamos, de un espacio constituido antagónicamente?, ¿no producen un segundo límite, así como el carnaval generaría una segunda vida y un segundo mundo, pero esta vez representable, palpable? Podríamos leer el transformismo como una estrategia para crear un segundo límite entre espacios divididos antagónicamente, mediante su trazo sobre el cuerpo de los sujetos que se transforman. El truco, el hechizo, el encanto son, precisamente, formas de duplicidad (vidas, mundos, límites) que se articulan, en cierto modo, con los dobleces subjetivos y corporales atribuidos a los gay de la ciudad. Tal vez el encantamiento más poderoso, y que sólo estos espectáculos producen, sea duplicar a los propios espectadores mediante estas mímesis sensitivas y libidinales. En algún sentido, es una forma de traer a los colectivos organizados binariamente a este espacio híbrido en el que habitan los gays. La mímesis más poderosa se produciría en el plano de lo que nunca se será, por lo tanto del deseo. De algún modo, sería una de las modalidades culturales de experimentación de los antagonismos, no de las similitudes. Ser como el otro, miméticamente, es constatar la imposibilidad de la identificación (Bhabha, 2002).

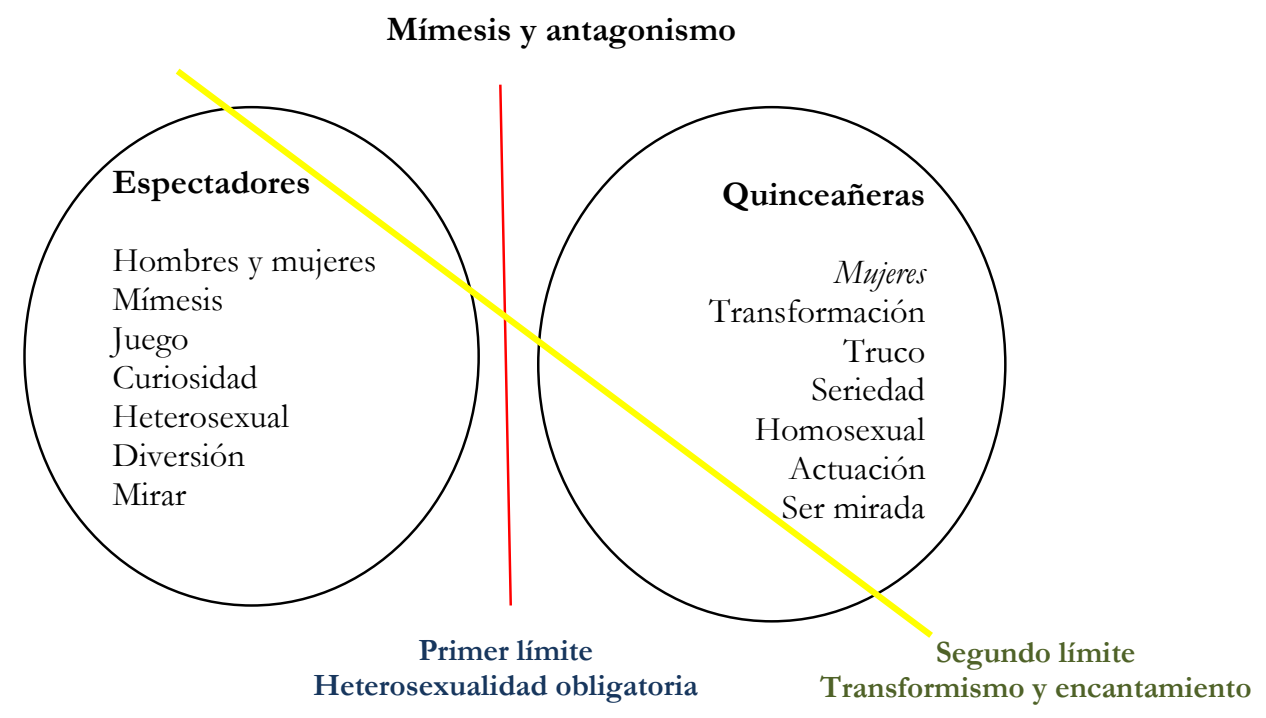


El truco no es sólo una forma de ocultar los genitales, para trasladar la masculinidad a algún escondite en la entrepierna y conducir al falo hacia la parte posterior del cuerpo, el truco también es una forma de duplicar al otro mediante una mirada encantada que reconoce, precisamente, el carácter artificial de cualquier transformación y la contingencia de esos cuerpos. Pero el truco es también un modo en que el falo desaparece mágicamente, restándole sus poderes clasificatorios, para que emerja una superficie lisa, una fantasía vaginal. El truco, acto por excelencia de cierto tipo de magia, hace desaparecer la diferencia sexual para reconstituirla como representación y espectáculo. El cuerpo de las transformistas es, por eso, un cuerpo vacío en muchos sentidos, que se posiciona en ese espacio híbrido y suscita la mímesis.

¿Se puede quitar un órgano para producir un cuerpo? Si se resta un órgano, ¿cómo se conserva el cuerpo? El truco es, ante todo, una forma de sostener el cuerpo (miméticamente) quitándole una parte. El cuerpo sin órganos, escriben Deleuze y Guattari, es un límite, un conjunto de prácticas (Deleuze y Guattari, 2010[1980]: 155-56). Cuando un cuerpo “está harto de órganos", entonces se pone en marcha ese Cuerpo sin Órganos (CsO). El truco es también una forma de materializar ese hartazgo: retraer el falo para producir la magia, quitar el órgano para suscitar los hechizos. El truco desarticula el organismo masculino para producir un CsO femenino. El organismo, sostienen estos autores, es un estrato del $\mathrm{CsO}$, "un fenómeno de acumulación, de coagulación, de sedimentación que le impone formas, funciones, uniones, organizaciones dominantes y jerarquizadas, trascendencias organizadas para extraer de él un trabajo útil” (ibid:: 164).

Cabría preguntarse, en este caso, si al sacar un órgano se desbarata el cuerpo o sólo se lo desplaza, es decir, que el transformismo constituya una ruta a través del CsO desde un organismo a otro, desde una corporalidad a otra. Pero el truco asegura itinerarios de ida y vuelta. Una vez que se deshace ese truco y el falo regresa a su posición frontal, en algún modo se reconstituye el cuerpo disuelto mediante estas sustracciones temporales. Detrás de este organismo, surge el $\mathrm{CsO}$ como “(...) conexión de deseos, conjunción de flujos, continuum de intensidades" (ibid:: 166). En ellos radicará el encantamiento que estos espectáculos producen en el público, como antes lo vimos. Tal vez el deseo más intenso busque acceder a una segunda vida y un segundo mundo, como lo ha dicho Bajtín. El transformismo sería una puerta de entrada, un umbral como Dominijanni ha definido la diferencia sexual, hacia otro mundo, así como el truco permite crear otro cuerpo. 


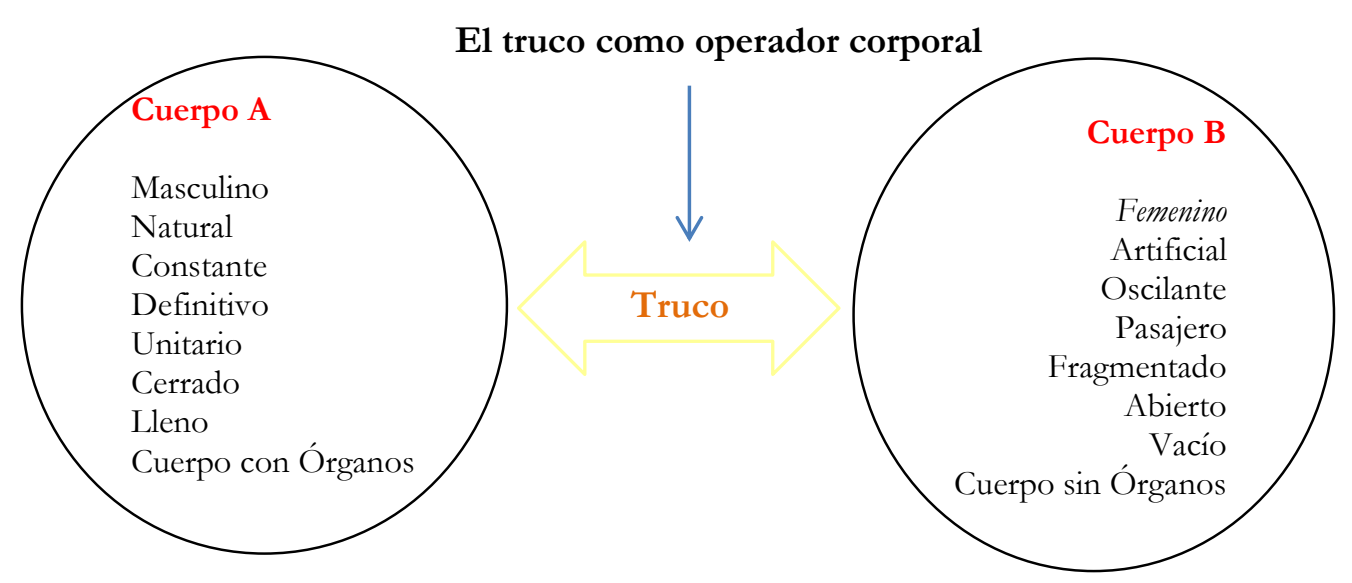

Bailes, amores y golpes: mapas de lo masculino

Un día sábado, antes de regresar de una visita de 7 días, fui con Alan y Saúl a visitar algunas de las cantinas de la ciudad. Estuvimos en La caña brava, un local de dos pisos, que funciona como table dance en la planta baja y como caguamero en la segunda. Arriba, donde nos sentamos, había varias mesas con hombres, algunas mujeres acompañadas por otros hombres y dos meseras. En una mesa, que estaba a nuestro costado, se sentó un grupo de herreros, según me dijo Alan. El dueño de la herrería, un hombre bajo, robusto, de unos 50 años, se acercó a saludar a Alan y nos presentaron. Me dice que sus respetos, pero que él no habla inglés. Algunos de sus trabajadores bailan con las meseras. La música en vivo del caguamero toca a Chico Ché, la Sonora Santanera, una canción de un camarón que no se deja arrastrar por la corriente. Entre los gritos, la música y las risas, no se escucha nada. Alan me dice que observe a dos de los herreros, uno moreno bajo baila con mucha gracia con una de las meseras, otro cada cierto tiempo le 'quita' su pareja y siguen bailando. Un tercero, más alto, vestido con overall, de bigotes, ya algo borracho, los mira. Cuando se levanta el moreno pone más atención, si sigo la lectura de Alan. A la media hora de bailes y cervezas el más alto de los tres quiere que el moreno baile con él, pero éste se niega. Lo toma por la espalda e insiste. Algo hablan entre todos. Unos le dicen que lo deje. Otros lo sujetan. Se va y regresan. El más alto sigue insistiendo, el moreno no acepta. Luego se marchan. No hay jotos ni putos, no hay afeminados. Tampoco hay sexo, pero sí una intención que causa un conflicto: dos hombres bailando, dos hombres de verdad, son una ruptura violenta del orden corporal, de las regulaciones corporales y sexuales. Dos hombres bailando no dejarán a nadie indiferente en ese lugar, un caguamero bullicioso y sucio. Alan lee todo como una historia de amor secreta, 'mira cómo lo cela', me 
dice. Yo he visto muchos bailes en mis visitas: hombres con mujeres, dos mujeres, putos con hombres o con mujeres, putos con putos. Nunca he visto dos hombres bailar juntos. Digo, dos hombres como los entienden en este lugar, con la corporalidad y el comportamiento que he descrito antes. Dos mayates, dirían los del Club.

El moreno no se levantó de la silla y el más alto no logró bailar con su colega. Ambos sabían las implicancias de un baile entre dos hombres, lo que comentarían los demás al otro día, los rumores que se esparcirían entre sus familiares, sus amigos, tal vez sus esposas. No sé si en broma o si en serio; si riéndose de todo o sospechando. Lo que sé es que ese baile abriría interpretaciones diversas que mejor se evitaban, por eso el herrero no se levantó de la mesa y el otro renunció, luego de tanto insistir. Un baile cualquiera, siguiendo el ritmo de una salsa mal tocada - "fue en un cabaret/donde te encontré bailando", canta el músico del local-, que no puede ser bailado; dos hombres no pueden bailar juntos en este lugar sin que los otros digan que son jotos, que se gustan, que se 'dan' entre ellos.

¿No hay mapas sociales, cartografías muy arraigadas y sistemáticas que permiten cierto tipo de actividad entre determinados cuerpos y que prohíben otras?, ¿por qué el baile y no los abrazos, toqueteos, manoseos constantes entre unos y otros que observé durante más de una hora en ese caguamero? Sin duda, hay una analogía con la pareja sexual, eso lo sabemos. Bailar es una forma sublimada de la sexualidad. También lo sabemos. Cuando he visto bailar putos con hombres, el puto siempre ocupa el lugar femenino, el hombre lo toma de las caderas, lo da vuelta, lo lleva. Él danza suavemente, esquiva, se acerca y se aleja, como si algo se pudiera tocar y evitar, a la vez.

Cuando todos han desistido, los herreros se levantan y se van. El señor robusto, más borracho de lo que estaba hace una hora, se acerca a la mesa a despedirse. Le da la mano a Alan, toca el hombro de Saúl, y me da la mano a mí, con su dedo índice restriega mi palma. Dos manos apretadas, la suya es gruesa y rotunda, la mía grande y más delgada, y un dedo que se mueve. Nadie vio nada. Yo sentí el roce de su dedo en mi palma. No dije nada, pero él sabía que entendía todo. Él no habla inglés, pero las manos son bilingües.

La caña brava había perdido su encanto cuando nos fuimos, casi no quedaba nadie y sin gente no hay diversión. Fuimos al JJ, un lugar que yo no conocía, a media cuadra del otro local. Música de rocola, algunas mesas ocupadas. Sólo una mesa con mujeres. Dos de ellas mayores, las otras tres adolescentes. Saúl me dice que todas son trabajadoras sexuales, pero madres e hijas. No me había percatado. Observo, las madres atentas, las hijas más quietas, como 
hundidas en sus sillas; los hombres dando vuelta, sentándose alternadamente al lado de unas y otras, platicando, pidiéndole cervezas a las meseras. Las más jóvenes hablan sin mirar de frente a sus pretendientes, ríen y luego platican entre ellas. Las madres siguen atentas. Saúl asegura que las madres están ahí prostituyendo a sus hijas y enseñándoles el oficio. Son muchachas jóvenes y bonitas. He visto a muchos hombres en otras cantinas y en otras visitas abalanzarse sobre muchachas como ellas, chamaquitas como he escuchado decir. He visto a esas mismas chamaquitas en una y otra cantina o en alguna de las casas de citas de la ciudad, que hemos visitado con Alan para repartir condones. Las he visto de día y luego en la noche, ya borrachas, con distintos hombres; muchas veces con alguno de los soldados afincados en la ciudad. Alguna vez les comenté a algunos amigos que me parecía que habían más trabajadoras sexuales menores de edad en las cantinas; muchachas de 13 o 14 años, según mi cálculo (podrían ser menores, dado el deterioro corporal que experimentan). Siempre he visto trabajadoras sexuales en las cantinas. Pocas mujeres entre muchos hombres, mujeres que van juntas a veces, mal vestidas, cansadas. Así las percibo. Algunas con cicatrices en sus vientres, que las playeras cortas delatan. Mujeres entre muchos hombres, algunos que las invitan, otros que no las miran. A veces sobrias, muchas veces borrachas. Algunas tímidas, otras muy desafiantes. He visto hombres bailando con ellas, a veces tocándolas casi como si estuvieran desnudas delante de ellos.

Trabajadoras sexuales que van en familia a una cantina. Y los hombres que sienten su llamado, la invitación que supone su sola presencia en territorio masculino. Cualquier mujer en una cantina es una puta, esa es la norma. Mayores, chamacas, bonitas, feas, delgadas, gordas. Da lo mismo, cualquier mujer que entre a un lugar así es prostituta. Los hombres lo saben y se acercan rápidamente. A veces abandonando a los putos que les pagaban la borrachera. Es natural, alguna vez escuché decir, porque el hombre es hombre y siempre va elegir a una mujer. No sólo es natural, sino también preferible, porque si va detrás de las mujeres demuestra que es un hombre y eso es lo que busca el puto: uno del que no se tengan dudas, una hombría absoluta que terminará en su cama. Al rato regresan, cuando las mujeres les canten su precio y acepten que no cargan un quinto y que desean seguir tomando y los que invitan son los putos de ahí, sentados en alguna mesa, bebiendo, riéndose, joteando. No hay competencia.

Saúl llega a una cantina y rápidamente se le acercan las trabajadoras sexuales para pedirle condones. Él las atiende, les platica. A veces las encuentra en el hospital, cuando van a renovar su tarjeta sanitaria. Llegan las mujeres, hablan con Saúl, a veces con Alan que también conoce a 
todas. Hablan en voz baja. Nunca he podido escuchar lo que platican. Hablan y se van a sus mesas, con sus clientes. Otras veces están con algunas vestidas, que se dedican al comercio sexual. Juntas bebiendo, con sus parejas masculinas, pero solas en muchos sentidos. Están atentas, buscando al cliente; sonrientes, sigilosas. Es una forma particular de beber, como si siempre tomaran con una intención y si se retrasaran en los tragos. Ese es el tiempo del 'fichaje', cuando se consigue un cliente. Una vestida borracha o una trabajadora sexual ebria pierde, ya no puede trabajar y se arriesga. Debe participar de la sociabilidad de las cantinas, pero siempre mantener un nivel de alerta, una sobriedad de buen comerciante.

En el $J J$ se me acercó un muchacho cuando fui al baño. Alan me había señalado una mesa y me había dicho: 'esos son pochomovileros'. ${ }^{41}$ Me senté dándoles la espalda. Alan sigue mirándolos: "mira, ese güerito guapo se casó con una chava que es profesionista, me dice, cuando llegó era bonito el hombre, enfatiza, y ella gana dinero de a madres, pero él es un inútil, ella le ha conseguido trabajos pero no dura, ahora le compró un pochimóvil”, concluye. Entre ellos estaba un muchacho que luego me abordaría en el baño, moreno, bajo, de unos 15 años. “QQué onda!”, me dice, “cómprame una bolsa de coca y me voy contigo.” Le respondo que no uso ni compro droga. Lo dejo. Cuando el $J J$ nos aburre salimos, cruzando la pista de baile donde las madres y sus hijas bailan con sus pretendientes. La mayor con un hombre muy gordo y borracho, una chavita con un soldado. Detrás de nosotros sale el muchacho moreno. Me insiste: “dame cien pesos para comprarme una bolsa de coca y me voy contigo.” No sé por qué supone que tengo interés en él, tampoco por qué es tan directo en su proposición. Conozco la regla: si andas con putos también lo eres. Le pregunto su edad y me dice que pronto cumplirá 16 años. Luego inquiero si ya ha estado con gays y me dice que sí: "con un chingo... con la tal, y la tal, y la tal". A todos los conozco. "¿Y qué tal?”, le pregunto; responde escuetamente: "bien, pero no apretaban mucho." Alan y Saúl se ríen efusivamente. La intimidad de sus amigos se trasiega en una acera en la madrugada. Sus cuerpos que no aprietan, las expectativas del muchacho de una resistencia de los músculos que le dieran placer. Nos despedimos, entre risas. "Y qué no quieres... por cien pesos".

\footnotetext{
41 Los pochimóviles son unas especies de motos que sirven como transporte público en la ciudad. La parte delantera tiene la forma de una motoneta, atrás llevan una asiento donde caben dos personas. La parte del conductor y la de los pasajeros están cubiertas por un plástico de colores. Se les dice pochomovileros a los muchachos que conducen esos vehículos, siempre hombres y la mayoría de las veces adolescentes. Su nombre deriva de una danza tradicional de la zona, que se conoce como la danza del pochó; véase Rubio, 2008.
} 
Sexo a cambio de algo. Muchas veces lo he escuchado. El sexo es un intercambio. Sexo a cambio de cervezas, de cigarros, de comida, de dinero, de otras cosas. Sexo a cambio de algo conseguido por las buenas o por las malas. Masculinidad y juventud a cambio de sexo. Parece que esa es la regla. Apoyos, ayudas, favores. No se intercambia algo específico, tampoco se ofrece algo tasado según tarifas. No se podría hablar, en este caso, de trabajo sexual, si se lo entiende como la venta de sexo por una cantidad de dinero. No es eso y nadie lo ve así. Es más bien una red intrincada de intercambios de todo tipo en la que se incluye al sexo.

El sexo forma parte, en este contexto, de las redes de intercambio. Un intercambio que pasa por el cuerpo, que hace del cuerpo el locus de lo que se recibe y lo que se otorga. Se toma la fuerza de trabajo sexual, el atractivo, el deseo, las fantasías, y se devuelve algo, que puede ser tangible -dinero, objetos- o intangible -favores, prestigios, relaciones, apoyos, recomendaciones-. Nadie 'vende' nada, nadie 'compra' nada; pero todo se intercambia de modo incesante. Cada cual participa en esa red con lo que tiene para dar y con lo que necesita, o desea, recibir. Sexo a cambio de dinero. Trabajo a cambio de favores sexuales. El lenguaje coloquial da cuenta de este intercambio: dar es una de las formas de describir una penetración en una relación homoerótica; se dirá que el sujeto pasivo en esas prácticas sexuales recibe. Dar y recibir, intercambiar mediante el sexo.

Pero el intercambio no sólo articula esta red, también es una forma de organización del deseo. En este sentido, he observado una gradiente entre quien desea y quien es deseado. Si los gays desean un hombre cabal y completo, el intercambio se convierte en una mediación entre ese deseo y la disponibilidad sexual de ese tipo de hombre. De algún modo, creo que el intercambio resta deseo y abre posibilidades eróticas, especialmente para las parejas de los gay. Muchos de ellos dirían que no hacen lo que quieren, pero de todos modos lo hacen. ¿Por qué lo hacen y no rasgan vestiduras morales o íntimas? Porque consiguen algo a cambio. Entonces, el deseo se fetichiza, en alguna medida: se desea lo que se dará a cambio del sexo, más que el sexo mismo. O, segunda posibilidad, se desea el sexo mediante la cosa dada.

Pero si el sexo es, ante todo, una relación social, no sólo se intercambian movimientos y posiciones amatorias, también estatus, relaciones de complicidad, alianzas, favores, deudas, posiciones sociales, oportunidades, lugares en una red. Sólo hablamos, y esto es relevante, de hombres intercambiando con otros. De hombres que se ubican en posiciones simbólicas diferentes a través de este intercambio. Una posición masculina por parte de los gays que les permite seducir, convencer y conseguir. Otra femenina de los mayates que los hace dejarse 
seducir, convencer y adquirir. Otra masculina de ellos mismos que los lleva a demostrar y representar su hombría. Otra femenina de los gays que buscarán un hombre completo, que los trate, en alguna medida, como una mujer. Posiciones alternas, en las que todos tendrán el cuidado de no develar la trama, porque sólo funciona implícitamente. Uno busca y el otro encuentra, uno se acerca y el otro cede. Oscilación simbólica. La trama está determinada, por eso es posible el juego.

No todo el sexo se ubica en estas coordenadas. Hay amor, interés, gusto; a veces junto con el intercambio o sin él. El sexo es también una trama subjetiva de necesidades, aspiraciones, deseos, temores, temblores, evitaciones, rechazos, gustos y disposiciones. Nadie participa sólo de una trama o de una red; todos de muchas. Por eso es pertinente hablar de red y de trama, porque son puntos sin un sujeto adherido a ellas que permiten ciertos trayectos, ciertas formas de relación y evitan otras. Las redes no requieren de coherencia ni concordancia de manera irrestricta. Hay puntos de conflicto, otros de tensión, unos más de acomodo, algunos de desentendimiento.

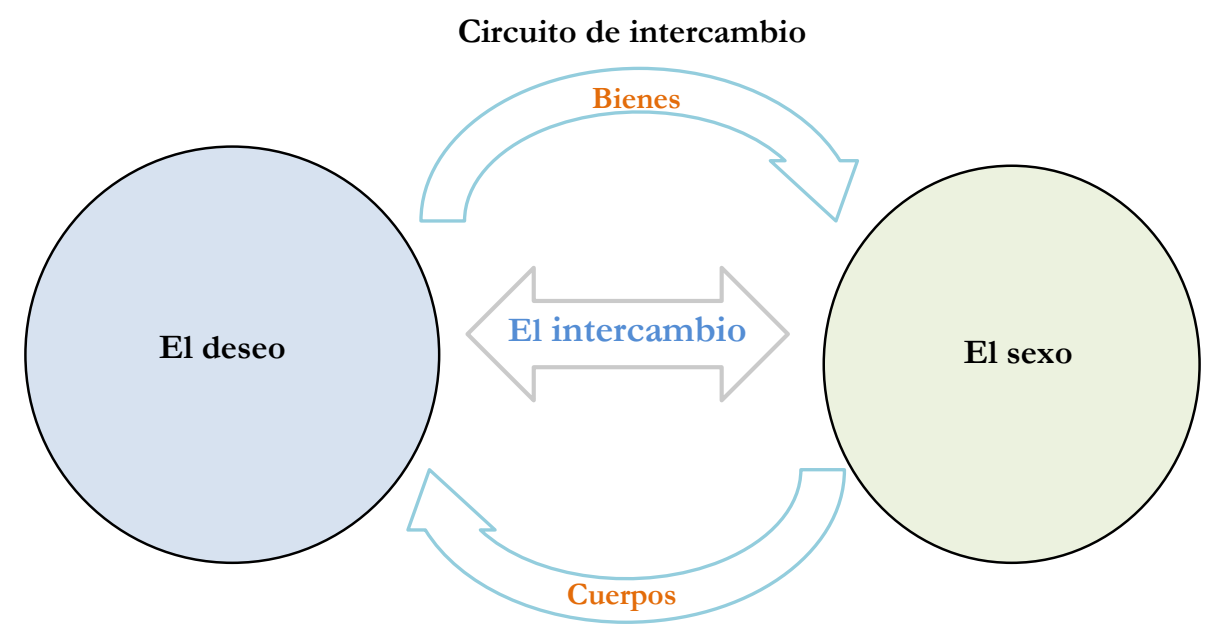

\section{Lineas rectas, mapas confusos}

En las entrevistas que he realizado con los hombres que se relacionan sexual y/o afectivamente con los integrantes del Club, que se conocen como mayates en la ciudad y el estado, aparece una clara divergencia entre ciertas prácticas sexuales y el curso de vida. Estos sujetos pueden vincularse sexualmente de modo esporádico o permanente con otros hombres, en algún momento de sus vidas o a lo largo de ella desde la adolescencia, sin que eso modifique sus 
trayectorias de vida heterosexuales, por así llamarlas. Así, tendrán novias, relaciones con diversas mujeres, se casarán en algún momento o comenzarán a vivir con una mujer, tendrán hijos. Esto conformaría una trayectoria de vida masculina normal. Los gays modifican ese curso tanto porque se relacionan exclusivamente con hombres en el plano sexual y afectivo, forman pareja con otros hombres, o desean hacerlo, como porque desisten o evitan tener hijos, casarse con una mujer y establecer una familia según un patrón clásico: heterosexual y reproductivo.

Los mayates siempre poseerán una apariencia masculina, comportamientos varoniles, vestimentas que no despierten sospechas. Serán, y se considerarán a sí mismos, hombres. La segunda ruptura que efectúan los gays será usar sus cuerpos de modos indebidos, adoptar gestos y actitudes sospechosos, transgredir las regulaciones corporales que se organizan en torno a la diferencia sexual y que son el sostén de un orden de sexo-género. Siendo hombres, se comportan como mujeres, se visten como tales o con algunas similitudes, hablan de manera afeminada, se mueven de manera poco varonil. La masculinidad es construida en este contexto de manera enfática: un hombre no tiene quiebres, es sólido en sus gestos y movimientos, habla con una voz profunda, sus atuendos no dejan dudas. Usa su cuerpo y lo representa según códigos de masculinidad implícitos, pero consistentes y categóricos. Cualquier quiebre, cualquier asomo de femineidad, será señalado por los otros y condenado, ridiculizado o estigmatizado. No pasará desapercibido. Y aquí, en este mandato enfático de la masculinidad, la estética y el cuerpo de los gays surgen como una ruptura y una transgresión.

Podemos constatar, así, una divergencia entre deseo, sexualidad y curso de vida. En el caso de los mayates su deseo, muchas veces no reconocido y, tal vez, tampoco enunciable, no implica ni supone un curso de vida. Tampoco su sexualidad. En este mapa, los caminos divergen y se juntan de manera particular. Es lo que nos dijo Juanito, en un capítulo anterior, antes del escándalo y la visibilidad gay los hombres se podían acercar a un puto para tener sexo con él sin problemas; todo quedaba en silencio, nadie esperaba que su amante dejara a su esposa o no tuviera hijos. Al contrario, porque tenía ambos se sabía que era un hombre completo, un verdadero hombre. Sólo la aparición pública de las identidades sexuales, las posibilidades de rupturas en el orden corporal, las terminologías declaratorias en torno al deseo y la sexualidad, comienzan a levantar sospechas, a impedir esos acuerdos tácitos, esos acercamientos soterrados, pero reales.

De este modo, se esboza una trayectoria sexual masculina que ya he descrito someramente: en la adolescencia se establecen múltiples relaciones con mujeres y/o con 
hombres $^{42}$, se consolida el primer noviazgo, se experimentan posibilidades eróticas diversas (que pasan por una exploración del cuerpo propio y el de los/as otros/as) y se asume cierto curso de vida. Ya en la primera juventud se establecen noviazgos más formales y se comienza a pensar en el matrimonio. En muchos casos, como todo esto no supone una planificación racional y estricta, se tienen hijos durante la adolescencia o los matrimonios y uniones se realizan a edades muy tempranas. ${ }^{43}$ Pero estoy reconstruyendo la trayectoria discursiva y no, ante todo, su concreción práctica. En ese sentido, cuando les he preguntado a muchachos muy jóvenes qué piensan hacer de sus vidas, el matrimonio y los hijos siempre aparecen entre sus expectativas.

\section{Deseo y trayectoria sexual masculina}

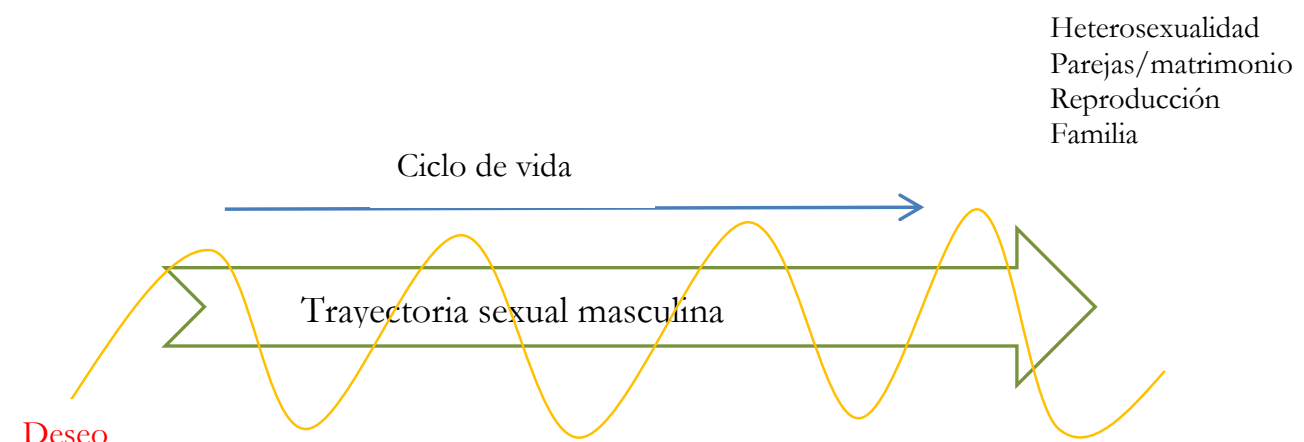

Otros erotismos Exploraciones sexuales

He señalado que esto no supone restricciones sexuales y, más bien, permite una exploración sexual bastante amplia. Es un 'camino' tan firmemente trazado, con pocas excepciones y divergencias, que posibilita extravíos múltiples. En muchos sentidos, creo que la identidad masculina depende del cumplimiento cabal de esa trayectoria, antes que de las prácticas

\footnotetext{
${ }^{42}$ La trayectoria que reconstruyo es parecida a un tipo ideal weberiano y sólo sirve para pensar el orden sexual que investigamos. No corresponde a las trayectorias de todos los hombres del lugar. Lo que me interesa remarcar son las posibilidades eróticas, no los actos. Muchos hombres jamás tendrán prácticas sexuales con otros hombres o con putos, siguiendo la terminología local.

43 El Instituto Nacional de Estadísticas reporta que en Tabasco, el año 2012, 16 de cada 100 nacidos vivos fueron de madres adolescentes entre 15 y 19 años (INEGI, 2013b: 8). Para ese mismo año, un 23\% de los adolescentes entre 12 y 19 años había iniciado su vida sexual, un 25\% de los hombres y un 20\% de las mujeres (ibíd.). Algunos de los rasgos de esta trayectoria sexual y vital coinciden con los documentados por Tuñón (2006), Tuñón, Ayús y Montejo (2004) y Tuñón y Ayús (2003).
} 
sexuales que se tengan y de los objetos sexuales, en términos psíquicos, elegidos. Un hombre es cabalmente un hombre si tiene esposa o mujer e hijos (de una misma o de muchas, no importa tanto). Si además 'se anda cogiendo putos' no tiene mucha relevancia. Al menos, es importante indicarlo, para los procesos subjetivos de conformación y reproducción de esa identidad y para los vínculos intersubjetivos entre varones. Algunos de ellos me contaron que si sus parejas mujeres (novias, esposas, amantes) se enteraran de sus relaciones con otros hombres los dejarían.

Ahora bien, esta trayectoria supone una organización moral de las relaciones y las prácticas sexuales. De este modo, las novias y las esposas son mujeres respetables. He escuchado a hombres decir, innumerables veces, que les gusta tener sexo con las putas o los putos porque pueden hacer lo que quieran. Con una mujer que se respete el repertorio sexual es más limitado, al menos en términos discursivos. Pero hay ciertas prácticas, como el sexo oral o anal, que implican cruzar una frontera de la moral sexual dominante. Si la mujer acepta tenerlas se arriesga a perder su respetabilidad ante los hombres; si se niega, puede verse confirmada en su lugar de 'mujer respetable', pero incita a que su pareja busque a otra, u otro, que acepte sus proposiciones. Notemos que esas fronteras sexuales son límites que se trazan en el cuerpo mismo: qué se hace con la boca o con el ano, qué se permite y qué se rechaza. De algún modo, el erotismo implica contravenciones a los usos normativos del cuerpo: la boca con la que se habla y se come, pero con la que también se besa; el ano por donde se defeca. Algo que aprecian los mayates con los que he conversado del sexo con los putos es que el ano aprieta más que la vagina y hace más placentera la penetración. Pero, a la inversa, muchas veces en las relaciones con hombres estos sujetos rechazan los besos, porque implican intimidad, afecto y gusto. Ellos mismos no le propondrían a sus esposas o novias practicar sexo anal; alguno me contó que se lo había sugerido a su esposa y que ella se había ofendido mucho, le contestó de manera escueta y tajante: 'respétame, soy la madre de tus hijos'. No hubo más discusión.

En las antípodas de las "mujeres respetables", las trabajadoras sexuales representan otros puntos de articulación del sistema de sexo-género de la ciudad y de su orden sexual. Disponibles por dinero, en torno a ellas se estructuran algunas polaridades morales que son relevantes para la organización social de la sexualidad y que repercuten en el campo del homoerotismo. Ellas materializan, en su propio cuerpo, en su sexualidad y en su trabajo, estas categorizaciones morales. No son mujeres 'respetables', por lo tanto están a disposición de los hombres; sin embargo, la fantasía masculina de un acceso completo y sin restricciones a esas 
mujeres se confronta con las prácticas reguladoras de su trabajo. El dinero, que opera aquí como la motivación del trabajo sexual, pero también como una forma de tarifar las prácticas sexuales, organiza su disponibilidad erótica. ${ }^{44}$ En diversas conversaciones he escuchado a hombres decir que por tanto dinero una trabajadora sexual accede al sexo anal. Un informante al que entrevisté me señaló que según el dinero que tuviera podía conseguir que una trabajadora sexual no utilizara condón al tener sexo.

Creo que la no respetabilidad de las trabajadoras sexuales, el estigma de su actividad y su relativa marginación dentro de la ciudad no se deben tanto a las prácticas sexuales que tengan, puesto que es un sexo altamente regulado y tarifado, sino a la disponibilidad sexual que este trabajo implica y requiere. La respetabilidad de las mujeres se fundamenta, en último término, en la exclusividad sexual y esto es lo que transgreden de manera flagrante las trabajadoras sexuales.

En este esbozo de una moral sexual práctica y discursiva, los valores se articulan sobre el cuerpo, que se transforma, así, en un mapa de relaciones sociales. Esta dicotomía entre mujeres respetables y las que no lo son es central en la organización de las relaciones de pareja, la paternidad asumida, los matrimonios, las prácticas sexuales, las valoraciones. Estamos en el corazón de un proceso de subjetivación vinculado con la sexualidad y el género. Porque, por otra parte, donde termina la respetabilidad empieza el placer. Ese límite será relevante para la experiencia erótica y afectiva de los hombres gay de la ciudad y las formas de valoración colectiva y subjetiva de las identidades sexuales. Esa experiencia erótica se vincula, mediante la producción de ciertas corporalidades, con un orden de género. Las trabajadoras sexuales son tan poco respetables como los gays para los hombres de esa comunidad, porque contravienen un orden moral. El cuerpo, entonces, será el efecto de estas fuerzas que obligan a ciertos comportamientos y que trazan sobre él, como lo vimos antes, un antagonismo. La exclusividad y la respetabilidad son expresiones de un orden social. El cuerpo de las trabajadoras sexuales está disponible por dinero; el de los homosexuales es utilizado de manera indebida. El placer masculino surge como una transgresión desplazada: son los otros (prostitutas y gays) quienes experimentan y usan su cuerpo en los límites del orden social, poniendo a disposición algunos órganos (el ano, la boca) y otras modalidades (el sexo rápido o pagado, el placer sin vínculos o

\footnotetext{
${ }^{44}$ Esto se ha documentado en otras investigaciones realizadas en México durante las últimas dos décadas (Allen $e t$ al., 2003; Checa et al., 2005; Lamas, 1993; Parrini, Amuchástegui y Garibi, 2014; Uribe, et al:: 2000).
} 
por dinero). Son estos personajes, que ya inquietaban a los políticos en otro capítulo, quienes deben asumir el costo de sus conductas.

Al preguntarse “¿qué es el cuerpo?”, Deleuze responde que será un campo de fuerzas plurales, que disputan entre sí y que cualquier relación de fuerzas constituirá un cuerpo "químico, biológico, social, político",

(...) por eso el cuerpo es siempre fruto del azar, en el sentido nietzscheano, y aparece siempre como la cosa más 'sorprendente', mucho más sorprendente realmente que la conciencia y el espíritu (...) El cuerpo es un fenómeno múltiple, al estar compuesto por una pluralidad de fuerzas irreductibles; su unidad es la de un fenómeno múltiple, 'unidad de dominación'. (Deleuze, 2008[1967]: 60-61).

Campo de fuerzas plurales, fruto del azar, más sorprendente que la conciencia y el espíritu, la unidad del cuerpo sería un fenómeno múltiple, una unidad de dominación, dice Deleuze. ¿Qué dominaciones unifican los cuerpos que acá interrogamos?, ¿qué pluralidades los habitan y qué azares los han constituidos?, ¿qué sorpresas encontraremos en ellos?, ¿cuáles son esas fuerzas irreductibles que los componen? Si fuéramos aún más específicos, podríamos preguntarnos por las fuerzas que constituyen el cuerpo de la trabajadora sexual, por los azares que rodean al cuerpo homosexual, por sus sorpresas y sus pluralidades inéditas, así como sus dominaciones múltiples.

¿No son estos cuerpos producidos por "fuerzas masculinas" que los catalogan y valoran, que los buscan y los cercan, que les pagan quizás?, ¿no es la ‘unidad de la dominación’ ese orden sexual que distingue entre personas respetables y quienes no lo son?, ¿cómo atraviesa la diferencia sexual esa 'pluralidad de fuerzas irreductibles'? En las trayectorias masculinas normales, que hemos esbozado, existe una certeza sobre el cuerpo. La corporalidad y los valores sociales, los comportamientos y las normas, la mirada de los otros y la reflexividad, parecen piezas que embonan entre sí. La disyunción corporal está en los otros, en las prostitutas que venden su cuerpo o en los gays que lo usan de modos indebidos. "El cuerpo, escribe Braidotti, viene a ser una interacción compleja de fuerzas sociales y simbólicas sofisticadamente construidas" (Braidotti, 2005: 37). La sofisticación está en la compleja red de relaciones y posiciones, simbólicas y sociales, que se teje en torno al cuerpo; pero, por contrapartida, el modelo es muy simple. El cuerpo es siempre masculino, como lo sostiene Irigaray (2009[1977]), y la diferencia está del lado de lo femenino. En ese sentido, gays y prostitutas están en otro lugar y no caben en la simplicidad del modelo, aunque los contenga; esa densa 
red de fuerzas los disloca. Ese espacio difuso e híbrido que delineamos arriba constriñe estas corporalidades discordantes, pero también introduce dosis de placer en el orden moral y desplaza las transgresiones desde el deseo masculino a los sujetos que lo permitirían o que lo sostendrian.

Esas corporalidades dislocadas, a mi entender, son como puntos de fugas de ese orden moral, que parece sólido pero es incierto. Innumerables veces he escuchado a alguien enunciar determinados valores o ciertas restricciones y hacer exactamente lo contrario. ¿Cómo se puede explicar eso? Los valores o las prohibiciones funcionan como orientaciones para moverse en las redes o tramas que hemos mencionado; orientan, pero no determinan. Por eso, podemos observar y ser testigos de acciones incoherentes o de prácticas divergentes con los sentidos que se han elaborado. Pero, también, porque el desorden se desplaza a esos sujetos y colectivos (trabajadoras sexuales y gays); por eso, los políticos deseaban crear zonas de tolerancia donde se reuniera, pero también se circunscribiera, todo el desorden que producen. La zona de tolerancia es la manifestación administrativa de ese espacio híbrido que exploramos.

\section{Enfermedades "psicológicas"}

A Tadeo (seudónimo), un policía municipal, lo conocí en la fiesta anual de Cabecera, una comunidad rural a 20 minutos de Tenosique, que se realiza en agosto. Formaba parte del grupo de policías que cuidaba los festejos. Amigo de Alan había sido, alguna vez, su amante. "Es mayatísimo, me dijo Alan, igual que todos sus hermanos". Estaba intrigado por saber quién era yo, porque no me conocía y se notaba que no era de ahí. Supo que era psicólogo. Días después me lo encontré en Tenosique, él estaba de guardia en el Palacio Municipal. Me dijo que quería pedirme un favor, le habían comentado que era psicólogo y deseaba que fuera a platicar con su chava y su hijo menor. Me dijo que ella estaba afectada psicológicamente, que por todo gritaba y se ponía histérica; y el niño era muy retraído y llorón. Me contó que ya no vivía con ella, pero que cuando habían convivido la había golpeado. Lo dijo al pasar, sin detenerse. Esa vez acordamos que me llamaría y que nos podríamos de acuerdo para ir a platicar con su chava y su hijo. Quería saber mi opinión sobre el estado psicológico de la mujer y el muchacho. Traté de explicarle que no me dedicaba a eso, pero sin resultados. Le dije que sí iría. Pasaron los días durante esa visita y nunca me llamó. Agosto de 2009. 
Durante mi estadía en marzo de 2010, Tadeo le preguntó a Alan por mí. Él le dijo que estaba alojado en el hotel que queda a la orilla del malecón antiguo de la ciudad y un día lo encontré en la entrada de ese lugar. Me saludó y me volvió a hablar de su chava y su hijo. Le di mi número y quedó de pasar al día siguiente para ir a visitarlos. Partimos en su moto, atravesando algunas colonias lejanas al centro de la ciudad, la Obrera, la Municipal. Luego de 15 minutos llegamos a una casa de concreto, amplia, con dos habitaciones y una sala unida con la cocina. Salieron a recibirnos los hijos de Tadeo, una muchacha de 13 años y su hijo de 11. Ambos morenos y delgados. Luego apareció la chava, una mujer baja, con un rostro bastante demacrado, nerviosa. Tadeo nos presentó y le dijo que era el psicólogo del que le había platicado antes y que me encontró nuevamente y me trajo para que conversáramos.

Tadeo se marchó y me quedé platicando en ella. No reconstruiré toda la historia, pero me interesa recalcar la parte que muestra la inmovilidad de las relaciones de género. Ema, así la llamaré, fue abusada por su padre al igual que su hermana menor. Cuando su progenitor intentó violarla ella lo denunció y se produjo un conflicto familiar en el que su madre acusó a sus hijas de ser 'unas putas' y de querer 'quitarle el marido'. Reproche que aún les hace. Ella dice que esos hechos la hicieron perder la confianza en las personas y que en las encrucijadas que luego viviría no tendría el apoyo de su familia. Es de una ciudad de Tabasco cercana a la capital, ya adulta vino a vivir con su hermana, que en ese tiempo residía en Tenosique. Aquí conoció a Tadeo. Él la comenzó a enamorar, quedó embarazada, luego se fueron a vivir juntos. A la niña, después de nacida, la llevaron con su abuela.

Ema me cuenta que desde que comenzaron a vivir juntos Tadeo la golpeaba casi todos los días, la insultaba y le gritaba. Me dice que hace poco se hizo exámenes neurológicos, porque sentía dolores de cabeza muy fuertes y temía que se debieran a esos golpes. Me dice que la azotaba contra la pared, que le daba puñetazos y patadas. Iba al Ministerio Público, pero le pedían testigos; como él era policía, y conocía a toda la gente de ahí, no le hacían caso. Así vivió durante cuatro años. Luego se separaron. Pero dice que las heridas de ese infierno no las puede sanar, que todo lo vio su hijo menor, que se escondía asustado detrás de ella en medio de las peleas y los golpes. Conversamos alrededor de dos horas.

Tadeo se paseaba nervioso afuera de la casa, mientras yo platicaba con su chava. Nos marchamos. Me invitó a conocer a Ramón (seudónimo), otro policía, que estaba en una cantina de la colonia Municipal. Llegamos y piden cervezas y botanas. Me presentan a un parroquiano que es electricista. Me dicen que el señor también es puto, es de Mérida, pero vive 
hace mucho tiempo en Tenosique. Tadeo me pregunta cómo vi a la chava. Le digo que muy mal, en mi opinión y que lo que mejor puede hacer él, si quiere ayudarla, es dejarla tranquila. Él me dice que ha tratado de cambiar, que no desea regresar con ella, pero que teme que termine suicidándose (lo ha intentado dos veces). Le pregunto si en su casa había violencia y me dice que sí, que su padre golpeaba seguido a su mamá. Dice que no le guarda odio a su papá, que cuando murió lo lloró mucho; pero que nunca pudo ver el cadáver de su madre, porque no aguantaba el dolor y que prefirió recordarla viva.

Luego cuenta que descargó sobre esa chava toda la rabia que le produjo su primera esposa al abandonarlo. Ramón le dice que estuvo mal, que no debió hacerlo, pero también considera que Ema se equivoca, porque si Tadeo ha cambiado - no la golpea- ella debiera reconocer su transformación. Agrega que él nunca ha golpeado a su mujer. Relata que su padre golpeó a sus hijos y a su esposa casi todos los días. Vivían en una ranchería cercana a la ciudad. Recuerda que cuando tenía 17 años llegó su padre borracho y su esposa le dio de comer, pero algo le molestó y le dio un golpe en la cara que le dislocó la nariz. El muchacho se paró y le dijo a su padre: "ésta es la primera y última vez que golpeas a mi mamá” y salió a buscar un machete. Cuando traía el machete, dispuesto a matar a su padre, su hermano mayor lo detuvo. No le importaba si era pecado o no, ya no quería que golpeara a su madre. Cuenta que su papá se quedó paralogizado, que tenía un machete a su lado, pero que no reaccionó. Muchas cosas cambiaron luego de ese incidente.

Siguen platicando de la violencia que vivieron y que ellos mismos han ejercido. Pienso en la dureza de esas relaciones, en el uso indiscriminado de la violencia que se yergue como el trasfondo de muchos vínculos -familiares, amorosos, sexuales, laborales- en este lugar. He oído de asesinatos, riñas, golpizas y venganzas constantemente. Es parte de la vida cotidiana. La violencia parece agazaparse detrás de cualquier relación, y sólo falta el motivo para que se exprese.

Convenciones, tratados, institutos, políticas públicas, campañas, nada ha cambiado los supuestos que justifican la violencia contra las mujeres. Forma parte de las relaciones familiares y la gente, en general, la acepta como una característica de los matrimonios. Así mismo, se golpea a los niños desde muy pequeños para educarlos.

El orden de sexo-género mantiene su fuerza y su capacidad de clasificar y discernir destinos, valores, prerrogativas, subordinaciones y sufrimientos; se fundamenta, en muchos aspectos, en la dominación masculina (Bourdieu, 2000). Dominación no sólo simbólica, sino 
material y cotidiana. El poder se ejerce directamente sobre los cuerpos, muchas veces a través de la violencia. No busca el consentimiento, sino el acatamiento. La figura del patriarca despótico sigue vigente en esta comunidad: un hombre violento, que somete a todos los individuos bajo su dominio. Es curioso, porque en muchos relatos que he escuchado sobre los padres resalta ante todo la violencia, más que la protección o el cuidado, por ejemplo, que podrían ser también características de un patriarca.

Llegamos a los límites del sistema de sexo-género que hemos explorado. Debemos entrelazar este límite con los otros, porque si el antagonismo tiene un potencial destructivo, aquí encontramos algunas de sus manifestaciones. La violencia contra los homosexuales empezará en el desprecio por sus transgresiones corporales, eróticas o biográficas. Pero será también este orden heteronormativo, sostenido en la dominación masculina, el que los exponga a la violencia y la justifique. No sostengo una equivalencia en la posición de las mujeres y de los gays; creo que hay muchas diferencias entre ambos colectivos. Lo que me interesa remarcar es que, moviéndonos en los mapas que hemos trazado, la masculinidad es la esfera que los incluye a todos y a partir de sus prerrogativas alguien puede relacionarse de manera distinta con mujeres respetables, con prostitutas y con homosexuales, para citar los tres colectivos que tratamos de delimitar. Esa inclusión, que es ante todo dominio, permite que los hombres desplieguen trayectorias afectivas distintas a las eróticas, que reafirmen la heterosexualidad normativa mediante sus transgresiones, que desprecien a los sujetos que justamente les permiten articular diversas manifestaciones de su deseo. La heteronormatividad es, ante todo, un aparato discursivo que traza distinciones entre sujetos y colectivos; no es una ortopedia para las prácticas sexuales, desde la perspectiva de los hombres.

La libertad erótica masculina es correlativa a las restricciones sexuales que pesan sobre las mujeres, que deben dar pruebas de su respetabilidad. Pero ese respeto, como el viejo honor mediterráneo (Brandes, 1991; Carmel, 2004; Peristiany, 1968; Pitt-Rivers, 1979), es una forma de controlar el erotismo y el deseo femenino y constreñirlo a relaciones conyugales o de pareja, a la formación de una familia y la reproducción. Transformado en vara moral para cualquier mujer, es también el límite que cruzan algunas cuando venden su sexo o están disponibles para más de uno. Los putos nunca han sido respetables, en ese orden, porque contravienen todos los mandatos. No es la heteronormatividad la que les ha dado un espacio social, sino una transformación en algunas tramas culturales y políticas. 


\section{Mapas de la masculinidad}

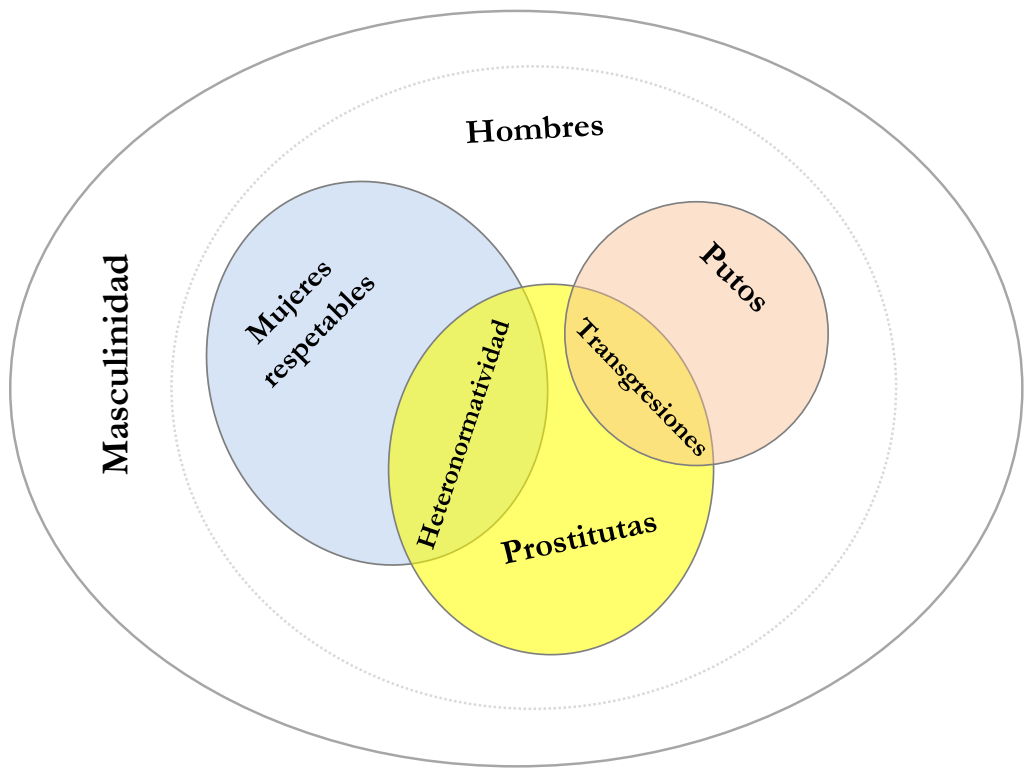

Que un hombre, tal como aparece dibujado en estas descripciones, tenga sexo con un puto no conmueve su masculinidad, como ya lo dijimos. Pero como hablamos de un sistema, no intentamos dar cuenta de todos los casos ni de todas las trayectorias. Hay hombres en la comunidad que nunca han tenido relaciones homoeróticas; otros que no son violentos. Deseamos mostrar que ciertas expresiones de la masculinidad oscilan entre una transgresión desplazada de la heterosexualidad y una violencia ratificadora de la dominación. Curiosamente, vemos que esa masculinidad es curva y no recta. Pero se curva sobre sus capacidades de dominio y sanción. Un puto siempre será despreciable; una mujer, un cuerpo dominado y constreñido.

\section{Deseo y diferencia}

Estaba sentado en una cantina esperando que llegaran algunos de mis amigos del Club cuando se me acercó un muchacho de unos 20 años. Me contó que trabajaba apilando materiales de construcción y quería que le invitara una cerveza. Le dije que sí, que se sentara. Me preguntó de dónde era y a qué me dedicaba; le respondí que vivo en la capital y trabajo como psicólogo. ¿Qué hago en Tenosique? Estoy trabajando con el Club Gay Amazonas. ‘'Va, pinches putos!', responde el muchacho. Bebe un vaso y otro. Me platica de su trabajo, de sus amigos, de su familia. No les gustan los putos, me dice, le dan asco, los evita, nunca ha estado con ninguno y no quiere hacerlo. "Sólo me gustan las mujeres", afirma taxativamente. Yo he permanecido en 
silencio, ha pasado una hora y se vaciaron tres botellas de cerveza de un litro cada una. Yo casi no bebo, así que todas se las tomó él. “Oye, pero a ti no se te nota, ¿qué onda?” Comienza a preguntarme sobre mi vida sexual y yo me río. Le digo vaguedades, respondo con preguntas. "Sí me sacas de onda güey, porque los putos acá son bien así... bien afeminados, que su brazalete, su ropita". Vuelvo a reírme. Me divierte, sin duda, que deduzca sobre mí a partir de mi trabajo o por la gente que conozco en la ciudad; pero también me sorprende el poder de esas deducciones. Nuevamente: si andas con putos es porque también lo eres. El muchacho sigue intentando averiguar algo de mí y yo prosigo con mis evitaciones y rodeos. Mientras más hermético me muestro más se desconcierta él. Ya perdí la cuenta de las botellas de cervezas, pero mi compañero de cantina está más borracho, aunque permanece consciente. Al menos no está ebrio y observo con asombro su capacidad para beber sin que se embriague de manera evidente. Llegan mis amigos y piden más cervezas, son dos gay bastante afeminados, divertidos, algo escandalosos. El muchacho los ve con recelo, pero no se ha marchado de la mesa. Ellos le platican poco y él los mira. Luego, al rato de convivir los cuatro, él me llama, me dice que vayamos al baño. Lo sigo, y me dice “¿qué onda?, ¿dónde nos vamos?”, “¿dónde quieres ir?", le pregunto, "ya sabes, a tu cuarto, pero sin que sepan tus amigas". Regresamos, yo sigo platicando con mis amigos, el muchacho me mira, hace gestos con las manos de partir. Se aburre, se va. No sé si con el mismo asco que sentía por los putos o con más.

Poder identificar al otro y ubicarlo en estos mapas del deseo es importante para resguardarse subjetivamente. El otro se devela mediante sus comportamientos, una estética, modales, formas de hablar. En este sentido, un puto es claramente identificable. Los problemas empezarán cuando no lo sea. Cuando esa circunferencia masculina, que clasifica y aparta, se vea invadida de masculinidades sospechosas o inauditas. Un homosexual masculino, por ejemplo, podría provocarle ansiedad a este sistema clasificatorio. El puto, ese hombre afeminado que ha perdido el rumbo corporal y que constituye un híbrido en términos de género, permite reafirmar el lugar de los hombres, tal como lo hemos esbozado en estas páginas. Ellos son diferentes, por eso si bien no se les toma en serio y pueden ser objetos de burlas y desprecios, tampoco interrumpen la mirada ni alteran las posiciones. Otros tipos de homosexualidades y homoerotismo constituirán desafíos más intensos a estos sistemas clasificatorios. En el capítulo sobre las epistemes vimos cómo se filtran esos sistemas y las posiciones de sujetos y se articulan formaciones discursivas específicas. Si bien puto, gay y homosexual parecen sinónimos, en muchos sentidos no lo son. No es un asunto semántico, es 
ante todo experiencial. Un puto, como lo dijimos, es alguien claramente identificable en todos los ámbitos, tanto personales como públicos. Un gay no lo es en la misma medida y la separación entre género y deseo supone una incertidumbre mayor. Es decir, que un hombre con apariencia masculina desee otros hombres no tiene el mismo efecto sobre el orden que hemos explorado que lo haga uno con aspecto femenino. Si bien podría haber muchas combinaciones y gradientes en estas configuraciones, nos detenemos en las polares para entender la lógica que opera en el orden de género y la organización social del deseo. La apariencia confunde el deseo, pero también la identidad. Implica, por tanto, que las separaciones tajantes son más bien relativas y que nadie está completamente seguro del lugar que ocupa.

Incluso, en términos generacionales dentro del mismo colectivo gay de la ciudad se han producido modificaciones en ese sentido. Los hombres de mayor edad se identificaron con mayor intensidad, desde la infancia, con un modelo binario sustentado en la polaridad masculino/femenino. Ellos se movieron o se ubicaron en un lugar femenino, algunos de manera definitiva y la mayoría de forma paródica, estratégica y oscilante. Eran 'mujeres' en el plano erótico, pero no necesariamente en el laboral, por ejemplo; elegían, por tanto, cuándo moverse en una dirección u otra. En cambio, los hombres de menor edad, que tenían a su disposición otros modelos de identificación sexual y erótica, adhirieron a formas gay de construir sus subjetividades y sus cuerpos, en las que la polaridad de género no es tan intensa, las expectativas eróticas no se articulan completamente en torno a ella y las corporalidades son, tal vez, más ambiguas. Un hombre mayor difícilmente se habría emparejado con otro gay, como sí lo hacen los más jóvenes. Sin embargo, el cruce identitario y corporal está disponible para todos ellos y el análisis que realizo no logra mostrar la intensa ambivalencia que he observado. Es decir, el mismo muchacho gay que se empareja con otro igual, luego se viste de mujer para una fiesta o tiene un nombre femenino; puede tener un amante mucho más masculino y sentirse 'mujer' con él. Pero también puede penetrar a otro hombre, sin mayor conflicto.

Los hombres mayores tendieron a localizarse de modo más drástico en ese lugar femenino y rechazar que intentaran moverlos de ahí. He escuchado, por ejemplo, muchas historias en las que un hombre masculino le pide a un hombre afeminado que lo penetre y éste lo corre o se escandaliza: "salió más mujer que yo" dijo alguno; otro lo echó de su casa, diciéndole "aquí la única mujer soy yo”. Sin duda hay algo chusco en todo esto y, generalmente, lo relatan con humor y entre risas. Pero, de todos modos, esas anécdotas develan expectativas en torno al 
deseo del otro, su identidad y su práctica sexual. Es un erotismo binario que necesita claridad en las posiciones de los personajes que lo representan, para satisfacer el deseo de quien ocupa el lugar femenino. En alguna medida, la propia artificialidad de esos posicionamientos exacerba la intensidad de su resguardo. En este caso, el deseo está organizado en torno a la diferencia sexual y sólo caben dos posiciones de sujeto y dos localizaciones eróticas: masculino o femenino.

En cambio, entre los más jóvenes el erotismo y las identidades parecen bastante más difusos y menos polares. Una pareja puede estar conformada por dos hombres y ninguno tendría que ubicarse en el lugar femenino, o ser la mujer de la relación, como dicen coloquialmente los gay del lugar. El problema, en este caso, es que el deseo homoerótico se desplaza al lugar masculino y las apariencias no sirven para resolver las identidades. Eso incrementa la ambigüedad dentro de la misma configuración social dominante de la masculinidad, en la que la heterosexualidad es uno de sus atributos centrales.

El muchacho de la cantina desplegó una estrategia para mantenerse en su lugar. Primero rechaza, luego pregunta, posteriormente invita. El deseo es un resultado final, después de muchas vueltas en las que se ha mantenido a resguardo. No hay dudas sobre su masculinidad, pero tampoco las debe haber sobre su deseo. Si no encuentra el espejo invertido de su identidad, es decir, un hombre afeminado, al que nombrará como mujer, entonces su deseo permanece opaco. Cuando ese deseo se refleja, si se me permite la expresión, en el espejo adecuado, la imagen que proyectará no es la del homoerotismo, menos la de la homosexualidad, sino de una heterosexualidad traspuesta. Pero esa operación óptica de inversión del reflejo requiere de la diferencia sexual y del binarismo de género para producirse. La queja y la sorpresa que se articulan en torno al "no se nota" corresponden, justamente, a la imposibilidad de realizar esa maniobra, porque si el otro no está invertido, la heterosexualidad no puede ser traspuesta, como dijimos.

En una de las figuras que elaboré para explicar la trayectoria sexual masculina, en especial la que es predominantemente heterosexual, dibujé el deseo como una línea curva que serpentea en torno a una línea recta de la trayectoria. ¿Es curvo el deseo y recta la orientación?; si el deseo fuera curvo, ¿qué trayectoria sigue: siempre zigzagueante, oscilante?, ¿hay formas rectas de deseo y curvas de vida?, ¿se curva la identidad o el cuerpo? No creo que haya respuestas definitiva a estas preguntas, pero formularlas muestra que los órdenes que exploramos están llenos de líneas de fuga, relativamente visibles o consistentes. Dijimos que en el caso del 
erotismo masculino, las curvas se producían a partir de la rectitud de la trayectoria. Es decir, era la configuración misma de la sexualidad la que proveía de excepciones y recovecos, por así llamarlos. Si la masculinidad es el Uno de la diferencia, tal como lo plantea cierto feminismo (Braidotti, 2005; Irigaray, 2009[1977]), el deseo es el 0 del erotismo. Muchas de las tensiones culturales que hemos explorado en estas diversas superficies etnográficas surgen de la imposibilidad de acomodar el deseo a la diferencia y viceversa. Esto no significa que sólo diverjan, pero sí que nunca coinciden; esa apertura suscita una serie de prácticas culturales que hemos investigado de diversas maneras, desde las clasificaciones de las mujeres hasta las formas de identificación de los homosexuales. Al contrario del intervalo del que hablaba Kristeva, en este caso 1-0 no están vinculados.

Falo y deseo

No obstante, creo que desde el punto de vista del erotismo el falo funcionará como un garante del orden masculino, que es muy difícil soslayar. Si bien es cierto que un hombre gay puede confundir sus apariencias y que el modelo del afeminamiento ya no es el único y, además, pierde terreno ante otro menos binario, el deseo se articulará en torno al falo de un modo enfático. Aunque un hombre sea muy masculino, incluso el que más, si muestra interés por otro hombre y por su falo, entonces será puto. En términos coloquiales, un puto es un hombre “al que le gusta la verga". En ese punto, cualquier apariencia se difumina, porque el deseo es una expresión desnuda de la subjetividad. Ante el deseo no hay refugio. Tal vez los gay afeminados lo saben con claridad: develan lo que de todos modos se mostrará. Ese deseo por el falo - la verga- será también el fin de cualquier homoerotismo, es decir, si un hombre que se vincula con otro bajo los efectos de esos reflejos invertidos de los que hablamos, que le permiten trasponer su heterosexualidad en otros cuerpos y otras subjetividades, muestra algún interés en el falo del otro, entonces el reflejo se invertirá de nuevo, pero “alumbrándolo” a él. Por eso, en algunas bromas mencionadas, los gay se escandalizaban, jocosamente, de que un hombre masculino fuera "más mujer" que ellos. Es decir, no que joteara o se vistiera; es más mujer que ellos porque también "le gusta la verga". Esa cantidad de feminidad sorpresiva empieza en el deseo, no en las apariencias ni en los comportamientos.

Algunos gays me han relatado sus esfuerzos para esconder su pene durante encuentros sexuales con sus amantes. Uno me contó que siempre usa un 'calzoncito', para que "no se le 
viera nada". Otro, que si bien está desnudo, usa las sábanas de su cama para evitar que se vean sus genitales. Ninguno de los dos se masturbaba durante el acto sexual. Si bien no estaban operados de sus genitales, la práctica sexual podría considerarse transexual; es decir, como una experiencia del cuerpo que evita los genitales para producir la fantasía de un cuerpo sin falo. El falo ausente, mediante estos otros trucos, intensifica la femineidad de esos sujetos, pero no por lo que son, sino por lo que no tienen o lo que esconden. En el registro de la fantasía, aunque no en el de las corporalidades, estos encuentros no tendrían que describirse, necesariamente, como homoeróticos. ${ }^{45}$ No son dos hombres o dos masculinidades las que se encuentran. Son dos desplazamientos del deseo en torno a la diferencia sexual: un hombre que encuentra una mujer anal; una mijer que recrea una feminidad truqueada, mediante evitaciones u ocultamientos. Esa mujer empieza, justamente, donde el falo intenta ocultarse o truquearse. Como Afrodita, nacida de la simiente de Urano, esta mujer nace de las performances de la castración.

Las trayectorias sexuales pueden ser curvas, al igual que el deseo, y poner en cuestión esta primacía del falo. Relataré dos, una que me contaron, otra de la que he sido testigo. La primera es de un hombre de una comunidad cercana a Tenosique, que tiene cerca de mil quinientos habitantes, y que durante su adolescencia y temprana juventud se relacionó sexualmente con muchos hombres de su pueblo; él era pasivo en esas relaciones, según me cuentan, pero nunca fue afeminado. Ahora está casado y tiene varios hijos. De pronto, por así decirlo, cambió de trayectoria o de deseo (no lo sabemos), pero dejó de tener sexo con sus vecinos y se transformó en un hombre heterosexual o en un hombre a secas, al menos en su forma de vida. Las personas que me relataron la historia hablaban con desconcierto de ese cambio. El individuo no era considerado puto en ese momento, aunque lo hubiese sido anteriormente. Sin embargo, pesaba sobre él una sospecha y convivía con amigos y vecinos con los que había tenido sexo. Todo esto sucede en una comunidad pequeña y rural donde las trayectorias vitales son muy consistentes. Este sujeto nunca se marchó de ese lugar, por lo que entiendo. Tal vez en otros contextos, habría vivido de otro modo, no lo sabemos. Pero él hizo un tránsito bastante sorprendente y poco común: dejó de ser puto para comenzar a ser hombre, en términos locales. Su posición ante el falo cambia: de desearlo pasa a tenerlo. El cambio que experimenta es ratificado por su matrimonio y los hijos que procrea.

\footnotetext{
45 Žižek escribe que “en la escena de la fantasía el deseo no se cumple, no se 'satisface', sino que se constituye (dados sus objetos y demás) -mediante la fantasía, aprendemos a 'cómo desear”" (Žižek, 1992: 163). La pregunta sería, en este caso, qué deseo se ha constituido y cuál es su aprendizaje.
} 
Pero quizás la sospecha sea indeleble. En otro caso, un hombre con el que he convivido tiene una esposa y varias hijas, pero es bastante afeminado, según los parámetros locales de masculinidad. Si bien parece ser un hombre heterosexual, constantemente le dicen que es puto y que se asuma como tal. Alan me cuenta que nunca lo ha visto con otro hombre, pero que le gusta convivir con los gay de la ciudad; yo lo he visto en algunas fiestas o eventos organizados por el Club. Alguna vez Alan lo invitó al programa de televisión que tiene en un canal local que se transmite por cable y él envió saludos a su mujer y sus hijas. Casi de inmediato llegaron varias docenas de mensajes al celular de Alan (con el que se comunica con el público) diciéndole que saliera de clóset, que se asumiera como gay, que era puto, que no se escondiera detrás de su mujer y sus hijas.

En este caso, parece que la apariencia impone el deseo y no puede ser discutida: si el tipo es afeminado también es puto. El hombre de la comunidad vecina puede salir de la homosexualidad porque no se le nota $\mathrm{y}$, salvo la memoria colectiva y los rumores, no queda evidencia de sus deseos anteriores. El afeminamiento es una forma de ensamblar deseo con identidad y de resolver las tensiones que produce un hombre que no cumple cabalmente con los modos masculinos, pero que ha seguido una trayectoria de vida heterosexual. ${ }^{46}$ La gente insiste que a ese individuo "le gusta la verga", es decir, que desea el falo; se lo dice y además censura que trate de negarlo. No acepta que esconda su deseo detrás de su trayectoria de vida: su esposa y sus hijas. Es como si él quisiera trazar la misma línea para su deseo y su sexualidad y colectivamente se lo impidieran. Son los otros quienes curvan su deseo e impiden, paradójicamente, la rectitud de su trayectoria sexual. Es como si una falsa heterosexualidad fuera peor que una homosexualidad verdadera. En cambio, el habitante de la localidad rural puede rectificar su deseo y acoplarlo a la trayectoria esperada socialmente y valorada moralmente. Pero en este caso, parece que colectivamente se privilegia la hombría, porque este individuo nunca fue afeminado y su sexualidad no era la que se esperaba de su apariencia. Traspuestos los términos, sería mejor una falsa masculinidad que un verdadero afeminamiento. Lo paradójico es que, en este último caso, el deseo es más evidente que en el otro, porque las historias que cuentan mencionan que tenía sexo con sus vecinos y amigos. En el otro, sólo hay

\footnotetext{
${ }^{46}$ En este caso, se cumple algo que Foucault describe para el homosexual decimonónico. En él, la homosexualidad "está presente en todo su ser: subyacente a todas sus conductas puesto que constituye su principio insidioso e indefinidamente activo; inscrita sin pudor en su rostro y en su cuerpo porque consiste en un secreto que siempre traiciona" (Foucault, 1981: 56).
} 
suposiciones. Pero como el deseo se puede esconder detrás de las apariencias, entonces en el segundo caso lo que falla es justamente el truco, como lo veremos luego.

Si pareamos los términos expuestos, entonces tenemos la falsedad del lado de la masculinidad (caso 1) o de la heterosexualidad (caso 2); y la verdad del lado de la homosexualidad y el afeminamiento (caso 2). Si el análisis fuera correcto, sólo la masculinidad puede ser truqueada, es decir, es la única posición falseable en este orden. Por eso, cuando las quinceañeras se hacen un truco lo que producen no es una feminidad distinta, sino una masculinidad truqueada, que sigue girando en torno al falo y la hombría, que son los parámetros definitivos de la identidad, en este campo. Restar el falo no es producir una nueva forma de feminidad sino de mover la masculinidad, así como algunos informantes evitaban que su pene apareciera en sus prácticas sexuales; al truquear su identidad se devela la verdad de la masculinidad (fálica). En el caso 1 también podríamos leer un tipo de truco en el que el deseo es desplazado detrás de la identidad, por así decirlo. Ese hombre suspende su deseo homoerótico, al menos visiblemente (el fuero interno es una incógnita en todos los casos) y ratifica una identidad y una trayectoria masculinas. La operación que realiza tiene un sentido inverso a la del transformismo: si en éste se esconde el falo, en la otra se lo evidencia (matrimonio e hijos). Pero en ambos casos, se produce un desplazamiento hacia atrás: en el de las quinceañeras, se esconde el falo (la identidad) para que emerja el deseo (¿femenino?); en el otro, se esconde el deseo (homoerótico) para que surja la identidad (masculina). Pero, también, se esconde el deseo para que aparezca el deseo; por ejemplo, el hombre de la comunidad rural abandona su deseo homoerótico (al menos el que se expresaba en las prácticas sexuales con sus vecinos) para permitir el heterosexual; tal como algunos informantes ocultaban su pene para no interrumpir su deseo, ni el de sus parejas. La heterosexualidad traspuesta de esos sujetos necesitaba un deseo escondido (truqueado) en sus parejas; es como si, en estos casos, el mismo deseo homosexual tuviera que ocultarse para cumplirse.

¿Cómo puede ser truqueado algo que se muestra, algo que aparece y no desaparece? Tal vez la masculinidad se puede falsear por partida doble, ya sea por la ruta de la identidad o por la del deseo. Cuando los gay relatan con escándalo y con sorna que un hombre resultó "más mujer que ellas", impiden que el truco se realice, porque si la apariencia no develaba su deseo, entonces cuando éste sale a la luz ellos lo denuncian y, de algún modo, lo vuelven a la oscuridad de las prohibiciones. Un hombre masculino que esconde su deseo en muchos sentidos lo truquea, pero sin que se note. Tal vez éste sea el truco más efectivo y más disruptivo. 
¿Pero es este tipo de truco el que realiza el hombre de la comunidad rural que deja de ser puto?, ¿cuál es el lugar del deseo en estas transposiciones? El deseo es subsidiario, en las lecturas colectivas que nos interesan, de las posiciones de los sujetos en el orden sexual. De este modo, si un hombre con deseo homoerótico (caso 1) se endereza y se casa y tiene hijos, socialmente se ratifica su cambio. Y en la misma línea, pero en un sentido inverso, si un hombre esconde su deseo detrás de su trayectoria (caso 2), colectivamente se lo saca a la luz ("sal del clóset", “asúmete”), como lo hacen los gay con los hombres "más mujeres que ellos”. En ese caso, se bloquea lo que se lee como un truco, es decir, como un engaño. La magia del deseo es interrumpida por la seriedad de las identidades.

\section{Zonas erógenas/Zonas de tolerancia. Antagonismo y proliferación de diferencias}

Una zona erógena, o zona de preferencia, como la denomina Joan Copjec, "provoca al mismo tiempo la pregunta por la identidad del sujeto y la imposibilidad de responderla" (Copjec, 2011: 44). La sexuación del sujeto, dice la autora, lo inclina u orienta "hacia una otredad por la que es tocado y a la que toca precisamente en tanto que no la aprehende” (ibíd.). La pregunta por la identidad, imposible de responder como lo hemos visto en este texto, produce una serie de medidas que permiten, al menos, restringir sus efectos. Si bien alguien podría desconocer los motivos de su deseo, eso no implicará, dirá Copjec, que no pueda experimentarlo, "la experiencia no depende del conocimiento de la causa, lo que explica por qué la verdadera pasión es siempre desconcertante, loca. Nunca tiene ni ton ni son y siempre parece el resultado de un encuentro casual" (ibid:: 45). Esa locura de la experiencia y del deseo es contenida tratando de cercar sus manifestaciones. Por eso, las zonas de tolerancia son como zonas erógenas colectivas, producidas gubernamentalmente. Literalmente, son zonas de preferencia, en Tenosique, porque planeaban circunscribir a los homosexuales y prostitutas en una vecindad deseante, pero inconsulta.

En muchos sentidos hemos estudiado, precisamente, esos puntos donde las zonas erógenas o de preferencia se tocan, por así decirlo, con las de tolerancia. $\mathrm{Y}$ a ese toque mutuo lo llamamos antagonismo. "Lo que los obstáculos sexuales revelan, escribe Copjec, es una falta, un desgarre en el universo simbólico; un vacío que se abre y que, por tanto, fuerza a lo simbólico a inclinarse o curvarse lejos de sí mismo" (ibíd: 64; énfasis mío). Exploramos muchas curvas de ese tipo a través de diversos intríngulis subjetivos y sociales. El antagonismo, en este 
campo, es curvo y revela, precisamente, la imposibilidad de comprender la diferencia sexual como un conjunto de características que se acoplan o, en términos contemporáneos, como una construcción cultural.

Laclau y Mouffe dirán que "el antagonismo es el fracaso de la diferencia y, en tal sentido, se ubica en los límites del lenguaje, y sólo puede existir como disrupción del mismo -es decir, como metáfora-" (Laclau y Mouffe, 2006: 168). En ese sentido, se preguntan:

“¿no hay ciertas "experiencias”, ciertas formas discursivas, en que se muestra no ya el continuo diferir del "significado transcendental", sino la vanidad misma de este diferir, la imposibilidad final de toda diferencia estable y, por tanto, de toda "objetividad"? (Laclau y Mouffe, 2006: 164).

Los autores responden que sí y que "esta 'experiencia' del límite de toda objetividad tiene una forma de presencia discursiva precisa, y que ésta es el antagonismo" (ibíd.). En el antagonismo, "la presencia del Otro me impide ser totalmente yo mismo. La relación no surge de identidades plenas, sino de la imposibilidad de constitución de las mismas” (ibíd: 168) ¿No son las 'experiencias' que hemos reconstruido parecidas a aquellas que expondrían la "imposibilidad final de toda diferencia estable"? Creo que podemos responder afirmativamente. El antagonismo no enfrenta identidades, sólo muestra que nunca podrán constituirse plenamente. Žižek por su parte, escribe que el antagonismo es "el núcleo imposible (...), un cierto límite que en sí no es nada", pero que impide el cierre "del campo social” (Žižek, 1992: 214).

¿Hay diferencia por el vacío y la curva?, ¿conocemos el antagonismo en tanto límite justamente porque presenciamos múltiples intentos para eludirlo o moderarlo? Cuando leímos la diferencia sexual como una forma de antagonismo rodeamos una tensión que ha atravesado los debates contemporáneos sobre este tema. Una postura lee la diferencia como el resultado de un proceso histórico y cultural que puede ser deconstruido y desmontado en muchos de sus aspectos y que podría suscitar una proliferación de posiciones en torno a ella o suprimirla definitivamente. Otra, en cambio, la interpreta como un límite para cualquier orden social y cultural, que no puede desarmarse como si fuera sólo una construcción cultural. ${ }^{47}$

\footnotetext{
${ }^{47}$ Esquemáticamente, la primera ha sido sostenida por el feminismo posestructuralista, algunas corrientes de la teoría queer y los estudios de género y sexualidad inspirados en sus planteamientos. La segunda, por un feminismo de corte lacaniano.
} 
En nuestro análisis elegimos no ceñirnos a ninguna de las dos posturas de manera estricta, porque el desafío era entender un material etnográfico complejo y ambivalente. De todos modos, seguimos algunas de sus intuiciones, pero por eso, de manera un poco desatenta, situamos la diferencia sexual junto con el orden de sexo-género, aunque sean conceptos distintos que apuntan, tal vez, a epistemologías diferentes. Optamos por leer las lateralidades etnográficas que nos interesaban como expresiones contingentes y locales de ese límite que constituye la diferencia sexual que, en última instancia, impide que un orden simbólico se cierre sobre sí mismo, pero también que la diferencia se sitúe sólo del lado de la cultura y la historia. Su carácter liminar, que es propiamente el antagonismo, tiene un efecto devastador en las certezas de los órdenes sociales, pero también en la posibilidad de transformarlos. Nos hemos detenido, en este capítulo y en otros, en las manifestaciones históricas y culturales de esa diferencia, que agrupamos bajo el concepto de sistema de sexo-género, siguiendo a Rubin (1975), o aparato de género, retomando a Butler (2004). En ese sentido, si bien constatamos el carácter estructural de la diferencia sexual, trabajamos con una proliferación de artefactos culturales y prácticas sociales que se producen en ella o la merodean, por así decirlo. Es decir, el carácter liminar del antagonismo no impide que esté en el centro de la producción de lo social, al menos en los campos que nos han interesado.

Quizás desde una perspectiva estrictamente teórica, ciertas aproximaciones serían incorrectas o tal vez confusas. Sin embargo, quisiera destacar que las dos posturas que delineamos antes sirven para leer el material que tenemos. Es como si pudieran alumbrar algunos de sus aspectos, sin que constituyan ninguna síntesis. Es decir, en este caso las teorías se ubican, junto con la etnografía, en una lateralidad difícil de soslayar; pero, además, el caleidoscopio cultural y subjetivo que tratamos de reconstruir no responde de manera cabal a ninguna narrativa ni a una sola mirada teórica. Las conexiones parciales de las que hablaba Strathern (2004) también son conceptuales.

El material que analizamos muestra una proliferación de las diferencias. Laclau y Mouffe han sostenido que no hay "principio único que fije -y así constituya- al conjunto del campo de las diferencias", y en este sentido, "la tensión irresoluble interioridad/exterioridad es la condición de toda práctica social” (Laclau y Mouffe, 2006: 151). Esa tensión implica que lo social no puede ser reducido ni a una interioridad fija ni a una exterioridad acabada. Esa tensión nosotros la denominamos entre. Y en ese 'espacio' localizamos a los gays y la homosexualidad: ni dentro ni fuera, ni interiores al orden social ni exteriores a él. Un discurso, 
sostienen Laclau y Mouffe, entendido como un sistema de identidades diferenciales, "existe como una limitación parcial de un 'exceso de sentido' que lo subvierte”, y dicho exceso será inherente a toda situación discursiva, que "es el terreno necesario de constitución de toda práctica social" (ibid.). Las prácticas sociales que acá exploramos son manifestaciones de ese exceso que se produce en los discursos, entendidos como fijaciones parciales de las diferencias; pero también los subvierten, de algún modo. Por eso ambos autores sostendrán que "no es la pobreza de significados, sino, al contrario, la polisemia, la que desarticula una estructura discursiva" (ibid.: 154).

Creo que, en este sentido, la polisemia que hemos explorado permite desarticular la diferencia sexual como estructura discursiva, pero no como límite. Esta distinción me parece capital para entender la ambivalencia y la intensa ambigüedad de los campos investigados. Si se introduce un exceso en esa estructura y se hacen proliferar los sentidos (entendidos como direcciones sociales y fijaciones semánticas), entonces la diferencia sexual se transforma en un terreno de disputas políticas y culturales. Pero, entendida como una forma del antagonismo, la diferencia sexual es un límite para cualquier polisemia o exceso.

Copjec habla de "un vacío que se abre y fuerza a lo simbólico a curvarse"; Žižek de un límite que "en sí no es nada"; Laclau y Mouffe de un "fracaso de la diferencia", que ubica al antagonismo en "los límites del lenguaje". La diferencia sexual como límite es la condición de cualquier exceso, no su resultado. Por eso, cuando los gobiernos detectan esa proliferación de las diferencias, esos múltiples excesos, incluidos los de carácter moral, y esas polisemias perturbadoras, intentan crear zonas de tolerancia que constriñan las experiencias de las zonas erógenas o de preferencia, como las ha llamado Copjec. Aunque el deseo desconozca su causa, puede actuar su locura. Las zonas de tolerancia son un intento estatal para fijar nuevamente la diferencia, discursiva y espacialmente. Muestran, por tanto, que el antagonismo está produciendo un orden social. Pero hemos visto muchos otros intentos para producir fijaciones semejantes: desde la violencia contra las mujeres y las clasificaciones de tipos de mujeres, hasta ciertas formas de evidenciar el deseo del otro y de cercarlo. En este caso, no exploramos sólo las grandes manifestaciones del antagonismo en torno a la diferencia sexual, sino otras menores, opacas, casi imperceptibles. En esos lugares donde los cuerpos son atados a los significados mediante tecnologías semióticas, como lo sostiene Haraway, también fuimos testigos de cómo se desatan y producen otros significados y otras prácticas. 
Hoy la diferencia sexual como estructura discursiva soporta una polisemia creciente y una proliferación de excesos. Pero, al menos en el campo que hemos investigado, esto sucede justamente a partir del antagonismo en tanto límite. Como ese límite está vacio, no es nada, e incluso se ubica más allá del lenguaje, podemos conocer sus manifestaciones, pero no desarmarlo ni destituirlo. Es precisamente esta intuición la que le permite al Club trabajar el antagonismo mediante estrategias representacionales, aplicando fármacos festivos a las tensiones estructurales. El vacío, la nada y el silencio son colindantes, en muchos aspectos, con el hechizo, el truco y el encantamiento, que no serían sino formas de curvar el orden simbólico. 


\section{VI \\ E1 Estado y la Bestia. Flujos, globalización y deseo}

Contempla deshacerse la historia a la sombra de la montaña.

J.M. Coetzee, Juventud, 2011:45

Uno de mis primeros intereses al inicio de esta investigación fue estudiar los vínculos entre los procesos locales, a los que me acercaba mediante una etnografía, y otros regionales, nacionales, transnacionales y globales, a los que sólo podía aproximarme a través de fuentes secundarias. Una vez que intensifiqué mi trabajo etnográfico, este segundo aspecto quedó relegado y quizás oscurecido por la vorágine de la vida cotidiana del grupo que investigaba y de las personas con las que me relacionaba en la ciudad. En muchos sentidos, percibía que esos niveles, por así llamarlos, se entrelazaban de maneras opacas, vistos desde esa perspectiva local. No bastaba afirmar el carácter nacional, transnacional o global de ciertos fenómenos o procesos sociohistóricos para encontrar la evidencia que los (re)localizara en Tenosique. Esta percepción se intensificaba cuando debía conectar la producción social de un deseo y una identidad, las formas de sociabilidad y los modos de ejercer cierta ciudadanía, con procesos cuyo origen y desarrollo se situaban muy lejos de la ciudad. No obstante, desde el principio esas referencias fueron fundamentales; por ejemplo, la adopción e interpretación por parte de los integrantes del Club Gay Amazonas de la identidad gay urbana y clasemediera, o la repercusión que los procesos de apertura democrática y fortalecimiento de los discursos de ciudadanía y derechos humanos tuvieron en determinadas condiciones de posibilidad para que surgiera esta organización. Yo suponía que debían enlazarse y era mi interés trazar una curva histórica para los procesos locales que investigaba.

Pero lo que se intuye no necesariamente logra 'probarse'. Lo local y lo global continuaron distantes y sus conexiones fueron difíciles de establecer. La pregunta que me hice, para tratar de encontrar una salida, fue cómo estaba pensando lo local y lo global (más los otros niveles que mencioné) y de qué manera concebía la ubicación geográfica e histórica de la ciudad con respecto a algunos de esos procesos. Los relatos de mis informantes apuntaban hacia ellos desde el principio, por ejemplo, cuando llegó el sida a la ciudad o por el emplazamiento -en los 
años noventa- de una zona militar a causa del levantamiento zapatista en Chiapas, que trajo el arribo de varios miles de soldados.

¿Se puede pensar e investigar algún vínculo entre deseo y globalización?, ¿entre los procesos sociopolíticos de reconfiguración del Estado-nación y las formas de experimentar una identidad sexual o el cuerpo?, ¿entre la guerra de baja intensidad y el amor?, ¿'entre los flujos de diverso tipo y las territorializaciones particulares que mis informantes realizaban de sus deseos y sus biografías, de sus interpretaciones y sus afectos?, ¿entre los procesos que tenían su origen en las grandes ciudades y los efectos que se experimentaban en los barrios y en las casas de esta localidad? Vuelvo a insistir que diferenciar los niveles y especificar los procesos, no implica comprender las conexiones, si las hubiese. Mi impresión era estar frente a un juego de dados en el que piezas lanzadas a miles de kilómetros golpeaban el tablero local, aunque nadie sabía cómo ni tampoco por qué. En este sentido, el azar era tan relevante como todas las determinaciones cuyo desarrollo y expansión podríamos seguir.

Explicaré dos de estas conjugaciones azarosas. Comenzaré por pensar el futuro. Cuando viajé a Tenosique por primera vez, en junio de 2006, faltaban algunos meses para que concluyera el gobierno de Vicente Fox. La mayor parte de mi trabajo de campo, en consecuencia, acaeció durante el sexenio del segundo presidente panista, Felipe Calderón. Una de las primeras acciones de su gobierno, sin duda la más determinante, fue declarar lo que en su momento se llamó una "guerra contra el narcotráfico". Los efectos fueron y han sido devastadores: miles de muertos, incremento de la violencia y de los delitos, zonas enteras del país bajo un estado de sitio de facto, miles de desaparecidos y una escalada sin fin de crueldad. ${ }^{48}$

En Tenosique comencé a percibir con mayor claridad las consecuencias de "la guerra" a partir del 2010. Se hablaba con insistencia de los Zetas, uno de los carteles de la droga más poderosos y violentos del país, que habían extendido su influencia a todo el sureste de México

\footnotetext{
${ }^{48}$ Las referencias que permiten conocer con detalle esta situación son muchas. Amnistía Internacional (2013) y Human Rights Watch (2011) han publicado informes sobre esta guerra. Para conocer el impacto del crimen organizado en la migración, véase Amnistía Internacional, 2011; CNDH, 2011; Fundar, 2011; I(dh)eas, 2011; Meyer y Brewer, 2010. Por otra parte, el secretario de Gobernación de la actual administración cifró en 70 mil los asesinados durante el sexenio de Calderón en el marco de esta "guerra" y en 20 mil los desaparecidos (El Universal, 15 de febrero de 2013). Javier Sicilia, fundador del Movimiento por la Paz, la Justicia y la Dignidad, en una entrevista concedida al diario El País estima en 30 mil las desapariciones (Santaeulalia, 2013). Hay diversos textos que exploran y analizan lo sucedido durante estos años y aventuran distintas explicaciones. Véanse, entre otros, Cadena, 2010; Maldonado, 2012; Pereyra, 2012; Wolf, 2011.
} 
y Centroamérica, y se dedicaba a la trata de personas, el tráfico ilegal de migrantes, el secuestro, la extorsión. ${ }^{49}$

Cuando inicié la investigación, ya había un flujo importante de migrantes indocumentados centroamericanos que utilizaba México como la única ruta para llegar a los Estados Unidos. Desde 2009 se incrementaron los rumores sobre la presencia del crimen organizado en la ciudad que, de pronto, estaba rodeada por diversas amenazas que no habitaban su centro, pero recorrían como fantasmas sus orillas y periferias. Hubo asesinatos, secuestros y denuncias de los defensores de derechos humanos. La ciudad mostraba indiferencia, de múltiples formas, al tránsito de los migrantes, que permanecen poco tiempo en ella y se apostan, fundamentalmente, en las vías del tren que acortará su viaje o en el refugio administrado por la iglesia Católica, pero los rumores y el temor colectivo aumentaban de entonces a la fecha. Se sumó a ello la presencia notoria de pandillas de adolescentes y jóvenes de las colonias populares de la ciudad que se disputaban el territorio mediante peleas y amenazas, además de verse inmiscuidos en delitos de distinta gravedad. En muchos sentidos se nutrían de las representaciones e imágenes provenientes del narcotráfico, aunque no tuvieran relación alguna con sus estructuras y actividades. Yo escuché muchas historias en las que nunca quise profundizar, pues estimé peligroso enterarme de narraciones contadas por otros en estado de ebriedad.

Sólo una vez tuve un contacto indirecto con ese espesor violento, pero fantasmal. Acompañé a uno de los amigos del Club con la intención de conocer hondureños en las vías del tren. Caminamos largas cuadras hasta llegar a una parte donde las vías dejan de ser la orilla de una calle y se adentran en los montes. Yo no quise continuar porque me pareció peligroso. Mi amigo me propuso que nos situáramos a la entrada de ese lugar para que contactara a los migrantes. Casi no había gente, salvo algunas personas que comían y platicaban en unos puestos hechos de madera y cartones a la entrada de ese trecho selvático del tren.

Después de estar un largo rato en el lugar, le propuse a mi amigo que nos marcháramos. Era de noche y el sitio no me inspiraba confianza. Estábamos detrás de un hotel de paso a la salida de la ciudad, cerca de un puesto del Instituto Nacional de Migración. En algún momento

\footnotetext{
49 La Comisión Nacional de Derechos Humanos indica que en los estados del sureste se efectuó el 67.4\% los secuestros de migrantes; Tabasco era el segundo estado más peligroso, luego de Veracruz (CNDH, 2011: 27). En el caso de Tenosique, se distinguen seis zonas peligrosas para los migrantes: la cabecera municipal, Faisán Vía, Boca del Cerro, Pénjamo, Arena Hidalgo y Sueños de Oro (ibíd: 30).
} 
se nos acercó un motociclista y nos dijo: "Los Zetas preguntan qué están haciendo aquí". Mi amigo, muy asustado, le respondió que nada, que sólo habíamos venido a conocer migrantes hondureños. Él quiso irse de inmediato y yo le dije que camináramos con calma, sin nerviosismo ni apuro, para no infundir sospecha por si, en efecto, estuvieran preguntando por nosotros. Al hombre de la moto yo lo había conocido de manera casual días atrás cuando caminaba con otro amigo por la colonia donde vivía entonces. En aquel momento, mi acompañante lo señaló como traficante de drogas. Por lo tanto, su relación con Los Zetas era probable. Regresamos por la línea del tren en dirección al centro de la ciudad y tomamos un taxi.

Nunca volvimos a saber de Los Zetas ni del hombre que se nos acercó. Tampoco si la pregunta era cierta o no, si usaba ese nombre como una pantalla para atemorizar o si había un interés efectivo en nuestra presencia. Pero advertí el potencial de amenaza de los fantasmas y preferí no indagar cuan tangible era. De pronto, un recorrido insospechado conectaba la geopolítica con el narcotráfico, que se había apoderado de las rutas de paso de los migrantes y desplazado parte de sus operaciones a Centroamérica, a unos kilómetros de Tenosique.

Esa caminata nocturna incubaba de algún modo el futuro: una frontera cada vez más peligrosa y violenta, a raíz de decisiones y acciones que se tomaban y tenían lugar a cientos de kilómetros. Justamente, el cierre de la frontera norte, tanto por los controles de los Estados Unidos, como por la intervención del Estado mexicano, había producido una modificación de la frontera sur, mucho más porosa y menos controlada. ${ }^{50}$

Pero ¿qué era el pasado? La ciudad de Palenque se encuentra a dos horas de viaje de Tenosique. Su principal atractivo es el sitio arqueológico del mismo nombre. Aprovechando su cercanía he ido varias veces. En una de mis visitas puse atención en las estelas del lugar, enormes grabados en piedra que representan algún hecho de relevancia para la ciudad. En una de ellas, conocida como la Escalera Jeroglífica, se narra la derrota de Pomoná a manos de Palenque en los años 659 y 663 de la era actual (Anaya, 2004). Pomoná está a 27 kilómetros de Tenosique, en la carretera que la conecta con Emiliano Zapata, al norte. Si bien la ciudad tabasqueña fue un asentamiento maya de menor importancia en una zona densamente

\footnotetext{
${ }^{50}$ Fábregas Puig establece una diferencia interesante entre las fronteras sur y norte de México; mientras en el caso de la última una diferencia política se suma a otra cultural, en la primera "(...) no es la identidad cultural el factor central, sino los nacionalismos estatales en ámbitos en los que las similitudes culturales son evidentes" (Fábregas Puig, 2005: 34-35).
} 
habitada, la guerra había sucedido en su territorio, por decirlo así. Desconozco cuáles son los efectos, si los hubiera, de esa derrota en la historia presente del lugar. Pero la inscripción me mostró una densidad histórica de la que formaba parte la ciudad, ya sea como testigo o remanente. Las antiguas guerras entre ciudades mayas de la cuenca del Usumacinta se vinculaban, de pronto, con las nuevas que mantenían las bandas de narcotraficantes con el Estado mexicano. Por supuesto, unas y otras no guardan relación alguna. Pero ambas ilustran cómo la violencia, las disputas, los conflictos, marcaron el desarrollo de ese territorio de maneras diversas y a través de largos periodos históricos.

Pero el presente abre las preguntas más importantes. No sabría establecer conexiones entre un momento y otro, entre el futuro aciago y el pasado belicoso. Tampoco sé si dichas interrelaciones existen. Pero ambos hechos podrían formar parte de las narrativas del presente. Los flujos, hasta cierto punto incontrolables, de migrantes, militares y funcionarios estatales; de drogas y mercancías ilegales; transforman Tenosique en un nodo de mapas múltiples y complejos, una línea de paso en la que subsisten los residuos (cadáveres, pertenencias que los migrantes no pudieron cargar, el aceite de los trenes, algunas mercancías baratas, algo de dinero), flujo de memorias arcaicas que relatan viejas guerras entre ciudades desaparecidas para siempre, narración de hechos que sucedieron en la carne y quedaron grabados en piedra. Tal vez no hay otro rastro que esas inscripciones, escritura pétrea de acontecimientos que perdieron cualquier capacidad de producir realidad. Escrituras y relatos enfrentados a estas nuevas fuerzas, violentas y temerarias, que reconfiguran la frontera y delinean el futuro.

La perspectiva de estos vínculos y superposiciones de historias podría leerse con el lente de la larga duración, en el sentido dado por Braudel y otros historiadores y antropólogos (Wallerstein, 1984; Wolf, 1987). No será la ruta que tome en este capítulo, porque excede mi investigación. Sin embargo, tampoco puedo separar el presente de sus múltiples determinaciones ni las estructuras y procesos que lo configuran de manera opaca, pero inexcusable. Como apunté antes, mientras me centré en el trabajo etnográfico, esas largas líneas históricas me parecieron demasiado confusas o brumosas para entender lo que observaba y escuchaba. El periodo que me interesaba de manera particular correspondía a los años de existencia del Club, aunque para explicar su aparición en esta ciudad debía extenderme al menos hasta los años setenta del siglo pasado, cuando se constituyeron las comunidades gay en las ciudades más importantes del país. 
Una vez que pensé la posición fronteriza de la ciudad, comencé a explorar otras temporalidades. Un dato fue clave: Tenosique ha sido durante al menos dos siglos un puerto fluvial, el más importante de la cuenca del Usumacinta. Ha sido, por tanto, lugar de paso en direcciones múltiples de diversos flujos: humanos, económicos, políticos y simbólicos (de Guatemala a México, de Chiapas a Tabasco, de Tabasco al sur del país, y viceversa ${ }^{51}$. Por su localización, la ciudad es una suerte de triple frontera: se encuentra a 58.5 kilómetros de Guatemala y, por lo tanto, es una de las pocas ciudades de la frontera sur; colinda entre Tabasco y Campeche, lo que le convirtió en una ruta de primera importancia en el sur de México; por último, es el límite oriental de la Selva Lacandona. Esta ubicación, entre flujos regionales, nacionales, transnacionales y globales, ayuda a entender una serie de fenómenos locales que he estudiado a lo largo de mi trabajo de campo.

Paradójicamente, si bien en Tenosique han sido una constante flujos de todo tipo, la ciudad mantuvo un relativo aislamiento hasta los años cincuenta del siglo XX. A partir de la inauguración del puente de Boca del Cerro, que une las riveras norte y sur del río Usumacinta, además de servir para el paso del tren que conectaba Mérida con el centro y el norte del país, la ciudad experimentó un crecimiento demográfico progresivo y dejó de ser una villa pequeña. ${ }^{52}$ En los años sesenta y setenta llegaron migrantes de diversas zonas del país, lo que conformó,

51 Algunas investigaciones muestran que la localidad ha formado parte de flujos económicos y sociales al menos desde la segunda mitad del siglo XIX. Tenosique fue uno de los lugares que sirvieron de base para la explotación económica de la Selva Lacandona y el comercio de maderas preciosas, lo mismo que el chicle (de Vos, 1996 y 2011). Las maderas bajaban por el río Usumacinta y eran clasificadas en Tenosique; luego conducidas hasta el puerto de Frontera, donde eran cargadas en barcos que las llevaban a Europa o Estados Unidos (de Vos, 1996: 28, 100). Jan de Vos describe a Tenosique como "la última población antes de entrar a la selva" (ibid:: 41), en la que se ubicaban las oficinas de las empresas que explotaban los bosques. De este modo, la localidad fue pieza importante en el funcionamiento de las monterías, campamentos de trabajadores forestales en medio de la selva. Sobre esos lugares, un historiador escribe que "es probable que en ninguna de las industrias del México independiente (...) los trabajadores hayan sido explotados más brutalmente que en las monterías de Chiapas, Tabasco y Guatemala” (Benjamin, 1981: 506). Algunas de las novelas de Bruno Traven son una incursión en este mundo, por ejemplo, La rebelión de los colgados (1936) y Macario, publicada en 1950 (Traven, 2003 [1936] y 2005 [1950]).

52 “El 13 de noviembre de 1940 llegó el tren de Campeche a Tenosique y el 18 de junio de 1949 el ramal que venía siendo tendido desde Coatzacoalcos se unió al ramal que continuaba desde Campeche, en el kilómetro 325 . Esto significó el fin del aislamiento de la península de Yucatán con el centro del país” (Novelo y Franco, 2011: 56). 
en muchos sentidos, una sociedad multicultural. ${ }^{53}$ Tenosique siguió transformándose con los planes nacionales de desarrollo, que contribuyeron a interconectar aún más el territorio. Es en ese contexto que la ciudad experimenta los efectos de la apertura de nuevas rutas internacionales que cruzan la zona.

\title{
Flujos y fronteras
}

\author{
El pensar-fluxus (telepática, astrofísica, magnética y monetariamente) \\ acaba con la hegemonía de la escolástica de la sustancia. \\ Peter Sloterdijk, En el mundo interior del capital., 2010: 76
}

La frontera política entre México y Guatemala que hoy conocemos, fue trazada en 1882, cuando ambos gobiernos firmaron un tratado que estableció los límites entre ambas naciones (Casillas, 2010: 297). Trazaron el contorno de las soberanías estatales en una zona donde existió un intercambio milenario y cuyos límites no coincidían exactamente con los establecidos en los tratados. ${ }^{54}$ La frontera sur abarca 1,139 kilómetros, de los cuales 962 colindan con Guatemala y 176 con Belice. Entre Tabasco y Guatemala hay 290 km de frontera. En 2000 se calculó que en esta frontera vivían, del lado mexicano y guatemalteco, un millón 930 mil 401 personas. En contraste, la frontera norte registró 11 millones 815 mil 287 habitantes. Si bien 50 de los 172 puntos de internación aérea, terrestre o marítima están ubicados en la zona sur, el movimiento de personas es menor con respecto al de la frontera norte: un millón 700 mil personas transitaron por ese linde hacia México durante el año. ${ }^{55}$

\footnotetext{
53 Un estudioso de la frontera sur escribe: "Los centroamericanos en su calidad de migrantes temporales y regionales, traen a México algo más que su fuerza de trabajo y de México llevan algo más que unos pesos y mercancías: son entes sociales que dinamizan una región transnacional, un mercado y una sociedad múltiple en las nacionalidades, lenguas, credos, actividades, culturas y economías que en ella se reúnen” (Casillas, 2010: 300).

${ }^{54}$ De Vos escribe que la frontera vigente entre México y Guatemala a mediados del siglo XIX fue "la que trazó en 1811 el ingeniero guatemalteco Domingo Caballero” y que siguió siendo válida cuando Chiapas declaró su independencia de Guatemala en 1821 y se integró a México en 1824. Sin embargo, la frontera que hoy conocemos fue establecida por el Tratado de Límites en 1882. Hasta 1859, gran parte de la Selva Lacandona pertenecía a Guatemala (de Vos, 1996: 51). La frontera con Belice quedó establecida tal como se la conoce en la actualidad en 1893, mediante arreglos con Gran Bretaña (Fábregas Puig, 1993: 4).

${ }^{55}$ En cambio, en las fronteras terrestres de los Estados Unidos se contabilizaron 243 millones de entradas legales durante 2011 (Alden, 2012: 112).
} 
La frontera sur fue un límite relativamente invisible hasta los años ochenta. Después, en los noventa, empezó a cobrar importancia en términos geopolíticos. " ${ }^{56}$ "La frontera sur, escribe un investigador, es un contexto marcadamente rural, y los escasos centros urbanos muestran notables desigualdades con sus homólogos en otras regiones del país” (Castillo, 2005: 54). Otro investigador la define como una frontera estable con sociedades intrafronterizas dinámicas (Casillas, 2010: 298).

Las fronteras son lugares privilegiados para cierto pensamiento. Han concitado una gran atención en las últimas décadas como espacios 'mágicos' del multiculturalismo, la hibridación, el tráfico de signos, la confusión de lenguas y la mezcla de personas. ${ }^{57}$ Estar en una frontera o cerca de ella podría ser una experiencia excitante y de proximidad, pero debo confesar que nunca tuve esa sensación de cercanía en Tenosique, aunque se encuentre a pocos kilómetros de una. Es tal vez el principal misterio: ¿se puede vivir en una frontera sin tener una cultura o una vida fronteriza en casi ningún sentido?, ¿existen fronteras secretas o ausentes? Frente al entusiasmo generalizado que suscitan las fronteras, me encontré con una sociedad indiferente y extremadamente parca frente a esa condición geográfica. Sin embargo, la frontera marca, en muchos sentidos, la vida cotidiana y el futuro del lugar. Especialmente la que colinda al sur con Guatemala. En mi trabajo de campo las referencias a ese país han sido muy escasas, a pesar de su proximidad. Algunas veces la gente comentaba que había ido de compras a El Ceibo, una zona libre de impuestos en territorio guatemalteco, especie de gigantesco mercado, donde pueden ingresar los ciudadanos mexicanos sólo con una identificación. Sin duda hay muchas más referencias a Mérida, en Yucatán, o a Palenque, en Chiapas, que a cualquier lugar de

56 Parte de esta invisibilidad podría explicarse por las débiles relaciones económicas entre México y Centroamérica. A pesar de las conexiones culturales, la frontera sur es menos activa económicamente que la norte. Sobre ello, Casillas escribe que "la cercanía geográfica no es determinante para el establecimiento de relaciones comerciales más dinámicas de México con Centroamérica. No lo fue antes ni lo es hoy. El comercio de México con los países de Istmo representó apenas el 1.6\% de su comercio total. En cambio, con una participación de casi $80 \%$ de sus intercambios comerciales en el periodo 1990-2007, Estados Unidos ha sido, y es, el socio comercial más importante para México. La proximidad con Estados Unidos es un elemento importante, pero no lo es así para el caso de los países centroamericanos. Del comercio que México mantiene con CA, un 49\% lo realiza con Guatemala, un 4\% con Belice" (Casillas, 2008b: 12).

57 Véase, por ejemplo, las antologías sobre teoría y/o antropología de las fronteras: Basail, 2005; Donnan y Wilson, 1994 y 1999; Grimson, 2000; Michaelsen y Johnson, 2003; Olmos, 2007. 
Guatemala. Tengo la impresión de que para los tenosiquenses, el país centroamericano es un lugar desconocido y lejano. ${ }^{58}$

Cuando comencé a trabajar el tema de frontera en la ciudad, me encontré con un mar de datos diversos, así como de procesos múltiples muy difíciles de desentrañar. No sabía muy bien qué buscaba ni porqué leía artículos y reportes sobre migración, frontera, seguridad, comercio e infraestructura, entre otros. Tenía dos datos claros, por así llamarlos, que habían aparecido de manera sistemática en mi etnografía.

Primero, los cambios que se produjeron en la ciudad, pero específicamente en la sexualidad homoerótica, a partir de la instalación de una zona militar. Según algunos investigadores, desde el levantamiento zapatista en 1994 se produjo una militarización creciente de la frontera sur, que primero estuvo orientada a la insurgencia interna, pero luego comenzó a dirigirse al control fronterizo. La frontera se transformó en un espacio militarizado, como indican Castillo y Toussaint:

A partir de entonces, un motivo de naturaleza interna propició la adopción o el desarrollo de una estrategia de control militar en la zona fronteriza, aunque es preciso anotar que el proceso social no seguía (...) una lógica fronteriza o que atendiera a las relaciones internacionales de la vecindad (...). A partir de entonces, las movilizaciones de los militares se volvieron cotidianas en la región fronteriza (Castillo y Touissant, 2010: 286)

Así, en 1994, Chiapas tenía 91 instalaciones militares en la zona que sumaban, oficialmente, 20 mil efectivos (Armijo, 2012: 42). La base de operaciones de la 38 Zona Militar se asienta en Tenosique, aunque su radio de acción incluye varios municipios de Chiapas.

De pronto, la ciudad se pobló por varios miles de soldados, la mayoría hombres jóvenes, solteros y fuereños. Junto con algunas transformaciones en la economía local, que brindó diversos servicios a estos contingentes, había muchas referencias en las conversaciones y en las historias de vida a la llegada de esos hombres. Algunos de ellos fueron parejas o amantes de los gays de la comunidad.

\footnotetext{
${ }^{58}$ La lejanía, al parecer, es mutua. Según datos del Instituto Nacional de Migración, en 2012 se expidieron 23,231 tarjetas de Visitante Trabajador Fronterizo (TVTF) en Chiapas y sólo 32 en Tabasco. En 2011 la cifra para Tabasco fue de 40 tarjetas (INM, 2012a: 22). Por otro lado, se expidieron 3068 Tarjetas de Visitante Regional (TVR) en 2011 y 3,151 un año después para Tabasco, en cambio para Chiapas se expidieron 69,896 y 58,165, respectivamente (ibid.: 20).
} 
Las "casas de citas", nombre que se les da a los lugares donde se practica el trabajo sexual, incrementaron su número para dar 'servicios' a estos soldados. Lo mismo sucedió con las cantinas y los clandestinos, que les ofrecían un espacio de recreación. Cuando empecé mi investigación había cuatro table dance en los que bailaban mujeres que se desnudaban completamente, departían con los clientes y les ofrecían "privados" para hacer cosas que en público estaban vetadas. Eran lugares para beber, mirar mujeres y conversar con ellas o tocarlas si se contaba con el suficiente dinero. Luego, algunos desaparecieron y abrieron otros.

Aunque parece un mercado oscilante, al igual que el de las cantinas, siempre hay lugares disponibles para beber y conocer mujeres. En las cantinas, si bien no hay desnudos, sí se practica el trabajo sexual. Si la policía catea a alguna de ellas, les pedirá tarjeta sanitaria, es decir, una autorización otorgada por el Ayuntamiento local, tras la realización de exámenes médicos y auscultamiento por personal de salud.

Los soldados movieron la organización social de la sexualidad al impulsar que se creara una infraestructura de entretenimiento más sofisticada y diversa, pero también al traer el anonimato a la ciudad. Gran parte de ellos eran fuereños y muchos de otros estados del país. No conocían a nadie en Tenosique, ni tenían relaciones de parentesco o amistad con la gente del lugar. En esa medida, eran inmunes al control social que se ejerce mediante el conocimiento cercano de las personas. Habitaban el lugar con una dinámica distinta que les permitía transgredir ciertas normas o eludir la vigilancia colectiva. Los militares son vistos como extraños por los habitantes de la ciudad y, en general, la gente no establece relaciones cercanas con ellos. Comúnmente están por un tiempo y luego se marchan. Son ajenos, aunque muchos de ellos hayan nacido en lugares parecidos a Tenosique. Lo que podría resultar un obstáculo para la integración de estos colectivos nómade, se convierte en una oportunidad para el sexo homoerótico. Las censuras que emergen del control social se debilitan en estas circunstancias.

Luego, ya en los primeros años de este siglo, otro flujo de hombres se añadió al de los militares: los migrantes centroamericanos que eligieron Tenosique como lugar de paso hacia el norte del país. Algunas modificaciones en las dinámicas migratorias, durante la primera década de este siglo, produjeron un flujo constante y creciente de transmigrantes. ${ }^{59}$ Por Tenosique

\footnotetext{
59 Algunos organismos calculan que cerca de 400 mil personas transitan por México hacia los EEUU (I(dh)eas, 2011), pero las cifras son divergentes. Para 2008, el Instituto Nacional de Migración (INM) estimó en 178 mil el número, comparado con las 450 mil personas de 2005, después del huracán Stan que causó estragos en
} 
pasa el tren que va hacia Villahermosa y Coatzacoalcos, en Veracruz. Esta es una ruta alternativa a la que empieza en Chiapas y continúa por Oaxaca. Miles de centroamericanos transitan durante todo el año por las inmediaciones de la ciudad. Son fundamentalmente hombres jóvenes, solteros y extranjeros. Nómades como los militares y anónimos como ellos.

Se trata de flujos humanos y eróticos; corporales, subjetivos, pero también sociales y políticos. Parecía que las frías aguas de la globalización tocaban las tibias orillas de esta localidad, de modos insospechados y extraños. ¿Cómo se podían pensar los vínculos entre procesos y niveles tan distintos?, ¿qué tránsito era necesario efectuar entre el deseo, la globalización y la historia?, ¿cómo investigar la trayectoria erótica de fenómenos que no lo son en su origen: la guerra y la migración? Las causas exploradas no explican los efectos registrados. Es decir, si bien hay un vínculo entre el levantamiento zapatista de 1994 en la Selva Lacandona y la formación de una zona militar en Tenosique, el movimiento zapatista no pretendía llevar a miles de hombres jóvenes hasta la ciudad en la que vivían hombres gay dispuestos a conocerlos y a convivir con ellos. El deseo fue un resultado insospechado de esos movimientos sociales y las transformaciones socio-históricas que ocasionaron.

Del mismo modo, el huracán que asoló a Centroamérica y Chiapas en 2005 y destruyó la línea férrea que unía Tapachula con Arriaga, supuso una modificación de los flujos migratorios que integraron a Tenosique en las rutas utilizadas para viajar hacia los Estados Unidos, pero tampoco causó que, de pronto, comenzaran a pasar miles de hombres jóvenes por la ciudad y los gays locales los buscaran como amantes o parejas, los alojaran en sus casas, les dieran de

Centroamérica y el sur de México. Para 2010 registra un total de 65,802 eventos de extranjeros devueltos, un 96\% de ellos centroamericanos y un 78.5\% de hombres; en 2011 la cifra fue de 61,202 (INM, 2012a: 31). Las estadísticas del Instituto indican que en las estaciones migratorias ubicadas en Tabasco hubo 12,770 eventos de alojamiento de migrantes durante 2010 y al año siguiente 6,081 (la reducción fue de un 52.4\%) (ibid.: 29). En Tabasco se realizaron 12,147 y 5,579 devoluciones, respectivamente (ibíd: 31-32). En 2012, Migración realizó 5,135 eventos de devolución de extranjeros en Tabasco (INM, 2012b.: 28). Aunque estas cifras dan una idea de la dimensión del fenómeno migratorio, un experto en el tema sostiene que "a ciencia cierta, no hay manera de demostrar estadísticamente que el flujo transmigratorio centroamericano ha crecido y sigue creciendo; tampoco hay manera de demostrar que ha decrecido. (...) La razón principal es que casi en su totalidad los transmigrantes centroamericanos transitan por México sin la visa correspondiente, es decir lo hacen de manera indocumentada. De ahí que se cuente con apreciaciones y deducciones indirectas de algunos registros de organismos civiles y de instancias oficiales" (Casillas, 2008a: 158). 
comer o tuvieran sexo con ellos y relataran luego sus aventuras. Si bien parece que no hay nexo causal entre deseo e historia, al menos sabemos que se entrecruzan. Ni los soldados ni los migrantes traen el deseo homoerótico, pero lo potencian. Los primeros ayudaron a crear la infraestructura de diversión y vida nocturna que todavía existe y en la que acontece parte importante de la vida gay de la ciudad; los segundos transformaron los bordes de la ciudad en una zona de ligue y contacto transnacional. Ambos colectivos cimbraron el sedentarismo sexual y vincularon los deseos con nomadismos sociales y emocionales que cruzaban la ciudad, pero no permanecían en ella. Así como otras eróticas y trayectorias sexuales arribaron de sitios distantes, las historias que de ellas se desprendieron migraron hacia lugares lejanos.

Pero estas causas difusas y esos efectos inesperados se tradujeron en una pregunta sobre la globalización y algunos procesos socio-históricos que permitían entender determinados fenómenos y acontecimientos sucedidos en Tenosique. Me interrogaba, desde el principio de mi trabajo de campo, cómo pasaba la historia por ese lugar y, luego, cómo lo hacía el mundo. He mantenido una mirada doble, por así llamarla: por un lado, atenta a los sucesos contemporáneos, por otro, a las trayectorias históricas que podrían vincularse con ellos.

Los diversos datos sobre migración y frontera muestran que Tenosique está reinscribiendo su lugar en la historia de México y en ciertos procesos políticos de carácter nacional, global y transnacional. Lo que era, en primera instancia, una práctica cotidiana que llevaba el flujo de la historia hasta los cuerpos y las alcobas, se convirtió en una reorganización del lugar de la ciudad en mapas sociopolíticos complejos, que han experimentado transformaciones profundas con múltiples consecuencias.

He analizado algunas de esas modificaciones, las que considero más relevantes para el estudio, si bien podría abordar otras. Primero, la conformación de una nueva frontera a partir del año 2000. Segundo, los flujos migratorios que no cesan de atravesar la ciudad y la frontera. Tercera, la irrupción del crimen organizado como un actor desterritorializado, pero poderoso, que produce una serie de cambios y será el sostén real o fantasmal de intervenciones estatales e incluso transnacionales en la frontera sur de México. Para poder investigar estos temas me he centrado en la noción de flujo. Desde mi punto de vista, este concepto permite entender fenómenos que se están configurando y cuya característica central es el movimiento. Además, el flujo remite a procesos de territorialización y desterritorialización que son pertinentes en este estudio. Es también una forma de explorar el tránsito de diversos actores (humanos y no humanos) y objetos (naturales y artificiales). Por ejemplo, sujetos y colectivos, pero también 
mercancías, medios de transporte, soberanías y legalidades, deseos y peligros, entre otros. Entiendo flujo como una relación de diferencias que traza el movimiento de un punto a otro de diversos sujetos y bienes, de dinámicas e instituciones, de objetos y medios. Appadurai concibe la diferencia como un atributo central del concepto de cultura:

cuando nosotros decimos que una práctica social, una distinción, una concepción, un objeto o una ideología posee una dimensión cultural (...), intentamos subrayar la idea de una diferencia situada, es decir, una diferencia con relación a algo local, que tomó cuerpo en un lugar determinado donde adquirió ciertos significados (Appadurai, 2001: 15).

Si el flujo se produce entre un punto y otro, como una relación entre diferencias, permite pensar dos registros distintos. Por un lado, el deseo como un flujo entre diferencias eróticas, corporales, sexuales, subjetivas, sociales y contingentes; por otro, como una diferencia entre colectivos, comunidades y sociedades. Un flujo, escribe Anna Tsing, “(...) es el movimiento estimulado a través de canales políticos y económicos" (Tsing, 2000: 338). Si utilizara un lenguaje más clásico, diría que la noción de flujo, entendido como una relación entre diferencias, articula los niveles macro y micro. Pero, asimismo, ayuda a entender cómo se vincula lo local con lo global en términos empíricos.

La diferencia no corresponde sólo a la relación entre dos o más términos, también incluye el flujo que dicha relación genera. Si se logran distinguir los términos, entonces también se podrá conocer el flujo. Por ejemplo, entre las explicaciones que se dan para la migración centroamericana hacia los Estados Unidos resaltan las diferencias salariales, la disponibilidad de trabajo y las características demográficas. Así, en los Estados Unidos el trabajo es mejor pagado que en los países de Centroamérica, habría mayor oferta laboral y necesidad de mano de obra joven. En Centroamérica el trabajo es mal pagado, hay pocos empleos, pero hay mucha gente en edad productiva. Si esos fueran los términos de las diferencias entre ambos mercados laborales, el flujo sería el movimiento entre unos y otros. Los migrantes centroamericanos viajan desde sus países y atraviesan México para conseguir los trabajos e ingresos que no lograrían si permanecen en ellos. Es tan clara e intensa la diferencia, que ni siquiera los peligros detienen el flujo ni modifican radicalmente las intenciones.

Parece una explicación esquemática; sin embargo, lo que me interesa subrayar es la diferencia que permite conectar el flujo de migrantes por Tenosique con otros procesos locales. Esta diferencia estaría situada, en términos de Appadurai, aunque los términos no 
necesariamente lo estén. Por eso los flujos producen diferencias que exceden lo local. He mencionado el interés erótico que los hombres gay de la ciudad sienten por los migrantes centroamericanos, especialmente por los hondureños. Entre ellos, en ese corto momento cuando se cruzan, se genera otro flujo. Las intenciones y los motivos de los hombres gay de la ciudad logran articularse con los de los jóvenes migrantes varones. ${ }^{60}$ Los primeros desean la juventud, virilidad y belleza de los segundos; éstos los bienes y los cuidados que pueden recibir de aquéllos. Esto no excluye la búsqueda del placer sexual. El deseo es más bien un nodo por el que atraviesan necesidades, requerimientos, intenciones y motivos diversos, sin que puedan jerarquizarse y estén, por lo contrario, traslapados unos con respecto a otros. Pero las narraciones que podamos reconstruir quizás privilegien un punto de esos traslapes. El más relevante en el trabajo de campo ha sido el que ocurre entre un deseo erótico y las necesidades básicas de alimentación y alojamiento. Los migrantes son, en su mayoría, individuos pobres, con pocas pertenencias y escaso dinero. A lo largo de su viaje, buscan formas de satisfacer algunas de sus necesidades básicas. Si bien en muchos lugares del trayecto hay organizaciones, fundamentalmente eclesiales, que les ofrecen ayuda, el número de migrantes supera la capacidad de dichos centros para atenderlos. Se genera una red informal de ayuda: gente que da comida o agua, lugares abandonados que sirven de alojamiento, trabajos esporádicos, entre otros.

En este caso, los favores sexuales se intercambian por comida y/o alojamiento e incluso dinero. Sin embargo, esta relación no se puede entender como una forma de trabajo sexual. ${ }^{61}$ Más bien, en un contexto en el que las relaciones entre hombres forman parte de los repertorios sexuales cotidianos, gozan de visibilidad social y cierta legitimidad cultural, las diferencias permiten que se establezca un flujo contingente y momentáneo. ¿Qué tiene para intercambiar un migrante joven y pobre? Su cuerpo, su sexualidad. ¿Qué tiene para ofrecerle

\footnotetext{
60 Según datos del Instituto Nacional de Migración, de las personas mayores de 18 años “alojadas" en las estaciones migratorias durante 2012, un 84.7\% eran hombres y un 74.8\% menores de 18 años (INM, 2012b: 27). Por otra parte, de los extranjeros "devueltos" por el INM durante ese mismo año, los datos fueron $88.2 \%$ y $77.3 \%$ respectivamente (ibid: 28 ).

${ }^{61} \mathrm{El}$ análisis de la migración masculina no puede extenderse al caso de las mujeres. Según algunas investigaciones, es común encontrar mujeres centroamericanas en los espacios y locales dedicados al trabajo sexual en Tapachula y otras ciudades de sur de México (Bronfman et. al., 2003; Fernández-Casanueva, 2009; Leyva y Quintino, 2011). Durante el trabajo de campo realizado en Tenosique he sabido de mujeres centroamericanas que trabajan en casas de citas o en table dance locales. Sin embargo, su presencia es puntual y esporádica.
} 
un hombre gay? Comida, alojamiento, dinero. Pero también placer, entretención, cuidados, conversación. El intercambio no es sólo económico sino afectivo, emocional, corporal y vincular. Pero es claro que, fundamentalmente, esto no sucede al revés: no son los migrantes quienes ofrecen comida y alojamiento, ni los hombres gay juventud y virilidad (aunque en algunos casos también puedan ofrecerlas). En el caso de los hombres hondureños, ${ }^{62}$ mis informantes aprecian algunos de sus atributos: guapos, dotados con penes grandes, buenos amantes, accesibles y fáciles de contactar. Pero, asimismo, se les considera peligrosos. Físicamente se pueden distinguir de los lugareños y de otros centroamericanos.

Si no hay diferencias no hay flujos. Éste sería el axioma que subyace al análisis. Pero debemos determinar cuáles son las diferencias centrales que se articulan en torno a un flujo específico. No todas las diferencias producen los mismos flujos. Quisiera enfatizar que el flujo es transindividual y no depende, en primera instancia, de la voluntad de los individuos. A su vez, los individuos se vinculan con esos flujos de maneras diversas. Por ejemplo, en el caso del deseo erótico, son los hombres gay quienes establecen contactos con los migrantes centroamericanos, que para el resto de la comunidad pasarán sin ser vistos o serán percibidos de otros modos. Las diferencias que produce el flujo migratorio se interceptan con otras como el erotismo, el deseo y las identidades sexuales. Se tocan, por así decirlo, y rápidamente se desacoplan. Los migrantes no se quedan en Tenosique, los hombres gay no los siguen en su viaje. En este sentido, no hay causalidad, sino un encuentro fortuito entre flujos diversos. Si cambiaran algunas condiciones, también se modificarían los flujos y sus entrecruzamientos.

Si extendemos las explicaciones esbozadas hasta ahora podemos agregar otros escenarios. Las políticas fronterizas de México han experimentado transformaciones intensas a partir de los atentados de septiembre de 2001 en los Estados Unidos. ${ }^{63}$ El flujo militar y político de ese

\footnotetext{
${ }^{62}$ Del total de extranjeros “alojados" durante el 2012 en las estaciones migratorias, un 45.3\% son guatemaltecos y el 32.6\% hondureños (INM, 2012b: 28). Un 44.1\% de los extranjeros “devueltos" durante ese año eran guatemaltecos y un $36.7 \%$ hondureños (ibid.: 31).

${ }^{63}$ En junio de 2001 se implementó el llamado Plan Sur, que buscaba fortalecer la vigilancia y el control de los flujos migratorios (Casillas, 2002: 202), pero que luego fue desechado por su inoperancia (Castillo y Toussaint, 2010: 282). Las transformaciones en la política de seguridad nacional de los Estados Unidos después de los atentados del 2001 afectaron a sus países vecinos; la frontera y la migración comenzaron a vincularse con el terrorismo. En 2005, el Instituto Nacional de Migración fue catalogado como Instancia de Seguridad Nacional (Castillo y Toussaint, 2010: 278), lo que se relaciona con los compromisos asumidos con los Estados Unidos: “el endurecimiento de las políticas migratorias tiene que ver también con el compromiso de México de funcionar
} 
país llegó hasta esta frontera, convirtiéndola en un lugar clave para su seguridad nacional (Alden, 2012; Armijo, 2011; Artola, 2005; Casillas: 2002; Castillo y Touissant, 2010). No lo era antes de esos acontecimientos. Pero, por otra parte, el interés de los gobiernos en promover y facilitar el comercio entre los países, ha permitido la creación de una red de caminos y carreteras que conectan las ciudades del sur de México con las del norte de Guatemala, antes aisladas o unidas por caminos de terracería en malas condiciones (Martí, 2008; Proyecto Mesoamérica, 2009b). Eso incrementó el flujo de transportes y mercancías, pero también favoreció el negocio de los carteles de la droga que desembarcan los cargamentos provenientes de Sudamérica en algunos países de Centroamérica y luego los transportan por México en camiones hacia los Estados Unidos (Dudley, 2011; UNODOC, 2010 y 2007).

Un flujo político y militar viene del norte y presiona a las autoridades de México y Guatemala para que transformen la frontera en un lugar 'seguro'; otro del sur, comercial e ilegal, provee de drogas al principal mercado mundial. Los entrecruzamientos entre esos flujos generalmente son violentos. Fuerzas del Estado chocan con las mafias, los migrantes transitan por las rutas del narcotráfico, las políticas de seguridad pública se transforman en otras de seguridad nacional (Arriola, 2009). En Tenosique muchos de esos flujos y de esas fuerzas convergen, produciendo ciertos resultados: paso de migrantes, ocupación de narcotraficantes, intervención del Estado. Nada se dirime localmente, aunque resulte cada vez más difícil pensar lo local sin considerar esos flujos y sus efectos.

Los argumentos y los análisis que trato de desarrollar en este capítulo me han llevado por caminos insospechados. Hay tres que quiero destacar porque se desprenderán, en parte, de lo que estudie en las páginas siguientes. Primero, el tema de la frontera y la migración me condujo al de la soberanía y éste me regresó al de sexualidad, como lo desarrollaré luego de manera más detallada. Pero, a su vez, la soberanía, relacionada con la migración, me llevó al tema de la bestialidad y la animalidad, materializadas en dispositivos sociotécnicos diversos. En este

como un filtro para los migrantes en su frontera sur, con el propósito de frenar su arribo a tierra estadunidense" (ibíd. 289). Esa zona se incorporó a lo que se llaman “ccírculos geopolíticos concéntricos’ de la seguridad estadunidense" (Calleros, 2010: 13) y el fallido Plan Sur fue reemplazado por el Programa de Migración para la Frontera Sur. La migración formará parte de los ámbitos considerados por la Iniciativa Mérida (acordada por los dos países en 2007), lo que permite la adquisición de equipos para la emisión de formas migratorias biométricas en la frontera sur y su cotejo automático (ibid.: 39). 
capítulo trabajaré un ejemplo que luego retomaré para vincularlo con la sexualidad, el cuerpo y las políticas sexuales. Por último, esos dos temas me condujeron a un tercero que me ayudará a explorar las formaciones y prácticas biopolíticas que se despliegan en Tenosique y la frontera desde la perspectiva de algunos colectivos subordinados. Esto me permitirá relacionar las transformaciones en la seguridad pública de la ciudad con la irrupción del narcotráfico en la escena local. Todo este conjunto de materias, junto con los análisis sobre ciudadanía, desemboca en una reflexión sobre el poder en esta localidad, visto fundamentalmente desde el campo de la sexualidad, pero sin restringirse a él.

Menciono todos estos trayectos futuros porque los vínculos que he nombrado me produjeron sorpresa, en un primer momento. Si bien entendí que era importante abordar el tema de la frontera y la migración, así como el de la seguridad, no sabía cómo se relacionarían con los otros que abordo en distintos capítulos. Pero no sólo se interconectaron, sino que esa conexión me condujo a algunas dimensiones destacadas sobre la configuración de la sexualidad en la ciudad. Esto me permitirá aumentar el lente de los análisis, por así decirlo, para tratar asuntos que han sido planteados, muchas veces, como conceptos abstractos o muy lejanos del contexto que investigo. La biopolítica; la discusión contemporánea sobre soberanía y excepción; el gobierno de los sujetos extraños, enfermos, anormales o marginales; los límites entre cultura y naturaleza; la intervención de agentes no humanos en las relaciones sociales; así como nuevas formulaciones del poder y las instituciones. Sin estar ausentes de mi reflexión, el hallazgo fue encontrar sustentos empíricos, nexos entre distintos ámbitos, argumentos teóricos nuevos.

Sospecho que mis hallazgos son signos de una modificación a gran escala en las formas de institucionalizar y ejercer el poder, en el gobierno de poblaciones y sujetos liminares, en las inscripciones colectivas de los cuerpos y las vidas, en las técnicas de exterminio y persecución, así como en las luchas venideras en el campo de la ciudadanía y los derechos, pero también de la sobrevivencia y los cuerpos. Me podré aproximar a todo esto con materiales que me parecen inéditos y se producen en una zona donde muchos procesos sociales, económicos y políticos adquieren un cariz particular. Las fronteras son como radiografías de los cuerpos sociales que descubren su podredumbre o su esperanza. 
Anna Tsing (2005) propone el concepto de fricción para pensar el encuentro conflictivo entre procesos globales y locales. En su extraordinaria etnografía sobre una isla de Indonesia reconstruye y relata esas fricciones, ocupando muchos puntos de vista con materiales diversos y perspectivas múltiples. En su escritura emerge un caleidoscopio de procesos sociales con ramificaciones gigantescas, pero también expresiones intensamente locales. Las bolsas de comercio se cruzan, en algún punto, con la venta de comida a cuadrillas de trabajadores, y las transnacionales con la reorganización del trabajo en una comunidad local que abandona sus medios tradicionales de subsistencia (o es obligada a ello) para dedicarse a labores mineras o agrícolas de tipo industrial. Los paisajes van cambiando conforme nuevos negocios se abren, se desarrollan y también fracasan. Y después quedan los rastros de una presencia humana invasiva que se ha retirado. Los bosques se confunden con el asfalto o con las máquinas, mientras los individuos y las comunidades intentan localizarse en esa trama imposible de entender y de reconstruir.

La historia es un tifón que todo lo modifica, pero que también se diluye. Las grandes explicaciones que privilegian un concepto por sobre un proceso sirven de poco, según Tsing, porque abren perspectivas analíticas demasiado amplias para entender su expresión o concreción local, pero también demasiado estrechas para visualizar y comprender la densa trama de relaciones que se anuda, por ejemplo, en torno a un bosque explotado de forma inmisericorde. ${ }^{64} \mathrm{~A}$ partir de ese proceso se modifican los ecosistemas, pero también las formas locales de vida. Miles de personas se trasladan a través de cientos de kilómetros, se conectan centros mundiales de comercio con intereses políticos nacionales, regionales y locales, y se desatan formas de violencia social y política que subordinan las poblaciones a los planes del Estado y las transnacionales, pero también a los jefes políticos locales.

Como metáfora, argumenta Tsing, la fricción “(...) nos recuerda que encuentros heterogéneos y desiguales pueden conducir a nuevos arreglos de cultura y poder” (Tsing, 2005: 5). Investigar las fricciones es una forma de entender cómo las culturas son coproducidas, así

\footnotetext{
${ }^{64}$ Raymond Williams escribe: “todas las complejidades conocidas, las tensiones experimentadas, los cambios y las incertidumbres, las formas intrincadas de la desigualdad y la confusión, se hallan en contra de los términos de la reducción y muy pronto, por extensión, en contra del propio análisis social” (Williams, 2009: 171).
} 
como identificar y conocer “(...) las cualidades difíciles, desiguales, inestables y creativas de la interconexión a través de la diferencia” (Tsing, 2005: 3).

La relación entre lo global y lo local ha producido ríos de tinta (Appadurai, 1999, Gupta y Ferguson, 1997; Hannerz, 1996; Kearney, 1995; Metcaff, 2001; Moore, 2004; Ulin, 2004). La antropología parece debatirse entre una nostalgia discreta por mundos más o menos discernibles y la sensación de que fenómenos ajenos a las dinámicas locales arrasan con las formas de vida y los espacios habitables, con los modos de comunicación y subsistencia. Lo global y lo local parecen campos disjuntos que no logran articularse sino a causa de pequeños alfileres que sujetan una tela sobre la pared resquebrajada de la historia. El entusiasmo cauto que en algunos suscitaron los flujos globales, las nuevas tecnologías de la información, la desterritorialización de la economía y de la política, las formas transnacionales de resistencia, los movimientos incesantes e incontenibles de sujetos y objetos, la erosión de las soberanías estatales, el multiculturalismo y otros fenómenos semejantes, se transformó en una melancolía vigilante cuando se observó lo que esas corrientes globales habían dejado en las orillas locales. Vemos las piedras y las ramas, también la basura, pero no sabemos de dónde vienen.

En el caso de Tenosique, gran parte de lo que sucede y que acá intento reconstruir y entender, está determinado por contextos y procesos completamente ajenos al espacio local. La comunidad no decide que el tráfico de drogas se traslade a Centroamérica o que los migrantes centroamericanos elijan esa frontera para ingresar a México. De pronto este mar global e histórico trae grandes corrientes que atraviesan la vida local y la modifican profundamente. El levantamiento zapatista ocurrió en las coordenadas de otros lugares y localidades, pero una zona militar se instaló en Tenosique como parte de la estrategia que el Estado mexicano elaboró para contener o responder a ese movimiento. Los grandes flujos de solidaridad y de interés internacional hacia los zapatistas no pasaron por Tenosique.

La ciudad fronteriza que estudio no contó con referentes culturales que trajeran también las propuestas globales de liberación y emancipación. Aprendió a convivir con los militares, así como ha aprendido, relativamente, a hacerlo con los migrantes, con los narcotraficantes, con los defensores de derechos humanos, con las constructoras, con los policías federales, con los burócratas estatales y federales que cada cierto tiempo encuentran la respuesta definitiva a todos los problemas fronterizos o diseñan programas ambiciosos de integración regional. Todos ellos se marchan, tarde o temprano. Algunos regresan, otros no. Pero parte de los procesos que luego se producen en la localidad se vincula con su presencia y acciones. Desde el 
migrante que pide comida, se aloja en el Hogar administrado por la Iglesia católica y luego intenta seguir su camino sobre el tren que va hacia Villahermosa y Coatzacoalcos, hasta el funcionario federal o internacional que visita la ciudad o la incluye en su trabajo, observa mapas y fotos de la frontera, piensa en vías de comunicación y corredores transoceánicos e intercontinentales que unirán todo Centroamérica con los Estados Unidos. Sin olvidar, por supuesto, al militar que vive unos meses en la ciudad y después es trasladado a otro lugar del país; que tiene sexo con las trabajadoras sexuales; se emborracha en las cantinas; alquila pequeños cuartos; compra en los comercios; se sienta en el parque central a un costado del Ayuntamiento local sin saber qué hacer, pero con tiempo suficiente para ver pasar la tarde o el traficante de drogas que llega en grandes camionetas y sigue hacia el sur, misterioso y temido, fantasmal pero drástico en sus acciones, poderoso sin duda, pero completamente esquivo y ajeno.

Lo local es esta orilla donde se acumulan los efectos, pero que cuenta con escasas herramientas para determinar su destino. Al futuro se lo tragó un dragón feroz. Pero también hay un denso mundo de vínculos y relaciones sociales que parece fuera de la historia, movilizado por el tiempo cansino de los barrios y las calles, de los parentescos y las amistades, de las rencillas políticas y los chismes, de cierta memoria colectiva y algunos proyectos comunes, de las fiestas y las celebraciones, del trabajo cotidiano y los encuentros casuales. Como si ante esos influjos tan intensos, pero también extraños, la única respuesta fuera una especie de tiempo disjunto que fluye de espaldas a la historia nacional y los procesos globales, una red apretada de enlaces y pláticas intensamente locales, barriales, familiares. Esa corriente perturbadora se enfrenta con la indiferencia de quien escucha el fragor del mundo, pero sigue haciendo sus cosas. Y no hablo, por supuesto, de una especie de ostracismo acorazado frente a lo que "más allá" acontece, sino a un registro del mundo que parece fuera del tiempo, en el que los individuos se relacionan y juntan, se separan y conviven, discuten, trabajan y aman e incluso mueren.

La comidilla cotidiana que describo está hecha de afectos y de chismes, de pequeñas historias y grandes problemas, de religión y política, pero sin que el estrépito de la Historia ni el de los flujos globales altere su gramática, tense sus emociones ni desarme sus prácticas. Pactos afectivos y territoriales implícitos, aunque poderosos, resguardan a los sujetos de la incertidumbre. Los ríos globales rugen, pero se les escucha lejos. Tal vez no es más que un convencimiento, una ilusión que se desbarata con las duras pruebas de la realidad, pero con 
una gran capacidad aglutinadora. La gente se reúne en torno a las mesas para comer, llena los salones de clases, cotillea en las puertas de las casas, va a sus trabajos, regresa, compra en los mercados, espera en los consultorios o en las estaciones. Y lo hace como si todo pudiera ser siempre del mismo modo, como si el mundo fuera algo ajeno, de cierta forma. Ve pasar a los migrantes, escucha historias de narcotraficantes, se encuentra con los militares, repite rumores sobre las autoridades y el gobierno, se queja de los policías y los médicos. Todo lo mira como si fuera importante, pero lejano.

¿Cuáles son las distancias que los sujetos y los colectivos elaboran entre sus vidas y el mundo, entre sus historias y la Historia, entre sus necesidades y la economía, entre sus conflictos y la política, entre sus saberes y la pedagogía, entre sus cuerpos y la medicina? Esas distancias se deben aquilatar localmente. No hay una medida general que permita saber dónde está un sujeto o una comunidad en relación con los procesos de mayor o menor escala. Si bien concuerdo con la importancia que Tsing da a las convergencias inconsistentes que forman y producen la globalización y las múltiples agendas, prácticas y procesos "que podrían estar o no profundamente interconectados en un momento histórico dado" (Tsing, 2000: 334), creo que también es necesario enfatizar la desconexión, a veces radical, de la vida cotidiana y lo que intentamos delimitar como procesos socio-históricos de carácter global. Sin duda la vida local no es inmune a estos procesos y, al contrario, es transformada por ellos, aunque sea de manera incierta e inesperada, pero las formas como se elaboran los sentidos, se producen afectos, inauguran interpretaciones, crean y reproducen prácticas sociales, son, en alguna medida, autónomas y específicas. Hay una dimensión autopoyética en lo local que es parte de su fortaleza y sólo grandes conflictos como guerras, revoluciones, crisis políticas o económicas, podrían socavarla.

Sin embargo, de pronto se producen alineaciones históricas con un particular poder. Acontecimientos lejanos producen cambios importantes en otro lugar; decisiones políticas o económicas modifican las vidas en zonas remotas; lo que parece llevar al progreso termina trayendo violencia y caos; viejas subordinaciones pierden, de pronto, las estructuras que las sostuvieron; antiguas alianzas y viejos pactos son barridos como el polvo por el viento del verano. 
La frontera de México con Guatemala fue, hasta entrados los años noventa del siglo pasado, un lugar relativamente invisible ${ }^{65}$ (Castillo, 2005; Flores, 1993). Salvo la zona cercana a Tapachula, en Chiapas, el resto del territorio despertaba escaso. Una larga secuencia de acontecimientos, crisis, medidas, cambios y procesos transformaron la zona. De pronto se convirtió en un espacio prominente para las políticas públicas de México, comenzó a figurar en los mapas de las agencias estadunidenses y concitó la atención de los medios de comunicación. Si bien en cada trayecto de esa franja se podrían especificar procesos y modificaciones, sólo atenderé a los que han afectado, fundamentalmente, a Tenosique.

El término fricción, propuesto por Tsing, permite analizar la forma cómo las instituciones, los movimientos sociales y políticos, los procesos socio-históricos y las transformaciones de carácter y amplitud diferentes se presentan (y concretizan) en un espacio local, dislocando tanto los supuestos sobre la globalización, como desplazando los de la localidad. Para pensar una fricción es necesario conocer cuáles son las superficies, por así llamarlas, de rozamiento.

Los procesos que he podido distinguir en este capítulo son específicos. Hay muchos otros que no incluyo, pero también juegan un papel destacado. Por ejemplo, desde que comencé mi trabajo de campo se han expandido considerablemente el uso de Internet y el acceso a redes sociales. Gran parte de las personas que conozco poseen perfiles en Facebook, especialmente los más jóvenes. Los lugares donde alguien puede conectarse a la red son cada vez más numerosos, así como se incrementa la cantidad de personas que acceden desde sus casas por medio de computadoras. Incluso en pequeñas localidades de menos de 2 mil habitantes, hay cafés u otro tipo de espacios en los que se puede acceder a la Red. Si bien es un proceso reciente, creo que modificará profundamente los esquemas con que se construyen los mundos locales y las referencias a espacios diversos: nacionales, internacionales y globales. La

\footnotetext{
${ }^{65}$ Es difícil determinar los criterios de visibilidad e invisibilidad para un lugar o una zona geográfica y cultural. Podrían ser muchos, desde la importancia política, la relevancia económica, la presencia mediática, entre otros. Por ejemplo, el conflicto zapatista atrajo la atención nacional e internacional hacia un área cercana a Guatemala, aunque en esa zona se habían asentado décadas antes refugiados guatemaltecos que huían de la guerra civil que asoló a ese país (Castillo, 1999). ¿Qué es visible?, ¿cómo adquiere un grupo, un fenómeno, un movimiento mayor visibilidad, o no? Durante el 2014 la frontera sur de México adquirió una particular visibilidad a raíz del éxodo de niños centroamericanos no acompañados hacia los Estados Unidos. Los autores, en general, tienen como vector de visibilidad al Estado, los organismos internacionales y los medios de comunicación. La prensa internacional, especialmente la estadounidense, 'descubrió' la miseria y la violencia de los países centroamericanos cuando sus niños repletaron las estaciones migratorias de su país.
} 
compresión del mundo que ha sido descrita por algunos se vuelve un fenómeno tangible (Appadurai, 2001; Hannerz, 1996; Harvey, 2000; Lash y Urry, 1998).

Las coordenadas con las que se piensa y experimenta la cercanía y lejanía han sido modificadas por los medios de comunicación en general, pero por la televisión e Internet de manera particular. El acceso a recursos culturales, a distintos canales de información, a redes que no pueden someterse a ningún tipo de censura y tampoco responden a intereses políticos particulares, cambiará el ejercicio de la ciudadanía, si no es que ya lo está haciendo. Estamos, me parece, ante un umbral en el uso de los medios de comunicación, en la formación de comunidades y colectivos virtuales de todo tipo, en la producción y distribución de la información que incidirá de manera profunda en las formas como se ejerce y representa la política. Los viejos patrones de opacidad comienzan a diluirse por la disposición masiva de medios de registro y transmisión; los antiguos secretos salen a la luz del día; las arcaicas barreras que separaban a los ciudadanos de sus representantes y a los sujetos de las instituciones se debilitan. Tsing sostiene que la globalidad es multirreferencial y permite articular registros muy distintos: económicos y culturales, centrales y periféricos, conservadores y progresistas (Tsing, 2000: 332). Ello no obedece a un esquema general, tampoco se puede prever y aunque podamos identificarlos, o incluso diferenciar sus efectos, la articulación será contingente y particular.

Cuando en 2005 el huracán Stan asoló Centroamérica y el sur de México, no eran previsibles sus consecuencias en los movimientos migratorios. La línea del tren entre Tapachula y Arriaga fue destruida y recientemente comenzó a ser reconstruida. Como lo indicamos, esto produjo que muchos migrantes modificaran sus rutas y tomaran otras, entre ellas Tenosique. El tren que pasa por esta ciudad seguía en funciones y conectaba directamente con Veracruz. Desde 2000, una combinación de factores sociales, climáticos y económicos afectó a los países centroamericanos y el número de migrantes se incrementó (Casillas, 2008a). El trayecto que pasa por Tenosique fue favorecido por los planes de interconexión regional impulsados por el Proyecto Mesoamérica, heredero del antiguo Plan Puebla-Panamá. ${ }^{66}$

\footnotetext{
${ }^{66}$ Cuando se inauguró el puente fronterizo, el entonces Presidente de la República mexicana declaró: "Hoy, con la inauguración de este Puerto Fronterizo El Ceibo y con la Carretera Lagunitas-El Ceibo, avanzamos en la estrategia de la integración de Mesoamérica, en el Proyecto Mesoamérica, porque estamos, no con discursos, sino con hechos, con energía eléctrica interconectada y con carreteras construidas, conectando y hermanando más que nunca a Mesoamérica y a Guatemala y a México”. En el mismo documento del Proyecto Mesoamérica donde se
} 
Con miras a facilitar el comercio entre los países, auspiciar la integración regional y mejorar la calidad de vida de los habitantes de estas zonas, se construyeron carreteras donde hubo sólo caminos de tierra. La ruta El Ceibo-Lagunitas en Guatemala fue financiada por el gobierno mexicano, lo que la conectó con la carretera federal que pasa por Tenosique. Una zona que había tenido enormes problemas de intercomunicación contaba con vías rápidas que facilitaban el paso de transportes de alto tonelaje y el movimiento de vehículos de todo tipo. Antes de estas obras los migrantes navegaban por el río San Pedro para acercarse a la frontera o caminaban muchos kilómetros. Las carreteras facilitaron sus desplazamientos e hicieron relativamente accesible el paso por Tenosique.

Esas mismas vías jugarán un papel importante en otro proceso. Cuando en 2007 el entonces Presidente de la República declaró una "guerra" contra el narcotráfico, con miras a recuperar tanto la soberanía territorial como el monopolio de la violencia, se desconocían los efectos que produciría dicha confrontación. Uno de ellos fue la intensificación del uso de los países de Centroamérica como plataformas para el arribo de los cargamentos de drogas provenientes de Sudamérica. ${ }^{67}$ Dadas las crecientes dificultades, pero sobre todos los costos, del internamiento por México, los principales carteles de las drogas comenzaron a operar de manera sistemática en esos países y se crearon rutas de transporte que empezaban en algún lugar de sus geografías y luego continuaban por México hasta los Estados Unidos. Una de las

citan estas palabras, se escribe que la "Red Internacional de Carreteras Mesoamericanas (RICAM) está compuesta por 13,132 kilómetros de carreteras distribuidos en 5 corredores cuyo avance abre nuevas posibilidades para la integración de Mesoamérica, al facilitar el flujo de bienes y personas en la región. De esta manera se busca conectar poblaciones, zonas productivas y los principales puntos de distribución y embarque de mercancías.” (Proyecto Mesoamérica, 2009a: s/p). En notas periodísticas publicadas en esas fechas, se expresaba el temor a que la carretera facilitara la presencia del crimen organizado; en una de ellas se escribe que los "habitantes de ambos lados de esta frontera entre México y Guatemala tienen esperanzas de progresar, pero junto con ello existe temor de facilitar el arraigo del crimen organizado con la próxima apertura de la carretera internacional que unirá a estas naciones." (Noreste, 2008: s/p).

${ }^{67}$ Informes de las Naciones Unidas indican que el 88\% de la cocaína destinada a los Estados Unidos transita por el corredor Centroamérica/México (UNODC, 2007). Los cargamentos llegan desde Sudamérica en barco o en avionetas, sea por el Pacífico o el Caribe. Los carteles mexicanos se afincaron en los países centroamericanos y, en algunos, comenzaron a tomar el control del tráfico de drogas (Dudley, 2010; UNODC, 2010). En Honduras, la tasa de homicidios de hombres (por 100 mil habitantes) era de 147 en 2010 y 162 en 2011; en Guatemala de 75 y 58, respectivamente (PNUD, 2013: 54). En Costa Rica fue de 19 en 2010 y en Chile de 2 (ibíd.). La Organización Mundial de la Salud considera que una tasa sobre 10 configura una epidemia (ibid:: 46). 
rutas inicia en el departamento de El Petén, en Guatemala, pasa por Tenosique y sus alrededores, sigue por Tabasco hacia Veracruz y finaliza en Tamaulipas. La ciudad de pronto quedó incluida en los mapas del narcotráfico, como un punto de paso de sus mercancías.

Pero estos dos fenómenos se conjugaron de manera aciaga. Una creciente migración y la presencia del crimen organizado transformaron el fenómeno migratorio en una de las grandes tragedias humanitarias de las últimas décadas en México: extorsiones y violaciones, secuestros y asesinatos, entre otros delitos, se multiplicaron durante los últimos 5 años. La mayoría sucede en las rutas que los migrantes siguen o en lugares aledaños. Tenosique quedó inserta en la expansión de las rutas internacionales, en los flujos criminales y en las adversidades de la migración. La prensa comenzó a relacionar su nombre con violaciones a los derechos humanos de los migrantes, así como con un lugar peligroso y temible. ${ }^{68} \mathrm{El}$ anonimato que la había caracterizado se transformó en una fama funesta que, en muchos sentidos, no corresponde con la visión de sus habitantes.

Como lo indica Tsing, los aspectos más prometedores de la globalización pueden estar conectados, profundamente, con los más peligrosos (Tsing, 2000: 334). La apertura de carreteras que disminuyan el aislamiento y alivien de algún modo a la deprimida economía local, supone abrir la caja de Pandora en esas latitudes y liberar los demonios del crimen organizado que amenazan la vida local. El vínculo entre expansión comercial, movimientos migratorios y actividades criminales confirma que las fricciones "desvían las trayectorias

\footnotetext{
68 Por ejemplo, una nota de El Universal, de febrero de 2011, lleva la cabeza "Tenosique, ruta de terror para migrantes", y comienza así: "La inseguridad que desde hace tiempo existe en la frontera sur de Tabasco es un riesgo constante para los migrantes centroamericanos, ya que a la fecha ninguna autoridad ha instrumentado acciones para prevenir y controlar la delincuencia común, que junto con el crimen organizado, mantiene su coto en la línea fronteriza de Guatemala y México, denunciaron organizaciones no gubernamentales defensoras de los derechos humanos" (Barboza, 2011: s/p). El título de una nota de El País, de abril de 2013, reza: "Las mafias se infiltran en albergues para inmigrantes centroamericanos”. En el cuerpo del texto se relata el viaje de un migrante, entrevistado en la ciudad de México: "en el camino lo golpearon, lo asaltaron, lo secuestraron, lo amenazaron. Las llagas de sus pies se hicieron insoportables tras caminar cientos de kilómetros. Y cuando finalmente llegó al refugio de Tenosique (Tabasco, sureste de México) se encontró con que las mafias que le habían hecho la vida imposible desde el inicio del viaje estaban ahí. Pedro reconoció a uno de los hombres que lo había secuestrado en la cocina del refugio." (Calderón, 2013: s/p).
} 
históricas a través del asentimiento, la exclusión y la particularización” (Tsing, 2005: 6; mi traducción).

Vistas desde el lugar donde estoy tratando de pensar esta tensión entre lo global y lo local, y desde las prácticas que describo, las fricciones son todavía más imperceptibles. El deseo es un campo donde se cruza migración con erotismo, de manera ocasional pero constante. En 2009 conocí a un muchacho hondureño, amigo de algunos gays de la ciudad, que diariamente andaba en el centro realizando pequeños trabajos. Lo vi en varias oportunidades durante ese año y luego desapareció. Me contó que era de Tegucigalpa y que lo habían deportado al entrar a los Estados Unidos. Lo detuvieron mientras caminaba por una carretera de ese país por la que sólo transitan coches. Una vez que lo dejaron en la frontera con México viajó hacia el sur y regresó a su país. Pero luego había decidido entrar nuevamente a los Estados Unidos. Mientras planeaba esta nueva incursión se detuvo un tiempo en Tenosique.

El chico desertó de una pandilla de su ciudad cuando le exigieron matar a un rival de otra banda. Su negativa representaba una traición, por lo que en cualquier momento sería asesinado. Por eso huyó hacia el norte. No podía regresar a Tegucigalpa sin riesgo de que lo mataran. Estaba suspendido en Tenosique entre los peligros de su ciudad natal y los del viaje al norte. Durante ese año trabajó en distintas actividades del Ayuntamiento. Se acercaban las elecciones y los políticos locales se apuraban en "hacer cosas" por la gente del municipio, aunque la miseria aumentara, las calles fueran casi intransitables por la cantidad y el tamaño de los baches que las cubrían y las inundaciones periódicas que anegaban algunas colonias populares y dañaban los cultivos en las comunidades rurales. Los políticos trazan una cronología previsible para actuar y visibilizarse: la cercanía de una elección y el comienzo de un mandato. En el primer tiempo se los ve en las calles, hablan con todo tipo de personas, parecen preocupados por la realidad local. Luego, reparten prebendas con puestos y reproducen una extraña sordina burocrática que sólo termina cuando de nuevo se aproxima otra elección.

Este muchacho hondureño se había beneficiado de la repentina presteza del alcalde de entonces, consciente de la animadversión que por él sentían sus gobernados a causa, entre otros motivos, de los daños producidos por las inundaciones de $2007 .{ }^{69}$ La política se juega

\footnotetext{
${ }^{69}$ A finales de octubre del 2007, Tabasco sufrió una de las mayores inundaciones de las que se tenga memoria. Más de 400 mil personas fueron afectadas directamente por el agua de los siete ríos que se desbordaron. El centro de la capital del Estado, Villahermosa, quedó cubierto por varios metros de agua, así como parte de las colonias
} 
entre esas opiniones generalizadas y algunos actos de beneficencia. Los políticos locales jamás dan algo sin pedir a cambio, su generosidad está corroída por el interés y el cálculo más mezquino orienta sus gestos de solidaridad. Ese trabajo había producido en el joven extranjero la expectativa de que el alcalde se preocupara por su situación migratoria. Era, como casi todos los centroamericanos que pasan por Tenosique, un indocumentado. En una de nuestras conversaciones me contó un sueño que había tenido: el alcalde tramitaba los papeles necesarios para que residiera legalmente en el país y tuviera un trabajo. Él lo interpretó como una premonición; confiaba en que algo así sucediera.

La esperanza siempre es más clara que la vida y la ley se mostraba benevolente en los sueños del muchacho, como si el derecho fuera a la vez un espacio onírico y un oráculo. El chico, atrapado entre la violencia de su país y la persecución que experimentaría en los Estados Unidos, habitaba Tenosique en un compás de espera. Exiliado de algún modo de su ciudad natal por las pandillas, expulsado por las autoridades estadounidenses y perseguido por las mexicanas, su lugar era incierto. Sólo en los sueños alcanzaba un estatus legal claro, en ellos experimentaba derechos y vencía el miedo. Como una Eurídice fronteriza y nómade, rastreaba en las profundidades psíquicas, pero también míticas, un sitio habitable.

Esta historia, que parece tan personal, entrecruza diversas fricciones: la inseguridad, la migración, la miseria y los viajes. El espacio social en el que vivía este migrante fue desarmado por procesos que atravesaron su vida. Su biografía no se entiende fuera de estas fricciones, pero también develan una historia singular. Quizás no conoce los procesos históricos que han marcado su vida, pero los encarna en viajes, huidas y expulsiones, en sueños fallidos y deseos.

\section{El Estado y la Bestia: soberanía y frontera}

La fábrica del Estado moderno tenía el emblema de la muerte en su centro hueco.

Claudio Lomnitz, Idea de la muerte en México, 2011: 210

En un reportaje sobre la franja fronteriza entre Chiapas con Guatemala, dos periodistas del diario The Washington Post escriben:

populares ubicadas a las orillas del río Grijalva. El río Usumacinta también se desbordó y anegó las colonias aledañas, construidas a veces sobre su cauce natural. 
Llamar a esta frontera "porosa" sería sugerir que hay partes que no lo son. Para los pueblos indígenas, sus ayudantes y los contrabandistas que la atraviesan libremente, no hay frontera alguna. Se trata de una línea en el mapa. En el río Suchiate, cerca de la costa del Pacífico, los barqueros con balsas improvisadas de palo atraviesan las corrientes, como los gondoleros, transportando granos, gasolina, cerveza y pañales hacia México o Guatemala a la vista de las autoridades. (Miroff y Booth, citado en Espach et. al., 2011: 24)

Esta descripción se repite en textos académicos, en informes de agencias estadunidenses y en los reportes de organismos de derechos humanos. Actores muy diversos concuerdan en algunas consideraciones álgidas: la frontera entre México y Guatemala es un espacio donde el Estado (de ambos países) tiene poca presencia, parece ingobernable y con un débil respeto por la ley. Los intereses y actores que convergen en estas descripciones son múltiples: agencias de los Estados Unidos que asesoran a las Fuerzas Armadas de ese país y describen un mundo caótico propicio para la instalación y el tránsito de terroristas que después atacarán a los estadounidenses; investigadores y académicos que intentan visibilizar los problemas que se acumulan en esa zona, pero también revelar su carácter multicultural y poroso; instituciones nacionales e internacionales interesadas en el desarrollo económico del área y en su potencial comercial; organismos que denuncian las violaciones a los derechos humanos de los migrantes centroamericanos en su paso por México y, específicamente, en las zonas inmediatas a la frontera; la prensa nacional e internacional atenta al área, principalmente por el fenómeno migratorio y la violencia que lo marca.

Esta convergencia descriptiva es extraña: ¿por qué actores tan distintos e incluso opuestos coinciden en algunas de sus evaluaciones?, ¿qué producirán estas narraciones sobre violencia, desgobierno y desorden?, ¿qué tipo de frontera se dibuja en estas representaciones?, ¿qué demandarían a los gobiernos y qué intervenciones futuras delinearían? No es una discusión conceptual en la mayoría de los casos, sino una demanda para que México y Guatemala actúen de otra manera en la zona. Quizás todos estos actores invocan, de manera más o menos clara, una verdadera frontera con modelos de control que garanticen el imperio de la ley. Si bien sus diagnósticos discrepan y algunos, como los de las consultoras estadounidenses, insisten en la conformación de una frontera sur de México a imagen y semejanza de la que colinda con Estados Unidos, otros reclaman un límite desmilitarizado que facilite el flujo de personas, pero resguarde sus derechos humanos; no obstante, lo que todos discuten, a mi parecer, es la soberanía estatal sobre estos territorios. 
La degradación, inexistencia o pérdida de la soberanía estatal puede deberse a causas múltiples, algunas históricas, otras políticas; unas de larga data, otras recientes. El Estado resolvería los problemas que se analizan si contara con los recursos y la voluntad política para ello. Los Estados Unidos pretenden que la vigilancia de esa frontera fortalezca la que ellos efectúan en la suya con México. Por otra parte, los organismos de derechos humanos pugnan porque el Estado mexicano asegure el paso de los centroamericanos por su territorio mediante dos acciones: consintiendo su tránsito y protegiendo sus derechos. La soberanía permitiría, a la vez, cerrar y abrir la frontera, militarizarla y hacerla transitable, restringir el paso de las personas y facilitarlo. No es extraño que estas disputas se den en torno a una frontera, pues se trata de un lugar privilegiado para atestiguar el debilitamiento de las soberanías estatales. ${ }^{70}$

$\mathrm{Al}$ parecer, la soberanía no es un bloque sólido, sino una amplia gama de instituciones, discursos, prácticas, leyes, procedimientos y recursos. De este modo, analizarla desde las microprácticas políticas que nos interesan en esta etnografía, es verla como un caleidoscopio. En la vida cotidiana la soberanía, ese ejercicio de imposición del Estado, no dependerá de los textos legales, fundamentalmente, sino de la densa e intrincada acción de las instituciones y las burocracias y de otros actores no estatales (Hansen y Stepputat, 2006). La soberanía molar se cruzará con otra molecular. Por ejemplo, cuando un agente del Instituto Nacional de Migración detiene o persigue a un migrante indocumentado, su proceder está sostenido por ciertos textos legales, por la organización y los presupuestos de dicho Instituto, pero no se agota en ellos. La persecución implica movimientos corporales, disposiciones anímicas y afectivas, medios técnicos, voluntades individuales. Remitir una práctica a sus representaciones supondría que sólo es un reflejo de tramas discursivas e institucionales, no su ejercicio real, por así llamarlo, su concreción en determinadas coordenadas espacio-temporales y sociales.

Sin embargo, un concepto legal y político de la soberanía adquiere aún gran importancia. Para Weber, por ejemplo, el Estado:

es aquella comunidad humana que en el interior de determinado territorio - el concepto de 'territorio' es esencial a la definición - reclama para sí (con éxito) el monopolio de la coacción física legítima. Porque lo específico de la actualidad es que a

\footnotetext{
${ }^{70}$ La discusión sobre lo global se intensifica en este debate. Por una parte, estas convergencias confirman los postulados de autores que estiman que la globalización debilita las soberanías estatales (Hardt y Negri, 2005, Appadurai, 1999). Por otro, también apoyan los argumentos de quienes apuestan por una transformación de las mismas (Ong, 2005, 2006 y 2012).
} 
las demás asociaciones o personas no se les concede el derecho a la coacción física en la medida en que el Estado lo permite. Éste se considera, pues, como fuente única del ‘derecho’ de coacción. (Weber, 2010[1922]:1056)

La noción de soberanía, central en el pensamiento político clásico, corresponde con esta definición del Estado que supone tanto un territorio como el monopolio de la violencia legítima. Aihwa Ong anota que convencionalmente la soberanía se define como "el poder del Estado, centralizado y concentrado en el aparato militar, para garantizar el orden y la estabilidad con miras a salvaguardar la integridad territorial del Estado-nación" (Ong, 2006: 76). Estas definiciones han sido debatidas por una copiosa literatura antropológica que concibe la soberanía como un tema central o la discute a partir de la investigación etnográfica. No es sólo una discusión académica, porque perfila la forma misma del Estado (Das y Poole, 2008), las prácticas del poder (Navaro-Yashin, 2003), la transnacionalización o globalización de las soberanías (Appadurai, 2001; Kearney, 1995; Ong, 2005 y 2001), las relaciones entre diversos actores (Hansen y Stepputat, 2006; Tsing, 2000 y 2005).

En una revisión de estudios antropológicos sobre el tema, Hansen y Stepputat mencionan que la antropología ha estudiado la dimensión práctica de la soberanía y no sólo su aspecto legal o institucional. A ese tipo de soberanía lo llaman de facto (Hansen y Stepputat, 2006: 296), anclada en la vida cotidiana antes que en los textos. La describen también como una soberanía informal en la que participan múltiples actores, y no sólo el Estado (ibíd:: 297). La soberanía sería una red de instituciones y prácticas que se presentan de forma más o menos cohesionada. La perspectiva antropológica que la aborda muestra la participación de diversos actores, las fluctuaciones históricas y políticas de su densidad e importancia, las transformaciones que ha experimentado como fruto de ciertos procesos culturales y económicos, así como la diversidad de demostraciones que la soberanía produce y requiere en su reafirmación o impugnación cotidiana y local.

En un documento preparado por Rand Corporation para la Fuerza Aérea de los Estados Unidos, se describe de la siguiente manera la frontera entre México y Guatemala:

Los límites que separan a Guatemala de México son una larga frontera de más de seis mil millas asoladas por la pobreza, la violencia, la corrupción y una absoluta ausencia de la presencia estatal. Representan una zona crecientemente utilizada y de importante tránsito para el trasiego de drogas, gente y otras formas de contrabando que a menudo alcanzan a los Estados Unidos. Tanto Guatemala como México enfrentan desafíos significativos para garantizar la seguridad en una región que constantemente cae bajo el 
control de actores no estatales como pandillas, organizaciones criminales y grupos de vigilancia. Estos grupos poseen la capacidad de aprovechar la debilidad del Estado para incrementar sus actividades ilícitas y conquistar el control sobre importantes zonas de tránsito. El potencial de dominio de esos criminales sobre la frontera, parece mucho mayor que el de las autoridades centrales en las capitales guatemalteca y mexicana (Boraz, 2007: 277; traducción y subrayados míos)

La imagen es clara: una frontera violenta, corrupta y sin presencia del Estado. Estas circunstancias serían el cobijo ideal para traficantes y mafiosos de todo tipo. Las pandillas y las organizaciones criminales aprovechan la debilidad estatal para apropiarse de importantes zonas de tránsito. Así, una frontera sin Estado se transforma en otra controlada por actores de tipo criminal. En ese documento, que intenta medir los niveles de ingobernabilidad de distintas zonas fronterizas en todo el mundo, el autor concluye que en esta frontera son altos (Boraz, 2007: 280). Los indicadores que utiliza incluyen 'la falta de presencia del estado' y la 'falta del monopolio de la fuerza'. Todos parámetros de soberanía, según la definición clásica de Weber.

Desde otra perspectiva, un académico guatemalteco describe la franja fronteriza como una "tierra de nadie" (Dadrón, 2003: 21), y agrega que:

(...) la ausencia institucional, de autoridades y la presencia de negocios ilícitos en los puntos de cruce, ba convertido a la franja fronteriza en un territorio donde la gobernabilidad se ejerce al margen de lo estipulado por las reglas constitucionales. Todo esto aunado al desconocimiento del volumen de transmigración, constituye un serio impacto en las poblaciones locales y el fomento a la violación de los derechos humanos y la violencia (Dadrón, 2003: 18; el subrayado es mío)

Otro texto académico describe un pueblo guatemalteco cercano a la frontera como un territorio "sin ley", en el que “(...) el Estado no tiene una presencia constante y el poder lo ejercen, fundamentalmente, los llamados coyotes (transportistas de migrantes indocumentados) que controlan los corredores transfronterizos” (Kron, 2007: 8). En ese contexto, los migrantes son descritos como "personas invisibles" (CNDH, 2011: 34) que experimentan todo tipo de abusos en su tránsito por México y la frontera misma como una "tierra incógnita" (Ruiz y Red de Casas del Migrante, 2001: 13).

¿Por qué se insiste en la anarquía de esta zona?, ¿qué soberanía se dibuja en estos informes y en las denuncias? Navaro-Yashin escribe que las narrativas "estado-céntricas" del sistema internacional operan a través de discursos normalizadores y que "el estudio de zonas de ilegalidad podría ayudarnos a tomar conciencia de 'lo anormal' que subyace a lo que en esos 
discursos se presenta como lo "normal"' (Navaro-Yashin, 2003: 115). En este caso, debemos tomar conciencia de otros modos de fortalecer esas narrativas estado-céntricas, ya no sólo mediante la constitución de zonas de ilegalidad que resultan ininteligibles, sino también a través de una anormalización añadida en contextos donde las relaciones sociales, las formas de control social, el uso de los territorios, las superposiciones culturales y étnicas, las mezclas y los intercambios, suceden bajo lógicas distintas a las de la soberanía o el Estado.

Si comparamos estos relatos y descripciones con las que elabora Navaro-Yashin (2003) para el norte de Chipre, encontraremos tal vez sus antípodas. Mientras ella habla de un Estado fantasma que obliga a sus ciudadanos a vivir en una zona indefinida entre la vida y la muerte, como los personajes de Pedro Páramo (novela que cita), y en una suerte de política de suspensión, todos estos textos parecen describir, falsamente a mi entender, una situación semejante. La frontera, al menos la que he podido estudiar, no es una tierra de nadie (no man's land), como llama Navaro-Yashin al lugar que investiga. Es un espacio habitado, apropiado, que genera formas de vida y cuenta con una gran densidad histórica. Es también un espacio conflictivo, que debe enfrentar una serie de procesos más allá de la escala local y su capacidad de modificarlos.

¿Por qué describir esta zona de un modo semejante?, ¿qué efectos se desean producir? Los argumentos son, ante todo, políticos. El retrato de una zona indómita, sin ley, abandonada, peligrosa e inhóspita, construye una narración que facilita la intervención de actores estatales o internacionales. Sea para evitar que los 'terroristas' se filtren por la frontera hacia Estados Unidos o para proveer de condiciones de seguridad a los migrantes centroamericanos, la frontera ha sido despojada de algunas de sus características más interesantes e importantes mediante un lenguaje militar o jurídico que la transforma en una tierra de nadie. Dada la relativa novedad de su delimitación legal, esa zona ha sido porosa durante siglos, ha permitido el paso de personas y objetos sin mayores restricciones, ha sido un espacio de transvase, de intercambio, de mezcla e hibridación (Casillas, 2010; Dardón, 2003; de Vos, 1996 у 2011; Escalona, 2011; Galemba, 2011).

Las lógicas estatales en Tenosique han sido tardías y han predominado otras cotidianas y locales. Si bien esto implica bajos niveles de institucionalización en ciertas áreas y debilidad del estado de derecho, es aventurado sostener que sea un lugar sin ley o sin gobierno. Tiene problemas semejantes a muchos otros lugares del país con respecto a la aplicación y vigencia de la ley. Al menos en el lado mexicano, la presencia del Estado y del gobierno es muy clara: 
hay luz eléctrica y escuelas, incluso en comunidades pequeñas; hospitales y centros de salud; universidades y preparatorias; formas de organización política y de la sociedad civil. ${ }^{71} \mathrm{El}$ supuesto de que todo este espacio es una tierra de nadie habla de un desconocimiento de todas esas redes institucionales.

Si jugamos con esa denominación, preguntaríamos: ¿de quién debería ser esta tierra? La soberanía, sin duda, es una respuesta tajante: del Estado. La discusión sobre el nombre y la propiedad de estas tierras no es baladí o sólo semántica; es, ante todo, un debate político. Y lo ha sido desde hace varias décadas. Las fronteras no sólo representan límites territoriales, son también demarcaciones políticas. Esta ruta nos permitirá entender qué tipos de movimientos están aconteciendo en esta zona, qué actores se posicionan ante ella y qué intereses tratan de articularse. Estos procesos no incumben sólo a México y Guatemala, sino a los Estados Unidos, que traza formas transnacionales de soberanía y de control territorial y poblacional, ineludibles para pensar el presente y el futuro de estos lugares. Pero también hay otros actores relevantes, estatales y no estatales. No sólo traficantes de drogas o de personas, como lo quieren los informes dirigidos a las Fuerzas Armadas estadounidenses. Hay actores locales, económicos y culturales; movimientos sociales; iglesias; migrantes. En este sentido, la frontera se transforma en una superficie donde se rediseñan y combaten los nuevos límites temporales de los que habla Silvio Mezzadra, que extienden el dominio global sobre territorios cada vez más amplios y extensos. Lo que él llama, siguiendo a Achille Mbembe, la 'domesticación del tiempo-mundo', articula distintos regímenes y disciplinas de trabajo que podrían pertenecer a tiempos históricos diversos. En este proceso se superponen varios tipos de fronteras:

(...) las fronteras 'geopolíticas' que articulan su carácter 'transnacional', las fronteras legales que reducen la movilidad y los derechos de las personas migrantes, los límites culturales y sociales producidos por los procesos de etnización, las fronteras de producción, las fronteras temporales que separan diferentes tiempos históricos y hacen posible que éstos sean traducidos al lenguaje unitario del valor (Mezzadra, 2007: s/p)

Este proceso produce diversas luchas y tensiones entre el "reforzamiento de las fronteras" o su “atravesamiento" (ibíd.), que involucrarán, especialmente, a las personas migrantes y las formas

\footnotetext{
71 Según datos del último Censo de Población y Vivienda, en 2010 Tenosique contaba con 234 escuelas de educación básica y media superior; asimismo, había 28 unidades médicas y el personal médico sumaba 131 profesionales. Casi el 100\% de las viviendas habitadas contaba con energía eléctrica y un 93\% de drenaje. (INEGI, 2013a).
} 
de movilidad. Domesticar el tiempo-mundo implica administrarlo bajo los mismos parámetros. ¿Sería esta tierra de nadie un espacio aún no domesticado?, ¿fallaría su administración y por lo tanto la intensidad de su domesticación? Bajo los criterios de la globalización, ¿qué significa esa condición indómita, sea real o discursiva?

De alguna manera, la reconstitución de la soberanía que exigen algunos actores implica sincronizar los tiempos de esta frontera con los tiempos domesticados del tiempo-mundo global. La demanda de mayor seguridad y legalidad es una forma de responder a la pregunta sobre la propiedad política de esa zona: debe pertenecer a un Estado que cumpla con sus compromisos internacionales. Las formas de vida y los arreglos locales entre la ley, las prácticas sociales y las necesidades colectivas deberían sincronizarse con los mandatos transnacionales de legalidad y seguridad. Esas demandas son contemporáneas a la expansión de la infraestructura de transporte e intercambio (carreteras, puertos, aeropuertos, pasos fronterizos). La lógica comercial que impera en estos planes y programas exige coordinar las acciones políticas y administrativas en otros campos; por ejemplo, incrementar la seguridad fronteriza.

Dinero y geografía: hendiduras

Enseña a nuestra filosofía la fortaleza para llegar arriba del ombligo.

Dereck Walcott, "Pleno Verano", Poesía selecta, 2012: 37

Como indiqué antes, el huracán Stan, que azotó a Centroamérica y la costa del Pacífico del sur de México en octubre de 2005, destruyó el trecho ferroviario que unía Tapachula con Arriaga y era utilizado por los migrantes centroamericanos para avanzar en su viaje hacia el norte del país. Entre las dos ciudades del estado de Chiapas hay $249.2 \mathrm{~km}$ que los migrantes recorrieron a pie. Si bien el Instituto Nacional de Migración esperaba que esto desalentara el paso de los centroamericanos, muchos eligieron tomar otra ruta que los conducía a un tren a pocos kilómetros de la frontera: Tenosique. ${ }^{72}$

\footnotetext{
${ }^{72}$ En el 2006 fueron aseguradas 23,287 personas en Tabasco, lo que representó el 12,8\% del total nacional (DPLF y Hogar de la Misericordia, 2008: 4). En una nota periodística publicada el 26 de agosto de 2007, se relata que "a la zona fronteriza entre Guatemala y Tabasco, donde en las primeras dos semanas de este mes se concentraron unos 3 mil indocumentados centroamericanos, hoy sólo arriban pequeños grupos que se encuentran con la
} 
El tren Chiapas-Mayab cubre todo el sur de México en dos rutas distintas, una en el Golfo de México y otra en el Pacífico, que suman 1,805 km. Ambos caminos se conectan a través del Ferrocarril Istmo de Tehuantepec (FIT), que une el puerto de Salina Cruz en Oaxaca con Medias Aguas en Veracruz. Una ruta inicia en el estado de Yucatán y llega hasta el puerto de Coatzacoalcos, en Veracruz, atravesando Campeche, Tabasco y una parte de Chiapas. La otra empieza en Tapachula y finaliza en la ciudad de Ixtepec en Oaxaca. Esta última tiene troncales que la conectan con Puerto Madero en Chiapas. A través de las conexiones del FIT se puede seguir una ruta hacia Coatzacoalcos u otra hacia el norte del país, cruzando Puebla, el Estado de México e Hidalgo. Lo que en términos mediáticos es conocido como La Bestia, tristemente famoso por los abusos que se cometen contra los migrantes montados en su 'lomo', es en realidad una intrincada red ferroviaria con diversos tramos y desvíos que pertenece a empresas distintas dedicadas al transporte de carga. El tren que pasa por Tenosique transita por una ruta distinta a la del Pacífico.

Si las vías y el tren son hendiduras en la soberanía estatal, que han sido interpretadas como tierra de nadie, lugar sin ley o frontera del terror, entre otras denominaciones, ¿qué procesos de subjetivación — puntuales, locales y específicos — producen esas hendiduras?, ¿qué sujeto atraviesa las líneas y se sube al tren?, ¿quién arriba de su viaje?, ¿quién cruza la frontera sur de México hacia su destino, pero también hacia el cumplimiento de su deseo?, ¿cómo protegerse de esa intemperie social y subjetiva en ese trayecto ominoso?, cla hendidura institucional es correlativa a otra subjetiva?, ¿es necesario hendirse subjetivamente para atravesar un lugar así y realizar ese trayecto sin nombre? Pero también hay que preguntarse si esa nada que se le atribuye al espacio también cubre el cuerpo de los migrantes, los atrapa y los engulle: ¿cómo se pueden proteger de todo esto?, ¿es posible nominar su travesía y los lugares por los que transitan?, ¿qué hacen los migrantes, entonces, con sus nombres?, ¿es necesario que darles un nombre, colectivamente? Y si se los diéramos: ¿qué sucedería?, ¿se restituye la hendidura en el espacio plano de la soberanía?, ¿es la ley correlativa a esa planicie estatal?, ¿adquiere la subjetividad la forma de esa meseta o admite otras topografías? Si las admitiera: ¿serían formas de protección para los migrantes?, ¿se les puede enseñar a hendirse individual y colectivamente?,

desalentadora noticia de que ya no hay tren para continuar su viaje hacia Estados Unidos” (López, 2007: s/p). La empresa propietaria del tren que pasa por Tenosique se había declarado en quiebra y había suspendido su servicio. Los migrantes tenían que caminar por Tabasco hacia el norte. El creciente número de migrantes varados inquietó a las autoridades y habitantes locales. En respuesta llegó un contingente de 300 policías federales. 
¿las estrategias de desaparición momentánea son útiles en este caso o reafirman la hendidura estatal?

No ser vistos y desear no ser vistos podría ser, en alguna medida, correlativo a no verlos, hacer como si no existieran, negarlos u ocultarlos. Dado que saltan la primera forma de visibilidad que son los documentos legales y migratorios (por eso se les llama indocumentados), no poseen otro estatuto, en territorio mexicano, que el de sujetos invisibles o fantasmales. Nadie sabe quiénes son, nadie los cuenta ni lleva un registro de ellos. Los documentos son el inicio de una desaparición paulatina, más o menos definitiva, que parte en la miseria de sus países y termina, en los casos más dramáticos, con la muerte. La lógica estatal que opera con formularios, permisos, sellos, autorizaciones, entre otros actos administrativos, desconoce a los sujetos sin registro. Algunos organismos del Estado los detienen si los detectan, y los devuelven a sus países, pero no logran establecer qué sucede con ellos, dotarlos de derechos, ofrecerles alguna protección. Los actores no estatales: redes de tratas de personas, pandillas y células del crimen organizado (sean locales o nacionales), parasitan de esta indefinición administrativa y legal. ¿A quiénes atacan?, ¿quiénes son los secuestrados?, ¿a quiénes extorsionan?, ¿quiénes son las mujeres violadas? Nadie sabe. A los criminales eso no les importa; al contrario, les facilita su tarea. La hendidura en la soberanía, estas rutas invisibles administrativa y legalmente, se transforman en fosas comunes. La antigua metáfora del cuerpo político adquiere aquí nueva connotaciones: el cuerpo renuncia a ciertas partes de sí y deja que se pudran. Los trenes que atraviesan el país y llevan pasajeros indocumentados diseminan esta infección a lo largo de todo el territorio, como si las arterias de este cuerpo desplazaran graves síntomas de una enfermedad política: la impunidad, la corrupción, el desinterés, la indiferencia, la ausencia de derechos.

Biehl y Locke, anotan que la imagen del hogar, "parecería haberse convertido en la topografía de nuestro ser íntimo. Una casa constituye un cuerpo de imágenes que da pruebas de humanidad o ilusión de estabilidad" (Biehl y Locke, 2010: 322; la traducción es mía). Los hogares que la Iglesia Católica administra a lo largo del trayecto de los migrantes son una forma de dotarlos de cuerpo, de un resguardo no sólo físico, también subjetivo. Las líneas de tren son tierra de nadie, lugares vacíos alejados de la habitabilidad, especies de patios traseros de las ciudades, sitios oscuros y peligrosos. Dormir en ellas es quedarse a la intemperie. ¿Quién se puede alojar en un lugar vacío?, ¿quién habita esa tierra baldía que circunda las líneas? Una red de alojamientos no es sólo una forma de ofrecer cierta seguridad y bienestar, también es un 
modo de reconstruir ese cuerpo político herido e infectado, de transformar la hendidura en hospitalidad.

¿No son las líneas férreas un entre que atraviesa los territorios, pero también expone las vidas e incluso mutila los cuerpos? Si la legalidad se resquebraja y diversos actores y grupos operan sin limitaciones, si la autoridad ha desaparecido o mira hacia otro lado: ¿qué tipo de entre sería éste? La hendidura espectraliza las subjetividades y a los individuos, pero también desmembra los cuerpos. La cabeza de una nota periodística, publicada en una página web dedicada a las noticias locales de algunos municipios fronterizos, anuncia: "La bestia le quitó los pies de un solo tajo". La bestia es el tren que pasa por Tenosique.

Un migrante centroamericano del que se desconoce el móvil de su muerte, y respondió en vida al nombre de Anastasio Celaya Romero, fue destrozado por las ruedas del ferrocarril, bautizado como la poderosa bestia de acero de la frontera sur.

El cadáver del indocumentado fue descubierto a las nueve de la mañana de este viernes por lugareños, entre el poblado Boca del Cerro y el ejido Faisán Vía, a la altura del arroyo Polevá, donde una locomotora que paso alrededor de las tres de la mañana con dirección para Coatzacoalcos, Veracruz, lo mutilo de la cintura, así como del brazo izquierdo.

Hasta este lugar, unos nueve kilómetros al poniente de esta ciudad, acudió Protección Civil, la Agencia del Ministerio Publico, junto con peritos y la policía ministerial, para dar fe, levantamiento y traslado de los restos mortales para el Semefo local.

Hasta el momento el hoy extinto de unos 24 años de edad, aproximadamente, que solo llevaba en sus bolsillos siete lempiras (moneda hondureña), luego de la necropsia lo depositarían en la cámara de refrigeración por espacio de 72 horas, mientras aparecen los familiares. (Paredes, 2013a: s/p)

La nota está acompañada de una foto impactante que muestra el cadáver de un hombre joven partido por la mitad. El cuerpo está emplazado en una superficie de concreto y las piernas en la parte de abajo, pero en posición horizontal con respecto al resto del cuerpo. Al cadáver le falta un brazo, que no se ve en la escena. El torso está cubierto con una playera y las piernas con unos pantalones. En la separación entre el cuerpo y las piernas están expuestos sus genitales.

El periodista dice que fue la "poderosa bestia de acero de la frontera sur" la que lo mutiló y mató. ¿Qué bestia es ésta?, ¿cómo puede ser una bestia de acero?, ¿cuál es su poder? Lo cierto es que mutila y eso es parte de su poder. Cuando el espacio entre la ley y la vida cotidiana se vuelve tan amplio, tan incierto, tan peligroso, entonces se transforma también en un abismo y 
una fosa: ¿quién reclamará el cadáver?, ¿quién hará un duelo por el joven? La separación brutal de su cuerpo se transformará en otra, también terrible, de su familia y su mundo: ¿aparecerán sus familiares, como espera la nota y el Ministerio Público?, ¿sabrán que ha muerto y cómo?, ¿vendrán desde Honduras a Tenosique? La muerte de un desconocido no genera un duelo. Quedan los restos y no hay sombra que se recoja.

João Biehl alude a los circuitos que parecen "independientes de las leyes y las normas" y que forman lo que en inglés denomina "inbetweenness" (¿intersticiedad?), a través del cual la vida social y las éticas son elaboradas empíricamente (Biehl y Locke, 2010: 324). Si bien es importante apuntar hacia esos espacios liminares en los que se producen la vida social y las éticas y que guardan distancia frente a otros más formales o institucionalizados regulados por leyes y normas, también es necesario determinar cuál es la extensión de ese espacio intermedio o de esa intersticiedad, si se me permite el neologismo. Un juego de palabras podría iluminar el efecto de una distancia demasiado aguda con respecto a las leyes y las normas en ciertos colectivos o sujetos: una delgada línea separa la intersticiedad de la excentricidad. Si esos colectivos y sujetos, que literalmente están entre (ciudades y descampados, leyes y documentos, prohibiciones y deseos, condiciones materiales y condiciones subjetivas, cultura y naturaleza, invisibilidad y reconocimiento) son empujados aún más hacia los márgenes, entonces la intersticiedad se transforma en excentricidad: una expulsión del centro social e institucional, un desalojo de ciertas coordenadas de reconocimiento y protección. Si la vida social es producida en este espacio liminar e intermedio, debemos considerar sus resultados ominosos. La defensa de los derechos humanos, por ejemplo, no sólo tiene efectos legales, sino discursivos y prácticos: es una forma de rellenar esa intersticiedad, cuando se vuelve demasiado peligrosa y profunda, cuando su efecto es la expulsión y no la autonomía. Los hogares que ofrece la Iglesia constituyen otro modo de reducir la intensidad de ese entre. La hendidura en la soberanía estatal que transforma a las líneas de tren, pero también al trayecto de los migrantes en su totalidad, en una tierra de nadie, en lugares sin ley, según algunas de las descripciones que revisamos, afecta el espacio al que apunta Biehl. Lejos de las leyes y de las normas, no sólo se crea la vida social de manera independiente, también se la destruye. En este sentido, Biehl y Locke señalan que una etnografía "hace visibles el entremezclamiento (intermingling) de las prácticas y las relaciones cotidianas, las historias institucionales y las estructuras discursivas" (Biehl y Locke, 2010: 325; la traducción es mía). 
En algún momento Foucault (1981) sugiere que la teoría política debe cortar la cabeza del rey para pensar de otro modo. Ese otro modo se interesaría menos por el Estado que por las formas y estrategias de gubernamentalización propias de las sociedades modernas. El Estado no sería la fuente del poder, sino el resultado de un amplio rango de formas dispersas del poder disciplinario que permitirían que aquél surgiera como una estructura aparte y por encima de la sociedad (Hansen y Stepputat, 2006: 4). Si se decapita el pensamiento centrado en el Estado, entonces podremos ver todos estos otros poderes, dispersos pero definitivos.

Haré un retruécano con estas ideas: ¿a qué obliga el cadáver de un joven partido por la mitad? Si bien no ha sido decapitado, su cuerpo ha sufrido una separación tajante entre sus partes: ¿qué pensamiento sobre el poder y sobre el Estado podría inaugurarse a las orillas de las vías del tren, al lado de este cuerpo mutilado? Los cadáveres exigen un responso, que en este caso las burocracias no permiten o dificultan. El cuerpo del joven, anónimo y solitario, no es sostenido por ninguna trama ritual, como la que describiremos para la muerte del hermano de Alan, en otro capítulo. Las indagatorias policiales y los procedimientos forenses agotan su partida, la sellan con la luz oscura de las oficinas y el ritmo lento de las burocracias. Si en los rituales empezaba una elaboración social de la muerte, en los trámites inicia su objetivación. Frente a la muerte densa del hermano de Alan aparece esta muerte superficial, por así decirlo, epidérmica. Luego de 72 horas en el Servicio México Forense, los cadáveres se entierran en la fosa común. En vez de las lápidas y las cruces, el anonimato final de un cuerpo, su desubjetivación completa. No hay sombra en este caso, salvo las administrativas, la escueta escritura de los partes y los informes.

¿No empieza en ese silencio, en esta ausencia de nombre, la soberanía del Estado y el dominio técnico de la muerte? Pero también en este episodio se interceptan formas legales de soberanía con otras tecnológicas. Sabemos que la muerte es un límite de la soberanía y el inicio, también, de las formas biopolíticas de los poderes modernos (Agamben, 2005 y 2007; Esposito, 2006; Foucault, 1981 y 2002; Mbembe, 2003). Sloterdijk escribe:

Pero ahora, la globalización, que lleva la exterioridad reticulada a todas partes, desgarra las ciudades abiertas al comercio, incluso las aldeas introvertidas, introduciéndolas en el espacio de tráfico, que reduce todas las peculiaridades locales a los comunes denominadores: dinero y geometría (Sloterdijk, 2010: 49)

Esa exterioridad es llevada al interior del cuerpo o a su lugar en el mundo. No sólo desgarra las ciudades abiertas al comercio y las aldeas introvertidas, también los cuerpos de los sujetos más 
vulnerables y más expuestos, en ese espacio de tráfico que es literal en este caso: las vías de un tren. Las peculiaridades locales no sólo son reducidas al dinero y la geografía, también a la burocracia y las técnicas administrativas. Ahí donde las formas de vida preveían rituales, el Estado crea fosas comunes y anonimato, junto con actas administrativas, estadísticas y cementerios. Desde este lugar, esta orilla, y desde este cuerpo desgarrado, la globalización siempre ha sido mortífera. Ha sido, por tanto, siempre biopolítica y necropolítica (Mbembe, 2003).

Las piezas de esta historia reúnen un cuerpo mutilado, un tren al que llaman La Bestia, un proceso migratorio contemporáneo, una frontera difusa, el Estado y la soberanía. ¿Por qué le dicen La Bestia al tren que pasa por Tenosique? Sabemos que es una transposición del nombre que se le da a otro que recorre Chiapas y Oaxaca. En la vida cotidiana de la ciudad al tren no se le da ese nombre. Fueron los periodistas (tal vez desinformados) y los sacerdotes dedicados a la defensa de los derechos humanos de los migrantes quienes comenzaron a llamarlo así. Pero esa Bestia reciente es el doble de la otra, que avanza a varios cientos de kilómetros de Tenosique. La Bestia y su doble: ¿Qué juegos miméticos se han puesto en marcha al denominar a trenes distintos con un mismo nombre? Para un lector desprevenido, parecería que se habla del mismo tren, lo que no es cierto. El trayecto que los migrantes realizan por Tabasco sería semejante al que hacen por Chiapas y Oaxaca. Un mismo nombre para dos trenes y dos trayectos. Como si entre una ruta y otra sólo existieran relaciones de semejanza y una fuera el reflejo de la otra. Las similitudes son muchas: ferrocarriles de carga que transportan migrantes de modo irregular, migrantes que son centroamericanos y sistemáticas violaciones a los derechos humanos. Desde esta perspectiva, cualquier tren es una Bestia, aunque haya otros que tengan nombres diferentes, como el que une Jalisco con Baja California, conocido como El Diablo. Pero el campo semántico es bastante cercano: bestias, demonios. Monstruos de metal que transportan mercancías. Una especie de inconsciente del capitalismo, un bestiario global, que intercepta flujos comerciales y criminales con otros escatológicos. Pero si bien las similitudes son intensas, su denominación común parece ocultar cualquier diferencia.

Aquí presenciamos, a mi entender, un proceso mediático y político de sobreposición que permite hablar de muchos trenes como si fueran uno y de muchos trayectos como si fueran el mismo. Dos poderosas instituciones hacen ese ejercicio: los medios de comunicación y la iglesia Católica. Monoteísmo ferroviario, en última instancia. Visto desde Tenosique, ese tren no siempre fue bestial y contiene una larga historia de viajes que forman parte de la memoria 
colectiva y personal de los habitantes, quienes llegaron a usarlo como pasajeros. Cuando el tren fue el medio que conectaba con otras ciudades, su función fue menos bestial. Los medios y los curas bestializaron ese tren, ejerciendo su enorme poder sobre los imaginarios, como si la bestialidad de las máquinas no fuera producto, ante todo, de la brutalidad de las instituciones.

Me parece un misterio que al abordar el problema de la soberanía aparezca una bestia (de nuevo cuño). La bestia y el soberano, escribe Derrida, "están fuera de la ley":

Es como si uno y otra se situasen, por definición, a distancia o por encima de las leyes (...). El estar-fuera-de-la-ley puede sin duda, por una parte, y es la figura de la soberanía, adoptar la forma del estar-por-encima-de-las-leyes y, por consiguiente, la forma de la Ley misma, del origen de las leyes, del garante de las leyes, como si la Ley, con L mayúscula, la condición de la ley, estuviese antes, por encima, y por consiguiente fuera de la ley, como si fuese exterior, incluso heterogénea a la ley; pero al estar-fuerade-la-ley puede también, por otra parte, y es la figura de lo que con más frecuencia se entiende como la animalidad o la bestialidad [el-estar-fuera-de-la-ley] puede situar el lugar donde la ley no aparece, o no es respetada, o se viola. (Derrida, 2010: 36)

La animalidad es la figura que puede situar "el lugar donde la ley no aparece, o no es respetada, o se viola”. Para Derrida, la bestia y el soberano se metamorfosean uno en otro:

En la intersección metamórfica de ambas figuras, la bestia y el soberano, presentimos pues que una profunda y esencial cópula ontológica está en marcha, trabajando esa pareja; es como un acoplamiento, una cópula ontológica, onto-zoo-antropo-teológicapolítica: la bestia se convierte en el soberano que se convierte en la bestia: hay bestia y el soberano (conjunción), pero también la bestia <es> el soberano, el soberano es la bestia. (ibid:: 37)

Pero en la ausencia de soberanía que algunos denuncian cuando hablan de la frontera, ¿qué significa esta metamorfosis entre bestia y soberano, que se suma a la otra entre dos trenes? Estamos, como ha escrito Derrida, ante 'representaciones animales' de lo político (Derrida, 2011: 13-14), pero también ante una revisión de lo político mismo: tierra de nadie, lugar sin ley, etc. La bestia no viene a fortalecer lo político, sino a debilitarlo. Si estar fuera de la ley sería la forma de fundar la ley misma, ¿qué soberanía se constituiría en esta tierra sin nombre con la bestialidad de sus máquinas?, ¿qué heterogeneidad es ésta? El soberano necesita esa referencia a un afuera que le permita constituirse, y esa referencia es una bestia. A la bestia la ofrecen, en este caso, los sacerdotes católicos y los medios de comunicación. El soberano está ausente y se reclama su presencia para dotar de ley a esa geografía. Dos bestias que son una. ¿No tiene todo 
esto el tono onto-zoo-teológico-político del que habla Derrida? Sólo el genio político de los curas podría crear una bestia para la soberanía herida del Estado y producir su doble. El lenguaje más antiguo del poder vuelve a articularse en todos estos juegos semánticos y políticos.

Derrida se pregunta:

¿Por qué la soberanía política o el Estado o el pueblo son presentados tan pronto como aquello que se eleva, por la ley de la razón, por encima de la bestia, por encima de la vida natural del animal, y tan pronto (o simultáneamente) como la manifestación de la bestialidad o de la animalidad humana, dicho de otro modo, de la naturalidad humana? (Derrida, 2010: 47)

La respuesta estaría, según Derrida, en la alegoría o la fábula del animal monstruoso, "el ejemplo más sobrecogedor de -la- figuración de lo político, del Estado y de la soberanía", elaborada "conforme a la lógica técnica o protética de un suplemento que suple la naturaleza añadiéndole un órgano artificial” (ibid.). La Bestia que nos interesa ¿̇ería otra alegoría de la figuración de lo político, del Estado y de la soberanía?, ¿por qué la monstruosidad está, ahora, justamente del lado de la "lógica técnica o protética"? En la Bestia se articularía tanto el nivel superior de la soberanía, como su registro inferior; tal vez no es extraño que en las disputas sobre esta Bestia tecno-mimética se interrogue a la ley y al derecho

La bestia y el soberano están por encima de las leyes, ha escrito el filósofo francés. Y esa exterioridad vertical es la que los constituye como fundamentos de la ley misma. En algún sentido, ese encima del que habla Derrida se superpone con el uso que los migrantes le dan al tren: se suben, fundamentalmente, a su techo, a su "lomo", como han escrito algunas notas periodísticas. Arriba de la Bestia que está por encima de la ley, están doblemente expuestos a la excepcionalidad de su estatus. ${ }^{73}$ Si la Bestia es heterogénea con respecto a la ley, los migrantes subidos en sus techos lo son en relación a ella. En ese lugar se confirma la liminaridad y la excentricidad de estos sujetos y de sus cuerpos. En ese juego peligroso entre la soberanía, la bestia y la ley empieza también el trato brutal que reciben estos individuos en sus trayectos.

\footnotetext{
${ }^{73}$ Hay que distinguir, en este caso, entre el tren como medio de transporte, regulado por leyes y contratos que, evidentemente, no se encuentra por encima de la ley, y La Bestia, que es el mismo tren pero relacionado, ahora, con los flujos migratorios y utilizado fuera de los marcos legales o contractuales. Sólo La Bestia está por encima de la ley. Ese doblez de una máquina mitologizada permite comprender el estatus de los migrantes cuando viajan encima de un tren/Bestia, de una máquina/mito. En las siguientes páginas lo analizamos con mayor detalle.
} 
Por eso, la excentricidad del cuerpo de ese joven es tan radical: partido por la mitad, ha transformado la linealidad del cuerpo en dos perpendiculares que sólo se tocan en el sexo. La diferencia sexual queda como testigo mudo de las otras diferencias y de ese atravesamiento bestial del que ha sido objeto. Pero también experimenta una excentricidad simbólica profunda porque, como lo dijimos, su muerte es elaborada por la burocracia, dentro de una serie de procedimientos legales. En ese territorio que se abre a la orillas del tren no habrá rituales, ni sombras, ni llantos, ni duelo. En la sequedad burocrática, los afectos se entierran en las fosas comunes, la memoria se transforma en un anonimato definitivo, la muerte en un acto legal.

Actores no bumanos, economías ocultas

Lo que nos queda es la magia del Estado. Michael Taussig, Desfiguraciones, 2010: 366.

El tren es una máquina, un medio de transporte y una tecnología. Forma parte de las infraestructuras básicas para que una economía global funcione. Sin embargo, nada de esto lo transforma en una Bestia, por lo cual la explicación debe estar en otro lugar y no en su racionalidad instrumental. Su nombre y los imaginarios que articula, así como las relaciones y prácticas sociales que se entrecruzan en su funcionamiento, hacen del tren mismo una fricción como las analizadas por Anne Tsing: “(...) encuentros heterogéneos y desiguales que pueden conducir a nuevos arreglos de cultura y poder" (Tsing, 2005: 5). El antiguo tren familiar, que teje una larga historia de movimientos de personas y de bienes, de conexiones y aperturas a lo largo de varias décadas, se transforma en una figura infernal vinculada, ante todo, con la muerte y la desaparición: nuevos arreglos de cultura y poder, como anota Tsing. Encuentros heterogéneos con resultados inéditos.

Sin embargo, la bestialidad de este tren reside en la convergencia de una serie de fenómenos y procesos de larga y mediana data que articula de un modo específico. Esto tiene, al menos, dos implicaciones: una, el tren es un tipo de actor no humano que interviene de cierto modo en estos hechos; otra, condensa en su funcionamiento y su nombre un proceso socio-histórico incipiente. Bruno Latour escribe que "lo social no está en lugar alguno en particular, como una cosa entre otras cosas, sino que puede circular por todas partes como un movimiento que relaciona cosas no sociales." (Latour, 2008: 156) A esas cosas no sociales las llama actores nohumanos. Agrega que: 
la acción social no sólo es controlada por extraños, también es desplazada y delegada a distintos tipos de actores que son capaces de transportar la acción a través de otros modos de acción, otros tipos de fuerzas completamente distintas (...) entonces cualquier cosa que modifica con su incidencia un estado de cosas es un actor o, si no tienen figuración aún, un actante (ibid.: 105-106)

Transportar la acción a través de otros modos de acción podría ser una definición adecuada para un tren. Incluir a los objetos como actores no-humanos es una forma de comprender el papel de los medios prácticos en las relaciones de poder y en las desigualdades, entendidos como "mediadores a través de los cuales se produce la inercia, la durabilidad, la asimetría, la extensión, la dominación" (ibíd:: 125). Si el tren en cuestión fuera un actor de este tipo, que no sólo transporta la acción social hacia otros modos de acción y otros tipos de fuerzas, y constituyera un mediador en relaciones de poder y desigualdad, resta por entender por qué eso sucede no sólo mediante su materialidad o su función técnica y económica, sino también a través de estos revestimientos míticos que lo cubren.

Si en el razonamiento de Latour a los objetos hay que devolverles una fuerza transformadora y mediadora de la acción social, para rescatarlos del lugar inerte, pero también inadvertido, en el que los había colocado el pensamiento social, en este caso el objeto regresa no sólo como máquina y como un actor no humano sino como significante y actor mítico, si se lo pudiera llamar así. Como lo indica Latour, la acción de los objetos es "mucho más variada, su influencia más ubicua, su efecto mucho más ambiguo, su presencia mucha más distribuida que lo que indican estos repertorios restringidos" (ibíd:: 125). Asumir esa ambigüedad y amplitud supone reconsiderar la diferencia categórica entre "acción humana y causalidad material" (ibid.).

Si bien el tren es un producto social (material, técnico, burocrático), en su inscripción en las relaciones sociales que empiezan con el uso que le dan los migrantes también es un medio de significaciones y no sólo de transporte. O de transporte de mercancías, de personas (indocumentadas y de manera no reglamentaria) y de discursos e imaginarios. Al flujo material de la energía mecánica que transita por rieles de acero y cruza el país transportando mercancías entre puertos y ciudades, se le superpone otro corporal, afectivo y político que utiliza la energía mecánica para reemplazar las limitadas energías corporales de los humanos. Es entonces cuando los flujos y las energías se superponen o interceptan bajo la forma de una fricción entre procesos globales de diverso tipo, otros locales y algunos nacionales. Pero, como anota Tsing, 
las fricciones ocurren en la materialidad de los encuentros prácticos de los procesos globales (2005: 1).

De la fricción surge el mito. La Bestia aparece cuando los migrantes usan el tren de carga para viajar hacia los Estados Unidos. La bestialidad del tren no está del lado de las mercancías, ni del comercio, ni del tránsito y sus efectos de conexión y fluidez transnacional. Ella comienza y finaliza con la migración. En algún sentido, pero paradójicamente, la bestialidad de este tren supone una distorsión de su funcionalidad económica por otra política. El flujo de productos y capitales que circula por las vías férreas y forma parte de los proyectos de conexión regional que se han desarrollado o intentan implementar, experimenta un cortocircuito o una distorsión cuando estos flujos humanos irregulares se ‘suben' a sus rutas para usarlas con fines distintos. Friccionan una racionalidad económica con prácticas de supervivencia. Ese destello -insistoproduce el mito.

Más acá de la funcionalidad de un actor no humano y más allá de las capacidades de los estados para gestionar los movimientos legales e ilegales, regulares e irregulares, se encuentra esa producción mítica que bestializa al tren. Flujos comerciales que son parasitados por flujos humanos nómades, trenes sobre cuyos lomos metálicos cabalgan masas de indocumentados pobres que buscan ingresar ilegalmente a los Estados Unidos y acceder a los rastrojos de la riqueza de ese país, delincuentes que a su vez parasitan de ese uso sui generis e intentan generar ganancias a partir del terror impune. Las fricciones que acá estudiamos suponen ya soberanías fragmentadas y parciales, actores diversos que juegan en un campo móvil de relaciones sociales.

En una definición sorprendente y fascinante de la política, Achille Mbembe, siguiendo a Bataille, escribe que: "La política sólo puede ser trazada como una transgresión en forma de espiral, como esa diferencia que rechaza la idea misma del límite. Más específicamente, la política es la diferencia puesta en juego por la violación de un tabú” (Mbembe, 2003: 16; la traducción es mía). Si algo produjo la escalada de violencia que ha vivido México en los últimos 8 años es la violación de todos los tabúes, especialmente aquellos que resguardaban al cuerpo y el cadáver. La política trazada como una transgresión en forma de espiral que desorienta la misma idea de límite. ¿Cuáles son los límites que contienen la acción política, pero también la violencia?, ¿qué transgresiones en forma de espiral hemos visto, de las que aún somos testigos?

Mbembe también ha escrito que “asesinar o dejar vivir constituyen los límites de la soberanía, sus atributos fundamentales. Ejercer la soberanía es ejercer control sobre la 
mortalidad y definir la vida como el dispositivo y manifestación del poder" (ibid:: 12). El largo y tenebroso registro de las violaciones a los derechos humanos de los migrantes es una constatación de estas palabras. Incluso de una ominosa victoria de la realidad sobre la ficción. ${ }^{74}$ Casi todos los límites han sido traspasados y los tabúes transgredidos. No creo que queden muchos otros por explorar. Se delinea una de esas figuras de soberanía cuyo proyecto central no es la lucha por la autonomía, sino "la instrumentalización generalizada de la existencia humana y la destrucción material de los cuerpos humanos y las poblaciones" (ibid.: 14).

En este contexto podemos preguntarnos sobre el vínculo entre el concepto de flujo como una relación entre diferencias y la política entendida como la diferencia que rechaza la idea misma de límite y es puesta en juego por la violación del tabú. En un primer momento, la diferencia fue importante para comprender cómo se relacionaba el deseo con los flujos globales (en sus diversas manifestaciones), pero ahora ella también podría explicar la violencia que suscitan los flujos o que es correlativa a ellos. Flujo, deseo y violencia aparecen como partes o dimensiones de una realidad compleja y ambigua y forman una densa trenza de fenómenos articulados de modos puntuales. Como escribiera Tsing, lo funesto convive con lo esperanzador. En las mismas vías donde son secuestrados algunos migrantes por grupos del crimen organizado, otros son buscados con fines sexuales. ${ }^{75} \mathrm{El}$ deseo y la violencia parecen converger en torno a este flujo humano, que a su vez, articula múltiples diferencias (culturales, económicas, políticas). La pregunta que permanece abierta es cómo poner límites a los flujos, si ellos fueran una manifestación de esos espirales políticos que propician las violaciones de los tabués.

"Las capilaridades del capitalismo racial al estilo sudafricano", escriben Jean y John Comaroff, "llegaron a ser visibles para cualquiera que se preocupara por contemplar el movimiento crepuscular de los varones migrantes a lo largo de un paisaje hendido" (Comaroff y Comaroff, 2003: 148, la traducción es mía). Un paisaje hendido (nuevamente las hendiduras) formado por una estación de trenes repleta de hombres negros que serían transportados hasta las minas y las fábricas de sus patrones blancos. ¿Cualquiera puede ver las capilaridades de este

\footnotetext{
${ }^{74}$ No entraré en detalles en este capítulo, pero el lector puede leer los testimonios recogidos por la Comisión Nacional de los Derechos Humanos (CNDH, 2011) y algunas organizaciones civiles (Amnistía Internacional, 2011; CODEHUTAB, 2011).

${ }^{75} \mathrm{La}$ coincidencia es espacial, no intencional. Quienes abordan con fines sexuales a los migrantes, no buscan secuestrarlos o extorsionarlos; al menos, no tenemos ningún indicio de que eso suceda.
} 
capitalismo fronterizo en los trenes repletos de migrantes centroamericanos?, ¿son visibles las relaciones sociales y económicas que explicarían, en última instancia, ese flujo incontenible de personas que cruzan fronteras y países en búsqueda de medios de subsistencia?, ¿cuál sería el vínculo entre esas relaciones y la bestialidad del tren que lleva a los migrantes hacia el norte?

A la economía que se forma en estos trances o, más bien, a sus representaciones locales, los Comaroff la llaman economía oculta: "un conjunto de prácticas (ya sea reales o imaginadas) que involucran la recurrencia a medios mágicos para fines materiales" (ibid.: 150; la traducción es mía). Creo que es una definición adecuada para entender la inscripción de un tren que traslada mercancías en el trayecto hacia un futuro, aparentemente más promisorio, de miles de personas indocumentadas. Esa economía articula, en el caso sudafricano, altas tasas de desempleo, el enriquecimiento repentino y veloz de una minoría, y la miseria apabullante de las mayorías con acusaciones de brujería, zombies y los linchamientos extrajudiciales de supuestos hechiceros. Los autores sostienen que los temas de los que hablan “(...) se relacionan con procesos globales o, más precisamente, con intersecciones específicas, en el aquí y el ahora, entre lo global y lo local” (Comaroff y Comaroff, 1999: 285). En una referencia que podría aplicarse al tren y su mitologización, agregan que: "con la reorientación radical de los contornos locales del deseo y la desesperación, de la riqueza y la desigualdad, lo diabólico se inviste con un poder ambiguo y provocador" (ibid.: 291). Una bestia que surge, en alguna medida, de esa reformulación de los contornos del deseo y de la desesperación, pero también del bienestar y la inequidad, asume sobre sus lomos los imaginarios que se fraguan en estos procesos históricos complejos e intrincados. Las acusaciones de brujería que los Comaroff estudian en Sudáfrica, ayudarían a explicar unos procesos sociales y materiales complejos mediante motivos humanos comprensibles, que vinculan procesos y eventos translocales con eventos y paisajes locales (ibid:: 286).

Si bien no he encontrado un proceso semejante al que describen Jean y John Comaroff, en el que relaciones económicas y sociales sean explicadas colectivamente mediante una referencia a procedimientos mágicos, me parece que la economía oculta que se fragua en estos espacios recurre a medios míticos (mágicos, dicen ambos autores) para entender fines materiales. Michael Taussig, que también se interesa por el entrecruzamiento entre magia, mitología y economía, plantea una pregunta pertinente para nuestro caso: “¿Por qué ese conjunto particular de ideas, con su incisivo significado y la riqueza de su intrincada mitología, eligió esa circunstancia y ese tiempo específicos, antes que otro conjunto de ideas y prácticas?” (Taussig, 1980: 15). ¿Por qué 
se ha elegido ese conjunto de ideas vinculadas con la bestialidad del tren, pero también aquellas que remiten al desorden, la ausencia de ley y la invisibilidad?, ¿Por qué la soberanía es leída desde la bestialidad? Taussig responde que:

Una vez que cultivamos esa pregunta, un modo diferente de interpretación se insinúa. Las creencias que nos conciernen nacen de un conflicto en el mundo, es decir, de una cultura que lucha creativamente por organizar nuevas experiencias dentro de una visión coherente, animada por sus implicaciones para actuar sobre el mundo. Las creencias mágicas son reveladoras y fascinantes no porque sean ecos poéticos de las cadencias que guían el curso más íntimo del mundo. La magia lleva el lenguaje, los símbolos y la inteligibilidad a sus límites más extremos para explorar la vida y, así, cambiar su destino (ibíd.)

Ahí donde el autor dice magia, nosotros debemos poner mito. ¿Es la Bestia una forma mítica de lo global, una encarnación metálica de los flujos que atraviesan la ciudad, que la conmueven, pero sobre los cuales no posee control alguno? El tren pasa por la ciudad, apenas se detiene. No hay intercambio entre la máquina y sus habitantes. La primera sólo cruza el territorio mientras suenan sus sirenas y se aleja en el monte. Una herida en el mapa urbano rodeado de pastizales y oscuridad. La extrañeza de la máquina forma parte de su bestialidad, que se intensifica por el uso que los migrantes le dan. Máquina que pasa velozmente y luego parte con pasajeros inesperados. Los habitantes de la ciudad son espectadores de hechos en los que no intervienen. Si bien no han sido ellos quienes han denominado de esa forma al tren, su nombre metaforiza una serie de relaciones sociales, muchas de ellas recientes, que no son producidas localmente y a mi entender, no logran articularse aún: flujos múltiples de humanos y mercancías diversas, que traen nuevos escenarios a la ciudad, pero no preguntan a las comunidades si desean participar en ellos. Se imponen fatalmente. No es extraño, en esta medida, que sea un sacerdote recién llegado el que nombra al tren, como un bautismo colectivo de temores y ansiedades que abre una serie de interpretaciones sustentadas en imaginarios religiosos. "La magia lleva al lenguaje, ha escrito Taussig, a sus límites más extremos para explorar la vida"; acá presenciamos unos de esos viajes semánticos hasta esos límites. La vida explorada es también la vida expoliada. ¿Qué, sino esto, guiará la cadencia más intima del mundo, como escribe Taussig?

Tal vez debemos invertir una pregunta que se hace Lévi-Strauss: “¿dónde termina la mitología y dónde comienza la historia?” (Lévi-Strauss, 2009: 69), para pensar ¿dónde termina la historia y dónde comienza la mitología? La Bestia podría ser uno de esos lugares donde 
termina la historia o se transforma en una mitología contemporánea, difusa, fragmentada, pero poderosa. $^{76}$ Como si el único lenguaje que, por ahora, pudiera hablar de ciertos acontecimientos o procesos fuera uno de tipo mítico. En el caso del tren que nos interesa, estamos en el albor de sus desplazamientos, su bestialidad es reciente, así como novedosos son los flujos migratorios por Tenosique. Pero la novedad no resta poder, porque los efectos ya se dejan sentir con intensidad. La bestialidad del tren no incumbe solamente a los migrantes, aunque ellos sean sus principales víctimas. Involucra a toda la ciudad de una u otra manera, o lo hará en un futuro no lejano.

A fines de noviembre de 2013 asistí a la inauguración de un pequeño altar que la compañía de teatro Línea de Sombra erigió a las orillas del tren que pasa por Tenosique. Era parte de las actividades que esa compañía realizó en la ciudad y culminaron con la presentación de su obra Amarillo, dedicada al tema migratorio, ya presentada en todo México y en diversos países. El altar hospeda una Virgen de Guadalupe que donó una comerciante que trabaja al lado de la vía. Se espera que sirva como un lugar de referencia para los migrantes, como un punto de apoyo mítico y una forma de dignificar su trayecto y el espacio baldío de las vías. Cuando Fray Tomás González, director del Hogar-Refugio para Personas Migrantes La $72,{ }^{77}$ bendijo el altar y su imagen, manifestó que las vías eran un lugar de maldición, puesto que en ellas se cometían todo tipo de tropelías contra los migrantes, y que en sus alrededores, en las casas y en los pequeños negocios fincados a las orillas del tren, se escondían los traficantes de personas y los asaltantes. El altar, añadió, era un lugar de bendición en medio de ese espacio maldito.

\footnotetext{
${ }^{76}$ Sloterdijk escribe que "Cuando escuchamos que el viejo Ford decía que la historia es una tontería, bistory is bunk, cualquiera de nosotros sabe lo que esto significa: que volvemos a vivir en un horizonte mitológico y no en el seno de tradiciones, porque tener una tradición significa que uno hereda un mundo completo. Y nosotros heredamos tan poca cosa...." (Sloterdijk, 2003b: 39) "Heredamos tan poca cosa", el viejo Ford sabe de máquinas y tal vez de mitologías, pero no de historia. La Bestia tampoco. Es extraño que heredar sea regresar, como si el futuro se encontrara 'atrás' y no delante y la historia fuera, en alguna medida, un déjà vu sistemático.

77 Fundada el 25 de abril de 2011, en la ciudad de Tenosique, este hogar es un proyecto de la Provincia Franciscana San Felipe de Jesús en sureste de México. Su nombre recuerda la matanza de 72 migrantes, la mayor parte centroamericanos, en la ciudad de San Fernando, Tamaulipas, en agosto de 2010, efectuada por células del crimen organizado en complicidad con la policía local (CNDH, 2013). Este hogar es el primero que encuentran los migrantes que entran a México por la frontera entre Tabasco y Guatemala; les ofrece alojamiento, comida, atención jurídica, orientación y primeros auxilios.
} 
Alrededor del fraile y del altar se apostaron migrantes, algunos vecinos, integrantes de la compañía de teatro y otras personas de la ciudad. La vecina que había regalado la imagen de la Virgen dirigió, también, algunas palabras. Su negocio está frente al altar y a las vías del tren, por lo que se sintió aludida de una u otra manera por las palabras del religioso. Ella dijo que Dios protegía a todos y había que cuidarse de los falsos profetas. Mientras el equipo encargado de esa intervención estaba construyendo el altar (con ayuda de albañiles hondureños que estaban alojados en $L a 72$ ), algunos sujetos con aspecto de "mareros", en palabras de los trabajadores, pidieron cuentas sobre lo que ahí levantaban. El altar - respondieron- era para todos los que por ahí transitaban.

En este pequeño evento, un lenguaje religioso, diría que mítico, de maldad y bondad, de imágenes religiosas y de creencias, de peligros y bendiciones, permitía elaborar un conflicto colectivo en torno a las vías del tren y el flujo migratorio. La historia era construida en un lenguaje distinto al de la política o la ciencia. El fraile acusaba a los vecinos de guarecer y proteger criminales, una vecina le espetaba que era un falso profeta. No se dirigía a nadie en particular y en las formas indirectas de la retórica religiosa se cruzaban acusaciones y se denunciaba el carácter maldito de un territorio. No se hablaba en el lenguaje técnico del derecho, por ejemplo, pero se evidenciaban las circunstancias históricas de la migración.

En ese lenguaje de maldiciones y bendiciones, de falsos profetas y vírgenes protectoras, se edificaba la historia reciente de esos parajes y de esos colectivos. Los mismos criminales interrogaban al altar y eran incluidos en sus bendiciones o en su acción mítica. El fraile mencionó que el tren mismo era maldito y que sólo la labor de defensa de los derechos y las vidas de los migrantes podría modificar ese signo aciago. La Bestia cubría de maldiciones los espacios aledaños a su paso, transformándolos en lugares de muerte. El tren mitificado producía efectos que podrían llamarse mágicos. En ese entramado mítico y político, los diversos sujetos se desplazaban: migrantes, criminales, vecinos. El mito se afincaba en los lugares y en los objetos antes que en las personas, como si tuviera un poder autónomo con respecto a ellas y fueran, de algún modo, los verdaderos protagonistas de las historias que se tejían a su alrededor. Las fricciones que nos interesan se manifestaban en esos lugares y objetos y se condensaban en ellos. El flujo humano que cruza la ciudad permanece en esa estructura territorial y objetual (las vías y el tren mismo). En algún sentido, esa lectura mítica se fundamenta en lo que persiste y en lo que se repite. 
Pero por otra parte, este proceso de interpelación múltiple coincide con una lectura que Lévi-Strauss propone del mito:

Todo mito es por naturaleza una traducción (...) se sitúa, no en una lengua y en una cultura o subcultura, sino en el punto de articulación de éstas con otras lenguas y otras culturas. El mito no es nunca de su lengua, es una perspectiva sobre otra lengua (LéviStrauss, citado en Viveiros da Castro, 2010: 223)

Creo que presenciamos en torno a La Bestia esas traducciones diversas que permiten establecer el punto de articulación entre distintas lenguas y culturas, pero también, como lo han indicado los Comaroff, entre registros diferentes de la realidad social: globales, nacionales y locales; económicos, políticos e históricos. Si el mito es por 'naturaleza' una forma de traducción, como sostiene Lévi-Strauss, La Bestia ha sido una de sus expresiones. Al menos articula un imaginario religioso con discursos políticos y económicos, del mismo modo que la hechicería le daba motivos humanos a procesos económicos impersonales. Se cumple algo que dice Michael Taussig: “(...) se necesita de un 'tono prehistórico' para una infraestructura social fantástica" (Taussig, 2010: 258). De alguna forma, la materialidad de las fricciones que nos interesan es traducida al lenguaje religioso. Si la fricción produce el mito, como antes sostuvimos, éste permite que sea interpretada.

\section{Globos paralelos}

Un etnógrafo atribulado observa las líneas de metal que se pierden en el horizonte y a la gente que rodea las vías. Piensa en el viaje que algunos de ellos emprenderán, en sus peligros, en los relatos que ha escuchado sobre ese trayecto. Mira la historia fluir a sus pies, como los ríos de Heráclito, siempre distintos y siempre los mismos. Ve el horizonte amenazante que se abre al final de las vías. Podría escuchar el tren, como muchas veces lo ha hecho, venir desde lejos, silbando durante la noche, cubierto de misterio y de simplicidad, de hechos infaustos y mercancías. Lúgubre y poderoso, a la vez. Un etnógrafo atribulado que intenta pensar ese mundo, rastrea datos y conceptos, lee y descifra, viaja de algún modo para traer los elementos que permitan una explicación; pero que también reconoce su impotencia: ¿es un albor de la historia o su resultado concreto y sólido?, ¿es cierto que el mundo pasa por estas vías y que los

globos se relacionan de modos insospechados con las líneas paralelas de un tren?, ¿el futuro está allá, donde perdemos la vista, pero mantenemos el corazón en vilo?, ¿se pueden explorar 
otras vidas y luego dejarlas seguir su curso? Ese lugar, esas orillas terrestres, que son como puertos improvisados al lado de las corrientes y los flujos, de esos mares humanos, de ese movimiento incesante, donde se levanta un pequeño altar para que Dios interceda por todos nosotros, para que Él contenga todas las tribulaciones, como una especie de refugio ante la inmensidad y una interpretación ante lo incognoscible, como si las bestias pudieran domesticarse de alguna manera y la imagen diminuta de una virgen fuera el domador adecuado. Una escatología que cubre esos espacios de maldiciones y bendiciones, de signos y de anuncios, de impotencia e ira.

El etnógrafo atribulado, que escucha las imprecaciones, como si el cielo se abriera por unos momentos ante los frágiles seres que lo invocan, ve erigirse un mito frente a sus ojos y reconoce el poder de la cultura para crear un mundo e interpretarlo, para asirlo y entenderlo. Jan Kott escribe, sobre Noche de Reyes de Shakespeare, "sin embargo, el mundo es siempre real y siempre el mismo, amargo, cruel y embriagador, un mundo con el cual no se puede estar de acuerdo ni, tampoco, huir de él; un mundo cuya única justificación es el hecho de que sólo él existe” (Kott, 1969: 337). Si bien no se puede huir del mundo, se lo puede interpretar. La realidad colinda con la crueldad y la embriaguez, así como el altar roza las líneas del tren. El mundo está ahí, es cierto, pero transformándose. Sólo él existe.

¿Cómo se vincula el mito con el deseo? En una entrevista video-grabada que el equipo de Línea de Sombra realizó a dos migrantes nicaragüenses que viajarían en bicicleta hasta Villahermosa y luego hacia el norte del país, el mayor de ellos dice que el norte siempre estará ahí y que, por lo tanto, él puede tardar en llegar hasta su destino porque es seguro que lo encontrará. Ellos pensaron viajar en bicicleta porque conocen los peligros del tren. Están seguros de arribar y de que el viaje será menos riesgoso. El mismo migrante habla del hambre que se pasa en su país y del valor de su moneda. Viaja para darles un mejor futuro a sus hijos. El norte no se moverá y esperará su deseo. Una de las entrevistadoras le regala un paliacate con la imagen de la Virgen de Guadalupe, que él se pone en la cabeza como los peregrinos que cruzan el país para rendirle tributo. En la imagen final del video los migrantes parten en bicicleta desde el Hogar de los franciscanos y uno de ellos porta el pañuelo en su cabeza. Viajan de esa forma para evitar los peligros de La Bestia y, como el altar a la orilla del tren, esperan que la Virgen los proteja. Una vez más, lo mítico y lo técnico se entrecruzan para sostener el deseo. Las bicicletas y las vírgenes, lo visible y lo invisible, lo mundano y lo sagrado. 
Los migrantes hablan del sueño americano como la posibilidad de construir un futuro distinto para ellos y sus familias mediante el dinero que conseguirán trabajando en los Estados Unidos. El sueño americano no se realiza en ese país, sino que se cumple a través suyo; porque es el sueño de una riqueza que se disfruta en el lugar de origen. El sueño nuevamente aparece como la escenificación de un deseo individual y colectivo. El muchacho hondureño del que antes hablé soñaba con tener papeles en México, los migrantes que cruzan Tenosique en su viaje hacia los Estados Unidos sueñan con los beneficios del dinero que ganen allá para construir algo en sus ciudades y pueblos. Es un sueño de regreso, de pertenencia. La riqueza, así como el derecho, se transforman en campos oníricos.

El sueño es el escenario del deseo, su expresión futura: la residencia, los bienes. Creo que es esta fuerza deseante, que impulsa el proceso migratorio, la que se encuentra con esa otra que estimula la búsqueda erótica. Sólo el deseo se puede articular con el deseo. El encuentro es fortuito y puntual, como antes lo relaté. Si fueran deseos paralelos, sólo la historia los intercepta. Podrían ser deseos simultáneos y también múltiples que hallan puntos de confluencia y también de separación. El flujo es su única consistencia: de energía libidinal y laboral, de personas y proyectos, de cuerpos y eróticas. Como el tren y sus vías, que permanecían ante el movimiento incesante. 


\title{
VII
}

\section{El abandono y su aura: Nuda vida e inmunidad}

\author{
(...) hay probablemente algo de bueno en el sólo hecho de vivir \\ Aristóteles, citado en G. Agamben, Homo Sacer I, 1996: 10
}

Este capítulo está dedicado, fundamentalmente, a la violencia, la enfermedad y la muerte. Creo que son temas que debemos abordar de manera específica, siguiendo algunas líneas de análisis que aparecieron en capítulos anteriores. Es, por así decirlo, un capítulo que retoma muchas hebras conceptuales y empíricas para desarrollarlas en torno a esos tres arcanos de la vida social y subjetiva. Mi propuesta central es que el abandono en el que viven o son colocados algunos sujetos y colectivos es un aura, en términos de Benjamin, que rodea sus cuerpos y sus vidas y que los hace profundamente vulnerables ante la acción de las instituciones y de ciertos grupos u otros sujetos. Estos colectivos y sujetos, en vez de ser invisibles, como algunas veces se ha creído, son hípervisibles para determinados aparatos sociales (sean estatales o no). Por eso diremos que proyectan un aura, que devela los códigos de una mirada y una práctica social violenta, excluyente y discriminadora. Un aura que es vista por ciertos actores en contextos específicos. Esa aura la leeremos a través de una antropología del abandono, propuesta por João Biehl (2007) y Elizabeth Povinelli (2011).

El aura que irradiaría el abandono debe ser inscrita en una dilucidación de los dispositivos explorados. Retomaremos, en este punto, las lecturas que hace Gilles Deleuze de los dispositivos foucaultianos, como modos en los que se produce y se organiza lo decible, pero también lo visible. La luz de los dispositivos la hemos leído como el aura de los sujetos.

Tres acontecimientos que sucedieron durante el trabajo de campo me condujeron a pensar esta relación entre aura y abandono. El primero, cronológicamente, fue el enorme cartel que tenía sobre su camilla, en un hospital local, un amigo que vive con VIH; con grandes letras azules, sobre su cuerpo delgado y desgastado, las siglas de la enfermedad brillaban en medio de la blancura del lugar y el silencio de las otras paredes y camas. Esa luminosidad hiriente me causó un hondo impacto. Era difícil saber por qué se añadía esa crueldad a la situación tan frágil de mi amigo. 
Durante la administración del primer alcalde perredista de la ciudad (formalmente de izquierda), el Director de Seguridad Pública, un excapitán del Ejército Mexicano traído desde la capital del país, aplicó una versión local de las políticas de tolerancia cero promovidas por el exalcalde de Nueva York, Rudolph Giuliani, que intentó emular un gobernante (también de izquierdas) en el Distrito Federal. Durante ese periodo, la seguridad pública se convirtió, fundamentalmente, en un acoso constante a ciertos colectivos y sujetos de la ciudad: hombres jóvenes de clase popular, trabajadoras sexuales y homosexuales, especialmente si estaban "vestidos de mujeres". Esto lo analizaré con mayor detalle más adelante, pero la Policía Municipal hacía redadas en los bares y cantinas de la ciudad en las que solicitaba identificación a determinados sujetos, los revisaba y, a veces, los detenía. Presencié varios de esos episodios y siempre me sorprendió la precisión con la que los policías se acercaban a ciertas personas, orientados por su apariencia.

Por último, un tercer incidente acaecido hace poco tiempo: a principios de 2014, una familia de migrantes salvadoreños que había conocido en el Hogar-Refugio para Personas Migrantes La '72, de Tenosique, se comunicó conmigo, al arribar al Distrito Federal, y me pidió que los alojara mientras seguían su viaje hacia los Estados Unidos. Ellos me contaron que durante su viaje, desde la frontera sur hasta la capital, policías federales y funcionarios de las terminales de autobuses o de las compañías de transporte los extorsionaron, al menos, tres veces. Esos pagos los habían dejado sin dinero. Al verlos me pregunté cómo pudieron reconocerlos, en medio de las multitudes que circulan por esos lugares, sin que tuvieran, en mi percepción, señas físicas distintivas respecto al común de los ciudadanos. ¿Qué brillaba en ellos?, ¿qué era lo que esos policías y funcionarios corruptos veían?, ¿qué hay detrás de sus apariencias que proyecta una luminosidad lo suficientemente intensa para que todo tipo de individuos rapaces se les acerquen y abusen de ellos?

\section{Elabandono}

Cuando trabajé la globalización, en el capítulo anterior, encontré algunos campos y relaciones inesperados. Si bien no podré desarrollarlos cabalmente y yace en ellos la continuación de esta investigación en nuevas direcciones, creo que hay un fondo común que abordaré desde 
ángulos específicos, pero que amerita otro estudio, en sentido estricto. ${ }^{78}$ Ese fondo es el abandono.

Llegué a él por dos rutas, la primera fue lo que denominé una antropología del abandono, sustentada en los textos de Biehl (2007) y Povinelli (2011), pero también en una larga, aunque dispar, tradición de estudio etnográfico de sujetos y colectivos ubicados, en alguna medida, al margen de las instituciones, el orden social o los mundos de vida. En México se podría trazar una línea desde los estudios clásicos de Oscar Lewis sobre pobreza urbana (2011[1961] y 2012[1964 y 1970]); hasta los contemporáneos sobre personas en situación de calle (Makowski, 2004) o pandillas juveniles (Náteras, 2008), entre otros, que formarían parte de esa tradición. El abandono sería, en este sentido, una forma de leer otras etnografías, construidas con categorías teóricas diferentes, pero también una característica común a los grupos estudiados.

La segunda fue una relectura del tríptico sobre el homo sacer, escrito por Giorgio Agamben (2005, 2006 y 2007). Biehl y Povinelli mencionan, en sus libros, los argumentos del filósofo italiano, pero creo que no le otorgan suficiente importancia para pensar el abandono.

Agamben dirá, al introducir una larga investigación sobre el poder contemporáneo, remecida por la experiencia de los campos de concentración, que se dirige a "ese punto oculto en que confluyen el modelo jurídico-institucional y el modelo biopolítico del poder" (Agamben, 2006: 15). Como un continuador crítico de los estudios de Foucault, sostiene que "en los umbrales de la vida moderna, la vida natural empieza a ser incluida en los mecanismos y cálculos del poder estatal y la política se transforma en bio-política" (ibíd.: 11); pero no será la vida natural sino la nuda vida (expuesta a la muerte) "el elemento político originario" (ibíd.: 114). Definirá la nuda vida como una "zona de indiferencia y de tránsito permanente entre el hombre y la bestia, la naturaleza y la cultura" (Agamben, 2006: 141). Nosotros llegamos por una ruta etnográfica a esa misma zona: toda la frontera sur ha sido llamada "tierra de nadie", "lugar sin ley", como vimos, pero también hemos sido testigos de extrañas y novedosas articulaciones entre la bestia y el hombre, entre naturaleza y cultura, que sólo intentamos entender, pero que exceden, por ahora, el alcance de esta investigación. No buscábamos, como dije, la soberanía, pero la encontramos; tampoco la nuda vida y nos topamos con ella. Nunca pensamos el abandono hasta que se hizo evidente, por así decirlo, su presencia.

\footnotetext{
${ }^{78}$ Desde fines de 2013 estoy investigando los flujos migratorios que transitan por Tenosique. Realizaré, durante los dos próximos años, una etnografía sobre el paso de los migrantes y su estadía en la casa del migrante local, que quisiera llamar una antropología del abandono. En ella espero profundizar los temas que acá sólo logro insinuar.
} 
No reconstruiré toda la compleja argumentación de Agamben, sólo recogeré algunas de sus intuiciones, pensando que nos serán útiles para entender el lugar paradójico de ciertos sujetos y colectivos en el orden social; que son regidos por la ley, como cualquier ciudadano, pero que a su vez son sometidos a formas de violencia y extorsión extra-legales o para-legales. Sujetos y colectivos que están dentro y fuera, al mismo tiempo y en un mismo lugar. Agamben llamará relación de excepción a esa "forma extrema de la relación que sólo incluye algo a través de su exclusión” (Agamben, 2006: 31). La excepción, añadirá el filósofo es la localiación fundamental,

que no se limita a distinguir lo que está dentro y lo que está fuera, la situación normal y el caos, sino que establece entre ellos un umbral (el estado de excepción) a partir del cual lo interior y exterior entran en esas complejas relaciones topológicas que hace posible la validez de un ordenamiento (ibíd: 31-32)

Esas complejas relaciones topológicas son las que incumben al abandono. Diremos que el umbral al que se refiere Agamben -que permite distinguir lo que está dentro y lo que está fuera, pero también quiénes lo están-, será el aura de los sujetos que experimentan alguna forma de abandono. Por tanto, no se trata sólo de topologías, sino también de corporalidades y visibilidades. Agamben se pregunta si es legítimo, e incluso posible, "mantener la separación entre tecnologías subjetivas y técnicas políticas" (ibíd: 15); nosotros responderemos que no lo es y el aura del abandono será una forma de acoplar esas tecnologías subjetivas con las técnicas políticas.

Llegamos al punto clave de la argumentación de Agamben, leída desde nuestra perspectiva. La excepción, dirá, es una relación de bando $0^{79}$; quien ha sido puesto en bando "no queda sencillamente fuera de la ley ni es indiferente a ésta, sino que es abandonado por ella, es decir que queda expuesto y en peligro en el umbral en que vida y derecho, exterior e interior se confunden"

\footnotetext{
${ }^{79}$ Bando remite, dice el traductor al español de Agamben, a "un entreverado complejo de categorías y realidades jurídico-institucionales” (Gimeno, en Agamben, 2006: 245). En la obra del filósofo adquiere matices semánticos múltiples, que no necesariamente corresponden a las definiciones ni sentidos que la palabra tiene en español. Abandono, cuya etimología se oscurece, significaría tanto libre voluntad y arbitrio como "quedar a merced" (ibíd. 251). Jean-Luc Nancy dirá que abandonar "es entregar, confiar o librar a un poder soberano, y entregar, confiar o librar a su bando, es decir a su proclamación, a su convocatoria y a su sentencia" (Nancy, citado en Agamben, 2006: 79-80). Por su parte, Corominas anota que abandonar deriva de una voz francesa que significa " dejar en poder (de alguien)', bandon 'poder, autoridad', y éste último del fráncico BANN, 'poder, autoridad”' (Corominas,
} 1980: 6-7). 
(ibid.: 44; las cursivas son mías). Agamben describe esa relación como ambigua, de la que es muy difícil desligarse; pero también como una fuerza, "a la vez atractiva y repulsiva", que ligaría la nuda vida y el poder (ibíd: 143). Esta relación de abandono explicaría, hoy en día, una vida "que está expuesta como tal a una violencia sin precedentes, pero que se manifiesta en las formas más profanas y banales" (ibid.: 146-47). Esas formas profanas y banales son las que nos interesan en este capítulo.

\section{Zonas de abandono}

Las zonas de abandono estudiadas por Biehl (2007) son, justamente, lugares donde esas formas profanas y banales de violencia se manifiestan cotidianamente. Los argumentos sobre el abandono que expusimos antes adquieren ahí una inscripción etnográfica precisa. El antropólogo dirá que esas zonas "visibilizan realidades que existen a través y más allá de la gobernanza formal y determinan la trayectoria de vida de un creciente número de gente pobre no considerada en el mapeo de las poblaciones" (Biehl, 2007: 4; la traducción es mía). Las personas que habitan esas zonas experimentarán un estatus ambiguo, "atrapados entre el cercamiento y el abandono, la memoria y el olvido, la vida y la muerte" (ibíd.). Su estudio se centró en Vita, un lugar en Brasil en el sobrevivían en condiciones inhumanas "enfermos mentales, pacientes con sida, jóvenes improductivos y ancianos” (ibíd.). Son zonas en las que la muerte de los indeseados se acelera, mediante un complejo entramado burocrático, que compromete al sistema de salud, las familias y las organizaciones no gubernamentales, entre otros actores.

Los abandonados, como los llama Biehl, "son portadores y testigos de los modos en que se deciden los destinos sociales de los más enfermos y los más pobres” (ibíd: 46). En esas zonas de abandono, dirá el antropólogo, no intervienen ni las autoridades ni las instituciones médicas, aunque envían a ellas a los indeseados (ibid.: 4). Por eso, lo que llama la "realpolitik del abandono", apunta a las responsabilidades institucionales e individuales involucradas en la creación de esos espacios biopolíticos (ibíd:: 14). Se pregunta, entonces, cómo reconstruir el contexto y el significado de las experiencias de abandono y cómo producir una teoría de los sujetos abandonados y sus subjetividades que esté sustentada etnográficamente (ibid:: 23).

Los abandonados ofrecerían una visión singular sobre "la fabricación de la muerte" (ibid:: 49), porque en sus cuerpos "formas políticas y sociales de vida, y por lo tanto la subjetividad, 
han entrado literalmente en simbiosis con la muerte" (ibid:: 51). De este modo, una etnografía del abandono tendría que mostrar las diversas fuerzas y escalas involucradas en su creación, para revelar "la sutil fabricación de las singularidades y la lógica que mantiene las cosas en un mismo estado" (ibid: 19).

\section{Economías del abandono}

Biehl documenta, a lo largo de su libro, cómo un haz de procesos sociales y económicos complejos permite que surjan las zonas de abandono que estudia. El arco de estos fenómenos incluye el incremento de la desigualdad económica y biomédica y la desestructuración familiar; de este modo "la experiencia de los individuos que viven en esos espacios/lenguajes de muerte está atravesada por los ajustes estructurales -como los que experimentó Brasil en las últimas décadas-, el funcionamiento inadecuado del sistema público de salud y la infamante y desigual distribución del bienestar" (Biehl, 2007: 46).

En esa misma línea, Elizabeth Povinelli sostiene que investigar las economías del abandono permitirá comprender los vínculos afectivos y las relaciones prácticas de los sujetos con "la desigual distribución de la vida y la muerte, de la esperanza y el daño, de la resistencia y el agotamiento", en lo que ella llama "el liberalismo tardío (late liberalism)" (Povinelli, 2011: 3; la traducción es mía). La antropóloga trabaja con materiales diversos, provenientes de distintas investigaciones; y articula su mirada en torno a la conformación de estas economías del abandono, producidas en ese cronotopo del liberalismo tardío, que expone a los sujetos a nuevas

formas de sufrimiento o intensifica las que ya experimentaban, pero atribuyéndoles la responsabilidad de que eso suceda. La naturaleza de ese sufrimiento es "ordinaria, crónica, severa y repugnante", dice Povinelli, antes que "catastrófica o sublime" (ibíd.).

A través de una mirada crítica sobre el neoliberalismo, que también preocupa a Biehl, la autora sostiene que aquél no fue sólo "el resurgimiento de antiguas formas ideológicas de la economía liberal (...) sino que una nueva forma de gubernamentalidad, a saber, una nueva forma en la cual se organizó y manifestó el poder sobre la vida y la muerte" (ibíd:: 22). En consonancia con las lecturas que Foucault y otros autores realizan del neoliberalismo, Povinelli sostiene que la biopolítica "no es un espacio de vida sino un espaciamiento de la vida; no una diferencia de vida sino un diferencial al interior de la vida" (ibid.: 109). De este modo, dice Povinelli, el neoliberalismo hizo resurgir formas de hacer morir y transformó las técnicas 
estatales de exterminio, orientadas fundamentalmente a resguardar la seguridad del mercado, verdadera "raison d'etre del Estado, el Estado mismo", escribe Povinelli, y a controlar o eliminar "cualquier forma de vida que no pudiera producir valores de acuerdo a la lógica del mercado" (ibid.: 22). Los diferenciales de la biopolítica serían producidos y operados por las economías del abandono, en las que se imbrican el Estado y el mercado.

Al revisar y pensar los materiales de su etnografía con aborígenes del norte de Australia, Povinelli muestra cómo las transformaciones de las políticas de bienestar del Estado australiano, pero también sus políticas de reconocimiento de los pueblos aborígenes, junto con dinámicas locales como las pugnas, por ejemplo, por la tierra, desplazan a un grupo importante de sujetos hacia los márgenes de las ciudades blancas cercanas a sus comunidades, profundizando su abandono social y cultural. Los cuerpos constantemente enfermos de sus informantes, su menor esperanza de vida, los problemas derivados del consumo de alcohol, más un cerco institucional y simbólico que dificulta cualquier forma de autonomía personal y cultural, quedan ubicados en "zonas precarias de ser y no ser" (ibíd:: 31). En esas zonas encontraríamos, por un lado, "las lógicas sociales de pertenencia y abandono" y, por otro, las condiciones materiales en las que un sujeto es abandonado (ibid.).

\section{El aura}

El aura que ilumina el abandono no sólo es reconocida visualmente, también es gestionada burocráticamente. En las tres escenas que sugerí al comienzo, el acto en común es la identificación: de la enfermedad, del trabajo o el estatus migratorio. En los tres casos la develación muestra una identidad, ya sea sexual, laboral o legal. El aura, en alguna medida, ilumina lo que es leído como una diferencia por los aparatos burocráticos y sus funcionarios: ya sea el sida, el trabajo sexual, la apariencia o la indocumentación. En este sentido, el abandono empieza donde se detecta una discordancia. Y podríamos pensar que está conformado, ante todo, por las prácticas institucionales y sociales que inician cuando un aura ilumina a un sujeto o un colectivo. El aura, leída de este modo, es el umbral del abandono. Benjamin sostiene que la reproducción técnica de la obra de arte afecta "un núcleo sumamente sensible" del objeto artístico: su autenticidad. Si bien, en estos casos no está en juego, en primera instancia, la autenticidad de los sujetos, como en el arte la del objeto, creo que percibimos un proceso 
parecido cuando se obliga su identificación. De algún modo, están en juego procedimientos de verdad, localizados en microprácticas sociales.

Lo que tienen en común, por otro lado, es el compromiso de la técnica, ya sea en la disolución de la autenticidad aurática como en la verificación de las identidades, también auráticas, según nuestra lectura. Esta presencia de la técnica será, a mi entender, uno de los vínculos entre el abandono y la biopolítica, entendida como la gestión técnica de la(s) vida(s). Roberto Esposito, en un texto dedicado a la biopolítica, advierte que "no existe vida natural que no sea, a la vez, también técnica" y que la relación entre bios y zoé "debe incluir a la téchne como tercer término correlacionado" (Esposito, 2006: 25). El aura, en esta perspectiva, es el brillo que la biopolítica suscita en las poblaciones que (re)produce. Benjamin escribe que en el concepto de aura se puede incluir "todo aquello cuya mengua estamos señalando y afirmar: en la época de la reproducción técnica de la obra de arte lo que se atrofia es el aura de ésta" (Benjamin, 2008[1939]: 97). Si el objeto perdió su aura en la era de la reproducción técnica, como lo sostiene Benjamin, el sujeto la adquirió en la era biopolítica. No sostengo que sean procesos conectados, o que el aura halla pasado del objeto al sujeto; sólo quisiera destacar el trasfondo técnico de la pérdida, pero también de la ganancia.

El aura, dirá Benjamín, corresponde "a las asociaciones que, a salvo en la mémoire involontaire, tienden a agolparse en torno al objeto" (citado en Taussig, 2010: 170). Parece que esas asociaciones agolpadas, protegidas por la memoria involuntaria de la que habla Proust, desaparecen o se debilitan con la reproducción técnica. En algún fragmento de su Libro de los Pasajes, Benjamin compara la huella y el aura y dice que la primera "es la aparición de una cercanía, por lejos que pueda estar lo que la dejó atrás”, en cambio, el aura "es la aparición de una lejanía, por cerca que pueda estar lo que la provoca"; si en la huella "nos hacemos con la cosa", en el aura "ella se apodera de nosotros" (Benjamin, 2013[1982]: 450). El aura que tratamos de definir o cuyo contorno nos interesa produce una lejanía, vinculada directamente con los procesos de abandono. El aura es un umbral, como dijimos, porque marca la interioridad o exterioridad de un sujeto en un contexto determinado: un migrante en una estación de buses, una persona transgénero en una cantina o en la calle, una trabajadora sexual en un bar, un enfermo en un hospital. El aura es el brillo de la diferencia, pero se agolpa en torno a un sujeto: se apodera de él, como de los objetos en el pensamiento de Benjamín.

El filósofo alemán dice, en otro texto, que las cosas de vidrio no tienen aura, y que "el vidrio es el enemigo número uno del misterio” (Benjamín, 1989[1933]: 171). La transparencia 
sería contraureática, en alguna medida, porque disuelve el misterio a través de una visión sin obstáculos. Algo que no tiene aura carecería de misterio, como el vidrio que confina el movimiento, pero no impide la mirada.

¿Es el aura que nos interesa una forma de transparencia?, ¿persiste alguna forma de misterio en torno a los sujetos expuestos al abandono? Para Agamben, el abandono es muy difícil de ver. Por ejemplo, en el caso más extremo, una figura conocida como el 'musulmán' entre los deportados de los campos de concentración, a pesar de su deterioro radical apenas puede ser vista. El filósofo habla de un principio según el cual "nadie quiere ver al musulmán”, elaborado y descrito por los sobrevivientes (Agamben, 2005: 59). Pero, como también lo ha escrito Agamben, la relación de abandono supone una “irreparable exposición” (Agamben, 2006: 109), como si fuera una especie de cristal social, una forma vitrial de lo vivo y del cuerpo.

¿Qué se escondería detrás del misterio?, ¿qué ocultaría lo que es opaco? Benjamin sostiene que junto con la reproducción técnica, las masas, cuya importancia sería creciente, "aspiran a que las cosas se acerquen"; de este modo, "cada día se hace más inevitable la necesidad de adueñarse del objeto en la máxima proximidad de la imagen, o mejor dicho, en la copia, en la reproducción” (Benjamin, (2008[1939]: 99-100). Y en esa cercanía desaparece el aura, porque ella supondría la aparición de una lejanía extraviada en el consumo masivo de objetos reproducidos idénticamente.

Es difícil transponer los rasgos de un objeto a los de un sujeto, pero tratamos de producir una analogía que nos oriente en esa visibilidad excesiva del abandono. El aura del objeto no es la del sujeto. Pero en el momento histórico cuando se inauguró la producción masiva de mercancías, también se delimitaron las poblaciones y se consolidó la biopolítica (Foucault, 2002 y 2007). Benjamin lo intuye, si se me permite la imagen, al elaborar un paralelo entre la ruptura de "la envoltura de cada objeto [al] hacer trizas su aura", y el avance de la estadística como forma de establecer regularidades sociales. Ambos procesos cobijan un "modo de percepción cuya 'sensibilidad para lo igual en el mundo' se ha desarrollado tanto que hasta lo extrae de lo singular mediante la repetición" (Benjamin, 2008[1939]: 100). Extraer de lo singular mediante la repetición corresponde al umbral que tratamos de distinguir en las relaciones y zonas de abandono.

Al sujeto auréatico de la biopolítica se le ha extraído lo singular mediante la repetición de medidas de control e identificación, es decir, esa extensa red de formas disciplinarias de baja intensidad que atraviesa la vida cotidiana. Sólo, como lo diremos al finalizar este capítulo, el 
deseo puede restituir lo singular y hacer trizas el aura biopolítica extendiendo otra que llamaremos un aura inmune.

\section{Dispositivos auréaticos o la luz del poder}

¿Dónde está el brillo que el aura emite: en el cuerpo, en la mirada, en el espacio entre ambos?, ¿cómo puede la mirada (estatal, por ejemplo) identificar ese brillo aureático?, ¿existen formas de opacar esa luminosidad, mediante estrategias de camuflaje que desvíen o confundan la mirada sagaz del Estado o de los criminales? Los dispositivos estudiados por Foucault, dirá Agamben, tendrían "la capacidad de capturar, orientar, determinar, interceptar, modelar, controlar y asegurar los gestos, las conductas, las opiniones y los discursos de los seres vivos" (Agamben, 2011: 257). Esos dispositivos, según Deleuze, son "máquinas de hacer ver y hacer hablar"; su luminosidad "está hecha de líneas de luz que forman figuras variables, inseparables de tal o cual dispositivo" (Deleuze, 2010c: 310). El aura depende del dispositivo, porque "cada dispositivo tiene su régimen de luz, la manera como la luz penetra en él, como se difumina y se propaga, distribuyendo lo visible y lo invisible, haciendo nacer o desaparecer un objeto que no existe sin ella” (ibíd.) ¿Cuáles son los regímenes de luz que organizan la visibilidad del abandono?, ¿son semejantes los que alumbran los hospitales, las redadas policiales o las cantinas? Si hay que definir regímenes de luz antes que sujetos u objetos, "mediante lo visible" (ibid.), entonces el aura podría entenderse como un régimen de luz, que atraviesa múltiples dispositivos, pero de maneras singulares, produciendo determinadas formas de visibilidad para sujetos y colectivos distintos.

Las visibilidades, según Deleuze, no son formas "que revelarían el contacto entre la cosa y la luz", sino luminosidades "creadas por la propia luz que no dejan subsistir los objetos más que como chispazos, brillos, centelleos" (ibid.: 225). Las visibilidades "nunca están escondidas", dice en otro texto, y su condición es que haya luz, "un modo de ser de la luz que hace surgir las visibilidades como chispazos y centelleos, como una 'segunda luz"' (Deleuze, 2010b: 226). El aura sería una forma de luminosidad, pero investigada a partir de sus reflejos, es decir, desde los chispazos, brillos y centelleos que la luz de los dispositivos produce en el cuerpo de los sujetos; en esa medida, constituiría una segunda lu₹. Hay que observarla para realizar una operación semejante a la que Deleuze propone con los objetos: abrirlos y "captar la forma en que la luz aparece en tal estrato y condiciona lo visible". Abrir el aura de los sujetos es encontrar su 
abandono, según creemos; pero para ello hay que evitar el brillo deslumbrante del poder y buscar sus reflejos en superficies diversas y disímiles: el cuerpo de una travesti o el de un enfermo, el fulgor de una prostituta o un joven campesino tatuado. De este modo, entenderemos cabalmente qué "puede ver una época", en función de sus "condiciones de visibilidad" (ibíd.).

Agamben dirá que sujeto es lo que "resulta de la relación cuerpo a cuerpo, por así decirlo, entre los vivientes y los dispositivos" (Agamben, 2011: 258). Justamente, en esa relación cuerpo a cuerpo surge la luz que nos interesa, los resplandores del aura. Si ésta es una segunda luz, los sujetos son un tercer término, surgido de la fricción entre dispositivos y seres vivientes. Por eso, no creemos que a la nuda vida -“y sus avatares en el mundo moderno (la vida biológica, la sexualidad, etc.)"-, "le sea inherente una opacidad", como sostiene Agamben, sino más bien una luminosidad que se vincula directamente con "su carácter político" (Agamben, 2006: 153).

\section{E1 aura de los enfermos}

¿Quién será capaz de comprender, quién de explicar, qué sea aquello que fulgura a mi vista y hiere mi corazón sin lesionarlo? San Agustín, en Rudolf Otto, Lo sagrado, 2008[1917]:41

Luz es una mujer que vive con VIH desde hace 9 años, o al menos lo sabe. Su esposo, que era militar, murió por causa del sida en el año 2005, en el norte del país. Al morir, ella perdió los servicios médicos que recibía por parte de la Secretaría de Defensa. Su hija menor, que nació luego de la muerte de su padre, también vive con VIH. Es una entre 5 hijos y su hermano tiene una parálisis que le impide moverse de su cama. Cuando Luz fue a inscribir al niño en la única institución que brinda rehabilitación para casos como el suyo en la ciudad le dijeron que no podían aceptarlo porque sabían que ella 'tenía sida' y los padres reclamarían. El niño sigue postrado en su cama.

El año 2009, la menor de las hijas de Luz debía entrar al jardín de infantes. Ella fue a inscribirla, pero la directora no la quiso aceptar. Por la misma razón: tiene sida y los padres reclamarán, nadie garantiza que no pueda infectar a otro niño. Alan organizó la resistencia. Conoce a todas las personas que viven con VIH en la ciudad y sabía, desde hace tiempo, que ese año varios niños seropositivos entrarían a la escuela o al jardín. Había intentado conversar con las supervisoras de la Secretaría de Educación Pública (SEP) estatal sobre el tema, pero 
nunca lo recibieron. Alan va a la radio a denunciar la discriminación de la que es objeto la menor. Las supervisoras reaccionan y citan a una reunión con todas las maestras de la escuela, la directora y algunos médicos del sistema público que les darán una charla sobre el sida, el VIH y sus formas de contagio. Alan se entera de la reunión y decide ir. Cita a Luz y me pide que asista como profesor universitario y psicólogo.

Llegamos a una sala típica de jardín infantil, con mesas y silla pequeñas. Sólo hay mujeres, salvo un médico regordete y canoso, Alan y yo. Cuando entramos, el médico les está dando algunas explicaciones archiconocidas sobre el VIH y sus formas de contagio, sin mucho ánimo y de manera desordenada. Luego, dice que tiene que retirarse. Sale el expositor fallido y se queda Alan al frente de la reunión. Las profesoras están sentadas en las sillas pequeñas en torno a las mesas pequeñas, como especie de Gullivers en una Lilliput amarga. La directora a un costado, como si participara y la vez no lo hiciera en la reunión. Las supervisoras de la SEP local en un lugar más alto dentro de la sala, como jueces y atalayas de sus propios efectos.

La maestra que recibiría en su curso a la hija de Luz le pregunta a Alan qué debe decirles a los padres cuando reclamen que una niña con sida conviva con sus hijos sanos. Él le responde que, sin ser grosero, lo primero que les preguntaría a las mamás es si se han hecho la prueba del VIH y si saben con quiénes se acuestan sus maridos. Luego les dice que, por favor, no arriesguen su trabajo por falta de información, porque él antes de asistir a la reunión platicó con personal de la Comisión Nacional de Derechos Humanos y de la Secretaría de Salud de Tabasco y que en ambas instancias le dijeron que estaban violando el derecho a la educación de la niña, garantizado por la Constitución Política ${ }^{80}$, y que eso podía implicar sanciones e incluso el despido. Les dice que esto se los había advertido, pero que nadie le hizo caso y que había otros cuatro niños en la misma situación, que sólo él y sus padres sabían.

Luz está sentada al fondo de la sala, con los hombros caídos. Mira pero no habla, otra Gulliver en esta Lilliput aciaga.

Alan me pide que intervenga como psicólogo y yo les digo que me parece que el principal tema será el miedo de los padres ante un posible contagio de sus hijos. Les digo que hay que considerar que esos temores son legítimos, aunque infundados, porque entre los millones de

\footnotetext{
${ }^{80}$ Alan cita el artículo 3ero de la Constitución Política de los Estados Unidos Mexicanos, que en su primer párrafo señala: “Todo individuo tiene derecho a recibir educación. El Estado -Federación, Estados, Distrito Federal y municipios-, impartirá educación preescolar, primaria y secundaria. La educación preescolar, primaria y la secundaria conforman la educación básica obligatoria” (Cámara de Diputados, 2011: 5).
} 
niños que viven con VIH en el mundo, y que van a la escuela con otros niños no infectados, no se ha presentado ningún caso de transmisión del virus, según las organizaciones de salud dedicadas al tema.

Alan insiste en que no se puede discriminar a la niña, porque Luz ha tenido la valentía de hablar públicamente de su 'problema', y de reconocer que está enferma, mientras mucha otra gente lo oculta. La niña, dice, no tiene la culpa de tener sida. Las Gullivers miran atentamente a Alan, que es cada vez más incisivo y cortante en sus afirmaciones. Dice, que de ser discriminada, deberán demandar a la escuela y a los maestros ante derechos humanos y la misma SEP. Las Gullivers abren los ojos y las sillas sostienen mal los movimientos de sus cuerpos tensos. Luz se hunde más en su silla y en su mutismo.

Se termina la reunión y la directora expresa que no habrá problemas en aceptar a la niña, pero que necesita que se den más 'charlas'. Las supervisoras se acercan a Alan para decirle que no estaban enteradas de estos problemas y Alan les recuerda que las visitó, pero no lo recibieron, y ellas se justifican con sus cargas de trabajo. Yo me quedo con una sensación extraña, de esa pax mexicana muy difícil de descifrar, pero que siempre anuncia tempestades antes que calma.

Luego seguí la historia por teléfono. Luz llevó los papeles y la directora no se los quiso recibir. Ires y venires, toma y daca. Finalmente Alan partió a Villahermosa y, por intermedio de un activista de la diversidad sexual y el VIH, se entrevistó con los jefes del área preescolar de la SEP local y ellos ordenaron a Tenosique que la niña fuera aceptada. Además, enviaron a un supervisor para enterarse en terreno de lo que sucedía.

¿Por qué Alan cita la Constitución y menciona los derechos humanos como referentes últimos para resolver esta situación?, ¿por qué esta escena local, esta arbitrariedad cotidiana e institucional a la vez, es conjugada con los textos centrales de la ciudadanía moderna en el país?, ¿cómo interpelan a estas personas esas referencias jurídicas?, ¿qué relaciones de poder logran impugnar o trasponer mediante su enunciación? Las preguntas no sólo apuntan a una dimensión discursiva en la que los derechos humanos y la ciudadanía amplían el campo de lo decible en términos políticos y sociales. También muestran a una práctica de los derechos humanos y de la ciudadanía, tal como lo señala Lefort (2004). En el centro de la intervención de Alan se encuentra la capacidad del discurso de los derechos humanos para concitar acciones políticas que los reivindiquen, pero también que los utilicen como soportes simbólicos para transformar subordinaciones y relaciones de poder excluyentes. 
La madre de la niña permanece en silencio, porque no es considerada una interlocutora legítima en esta escena. Nadie le pregunta su parecer, no obstante es una de las principales afectadas. No tiene voz. Presencia una discusión que gira en torno a su vida, su intimidad y la de su familia, en silencio, como si fuera una mera espectadora de lo que los otros dicen sobre ella. Es testigo de su propio testimonio (ausente). Testigo especular, entonces, que escucha lo que ha dicho en boca de otros que lo reproducen, lo juzgan, lo representan o lo restriegan. En esta escena, donde lo decible se topa con la intensidad física de las diferencias entre los sujetos y las corporalidades cuerpos, las bocas y las palabras, el cuerpo de esta mujer es mero espectador de su propia descripción colectiva. Es mudo, en algún sentido; otros, en este caso Alan, hablan en su nombre. Es como si se cumpliera de manera literal una de las condiciones que Rancière discierne para las relaciones de dominación, en las que potencialmente empieza la política y también termina:

La distribución simbólica de los cuerpos divide en dos categorías: aquellos a quienes se ve y aquellos a quienes no se ve, aquellos de quienes hay un logos (...) y aquellos de quienes no hay un logos, quienes hablan verdaderamente y aquellos cuya voz, para expresar placer y pena, sólo imita la voz articulada (Rancière, 1996: 37).

Para esta mujer no hay logos. Tiene una voz articulada, pero no una palabra legítima. Su silencio confirma su estatus como seropositiva en esa ciudad: aislada, viviendo una muerte social abrumadora, discriminada y señalada. En muchos sentidos, estamos en las antípodas de cualquier ciudadanía. Lo único distinto es que alguien puede citar los derechos humanos y la Constitución como si hablaran de ella, como si mencionaran su caso de algún modo. Un artefacto legal, como ese artículo constitucional, se difunde entre los presentes recordando el derecho a la educación que tiene la niña. Esta mención cotidiana de la ley y de los derechos produce un efecto de exterioridad con respecto al poder, tal como lo señala Lefort, "(...) una exterioridad indeleble" (Lefort, 2004: 200). Exterioridad que escinde el campo institucional, al remitir las prácticas institucionales a su marco normativo más amplio y atravesar el sopor aparente de la vida diaria con las peculiaridades discursivas de la ley; al detener la arbitrariedad y la discriminación con la fuerza textual de los derechos.

No obstante, Luz y su hija no son invisibles y su vulnerabilidad reside, justamente, en que son demasiado visibles. Diferimos de Rancière, en este punto, que vincula la incapacidad de emitir un logos, es decir, de producir un discurso, con la invisibilidad de los sujetos incapaces de articular una voz verdadera. Es cierto que Luz no puede hablar, o más bien, que no se atreve a 
hacerlo; permanece en silencio en la escena descrita y en muchas otras en las que la he visto, pero no oculta ni invisible porque parte de su silencio se debe, precisamente, a su visibilidad. Cuando va a inscribir a su hija la directora la reconoce, sabe que "tiene sida", porque la ha visto, se lo han dicho. La puede identificar. Si Luz hubiese guardado silencio sobre su enfermedad, no la conocerían tal vez. Su silencio es consecutivo a su visibilidad, al contrario de lo que sostiene Rancière.

Vemos cómo el abandono produce un aura que cubre al sujeto abandonado, es decir, a quien está dentro y fuera, que es interior y exterior a una comunidad, puesto en un estado de excepción vital que lo expone a la ley y lo aparta de ella, en un mismo gesto. Luz no puede defenderse a sí misma porque su aura lo impide, porque la excepción de su estatus clausura, exactamente, cualquier referencia a la ley que debería protegerla. Otros pueden atravesar su abandono y resguardarla; otros deben cubrirla con su opacidad para que el brillo de su aura no la dañe aún más. Luz brilla junto con su hija, que ni siquiera sabe que vive con VIH. El fulgor de la enfermedad, el resplandor del estigma, las envuelve a ambas, abandonándolas juntas ante un orden social excluyente e instituciones avasallantes. Como el pequeño niño que permanece abandonado en su cama sin poder acceder a rehabilitación alguna. Un brillo familiar que los daña a todos, que los acompaña de forma insistente; auras colectivas para abandonos sucesivos.

\section{Postrados}

A finales de 2012, antes de regresar al Distrito Federal, luego de estar por unos días en la ciudad, un amigo que vive con VIH, y que conozco desde hace cuatro años aproximadamente, me mandó un mensaje al celular. Me pedía disculpas por no haberme visto y me contaba que lo habían internado de urgencia en el Hospital Municipal, porque tenía diarrea y vómitos y estaba deshidratado. Unas horas antes de abordar el autobús rumbo a la capital de Tabasco, fui a visitarlo. Le pedí a Alan que me acompañara para entrar sin problemas. Llegamos a la sala de espera de urgencias del hospital y saludamos a la hermana de mi amigo y a otra pariente, que esperaban que lo dieran de alta. Alan pasó primero y me dijo que lo fuera a ver. Entré a un pasillo y en la primera camilla arrimada a la pared estaba recostado mi amigo, con suero inyectado en su brazo. Otros pacientes en el mismo pasillo y algunos dentro de habitaciones que tienen las puertas abiertas. Le pregunto cómo se siente, si se ha hecho exámenes y si está 
tomando medicamentos antirretrovirales. Me dice que se ha hecho la "recarga viral" " y que no sabe los resultados. Los médicos en Villahermosa le dijeron que "aún no necesitaba remedios", aunque pese menos de 50 kilos, esté constantemente enfermo y se vea cada día más decaído.

Observo que junto a la camilla hay un letrero en el que está escrito el nombre de mi amigo, su edad, y con letras azules y muy grandes "VIH positivo". Miro las otras camillas y sólo la suya tiene pegado un rótulo de ese tipo. La Norma Oficial señala que el personal de salud debe "tratar sin discriminar a las personas que viven con VIH/SIDA respecto a otros enfermos, evitando difundir informaciones sobre su condición de infectado por el VIH o enfermo con SID $A$, entre quienes no tienen relación con su atención médica" (Secretaría de Salud, 2010: 17; el énfasis es mío).

Otra vez el brillo que nos interesa. La enfermedad de mi amigo reluce en las paredes blancas, escrita con plumones de colores visibles a lo lejos, que no dejan lugar a dudas. El aura de los enfermos, ese fulgor persistente que los acompaña y los hace vulnerables. Él es el único paciente cuyo diagnóstico es público; los otros permanecen velados. El sida brilla y su irradiación condensa una larga historia de rechazos y condenas. Como Luz, mi amigo vive en ese estado de excepción donde su vida se ha transformado en nuda vida, aún con mayor intensidad. Delgado, su piel escariada y seca, sus labios partidos, la voz casi inaudible y un resplandor indescriptible en sus ojos, que sólo he visto en quienes sufren demasiado o están cerca de la muerte. Pero su abandono se intensifica al entrar en una institución médica, aunque esperaríamos que menguara. Las paredes gritarán su enfermedad y la crueldad social, que surge del desprecio y la indiferencia, horadará su dignidad y su salud. Como los abandonados de Biehl, mi amigo entra en una zona que lo des-cubre, que lo des-ampara y que lo ex-pone; es decir, que lo ubica en esas topologías, de las que hablaba Agamben, donde los sujetos son sometidos a formas profanas y banales de violencia.

\footnotetext{
${ }^{81}$ Los errores con respecto al nombre de este examen -carga viral-, específico para el seguimiento del VIH y los resultados de los tratamientos antirretrovirales, son compartidos por autoridades estatales: en una recomendación que emitió en 2008, la Comisión Estatal de Derechos Humanos se indica, con respecto al tratamiento de un interno que vive con VIH en un centro penitenciario, que “(...) se le tramita y gestiona el costo de sus descargas virales" (CEDH, 2008: 15). Es necesario pensar qué significa esta confusión en los nombres, que sucede en un contexto de desinformación y desconocimiento de la enfermedad. Los errores pueden parecer banales, pero creo que son sintomáticos del relativo abandono y aislamiento en los que viven las personas seropositivas en el Estado. Nombrar con precisión es participar de un saber y tener capacidades técnicas, pero también sociales, para argumentar.
} 
En esta escena, tan discriminadora como la otra, consistente con este mapa social del estigma que se repite día con día en la ciudad y el país y que aísla de manera tan grave a las personas afectadas por la epidemia, no hay artículos constitucionales ni derechos humanos ante el desgaste evidente de la salud de mi amigo. No hay quien los enuncie, aunque estén escritos y disponibles. Nadie, en este contexto, imagina que tiene derechos ni los declara o reclama; ni mi amigo o su familia, tampoco Alan o yo. ¿Qué habría que hacer?, ¿ir con el director del hospital y enrostrarle la Norma Oficial que no está cumpliendo, pero que regula su trabajo?, ¿pelear con los médicos y las enfermeras para que luego lo traten peor cuando regrese con un cuadro de salud semejante?, ¿poner una queja ante la Comisión Estatal de Derechos Humanos?

Las acciones que realizó el Club para evitar que la pequeña fuera rechazada en la escuela, contrastan con este silencio ante las prácticas discriminadoras que suceden en las instituciones públicas de salud y que, según mi registro etnográfico, son cotidianas. Tal vez la situación de la niña no era tan dramática como la de mi amigo, cuya vida estaba en peligro, y en esa medida su recuperación, aunque sea momentánea, se antepone al trato o a sus derechos. La exterioridad del derecho con respecto al poder, que enuncia Lefort, se vuelve intimidad del poder consigo mismo, de espaldas a cualquier derecho, en la cotidianidad de las prácticas institucionales, en la densidad de las relaciones de poder que las sostienen, en la distribución simbólica de los cuerpos que, en este caso, exhibe a uno de ellos en sus padecimientos y su destitución social, lo hace visible en su diferencia, pero no le otorga un logos.

En este caso, podemos observar cómo se vinculan las tecnologías subjetivas con las técnicas políticas. El abandono no surge sólo de la ubicación de un sujeto en una topología social del poder; también de las formas en que se constituye como enfermo, como sidoso, como culpable o despreciable. Aquí las tecnologías subjetivas son indiscernibles de las técnicas políticas y no hay soporte para desvincularlas, como sucedió en el caso de Luz, para producir una exterioridad del derecho con respecto del poder. Ese soporte, lo vimos, fueron los derechos humanos, que sitúan el problema en el campo de las técnicas políticas y lo destierran de las tecnologías subjetivas.

En el caso de mi amigo enfermo, todo el aparato médico es una tecnología subjetiva; su estancia en el hospital, señalado y aislado, pero con necesidades urgentes de atención y tratamiento, lo expone como sujeto abandonado... a sí mismo. La culpa, en este sentido, sería una de las tecnologías actuantes; si tiene sida es por su sexualidad, su deseo, sus 
comportamientos; es el resultado de sus conductas. A la niña, al menos, se le podría atribuir inocencia; es una víctima de la vida de sus padres. Pero no a mi amigo, que se abandonó de alguna forma y los resultados son su enfermedad. ${ }^{82}$ A su vez, en ese estado, este sujeto se encuentra inserto en relaciones de soberanía: expuesto a la muerte, su vida es nuda vida y su cuerpo un cuerpo biopolítico (Agamben, 2006: 15-16). Si el elemento político originario, en palabras de Agamben, no es "la simple vida natural, sino la vida expuesta a la muerte (la nuda vida o vida sagrada)" (ibid:: 114), somos testigos de su juego en un hospital de provincia. No se pueden desvincular las tecnologías subjetivas de las técnicas políticas sin poner en riesgo la vida de este sujeto. Lo que ha sido descrito como indiscernible -el estado de excepción- también es indescomponible -la nuda vida-.

\section{Los muertos}

¿Qué es eso que expresáis con vuestros ojos? Walt Withman, Canto a mí mismo, 2009[1890]: 95

La última vez que me encontré con Esteban estaba sentado en una pequeña carnicería en una calle del centro de la ciudad. Cuando me vio salió a saludarme y platicamos un rato. Estaba muy delgado y su rostro parecía deforme; no sé si eran rastros de un sarcoma. A las pocas semanas me contaron que había muerto. Nunca supe bien quién era Esteban, aunque lo conocí en mis primeras visitas a Tenosique; ayudaba a Alan en distintas tareas. Desde el primer momento me comentaron que 'tenía sida'. No era gay, según me contó. Tenía tres hijos y había estado casado. Vivía con su madre en una pequeña casa, rodeada de árboles y animales. Esteban se difumina en mi recuerdo, conversé poco con él aunque lo vi muchas veces. Un día que lo encontré me pidió dinero, me comentó que llevaba tres días sin comer y que no había conseguido nada aún. La enfermedad se sumaba a la miseria y, ambas, al aislamiento. Cuando salió de la carnicería, el dueño, un hombre hosco, me miró con alivio como si le quitara un peso de encima.

\footnotetext{
82 Podríamos pensar, incluso, que casi toda las estrategias de prevención del VIH, lejos de corresponder a métodos objetivos para conseguir ciertos resultados sanitarios, son ante todo tecnologías subjetivas (el autocuidado), orientadas por técnicas políticas (la salud pública), que pretenden que los sujetos resuelvan, con sus propios medios, el abandono (social, legal, simbólico, afectivo) en el que viven.
} 
Esteban había entrado, según percibí, en una zona brutal de abandono que lo hacía morir con antelación a su muerte física. Si bien había estado hospitalizado, nunca supe si recibía tratamiento contra el VIH o no. Atenderse suponía viajar a Villahermosa, en ese momento, y eso implicaba dinero para los pasajes, al menos. Luego instalaron en la ciudad un Centro Ambulatorio para la Prevención y Atención en SIDA e Infecciones de Transmisión Sexual (CAPASITS), a cargo de la Secretaría de Salud estatal. Hoy las personas que viven con VIH reciben ahí su tratamiento y realizan un seguimiento médico. Esteban murió antes. Su cuerpo había sido abandonado, pero su aura bloqueaba las relaciones sociales; nadie se le acercaba, especialmente cuando mostraba signos evidentes de deterioro. Su quebranto y su muerte fueron el resultado infausto de relaciones sociales cotidianas, historias institucionales y estructuras discursivas, como apunta Biehl, que lo desplazaron hacia esa zona de muerte social, pero que a la vez consideraron que su situación era 'autogenerada' o su exclusiva responsabilidad (Biehl, 2007: 23).

Lo mismo sucedió con Alondra. La conocí tempranamente también. Durante varios años fue mesera en una cantina del centro de la ciudad. Nunca supe su nombre, todo el mundo la conocía como Alondra; tampoco sé cómo se definía a sí misma, pero vistió de mujer hasta su muerte. Era alguien afable, aunque silencioso. Alguna vez me comentaron que la habían arrestado por vender drogas; el lugar donde trabajaba tenía fama de ser un punto de distribución de estupefacientes. Pero sólo reconstruyo un rumor. También me habían dicho que "tenía sida". Desde el 2011 comenzó a deteriorarse físicamente. Ya no trabajaba en la cantina, pero la vi varias veces en otros locales, bebiendo sola. Adelgazó notoriamente durante ese tiempo. Recuerdo que vestía la misma ropa, pero que le quedaba cada vez más suelta, como si su delgadez no cupiera en ninguna prenda. Es raro que alguien beba solo en las cantinas, en ese contexto tomar es una actividad fundamentalmente social. Alondra estaba sentada en una mesa con una cerveza, la saludamos al pasar. Nadie se le acercó, la rodeaba un silencio profundo, el brillo aciago de la desgracia.

En mayo de 2012 me comentaron que se había suicidado. Una nota en un portal de noticias local tituló: “Truncó la vida con sus manos” y añadía que "a unos cuantos días de las madres la señora Á., sufrió el golpe más duro de su vida, ya que su hijo el mesero J. A., de 34 años, más conocido en su trabajo como 'Alondra', casi en su presencia se quitó la vida en el interior de la humilde vivienda que compartían.” (Paredes, 2012: s/p; texto corregido). Luego 
agrega que "por la tarde llegó tomado y sin mencionar nada de sus intenciones fatales, éste se puso a llorar mencionando que le dolían las piernas." La nota relata el suicidio:

alrededor de las tres de la mañana la división de madera donde se encuentra colgada una fotografía del occiso comenzó a moverse de un lado para otro, por lo que presintiendo una tragedia, se levantó para cerciorarse que era lo que estaba pasando atrás de la improvisada pared sin puerta (...) Estaba colgado de una lía de la misma hamaca amarrada a una viga, sin que supiera que hacer (...), explica doña Á., quien pasará este 10 de mayo, día de las madres, con inmenso dolor por la pérdida de su vástago, quien la acompañaba desde hace algunos en su soledad. (ibid., texto corregido) Alondra conocía muchos gay en la ciudad, había participado en los carnavales y en algunas actividades del Club. Cuando se deterioró marcadamente, al igual que Esteban, el aura de la muerte fue un obstáculo para que sus amigos se relacionaran con ella. Como Esteban, había quedado sola y había muerto antes de morir físicamente. Tal vez ahí reside la razón de su suicidio, una escapatoria al sufrimiento.

Esta doble muerte tal vez es uno de los efectos más devastadores del sida. Enrique recuerda a una persona enferma, que había muerto hace un par de meses, cuando platicamos sobre este tema en el año 2007. Sobre su muerte dice que:

No lo mató tanto la enfermedad sino el aislamiento que le hicieron, se sentía triste, no veía a sus sobrinos, a sus tíos, a sus hermanos, si lo veían era de 'hola', 'hola' pero de lejos y se sentía más enfermo y nos decía que 'no nos morimos a veces por la enfermedad, yo me siento enfermo, pero no por la enfermedad sino por la familia que no me quiere por lo que tengo' (Enrique)

Antes de la muerte biológica, se produce una muerte social, dice Biehl sobre los abandonados (Biehl, 2007: 52). Pero no es una muerte que se explique sólo por la lejanía de la familia o por la discriminación cotidiana; es una muerte producida social e institucionalmente. En este aspecto, la antropología del abandono es consistente; tanto Biehl como Povinelli apuntan en esa dirección cuando tratan de explicar la mortalidad feroz de sus informantes: sin atención médica, a edades tempranas, por enfermedades prevenibles o curables, sin ayuda y sin compañía. La muerte es un acto de larga duración, en muchos casos, que se puede extender durante años. Cuando algún sujeto localizado en una zona de abandono o inserto en las economías del abandono muere, ese desenlace no hay que remitirlo a su propio cuerpo -que ha fallecidosino a un sistema social y económico que lo ha abandonado. El abandono produce muertes lentas y aplazadas. Esteban y Alondra sobrevivieron durante años, pero se fueron deteriorando 
paulatina e inexorablemente. Si no hubiesen estado abandonados previamente, el resultado habría sido otro. Ambos son testigos del rol pedagógico del abandono, en palabras de Biehl, incapaces de producir algo distinto de la enfermedad y un sufrimiento silente (ibid:: 65). Su muerte social, dirá el antropólogo, "es la imagen negativa del futuro" (ibíd.).

Pero esa pedagogía del abandono, y la imagen negativa del futuro que produciría, se dirige no sólo a quienes sufren sus efectos más devastadores, sino a muchos otros sujetos que potencialmente podrían experimentar lo mismo. Es una pedagogía del umbral y del aura, que se sustenta en el temor a vivir algo semejante. Juan lo dice con claridad: no sólo es la muerte lo que nos atemoriza, es la humillación y el rechazo que la enfermedad genera,

Tú sabes que la palabra sida hasta decirla da miedo, yo creo que al pueblo sí le impacta saber que existe. Ahora a mí en lo personal sí me impacta mucho porque, no es que te vayas a morir, no es siquiera el temor a que te vayas a morir, el temor es al rechazo, a esa discriminación, a la humillación. (Juan)

Según Roberto Esposito, la productividad de la biopolítica puede tomar dos direcciones divergentes: "la de subjetivación y la de muerte (...) O la biopolítica produce subjetividad, o produce muerte. O torna sujeto a su propio objeto, o lo objetiviza definitivamente" (Esposito, 2006: 53). El sujeto objetivizado definitivamente se llama cadáver, paradigma del abandono, ejemplo ominoso de su pedagogía.

En dos notas periodísticas publicadas en un portal de noticias locales, se relata el caso de Juan Carlos, quien vivía con VIH. La primera nota, titulada "Abandona hospital a enfermos de SIDA", relata que:

Con fiebre y dolores por inflaciones en las rodillas y demacrado, Juan Carlos, con domicilio temporal en la colonia Pomoná, sobrevive desde hace dos meses gracias a la ayuda humanitaria de la población y comenta que recurrió al Capasits, con la finalidad de que le otorgaran atención médica, estudios y fármacos, ya que no tiene recursos al no poder trabajar (Soberano y Buendía, 2012: s/p).

Pero en el centro médico le negaron la atención, dice la noticia, porque no cuenta con "los documentos que le respalden tener la enfermedad”. Mientras trata de resolver esta situación, escribe el periodista, el sida "acaba aceleradamente con la vida de Juan Carlos".

Una segunda nota relata que "soportando los terribles dolores físicos y del alma, Juan Carlos sobrevive en una casucha de 6 metros cuadrados, donde la temperatura ambiente llega a subir hasta los 42 grados centígrados en esta época de calor. Ahí, recuerda su triste historia.” (Buendía, 2012: s/p). Luego añade que: 
los ataques han sido más constantes, ya que las bajas defensas de su cuerpo, le provocan fuertes dolores en el riñón y el hígado, los cuáles ya no soporta y llora, se queja; pero, como campesino, no tiene dinero para asistir a una clínica particular y ha vivido de la ayuda humanitaria de la gente, sin embargo, eso se acaba, comenta. (ibid.)

Juan Carlos, anota el periodista, se "encomienda a Dios" y dice "con toda su alma: Yo quiero vivir". Finalmente hace "un llamado a la Secretaría de Salud para que su caso sea tomado en cuenta" (ibíd.). Ni Dios ni la Secretaría de Salud respondieron y Juan Carlos murió, pidiendo limosna a sus vecinos ${ }^{83}$ y caridad a las autoridades. Pero en esos entramados kafkianos, tan comunes en México, el enfermo no fue atendido porque no contaba con "los documentos que respalden (sic) tener la enfermedad". Esta es la pedagogía del abandono: invertir los papeles para que las instituciones se deslinden y la responsabilidad recaiga en los sujetos abandonados: el problema no era la enfermedad sino la ausencia de papeles que la probaran. Infinitas

83 "La limosna es el fruto de una noción moral del don y de la fortuna, por un lado, y de una noción de sacrificio, por el otro. La liberalidad es obligatoria, por la Némesis que venga a los pobres y a los dioses del exceso de dicha y de riqueza de algunos hombres que deben deshacerse de ellas: es la vieja moral del don convertida en principio de justicia” (Mauss, 2012 [1925]: 103). La vieja moral del don convertida en principio de justicia sólo es ejercida por los vecinos y amigos de los enfermos, en estos casos. La justicia se recrea en las calles y en las relaciones cotidianas, pero no en las estructuras que debieran garantizarla. Hay un elemento sacrificial en las prácticas de las instituciones médicas que hemos revisado: exponer, excluir, dejar morir. Por eso, tal vez, Agamben invite a "despedirse sin reservas todas las representaciones del acto político originario que consideran a éste como un contrato o una convención que sella de manera precisa y definitiva el paso de la naturaleza al Estado". En su lugar, dirá, existe "una zona de indeterminación mucho más compleja entre nómos y physis, en que el vínculo estatal, al revestir la forma de bando, es ya siempre, por eso mismo, no estatalidad y seudonaturaleza, y la naturaleza se presenta siempre como nómos y estado de excepción" (Agamben, 2006: 141). En la enfermedad, sometida al bando, aparece esa zona de indeterminación compleja entre nómos y physis; de alguna manera, los padecimientos del abandono, dirían Biehl y Povinelli, son un tipo de seudonaturaleza, es decir, manifestaciones del estado de excepción. Las exigencias que se podrían formular al Estado -cuidado, protección, atención- son asumidas por ese entramado de vecinos y familiares, de solidaridad y limosna, que resguarda, en la medida de lo posible, la vida de Juan Carlos. No conocemos aún la Némesis que vengará a los abandonados, pero conocemos "el exceso de dicha" de algunos individuos de la localidad, que medran de los dineros públicos, por ejemplo. ¿Qué podría convertirse, en esta historia, en "un principio de justicia"?, ¿dicho principio podría trizar el aura de los abandonados, creando una luminosidad distinta, que no alumbre esas zonas de indeterminación sino otras de protección? 
burocracias que tejen un laberinto en torno a los sujetos abandonados. ¿No estamos ante las distribuciones desiguales de la vida y la muerte, de la esperanza y el daño, de la resistencia y el agotamiento a las que apunta Povinelli, al definir sus economías del abandono? Si observamos la nota como una topología textual de esas distribuciones desiguales, vemos que la vida, la esperanza y la resistencia están del lado de Juan Carlos, que intenta sobrevivir a su abandono, en medio de los dolores y la miseria. La muerte, el daño y el agotamiento se ubican del lado de las instituciones, médicas en este caso. Juan Carlos es parte de una humanidad atrapada entre "la visibilidad y la invisibilidad y entre la vida y la muerte" (Biehl, 2007: 24).

\section{Entre dos cuerpos}

Como hemos visto en otros capítulos, la acción política del Club Gay Amazonas, que se centra en la vida cotidiana, intenta transformar las redes de significación que se han construido en torno a la sexualidad, las distintas formas de deseo e identidad sexual, los modos de convivencia entre sujetos y colectivos diversos. Si bien no logra, o no pretende, transformar específicamente las definiciones institucionales y estatales, atiende a la construcción de sentidos colectivos en su nivel más microfísico, por así decirlo. Del mismo modo, en su acción sobre las instituciones no intenta modificar sus definiciones normativas o sus parámetros discursivos y apunta a las prácticas institucionales. La distancia entre los parámetros normativos y las prácticas cotidianas de las instituciones es fundamental para producir esa separación entre los cuerpos. Los cuerpos que legalmente tienen vOz, no necesariamente la conservan cuando se inscriben en ciertas dinámicas institucionales.

Luz no es gay, tampoco su hija; muchas de las personas seropositivas no lo son, pero son defendidas por un colectivo gay ¿Por qué? Creo que han sido las circunstancias históricas de la epidemia, que la transformaron en un asunto de homosexuales. Pero en este caso, la operación política es más dramática: Alan interpone su voz, y su cuerpo, ante el mutismo y la indefensión de Luz y su hija. Él habla en su nombre, porque es el único que acepta asumir su voz. Traduce sus tragedias cotidianas al lenguaje de las instituciones que ellas no dominan Y las lleva hasta los derechos que no pueden ejercer. Y en esos actos y gestos, en esas hablas y esos silencios, Alan y los integrantes del Club quedan entre dos cuerpos: el cuerpo sano y el cuerpo enfermo, el cuerpo vivo y el muerto. Ellos saben que en el VIH se juega parte importante del estatuto de sus propios cuerpos, pues condensan la infección y la representan ante la ciudad. Si las 
personas que viven con VIH son discriminadas y maltratadas, lo serán ellos también. El virus es una metáfora de todos los rechazos y los odios, del asco y las evitaciones que se arremolinan en torno a los homosexuales. Es una enfermedad que se sumaría a la enfermedad fundamental que ellos representan: el sexo, el cuerpo y la naturaleza, en último término.

El cuerpo con sida es un extra-cuerpo, distinto del cuerpo personal y también del cuerpo médico, una especie de cuerpo flotante que no puede ser localizado, nuevamente, en otro lugar que no sea el de la espera, la sospecha o el abandono.

Alan y el Club interponen su voz para que hablen unos cuerpos que ni siquiera son parlantes. Los mismos gays dicen que alguien infectado está ‘arañado’ o que 'lo pateó la burra'. Finalmente está defectuoso. Pero en esta interposición, ellos quedan entre dos cuerpos y su acción política, el campo de su legitimidad, inteligibilidad y visibilidad, se circunscribe al sexo y la enfermedad o al deseo y la muerte. Es un plano, en muchos sentidos, completamente patológico: puro cuerpo, nada más que cuerpo, sólo cuerpo.

Me parece que lo descrito y analizado permite tener una noción más clara de la acción política del Club y de sus límites. Sin Alan y el Club la hija de Luz no tendría educación, porque nadie la habría defendido. Entonces la voz de los gays aprovecha estos intersticios que permite el 'entre' de los cuerpos; ellos se transforman en voceros de los derechos humanos, defienden a una niña de la discriminación asumiendo los artículos de la Constitución Política como argumentos. Es decir, articulan los argumentos clásicos de la ciudadanía para resolver los nuevos dilemas del biopoder. Este ejercicio, que es un litigio dramático ante la exclusión y la muerte, es político en primera instancia, porque afecta la distribución de las voces y de los cuerpos en la ciudad.

A finales de la década de los noventa el sida se había instalado en la ciudad y sumaba muchos muertos, algunos de ellos hombres gay muy conocidos en Tenosique. Y junto con el sida habían llegado nuevas formas de discriminación y estigma. Alan recuerda que un viejo médico "recetaba" públicamente "quemar a todos los maricones" para acabar con la cepa del virus, “que traían en el culo”. Esas imprecaciones motivaron a los hombres gay de la ciudad a organizarse en dos direcciones: defenderse de la discriminación y el estigma crecientes y trabajar en la prevención de la transmisión del virus, primero entre ellos y luego en toda la comunidad. Y en estas luchas médicas, al borde la enfermedad y la muerte, los gays debieron batallar con los aparatos médicos y educativos y con las formas de discriminación más tradicionales. Si el homosexual es concebido socialmente como un enfermo o un desviado, si 
se esgrimen diversas causas para sus inclinaciones (violaciones infantiles, desajuntes hormonales, fallas en la crianza, entre otras), y se le considera incompleto, mal hecho, inacabado, inmaduro; el sida suma enfermedad a la enfermedad y error a los errores consabidos. El homosexual, ante la amenaza del sida, es doblemente enfermo y, asimismo, la enfermedad biológica traza su destino más profundo como sujeto enfermo, desviado y/o anormal.

\section{El aura de los perseguidos}

Hace unos meses fuimos con Alan a la oficina de comunicaciones del Ayuntamiento local. En una sala pequeña y en torno a una mesa redonda estaban sentados varios funcionarios que saludaron efusivamente a Alan e hicieron bromas. Luego de las risas, uno de ellos le preguntó qué pensaba "de los asesinatos de homosexuales que habían ocurrido recientemente". El funcionario agregó que le desconcertaba lo que sucedía, porque la ciudad no era "homofóbica". ¿Cómo en un lugar tolerante, por así llamarlo, la violencia contra los gay era tan aguda? Desde el inicio de la investigación escuché relatos de muertes de hombres gay locales. Algunos casos eran famosos y luego de años la gente seguía hablando de ellos. Especialmente de dos: el de un profesor muy conocido en la ciudad, activista cultural y gran orador que fue asesinado en la recámara de su casa y el de un médico que se había afincado en Tenosique y que fue asesinado el año 2002, cuyo cadáver encontraron en la sala de su casa junto a una caja fuerte cerrada. En ambos casos, se acusó a hombres centroamericanos de ser los responsables. Entiendo que en el caso del médico se detuvo a su pareja, un muchacho guatemalteco. En el otro, fue un rumor, porque nunca se detuvo a nadie.

El funcionario hablaba de una serie de asesinatos ocurridos desde 2011 a la fecha. Los homicidios se habían intensificado durante los últimos dos años. Dos maestros fueron encontrados muertos en sus casas, sin que nadie viera nada. En el lapso de unos meses, un muchacho de un municipio cercano fue asesinado en un terreno baldío y luego un homosexual conocido de la ciudad en un lugar cercano. A ambos les destrozaron la cabeza con una piedra. Esto había despertado preocupación, porque sus asesinos los habrían contactado en las cantinas de la ciudad, donde fueron vistos por última vez. Los gays locales pensaron que se trataba de un asesino serial que mataba homosexuales por alguna causa, aún desconocida. Los rumores hablaban de un hombre homofóbico, de alguien que se vengaba de los homosexuales por alguna razón e incluso de un sujeto que viviría con VIH y que asesinaba como venganza por 
haber "sido infectado", como alguien me comentó. También se apuntaba a los "hondureños" como potenciales responsables.

En alguna medida, el funcionario que interrogó a Alan tenía razón. Los asesinatos sucedían en un contexto donde los gay podían moverse con bastante libertad. Los datos de la Encuesta Nacional de Discriminación, aplicada durante el 2010 en la ciudad, mostraban una opinión pública discriminadora, pero en menor grado que la estatal o nacional. ${ }^{84}$ Esos datos coincidían con los de una encuesta que realizamos, durante ese mismo año, entre los colectivos de la diversidad sexual locales y que revelaban una integración intensa a la sociedad local. ${ }^{85}$ Es decir, los asesinatos sucedían en un contexto que era menos discriminador que otros, comparativamente.

Pero, a su vez, desde el 2010 hubo un giro en las políticas de seguridad locales que se tradujo en una mayor persecución de los gay y las trabajadoras sexuales y que se expresó, fundamentalmente, en revisiones y detenciones arbitrarias de individuos que no se dedicaban al trabajo sexual, pero a quienes se les exigía contar con los permisos municipales para ejercerlo.

${ }^{84} \mathrm{Si}$ se comparan los resultados para Tenosique de la ENADIS 2010 (Conapred, 2011), con los nacionales, estatales y con los de Tapachula, otra ciudad fronteriza y cercana en términos culturales, demográficos y sociopolíticos, constatamos que la opinión pública de este lugar es menos discriminadora que la de los otros tres lugares o niveles. Por ejemplo, a la pregunta “¿Estaría dispuesto o no estaría dispuestos a que en su casa vivieran personas....? Homosexuales", un 57.1\% de los encuestados en Tenosique dijo estar dispuesto, frente a un $38.5 \%$ de Tabasco, un 34.8 de Tapachula y un $42.5 \%$ a nivel nacional. Entre la ciudad y el estado de Tabasco, que sería el referente cultural y social más inmediato, hay casi 20 puntos porcentuales de diferencia (18.6); con respecto al país completo, la diferencia es de casi 15 puntos (14.6). Así, el 47.5\% de los encuestados a nivel estatal respondió no estaría dispuesto a que un homosexual viviera en su casa, un 48.3\% de los encuestados en Tapachula y un 43.7\% a nivel nacional, frente a un 30.6\% en Tenosique. Cuando se les preguntó si estarían dispuestos a que en su casa viviera una lesbiana, en Tenosique el 52\% respondió que sí, ante un 39.7\% que dio la misma respuesta en Tabasco y un $35.3 \%$ en Tapachula. Cuando esa pregunta se refería a un "enfermo de sida", en Tenosique un $72.4 \%$ de los encuestados contestó que estaría dispuesto a que este tipo de personas viviera en su casa, frente a un $48.8 \%$ de Tabasco y un $37.5 \%$ de Tapachula.

85 Quizás el resultado más sorprendente de la encuesta que nosotros hicimos fue que la percepción de discriminación entre los encuestados era menor en la ciudad que en el país. El 83.2\% de los encuestados respondió que creía que sí había discriminación contra los homosexuales en el país frente a un $68.9 \%$ que consideró que la había en Tenosique. Aunque ambas cifras indiquen una altísima percepción de discriminación, es llamativo que los encuestados perciban menor discriminación en su ciudad. Cuando se les preguntó si habían experimentado algún acto de discriminación, el $73.1 \%$ respondió que no y un 25\% que sí. 
Es difícil establecer relaciones entre los tres fenómenos que describí antes y no cuento con evidencia que me permita explicar unos a través de los otros. No sé cómo se vincula la menor homofobia de la opinión pública local con la serie de asesinatos de hombres homosexuales ni ambos con la modificación de las políticas públicas de seguridad. El dato más consistente es que son fenómenos contemporáneos y que afectan de manera directa el estatus de un colectivo dentro de esta localidad. Tal vez sea necesario recordar algo que discutimos en un capítulo anterior: es muy difícil establecer relaciones entre distintos niveles de conformación de una realidad, por lo que es mejor trabajar con algunas conexiones parciales que puedan distinguirse entre ellos (Strathern, 2004). El abandono y su aura es una conexión parcial, en ese sentido, que no intenta explicar todos los vínculos entre los niveles estudiados, sino apuntar algunos significativos.

\section{Asesinatos}

Una nota periodística, publicada el 10 de diciembre de 2011, informa que "B. C. T. quien se desempeñaba como catedrático del colegio de bachilleres plantel 13 de Tenosique, fue encontrado sin vida en el interior de su casa ubicada en la calle 31 por 34 del centro de esta ciudad, el cadáver se encontraba en estado de descomposición” (Hernández, 2011: s/p). La misma nota añade que:

según hipótesis el maestro "M.” como era conocido cariñosamente por la gente, asistió a dar clases y a la junta de maestros el jueves por la mañana, no regresando al día siguiente por lo que creen que fue asesinado por el anochecer-madrugada del viernes cuando se encontraba calificando exámenes en el comedor de su casa (ibíd., texto sin correcciones)

Dado que se encontraron manchas de sangre, escribe el periodista, se cree que fue asesinado con un martillo o un tubo, "con lo que le dieron en la cabeza y desde ahí lo pudieron haber arrastrado hasta su recamara, versión no confirmada por las autoridades ministeriales quienes investigan los hechos" (ibíd:; texto sin correcciones). La nota añade, al final, que "los asesinos se llevaron tarjetas bancarias y su automóvil color gris Tida".

El 14 de abril de 2013 otra nota periodística informa que:

Tras haber sido asesinado y violado el profesor del CBTIS 249 C. R. C. fue lanzado a un pozo artesiano de cuatro metros de profundidad. Con relación a estos hechos hay tres personas como sospechosas quienes ya no se encuentran en la comunidad. 
Una mancha de sangre a la orilla del brocal del pozo alertó al hermano del fallecido (Noticias por Minuto, 2013: s/p; texto sin correcciones)

Una vez que su hermano vio la sangre en la orilla del pozo, se acercó a ver su interior "y se percató que el cuerpo que estaba flotando en la porción de agua era el de su consanguíneo, por lo que enseguida dio aviso al resto de su familia para que certificaran el hecho" (ibíd.). Antes de ser arrojado a ese lugar, agrega la noticia, "en el interior de su cuarto lo masacraron a golpes en el rostro y luego con una soga lo arrastraron hasta el pozo para ocultar el cadáver que presuntamente ultrajaran sexualmente" (ibid.).

Cinco meses después de este asesinato, en un portal de noticias locales se publica otra nota titulada "Lo matan a garrotazos". En ella se relata que:

bañado en sangre y semidesnudo fue localizada el cuerpo de una persona de la colonia Municipal presuntamente masacrada a garrotazos por desconocidos hasta el momento. El hallazgo de los restos del occiso fue localizado la tarde de este sábado por vecinos del lugar en la parte trasera de una caseta de policía cerca de una fábrica de block dentro de ese perímetro de ese sector poblacional al sur de esta ciudad. (Paredes, 2013b: s/p)

Luego de dar el nombre de la víctima, se informa que su muerte pudo ser causada "por golpes contusos". Dos fotos muestran el cadáver de un hombre con la cara desecha, tirado en un lugar abandonado, entre maderas y escombros.

En un perfil de Facebook donde se reprodujo la noticia, algunos gays locales expresaron sus opiniones sobre el asesinato. Uno escribió: "otro compañero más que aparece muerto con los mismos síntomas hasta cuando DIOS descanse en paz J. conocido como la AVISPA ERA TRAVIEZO PERO NUNCA MALO" (anónimo); y otro: "lo único que se sabe hasta el momento es que apareció muerto atrás de la caseta de policías que se ubica a la entrada de la Muni y la Lázaro tenía destrozada su cabeza y señales de machete” (anónimo). Un tercero, "la comunidad gay de Tenosique está de luto”.

Hay una memoria colectiva de la violencia que han experimentado hombres homosexuales en la localidad. Muchos de los integrantes de Club recordaban amigos asesinados o heridos y habían integrado la violencia a sus biografías, al menos como un horizonte potencial. Cada muerte develaba la vulnerabilidad de todos, tal vez por eso los crímenes eran atribuidos a extraños, como una forma de disipar las sospechas en torno a los conocidos. Al recordar el asesinato de dos amigos suyos, Danilo sostiene que: 
los dos casos llevaron tendencias con dos personas que no eran de aquí, fueron desgraciadamente de otros lados, de otros países, en el primer caso fue un chavo que parece era de Guatemala y en el segundo caso había señas que probablemente eran hondureños, ya ves que Tenosique es frontera y mucha gente llega a Tenosique y que de una u otra forma es por la putería, los ve uno sabrosos y en la madre, hay que tener su cuidado, no sabemos de dónde vienen, no sabemos de dónde son, generalmente se dice que vienen huyendo de algún crimen que hicieron allá, se les hace fácil matar a sangre fría. (Danilo)

Un amigo de la ciudad con el que platiqué por chat luego del último asesinato, me dijo que "había que tener cuidado porque aquí en Teno anda mucha gente de fuera que ni siquiera habíamos visto sus caras, hay mucha gente indocumentada." Cuando le pregunté quiénes podría ser los asesinos, me respondió que "pues gente que viene de fuera y que ni siquiera conocemos como son, pura gente de Guatemala y de otros lados, andan por dondequiera aquí en Tenosique y unos malencarados que de volada se le conoce que no son gente de fiar". Durante el año 2013 había cambiado la dinámica de desplazamiento de los migrantes que transitan por Tenosique y muchos de ellos comenzaron a entrar a la ciudad y recorrer el centro. Antes habían permanecido en las orillas o en las vías del tren. Incluso era común ver a "hondureños" en las cantinas del lugar. Había una sensación colectiva de que gente desconocida ocupaba los espacios comunes, sin que se conocieran sus intenciones. La extranjería constituía un argumento para la sospecha. Pero por el perfil de los crímenes, era probable que los asesinos fueran conocidos de las víctimas. Dos de los que relatamos habían sucedido en sus casas, es decir, que los victimarios habían entrado de algún modo, lo más posible con la venia del dueño. En el caso del tercer asesinato, la víctima había estado bebiendo en una cantina local y lo vieron salir de ahí, aunque no queda claro si acompañado o solo.

De todos modos, el efecto era una sensación de temor, que se extendió entre los gays de la ciudad. Mi amigo me dijo, en esa conversación virtual, que "ya no es el Tenosique de antes que podías salir tranquila sin andarte cuidando la espalda, hay mucha maliantada"; en su caso había optado por salir siempre con gente conocida, "porque hay muchos heterosexuales que le tienen odio a las lokas."

El odio y la extrañeza parecen ser los arcanos de estos crímenes. Los estudios e informes sobre crímenes contra sujetos de lo que se denomina diversidad sexual se centran, en general, en las grandes ciudades (Carrara, 2004; Carrara y Viana, 2006; CNDH, 2010; Lacerda, 2006; Letra 
S, 2009; Mott, 1996 y 2001; Parrini y Brito, 2012). La situación de las ciudades pequeñas y de los pueblos es desconocida y no creo que se pueda extender la reflexión urbana o metropolitana a otros contextos, sin considerar sus diferencias. Una de las más importantes, a mi parecer, es el conocimiento mutuo de la gente de un lugar relativamente pequeño, en contraste con el anonimato de lugares como el Distrito Federal. Es probable que los responsables de los crímenes que relatamos hayan conocido a sus víctimas y que otras personas los hayan visto juntos, pero esa misma cercanía impediría la denuncia.

Un cadáver no tiene aura, la nuda vida termina con la muerte, incluso en su expresión más radical. Es necesario, entonces, entender por qué asesinaron a estos hombres y cuál era su forma de abandono, si hubo alguna. ¿Estos homicidios son manifestaciones de las formas profanas y banales de violencia que antes mencionamos? No tengo elementos para responder a esta pregunta. Un crimen queda, muchas veces, sólo en una nota o en un recuerdo. Las evidencias de todo tipo se pierden con rapidez y, quizás, profundizar en ellas sería abrir una senda oscura hacia el secreto y la complicidad, sin que sepamos hasta dónde nos conducirá.

Sin embargo, el aura que proyecta un asesinato de este tipo cubre, por extensión, a todos aquellos en riesgo de vivir una situación semejante. Es un aura transpuesta en el cuerpo de los otros semejantes, que abandona el cadáver para esparcirse entre los vivos. Tal vez, como lo trabajaremos en el siguiente capítulo, acá estamos ante una sombra en vez de un aura o de un aura oscura, si me permite el oxímoron. La sombra que se elabora durante los funerales y que duplica al muerto en una materialidad que permite un doble entierro y un duelo duplicado, pero diferido, se proyectaría, en estos casos, sobre todos aquellos que podrían correr la misma suerte. Es el aura de una amenaza que nadie profiere, pero tampoco impide. Los crímenes quedan impunes, los asesinos continúan con sus vidas y la normalidad espesa que sigue a estas rupturas implica un frágil olvido, que sólo termina cuando todo vuelve a suceder. Los crímenes son muy parecidos entre sí, tal vez incluso existe un patrón que podría leerse en términos criminológicos como una serialidad: son hombres que viven solos, mayores de 35 o 40 años, profesionistas muchos, que son asesinados en sus casas, fundamentalmente, con objetos contundentes, sin que se sepa quién lo hizo.

El asesinato es una sorpresa colectiva, en algún sentido. Por eso, una de las respuestas sociales a estos crímenes culpa a extraños o extranjeros. Para la gente de Tenosique es muy perturbador aceptar que los asesinos sean conocidos o residentes y sigan viviendo ahí, luego de cometer los homicidios; sería tranquilizador pensar que sólo iban de paso y se marcharon. 
Si los cadáveres no tienen aura y la nuda vida brilla de manera particularmente intensa cuando un cuerpo se acerca a esa zona agónica en la que ya no pertenece al mundo de los vivos, pero tampoco al de los muertos, estas víctimas resplandecieron mientras ocuparon ese espacio liminar, ese entramado de relaciones topológicas, que no se limita a distinguir "lo que está dentro y lo que está fuera, la situación normal y el caos” (Agamben, 2006, 31), sino que establece un umbral, que Agamben llamará estado de excepción. El estatus paradójico de estos sujetos, que los acompañó durante sus vidas y que brilló en torno a ellos, se confirma cuando las explicaciones atribuyen a sujetos foráneos sus muertes, es decir, a individuos que habrían cruzado el umbral desde fuera hacia dentro, desde el caos a la normalidad, para cometer sus crímenes. Eso dejaría sin mella la normalidad de este interior local y expulsaría tanto a las víctimas como a los victimarios fuera de ella. Vimos, en otro capítulo, que los homosexuales ocupaban una posición paradójica, que los ubicaba dentro/fuera de este mundo, que eran ajenos pero también conocidos de sus habitantes. Ahora podemos llamarla estado de excepción y observar sus consecuencias, pero también testificar su brillo y su resplandor. Si regresáramos a la luminosidad de los dispositivos que inquietaba a Deleuze, diríamos que la homosexualidad es, entera, un régimen de visibilidad específico, que produce ciertas formas de luz, "figuras variables inseparables de tal o cual dispositivo" (Deleuze, 2010c: 310).

El aura de los objetos los alejaba de sus usuarios y los ponía aparte, en algún sentido. Si recordamos, el vidrio era para Benjamin un enemigo del aura. La oscuridad de los crímenes que acá hemos descrito, su carácter nocturno y secreto, confirma esa intuición. No estamos ante la transparencia física de los cristales, sino la densa opacidad de las burocracias. No es extraño que se llame transparencia a la exigencia de clarificar los procedimientos, acciones y decisiones del Estado y que México repruebe de manera grosera en este ámbito (Transparencia Mexicana, 2014). No estamos ante una asociación caprichosa, a nuestro entender, porque la transparencia estatal tiene que ver con el respeto a la legalidad, es decir, con la exterioridad del derecho con respecto al poder, como lo ha dicho Lefort. Como vimos, la posición de estos sujetos es ambigua en relación a la ley. Como el homo sacer de Agamben, nadie los debería tocar, pero si son asesinados tampoco hay responsables. El bando, del que ya hemos hablado, "liga los dos polos de la excepción soberana: la nuda vida y el poder, el homo sacer y el soberano. Y sólo por esta razón puede significar tanto la enseña de la soberanía (...) como la expulsión de la comunidad" (Agamben, 2006: 143). Tal vez esto quede más claro si constatamos que la nuda vida y el poder, el homo sacer y el soberano confluyen en torno a estos asesinatos impunes. No 
se trata sólo de una ineficiencia administrativa y técnica, también de una ausencia de voluntad que impide que estos crímenes sean investigados. El abandono, ha escrito Nancy, "se produce siempre con respecto a una ley" (ibíd:: 79).

Las soberanías fragmentarias que estudiamos en el capítulo anterior, disueltas en muchos actores y diversos procedimientos, multiplican las 'enseñas de la soberanía' y las formas de 'expulsión de la comunidad', a las que apunta Agamben. Si el derecho soberano, por excelencia, implica una decisión sobre la vida y la muerte (Foucault, 1981: 163-64), en estos casos presenciamos múltiples gestos, sin que haya un actor principal que los realice, pero con la aquiescencia de una amplia y densa red de soberanías que garantizan su impunidad. El soberano es hoy un rostro oscuro, que elude cualquier transparencia, pero que decide sobre la vida y la muerte de los sujetos. Los homosexuales son sacrificables, como lo es el homo sacer, porque son despreciables, porque están dentro y fuera y, también, porque están abandonados. Su aura los aleja, en alguna medida, de sus comunidades y los hace brillar ante los agentes de las soberanías dispersas, pero efectivas.

Ese cadáver sin aura, que encontró la muerte en alguna zona de abandono y para quien no habrá justicia, es un sôma en torno al cual se constituye un "cuerpo biopolítico". "La unidad de la vida, escribirá Agamben, se conseguirá después de la muerte” (Agamben, 2006: 88), y se

realizará en ese sôma/cadáver, que ha quedado como buella de la soberanía. Benjamin ha definido una huella como "la aparición de una cercanía, por lejos que pueda estar lo que la dejó atrás" (Benjamin, 2013[1982]: 450). Creo que la definición es pertinente, porque ese cadáver oscurecido implica una cercanía ominosa para todos los sujetos que podrían seguirle. El aura de la huella es la cercanía de la nuda vida a los colectivos abandonados que estamos investigando. El cadáver es huella, cercanía, de la nuda vida y reflejo opaco del aura del abandono.

\section{Persecuciones}

Durante el 2011 un amigo de Tenosique me contó que la policía lo había detenido en una cantina que frecuenta y que lo habían acusado de ejercer la prostitución sin permiso. Platicamos por chat:

$$
\begin{aligned}
& \text { C: Ese día me tomaron fotos y todo, me hicieron que me quitara la camisa } \\
& \text { R: ¿Por qué? }
\end{aligned}
$$


C: $y$ me tomaron fotos

$\mathrm{R}:$ ¿pero por qué?

C: y me trataron mal, me pidieron tarjeta y le dije que yo no cargaba eso y ni sabía qué era, porque yo solo andaba tomándome la cerveza.

R: ¿Y?

C: y pues me subieron a la patrulla y ya no solo hasta al día siguiente que me fueron a sacar mi mamá. Cumplí las 12 horas ahí y me dijeron que si no quería tener problemas que mejor sacara tarjeta y en qué lugar andaba yo trabajando

R: ¿y tú no les preguntaste por qué lo estaban haciendo?

C: ¿Cuál era mi lugar de trabajo? nosotros somos homosexuales, pero no por eso significa que andemos haciendo la prostitución (texto editado y corregido)

Muchas personas gay de la ciudad vivieron algo semejante: la Policía Municipal llegaba a las cantinas y bares, se acercaba a algunos clientes y les pedía tarjeta para realizar trabajo sexual. Los interrogados eran siempre los mismos: las mujeres y los homosexuales afeminados. Si no contaban con el permiso municipal, entonces los llevaban detenidos.

El título décimo segundo del Bando de Policía y Buen Gobierno del Ayuntamiento local, en su capítulo IV, titulado "De la prostitución, vagancia y embriaguez", define prostitución como "el comercio carnal de una persona con cualquiera otra” (Municipio de Tenosique, 2010: 59). En el artículo 173 de dicho Bando, se indica que "las personas que ejerzan la prostitución como medio de vida, serán inscritas en un Registro especial que llevará la Dependencia Municipal encargada de ello, la Secretaría de Salud le practicará un Examen Médico Periódico y le prestará los Servicios de Salud correspondientes" (ibíd.); y en el artículo 174 se estipula que:

quienes practiquen la Prostitución y no acaten lo estipulado en el artículo anterior, serán sancionados conforme a las disposiciones del presente Bando y las demás disposiciones legales aplicables, de constituir su conducta, la posible comisión de algún delito, serán puestas a disposición del Ministerio Público (ibíd.)

En ese Bando no queda claro cuáles serán las sanciones, porque en la parte dedicada a ellas no se retoma "la prostitución". El documento fue emitido al inicio de la gestión del primer alcalde del Partido de la Revolución Democrática (PRD) y que antes fue diputado local por el mismo partido. En el mismo periodo, como dijimos, el Director de Seguridad Pública aplicó una versión local de las políticas de "tolerancia cero", implementadas en la capital del país. La gestión de este director fue muy polémica y motivó denuncias penales y periodísticas. Pero no 
creo que la persecución que experimentaron algunos gays de la localidad se explique por su personalidad o su gestión.

La entonces diputada local exhortó, en el Congreso Estatal, al Presidente Municipal para que respetara los derechos de las trabajadoras sexuales del municipio. "La autoridad municipal y de seguridad pública local no otorgan un trato digno a quienes ejercen el oficio de sexoservidoras y de manera arbitraria les aplican multas, en quebranto de sus economías y les impide alcanzar una mejor calidad de vida a sus familias”, declaró la diputada, según una nota periodística (Vázquez, 2012: s/p).

Lo que relató mi amigo le sucedió a otros gay. Alguno me comentó que lo detuvieron y le cortaron el pelo, por ejemplo. Nadie presentó una denuncia por estos hechos. En cierta medida, las coordenadas morales de muchos gays locales justificaban esos abusos. Cuando comenté con algunos de ellos lo que sucedía, y exploré la posibilidad de presentar una queja ante la Comisión Estatal de Derechos Humanos, me comentaron que habían platicado con el Director de Seguridad Pública y que les había dicho que a "los homosexuales decentes no los molestaban". Les pregunté quiénes eran esos "homosexuales decentes" y me respondieron que aquellos que no andaban vestidos de mujeres, en las cantinas o haciendo escándalos. Alguno me sugirió que no me "metiera en problemas" con la Policía Municipal porque yo era extranjero, no conocía la localidad y podía resultar afectado. Nunca supe cómo, pero entendí que se deslizaba una amenaza. Otro me dijo que la violencia la vivían aquellos "que se portaban mal".

El Bando municipal no estipula las sanciones para el ejercicio de la prostitución, pero los abusos que las autoridades comenten contra las trabajadoras sexuales estarían justificados por su misma actividad. El Bando es literalmente un a-bando-no que, como vimos, "se produce siempre con respecto a una ley" (Nancy, citado en Agamben, 2006: 79). La ley a-bando-na, porque regula sin proteger. El "comercio sexual de una persona con cualquier otra" es una definición vaga y podría extrapolarse a muchas relaciones en las que el dinero no es la principal motivación. Una de las definiciones citadas por la Real Academia de la Lengua dice que comercio es "comunicación y trato secreto, por lo común ilícito, entre dos personas de distinto sexo" (RAE, 2001: s/p). Las autoridades locales se deshicieron de la diferencia sexual, pero conservaron el carácter ilícito del trato. Estamos a las puertas de una economía del abandono, como las analizadas por Povinelli (2011), que empieza en el sexo. Es decir, si ésta fuera también una economía libidinal, resta por pensar cómo se articula con otra del abandono. El 
entrecruzamiento entre abandono, sexualidad y economía lo hemos encontrado en diversos puntos de esta investigación, pero falta dilucidar con mayor profundidad sus lazos.

En el primer capítulo, sostuvimos que en torno al Club acontece una batalla para definir el sentido y las manifestaciones prácticas de esa economía. La economía libidinal, en palabras de Guattari, "no cesa de desplazar sus intensidades sobre un continuum cuya existencia recusa por adelantado los sistemas de opción cristalizados según una lógica de objetos totalizados, de personas responsabilizadas, de conjuntos cerrados" (Guattari, 2013: 135). Pero en estas dinámicas, relacionadas con la seguridad pública, vemos cómo se elabora un sistema de opción cristalizado y se implementan prácticas institucionales que localizan, incluso violentamente, a determinados sujetos y colectivos en esa "lógica de objetos totalizados, personas responsabilizadas y conjuntos cerrados".

Lo que primero fue una exploración de discursos sociales, se transforma en otra de prácticas institucionales. Las amenazas que suponía el libertinaje son enfrentadas a través de medidas estatales para controlar los colectivos libertinos. La seguridad pública se transforma en un artefacto regulador de una dimensión de la economía libidinal: el uso de los espacios sociales para desplegar el deseo. No es baladí que sean las cantinas los lugares de implementación de esos controles; espacios abiertos y bastante democráticos, en los que convergen individuos y grupos diversos. El orden público es una expresión de taxonomías morales, como lo vimos en el primer capítulo, y los homosexuales colindan con las trabajadoras sexuales, en muchos discursos públicos, porque sus cuerpos están ubicados en puntos conflictivos de esas economías libidinales. Donde termina la gratuidad supuesta del sexo (trabajo sexual) empieza el control sanitario de los cuerpos que se venden; pero, del mismo modo, donde finaliza la heterosexualidad inicia el control social de los cuerpos desviados. El dinero y la heterosexualidad constituyen, en este sentido, los dos puntos donde una economía libidinal se convierte en otra de abandono. El sexo pagado y el no heterosexual son expresiones de una economía libidinal del abandono, si se me permite la imagen.

El juego entre soberanía y sexualidad puede ser muy sutil. No sólo las intervenciones evidentes en este campo lo expondrán de manera clara. Podremos distinguir entre procesos legales que promueven una expansión de los derechos en este ámbito y una emancipación (aparente) de los sujetos, de otros que profundizarían esa relación entre soberanía y sexualidad. Ese juego debemos detectarlo no en el ámbito de las reivindicaciones o de los discursos explícitos sino en otro que, si bien no tiene a la sexualidad como su objeto directo, termina 
cercándola de modos diversos. Uno de ellos sería la seguridad pública. Aquí debemos detenernos ante los efectos, no los discursos; parte de lo que hemos investigado ocurre en silencio, a voz baja, por así decirlo. ¿Cómo interviene el discurso de la seguridad pública en la sexualidad? Primero, reorganizando el uso de los espacios públicos (calles, parques) y colectivos (comercios, bares, cantinas, discos); segundo, clasificando a los sujetos según la peligrosidad que se les atribuye; luego, estableciendo parámetros corporales de normalidad o de apego a la norma; por último, determinando quién puede permanecer en determinado espacio y quién no o bajo qué condiciones.

\section{La Bestia y el bicho. Soberanía y sexualidad}

"Aquello que llamo nuda vida, dice Agamben en una entrevista, es una producción específica del poder y no un dato natural" (Agamben, 2007: 18). Al virus del VIH lo llaman bicho en Tenosique. No es un dato natural, es una huella biopolítica y es el aura íntima de un cuerpo vulnerado. Al tren que cruza la ciudad lo bautizaron como la Bestia, tampoco es un dato natural, es una máquina sofisticada que transporta mercancías y, además, migrantes. No es sólo una tecnología, es también un aparato biopolítico que cubre con su aura salvaje los cuerpos expuestos de quienes se suben a ella para poder viajar hacia un destino promisorio. Entre el deseo y la muerte, el bicho se desplaza como una amenaza; entre la miseria y la promisión la Bestia cruza los territorios hendidos del Estado-nación. Entre estas dos coordenadas seudonaturales se organizan y se despliegan las formas de soberanía que hemos explorado. Por eso cuando investigamos una - la Bestia- nos encontramos con la otra - el bicho-; porque son manifestaciones de una producción estructural de nuda vida.

¿Cómo se vinculan esas formas de soberanía que se articulan en torno a un tren, que implican una bestialidad-técnica o una tecno-animalidad, con otras formas de representar, pero también delimitar, el estatus de lo humano, específicamente en el campo de la sexualidad? Estamos ante una zona de indeterminación entre nómos y physis, "en que el vínculo estatal, al revestir la forma de bando, es ya siempre, por eso mismo, no estatalidad y seudonaturaleza, y la naturaleza se presenta siempre como nómos y estado de excepción” (Agamben, 2006: 141). La Bestia y el bicho son, ambos, formas en las que el vínculo estatal se expresa como seudonaturaleza y la naturaleza como nómos y estado de excepción. Si La Bestia, como vimos, está por encima de la ley; el bicho está por debajo de ella. En esa posición antitética frente a la 
soberanía, ambos se develan como manifestaciones de la nuda vida. Ambos son, también, coordenadas para los frágiles cuerpos humanos, en su conformación biopolítica.

De este modo, el desafío ha sido entender, en este contexto, cómo las transformaciones en la soberanía estatal, que están en ebullición, se vinculan con otras en la sexualidad. Necesitábamos saber si la sexualidad es hoy día un campo de soberanías, un locus para su ejercicio, su expansión o retracción, e identificar cuáles, si así fuera. No basta con elaborar un mapa general que abarque todos los contextos y atraviese la historia. Precisamos conocer cómo se produce en contextos determinados y de formas específicas. El gran lienzo foucaultiano, como los buenos cuadros barrocos, llena todo el espacio, pero no permite observar el vacío, y en él se juega la especificidad. Si reconocemos la creación de ese gigantesco dispositivo llamado sexualidad y su proliferación contradictoria a lo largo y ancho de la vida social y cultural, tenemos que entender también cómo se articuló localmente. No se trata de una diferencia sólo cultural o histórica, aunque también lo sea. A mi entender, se trata, más intensamente, de determinar la profundidad de su transformación.

\section{Abandono e inmunidad: las agudas certezas de la muerte}

Pareciera que el abandono es tan intenso en los casos que hemos estudiado, que no habría posibilidad de morigerarlo o transformarlo. No creo que debamos concluir algo así; al contrario, ya en otros capítulos encontramos una pista que retomaré en éste: la inmunidad. Cuando sostuvimos que el Club operaba, en alguna medida, como un fármaco que era, a la vez,

remedio y enfermedad, apuntábamos en esa dirección. Pero fue la noción de esfera la que profundizó esa lectura. La dejé pendiente, porque su importancia social y su capacidad interpretativa sólo podían emerger luego de describir el daño y la exposición de algunos sujetos. Si la esfera apuntaba, en primer término, a un espacio de protección, cuya importancia vimos para la conformación del Club y de una sociabilidad gay en Tenosique, también implicaba invasiones potenciales que la destruirían. Por eso, dice Sloterdijk, la esfera "adopta los rasgos de un sistema cultural de inmunidad", que integraría "respuestas innatas o institucionalizadas a heridas o lesiones", basadas en un "principio de prevención, que va coordinado al principio de invasión" (Sloterdijk, 2011: 342). Los humanos desarrollan su existencia, escribe Sloterdijk en otro texto, "no sólo en determinadas 'condiciones materiales', sino también inmersos en sistemas inmunológicos simbólicos y bajo velos rituales” (Sloterdijk, 
2012: 16). Esos sistemas inmunológicos apuntan, a mi entender, a formas de modificar el abandono y, también, de transformar su aura. Los sistemas inmunológicos son límites entre dentro y fuera, entre cuerpo y medio ambiente, entre psiquis y orden social que podrían reconfigurar los estados de excepción relacionados con el abandono y que, justamente, se localizan en esos límites, como lo vimos antes. Ver el abandono desde el estado de excepción es percibir la invasión; observarlo desde los sistemas inmunes es denotar la protección. No son lecturas antitéticas, pero tienen énfasis y resultados distintos.

De este modo, podremos comprender la importancia cultural, pero también subjetiva, de lo que Alan ha dicho sobre las tareas del Club en la prevención del VIH y el sida

se han muerto hombres gay, y se han muerto de sida, pero no hombres gay del grupo Amazonas, tú puedes preguntarle a cualquiera de Tenosique y te van a decir que no, en el Club Gay Amazonas tenemos dos compañeros que están infectados con sida, están tomando medicamento, pero ellos no estaban aquí, ellos son personas de aquí que se fueron a trabajar fuera, regresan a Tenosique y ya regresan infectados y ya se integran al grupo.

No importa si esta afirmación es cierta o no en términos fácticos. Lo más relevante, a mi entender, es que Alan considera que el Club ha servido como un sistema inmune colectivo para sus integrantes, que los ha protegido del sida, la enfermedad del sistema inmune orgánico por excelencia. El Club, en este aspecto, es una esfera inmune que protege del abandono. Las esferas, vista desde esta perspectiva, serían "unidades autoorganizadas que se conservan y reproducen en una relación constante con un mundo circundante invasivo e irritante tanto en potencia como en acto" (Sloterdijk, 2012: 21-22). El mundo invasivo e irritante donde surge y se desarrolla en Club ha sido descrito con detalle. Lo que quedaba por dilucidar era la estrategia de sobrevivencia que garantizó su subsistencia en medio de muchas adversidades: una inmunología grupal, como respuesta al abandono.

Incluso, analizadas de este modo, las homoprácticas también serían formas de inmunidad. Sloterdijk definirá las antropotécnicas, de cuyo conjunto las homoprácticas son parte, como "los procedimientos de ejercitación físicos y mentales, con los que los hombres de las culturas más dispares han intentado optimizar su estado inmunológico frente a los vagos riesgos de la vida y las agudas certezas de la muerte" (Sloterdijk, 2012: 24). Las agudas certezas de la muerte atraviesan todo este capítulo y tal vez son las únicas que restan cuando un sujeto entra las zonas de abandono que describimos. Pero las homoprácticas, como estrategias de autocuidado 
y prevención subjetivas y emocionales, disponen de certezas distintas: las de la dignidad, del nombre y el respeto, entre otras. También del cobijo y la protección mutua. Las homoprácticas corresponderían a "un sistema de prácticas socio-inmunitarias, especialmente las jurídicas o las solidarias", diferenciado por Sloterdijk, y a otro "de prácticas simbólicas, o bien psicoinmunológicas", que le permiten a los humanos sobrellevar "su vulnerabilidad ante el destino, incluida la mortalidad, a base de antelaciones imaginarias y del uso de una serie de armas mentales" (ibid:: 23-24).

Podríamos entender todas las formas de prevención que el Club ha desplegado, desde los desfiles hasta las pláticas, incluyendo las fiestas, los estands informativos, las entrevistas en los medios de comunicación, las conversaciones cotidianas, el reparto de condones, las conversaciones con los médicos y los pacientes, entre decenas de otras acciones, como antelaciones imaginarias de carácter inmunológico que produjeron una esfera de protección, una atmósfera de autocuidado, y formas de solidaridad que aminoraban el abandono. Fueron prácticas socio-inmunitarias y psico-inmunológicas.

Entre los diversos tipos de inmunidades, "la inmunidad-nosotros" sería la más profunda e importante (Sloterdijk, 2009a: 15). La experiencia del Club parece confirmarlo. Juan dice que mucha gente que ha muerto "no se ha acercado al grupo". Relata el caso de un amigo, de un amigo que no tenía ninguna responsabilidad con el grupo pero que sí tenía una participación bastante buena, porque él era uno de los grandes para los eventos, entonces, el caso más terrible es que este niño, y que nadie se atreve a decirlo, es que tenía el problema y no se acercó al grupo aun sabiendo todo lo que nosotros hacemos por esa gente no se acercó al grupo. Quizás diría que entre nosotros mismos lo íbamos a denigrar y no se acercó, su vanidad fue más fuerte y se cerró, tampoco busco ayuda por otros lados, por otros medios, entonces a este amigo le pasó lo que le tenía que pasar, lo lógico es que falleció.

Para Juan su muerte no se debe tanto a la enfermedad como a la falta de cobijo y de cuidado. Eludió al grupo para evitar las humillaciones y los comentarios, pero perdió, quizás, el único camino que tenía disponible para acceder a la atención médica y salvar su vida.

y eso es lo raro y es lo triste porque cualquiera de nosotros sabemos que estamos conscientes de lo que es el sida, entonces sabemos cuál es el camino de ir a un hospital a hacerte unos análisis y que si sales positivo ya conocemos el camino para ir a solicitar el medicamento, o sea ¿me entiendes? Y este niño no lo hizo y era del grupo y él nos 
ayudaba a repartir condones, o sea que él estaba consciente de la ayuda que nosotros otorgamos de alguna manera y él no lo buscó, no lo hizo, se nos fue. (Juan)

Sostuvimos, en otro capítulo, que el Club mismo era un sistema inmune que se interponía entre la enfermedad y los cuerpos y entre los sujetos y las instituciones. Acumulaba un saber práctico para enfrentar la enfermedad que resguardaba a los sujetos, en alguna medida. Es cierto que, en otros casos, los chismes y rumores han surgido del Club, o de otros gay, y han colaborado en el aislamiento de las personas seropositivas. El amigo que visité en el hospital, cuya historia referí antes, había conocido su diagnóstico mediante una prueba rápida que se realizó en el parque central de la ciudad, frente al Ayuntamiento, dentro de las actividades de 'prevención' de una fundación internacional dedicada a la lucha contra el VIH. Pero, dado el contexto, la noticia se esparció velozmente y sólo pasaron unas horas de su diagnóstico para que yo me enterara. La inmunidad es ambigua, sin duda, pero estamos ante fenómenos oscilantes, que valoramos desde la perspectiva del abandono que describimos, y no frente a categorías o comportamientos éticos definitivos. El cuidado y el rumor pueden surgir de un mismo colectivo o de los mismos sujetos. Es paradójico, pero real.

Si regresamos al contraste que planteamos entre Juanito y otros integrantes del Club, veremos que aquél no contaba, en principio, con las formas esféricas autógenas, pero tampoco con las manifestaciones inmunitarias necesarias para devenir un sujeto sexual singular. Por eso, de manera muy perspicaz, se ubicó en un lugar opaco, protegido por el silencio y el sobreentendido. Cuando tuvo los medios para salir de ese espacio y vivir otras formas de comunicación y de interiorización, se percató que ambos desarticulaban su deseo. En cambio, los integrantes más jóvenes del Club nacieron con un medio más propicio y con una inmunología más desarrollada. Pero la generación clave, según entiendo, fue la que formó el Círulo Interior, cuyo representante más notable es Alan. ${ }^{86}$ Es una generación de transición entre el mundo soslayado de Juanito, para usar una descripción de Monsiváis (1998), y los mundos esféricos, pero también identitarios, de los gays más jóvenes de la ciudad. Sin embargo, para esa generación la inmunidad se expresó de modo dramático: salvo Alan, los otros integrantes del Círculo murieron de sida, es decir, como efecto de una destrucción irreversible del sistema

\footnotetext{
${ }^{86}$ Desde una perspectiva nacional, esta generación fue clave para la formación de un movimiento político de las minorías sexuales y la emergencia de identidades y comunidades sexuales diversas (Díez, 2011; de la Dehesa, 2010; Argüello, 2013). Pero también fue la que articuló las primeras respuestas ante la epidemia del VIH (Murcia et al., 2010).
} 
inmunológico. Murieron, hay que decirlo con claridad, de la primera enfermedad homosexual de la historia de la salud pública del país (y tal vez del mundo). Sabemos que en términos clínicos nunca lo fue, pero nos importa que lo haya sido en términos sociales y culturales. La coincidencia histórica entre la formación de una inmunidad esférica para los colectivos homosexuales y la expansión del VIH es como un enigma que arrojara una Efigie contemporánea en el cruce de caminos inesperados. Sabemos, como Edipo, que la peste arrasa la ciudad, pero no conocemos las razones por las que lo hace.

\section{El deseo y el aura}

El musulmán, esa figura fatídica de los campos de concentración, sujeto del más extremo abandono, había sido despojado de cualquier deseo. En él la nuda vida alcanzó un registro quizás inédito, también insuperable. Si bien los casos que nosotros investigamos no son extremos a tal grado, podemos pensar que el despojo de los deseos es una forma de abandono muy profunda y, quizás, la luminosidad más desoladora. El musulmán parecía incapaz de crear algo, por eso pensamos que fue destituido de su deseo. Esteban y Alondra, Juan Carlos, experimentaron una destitución semejante, a nuestro entender. El abandono, el deterioro y la muerte son consecutivos a una extinción vital definitiva.

Si la inmunidad fuera una respuesta al abandono, el deseo lo sería a su aura. Lo leemos como una forma de luminosidad inmune, un fulgor protector frente al funcionamiento de los dispositivos, especialmente en sus prácticas más brutales. El aura del deseo es colectiva antes que individual; es el brillo de lo que se puede hacer junto con los otros, de los mundos creados, las formas de vida, los lenguajes, las afectividades, los vínculos y las prácticas. Es el fulgor de las capacidades individuales y sociales de producir vidas y mundos. El largo recorrido que hemos hecho por la historia del Club y de sus integrantes es una muestra de esa inmunidad auréatica. Nunca será definitiva, eso es claro y lo hemos visto; pero sí aminorará las agudas certezas de la muerte que se han solazado a veces con ellos, y la invasión destructora de la violencia, el aislamiento y la discriminación.

Creo que frente a las manifestaciones específicas del abandono en estos colectivos, ellos

desplegaron tácticas del encantamiento. Ellas fueron elaboradas como "prácticas simbólicas y psico-inmunológicas" que atemperaron los efectos del abandono, creando relaciones libidinales y miméticas con los otros; formas vacilantes de misterio. El encanto es la luz mimética del deseo, 
así como el aura era el brillo de la nuda vida. El encantamiento es un modo de producir el aura inmune que nos interesa, que regresa una recóndita singularidad a cada sujeto y restituye parte de su opacidad, cuando se moderan las presiones de las transparencias biopolíticas que hemos analizado.

Agamben sostiene que, frente a los múltiples dispositivos que cercan las vidas humanas desde todos sus costados, y "ponen aparte", hay que desplegar una profanación constante que restituya "el uso común de aquello que fue tomado y separado" (Agamben, 2011: 264). Poner en común es encantar, a mi entender. Eso fue lo que hicieron los integrantes del Club cuando celebraron sus XV años, y en muchos otros eventos, poner en común la producción social de los cuerpos y los deseos, profanar el misterio de la diferencia sexual, restituir las antelaciones imaginarias a las vidas, incluso las más sojuzgadas, compartir algo del aura de una inmunidad deseante, exhibir el abandono y mostrar las protecciones que podrían cobijar a los sujetos expuestos. Ampliar, en última instancia, la esfera para que, mediante el encantamiento, cubra a otros. De este modo, desear en común constituye, a mi entender, la estrategia más significativa de profanación. Encantar será una forma de romper los hechizos de alejamiento de los múltiples dispositivos; el deseo, si se me permite la imagen, es el encantamiento de lo común que restituye a los sujetos y los colectivos lo que les ha sido quitado.

Si observamos ahora la lateralidad que nos interesó en algún momento, podremos constatar que el abandono es una de sus manifestaciones y que, justamente, pone aparte a los sujetos y los colectivos, en una posición tangente con respecto al orden social, jurídico y administrativo: en los hospitales, en las cárceles, en las cantinas, en las calles, en las estaciones de autobuses, entre muchos otros lugares. Dentro y fuera de esos lugares, abandonados y pertenecientes, a la vez, esa lateralidad es producida, en alguna medida, por las prácticas institucionales y por esa densa red de actores de las soberanías fragmentarias que encontramos. 


\title{
VIII
}

\section{La escritura y su sombra Etnografía, subjetividad y deseo}

\author{
Desde ahora, el intelecto conmovido por la idea de las esferas \\ está incurablemente enfermo de un pathos \\ del que no se puede decir si es claro u oscuro: el asombro. \\ Peter Sloterdijk, Esferas II. Globos. Macroesferología, 2011: 26.
}

¿Cómo integrar los sueños en una etnografía?, ¿qué hacer con los residuos psíquicos, corporales, imaginarios y materiales de un trabajo de campo?, ¿cómo regresar a un lugar sin abandonar completamente otro, vivir de algún modo en un intermezzo de larga duración que nos permita reflexionar, aquilatar, pero también olvidar? Luego de varios años comencé a sentir y percibir que la diferencia entre estar o no en el lugar que investigo se debilitaba paulatinamente. Había emergido, de pronto, una continuidad afectiva que morigeraba la distancia, pero también la diferencia, entre estar presente, o no, en Tenosique. Un anuncio de ese vínculo más continuo me lo dio un sueño.

Algunas personas de la ciudad me habían contado sus sueños como si quisieran compartir conmigo algo íntimo, quizás secreto, creyendo que yo tenía algunas claves para entenderlos. Me confiaban los sueños como si consultaran un oráculo. Mis respuestas no eran terapéuticas, en términos técnicos, sino intuitivas. Les decía qué era lo que me producían sus sueños, como si las reacciones posteriores que generaba el relato fueran parte de su devenir diurno. Soñar es, también, tener algo que contar, disponer de un misterio personal narrable y ostensible. Soñar abre un surco en la noche para que entremos juntos a esos lugares extraños, como si alguien hubiese encontrado una puerta secreta que quisiera compartir.

Durante mucho tiempo me inquietó que no tuviese sueños con Tenosique y su gente. No entendía muy bien mi desasosiego, porque soñar no era un mandato y no formaba parte del trabajo de campo, visto como un ejercicio profesional. Sin embargo, la experiencia que se iba sedimentando luego de muchos viajes no era solo de carácter profesional, sino afectivo y personal. En esa medida, soñar o no era un parámetro para saber cuán profundo había calado en mí ese mundo y su gente. Esperaba que la conexión la anunciara mi inconsciente. ¿Qué sucedía si mi subjetividad, quizás en sus capas más profundas, comenzaba a elaborar mis 
experiencias, los vínculos, los diálogos, de un modo distinto al racional y consciente?, ¿qué develaba eso de mí?; pero, también, ¿qué me permitía comprender de los otros? No me interesaba, por supuesto, delimitar una sintomatología individual. Más bien deseaba encontrar ecos del trabajo de campo en otros espacios psíquicos y corporales que me revelaran nuevas rutas de interpretación. Pero también quería hundirme en el campo, dejar de poner resistencia a los vínculos, tener la serenidad suficiente para incrementar mi apertura. Mientras no soñara me sentía como un comerciante que vive calculando costos y beneficios; mezquino y temeroso, en algún sentido.

Cuando estaba en Tenosique mis sueños se tornaban lejanos. En ellos aparecía mi familia en Chile, el mundo de la infancia. No recuerdo un sueño que involucrara a la ciudad. Apenas soñaba con mi vida en México. Parecía que el tiempo y la distancia eran un aliciente para que antiguos materiales psíquicos y biográficos regresaran por los turbios caminos del sueño. En Tenosique me encontraba con Chile. La diferencia era una tensión interior que contraponía un lugar con otro, un mundo con otro. El ambiente cerrado y autoritario de Chile, mi país natal, con el ambiguo y extravagante de Tenosique. Eran mis parámetros clasificatorios: Tenosique resultaba confuso y extraño con respecto a lo que Chile representaba para mí: clausura, control, persecución, normalidad. No sabemos que hemos llegado a un paraíso subjetivo o emocional hasta que reconocemos los infiernos de los que huimos. Los sueños me lo indicaban, antes de cualquier reflexión; esa posición, si se me permite llamarla así, es anterior a cualquier consciencia. Mis afectos supieron ubicarse, pero también mostrarse, a través de los sueños: Chile, distante y gélido; Tenosique, cercano y cálido. Pero también, Chile materno y cotidiano y Tenosique extraño e inhóspito. Las cualidades dependen de una fina calibración de los afectos. La diferencia, me parecía, empezaba ahí, en esa humedad interior que nos conmueve.

Cuando soñé con Alan supe que algo había cambiado. En mi sueño estaba con él y algunas personas cercanas en un mercado, teníamos un pequeño puesto en el suelo, donde vendíamos productos de metal como lámparas o sartenes (parecidos a los utensilios de cobre que venden los gitanos en Chile). El lugar era extraño, porque parecía el mercado de una medina o ciudad árabe. Alan conversaba con la gente, se movía tal cual lo hace en la vida real. El sueño era largo, pero sólo recuerdo esos trozos. En la mañana, al despertar, le envié un mensaje por mi celular contándole que había soñado con él. Sólo como una forma de saludarlo. Alan respondió enseguida y me dijo que uno de su hermano estaba grave en un 
hospital de la ciudad, con pocas posibilidades de sobrevivir. Interpretó el sueño como una conexión con su circunstancia familiar. Me sentí perplejo, aunque también entendí que se había producido un vínculo tal vez azaroso, pero real, entre su vida y la mía en un momento determinado. Ese mundo navegaba en mi interior, ya tenía un lugar psíquico. Su hermano murió a los pocos días.

Era la segunda muerte en menos de cinco meses que asolaba a la familia. A principios de 2012 su hermano menor se había suicidado. Esa ocasión yo estaba de visita en la ciudad y viví todo de cerca. Me enteré casi recién sucedidos los hechos, fui a su casa, participé en el velorio y el novenario, asistí al entierro. La muerte producía una extraña solidaridad repentina, aunque todos estuviésemos algo pasmados. Llegó mucha gente a la casa de los ancianos padres de Alan. Su familia es grande y conocida en la ciudad. El hermano fue un maestro muy apreciado por sus alumnos. La muerte causó gran impacto en la ciudad. Mucha gente llegó a expresar su solidaridad y tristeza. Tal vez la muerte les exige a los vivos un reacomodo y el largo tránsito ritual que sigue abre esa posibilidad. Cada uno sopesa, con mayor o menor claridad, su lugar y futuro. Una filosofía cotidiana emerge e intenta comprender lo que ha sucedido, darle un sentido, pero también advierte que nadie está libre de ese destino. La aflicción rodea al muerto y la familia, pero también a los vivos y sus temores.

El sueño con Alan era una suerte de transición entre la muerte de cada hermano, una forma de conectarme con su duelo y estar cerca de él mientras estaba lejos. ¿Es afectivo este espacio entre una muerte y la otra, pero también entre Alan y yo?, ¿es un tiempo vincular el que se juega entre estos acontecimientos? No se trata de pensar sólo la relación entre un etnógrafo y su informante, sino de explorar algo que no se circunscribe a un vínculo en particular. Los hechos mostraban que algo se había reconfigurado: Tenosique no sólo se filtraba profundamente en mí, también era más interpretable o asible. Antes, por ejemplo, sus huellas se registraban en mi cuerpo: al regresar del trabajo de campo enfermaba de manera casi inmediata, pasaba una semana o diez días en cama. Un cansancio intenso me invadía, sentía que no podía hacer nada. Percibía en mí una añoranza por el lugar y su gente, pero también una saturación. Era como si estuviese hundido y, a la vez, excedido. Mi cuerpo tardaba en recobrar su equilibrio, pero lo conseguía. No obstante, algo quedaba pendiente, una sensación difusa, pero persistente: la imposibilidad de regresar a mi vida. Ese periodo era como un pequeño duelo, expresado primero como enfermedad y cansancio, luego como melancolía. 
Cuando tuve el sueño que relaté antes sentí que este proceso llegaba a su fin. Desde hace un tiempo los regresos ya no eran tan duros. La melancolía era menor, pero a la vez me sentía más comprometido con las personas de la ciudad, especialmente con las que me relacionaba de modo cercano. Soñar con Alan y su familia, regresar a ese mundo por medio de aquellos viajes nocturnos hechos de manera imprevista, saber de algún modo lo que le estaba sucediendo, confirmaba la fortaleza del vínculo. No necesitaba estar abí para relacionarme con la gente de allá. Pero creo que era también una reconfiguración de los vínculos. Si antes el duelo devenía en enfermedad, ahora lo hacía como sueño. Los duelos de mi cuerpo transmutaron en los duelos de los otros, que podía acompañar de alguna manera.

La muerte moviliza afectos poderosos, redes de solidaridad y sociabilidad que actúan en torno a una pérdida. Mucha gente se acercó a la familia de Alan cuando su hermano se suicidó. Una corriente de apoyo y cercanía cruzó la casa de sus padres y sus vidas. Los dos ancianos estaban sentados en el pasillo que empieza en la puerta de entrada y llega hasta el comedor de la casa. La gente se les acercaba a darles el pésame, esa forma protocolar de compartir el dolor del otro. Quedaba poco espacio para caminar. Había comida, los niños jugaban en distintos lugares, la gente entraba y salía, como si ese movimiento incesante fuera un modo de vivir el duelo colectivo, que creaba corrientes corporales, afectivas y vinculares. El pesar de los dolientes también era transformado por esa presencia colectiva: estábamos dentro del duelo, cobijados por la multitud y su movimiento continuo, guarecidos por una cercanía ocasional. La muerte parecía algo extraño o ajeno. Los vivos rodean al muerto para cuidar sus propias vidas, se acercan unos a otros para disminuir la profunda grieta afectiva que abre la muerte, ese boquete existencial que nos deja pasmados. Presenciamos una fuerza transpersonal. No se trata solo de afectos que enlazan a unos individuos con otros, sino de relaciones sociales y flujos corporales densos, intensos, vivaces.

Pero todo ello también prepara el olvido. El trabajo emocional y afectivo inaugurado con la muerte comienza a ubicar al difunto en un lugar diferente. El movimiento colectivo del que hablo elabora la pérdida y acota el duelo. El olvido es un proceso pautado socialmente. Un ejemplo: el novenario tras la muerte del hermano de Alan, celebrado tres veces al día (mañana, tarde y noche), es el segundo círculo del duelo; el primero fue el entierro. Luego se hacen oraciones en momentos importantes: cuando se cumple un mes, tres meses, seis meses, para día de muertos, un año. Los círculos temporales son cada vez más amplios, pero también más 
íntimos, porque en ellos participan fundamentalmente personas cercanas al difunto o su familia.

Al noveno día se recoge la sombra, es decir, la cruz hecha de flores y otras plantas, colocada donde estuvo el ataúd, y se la lleva a su tumba. Así concluye el rito inmediato a la muerte. El muerto se entierra dos veces: primero su cuerpo, luego su sombra. ${ }^{87}$ La muerte definitiva llega sólo cuando ambos han sido sepultados. Pero también significa que el duelo tiene dos momentos: el entierro del cuerpo, luego el de la sombra. El intervalo entre la muerte y el levantamiento de la sombra permite una simbolización paulatina de la pérdida. La sombra no es el cuerpo, sino su huella. Se entierran primero los despojos y después sus reflejos. La sombra es el resto de los restos. Al levantar la sombra, como si se alzara el cuerpo del difunto, se recoge su presencia aún intensa entre los vivos que la llevan hasta su tumba. ¿Qué portan cuando cargan esa sombra? Quizá al despojarse los vivos del muerto, entregan o devuelven un reflejo que aún refracta sobre ellos. Lo olvidan ritualmente, pero también lo apartan de sus cuerpos y subjetividades, por eso lo entierran dos veces. Entonces no sólo se suscita el duelo, también el olvido, la separación definitiva entre los vivos y el muerto.

Mi sueño ocurre entre una muerte y otra, en la superposición de pérdidas y duelos que experimentaron Alan y su familia. En los primeros meses de 2012 deseaba establecer cierta distancia con la ciudad y su gente. Regresé nueve meses después a la feria local. Poner distancia implicaba para mí elaborar una pérdida momentánea. Había viajado con mucha frecuencia a la

\footnotetext{
${ }^{87} \mathrm{El}$ término sombra aparece en muchos trabajos antropológicos vinculados con la constitución del ser humano en las culturas mesoamericanas y con las concepciones sobre la muerte y los rituales que la siguen. Creo que nos falta profundizar en este aspecto y realizar una exploración etno-histórica de este concepto y de sus usos. Intentaré hacerlo en otro momento. De la Garza dice que "el tonalli o la sombra es la parte del espíritu que se separa del cuerpo en la muerte (...) abandona el cuerpo al momento de la muerte porque es la parte inmortal del alma" (de la Garza, 2012: 120). En su estudio sobre San Miguel de los Aguasuelos, Veracruz, García indica que "las manifestaciones del alma en forma sensible se conocen como sombra (...) La sombra se manifiesta principalmente por su ausencia (...) una persona al morir pierde el alma, cuya ausencia tiene como efecto o signo sensible, un cuerpo muerto" (García, 1987:17); el rito de levantamiento de la sombra en esta comunidad "hace referencia al hecho de que el alma es recogida en formas materiales antes de ser incorporada al cuerpo" (ibíd: 18). En su estudio sobre los ritos funerarios en Huaquechula, Puebla, Carreón refiere que luego del enterramiento el cuerpo, levantar la 'sombra' "sugiere que la presencia incorpórea del muerto pasa a ocupar su lugar correspondiente, o sea, el cuerpo" (Carreón, 2009: 86). En una detallada reconstrucción del término entre diversas culturas y lenguas mesoamericanas, Martínez González dice que a pesar de que los datos son escasos -la ausencia de referencias en "fuentes antiguas", motivó a Aguirre Beltrán a proponer que la 'sombra' era una concepción subsahariana, traída por los africanos a México (Martínez González, 2006: 186)-, se pueden identificar algunas características de la 'sombra' como entidad anímica; entre ellas, que "se trata de una entidad fría y obscura (...), atada de forma débil a la envoltura corporal del ser humano" (ibid.: 189); sería también "un componente anímico que, tras la muerte, se desprende del cuerpo y queda rondando sobre la superficie terrestre por cierto tiempo" (ibíd: 189-190). Añade que "en algunos casos dicha entidad puede ser reintegrada al cadáver mediante ciertos procedimientos rituales, sobre todo cuando se trata de muertes violentas, la sombra es atraída por el lugar del deceso convirtiéndose en un sitio 'sombroso"' (ibíd.)
} 
ciudad y ese tiempo de espera marcaba una diferencia en mi relación con ella. En algún sentido mi duelo etnográfico se interpuso al duelo familiar de mi principal informante en ese lugar. Pero ahora mi cuerpo no registraba la perturbación. Pienso que en alguna medida nunca enterré mi sombra etnográfica o afectiva. Hice una pausa, pero no produje una ruptura. Deseaba descansar y guardar distancia, no olvidar. Pero el sueño reafirmó mi sensación de que una separación temporal no se traduciría en otra afectiva. Mientras los vínculos dependieran demasiado de mi presencia seguirían siendo débiles, por así decirlo.

Pero ese registro inconsciente representaba una nueva profundidad. La etnografía había atravesado ese delicado límite entre la actividad diurna y consciente y otra nocturna e inconsciente. Los afectos, como flujos transpersonales, atravesaban mis sueños creando otras formas de vinculación. Los duelos permitían reelaborar las relaciones. Empezaba a trabajar con la sombra que la larga experiencia etnográfica había creado en mí, una especie de sedimento múltiple y complejo. Entiendo que la profundidad implica una apertura radical, pero paulatina, al otro y no es una especie de socavón experiencial en el que caemos repentinamente. No me interesaba analizar mi aparato psíquico, sino experimentar conmigo mismo una etnografía de los afectos y del deseo, transformarme también en un espacio o una superficie de exploración conceptual y experiencial. Ofrecer mi subjetividad a la etnografía. La sombra reemplazaba al cuerpo como lugar de padecimiento. Quizás era inevitable un monto de sufrimiento psíquico y corporal. Era necesario brindar algo a las fuerzas que tocaba en mis viajes y en mi reflexión que fuera contiguo a lo investigado. Ofrecía mis padecimientos, primero físicos, luego emocionales. No podía desechar el mundo, las personas y los hechos a los que tenía acceso o ponerlos entre paréntesis. En algún sentido, la sombra es todo eso: ese flujo que no se detiene, lo que se elabora poco a poco, aquello que nunca logra comprenderse o localizarse cabalmente.

El olvido se infiltra en esos procesos complejos y ambiguos. Si el duelo era una elaboración colectiva del olvido, la sombra es su espacio ritual y simbólico. De algún modo, las enfermedades expurgaron en mi cuerpo muchos recuerdos, registros tal vez imperceptibles que lo habían marcado o conmovido. Una etnografía es un juego con ese olvido y la memoria. Un diario de campo intenta moderarlo o controlarlo, pero nunca lo logra. Regreso a mis notas como si fuesen agujeros experienciales. Apenas reflejan lo que ocurrió o lo que me dijeron. La escritura es una sombra de la experiencia y de la vida. La angustia rodea al texto, lo remece. Las notas me conducían, como el hilo de Ariadna, por un laberinto de acontecimientos, conversaciones, lugares y personas, de actos, silencios y tiempos. En la escritura horizontal las 
líneas transversales deshacían la certeza del relato. La descripción es un remedo de la realidad, también su sombra. ¿Cómo podría registrar los tonos de voz de una plática, el movimiento de los cuerpos, la luz de un lugar, la temperatura, la brisa?, ¿qué tipo de descripción me permitiría reconstruir un baile, los múltiples planos de las relaciones sociales que se conjugan en un acto de ese tipo, mis pensamientos y los que otros tienen, los afectos, los deseos, las proximidades y las huidas? Es imposible y en ese obstáculo empieza el esfuerzo tal vez ingenuo de registrar y dar cuenta. Quedarse con poco de lo mucho, con algunas palabras en vez de la vida. Con algunos matices que intentan suplir la gama gigantesca de colores y tonos que observamos.

Pero si alguien lo recordara todo, como un Funes etnográfico, no podría reconstruir nada. Los procesos y las relaciones sociales son, también, productos del olvido. Los ritos mortuorios intentan reconfigurar el vínculo colectivo con alguien que ha muerto para mostrarles a sus deudos formas de olvido más o menos paulatinas. Los sueños, al contrario, inauguran una nueva memoria. Podemos pensarlos como notas de campo escritas en otros lenguajes, pero que sirven para trazar descripciones, análisis e interpretaciones desde ángulos distintos. Un diario de campo, escrito con la conciencia diurna, implica una tensión entre los detalles y las generalidades, entre lo singular y lo colectivo, entre lo central y lo accesorio. Es una escritura que exige control y esmero. Pero las notas oníricas se han liberado de todas esas exigencias y trazan su propio relato.

También podríamos pensar el cuerpo como otro diario que se escribe en otro lenguaje o en una forma distinta de escritura. ¿Hay una narrativa en las enfermedades que produce un trabajo de campo?, ¿los síntomas son radiaciones de otras relaciones sociales, otras subjetividades, de otros cuerpos e incluso otras enfermedades?, ¿se articula una voz soterrada, pero persistente, en esos padecimientos? Si leyera los síntomas de mis enfermedades como notas corporales de un trabajo de campo, como complementos de una etnografía: ¿qué me dicen?, ¿qué develan?, ¿qué permiten entender que otros registros no consiguen? Si en ese proceso las notas se multiplican, así como los lenguajes, podemos intuir que hay algo que no logramos entender. En otras palabras, el exceso corporal, onírico, afectivo y emocional no es sólo un resultado residual del trabajo de campo. También es señal de una carencia interpretativa. Hay algo que no logramos elaborar simbólicamente, hay espacios experienciales que no podemos registrar en el lenguaje.

Ahí empieza otra exploración y una espera. La exploración de territorios etnográficos tal vez ignotos, pero también la espera de eslabones que liguen un campo con el otro: la 
descripción detallada de un diario de campo con las experiencias del cuerpo o del inconsciente. Nunca se remiten unos a otros, ni se pliegan, a mi entender. La tensión que debemos explorar es la de su resolución imposible, como placas tectónicas que se superpusieran y en determinados puntos nos avisaran que unas están encima de las otras. Estos campos no se pueden homologar, pero necesitamos registrarlos y entenderlos, dentro de lo posible. Tal vez develan, como en el caso del sueño y del duelo, ciertas sincronías. La pregunta es cómo vincularnos con la enorme diversidad de experiencias, hechos, narrativas, espacios y sujetos que implica un trabajo de campo, sin renunciar al registro afectivo que todo esto genera, pero sin hundirnos en él.

No hay una sola conexión ni un solo camino. Mientras mayor consciencia tengamos de la diversidad de procesos y la disyunción de registros, mejor podremos valernos de ellos. Por ejemplo, el sueño fue una forma eficaz de conectarme con los duelos. No bastaba que estuviera presente, que luego anotara, que participara del dolor y a la vez lo observara. La conexión seguía pendiente. El sueño me reveló una nueva apertura hacia las personas con las que me relacionaba y sus vidas. Los padecimientos corporales me permitieron reflexionar sobre la posición de los sujetos que investigaba en el orden social. Había algo que no podía aislarse de un pathos intenso, vibrante, pero también doloroso, que yo registraba en mi cuerpo y después se reconfiguraba como enfermedad.

\section{La letra muerta}

Si el método propuesto fuera analógico, entonces habría que multiplicar sus niveles y campos para incluir los cuerpos, los sueños, las reflexiones y los afectos, las teorías, los objetos, los espacios y las temporalidades. Pero también habría que buscar los eslabones que permitieran conectar unos procesos con otros: lo personal con lo colectivo, lo corporal con lo social, lo onírico con lo político, lo afectivo con lo económico, por mencionar algunos.

En una etnografía estamos, de algún modo, en un presente continuo, aunque trabajemos con las huellas del pasado (social y personal) y con las expectativas del futuro. En ese sentido, esa radical inmanencia del trabajo de campo mismo, que sólo puede ser modificada por una reflexión posterior que busque, por ejemplo, las determinaciones estructurales del devenir, supone que en ese momento, en cada instante, se está jugando todo el conocimiento que tenemos del mundo que estudiamos, de los sujetos y de nosotros mismos. El proceso posterior 
en que seleccionamos, descartamos, ordenamos y redistribuimos, vinculamos y reflexionamos los materiales que hemos podido reunir resta poder a esa inmanencia. La etnografía como texto es un sedimento y una elaboración retroactiva de algo que sigue vibrando en algún registro, aunque no sea necesariamente el de la conciencia. En ese sentido, cualquier presente escritural es una sombra de la vivencia y la experiencia. La analogía, permitiría, de algún modo salvar esa distancia temporal. No sutura el tiempo, pero traza relaciones productivas entre los acontecimientos y su lectura, entre los hechos y su orden, entre la interpretación y el devenir. Bernard Lahire escribe que:

La misma metáfora permite también insistir en la importancia del presente para movilizar los archivos incorporados del pasado: si no hubiera nuevos casos que "tratar", el pasado no sería movilizado en función de las características propias a la lógica de esos nuevos casos. (...) Al apropiarse de un objeto, una situación, una institución, un lugar, el actor le da vida a lo que hubiera quedado como letra muerta, pero, inversamente, es porque fue puesto en presencia del objeto, de la situación, de la institución o del lugar, que se revela en él eso que, de no ser así, podría haber quedado temporaria o más durablemente, en estado de vigilia (Lahire, 2006: 74)

Son sugerentes las imágenes que el mismo Lahire trae del proceso de apropiación del pasado y de reactivación del presente. Habla de una "letra muerta" y de un "estado de vigilia". Es decir, remite de alguna manera a dos experiencias que he abordado en estas páginas: el duelo y el sueño. Y propone dos soluciones: dar vida a la letra muerta y revelar el estado de vigilia. Vida y revelación serían, en sus análisis, las dos formas de movilizar "los archivos incorporados del pasado". En una etnografía: ¿cuál es su letra muerta?, ¿dónde se da vida a esa letra muerta?, ¿en la escritura, en el diario de campo, en el registro inmediato?, ¿esa letra es también la sombra de la escritura... etnográfica? Asimismo: ¿cómo se revelan el objeto y la institución, el lugar o la situación?, ¿qué sucede en nosotros, el actor dice Lahire, para que dicha revelación ocurra?, ¿'son formas directas de revelación o las hay difusas, oblicuas y laterales?

Yo leí mi sueño como una revelación etnográfica, pero también el duelo como una escena en la que la letra muerta de las instituciones, los objetos, las situaciones y los lugares comenzaba a cobrar vida. El sueño fue una conexión, pero también una forma de revelación, que me permitía calibrar la profundidad de los vínculos y el talante de mi propia entrega y compromiso. El trabajo de campo se filtraba, suavemente, en mi inconsciente y ahí empezaba la revelación. ¿Podía distinguir de manera tajante lo que se revelaba de mí de lo que se mostraba de los otros (instituciones, objetos, situaciones, lugares, sujetos)? Antes, lo mencioné, esa 
sequedad emocional y esa distancia afectiva las leí como una letra muerta, que clausuraba la escritura. ¿Se puede escribir con letras muertas?, y si fuera el caso: ¿de qué tipo de escritura hablamos? Cuando los deudos llevan la sombra a la tumba del difunto recién enterrado, luego de nueve días de oraciones y rituales, ¿no llevan, de alguna manera, esta letra muerta representada en la cruz de flores que reemplaza al ataúd durante el velorio? Al parecer, la escritura también necesita inhumación. Las letras hay que enterrarlas porque están muertas, sólo así cobrarán vida.

¿Por qué la revelación, es decir el sueño, sucedió entre dos muertes? Tal vez una pista sea el carácter mismo de la muerte: límite de cualquier vínculo social, pero también institución, objeto, situación, lugar. Siguiendo la antigua definición de Durkheim, la muerte es un hecho social total (Mauss, 2012 [1925]) que moviliza diversos registros sin que puedan desligarse unos de los otros: el rito de la emoción, la representación de los vínculos, los gestos de las palabras, los signos de las relaciones. Esa aparente totalidad facilitó la revelación etnográfica como una forma de acceder al campo, pero también a su interpretación, de un modo más completo. La letra muerta era, para mí, la imposibilidad de conectar registros muy distintos: personales, corporales, emotivos, afectivos, racionales, históricos, vinculares y también políticos.

Cuando se reactivan los archivos incorporados del pasado: ¿qué se revela? El sueño que relaté movilizó dichos archivos, que se desplazaron desde el inconsciente hacia la consciencia, que no es sino un recuerdo inmediato $y$, en ese sentido, un nuevo archivo de corto plazo. Los padecimientos que había experimentado al regreso de mis viajes a Tenosique se habían archivado de algún modo, esperando que encontrara la letra viva que resignificara (¿resucitara?) la letra muerta. Pero el desplazamiento fue transitivo. La muerte movió mi propio lugar en el campo y mi relación con la escritura. Diré que los otros me revelaron mi lugar, esa contigüidad emocional e íntima que se crea con quienes convivimos, y pusieron en marcha un archivo afectivo, de pronto perturbado por alguna situación. La muerte es un límite que conmueve las certezas y transforma los vínculos. Tal vez en este sentido Lahire escribe que:

La acción humana debe ser comprendida en el cruce de las experiencias individuales pasadas que hayan sido incorporadas en forma de disposiciones para ver, creer, sentir o actuar, y de una situación social presente. En cada situación "nueva", el individuo socializado actuará "movilizando" (sin tener necesariamente conciencia de tal movilización) esquemas o disposiciones incorporados, convocados, desencadenados (y en ocasiones despertados) por la situación. (Lahire, 2006: 73) 
Para mí la muerte ha sido siempre la muerte de mi padre, ha tenido su forma. Pero esta vez, enfrentado a otros fallecimientos, que eran elaborados socialmente de modos diversos, la situación requería de otros esquemas o, más bien, el contexto etnográfico permitía observar los esquemas con que otros sujetos resolvían, individual y colectivamente, el deceso de un familiar. En mi experiencia infantil había persistido una gran interrogante: ¿qué hacemos con la muerte? Una familia sin prácticas religiosas como la mía la había resuelto de manera brusca, por así decirlo, sin esa sutileza que significan nueve días de duelo, oraciones, comidas, sombras y homenajes. Al observar los rituales que siguieron a la muerte del hermano de Alan presencié el acercamiento colectivo a un límite y atestigüé su elaboración cuidadosa y pautada. En mi infancia me había quedado la impresión de que simplemente se moría y luego se inauguraba una ausencia definitiva que cada cual debía resolver de algún modo. No había cuerpo social que nos (me) cobijara, ni rituales que mitigaran la intemperie emocional y afectiva que se abría. El dolor se anclaba al silencio de manera irremediable. Sólo muchos años más tarde logré elaborar el duelo, mi propio duelo, o la sucesión de duelos que me aprisionaban. Mi sorpresa fue descubrir que, a la larga, los había incorporado o encarnado, había creado, por así decirlo, un archivo corporal doliente, que perpetuaba el duelo en un registro poderoso, pero alterno a la consciencia y a cualquier proceso significante. Otra vez, fue el cuerpo la ruta que me mostró ese archivo.

La revelación será, en ese sentido, el acceso a los archivos incorporados con los que estamos trabajando en el campo. Si bien podríamos pensar un acceso metódico y racional, creo que el trabajo de la analogía es construir los puentes que permitan identificar y explorar esos archivos. Sobre la analogía, Derrida escribe:

Cualquiera que sea la manera en que entendamos el término, una analogía es siempre una razón, un logos, un razonamiento, incluso un cálculo que remonta hacia una relación de proporción, de semejanza, de comparabilidad en la cual coexisten la identidad y la diferencia. (Derrida, 2011: 33)

¿Cuál es la proporción, la semejanza que trazan un duelo o un sueño?, ¿qué relaciones de identidad o diferencia se articulan en ellos?, ¿cómo podemos distinguirlas e interpretarlas?, ¿cómo garantizar que ese logos que refiere Derrida no sea una letra muerta?, ¿qué arriesgamos en una analogía? Algo de lo que narré antes, muestra que las relaciones de identidad y diferencia transitan o se muestran también en las formas en las que entendemos y dirimimos lo íntimo, lo subjetivo, lo afectivo y lo inconsciente. 
La muerte mi padre fue diferente a la del hermano de Alan: no el hecho físico solamente, sino su elaboración social y cultural. Pero podía encontrar una identidad en los procesos del duelo, especialmente en eso que no puede ser acomodado por los rituales ni los gestos. Alan me ha comentado en algunas ocasiones la soledad en la que ha enfrentado su duelo, a pesar de estar rodeado de gente y de la gran cantidad de personas que lo(s) acompañaron. Había algo insalvable entre la disposición colectiva y la elaboración subjetiva. Pero ese campo de disyunciones, esas muñecas rusas que se guardan en el cuerpo y en la memoria y no son visibles, necesariamente, a los otros, implicaba un espacio de identidad entre su experiencia e interpretación y las mías. Él con su hermano, yo con mi padre.

El énfasis de la antropología en el estudio de la alteridad tal vez oscurece los potenciales analógicos y el lugar de la experiencia personal y de la memoria en su movilización. No deseo entender al otro comparándolo conmigo, pero sí quisiera comprenderlo a través de mí en alguna medida; pero también vislumbrarme a través del otro. El sueño, como revelación y como sendero a un archivo personal, pero también cultural, fue una forma de concretizar ese 'a través'. La analogía es posterior, es una epifanía conceptual que sucede de manera tardía. Las iluminaciones, si utilizamos una palabra cara para Benjamin, sólo podrían suceder en el cruce intempestivo de la experiencia, los archivos y las estructuras sociales y culturales.

Biehl y Locke advierten que es necesario reconocer en las personas que investigamos las mismas complejidades que registramos en nosotros mismos, para incluirlas en el conocimiento que producimos (Biehl y Locke, 2010: 317). Pero considerar esas complejidades en un horizonte de semejanza, por lo tanto potencialmente analógico, como señala Derrida, no requiere sólo una operación epistemológica o metodológica, sino también de una sensibilidad. Navaro-Yashin escribe sobre ese punto unas líneas iluminadoras:

Me pregunto si la formación racionalista de los antropólogos nos desensibiliza sobre las mismas cuestiones que nos propusimos estudiar. Plenamente conscientes y siempre racionales, jamás perdimos el rumbo. Me pregunto si otro tipo de sensibilidad puede mantenernos dentro del dominio de la experiencia subjetiva que lo político genera, de tal suerte que podamos sentir, capturando dicha sensibilidad mientras se desvanece o antes de que sea normalizada, y escribir acerca de ella sin que sea avasallada por el discurso racionalista de las ciencias sociales. (Navaro-Yashin, 2003: 109)

¿Podemos comprender sin calcular?, ¿es posible conservar una sensibilidad sin renunciar a la razón?, ¿podemos movernos en ambos registros e intercalar los archivos: racionales y emocionales, simbólicos y corporales, discursivos y afectivos, conceptuales y estéticos? La 
pregunta no sólo contempla la aproximación al campo, también las formas en las que producimos un conocimiento. Cuando reconocemos que los otros son tan complejos como nosotros y que esa complejidad debe incluirse en el conocimiento que deseamos producir y socializar: ¿qué tipo de complejidad tenemos en mente? Pero aún más importante: ¿tenemos las herramientas para dar cuenta de esa 'complejidad'?, ¿basta la escritura para revelarla? Asimismo: ¿qué nos exige dicha complejidad?, ¿debemos reconocer primero la nuestra antes de integrar la de los otros?, ¿una nos permite reconocer y comprender la otra? En ese sentido, estaríamos siempre en el terreno de la analogía, sostenidos de alguna manera por las semejanzas y las comparaciones, atravesados por las relaciones de identidad y diferencia en las que nos movemos, pero que también estudiamos.

Es necesario que nos preguntemos cómo escribir una etnografía que resguarde la sensibilidad, que no renuncie a la razón, y que dé cuenta de las complejidades cruzadas que forman parte de un campo: las propias y las ajenas. Una etnografía que no se deslinde de la subjetividad que escribe, de la complejidad viva que intenta investigar, pero que no se reduzca a ella, que no quede pasmada en el relato biográfico ni en la anécdota personal.

Podemos aventurar que una analogía no es sólo una comparación o una semejanza. O más bien, ver cuán problemática puede resultar dicha semejanza. Derrida escribe: “(...) cuanto más otro es el otro, menos otro es. Y, al revés, cuanto menos otro es, más otro es. Cuando más otro, menos es el otro; cuando menos otro, más es el otro" (Derrida, 2011: 183). Parece un juego de palabras, y tal vez lo es, pero abre un camino interesante para nuestra reflexión sobre la analogía y la alteridad. De este modo, el más parecido es el más otro, el más distinto es el menos otro. La alteridad se constituye mediante esta otredad semejante, pero diferida.

Al reflexionar sobre Robinson Crusoe, Derrida cita algunos ejemplos de la alteridad que preocupan al naufrago y que sirven para comprender con mayor cabalidad este punto: el mar y la tierra, los animales salvajes y los caníbales a los que el náufrago teme de manera especial. Los dos primeros son marcadamente diferentes, el último semejante. Pero son los antropófagos los radicalmente otros: "su alteridad está tanto más marcada cuanto menos marcada es" (ibíd.). De este modo "ser-entregado al otro es un ser-entregado a lo semejante" (ibíd: 187). Son las relaciones de semejanza las que producen la alteridad. Es decir, que la analogía no es, ante todo, una ruta para investigar las semejanzas o las identidades, sino más bien para explorar las diferencias. Mi experiencia de la muerte y la de Alan, si bien muy parecidas en muchos aspectos, se tornaban muy distintas justamente por su semejanza. La comparación no inaugura 
una identidad sino que despliega una diferencia. Parece que la analogía se sustentaba en una continuidad de algún tipo, pero más bien es un salto en la alteridad del otro desde su semejanza.

Derrida plantea esta pregunta por la alteridad en el marco de una reflexión sobre la muerte. Se pregunta. “¿qué es el otro?” y añade:

¿Qué es lo que el otro o los otros van a hacer de mí cuando, tras el paso de alejamiento del tránsito, tras ese paso, cuando yo sea pasado, cuando yo haya pasado, cuando haya partido, cuando me haya alejado, cuando haya desaparecido, cuando esté totalmente sin defensa, desarmado entre sus manos, es decir, como suele decirse, por así decirlo, muerto? (...) Por poco que yo sepa acerca de lo que quiere decir la alteridad del otro o de los otros, he tenido que presuponer en efecto que el otro, los otros son precisamente aquellos que siempre pueden morir después de mí, sobrevivirme y disponer así de lo que queda de mí, de mis restos. ¿Qué son los otros? Aquellos y aquellas que pueden sobrevivirme (Derrida, 2011: 170)

La alteridad empieza con la muerte y será ésta la que muestre qué es el otro, quiénes son los otros. Luego de la muerte de los hermanos de Alan se inaugura una alteridad radical, irresoluble, entre los muertos y los vivos, aquellos que sobreviven y que se hacen cargo de los restos de los muertos. ¿Pero es el otro quien me sobrevive? Derrida escribe desde el punto de vista del muerto, cuyo cadáver queda a disposición de los vivos. Pero si pensamos desde la perspectiva de los deudos, de quienes han sobrevivido: ¿quién es el otro?, ¿quiénes son los otros? El duelo y los rituales que lo sostienen permiten una elaboración pausada, pero sistemática, de la alteridad del muerto. Éste estaría entregado completamente al otro, al que lo sobrevive, sin defensa y desarmado. ¿En qué posición está el otro ante el muerto?, ¿es el duelo una forma de darles a los sobrevivientes un lugar después de la muerte?, ¿cómo se transforman esas relaciones de alteridad una vez acaecida la muerte? Alan sobrevive a sus hermanos, sus padres sobreviven a sus hijos. Hay una larga lista de sobrevivientes, algunos tienen una posición clara -viuda, huérfano-; otros no: padres y hermanos.

¿Llevar la sombra es resolver esa alteridad radical?, ¿es una forma de borrar las huellas y de inaugurar la sobrevivencia? Hablé de ella como el resto de los restos, esos que preocupan a Derrida a partir de su pregunta por el otro. La sombra es el otro del otro. Recoger la sombra y llevarla a la tumba es deshacer cualquier semejanza entre el muerto y sus sobrevivientes. Es el fin de cualquier analogía, pero también el principio de un pensamiento sobre la diferencia. Ahí donde parece que todo termina, también empieza. 
¿Empieza la escritura, pero también la comprensión, cuando nos enfrentamos a formas radicales de diferencia, que suponen semejanzas igualmente intensas?, ¿es una etnografía una exploración acuciosa de todas estas tensiones y sus puntos ciegos? Michel Serres se pregunta:

¿Qué es necesario recordar? Sí, el sujeto que muere y que nosotros olvidamos, que debemos resucitar a cada instante de entre los muertos. Pero también, pero ante todo, aquel tiempo, el tiempo (...) La memoria perdura por este múltiple paso, gracias a esta confusión (Serres, 2002: 236)

Recordar, nuevamente, es un acto vinculado con la muerte. Recordar, en palabras de Serres, es resucitar al sujeto que muere. Pero, ¿cómo se hace el tránsito entre el sujeto muerto y el resucitado?, ¿cómo se dilucida la presencia real del recuerdo?, ¿cómo distinguir el cuerpo de su sombra? A su modo, ¿no son éstos también asuntos que competen a la escritura etnográfica? La memoria perdura en ese "múltiple paso" y gracias a una "confusión", que nosotros intentamos aclarar de algún modo, tal vez morigerar. Recordar el tiempo podría definir una escritura, que siempre bordea la descripción, pero que luego se pierde en sí misma, en su flujo, en su alteridad.

Pensemos, entonces, que la analogía es una propuesta sobre cómo confeccionar la sombra de un muerto. Sólo son sus huellas, los restos de los restos, su alteridad radical. Y en ese punto su mayor cercanía, la intensidad de cualquier semejanza. Despertamos, de pronto, a lo que es semejante entre los otros y nosotros y la otredad que eso devela. Creo que el juego entre la muerte, el sueño y la sombra permite imaginar alteridades consecutivas que se topan, como reflejos de luces distintas en una misma superficie. La alteridad subjetiva que implica el sueño, la otredad que inaugura la muerte y la semejanza que intenta purgar la sombra. El sueño también es una huella y un resto. Huella de otros espacios psíquicos, resto nocturno que intentamos ubicar (o no) durante el día. En alguna medida, el sueño también es una sombra.

\title{
Gestos de conmemoración
}

\author{
¿Tenemos necesidad de imaginar un entendimiento que reúna los sentidos?
}

Michel Serres, Los cinco sentidos, 2002: 242

No basta con pensar, escribía Navaro-Yashin, también hay que sentir. El obstáculo es transformar las sensaciones, los afectos, las emociones, los procesos inconscientes, el rumor vibrante, pero elusivo, de la vida, en una escritura que guarde la intención de entender, explicar 
e interpretar. Una etnografía, en ese sentido, no es una ficción; es un intento, más o menos logrado, de mostrar y describir un mundo ajeno y distinto. Creo que la principal tensión de la escritura etnográfica no proviene de la imaginación sino de la realidad. ¿Podemos analizar sin destruir?, ¿es posible elaborar una escritura que no renuncie a la confusión del mundo, pero tampoco a la claridad? En un texto muy bello, Serres escribe:

El conocimiento claro y distinto resulta del análisis que divide o separa, irreprimiblemente asqueado de lo confuso. Separar o dividir supone un espacio, y distinguir puntea en éste o sobre éste una localidad singular, todas operaciones topológicas simples. La confusión o la inclinación múltiple, anudada o cambiada en una confluencia, también supone un espacio, pero con un poco más de cuidado. Representa de hecho la operación directa de la división o la separación: una especie de suma o de multiplicación. Quien sabe deshacer un nudo y desplegar de éste las hebras durmientes no condena de ordinario al que anida las hebras libres o corrientes; él mismo conoce los dos gestos. (Serres, 2002: 222)

En la escritura etnográfica: ¿cuál es ese espacio del que habla Serres?, ¿cuál sería el espacio alterno al que surge del análisis, ese espacio de confusión e inclinación múltiple?, ¿habría otra forma de trabajar con los nudos que no fuera el corte analítico? Es difícil de resolver ese espacio entre la sensación, la emoción o la experiencia y la proposición. Y no se trata, solamente, de resolverlo ontológicamente, suponiendo que el lenguaje llena todos los espacios por anticipado. Se trata, a mi entender, de escribir en esa agonía entre el sentido y la experiencia. Pero también de abrir la escritura a una vibración múltiple, a veces confusa, que se articula con dificultad en el lenguaje, pero lo infiltra, lo conmueve y lo desordena.

Luego del año nuevo de 2012, Hernán, un amigo de Tenosique, me regaló un Niño Dios que, a su vez, le habían regalado años atrás. Lo tenía en mucha estima y varias personas se lo habían pedido antes, pero él decidió dármelo a mí porque, según sus palabras, “yo era buena onda”. Para Navidad y día de Reyes la gente, en Tenosique, pone pesebres en sus casas y un Niño Dios, que los acompañará desde fines de diciembre hasta el día de la Candelaria, el 2 de febrero. El Niño duerme desnudo en la cuna y el 24 de diciembre se viste con un ropón comprado especialmente por una madrina o un padrino. Otras personas eligen el 31 de diciembre para vestirlo. Se queda en el altar casero hasta el 6 de enero, Día de Reyes, y luego se guarda en el lugar donde permanecerá todo el año. Algunas personas me dijeron que debía guarecerlo; otras que lo hiciera visible en una cuna o en una silla. El 2 de febrero, el Niño Dios es bendecido en una misa. 
Hernán me regaló su Niño con el compromiso de cuidarlo. Se trata de una escultura de yeso sencilla con los bracitos trizados. Una amiga fue su madrina y juntos compramos la ropa en el Mercado de Coyoacán: un traje azul muy parecido al que visten los infantes en las pinturas coloniales. Lo elegimos entre una multitud de trajes, gorritos, zapatos, capas y otras prendas. En algún sentido, el regalo inauguraba otro vínculo con mi amigo, porque me daba algo que él apreciaba mucho y era un objeto sagrado. Me obligaba a realizar el ritual al menos durante 6 años con esa figura y a buscar parientes espirituales que le compraran ropa u otras cosas al Niño. La figura está en mi casa y reposa en una cuna de mimbre que adquirí en el mismo mercado.

La primera vez que observé parte de los rituales que rodean al Niño Dios fue ese mismo año, en casa de Edgard, otro amigo, que me había invitado a cenar junto con su madre, Hernán, Pablo y Luisa Fernanda. Una vez que cenamos, Edgard y Pablo, padrino de ropa del Niño, se levantaron para vestirlo y colocarlo en un pesebre que cubría un octavo de la sala donde estábamos. El Niño era la figura central entre una multitud de otras imágenes animales, ángeles y vírgenes, rodeadas de heno en diversas presentaciones y luces que enmarcaban el cuadro. Como en los cuadros barrocos, el pesebre no tenía espacios vacíos.

Durante la cena, al momento de brindar, pedí a los comensales que compartieran sus deseos para el año que comenzaba. Mis cuatro amigos coincidieron en salud, trabajo y bienestar para sus familias. La mamá de Edgard habló, entre lágrimas, sobre la precaria salud de su madre y su hermana; deseaba se recuperaran. Su pareja se había retirado antes de la cena, ya bastante borracho. Permanecí con una sensación extraña pues dudé sobre la pertinencia de preguntar por sus deseos. Ellos habían puesto uvas en un plato para que cada cual comiera 12 granos que correspondían a una igual cantidad de deseos que se le pedían al Año Nuevo. Pero nadie los explicitaba. Al preguntar, trastoqué el ritual, tal vez por ello la respuesta fue melancólica. Desear en secreto parecía más prudente que hacerlo en público. La realidad, cruda e ineludible, cerca cualquier deseo. Por eso no se comunica cuáles son. La sencillez de las peticiones, que también compartía con ellos, y el llanto de la madre de Edgard, me conmovieron profundamente. Una corriente afectiva muy intensa y honda atravesaba el pequeño espacio donde estábamos y las mesas, pegadas entre sí, que nos servían para comer. Los afectos de unos por los otros, de cada uno por su familia, las expectativas sobre sus vidas, pero también las dificultades y los obstáculos que cado uno enfrentaba. La enfermedad que aquejaba a los parientes de Edgard y el fantasma de la muerte. 
El hermano de Alan se suicidaría a los pocos días. Ninguno de los dos estaba presente en esa cena, pero sí en la reconstrucción de las historias que ahora relato. Por entonces experimenté la transformación de dos cuerpos: el del Niño desnudo y el del hermano de Alan. Un cuerpo sagrado de yeso y otro humano convertido en cadáver. ¿Qué hacer con el Niño?, ¿cómo llevarlo de regreso a la ciudad de México sin que se rompiera? Cualquier cosa que le pasara sería leída como signo de desgracia, porque era Dios mismo a quien llevaba entre mis pertenencias. Pero también era el vínculo con mi amigo, el privilegio que me había dado al regalarme un Niño que muchos otros querían y que, al parecer, estaba colmado de bendiciones. Pero la excepcionalidad era un arma de doble filo: el maltrato involuntario o la pérdida del Niño se leerían como infortunio y mal augurio. La figura de yeso, pequeña y delicada, requería los mismos cuidados de un bebé, como si su fragilidad fuera carnal. ¿No era justamente esa fragilidad tan radical e irresoluble lo que hacía sagrado al Niño?, ¿๐ lo eran los deseos que podía cumplir y la bendiciones que traía?, ¿o lo sagrado estaba en las peticiones de muchas personas que deseaban que les regalaran la figura?

El hermano de Alan había vivido desde niño en una silla de ruedas a causa de la poliomielitis. Se había recuperado en la adultez y comenzado a caminar de manera casi normal, pero en un accidente automovilístico perdió una pierna y volvió a la silla de ruedas. Cuando lo conocí tenía una pierna, pero luego le amputaron la otra, al parecer por complicaciones de la diabetes. Alan me contó, en su momento, que esto le había provocado una depresión muy intensa. Al tiempo se colgaría del pestillo de una ventana en su habitación. Alan entró apenas unos minutos después del hecho, lo descolgó, pero ya había muerto. Era un cadáver y empezaba la larga elaboración de la muerte. La fragilidad del Niño Dios parecía contigua a la del hermano de Alan, aún más débil después de la muerte.

Serres escribe:

Ahora bien, la teoría del conocimiento, que desanuda y no quiere anudar, sólo tolera las operaciones inversas o analíticas: cortar, deshacer, sustraer, dividir, diferenciar. Destruir. Analizar quiere decir destruir (...) Ahora bien, la confusión compone una multiplicación fluida, en la que las multiplicidades en juego, no discretas, se transforman en variedades continuas. Estas fluyen conjuntamente, varían de concierto, son función de numerosas variables. (Serres, 2002: 222)

¿Se puede desatar el nudo de los cuerpos frágiles del Niño y el cadáver?, ¿'se puede distinguir a Dios de sus figuras y a la muerte de sus restos? En mi experiencia estaban el Niño y el muerto, 
como tonos contrastantes de la vida humana: el nacimiento y la muerte, el inicio y el término. El Niño y el cadáver, distintos analíticamente (deshechos, divididos, diferenciados, diría Serres) formaban parte de un flujo experiencial continuo. Cuando regresé con el Niño a la ciudad de México, llevaba también el duelo. Su nacimiento estaba emparentado con la muerte, aunque, sin duda, no eran lo mismo. ¿No era también un Niño el hermano de Alan, destrozado por la enfermedad?, ¿no tenía él las piernas amputadas como mi Niño los brazos partidos, remendados con cinta adhesiva? No en el mundo, no en las relaciones causales, no en las explicaciones. Su contigüidad sucedía en mi experiencia confusa, en la intensidad de todas las emociones propiciadas por el regalo y la muerte, ejemplo de esas "multiplicidades no discretas" enunciadas por Serres. “¿Qué hay que recordar, tan frágil y olvidable, para rehacer y unir los gestos de conmemoración que vuelven a encontrar la memoria?”, se pregunta el filósofo francés (ibid:: 234).

Cuando regresé a fines de 2012 a Tenosique, pasé el año nuevo con la familia de Alan. Había unas pocas personas, sus padres, algunos amigos. Al llegar las doce nos dimos los abrazos de costumbre. Él abrazó a sus padres y dijo conmovido, en voz alta, que todos estábamos de paso en esta vida y debíamos marchar, como sus hermanos, que habían partido antes. Su padre tiene 88 años, es un hombre alto y delgado, afable y conversador. Dueño de una gran memoria, recuerda la vida de la ciudad desde los años 30 del siglo pasado. Siempre ha vivido ahí. La madre, algunos años menor, sufre un Parkinson que la ha dejado progresivamente inválida. Ya estaba enferma cuando la conocí. No habla aunque está completamente lúcida. Necesita ayuda para comer e ir al baño. En medio de la conmemoración regresaba la muerte como un recuerdo de la fragilidad personal y compartida. Yo había cumplido, antes de viajar a Tenosique, con los ritos que como encargado del Niño me comprometían: busqué una madrina que le regalara ropa nueva, compré una cuna, armé un pesebre (era mi primera vez), lo mecí y vestí sobre una tela blanca el día 24 con mis invitados. Fotografías de cada paso las envié a mi amigo, su antiguo cuidador. El 6 de enero guardé al Niño y el 2 de febrero lo llevé a misa para la bendición. A esa misa me acompañaron un amigo que en ese entonces vivía en casa y la señora que desde hace años hace el aseo. Compré tamales según dicta la tradición y los tres comimos. Era un día de la Candelaria completo: Niño, misa y tamales.

"El yo pensante se estremece a lo largo de la espina dorsal: yo pienso por todas partes" (Serres, 2002: 96). ¿Se puede pensar por todas partes?, ¿se puede pensar por el cuerpo propio y el 
de los otros?, ¿por la piel, los sentidos, los órganos?, ¿se puede pensar por el cuerpo frágil de un Niño de yeso o por el cuerpo frío de un cadáver? Pensar es estremecerse, sostiene Serres. Y ese estremecimiento permite transformar todas las partes en fragmentos pensantes.

Nada es más abstracto, ni más sabio, ni más profundo que esta inmediata mediación sobre lo mixto, ni más fino, ni más difícil de captar que esta refundición local y compleja, que esta conversión trastornada o estos virajes inestables; sin duda no hemos dicho nada del cambio, de la transformación en general que no haya ocurrido allí, en la proximidad fina de nuestra contingencia. (Serres, 2002: 32)

En la proximidad de mi contingencia sucedió el regalo y la muerte. Nada es más difícil de captar que esa mixtura entre la muerte y el nacimiento, lo sagrado en tonalidades mortuorias y fecundas, entre los lazos infinitos que inauguran los regalos y los que cercena la muerte. "Refundición local y compleja" en la que se juega de lleno una etnografía: "conversión trastornada, virajes inestables.”

\section{Confesiones (im)personales}

Tranquilícense, esta especie de autosocioanálisis no tendrá nada de confesión y, si algo confiesa, sólo serán cosas muy impersonales. Pierre Bourdieu, El oficio del científico., 2003: 165

Serres escribe unas palabras espléndidas: "La confusión asocia, multiplica, esparce, anuda y no desanuda, no deshace ni separa, hace confluir lo no analizado: en esto consiste el tiempo" (Serres, 2002: 229). En mí se extiende el duelo y la alegría. Escribir es regresar a las evocaciones que la memoria suscita. ¿Esto es el tiempo?, en esa confluencia de lo 'no analizado', ¿cuáles son los nuevos nudos que se han formado?, ¿el nudo del Niño con el cadáver, el de la muerte con el don, el del inicio con el fin? Las asociaciones podrían multiplicarse: los nudos conceptuales con los de la soga que ahorcó al hermano de Alan y las vendas que cubren los brazos del Niño para que no se desprendan; un recién nacido de yeso con signos de deterioro, como el pariente fallecido que estuvo en silla de ruedas desde su infancia. ¿Pensar es atar esos nudos o desatarlos?

$\mathrm{Al}$ releer los textos de Serres percibo la intensidad de sus verbos: cortar, deshacer, sustraer, dividir, diferenciar. Verbos mortuorios, en muchos sentidos. Oscuros y también violentos. ¿Cómo permanecer al lado de un cadáver o de un Niño roto sin intensificar su fragilidad?, ¿qué escritura, si hubiese alguna, podría mecer una figura en Nochebuena o recoger la sombra de los 
cadáveres en Tenosique? En la proximidad de nuestra contingencia también se sedimentan los procesos personales, los afectos, las sensaciones, como si ayudaran a mediar sobre lo mixto, como dice Serres, desde su indefinición, en su propia mixtura: conversión trastornada y virajes inestables.

¿No es el sueño una conversión trastornada y un viraje?, ¿no lo he leído así, como un mediador entre dos muertes, pero también como un sendero hacia la experiencia más silente? Mi sensación durante los largos años de trabajo de campo ha sido vivir en medio de conversiones y virajes, abierto a ellos o evitándolos como pudiera. Ambos son, a mi entender, los signos de la diferencia, de lo que no encaja con nuestros esquemas, pero que de algún modo se parece a ellos. Hay algo correlativo entre ese "pensar por todas partes" que antes mencionamos y las conversiones y los virajes. ¿Desde dónde nos llega el mundo?, ¿cómo percibimos y sentimos a los otros?, ¿qué sensación tenemos de nosotros mismos en esos lances?, ¿cuáles aperturas son necesarias y qué clausuras se requieren para vivir pero también para sobrevivir a todo lo que vemos, escuchamos, sentimos y pensamos? Ese trabajo con los límites y la finitud de la escritura es central para una escritura etnográfica atenta al lenguaje, a los giros, pero también a las imposibilidades. Una escritura que no coloniza en secreto la contingencia, pero se atreve a elaborar un tiempo y un ritmo.

Esto daría entrada a ámbitos que las epistemologías e intervenciones dominantes no considerarán (Biehl y Locke, 2010: 318), pero también permitiría explorar otras formaciones conceptuales y empíricas. Es decir, no basta con investigar temas o campos fuera de los intereses científicos o académicos privilegiados o sujetos y colectivos que han sido excluidos de ellos. Es necesario crear nuevas herramientas de exploración. Pero no es un asunto que se resuelva técnicamente, en primera instancia. El problema no es sólo la escritura también lo somos nosotros mismos. Tanto etnógrafos como investigadores sociales debemos acomodarnos, de una u otra manera, al mundo que estudiamos, a los sujetos, a los hechos, a los espacios, a las estéticas. Sin embargo, hay un residuo o algo que nunca logra situarse, que siempre está fuera de lugar. Algo desencajado. Y en esos intersticios empiezan las revelaciones. Serres escribe: "las enfermedades más instructivas, los malestares de la identidad, afectan la piel, forman tatuajes que ocultan trágicamente el abigarramiento del nacimiento y de la experiencia. (...) El abecedario de la patología se graba sobre el pergamino.” (Serres, 2002: 64). Escribimos sobre este pergamino más o menos enfermo. Por lo tanto, cualquier escritura es ya una reescritura. Eso lo sabe hace mucho tiempo la lingüística, la teoría literaria y cierta filosofía. 
Lo que no han resuelto es cómo reescribir una escritura tatuada en el cuerpo y en la memoria. ¿Qué hacemos con nosotros mismos si no podemos desligarnos de un campo, pero tampoco lo podemos ocupar completamente?, ¿si estamos invitados, pero siempre somos extraños?, ¿si pertenecemos de manera ambigua y oscilante?, ¿qué hacemos con nosotros mismos si nuestro cuerpo, nuestros sueños, nuestras emociones, los afectos, la memoria, se han transformado en aparatos de exploración que funcionan, muchas veces, con independencia de nuestra voluntad y nuestros planes?, ¿qué escritura empieza ahí, justo cuando perdemos el conocimiento, literal y metafóricamente? El descentramiento epistemológico advertido por Biehl y Locke es consecutivo a otro subjetivo y personal. No se trata sólo de los otros, también de nosotros.

Al preguntarme sobre los hallazgos que la escritura me ha permitido hasta el momento, diría que ligar acontecimientos desconectados por mucho tiempo. Ligar, pero no atar; unir, pero sin hacer nudos. Tal vez el Niño y el cadáver se puedan enlazar con muchos otros acontecimientos y prácticas culturales, incluso con estructuras, cumpliendo así lo que Biehl y Locke mandan a una etnografía: conocer las formas en que se entremezclan “(...) prácticas y relaciones cotidianas, historias institucionales y estructuras discursivas" (ibíd: 325). Pero antes que eso, debo confesarlo, obtuve una comprensión personal. En algún sentido la confusión había persistido y sólo cuando traté de entender qué era lo que había sucedido, qué mostraban esos hechos, sus interpretaciones y sus prácticas del campo que estudio, comencé a experimentar mayor claridad. ¿Hay una explicación posible para todo lo que he relatado? Sin duda podría seguir otros caminos y desplegar otras lecturas. Estamos en un ámbito donde lo múltiple predicado por Serres se cumple cabalmente. Hay otras explicaciones para las relaciones de parentesco, las de intercambio o las formas de habitar los espacios.

Pero si me preguntaran también cómo he comprendido, diría que sólo esperando y mezclando, dejando que las sensaciones vibren, recorriendo la memoria como un camino cien veces bifurcado. Pensar los hechos y repetir las palabras. Experimentar conmigo mismo hasta conseguir cierta inteligibilidad. Si revisamos algunos de los aspectos que describí veremos que todos son intersecciones de procesos culturales y sociales con otros subjetivos: el sueño y el duelo, la muerte y el nacimiento, los regalos y las pérdidas, las sombras y las figuras. Experimentando conmigo pude ubicarme en esas confluencias reveladoras. Es decir, seguir el sueño no como un síntoma sino como una forma de escritura etnográfica, portar al Niño y cumplir con sus ritos (crea en ellos o no), acompañar al cadáver rememorando mis propios duelos y regresando al dolor de sus deudos. Serres escribe: 
Nosotros nos cubrimos con capas o abrigos por pudor o vergüenza de mostrar nuestro pasado, nuestra pasividad, para ocultar nuestra piel historiada, mensaje privativo, mensaje caótico, lenguaje indecible, demasiado desordenado para ser comprendido, para que reemplace por la impresión convencional o se intercambie por los trajes, por el orden simplificado de la cosmética. No vivimos nunca desnudos, rigurosamente hablando, ni nunca vestidos realmente, nunca velados, nunca develados, exactamente como el mundo. (Serres, 2002: 45)

Bien, experimentar una inscripción en un campo y un ejercicio de escritura sería evitar ese intercambio entre lo que nos avergüenza o nos aflige y las impresiones convencionales y una simplificación cosmética. "No vivimos nunca velados, nunca develados, exactamente como el mundo". Nunca. Ese espacio cobija una experimentación amable o cuidadosa: velarse, develarse, así como el mundo lo hace. Velorios, desvelos, develaciones, revelaciones. En algún sentido, el Niño cumple con este anuncio: no vivimos nunca desnudos, pero tampoco vestidos realmente. Vivimos, más bien, vistiéndonos y quitándonos esos vestidos, así como somos velados y develados. Los cuidados que debemos seguir con esa figura son consecutivos a nuestra propia subjetividad, que existe por el otro que nos (la) regala.

Tal vez se podría clasificar esa reflexión como narcisista. Así lo advierte Pierre Bourdieu:

Pero tienen -los científicos- que escapar previamente a la tentación de plegarse a la reflexión que cabría llamar narcisista, no sólo porque limita muchas veces a un regreso complaciente del investigador sobre sus propias experiencias, sino también porque es en sí misma su final y no desemboca en ningún efecto práctico. (Bourdieu, 2003: 15556)

Bourdieu, en cambio, propone una reflexión que objetive al sujeto de la objetivación. No le interesa "la especificidad viviente del sujeto conocedor, sino sus condiciones sociales de posibilidad" y añade que:

Lo que se pretende dominar es la relación subjetiva con el objeto que, cuando no está controlada y es él quien orienta las elecciones de objeto, de método, etcétera, es uno de los factores de error más poderosos, y las condiciones sociales de producción de esa relación, el mundo social que ha construido no sólo la especialidad y el especialista (etnólogo, sociólogo o historiador), sino también la antropología inconsciente que él introduce en su práctica científica. (Bourdieu, 2003: 162-3)

¿Qué significa dominar esa antropología inconsciente que se introduce en la práctica científica?, ¿por qué sería narcisista una atención a las propias experiencias y no lo sería si se dirige a las 
condiciones sociales de producción de los objetos científicos? Las confesiones que Bourdieu admitiría serían sólo de carácter impersonal (ibid::165). ¿Esa impersonalidad garantiza la cientificidad de la reflexión y su claridad?, ¿las condiciones sociales de posibilidad "y los límites de las formas de pensamiento científico que el científico ignorante de estas condiciones pone en juego sin saberlo en su investigación" (ibid::157), no tienen vínculo alguno con la experiencia personal que Bourdieu rechaza? Lo que se pretende objetivar “(...) no es la especificidad viviente del sujeto conocedor, sino sus condiciones sociales de posibilidad y, por tanto, los efectos y los límites de esa experiencia y, entre otras cosas, del acto de la objetivación" (ibid.: 162).

Si hubiese seguido la ruta anterior: ¿qué habría podido conocer de la muerte, el sueño, los rituales caseros, las sombras? Si todo esto, en alguna medida, incluía algunas experiencias, en el proceso de objetivación del sujeto que objetiva (si es que esto fuera lo que estaba haciendo), ¿dónde podía ubicarlas?, ¿qué haría con el sujeto viviente oculto o desplazado por el epistemológico? El mismo Bourdieu ha escrito que "la ciencia social es una construcción social de una construcción social" (ibid.: 153) y que el analista "forma parte del mundo que intenta objetivar y la ciencia que produce no es más que una de las fuerzas que enfrentan en ese mundo" (ibid.: 154).

Creo que es necesario clarificar de qué modo un etnógrafo forma parte del mundo que intenta "objetivar" y, si fuera el caso, pensar qué significa esa distancia en la producción de un conocimiento científico. En este tema el debate en la antropología es de larga data, pero no se ha agotado (Abu-Lughod, 2012; Clifford, 1995 y 2008; Clifford y Marcus, 1986; Fabian, (2002[1983]); Geertz, 1989 y 2005[1973]; Guber, 2004; Krotz, 2002; Marcus, 2007; Marcus y Fischer, 1998; Moore, 2007; Mutman, 2006; Rosaldo, 1991; Strathern, 2004 y 1988; Thomas, 1991). Preguntarse ¿qué significa conocer lo que desconocemos?, ¿qué implica objetivar desde una posición externa o semi-externa?, son interrogantes que producirán una gran tensión al cavilar sobre un trabajo de campo. Describir y entender la posición que ocupa el antropólogo en un contexto específico es, sin duda, relevante. Muchos lo han hecho. Pero eso no resuelve la otra pregunta: ¿qué hacemos con nosotros mismos? La antropología inconsciente que refiere Bourdieu sería una fuente de errores importantes en la práctica científica, y es llamativo que la solución a esos equívocos sea el control de ese inconsciente. La vieja tradición psicoanalítica enseña que cualquier intento de controlar el inconsciente sólo fortalece su expresión. 
La conexión entre ciertos sucesos y la huella que dejaron en uno no es la única forma de construir un conocimiento científico sobre un determinado 'objeto' de estudio. Pero tampoco se la puede descartar invocando una despersonalización que le restaría a una etnografía la presencia compleja de un sujeto en el campo. Esas confesiones impersonales son indicativas de una lectura de la subjetividad que tal vez deba revisarse. Pero antes, quisiera agregar que la escritura etnográfica trabaja con materiales muy diversos, algunos producidos directamente en el campo, otros intencionalmente por el etnógrafo.

Durante mi trabajo en Tenosique realicé entrevistas, grupos, llevé un diario, recopilé notas periodísticas, revisé textos históricos, tomé fotos, analicé datos demográficos. Pero también apliqué una encuesta a más de 170 personas homosexuales, lesbianas, bisexuales o trans de la ciudad en lo que era un primer ejercicio de ese tipo en una ciudad rural de México. Es decir, tengo datos producidos por diversos medios y técnicas, textos muy distintos entre sí, formas alternas de generar conocimiento científico. Mi escritura surge de la complejidad de todos estos registros. Tal vez faltarían otros, pero son bastantes. ¿Esto obliga un tipo de confesión que impide otros?, ¿qué lugar ocupa el investigador en todo ese tejido?, ¿los registros son excluyentes o puede elaborarse una escritura que permita vincularlos, guardando el estatuto de cada cual?, ¿sería la confesión personal, si así la llamamos, el final del esfuerzo científico?, ¿qué termina en ella? Pienso que es el inicio de una ruta de exploración, que no impide seguir otras, por ejemplo, la objetivación del sujeto que objetiva.

¿Por qué termina la ciencia cuando empieza la subjetividad y viceversa? El debate ha sido tan largo que sólo podríamos añadir una ondulación al agua de tan inmenso río. Pero quizás una aproximación desde el trabajo científico más cotidiano, al menos el antropológico, muestre los callejones sin salida a los que nos conduce esta discusión. James Clifford escribe:

La observación participante obliga a sus practicantes a experimentar, a un nivel tanto intelectual como corporal, las vicisitudes de la traducción (...) Hay, por supuesto, todo un mito del trabajo de campo. La experiencia concreta, cercada de contingencias, rara vez alcanza la altura de lo ideal; pero como medio para producir conocimiento a partir de un compromiso intenso e intersubjetivo, la práctica de la etnografía conserva un estatus ejemplar. (Clifford, 2008: 143)

Parece una cita clara, pero a mí me parece oscura. Dice muchas cosas en pocas palabras, pero deja varios cabos sueltos. Primero, reconoce las vicisitudes intelectuales y corporales de un trabajo de campo, pero luego habla de un mito. Luego dice que la "experiencia concreta" 
nunca está "a la altura de lo ideal"; aunque la etnografía conserve un "estatus ejemplar". Lo que Clifford contrapone es la experiencia al ideal, sea leída como mito o como ejemplo. Lo que Bourdieu rechaza como fundamento de una crítica, para Clifford opera como la explicación última de una práctica. Una etnografía sería un conjunto de experiencias más o menos complicadas, tanto intelectual como corporalmente, que se compararía con un ideal que, si bien nunca se cumple, marca los estándares de esta práctica. ¿Qué tipo de experiencia sería ésta que tiene un componente mítico pero también constituye un ejemplo? Las vicisitudes están del lado de la experiencia, así como la contingencia. El ejemplo y el mito del lado de la etnografía como práctica formalizada. Es claro que Bourdieu no quiere mito alguno, por eso llama a evitar el inconsciente antropológico; en cambio Clifford no retrocede ante él. Pero ambos contraponen sus molinos epistemológicos a la experiencia de investigación, sea o no etnográfica.

Si para Bourdieu la ciencia empieza después de la experiencia, para Clifford junto con ella, aunque luego la abandone. Escribe, en ese sentido, que "el desarrollo de la ciencia etnográfica no puede entenderse en último análisis prescindiendo de los debates políticos y epistemológicos más generales sobre la escritura y la representación de la alteridad" (Clifford, 2008: 143). Cuando se debaten estas dimensiones, ¿se prescinde de la experiencia?, ¿se la supera mediante procesos de formalización del conocimiento?, ¿queda alguna huella a nivel corporal e intelectual de las vicisitudes de la traducción? Clifford mismo se pregunta:

Si la etnografía produce interpretaciones culturales a partir de intensas experiencias de investigación, ¿cómo es que la experiencia, no sujeta a reglas, se transforma en un informe escrito autorizado? ¿Cómo es, precisamente, que un encuentro transcultural, locuaz y sobredeterminado, atravesado por relaciones de poder y desencuentros personales, puede ser circunscrito como una versión adecuada de "otro mundo" más o menos discreto, compuesto por un autor individual? (Clifford, 2008: 143)

La respuesta estaría, para Clifford, en la escritura, que conecta la experiencia heteroglósica y no sujeta a reglas del trabajo de campo, con los cierres autorales y narrativos de un texto científico. "Al analizar estas complejas transformaciones -escribe- se debe tener en mente el hecho de que la etnografía está, desde el principio hasta el fin, atrapada en la red de la escritura" (ibid.). La escritura sería la condición de la experiencia como fundamento de una práctica científica, pero también su límite. La etnografía, sea como texto o como práctica, se constituye en esa tensión irresoluble. ¿Pero por qué habría un mito del trabajo de campo, 
cuando siempre está atrapado por la escritura, y una ejemplaridad de la práctica etnográfica que se encuentra sometida a esa misma red? La condición del mito sería, justamente, esa experiencia "no sujeta a reglas" y la del ejemplo la traducción que permite la escritura de la experiencia. El ejemplo tiene "una forma textual”, en palabras de Clifford. Ese proceso, agrega, “(...) está complicado por la acción de múltiples subjetividades y de constricciones políticas que se encuentran más allá del control del escritor” (ibíd.). En esto estaría de acuerdo Bourdieu, salvo que excluiría las múltiples subjetividades y dejaría sólo las constricciones políticas. La experiencia es siempre un más allá: está antes de la escritura como su sustento, pero también, como su memoria; está después de ella cual vicisitud, contingencia y ausencia de reglas, ajustables a una forma textual. Si bien sería la base de la experiencia etnográfica, no lo es inmediatamente de la escritura etnográfica.

¿Qué estatus adquiere, entonces, la experiencia en este juego entre sustento y obstáculo que delinea Clifford? Parece que se convierte en un fantasma que suscita y merodea la escritura, pero que también permite la añoranza. La escritura etnográfica constituiría un duelo, en tanto remite a un objeto perdido (la misma experiencia con todos sus intríngulis) que se intenta recuperar, aunque nunca cabalmente. En este sentido, la experiencia es la sombra de la escritura, para retomar las primeras discusiones de este capítulo. Y es en ese espacio en el que la etnografía como práctica puede constituirse en un mito, aunque como escritura se transforme en ejemplo. Ambos ejercicios, el mitológico y el alegórico, se constituyen en torno a esa sombra que la experiencia nunca disipa. Derrida habla de un afecto y un fantasma de la nostalgia, pero también homologa duelo y relación con el otro: “(...) pues el duelo no espera a la muerte, es la esencia misma de la experiencia del otro como otro, de una alteridad inaccesible y que no se puede perder sino cuando la amamos - o también cuando la odiamos. Siempre estamos en duelo por el otro" (Derrida, 2011: 216). Siempre estamos en duelo por la experiencia, especialmente cuando escribimos, podríamos decir parafraseando a Derrida. Pero también se podría decir que estamos en duelo por la escritura.

Pero si fuera correcto hablar de un duelo doble, ¿cuál es el fantasma de la etnografía en tanto práctica y escritura?, ¿es el mismo para ambas o hay más de uno? Clifford escribe:

'Observación participante' sirve como taquigrafía para un oscilar continuo entre el 'adentro' y el 'afuera' de los sucesos: por un lado, atrapar empáticamente el sentido de eventos y gestos específicos; por el otro, dar un paso atrás para situar esos significados en contextos más amplios (...) Literalmente entendida, la observación participante es 
una fórmula paradójica y equívoca; pero se la puede tomar en serio si se la reformula en términos hermenéuticos como una dialéctica entre la experiencia y la interpretación. (Clifford, 2008: 152)

En la versión de Clifford, la observación ya es una escritura: una taquigrafía, aunque oscilante puesto que se sitúa tanto dentro de los sucesos como fuera de ellos. Pertenece a los sucesos, pero de inmediato se exilia de ellos para buscar cobijo en contextos más extensos. ¿Cómo se puede escribir, en un sentido amplio, con esa oscilación continua?, ¿será la dialéctica la respuesta, una que suceda entre la experiencia y la interpretación? Si así fuera, la observación participante sería el 'verdadero' fantasma de la etnografía: ni vivo ni muerto, ni experiencia ni interpretación, sólo una oscilación continua entre adentro y afuera, tal como un fantasma habita ese espacio imposible entre la vida y la muerte. Se le pide a la observación una garantía para la interpretación, pero también la veracidad de la experiencia. La escritura, como red, sería justamente el movimiento que permitiría vincular el afuera experiencial con el adentro interpretativo. Por acción del fantasma, escribe Derrida, por su poder y su fuerza, "lo más próximo y lo más lejano, lo mismo y lo otro se tocan y entran en contacto (...)" (Derrida, 2011: 112).

¿Cómo se vincularía este duelo científico con el otro afectivo?, ¿qué se pierde en la escritura que sería consecutivo a lo perdido con la muerte de alguien?, ¿merodean estos muertos del mismo modo en que lo hace la experiencia en la tensa hora de la escritura?, ¿es la experiencia la sombra de la escritura así como la cruz del cadáver, aunque también reflejo, último sostén, analogía crepuscular? Pero por otro lado, ¿no hay en la escritura algo así como un nacimiento, un inicio?, ¿no es la escritura una nueva aurora para la experiencia, así como el Niño es el principio de algo, también su continuidad?, ¿no cruza de este modo la escritura la muerte y el nacimiento, la aurora y el crepúsculo, el inicio y el fin? Tal vez en un sentido semejante, aunque con otros materiales, Derrida escribe sobre Robinson Crusoe:

Lo mismo, por lo demás, que cualquier huella, en el sentido que le doy a esta palabra y a este concepto, un libro es un muerto viviente, enterrado y engullido vivo (...) cada vez que trazamos una huella, cada vez que se deja una huella, por singular que sea, y antes incluso que tracemos activa o deliberadamente una huella gestual, verbal, escrita u otra, pues bien, esa maquinalidad confía virtualmente la huella a la per-vivencia en la cual la oposición entre lo vivo y lo muerto pierde y debe perder toda pertinencia, todo filo cortante. (Derrida, 2011: 174) 
Así como los deudos, la escritura es un sobreviviente: "Eso es asimismo la finitud, la fortuna y la amenaza de la finitud esa alianza de lo muerto y de lo vivo. Esa finitud, diría yo, es supervivencia" (ibíd.). En mi etnografía esta alianza entre lo muerto y lo vivo es inextricable y está marcada por la finitud, en sus dos sentidos de cierre y apertura. Per-vive en la experiencia y sobre-vive en la escritura. Una alianza secreta se traza entre los muertos y los vivos, los cadáveres y las figuras, los Niños y los adultos. Una red profunda, pero visible, que no podría ser más que la cultura misma, según la definición clásica de Geertz (2005[1973]). En esa pervivencia y supervivencia se juega la relación con los otros. En palabras de Derrida:

Y es ahí donde hay algo otro que dispone de mí, ahí es donde todo yo está sin defensa. Eso es el yo, eso es lo que yo soy, lo que el yo es, tanto si estoy como si no estoy ahí. El otro, los otros, es aquello mismo que me sobrevive, que está llamado a sobrevivirme y que yo llamo el otro en cuanto él está llamado, de antemano, a sobrevivirme, y es estructuralmente mi sobreviviente. No mi superviviente, sino el superviviente de mí, el allá más allá de mi vida. (Derrida, 2011: 175)

Ese juego entre ahí y allá, entre más acá y más allá, que es constitutivo de los límites del mundo, pero también de la experiencia, es fundante de la etnografía como una práctica situada, contextual, carnal en muchos sentidos. Pero también de las topologías y afectos que se elaboran en la escritura: escribir aquí sobre lo que sucedió allá, elaborar un duelo mediante la presencia vacilante de las palabras y los sentidos de las experiencias densas de la vida. Añorar, mediante la escritura, lo que en ella distanciamos y recreamos en otro tiempo y en otro espacio.

\section{Afectopografías}

Al escribir y rememorar el duelo y el nacimiento elaboro también, si se me permite el neologismo, una afectopografía, es decir una escritura de los lugares de los afectos, de su emplazamiento: casas, ataúdes, comedores, cementerios, altares, iglesias, dormitorios. Los afectos se emplazan y desplazan a través de una geografía más o menos extensa: Tenosique, ciudad de México. Chile en los sueños. El más allá y Belem en las prácticas rituales. El vientre y la tumba donde empieza/termina el cuerpo. Lugares de una elaboración múltiple de los afectos, la memoria y los procesos, de las narrativas y los vínculos. Pero también espacios en los que la alteridad se aproxima e interpreta, donde se vela y desvela consecutivamente, sea en la muerte o el nacimiento, la alegría o el duelo. ¿No es la nostalgia que atribuimos a la escritura 
etnográfica el afecto topológico por excelencia?, ¿un intento por recuperar el hogar irremediablemente perdido, así como lo está la experiencia? Clifford dice que la experiencia sería la fuente de la autoridad en el trabajo de campo y fundamentaría la autoría experiencial, basada

[...] en un 'sentimiento' hacia el contexto extraño, una especie de sentido común acumulado y una sensibilidad hacia el estilo de un pueblo o de un lugar (...) el yo estuve allí del etnógrafo como poseedor de conocimientos de primera mano y como participante (Clifford, 2008: 153)

No sé por qué el sentimiento está entre comillas, como si el autor quisiera distanciarse de la palabra, aunque no la pueda eludir. Pero apunta a una sensibilidad que permitiría un trabajo de campo. La experiencia se ubica entre un sentimiento entrecomillado y una sensibilidad difusa, que son sustentados, en última instancia, por un "yo estuve alli’". En este sentido, la escritura etnográfica sería la de un testigo sensible. Clifford habla de la ambigüedad de la noción de experiencia:

Precisamente porque es difícil de restringir, la 'experiencia' ha servido como una garantía efectiva de la autoridad etnográfica. Hay, por supuesto, una ambigüedad notable en este término. La experiencia evoca una presencia participatoria, un contacto sensitivo con el mundo a comprender, un rapport con su gente, una tangibilidad de percepción. También sugiere un conocimiento acumulativo, en profundización constante. (Clifford, 2008: 155)

La experiencia garantiza la autoridad, sustenta la presencia y profundiza el conocimiento. Autoridad, sostén, hermeneuta. Pero en este relato, la experiencia se organiza, primero, en torno a la sensibilidad y los afectos y luego permite el conocimiento y su profundización. En esa medida, delinea no sólo una topología de la investigación etnográfica, sino también una temporalidad: el antes de la experiencia es luego el ahora de la escritura. El tiempo de los afectos se transforma en otro del conocimiento.

Serres dirá que la experiencia, en su caso de los sentidos, no debe ser leída como más simple que la escritura (o que el lenguaje, en general). Al contrario, la experiencia "rica, compleja, vivaz de los sentidos", requiere de un nuevo esfuerzo de abstracción, que tal vez sea consecutivo al que suponemos realiza la escritura etnográfica, guardando las debidas distancias entre Clifford y Serres.

Volvamos de nuevo a la mezcla y al concepto de variedad, inmediatos en la experiencia rica, compleja, vivaz de los sentidos y, sin paradoja, más abstractos que las operaciones 
inversas y simples del análisis, o, mejor, posteriores a lo que nosotros llamamos abstracción. La sensación apela a un abstracto más difícil y complejo que lo tradicional. Se dirá: que los sentidos piden, para ser comprendidos, un nuevo esfuerzo de abstracción, para componer lo que el análisis separa; o que el progreso hacia un abstracto más complejo dará resultados sensacionales o sensuales. (Serres, 2002: 222-3)

En esta medida, la escritura como recurso analítico fundamental sería menos abstracta que los sentidos mismos: "la sensación apela a un abstracto más difícil y complejo que lo tradicional". Una escritura que regresara a la experiencia, si eso fuera posible, produciría "un abstracto más complejo -que- dará resultados sensacionales o sensuales". Así la escritura recuperaría "las vicisitudes intelectuales y corporales que ha generado la traducción y la experiencia concreta, cercada de contingencias", como ha escrito Clifford (2008: 143). ¿Sólo la experiencia está cercada de contingencias o también la escritura? Si así fuera: ¿cuáles serían las de una y las de la otra?, ¿'son las mismas contingencias o son distintas? Para Serres la escritura, y el conocimiento en general, no empezaría luego de la experiencia sino en ella. Una escritura que dependiera sólo de operaciones analíticas y no de prácticas sensuales o sensitivas, sería menos abstracta que otra aún no debilitada por esa dependencia.

¿Qué significa sentir para una práctica etnográfica y la escritura antropológica?, ¿es sólo un remedo de la experiencia, un residuo del conocimiento científico o es el soporte de esa experiencia, el camino hacia una abstracción más compleja?, ¿qué hacemos con aquellos que sienten, sean los sujetos con los que interactuamos en el campo o el autor de un texto?, ¿los borramos analíticamente?, ¿los integramos sensualmente? Dicho esto, ¿qué significaría confesar sólo “cosas impersonales”?, ¿qué guardarían de la experiencia sensitiva esas confesiones? Y si no guardaran nada, ¿seguirían siendo confesiones o más bien serían análisis que integran al sujeto que los realiza en sus propias operaciones y objetivizan al sujeto de la objetivación, como ha dicho Bourdieu?

Serres regresa al fantasma y escribe que "el problema del conocimiento, de lo sensible y del lenguaje se plantea en este abanico graduado, entre este espectro, en su empalme de la dureza con la suavidad, intervalo separado, tabicado, mezclado de obstáculos, de caminos y de embrollos." (Serres, 2002: 150). Abanico, espectro... espacio entre: "empalme de la dureza con la suavidad". ¿No forma parte del duelo de la escritura etnográfica la dureza del campo y la suavidad de la escritura o, a la inversa, entre la dureza de la escritura y la suavidad del campo? 
Es muy difícil calibrar la experiencia, por eso el camino está lleno de embrollos y de obstáculos. Lo saben Serres y Clifford. ¿Pero cómo resolver esa tensión?

Frente a los cuerpos destruidos que hemos encontrado y descrito en este texto, ante las diversas formas en las que el cuerpo se disgrega, ya sea por la muerte o por la enfermedad y la vejez, ¿está la escritura del lado de esa materia que se disuelve en las dimensiones absolutas de la muerte y del tiempo?, ¿o, por el contrario, representa una sutura escueta, pero profunda, de las heridas, las atrofias, una especie de prótesis para esos cuerpos destrozados o enfermos? Ante la muerte, toda antropología es forense. Y una escritura forense, que rodee los cuerpos y sus males, las enfermedades y sus síntomas, los sufrimientos y sus lenguajes, también es un responso que intenta dar respuestas o encontrar sentidos ahí donde todo parece sumergirse en la insondable verdad de la muerte. Tal vez algo sorprendente en nuestros relatos sea que los cuerpos descritos correspondan a sujetos que guardaron su lucidez hasta el final o que aún la conservan. En esta medida, la escritura está del lado de la consciencia, por efímera que ella sea. Es como si al escribir sostuviéramos esas consciencias moribundas, que aún son capaces de hablar de sí mismas, reclamar algo, de pedir u olvidar. Y éste es el responso: escribir al lado de los que mueren o han muerto para encontrar, quizás, un lenguaje que sin desmentir los daños y los agravios, halle otras fuentes vitales para el pensamiento y la acción. Al menos en mi caso, creo que esas personas y sus historias han sido mis más sentidos maestros, quienes han compartido algo en el límite y han sido dignas en medio del desastre. Mi escritura, entonces, es un homenaje, un relato de la muerte y, quisiera, una ventana a la profunda y frágil dignidad humana. 


\section{IX \\ Archivos del futuro \\ Posiciones de deseo y prácticas de la diferencia}

¿Disponemos de alguna oreja para la algarabía colectiva?

Michel Serres, Los cinco sentidos, 2002: 141

La pregunta fundamental de una antropología del deseo será cómo surge lo nuevo, no cómo funciona lo viejo. Es una pregunta que Deleuze le hace a Foucault, sin que haya respuestas claras, aún. Podemos argumentar, perentoriamente, que si continuamos atados y fascinados por el estudio del poder nunca podremos arribar a un campo que avizore lo nuevo. Ese campo es el deseo, según lo he sostenido antes. Toda esta investigación ha sido una búsqueda de algunas claves de interpretación, de escritura, pero sobre todo de experimentación. La antropología del deseo es una perspectiva experimental, porque trabaja con experimentos sociales -el Club Gay, por ejemplo- y con formas de experimentación, propias y ajenas. Una etnografía del deseo constituye un ejercicio experimental en que el etnógrafo trabaja con sus procesos y materiales (psíquicos, emocionales, corporales, inconscientes, políticos, estéticos), a la vez que explora el mundo que intenta estudiar. Eso sería, a fin de cuentas, una deseografía: una labor intransitiva sobre uno mismo en otro mundo, con y a través de los otros, un ejercicio en que los límites deberían atenuarse para dejar entrar la energía colectiva del deseo. Una mirada materialista que nunca se desapega de los cuerpos, de las instituciones, las espacialidades, de las violencias o los placeres para refugiarse en la caverna de los significados, las representaciones o los discursos.

“¿Cómo es posible la producción de algo nuevo en el mundo?”, se pregunta Deleuze. Esa ha sido nuestra pregunta tutelar. Hay algo mágico en el surgimiento de lo nuevo, de lo inédito y lo inesperado. El anuncio que relata Alan, al recordar la fundación de Club, es uno de esos raros momentos en los que podemos identificar que algo empieza: "somos 43 personas decididas a pelear por el orgullo gay". Lo actual, dirá Deleuze, es aquello en lo que nos convertiremos, “(...) aquello en lo que nos estamos convirtiendo: la parte de la historia y la parte de lo actual' (2007c: 309). ¿Cómo reconocer eso en lo que nos convertimos?, ¿de qué manera lo 
podemos diferenciar de lo que ya somos?, ¿dónde está la cesura que distingue la 'parte de la historia' y la 'parte de lo actual'?

"La historia es el archivo, el contorno de lo que somos y dejamos de ser, mientras que lo actual es el esbozo de aquello en que nos convertimos" (ibíd.). En esa conversión inédita, en ese proceso que se abre entre lo que somos y lo que seremos, se constituyen los archivos del futuro. Si la historia, y su archivo, es lo que aún nos separa de nosotros mismos, el archivo del futuro cobija lo que seremos, el registro de nuestras conversiones, "de ese Otro con quien ya estamos coincidiendo”, en palabras de Deleuze. En esa tensión aparece una pista importante: podemos identificar si el dispositivo que investigamos, la sexualidad en este caso, se está transformando o se ha cerrado en torno a lo que Deleuze llama "líneas más duras o más rígidas". Creo que tenemos material suficiente para pensar que, al contrario, el dispositivo actual se resquebraja, poco a poco, "a favor de un dispositivo futuro" (ibid.). Aún no lo conocemos, tal vez ni siquiera exista, pero ya se sugiere, despunta en el horizonte del deseo que investigamos. Por eso, es importante considerar un archivo del futuro que contenga los rastros actuales, los materiales contemporáneos de lo que viene, de lo que se asoma.

En esta perspectiva, diremos al cerrar el texto que el dispositivo de sexualidad constituye el principal obstáculo para pensar el deseo. Luego, que podemos anunciar el albor de un nuevo dispositivo, aún inédito, especialmente por las líneas de subjetivación que pudimos trazar. Sobre ellas, Deleuze dirá que "en la medida en que escapan a las dimensiones de saber y poder (...) parecen particularmente aptas para trazar las vías de la creación, que no dejan de abortarse pero también de renacer, de modificarse, hasta la ruptura con el antiguo dispositivo" (ibíd.). Lo venidero debería ser la ruptura del antiguo dispositivo a favor del deseo. Esas líneas de subjetivación las leeremos a través de las posiciones de deseo, es decir, los puntos en los que formas heterogéneas de deseo, subjetividad, corporalidad y sociabilidad se encuentran, tal vez se articulan, de manera contingente, para esbozar otras formas de vida, nuevos dispositivos, subjetivaciones aurorales. Las posiciones de deseo que identificamos -gay, homosexual y putoson estrictamente históricas y su proceso de disolución ya está en marcha. No nos interesan las identidades que podrían suscitar o resguardar, sino el diagrama que forman. Porque en ese diagrama, en el espacio entre cada posición -“el lugar de las mutaciones”, según Deleuze (2007b: 229) - se realizarán las prácticas de la diferencia con las que finalizaremos este escrito. Ellas son las formas en que la heterogeneidad deseante se transforma en prácticas sociales y experiencias subjetivas reconocibles. Las prácticas de la diferencia serán, también, los modos 
en los que el dispositivo de la sexualidad se desmorone desde dentro, erosionado por su propio movimiento, pero también por las corrientes colectivas y subjetivas que horadan su consistencia y su funcionamiento.

La ruptura del dispositivo de la sexualidad, el diagrama de las posiciones de deseo y la acción de las prácticas de la diferencia constituyen el archivo del futuro que antes mencionamos. Ese archivo será el espacio para "pensar el pasado contra el presente" (Deleuze, 2010b: 223); un lugar para lo intempestivo, en palabras de Nietzsche. Hay un devenir del pensamiento, dirá el filósofo francés, "que se superpone a las formaciones históricas y las atraviesa, pero que no se asemeja a ellas" (ibid.). A ese devenir lo llamamos archivos del futuro.

\section{Temporalidades dislocadas}

El dispositivo de sexualidad, que habría tenido su albor en los siglos XVIII y XIX de la modernidad europea, es hoy una red global gigantesca, casi indescriptible e inabarcable, que incluye desde fantasías personales hasta industrias multimillonarias. Foucault lo describe como "una gran red superficial donde la estimulación de los cuerpos, la intensificación de los placeres, la incitación al discurso, la formación de conocimientos, el refuerzo de los controles y las resistencias, se encadenan unos con otros según grandes estrategias de saber y de poder" (Foucault, 1981: 129). La sexualidad sólo sería esa red, porque no encontraremos nada "por debajo" de ella. En esa red, en su infinita extensión, estamos atrapados hoy. Este dispositivo inmenso supuso en su formación "una distribución nueva de los placeres, los discursos, las verdades y los poderes" (ibíd: 149), para "penetrar los cuerpos de manera cada vez más detallada y controlar las poblaciones de manera cada vez más global” (ibíd: 130). El dispositivo opera, también hoy, en esos dos niveles de forma simultánea, aunque diferenciada, individualizando los cuerpos y controlando las poblaciones.

Creo que esa descripción aún es válida. Parte de nuestra investigación se centró en la constitución de ese dispositivo en un lugar muy lejano al de su formación y en otro momento histórico. La red se extendió de manera casi ilimitada, pero también transformó parte de sus propias estrategias. En el caso de Tenosique, junto con las instituciones y discursos médicos y pedagógicos, supuso la intervención de los sujetos que, en alguna medida, eran producidos por el dispositivo mismo. Por eso, describimos al Club como un factor de sexualización, como una 
pieza en la formación de un dispositivo local, del que aún participa y al que ayuda en su proliferación incesante.

Sin embargo, lo que acabamos de sostener corresponde, también, al efecto homogenizante del mismo dispositivo. Si Foucault dice, con respecto al poder, que debemos ser nominalistas, porque aquél es "el nombre que se presta a una situación estratégica compleja en una sociedad dada" (ibid:: 113), nosotros sostendremos que hoy la sexualidad, incluso en su propia develación, impide pensar la "situación estratégica" del deseo. Hay que romper con el nominalismo, en este campo, porque es una forma de universalización. Deleuze dirá que una "filosofía de los dispositivos" (o una antropología, añadimos), debe rechazar "los universales", porque no explican nada y, al contrario, ellos "requieren explicación" (Deleuze, 2007c: 308). En el socavamiento de la universalidad del dispositivo encontraríamos, tal vez, "el principio de un movimiento para desmantelarlo", ya avizorado por Foucault (1981: 139).

Para entender el efecto universalizante y generalizante que ha producido el dispositivo de sexualidad, seguiré la lectura que el historiador hindú Dipesh Chakrabarty realiza de las formas de temporalidad poscoloniales y las memorias heterogéneas de los subalternos con respecto al discurso de la historia académica. Su tema es otro: las formas de producir conocimiento histórico sobre el trabajo en la India colonial y los puntos intraducibles que encuentra al revisar los archivos e intentar traducirlos al lenguaje universal de las ciencias sociales. Me pareció iluminadora la similitud de sus dificultades con los obstáculos que impone el uso de otra categoría universal como la sexualidad.

Chakrabarty argumenta la imposibilidad de entender las prácticas y las representaciones del trabajo en la India colonial a partir de la categoría sociológica 'trabajo', elaborada por el pensamiento europeo. Dice, en sentido, que:

lo 'real' ha de referirse a clases diferentes de lo 'social', que podría incluir dioses y espíritus, y, por lo tanto, también órdenes diferentes de temporalidad. En principio, debería incluso permitir la posibilidad de que esos horizontes temporales sean mutuamente inconmensurables. La transición de lo 'real' a lo 'abstracto' es, así, también un asunto de transición-traducción de muchas, y posiblemente inconmensurables, temporalidades al tiempo homogéneo del trabajo abstracto, la transición de la no historia a la historia. (Chakrabarty, 2010: 136)

Nos preguntamos cómo lo real múltiple de lo sexual y lo erótico ha sido traducido, localmente, a lo 'abstracto' de la sexualidad. También quisiéramos examinar si esa traducción implicó un 
cese de heterogeneidades temporales y experienciales que hoy asoman aglomeradas, pero también homogeneizadas, bajo un mismo rótulo: homosexualidad, primero; gay después.

Los trabajadores que investiga el historiador hindú vivían en un mundo lleno de dioses y espíritus y su actividad era tanto secular como religiosa. Pero, Chakrabarty escribe, "seguimos teniendo que traducir al tiempo de la historia y al relato universal y secular del 'trabajo' narraciones acerca de modos de ser humano que incorporan agencia por parte de dioses y espíritus" (ibid:: 132). En nuestro caso, no son dioses ni espíritus los que develan o sostienen formas plurales de subjetividad y deseo; son vidas que nunca habitaron una identidad o que se movieron por los intersticios que dejaba un orden sexual excluyente. Juanito, de quien relaté parte de su vida, no tiene cabida en el relato secular de la sexualidad; traducir su vida implica perder cualquier rastro de su diferencia, en los lenguajes homogéneos de las traducciones culturales.

Chakrabarty se pregunta: “CCómo hemos de llevar a cabo tales traducciones de manera que resulten visibles todos los problemas de traducir mundos diversos y encantados al lenguaje universal y desencantado de la sociología?” (ibíd: 133). ¿Cómo traducir lo puto a lo homosexual o a lo gay?, ¿qué sería imposible traducir entre esas posiciones de deseo? No creo que este hiato se pueda resolver, porque los archivos de esas memorias se perdieron de forma irreparable. Tan solo podemos, como lo indica Chakrabarty, quedarnos "con la heterogeneidad del momento" y con la diferencia entre los gestos (los del campesino y los del historiador, en su caso), porque ambos "nos ponen en contacto con las formas plurales de ser que conforman nuestro propio presente" (ibid:: 156).

La naturaleza "dislocada del ahora”, como la denomina Chakrabarty, sería la ruta hacia otras formas de subjetividad y deseo, marcadas profundamente por la imposibilidad de dejar huella alguna. Pero de todos modos, mantener la diferencia entre los gestos, como ha dicho el historiador, implica reconocer la heterogeneidad del momento. Juanito, mi informante, no puede leerse como un hombre gay o sólo lo hace tardíamente. Su heterogeneidad subjetiva es un archivo para pensar una naturaleza dislocada del 'ahora' del deseo o de la sexualidad. No sabemos, sin embargo, qué perdió de sí mismo cuando hizo esa traducción personal entre posiciones de deseo y se integró, de algún modo, a las formas de subjetividad que impone la sexualidad. Una red homogénea, a mi entender, que lee una pluralidad subjetiva y social a través de una pauta recursiva. El problema no es saber si Juanito fue siempre un homosexual que 
usó distintos significantes para pensarse y relacionarse consigo mismo, sino descubrir una pluralidad subjetiva y temporal que no cabía dentro de esa denominación.

Asumamos la propuesta de este historiador y pensemos en una radical intraducibilidad, como él la llama, que impediría utilizar categorías universales que pretendieran funcionar "como una construcción general adventicia que medie entre todos los particulares que haya en juego". Es decir, la sexualidad no puede ser el término que resuelva la heterogeneidad que nos interesa, porque ella supone un tiempo homogéneo y vacío. Los dioses de los trabajadores hindúes significan diferencias, anota el historiador. Por eso, no se pueden traducir mediante el lenguaje universal de la ciencia - "que significa cierto tipo de identidad en nuestra comprensión del mundo en culturas distintas"-, que las conduciría a una identidad universal. Lo mismo sucederá con las posiciones de deseo que exploramos: si bien parecen explicadas por la sexualidad, en realidad están homogeneizadas por ella. La posición de puto no es traducible a homosexual ni a gay. Es un 'terreno de diferencias' que nos conduce a mundos heterogéneos y a deseos que nunca cupieron totalmente en las nuevas descripciones ni en los lenguajes dominantes. Si no podemos pensar los trabajadores hindúes 'despojados de sus dioses', tampoco a nuestros informantes si sustraemos sus deseos y los leemos mediante el código universal de la sexualidad.

Si evitamos esa universalización, es mi apuesta, entonces accedemos a múltiples tiempos sociales y personales y a subjetividades y deseos disjuntos. Pero también al dispositivo, si es que fuera uno, que emergería entre los restos del que desaparece paulatinamente. Esas multiplicidades serían "puntos de desterritorialización de los dispositivos de deseo" (Deleuze, 2010a: 126). ¿Reemplazará un dispositivo de deseo al de la sexualidad?, ¿existe algún dispositivo de deseo contemporáneo?, ¿hay algún registro en el dispositivo de sexualidad de su mutación hacia uno del deseo?

\section{Posiciones de deseo}

$\mathrm{Al}$ investigar las formas en las que se produce un deseo homoerótico en Tenosique, me encontré con tres posiciones de sujeto, es decir, locus que articulan discursos, que también son posiciones de deseo. Una posición de deseo constituirá un modo socio-histórico de producir el

deseo o sus formas. Felix Guattari escribe, en ese sentido, que "el deseo es siempre el modo de producción de algo, el deseo es siempre el modo de construcción de algo" (Guattari, 2005: 319). Si una 
posición de sujeto, según Laclau y Mouffe (2006: 157), implica que todo sujeto es producido dentro de una estructura discursiva que permanece siempre abierta y nunca fija sus posiciones en un sistema cerrado de diferencias (que esencializarían al sujeto y que lo transformarían en un antecedente de la estructura discursiva y no en su secuela), una posición de deseo será el resultado de un entrecruzamiento complejo de formas de subjetivación, dispositivos de sexualización, modos de producción de los cuerpos y una organización social de la diferencia sexual, el género y la sexualidad.

Una posición de deseo no sería solamente una posición en una estructura discursiva, sino una intersección de discursos, afectos, corporalidades, prácticas sociales y materialidades con líneas inconscientes, apenas formalizables, y otras discursivas más evidentes. Investigar dichas posiciones nos aproximaría al estudio lo que Guattari, por su parte, denomina "las formaciones sociales del deseo en el campo social" (Guattari, 2005: 181).

\section{Modos de existencia y líneas de subjetivación}

"Los modos de existencia, dice Deleuze, deben pensarse de acuerdo con criterios inmanentes, de acuerdo con su contenido de 'posibilidades', de libertad, de creatividad, sin recurso alguno a valores trascendentes" (Deleuze, 2010c: 309). Una posición de deseo corresponde a un criterio inmanente. Nosotros identificamos algunas y proponemos ciertos entrelazamientos; podrían encontrarse muchas otras con conexiones distintas. Lo que resguardamos en cada posición, pero más intensamente en su interjuego, son sus "posibilidades de libertad y creatividad", como ha dicho Deleuze. En una posición no hay nadie; no corresponde, por supuesto, con ningún sujeto, ni menos con una existencia real. Son posiciones formales, no sustantivas. Pero, por otra parte, dado que permiten formar un diagrama - “el lugar de las mutaciones" según Deleuze (2007b: 229)-, muestran el espacio a través del cual los sujetos pueden moverse ‘dentro' de ellos mismos y en los órdenes discursivos y prácticos en los que participan. Es decir, las posiciones de deseo son el acceso a una multiplicidad subjetiva y social. Los tiempos heterogéneos que interesaban a Chakrabarty, son también subjetivaciones heterogéneas, que no sólo recorren grandes líneas de subjetivación, como la sexualidad, sino otras pequeñas, quizás apenas imperceptibles. Como Juanito, nuestro informante, que dispuso en su vejez de la identidad gay, pero que siguió al abrigo de viejas prácticas eróticas, en los tramos esquivos del silencio y la opacidad. 
La primera posición de deseo que encontramos fue puto, la más antigua de todas y la menos institucionalizada. Era la forma consuetudinaria de producir y nombrar un deseo homoerótico, casi sin antecedentes históricos, pero con una presencia casi inmemorial en los discursos públicos y las hablas cotidianas. Si bien puto era la subjetividad con una mayor sedimentación histórica, apenas producía memoria. Al rastrear su presencia en el español escrito encontré referencias tempranas en el siglo $\mathrm{XV}, \mathrm{y}$ tal vez un uso más antiguo contiguo a palabras del italiano y de otras lenguas romances. Corporalmente estuvo vinculada con el ano y el pene; es decir, nombres para prácticas sexuales 'sodomíticas', usados con asco, humor y descaro. Lo extraño, como antes indiqué, era que esa larga tradición en torno a un significante estuviera borrada de su uso; es decir, que al utilizarse en el lenguaje cotidiano se lo hiciera en una especie de presente continuo ahistórico. En esa medida, casi no producía ni guardaba memoria, que no fuera la de aquellos a quienes se había marcado o agraviado con el término.

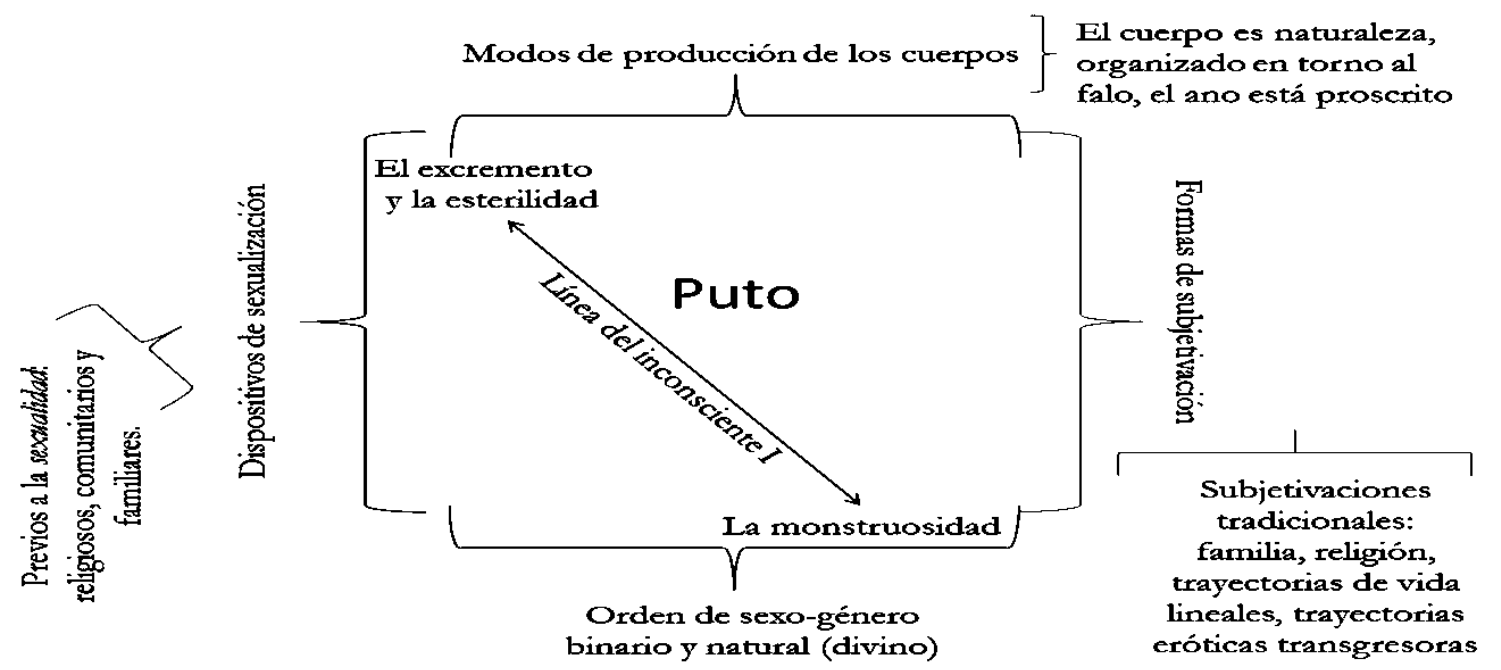

La segunda posición fue homosexual, el significante de la ciencia. Se la podía rastrear al menos a lo largo del siglo XX en boca de médicos, psiquiatras, abogados, políticos, sacerdotes. Sedimentaba una memoria institucional bastante densa, en la que habían sido inscritos los sujetos como esos hombres infames de los que hablaba Foucault, visibles sólo en su encuentro con el poder. Era la posición del deseo patológico y anormal, nacida de una multiplicidad de discursos y prácticas sociales que cercaron las pasiones y los cuerpos con gnoseologías, descripciones, sintomatologías y tratamientos. Era la lengua de los expertos que sondeaba las profundidades del deseo para hacer emerger a los "invertidos" del orden sexual e intentar rectificarlas. Lenguajes del Estado, de las burocracias, de los medios de comunicación, de la 
policía.
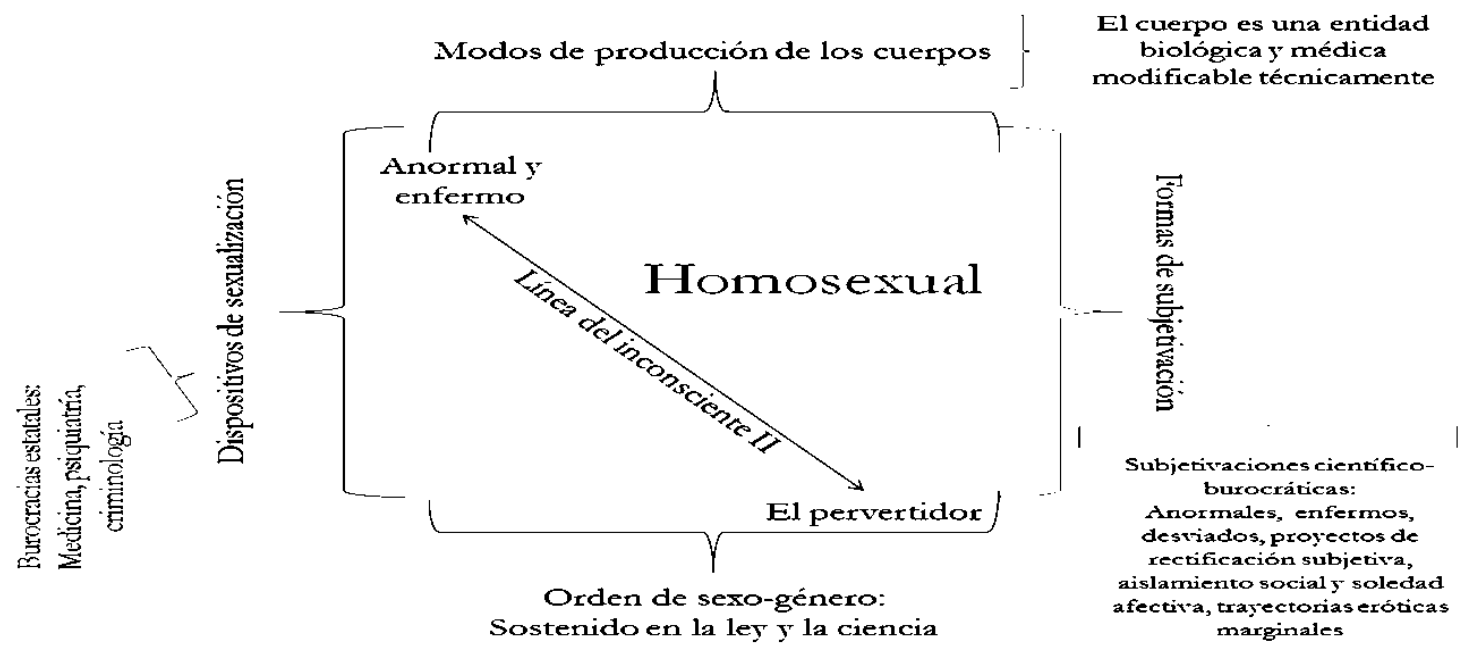

La tercera era gay, la posición moderna, identitaria y global. Lengua extranjera para deseos locales. Era la única en la que el balance entre el orgullo y el oprobio favorecía al primero. Lengua política, significante de estilos de vida, movimientos sociales, comunidades. Era la forma de identificarse de los sujetos que investigaba, daba nombre al Club, era el locus de las interlocuciones que establecían con el Estado y otras instituciones. La posición de deseo gay permitía una referencia a otros mundos, pero también un discurso autónomo no patologizante; no era completamente local, pero tampoco médica como la homosexual. Sin duda ha sido la que ha ocupado el mayor espacio social y hoy, en este campo, es la posición dominante.

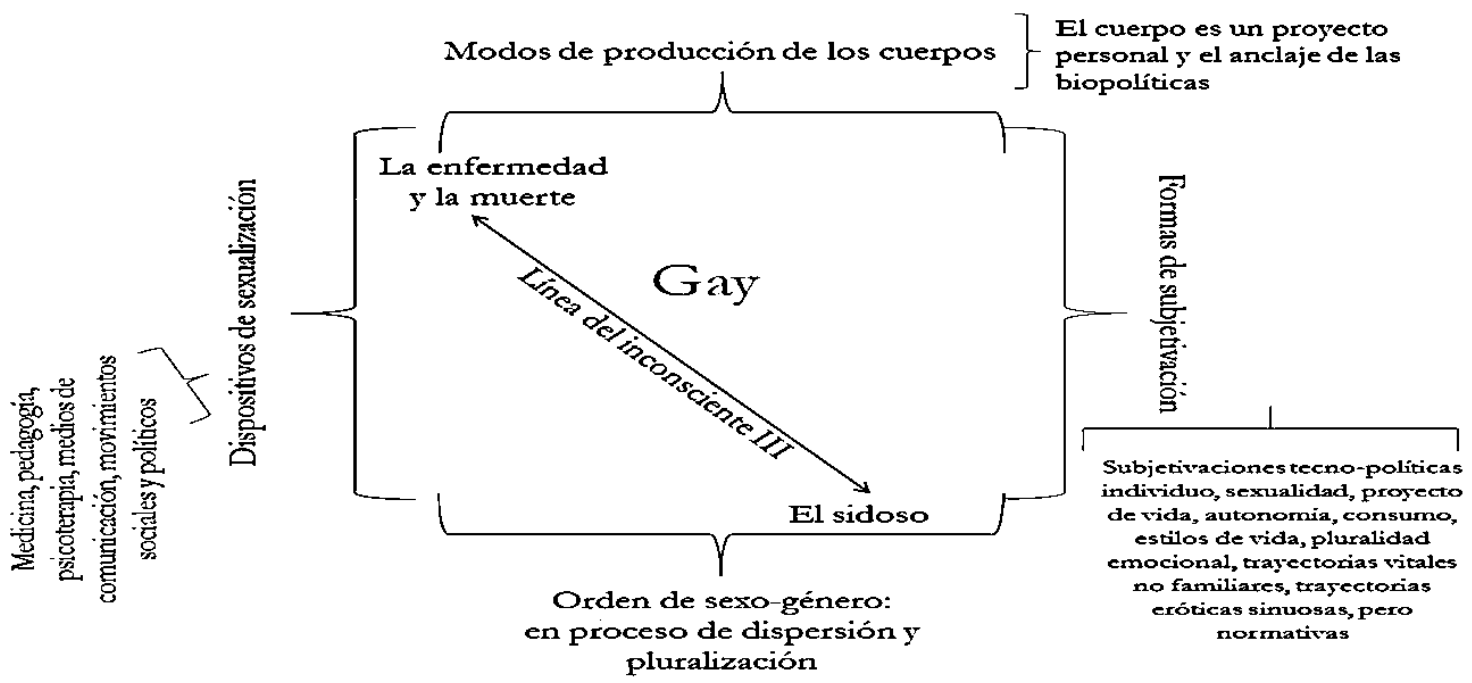




\section{Caminos laterales}

El cruce de líneas de subjetivación, sostiene Deleuze, "se produce cuando la línea se encorva, dibuja meandros, se hunde y se vuelve subterránea o, mejor, cuando más que entrar en relación lineal con otra fuerza se curva sobre sí misma, se ejerce sobre sí misma y se afecta a sí misma.” (Deleuze, 2010c: 307). Exploramos esos encorvamientos a lo largo de este estudio, por ejemplo, cuando las fuerzas culturales, históricas, pero también deseantes y corporales, de la "línea puto" se encorvaron bajo la línea hegemónica gay y cómo ésta logró que la tercera línea, la homosexual, se hundiera bajo los nuevos discursos y las representaciones emergentes del deseo que aquélla trajo y produjo.

En ese encuentro conflictivo de líneas y fuerzas, surgirán las líneas de fuga, que "escapan a las líneas precedentes, huyen de ellas" (Deleuze, 2010c: 307). Esa huida constituye, a nuestro entender, los archivos del futuro, que sólo podremos explorar si tenemos algunas coordenadas que nos orienten hacia ellos. Si la subjetivación es un proceso, "una producción de subjetividad en un dispositivo" (ibid.), sus límites serán los del dispositivo mismo, pero una nueva posición de deseo conmoverá esas demarcaciones, engendrando "un proceso de individuación de grupos o de personas que se sustrae a las relaciones de fuerzas establecidas como a los saberes construidos: una especie de plusvalía" (ibíd.). El mismo Deleuze sostiene que esas líneas "son el borde extremo de un dispositivo [y] esbozan el paso de un dispositivo a otro: en este sentido, anunciarían "líneas de fractura" (ibíd.). Pensamos que las posiciones de deseo permiten recorrer ese borde, mediante un movimiento incesante entre los lugares centrales de un dispositivo y sus 'líneas de fractura'. Creo que sería una descripción justa para esta etnografía: hemos estado en las instituciones de gobierno y las casas de citas, desde las vías férreas hasta las iglesias, con los enfermos y los poderosos, platicando con los médicos o conversando con las trabajadoras sexuales; en las cárceles y los comercios. Al centro de los dispositivos y en sus bordes.

Esta imagen se puede trasponer, también, a la producción de la subjetividad. Porque si las posiciones de deseo son un diagrama de las heterogeneidades personales, afectivas, corporales y deseantes, entonces cada sujeto puede moverse en sus deslindes, desde el centro de sus definiciones, por ejemplo las identitarias, hasta los meandros de sus fantasías. Atravesar múltiples posiciones, habitar algunas, dejar otras, regresar a ellas. Pero no lo hará sólo por voluntad, lo agitará ese material denso, pero muchas veces difuso, que forma la historia y el 
destino, las viejas subordinaciones y las nuevas libertades, los cuerpos tal como los hemos vividos, pero también como podrían experimentarse.

Aquí, dirá Deleuze, vemos “el primado del deseo, porque el deseo está justamente en las líneas de fuga, en su conjugación y disociación de los flujos” (Deleuze, 2010a: 126). Las posiciones de deseo son condensaciones socio-históricas para los flujos de deseo que atraviesan los campos sociales y las subjetividades. En el caso de Tenosique, si bien las posiciones modernas, por así llamarlas, eran gay y homosexual, el potencial de disociación de los flujos, por lo tanto del deseo mismo, está en la del puto, pero también en otra que hemos explorado de manera somera: el mayate. No creo que perduren indemnes a los efectos aglutinantes del dispositivo de sexualidad, pero se fugan de él constantemente. Quizás lo más relevante de ambas posiciones es que nadie las puede ocupar, son posiciones vacías. Alguien puede ser puto y mayate o sólo puto o sólo mayate; puede serlo por un tiempo y luego dejar de serlo; puede estar en esa posición una noche o toda su vida; una parte de sí o su totalidad; puede comprender su deseo, pero no su cuerpo o sólo su cuerpo y no su deseo. Las combinatorias serían, a mi entender, casi infinitas. "Todo en una sociedad se fuga, dice Deleuze, todo se desterritorializa" (ibíd.).

Por eso, más que resistencia, encontraremos desafección. Tal vez podríamos pensar que el movimiento de fuga que se da dentro del dispositivo de sexualidad y que lo desarma desde dentro, sin resistirlo solamente, es una manifestación del éxodo del que hablan algunos teóricos italianos. Paolo Virno lo define como "una acción colectiva", sustentada en el "principio paralogístico del tertium datur", es decir, "ni aceptación resignada ni lucha para apoderarse del poder en un determinado territorio, sino un excéntrico B" (Virno, 2011: 81). Ese 'excéntrico B' implica un camino lateral, "no señalado en los mapas sociopolíticos". Por ese camino los colectivos y los sujetos se fugan del dispositivo, mediante la creación de alternativas distintas, quizás aún no formalizadas completamente. Por eso, lo nuevo no se muestra con claridad, porque vemos a través de los mapas sociopolíticos y conceptuales con los que contamos o a los que estamos habituados. Miramos lo nuevo con los ojos de lo viejo. El éxodo, cuyo paradigma es el viaje del pueblo judío a través del desierto, ha levantado demasiado polvo. El éxodo, dirá Virno, es una modificación profunda en la gramática de los discursos, que da "relieve a factores secundarios o heterogéneos", que conducen a un problema inédito y distinto de las alternativas ya asentadas: "cómo realizar una defección y experimentar formas de autogobierno antes inconcebibles" (Virno, 2011: 81-81). La modificación, desde nuestra 
perspectiva, no sólo ocurre en los discursos, también las prácticas y en las formas de producir subjetividad, corporalidad y sociabilidad. El deseo contiene, a nuestro entender, las formas inconcebibles, de las que habla Virno, y es el motor del movimiento de fuga.

Prácticas de la diferencia

En el fondo se trata de mezclas. Se mezclan las almas en las cosas y las cosas en las almas. Se mezclan las vidas y así es como las personas y las cosas mezcladas salen cada una de su esfera y se mezclan: eso es precisamente el contrato y el intercambio.

Marcel Mauss, Ensayo sobre el don, 2012 [1925]: 109

En una entrevista, Giorgio Agamben sostiene que para pensar a los humanos debemos abandonar el "mitologema de la articulación" (Agamben, 2007: 18). Si tradicionalmente se ha pensado a los humanos como "la articulación y la conjunción de dos principios opuestos; un alma y un cuerpo, el lenguaje y la vida, en este caso un elemento político y un elemento viviente" (ibíd: 16), ahora debemos pensarlos como "aquello que resulta de la desconexión de estos dos elementos e investigar no el misterio metafísico de la conjunción, sino el misterio práctico y político de la separación” (ibíd.). Para investigar, etnográficamente, ese misterio práctico y politico de la separación propongo las prácticas de la diferencia. "El sujeto, dirá Agamben, se presenta como un campo de fuerza recorrido por dos tensiones que se oponen: una que va hacia la subjetivación y otra que procede en dirección opuesta" (ibid.). Si el sujeto no es otra cosa "que el resto, la no-coincidencia de estos dos procesos", las prácticas de las diferencia son los modos concretos en que dicha no coincidencia es producida y experimentada por sujetos específicos. Son conmutadores tanto de procesos subjetivantes como de otros desubjetivantes.

El misterio político que me inquietó a lo largo de este estudio fue cómo un colectivo como el Club, formalmente casi inexistente, pudo producir prácticas políticas sin articular un discurso sistemático, cómo realizó intervenciones políticas con un soporte organizacional tan débil y consiguió transformaciones sin declamar un proyecto emancipatorio evidente. La exploración de los discursos que lo concitaron, pero que también lo rodean, no ofreció una respuesta clara a ese misterio; por eso, creo que la noción de prácticas de la diferencia entregará pistas valiosas. 
Una "irreductible distancia", dice Roger Chartier en un ensayo sobre Foucault, impide reducir las prácticas a los discursos, dado que "entre ambos no hay ni continuidad ni necesidad", y su articulación se produciría "a partir de la distancia existente entre la ‘especificidad singular de las prácticas discursivas' y todas las demás” (Chartier, 1996: 29-30). El Club se ha mantenido en una doble distancia con respecto a las formas institucionales de la política, pero también a los modos de subjetivación de la sexualidad. De esta manera, las prácticas de la diferencia permiten pensar, también, las heterogeneidades subjetivas y deseantes, que no pueden ser articuladas por ninguna identidad. El Club es tanto un espacio de socialización como otro de desconexión, en el que los sujetos pueden transitar en diversas direcciones a través del mundo y de sí mismos.

El feminismo italiano enarboló, en los años setenta y ochenta del siglo pasado, la "primacía de las prácticas". Luego de un largo interludio hípertextualista, performativo y, en general, políticamente opaco, creo que es posible revalorar dicha primacía y actualizarla bajo otros modos de conceptualización y acción política. "La práctica, dice una filósofa feminista italiana, es un corte en el orden social y simbólico establecido" (Dominijanni, 2012: 63; énfasis mío), que podemos leer, por tanto, como una desconexión con los dispositivos subjetivantes los aparatos de subordinación corporal y subjetiva. Entiendo que las prácticas de la diferencia son formas colectivas y subjetivas en las que se resuelven las diferencias que marcan las relaciones sociales y los procesos de subjetivación. Leída como una práctica, la diferencia permite la creación de nuevos escenarios y nuevas relaciones; inaugura otras formas de subjetividad, pero también de asociatividad.

Las prácticas de la diferencia permiten a un sujeto pasar a través de sí mismo entre diversas temporalidades, sin restringir su deseo a los mandatos de una identidad, aunque la asuma narrativamente. Esas prácticas son conmutadores subjetivos que dan acceso a una pluralidad subjetiva, deseante, corporal y vincular. Una de sus expresiones más notorias es la ambigüedad, que exploramos a lo largo de esta investigación. Pero ahora la podemos leer de una manera distinta, la ambigüedad o la ambivalencia, cuyo horizonte serían formas supuestamente claras o definitivas (sean cognitivas, éticas, corporales, sociales o estéticas), se producen por esta pluralidad subjetiva y temporal, señal de que ningún sujeto o colectivo se ha resuelto de manera definitiva en ninguna identidad o tiempo histórico. En esa dirección, Dominijanni escribe que: 
el sujeto de la diferencia es una singularidad corporeizada (...), un sujeto que ya no es uno, un individuo que ya no es indivisible, una identidad que ya no es idéntica a sí misma o ya no se autoidentifica, sino que siempre está dislocada y cruzada en su propia constitución por la diferencia y la alteridad, en relación al otro incluso dentro de sí mismo. (Dominijanni, 2012: 69-70; el énfasis es mío)

La diferencia, en esa medida, sería la distancia entre las diversas formaciones sociales y subjetivas y las prácticas los modos de transitar entre ellas, de salvar esas distancias o de intensificarlas, si fuera el caso. Pensar las prácticas de la diferencia implicaría "repensar la subjetividad según una ontología de la diferencia” (Dominijanni, 2012: 69). Las prácticas de la diferencia son modos de (des)articular diversas subjetividades y modos de existir; son haceres cotidianos que permiten crear nuevos espacios de existencia y nuevas singularidades; son modos afirmativos que permiten fundar y sostener formas de vida. Nietzsche opondrá "al elemento especulativo de la negación”, escribe Deleuze, “el elemento práctico de la diferencia: objeto de afirmación y de placer" (Deleuze, 2008[1967]: 18).

Las prácticas de la diferencia permiten otros agenciamientos sociales y culturales, otras territorializaciones del espacio y del tiempo, nuevas corporalidades, afectos distintos. Si bien no es una creación ex nibilo, su producción constante marca un punto crítico en el que las prácticas de la diferencia promoverán prácticas de la libertad. Ese punto crítico se suscita cuando estas prácticas comienzan a crear nuevos tipos de sujetos y otras formas de subjetivación. Nunca son completamente nuevos ni tampoco inéditos, pero en cierto momento logran una densidad y una intensidad que los hace visibles y permite una formación o acción política particular. Las prácticas de la libertad desplazarán, paulatinamente, las prácticas de la diferencia, creando otros espacios y horizontes de emancipación y otras temporalidades y espacialidades afectivas y corporales.

Las prácticas de la diferencia producen un mundo, por eso engloban otras dimensiones como las discursivas, las éticas y las vinculares. En algún sentido, las prácticas de la diferencia son una metapráctica que agrupa prácticas diversas y promueve la innovación. En ellas “pensamiento, praxis e imaginación convergen en este desafío común: volver posible la vida” (Agamben, 2007: 16). 
Archivo y futuro

Pienso que la caducidad del dispositivo de sexualidad hay que indagarla en su misma configuración. Cuando supe que el Círculo Interior estaba inspirado en un libro de Xaviera Hollander, comencé a buscarlo, pero infructuosamente. El texto que había sido un bestseller era inencontrable. Ese Evangelio desapareció con tanta prontitud como fue leído. Su actualidad se agotó rápidamente y la vanguardia que representaba se transformó en un registro vetusto del pesado archivo de la sexualidad. Hollander no estaba en las bibliotecas, ni en las librerías de viejos, ni en las casas de mis amigos. Tampoco en las tiendas virtuales que venden casi cualquier cosa. Un amigo que me ayudó en la búsqueda y, finalmente, encontró el libro, logró dar con él a través de un blog que administraba un admirador de Hollander. Le escribió un correo y le pidió copiar el ejemplar que tenía, el único del que habíamos tenido noticias, una especie de incunable de la reproducción técnica y la caducidad mercantil. Ese admirador tardío de Hollander, le comentó a mi amigo que había aprendido mucho de sus textos y que era lamentable que hubiesen caído en el olvido, luego de tener tanto éxito.

En un escrito dedicado a los sueños, Foucault sostiene que "el punto esencial del sueño no es tanto lo que resucita del pasado, como lo que anuncia del futuro" (Foucault, citado en Agamben, 2010: 143). A mi entender, el sueño que relaté en otros capítulos media entre la experiencia y la escritura, en ese tiempo que Agamben llamará futuro anterior y que tiene "la forma de un pasado en un futuro" (ibíd.). La experiencia constituiría un mito si se la considerara sólo como el pasado de la escritura; y la etnografía sería una actualización de esos pasados (relativamente lejanos), mediante su escritura (relativamente cercana). Si, en este caso, el sueño fuera un anuncio lo sería de un punto en el que la experiencia corresponde, arqueológicamente, con la escritura y ésta con aquélla. El sueño, escribe Agamben "comienza destruyendo y fragmentando todo mundo real, arrastrándose ante todo a sí mismo en esa destrucción" (ibíd: 141); se retrotrae sólo "para saltar por encima del universo objetivo y subjetivo" (ibíd.).

El libro de Hollander portaba el futuro cuando se publicó. Anuncio de las nuevas sexualidades que no sabrían sino proliferar. El sueño parece una regresión. Pero tal vez los papeles se han invertido y el libro se transformó en una pieza de pasados difíciles de remontar y el sueño de futuros desconocidos. Por esto, la única forma de construir un archivo del futuro será una arqueología. No buscamos un 'antes' de la sexualidad, porque no lo podremos encontrar; nos interesa detectar su escisión, en términos de Agamben, es decir el momento en 
que se distingue un 'antes' y un 'después'. En ese punto, escribe el filósofo, “el pasado no vivido se revela como lo que era: contemporáneo del presente, y de este modo deviene por primera vez accesible, se presenta como 'fuente"' (ibid.: 139). Juanito nos condujo a esa escisión -que, como indica Agamben, determina el 'antes' que develaría-, no porque su experiencia fuera el pasado del presente de un dispositivo; al contrario, porque era 'contemporánea del presente' y, por eso mismo, su 'fuente'. El sueño que relatamos y las experiencias de Juanito fueron las "únicas vía de acceso al presente”, y por eso prácticas de una arqueología "que se remonta más acá del recuerdo y del olvido" (ibíd.).

Un archivo, escribe Agamben, es "el margen oscuro que circunda y delimita cada toma concreta de palabra" (Agamben, 2005: 159). Hemos explorado ese margen, hasta llegar a los confines del dispositivo, para encontrarnos, quizás, con su configuración más densa y también sus líneas de fuga. El archivo también sería "lo no dicho o lo decible que está inscrito en todo lo dicho por el simple hecho de haber sido enunciado" (ibid.: 151). Los archivos del futuro que producirían las deseografías no son el registro de una plenitud sino de una ausencia. Están ahí los expedientes psiquiátricos elaborados en torno a los homosexuales, entendidos como individuos patológicos; los documentos de quienes enfermaron y murieron de sida; los archivos de los movimientos políticos minoritarios; la literatura, el cine, las narrativas ocasionales de estos colectivos; sumarios policiales y jurídicos; autobiografías y poemas.

Foucault escribe que un análisis del archivo "comporta una región privilegiada: a la vez próxima a nosotros, pero diferente de nuestra actualidad, es la orla del tiempo que rodea nuestro presente, que se cierne sobre él y que lo indica en su alteridad” (Foucault, 2010[1969]: 222). Añade que la descripción de archivo, “(...) comienza con el exterior de nuestro propio lenguaje; su lugar es el margen de nuestras propias prácticas discursivas” (ibíd.). Nuevamente el archivo nos remite a una exterioridad: el deseo mismo diremos nosotros, que es en estricto sentido, imposible de archivar. Alteridad que incita la memoria, pero que no se deja capturar/registrar por ella y que produce una heterogeneidad irreductible.

Cuando exploramos, y constituimos, esos archivos nos percatamos que lo contemporáneo deviene rápidamente pasado y que el pasado se transforma en un futuro anterior. El libro de Hollander fue recuperado mediante un gesto estrictamente arqueológico, que exploró la escisión entre 'antes' y 'después' que lo convirtió, prontamente, en un texto caduco. El sueño también corresponde a un gesto de ese tipo, que investiga "ese pasado que habrá sido", luego que el arqueólogo haya despejado "los fantasmas del inconsciente" (Agamben, 2010: 144). 
Entre el texto de Hollander y los círculos que produjo, el sueño y las conexiones que develó y la historia de Juanito y su actualidad pasada, emergen las deseografías: antropología del futuro anterior. 


\section{Bibliografía}

Abu-Lughod, Lila (2012) "Escribir contra la cultura", en: Andamios, vol. 9, núm. 19, mayoagosto, pp. 129-157.

Agamben, Giorgio (2005) Lo que queda de Auschwitz: El archivo y el testigo. Homo sacer III, Valencia: Pre-Textos, traducción de Antonio Gimeno.

- (2006) Homo sacer I, El poder soberano y la nuda vida, Valencia: Pre-Textos, traducción de Antonio Gimeno.

- (2007) Estado de excepción. Homo Sacer, II, I, Buenos Aires: Adriana Hidalgo, traducción de Flavia Costa e Ivana Costa.

- (2010) Signatura rerum. Sobre el método, Barcelona: Anagrama, traducción de Flavia Costa y Mercedes Ruvituso.

- (2011) “¿Qué es un dispositivo?”, en: Sociológica, año 26, núm. 73, mayo-junio, pp. 249-264.

Alcántara, Eva e Ivonne Szasz (2013) "Between the Local and the Global: Chronicles for Understanding the Field of Sexology in Mexico", en: International Journal of Sexual Health, vol. 25, Special Issue: Sexology in Latin America, pp. 27-46.

Alden, Edward (2012) "Immigration and Border Control", en: Cato Journal, vol. 32, núm. 1, invierno, pp. 107-124.

Allen, Betania; Cruz, Aurelio; Rivera, Leonor; Castro, Roberto y María Ernestina Arana (2003) "Afectos, besos y condones: el ABC de las prácticas sexuales de las trabajadoras sexuales de la Ciudad de México”, en: Salud Pública de México, vol. 45, supl. 5, pp. 594-607.

Almaguer, Tomas (1995) "Hombres Chicanos: una cartografía de la identidad y del comportamiento homosexual”, en: Debate Feminista, año 6, vol. 11, abril, pp. 46-77.

Altman, Dennis (1996) "Rupture or continuity? The internationalization of Gay identities", en: Social Text, núm. 48, pp. 77-94

Amnistía Internacional (2011) Victimas invisibles. Migrantes en movimiento en México, Madrid: Editora Amnistía Internacional, disponible en: www.amnesty.org/es/library/asset/AMR41/.../amr410142010es.pdf (visitado 22 de octubre, 2013).

- (2013) Informe Amnistía Internacional 2013. El estado de los derechos humanos en el mundo, Madrid: Editora Amnistía Internacional, disponible en: http://files.amnesty.org/air13/AmnestyInternational AnnualReport2013 complete es.pdf (visitado el 22 de octubre, 2013). 
Amuchástegui, Ana (2001) Virginidad e iniciación sexual en México. Experiencias y significados, México: Population Council/EDAMEX.

Anaya, Armando (2004) El Reino de Pomoná y su Región Interior, Fundación para el Avance de los Estudios Mesoamericanos (FAMSI), traducido del inglés por Silvia Sullivan, disponible en http://www.famsi.org/reports/00082es/00082esAnayaHernandez01.pdf (visitado 27 de octubre, 2013).

Appadurai, Arjun (1999) "Soberanía sin territorialidad: notas para una geografía posnacional", en: Nueva Sociedad, núm. 163, septiembre-octubre, pp. 109-124.

- (2001) La modernidad desbordada. Dimensiones culturales de la globalización, Montevideo, Buenos Aires y México: Trilce, Fondo de Cultura Económica.

Argüello, Sofía (2013) "El proceso de politización de la sexualidad: identificaciones y marcos de sentido de la acción colectiva", en: Revista Mexicana de Sociología, vol. 75, núm. 2, abril-junio, pp. 173-200.

- (2014) "Identidades en disputa: avatares entre los discursos científicos, el papel de los medios de comunicación y las estrategias políticas del Movimiento de Liberación Homosexual mexicano, 1968-1984", en: Rodrigo Parrini y Alejandro Brito (coords.) La memoria y el deseo. Estudios gay y queer en México, México: Universidad Nacional Autónoma de México, Programa Universitario de Estudios de Género, pp. 25-50.

Armijo, Natalia (2011) "Frontera sur de México: los retos múltiples de la diversidad", en: Natalia Armijo (ed.), Migración y seguridad: nuevo desafío en México, México: Colectivo de Análisis de la Seguridad con Democracia (CASEDE), pp. 35-52.

Arriola, Luis Alfredo (2009) "Seguridad y migración en el espacio fronterizo Tabasco-El Petén”, en: Migración y Desarrollo, núm. 13, pp. 27-45.

Artola, Juan (2005) "Debate actual sobre migración y seguridad", en: Migración y Desarrollo, núm. 5, segundo semestre, pp. 136-150.

Auden, W.H. (1996) Iconografía romántica del mar, México: Universidad nacional Autónoma de México, traducción de Ignacio Quirarte.

Badiou, Alain (2005) El siglo, Buenos Aires: Manantial, traducción de Horacio Pons.

Bajtín, Mijail (1990) La cultura popular en la Edad Media y en el Renacimiento, México: Alianza, 1a reimpresión, traducción de Julio Forcat y César Conroy. 
Barboza, Roberto (2011) “Tenosique, ruta de terror para migrantes", en: El Universal, 5 de febrero de 2011, disponible en: http://www.eluniversal.com.mx/estados/79481.html (visitado 25 de agosto, 2013).

Barthes, Roland (2002[1957]) Mitologías, México: Siglo XXI, decimotercera edición, traducción de Héctor Schmucler.

Bartra, Eli (1999) "El movimiento feminista en México y su vínculo con la academia", en: La Ventana, núm. 10, pp. 214-234.

Bartra, Eli; Fernández Poncela, Anna y Ana Lau Jaiven (2000) Feminismo en México, ayer y hoy, México: Universidad Autónoma Metropolitana, colección Molinos de Viento.

Basail Rodríguez, Alain (2005) Fronteras des-bordadas. Ensayos sobre la frontera sur de México, México: Ediciones Casa Juan Pablo.

Benjamin, Thomas (1981) "El trabajo en las monterías de Chiapas y Tabasco 1870-1946", en: Historia Mexicana, vol. 30, núm. 4, abril-junio, pp. 506-529.

Benjamin, Walter (1989[1933]) Discursos interrumpidos I, Buenos Aires: Taurus, traducción de Jesús Aguirre.

- (2008[1939] Sobre la fotografía, Valencia: Pre-textos, traducción y edición de José Muñoz.

- (2013[1982]) El libro de los pasajes, Madrid: Akal, cuarta reimpresión, edición de Rolf Tiedemann y traducción de Luis Fernández., Isidro Herrera y Fernando Guerrero.

Berardi, Franco (2010) Generación pos-alfa. Patologías e imaginarios en el semiocapitalismo, Buenos Aires: Tinta de Limón.

Bhabha, Homi (2002) El lugar de la cultura, Buenos Aires: Manantial, traducción de César Aira. Biehl, João (2007) Vita: Life in a zone of abandonment, Berkeley y Los Angeles: University of California Press.

Biehl, João; Good, Byron y Arthur Kleinman (eds.) (2007) Subjectivity: Ethnographic investigations, Berkeley y Los Angeles: University of California Press. |

Biehl, João y Peter Locke (2010) "Deleuze and the Anthropology of Becoming", en: Current Anthropology, vol. 51, núm. 3, junio, pp. 317-351.

Bonnefoy, Yves (2013) El territorio interior, Madrid: Sexto Piso, traducción de Ernesto Kavi.

Boraz, Steven (2007) “The Guatemala-Chiapas Border” en: Ungoverned Territories: Understanding and reducing terrorism risks, Santa Monica, Arlington, Pittsburg: RAND Corporation, pp. 277-305, disponible en: 
http://www.rand.org/content/dam/rand/pubs/monographs/2007/RAND_MG561.pdf

(visitado 31 de octubre, 2013).

Bourdieu, Pierre (2000) La dominación masculina, Barcelona: Anagrama, traducción de Joaquín Jordá.

- (2003) El oficio del cientifico. Ciencia de la ciencia y reflexividad, Barcelona: Anagrama, traducción de Joaquim Jordá.

Braidotti, Rosi (2005) Metamorfosis. Hacia una teoría materialista del devenir, Madrid: Akal, traducción de Ana Varela.

— (2009) Transposiciones. Sobre la ética nómada. Barcelona: Paidós, traducción de Alcira Bixio.

Brandes, Stanley (1991) Metáforas de la masculinidad: sexo y estatus en el folklore andaluz, Madrid: Taurus, traducción de Antonio J. Desmonts.

Bronfman, Mario; Leyva, René, Negroni, Mirka y Cristina Herrera (2003) "El sida en las fronteras", en: Donato Alarcón y Samuel Ponce de León (eds.) El SIDA en México: veinte años de la epidemia, México: El Colegio Nacional, pp. 169-201.

Buendía, José (2012) "Yo quiero vivir" en: Noticias sin Fronteras, no disponible.

Buffington, Robert, (1998) "Los jotos. Visiones antagónicas de la homosexualidad en el México moderno", en: Daniel Balderston y Donna J. Guy (comps.), Sexo y sexualidades en América Latina, Buenos Aires: Paidós, pp. 185-204.

- (2001) Criminales y ciudadanos en el México moderno, México: Siglo XXI, traducción de Enrique Mercado.

Burchell, Graham (1993) 'Liberal government and techniques of the self', en: Economy and Society, vol. 22, núm. 3, pp. 267-282.

Butler, Judith (1993) Bodies that Matters. On the discursive limits of 'sex', Nueva York y Londres: Routledge.

- (2001) El género en disputa: el feminismo y la subversión de la identidad, México: Programa Universitario de Estudios de Género/UNAM, traducción Mónica Mansour y Laura Manríquez.

- (2004) Undoing gender, Nueva York y Londres: Routledge.

Cadena, José Luis (2010) “Geopolítica del narcotráfico. México y Colombia: la equivocación en el empleo de las fuerzas militares", en: Revista Mexicana de Ciencias Políticas y Sociales, vol. 52, núm. 210, diciembre, pp. 45-58. 
Calderón, Verónica (2013) "Las mafias se infiltran en albergues para inmigrantes centroamericanos", en: El País, 27 de abril de 2013, disponible en: http://internacional.elpais.com/internacional/2013/04/27/actualidad/1367092067 827354.ht $\underline{\mathrm{ml}}$ (visitado el 22 de julio, 2013)

Calleros, Juan Carlos (2010) “El vínculo entre seguridad nacional y migración en México”, en: Revista Mexicana de Política Exterior, núm. 88, noviembre-febrero, pp. 9-43.

Cano, Gabriela (1996) “Más de un siglo de feminismos en México”, en: Debate Feminista, año 7, vol. 14, octubre, pp. 345-360.

Cámara de Diputados del H. Congreso de la Unión (2011) Constitución Política de los Estados Unidos Mexicanos. Constitución publicada en el Diario Oficial de la Federación el 5 de febrero de 1917, http://www.diputados.gob.mx/LeyesBiblio/pdf/1.pdf (visitado 20 de agosto, 2011). Carrara, Sergio (2004) “A violência letal contra homossexuais no município de Rio de Janeiro: características gerais”, en: Carlos Cáceres, Tim Frasca, Mario Pecheny y Veriano Terto (eds.) Ciudadanía sexual en América Latina: abriendo el debate, Lima: Universidad Cayetano Heredia.

Carrara Sergio y Jane Russo (2002) “A psicanálise e a sexología no Río de Janeiro de entreguerras: entre a ciência e a auto-ajuda", en: História, Ciências, Saúde-Manguinhos, vol. 9, núm. 2, mayo-agosto, pp. 273-290.

Carrara, Sergio y Adriana Viana (2006) “'Tá lá, o corpo estendido no chão’: a violência letal contra travestis no município de Rio de Janeiro", en: Phisis, Revista de Saúde Colectiva, 16(2), pp. 233-249.

Carreón, Jaime (2009) "La muerte y sus representaciones en Huaquechula, Puebla”, en. Dimensiones Antropológicas, año 16, vol. 46, enero-abril, pp. 75-98.

Carrillo, Héctor (2002) La noche es joven: la sexualidad en México en la era del sida, México: Océano. Cassar, Carmel (2004) Honor y vergüenza en el Mediterráneo, Barcelona: CIDOB/Icaria, traducción de Manu Manzano.

Casillas, Rodolfo (2002) "El Plan Sur de México y sus efectos sobre la migración internacional”, en: Ecuador Debate, núm. 56, agosto, pp. 199-210.

- (2008a) "Las rutas de los centroamericanos por México, un ejercicio de caracterización, actores principales y complejidades", en: Migración y Desarrollo, No. 10, primer semestre, pp. 157-174.

- (2008b) Mesoamérica. Sur mexicano y Centroamérica. Fortalezas y debilidades, Cuadernos del Consejo Mexicano de Asuntos Internacionales, No. 4, México: Consejo Mexicano de Asuntos 
Internacionales, disponible en: http://www.iadb.org/intal/intalcdi/PE/2010/07202.pdf (visitado 3 de noviembre, 2013)

- (2010) “Auge y forja de identidades en el sur de México”, en: Roberto Blancarte (coord.) Culturas e identidades. Los grandes problemas de México, vol. XVI, México: El Colegio de México, pp. 295-318.

Castillo, Miguel Ángel (1999) "La vecindad México-Guatemala: una tensión entre proximidad y distancia”, en: Estudios Demográficos, vol. 14, núm. 1, pp. 193-218.

- (2005) "Fronteras, migración y seguridad en México", en: Alteridades, vol. 15, núm. 30, pp. $51-60$.

Castillo, Miguel Ángel y Mónica Toussaint (2010) “Seguridad y migración en la frontera sur”, en: Arturo Alvarado y Mónica Serrna (coords.) Seguridad nacional y seguridad interior. Los grandes problemas de México, vol. XV, México: El Colegio de México, pp. 269-300.

Castro-Gómez, Santiago (2010) Historia de la gubernamentalidad. Razón de estado, liberalismo y neoliberalismo en Michel Foucault, Bogotá: Siglo del Hombre Editores, Pontificia Universidad Javeriana y Universidad Santo Tomás.

Chakrabarty, Dipesh (2010) Al margen de Europa. Pensamiento poscolonial y diferencia histórica, Barcelona: Tusquets, traducción de Alberto Álvarez y Araceli María.

Chartier, Roger (1996) Escribir las prácticas. Foucault, de Certeau, Marin, Buenos Aires: Manantial, traducción de Horacio Pons.

- (2005) El mundo como representación. Estudios sobre historia cultural, Barcelona: Gedisa, traducción de Claudia Ferrari.

Chatterjee, Partha (2005) "Sovereign Violence and the Domain of the Political", en: Thomas Blom Hansen y Finn Stepputat (eds.), Sovereign Bodies. Citizens, Migrants, and States in the Postcolonial World, Princeton y Oxford: Princeton University Press, pp. 82-100.

Chávez, José Ricardo (2005) 'Elaboraciones literarias cultas y populares sobre lo 'homosexual' en el cambio del siglo XIX al XX en México”, en: Acta poética, núm. 26 (1-2), primavera-otoño, pp. 425-441.

Checa, Alberto; Córdoba, Isela y Salvador Sapién (2005) "Entorno, experiencias sexuales e imagen corporal de sexo servidoras de la Zona Metropolitana”, en: Psicología y Sociedad, Vol. 7, núm. 1-2, pp. 51-62.

Clifford, James (1995) Dilemas de la cultura. Antropología, literatura y arte en la perspectiva posmoderna, Barcelona: Gedisa, traducción de Carlos Reynoso. 
- (2008) "Sobre la autoridad etnográfica", en: Carlos Reynoso (comp.) El surgimiento de la antropología posmoderna, Barcelona: Gedisa, pp. 141-170.

Clifford, James y George E. Marcus (1986) Writing Culture: The Politics and Poetics of Ethnography, Berkeley: University of California Press.

Coetzee, J.M. (2011), Juventud, Barcelona: Mondadori, traducción de Cruz Rodríguez Juiz.

Cohen, Ed (2008) “A Body Worth Having? Or, A System of Natural Governance”, en: Theory, Culture \& Society, vol. 25, num. 3, pp. 103-129.

Comaroff, Jean y John Comaroff (1999) "Occult economies and the violence of abstraction: notes from the South African postcolony", en: American Ethnologist, vol. 26, núm. 2, pp. 279303.

- (2003) "Ethnography an awkward scale. Postcolonial anthropology and the violence of abstraction", en: Ethnography, vol. 4, núm. 2, pp. 147-179.

Comisión Estatal de Derechos Humanos de Tabasco (2008) Expediente número: 0633/2008 PLYVD Agraviados: Internos en el Centro de Readaptación Social de Macuspana, Tabasco Villahermosa, Primera Visitaduría General Tabasco, 17 de septiembre de 2008, disponible en: http://www.cedhtabasco.org.mx/sistema/documentos/recomendaciones/2008/recomendaci on18.pdf (visitado 21 de agosto, 2011).

Comisión Nacional de Derechos Humanos (2010) Informe Especial de la CNDH sobre Violaciones a los Derechos Humanos y Delitos Cometidos por Homofobia. México: CNDH.

- (2011) Informe especial sobre secuestro de migrantes en México, México: CNDH, disponible en: http://www.cndh.org.mx/sites/all/fuentes/documentos/informes/especiales/2011 secmigra ntes 0.pdf (visitado 3 de noviembre, 2012)

- (2013) "Recomendación No. 80/2013. Caso de privación de la vida de 72 personas migrantes y atentados a la vida de los extranjeros v73 y v74, en el municipio de San Fernando, Tamaulipas", México, CNDH, 23 de diciembre de 2013, tomado de < http://www.cndh.org.mx/sites/all/fuentes/documentos/Recomendaciones/2013/REC 20 13 080.pdf $>$, (visitado 3 de noviembre, 2012)

Comité de Derechos Humanos de Tabasco (2011) La ruta sin ley. Tabaco zona de secuestro, extorsión, robo, maltrato y abuso a migrantes centroamericanos, Villahermosa: CODEHUTAB A.C.

Consejo Nacional para Prevenir la Discriminación (2011) Encuesta Nacional sobre Discriminación en México (ENADIS 2010). Resultados sobre diversidad sexual, México: CONAPRED, disponible 
en: $\quad$ http://www.conapred.org.mx/redes/userfiles/files/Enadis-2010-DS-Accss-001.pdf (visitado el 19 de agosto, 2011)

Copjec, Joan (2011) El compacto sexual, México: Paradiso Editores/17, Instituto de Estudios Críticos, traducción de Teoría Crítica y Psicoanálisis A.C.

Corominas, Joan y José Pascual (1980) Diccionario críticos etimológico castellano e hispánico. Volumen I, Madrid: Gredos, $5^{\text {a }}$ reimpresión.

Dardón, Jacobo (2003) "Franja fronteriza de Guatemala con México: características, sitios de cruce, flujos migratorios y gobernabilidad", ponencia presentada en el I Encuentro Internacional sobre Desarrollo e Integración Regional en el sur de México y Centroamérica, San Cristóbal de las Casas 4 a 6 de junio de 2003, mimeo.

Das, Veena y Deborah Poole (2008) “El Estado y sus márgenes. Etnografías comparadas”, en: Cuadernos de Antropología Social, enero-junio, núm. 27, pp. 19-52.

de Certeau, Michel (2007) La invención de lo cotidiano. Las artes de hacer, volumen 1, México: Universidad Iberoamericana, traducción de Alejandro Pescador.

de la Dehesa, Rafael (2010) Queering the Public Sphere in Mexico and Brazil. Sexual rights movements in emerging democracies, Durham y Londres: Duke University Press.

de la Garza Mercedes (2012) Sueño y éxtasis. Visión chamánica de los nabuas y los mayas, México: Universidad Nacional Autónoma de México/ Fondo de Cultura Económica.

de Vos, Jan (1996) Oro verde. La conquista de la Selva Lacandona por lo madereros tabasqueños, 18221949, México: Fondo de Cultura Económica.

- (2011) Una tierra para sembrar sueños. Historia reciente de la Selva Lacandona, 1950-2000, México: Fondo de Cultura Económica.

Deleuze, Gilles (2008[1967]) Nietzsche y la filosofía, Barcelona: Anagrama, octava edición, traducción de Carmen Artal.

- (2007a) "Deseo y placer", en: Dos regimenes de locos. Textos y entrevistas (1975-1995), Valencia: Pre-textos, traducción de José Luis Pardo, pp. 121-129.

- (2007b), "Sobre los principales conceptos de Michel Foucault", en: Dos regímenes de locos. Textos y entrevistas (1975-1995), Valencia: Pre-textos, traducción de José Luis Pardo, pp. 223236.

— (2007c) “¿Qué es un dispositivo?”, en: Dos regimenes de locos. Textos y entrevistas (1975-1995), Valencia: Pre-textos, traducción de José Luis Pardo, pp. 305-312. 
Deleuze, Gilles y Felix Guattari (1985[1972]) El Antiedipo. Capitalismo y esquizofrenia, Barcelona: Paidós, traducción de Francisco Monge.

- (2010[1980]) Mil mesetas. Capitalismo y esquirofrenia, Valencia: Pre-Textos, traducción de José Vásquez Pérez con la colaboración de Umbelina Larraceleta.

Derrida, Jacques (2003[1967]) De la gramatología, Siglo XXI: México, traducción de Óscar del Barco y Conrado Ceretti.

- (2007[1968]) La diseminación, Madrid: Fundamentos, traducción de José María Arancibia.

- (2010) Seminario La bestia y el soberano. Volumen I (2001-2002), Buenos Aires: Manantial, traducción de Luis Ferrero, Cristina de Peretti y Delmiro Rocha.

- (2011) Seminario La bestia y el soberano. Volumen II (2002-2003), Buenos Aires: Manantial, traducción de Luis Ferrero, Cristina de Peretti y Delmiro Rocha.

Descola, Philippe (2012) Más allá de la naturaleza y la cultura, Buenos Aires: Amorrortu, traducción de Horacio Pons.

Díez, Jordi (2011) "La trayectoria política del movimiento Lésbico-Gay en México", en: Estudios Sociológicos, vol. 29, núm. 86, mayo-agosto, pp. 687-712.

Domínguez-Ruvalcaba, Héctor (2007) Modernity and the Nation in Mexican Representations of Masculinity, Nueva York y Hampshire: Plagrave MacMillan.

Dominijanni, Ida (2012) "La historia viviente. El estrabismo de Venus: una mirada de crisis de la política desde la política de la diferencia”, en: Debate Feminista, año 23, vol. 45, abril, pp. 6078.

Donnan, Hastings y Thomas Wilson (1994) Borders approaches: Anthropological perspectives on frontiers, Lanham y Londres: University Press of America.

- (1999) Borders: Frontiers of Identity, Nation and State, Oxford y Nueva York: Berg.

Dudley, Steven S. (2010) Drug Trafficking Organizations in Central America: Transportistas, Mexican Cartels and Maras, Working Papers Series on U-S.-Mexico Security Collaboration, Woodrow Wilson International Center for Scholars, Mexico Institute y University of San Diego, TransBorder Institute, disponible en: http://stevendudley.com/pdf/Wilson $\% 20$ Center $\% 20$ Central $\% 20$ America $\% 20$ Dudley $\% 2005$ \%2017\%2010.pdf (visitado 3 de junio, 2013)

Due Process of Law y Hogar de la Misericordia (2008) La crisis de los derechos bumanos en la frontera sur de México, DPL y Hogar de la Misericordia, agosto, disponible en http://www.dplf.org/uploads/1221486169.pdf (visitado el 24 de octubre, 2013) 
Durkheim, Emile y Marcel Mauss (1969[1903]) Primitive Classification, Londres: Cohen and West, traducción de Rodney Needham.

El Universal (2013) "Sexenio pasado dejó 70 mil muertos: Osorio", en: El Universal, 15 de febrero, disponible en http://www.eluniversal.com.mx/notas/903572.html (visitado el 10 de julio, 2013)

Escalona, José Luis (2011) "El incompleto imaginario del orden, la inacabada maquinaria burocrática y el espacio de lucha. Antropología del Estado desde el sureste de México”, en: Alejandro Agudo y Marco Estrada (eds.) (Trans)formaciones del Estado en los márgenes de América Latina. Imaginarios alternativos, aparatos inacabados y espacios transnacionales, México: El Colegio de México, Universidad Iberoamericana, pp. 45-86.

Espach, Ralph; Meléndez, Javier; Haering, Daniel y Miguel Castillo (2011) Organizaciones y tráfico ilicito en las comunidades fronterizas de Guatemala, Center for Naval Analyses (CNA), disponible en: http://www.cna.org/sites/default/files/research/Orgs $\% 20$ Criminales $\% 20$ en $\% 20$ Com $\% 20$ Fro nterizas\%20de\%20Guatemala\%20Dic2011.pdf (visitado el 21 de octubre, 2013).

Esposito, Roberto (2006) Bíos. Biopolítica y filosofía, Buenos Aires: Amorrortu, traducción de Carlo Molinari.

Fabian, Johannes (2002[1983]) Time and the Other. How Anthropology makes its object, Nueva York: Columbia University Press.

Fábregas Puig, Andrés (1993) El concepto de frontera en la frontera sur, Tuxtla Gutiérrez: Gobierno del Estado de Chiapas, Consejo Estatal de Fomento a la Investigación y Difusión de la Cultura. - (2005) “El concepto de frontera: una formulación”, en: Alain Basail Rodríguez (coord.) Fronteras des-bordadas. Ensayos sobre la frontera sur de México, México: Ediciones Casa Juan Pablo, pp. 21-52.

Fernández-Casanueva, Carmen (2009) "Experiencia de mujeres migrantes que trabajan en bares de la fronteras Chiapas-Guatemala", en: Papeles de Población, vol. 15, núm. 59, eneromarzo, pp. 173-192.

Flores, Carlos (1993) "La frontera sur y las migraciones internacionales ante la perspectiva del Tratado de Libre Comercio”, en: Estudios Demográficos, vol. 8, núm. 2, pp. 361-376.

Foucault, Michel (1981) Historia de la sexualidad. 1. La voluntad de saber, 7a. ed., México: Siglo XXI, traducción de Ulises Guiñazú.

- (2002) Defender la Sociedad. Curso en el Collège de France (1975-1976), México: Fondo de Cultura Económica. 
- (2005), El poder psiquiátrico. Curso en el Collège de France (1973-1974), Buenos Aires: Fondo de Cultura Económica, traducción de Horacio Pons.

- (2007) Nacimiento de la biopolítica. Curso en el Collège de France (1978-1979), Buenos Aires: Fondo de Cultura Económica, traducción de Horacio Pons.

- (2008[1968]) Las palabras y las cosas. Una arqueología de las ciencias humanas, México: Siglo XXI, traducción de Elsa Cecilia Frost.

- (2010a[1969]) La arqueología del saber, México: Siglo XXI, traducción de Aurelio Garzón del Camino.

- (2010b) "La 'Gubernamentalidad”, en: Obras Completas, Barcelona: Paidós, traducción de Ángel Gabilondo, pp. 837-856

- (2010c) "La ética del cuidado de sí como práctica de la libertad", en: Obras Completas, Barcelona: Paidós, traducción de Ángel Gabilondo, pp. 1027-1057.

- (2010d) “Subjetividad y verdad”, en: Obras Completas, Barcelona: Paidós, traducción de Ángel Gabilondo, pp. 907-912.

- (2010e) "La vida de los hombres infames", en: Obras Completas, Barcelona: Paidós, traducción de Fernando Álvarez Uría y Julia Varela, pp. 677-692.

- (2010f) “Técnicas de sî", en: Obras Completas, Barcelona: Paidós, traducción de Ángel Gabilondo pp. 1069-1095

Fundar, Centro de Análisis e Investigación (2011) Informe sobre la situación general de los derechos de los migrantes $y$ sus familias, México: Fundar, disponible en: http://fundar.org.mx/mexico/?p=3981 (visitado el 22 de octubre, 2013).

Galemba, Rebecca (2011) “'Un poco legal, un poco ilegal': la vida cotidiana en un camino clandestino de la frontera de México-Guatemala”, en: Alejandro Agudo y Marco Estrada (eds.) (Trans)formaciones del Estado en los márgenes de América Latina. Imaginarios alternativos, aparatos inacabados y espacios transnacionales, México: El Colegio de México, Universidad Iberoamericana, pp. 339-367.

García Murcia, Miguel; Andrade, Magdalena; Maldonado, Ricardo y Claudia Morales (2010) Memoria de la lucha con el VIH en México. Los primeros años, México: Consejo Nacional para Prevenir la Discriminación.

García Valencia, Enrique (1987) “Análisis estructural de los ritos funerarios de San Miguel Aguasuelos, Veracruz” en: La Palabra y el Hombre, abril-junio, núm. 62, pp. 15-21. 
Geertz, Clifford (1989) El antropólogo como autor, Barcelona: Paidós, traducción de Alberto Cardin.

- (2005[1973]) La interpretación de las culturas, Barcelona: Gedisa, traducción Alberto L. Bixio. Genette, Gerard (1989[1962]) Palimpsestos. La literatura en segundo grado, Madrid: Taurus, traducción de Celia Fernández.

Giddens, Anthony (2011[1984]) La constitución de la sociedad. Bases para la teoría de la estructuración, Buenos Aires: Amorrortu, traducción de José Luis Etcheverry.

Girard, René (2006) Literatura, mímesis y antropología, Barcelona: Gedisa, traducción de Alberto Bixio.

Godelier, Maurice (1998) El enigma del don, Barcelona: Paidós, traducción de Alberto López.

González Mateos, Adriana (2005) "El fifí y su chofer: control social, homosexualidad y clase en un periódico del México posrevolucionario”, en: Signos Literarios, núm. 2, pp. 103-125.

Goody, Jack (2008) La domesticación del pensamiento salvaje, Madrid: Akal, traducción de Marco Virgilio García.

Grimson, Alejandro (2000) Fronteras, naciones e identidades. La periferia como centro, Buenos Aires: CICCUS y La Crujía.

Gruzinski, Serge (1986) "Las cenizas del deseo. Homosexuales novohispanos a mediados del siglo XVII”, en: Sergio Ortega (coord.), De la santidad a la perversión, o de por qué no se cumplía la ley de Dios en la sociedad novohispana, México: Grijalbo, pp. 255-290.

Guattari, Felix (2000) Cartografías esquizoanaliticas, Buenos Aires: Manantial, traducción de Dardo Scavino.

- (2013) Lineas de fuga: por otro mundo de posibles, Buenos Aires: Cactus, traducción de Pablo Ariel Ires.

- y Sueli Rolnik (2005) Micropoliticas. Cartografías del deseo, Buenos Aires: Tinta Limón/Traficantes de Sueños, traducción de Florencia Gómez.

Guber, Rosana (2004) El salvaje metropolitano, Buenos Aires: Paidós.

Guerrero, Fabrizzio (2014) “(Re)trazos de una historia de la homosexualidad y las ciencias biomédicas en México a través del siglo XX”, en: Rodrigo Parrini y Alejandro Brito (coords.) La memoria y el deseo. Estudios gay y queer en México, México: Universidad Nacional Autónoma de México, Programa Universitario de Estudios de Género, pp. 51-76. 
Gupta, Akhil y James Ferguson (1997) "Beyond 'Culture': Space, Identity, and the Politics of Difference", en: Akhil Gupta y James Ferguson (eds.) Culture, Power, Place. Explorations in Critical Anthropology, Durham y Londres: Duke University Press, pp. 33-51.

Hannerz, Ulf (1996) Transnational Connections: Culture, People, Places, Londres: Routledge.

Hansen, Thomas y Finn Stepputat (2006) "Sovereign Revisited", en: Annual Review of Anthropology, vol. 35, pp. 295-315.

Haraway, Donna (1995) Ciencia, cyborgs y mujeres. La reinvención de la naturaleza, Madrid: Cátedra, traducción de Manuel Talens.

Hardt, Michael y Antonio Negri (2005) Imperio, Barcelona: Paidós, traducción de Alcira Bixio.

Hartsock, Nancy (1983) “The Feminist Standpoint: Developing the ground for a specifically feminist historical materialism", en: Sandra Harding y Merryll B. Hintikka (eds.) Discovering Reality: Feminist Perspectives on Epistemology, Metaphysics, Methodology, and Philosophy of Science, Dordrecht: Reidel, pp 283-310.

Harvey, David (2000) Spaces of Hope, Berkeley y Los Angeles: University of California Press. Hollander, Xaviera (1983) El círculo interior, México: Grijalbo, traducción de Daniel Scipione. Hoover, Paul (2012) En el idioma y en la tierra, México: Consejo Nacional para la Cultura y las Artes, edición y traducción de María Baranda.

Hernández, Leonardo (2011) “Asesinan a catedrático del COBATAB de Tenosique”, en: Bitacoras.com, disponible en: http://bitacoras.com/anotaciones/asesinan-a-catedratico-delcobatab-de-tenosique/24485636/ (visitado 15 de diciembre, 2011)

Human Rights Watch (2011) Ni seguridad, ni derechos. Ejecuciones, desapariciones y torturas en la "guerra contra el narcotráfico" de México, Nueva York: Human Rights Watch, disponible en: www.hrw.org/sites/default/files/reports/mexico1111spwebwcover.pdf (visitado el 5 de abril, 2013)

I(dh)eas, Litigio Estratégico en Derechos Humanos (2011) En tierra de nadie, el laberinto de la impunidad. Violaciones de los derechos humanos de las personas migrantes en la región de Soconusco, México: $\mathrm{I}(\mathrm{dh})$ eas, disponible en http://www.idheas.org.mx/wp-content/uploads/docs/ResumenEjecutivo-5-Pag-Informe-En-Tierra-de-Nadie.pdf (visitado el 10 de octubre, 2013).

Ingarden, Roman (2005[1968]) La comprehensión de la obra de arte literaria, México: Universidad Iberoamericana, traducción de Gerald Nyenhuis.

Instituto Nacional de Estadística y Geografía (2013a) "México en cifras. Información nacional, por entidad federativa y municipios. Tenosique, Tabasco", México: INEGI, disponible en: 
http://www3.inegi.org.mx/sistemas/mexicocifras/default.aspx (visitado 16 de noviembre, 2013).

- (2013b) "Estadísticas a propósito del Día Internacional de la Juventud. Datos de Tabasco", México: INEGI, disponible en:

http://www.inegi.org.mx/inegi/contenidos/espanol/prensa/Contenidos/estadisticas/2013/ju ventud27.pdf (visitado 18 de diciembre, 2014).

Instituto Nacional de Migración (2012a) Sintesis 2011. Estadística migratoria, México: Centro de Estudios Migratorios, Secretaría de Gobernación, disponible en: http://www.inm.gob.mx/estadisticas/Sintesis Grafica/2011/Sintesis2011.pdf (visitado 5 de octubre, 2013)

- (2012b) Sintesis 2012. Estadística migratoria, México: Centro de Estudios Migratorios, Secretaría de Gobernación, disponible en: http://www.inm.gob.mx/estadisticas/Sintesis Grafica/2012/Sintesis2012.pdf (visitado 5 de octubre, 2013)

Irigaray, Luce (2009[1977]) Ese sexo que no es uno, Madrid: Akal, traducción de Raúl Sánchez. Irwin, Robert, Michelle Nasser y Edward McCaughan (2003) "Introduction: Sexuality and Social Control in Mexico, 1901”, en: Robert Irwin, Michelle Nasser y Edward McCaughan (comps.), The Famous 41, New York y Londres: Palgrave MacMillan, pp. 1-20.

Kearney, Michael (1995) "The Local and the Global: The Anthropology of Globalization and Transnationalism", en: Annual Review of Anthropology, vol. 24, pp. 547-565.

Kott, Jan (1966) Apuntes sobre Shakespeare, Barcelona: Seix Barral, traducción de Jadwija Maurizio.

Kristeva, Julia (1981[1969]) Semiótica I, Madrid: Espiral, segunda edición, traducción de José Arancibia.

Kron, Stefanie (2007) Coyotes, norteños transeúntes y viudas blancas. Transmigración, género y ciudadanía en la frontera guatemalteco-mexicana, Conference Papers, Berlín: OBREA/EULARO, Freie Universität-Berlin, disponible en: http://www.lai.fuberlin.de/forschung/publikationen/workingpaper/Kron Guatemala.pdf (visitado 2 de julio, 2013)

Krotz, Esteban (2002) La otredad cultural. Entre utopía y ciencia, México: Universidad Autónoma Metropolitana (Iztapalapa)/Fondo de Cultura Económica, traducción de Claudia Cabrera. 
Lacerda, Paula (2006) O drama encenado: assassinatos de gays e travestis na imprensa carioca. Dissertação (mestrado), Universidade do Estado do Rio de Janeiro, Instituto de Medicina Social.

Laclau, Ernesto (1993) Nuevas reflexiones sobre la revolución de nuestro tiempo, Buenos Aires: Nueva Visión.

Laclau, Ernesto y Chantal Mouffe (2006) Hegemonía y estrategia socialista. Hacia una radicalización de la democracia, Buenos Aires: Fondo de Cultura Económica, traducción de Ernesto Laclau.

Laguarda, Rodrigo (1997) "Gay en México: lucha de representaciones e identidad”, en: Alteridades, enero-junio, vol. 17, núm. 33, pp. 127-133.

- (2009) Ser gay en la ciudad de México. Lucha de representaciones y apropiación de una identidad, 19681982, México: Instituto de Investigaciones Dr. José María Luis Mora, Centro de Investigaciones y Estudios Superiores en Antropología Social.

Lahire, Bernard (2006) El espíritu sociológico, Buenos Aires: Manantial, traducción de Laura Lambert.

Lamas, Marta (1993) "El fulgor de la noche: algunos aspectos de la prostitución callejera en la ciudad de México", en: Debate Feminista, septiembre, núm. 8, p. 103-136.

Lash, Scott y John Urry (1998) Economias de signos y espacios. Sobre el capitalismo de la posorganización, Buenos Aires: Amorrortu, traducción de José Luis Etcheverry.

Latour, Bruno (2008) Reensamblar lo social. Una introducción a la teoría del actor red, Buenos Aires: Manantial, traducción de Gabriela Zadunaisky.

Lazzarato, Maurizio (2010) Políticas del acontecimiento, Buenos Aires: Tinta Limón, traducción de Pablo Esteban Rodríguez.

Lefort, Claude (2004) La incertidumbre democrática. Ensayos sobre lo político, Madrid: Anthropos, traducción de Esteban Molina.

Letra S (2009) Informe de crimenes de odio por homofobia. México 1995-2008. Resultados preliminares, México: Letra S, Sida, Cultura y Vida Cotidiana, A.C., disponible en: http://www.letraese.org.mx/wp-content/uploads/2010/05/Informe.pdf (visitado 10 de diciembre, 2014)

Lévi-Strauss, Claude (2009 [1962]) El pensamiento salvaje, México: Fondo de Cultura Económica, traducción de Fracisco González.

— (2011[1955]) Tristes Trópicos, Madrid: Paidós, traducción de Noelia Bastard. 
Lewis, Óscar (2011[1961]) Antropología de la pobreza: Cinco familias, México: Fondo de Cultura Económica, 25ava reimpresión.

- (2012[1964 y 1970]) Los hijos de Sánchez/Una muerte en la familia Sánchez, México: Fondo de Cultura Económica, $1^{\text {a }}$ edición de ambos estudios.

Leyva, René y Frida Quintino (2011) Migración y salud sexual y reproductiva en la frontera sur de México, Cuernavaca: Instituto Nacional de Salud Pública.

Lomnitz, Claudio (2011) Idea de la muerte en México, México: Fondo de Cultura Económica, traducción de Mario Zamudio.

López, René (2007) "Buscan migrantes centroamericanos rutas alternas hacia Estados Unidos", en: La Jornada, 26 de agosto de 2007, disponible en: http://www.jornada.unam.mx/2007/08/27/index.php?section=estados\&article=034n1est (visitado 18 de agosto, 2013).

Lutz, Catherine (1998) Unnatural Emotions. Everyday sentiments on a Micronesian Atoll \& their challenge to Western Theory, Chicago y Londres: The University of Chicago Press.

Macías-González, Víctor (2004) "Entre lilos limpios y sucias sarasas: la homosexualidad en los baños de la ciudad de México, 1880-1910”, en: María del Carmen Collado (coord.) Miradas recurrentes: la ciudad de México en los siglos XIX y XX, volumen II, México: Universidad Autónoma Metropolitana, Azcapozalco, Instituto de Investigaciones Dr. José Luis Mora, pp. 293-330.

Maldonado, Salvador (2012) "Drogas, violencia y militarización en el México rural. El caso de Michoacán”, en: Revista Mexicana de Sociología, vol. 74, núm. 1, enero-marzo, pp. 5-39.

Makowski, Sara (2004) Memorias de la intemperie. Exclusión social y espacio: los chavos de la calle en el centro bistórico de la Ciudad de México. Tesis de Doctorado en Ciencias Antropológicas, Universidad Autónoma Metropolitana, Iztapalapa.

Marcus, George (2007) "Ethnography two Decades after Writing Culture: From de Experimental to de Baroque”, en: Anthropological Quarterly, vol. 80, núm. 4, pp. 1127-1145.

Marcus, George E. y Michael M.J. Fischer (1998) Anthropology as Cultural Critique, Chicago: University of Chicago Press.

Martí, Bosco (2008) "Proyecto Mesoamérica: fortaleciendo la integración y el desarrollo regional”, en: Revista Mexicana de Política Exterior, núm. 83, junio, pp. 9-39.

Martínez González, Roberto (2006) "El ihiyotl, la sombra y las almas-aliento en Mesoamérica”, en: Cuicuilco, vol. 13, núm. 38, septiembre-diciembre, pp. 177-199. 
Mauss, Marcel (1979[1938]) “Sobre una categoría del espíritu humano: la noción de persona y la noción del 'yo"', en: Sociología y antropología, Madrid: Tecnos, traducción de Teresa Rubio.

- 2012 [1925] Ensayo sobre el don. Forma y función del intercambio en las sociedades arcaicas, Madrid: Katz, traducción Julia Bucci.

Mbembe, Achille (2003) “Necropolitics”, en: Public Culture, vol. 15, núm. 1, pp. 11-40.

Mc Manus, Fabrizzio (2013) "Homosexuality, Homophobia, and Biomedical Sciences in

Twenty Century Mexico”, en: Sexuality \& Culture. An Interdisciplinary Quarterly, vol. 17, num. 2, junio, pp. 235-256.

Mezzadra, Silvio (2007) "Vivir en transición. Hacia una teoría heterolingüe de la multitud", Instituto Europeo para Políticas Culturales Progresivas, (EIPCP), disponible en: http://eipcp.net/transversal/1107/mezzadra/es (visitado el 10 de octubre, 2013).

Metcaff, Peter (2001) “Global 'Disjuncture' and the 'Sites' of Anthropology”, en: Cultural Anthropology, vol. 6, núm. 2, mayo, pp. 165-182.

Meyer, Maureen y Stephanie Brewer (2010) Un trayecto peligroso por México: violaciones a derechos bumanos en contra de los migrantes en tránsito, México y Washington: Oficina en Washington para Asuntos Latinoamericanos (WOLA) y Centro de Derechos Humanos "Miguel Agustín Pro Juárez" (Centro PRODH), disponible en: http://www.wola.org/es/informes/un trayecto peligroso por mexico violaciones a derech os humanos en contra de los migrantes (visitado 23 de octubre, 2013).

Michaelsen, Scott y David E. Johnson (2003) Teoría de la frontera. Los límites de la política cultural, Barcelona: Gedisa, traducción de Gabriela Ventureira.

Molina, Fernanda (2010) "Los sodomitas virreinales: entre sujetos jurídicos y especie”, en: Anuario de Estudios Americanos, vol. 67, núm. 1, enero-junio, pp. 24-52.

Monsiváis, Carlos (1997) "Los que tenemos manos que no nos pertenecen”, en: Debate Feminista, año 8, vol. 16, octubre, pp. 11-33.

- (1998) "El mundo soslayado (donde se mezclan la confesión y la proclama)", introducción a La estatua de Sal, México: Fondo de Cultura Económica, pp. 13-72.

- (2010) “Los gays en México: la fundación, la ampliación, la consolidación del”, en: Que se abra esa puerta. Crónicas y ensayos sobre diversidad sexual, México: Paidós, pp. 109-140.

Moore, Henrietta (2004) "Global Anxieties. Concept-metaphors and pre-theoretical commitments in anthropology", en: Anthropological Theory, vol. 4, núm. 1, pp. 71-88. 
- (2007) The Subject of Anthropology. Gender, Symbolism and Psychoanalysis, Cambridge y Malden: Polity.

Mott Luiz (2001) Causa mortis: bomofobia. Violacao dos direitos bumanos e assassinato de bomossexuais no Brasil, 2000, Salvador: Editora Grupo Gay da Bahia.

- (1996) Epidemic of hate. Violations of the Human Rights of Gay Men, Lesbians, and Transvestites in Brazil, Informe del Grupo Gay de Babia, Salvador: Editora Grupo Gay da Bahia.

Municipio de Tenosique (2010) Bando de Policia y Buen Gobierno del Municipio de Tenosique de Pino Suárez, Tenosique: Municipio de Tenosique de Pino Suárez.

Murray, Tania (2007) “Governamentality”, en: Antbropologica, vol. 46, núm. 2, pp. 275-281.

Mutman, Mahmut (2006) "Writing Culture: Posmodernism and Ethnography", en: Antbropological Theory, vol. 6, núm. 2, pp. 153-178.

Náteras, Alfredo (2008) "Etnografías al límite: espacios de las violencias y las muertes en sujetos trasnacionales", en: E-Compós, vol. 11, núm. 3, septiembre-diciembre, pp. 2-11.

Navaro-Yashin, Yael (2003) “Life is dead here'. Sensing the political in 'no man's land”, en: Anthropological Theory, Vol. 3, No. 1, 107-125.

- (2009) "Affective Spaces, Melancholic Objects: Ruination and the production of anthropological knowledge", en: Journal of the Royal Anthropological Institute, 15, pp. 1-18.

Noreste (2008) "Los unirá carretera 'peligrosa", Noreste. El portal de Sinaloa, 8 de septiembre, disponible en: http://www.noroeste.com.mx/publicaciones.php?id=408618\&id seccion=145 (visitado 25 de septiembre, 2013).

Noticias por Minuto (2013) “Asesinan y violan a un profesor en Tenosique", disponible en: http://www.nxm.mx/noticia.php?ID=16241 (visitado el 16 de abril, 2013)

Novelo, Claudio y Luis Franco (2011) "La estación de Ferrocarriles Nacionales de México en Campeche: un ejemplo de patrimonio industrial”, en: Mirada Ferroviaria, septiembre-diciembre, núm. 15, pp. 53-60.

Núñez Noriega, Guillermo (2000) Sexo entre Varones. Poder y resistencia en el campo sexual, México: Universidad Nacional Autónoma de México.

- (2007) Masculinidad e intimidad: identidad, sexualidad y sida, México: Programa Universitario de Estudios de Género, El Colegio de Sonora y Miguel Ángel Porrúa.

- (2009) Vidas vulnerables, hombres indígenas, diversidad sexual y VIH/SIDA, México: Centro de Investigación en Alimentación y Desarrollo, Octavio Antonio Colmenares y Vargas editor. 
Obeyesekere, Gananath (1981) Medusa's Hair. An Essay on Personal Symbols and Religious Experience, Chicago y Londres: The University of Chicago Press.

Olmos, Miguel (2007) Antropología de las fronteras. Alteridad, bistoria e identidad más allá de la línea, México: El Colegio de la Frontera Norte y Miguel Ángel Porrúa.

Ong, Aihwa (2001) "Splintering Cosmopolitanism: Asian Immigrants and Zones of Autonomy in the American West", en: Thomas Blom Hansen y Finn Stepputat (eds.) Sovereign Bodies. Citizens, Migrants, and States in the Postcolonial World, Princeton y Oxford: Princeton University Press, pp. 257-275.

- (2005) "Graduated Sovereignty in South-East Asia", en: Jonathan Xavier Inda (ed.) Anthropologies of Modernity. Foucault, Governamentality, and Life Politics, Malden, Oxford y Carlton: Blackwell, pp. 83-104.

- (2006) Neoliberalism as Exception. Mutations in Citizenship and Sovereignty, Durham y Londres: Duke University Press.

- (2012) "Powers of sovereignty: State, people, wealth, life", en: Focaal-Journal of Global and Historical Anthropology, No. 64, pp. 24-35.

Ortner, Sherry B. (2005) "Subjectivity and cultural critique", en: Anthropological Theory, Vol. 5, No. 1, pp 31-52.

Paredes, Hilario (2012) “Truncó la vida con sus manos”, en: Noticias sin Fronteras, disponible en: http://www.noticiassinfronteras.com.mx/noticia.asp?id=9421 (visitado 30 de mayo, 2012)

- (2013a) "La bestia le quito los pies de un solo tajo", en: Noticias sin fronteras, $1^{\circ}$ de febrero de 2013, disponible en: http://www.noticiassinfronteras.com.mx/noticia.asp?id=12199 (visitado el 22 de marzo, 2013)

- (2013b) "Lo matan a garrotazos", en: Noticias sin Fronteras, disponible en: http://www.noticiassinfronteras.com.mx/notas.php?id noticia=527 (visitado el 10 de octubre, 2013)

Otto, Rudolph (2008[1917]) Lo sagrado, Buenos Aires: Claridad, traducción de Eduardo García Belsunce.

Parrini, Rodrigo (2011) "Excepción, tiempo y nación. La formación de un sujeto minoritario", en: Mónica Cejas y Ana Lau Jaiven (coords.) En la encrucijada de género y ciudadanía. Sujetos políticos, derechos, gobierno, nación y acción política, UAM/Itaca Editores, pp. 207-241. 
- (2012) “La nación invertida. Genealogías del sujeto homosexual, México siglo XX”, en: Mario Rufer (ed.) La nación en disputa: conmemoración, ritualidad y producción simbólica, México: UAM/Itaca Editores, pp. 207-240.

Parrini, Rodrigo; Amuchástegui, Ana y Cecilia Garibi (2014) "Fronteras, excedentes y placeres: Discursos sobre el trabajo sexual en una zona rural de México" en: Sexualidad, Saludy Sociedad. Revista Latinoamericana, abril, núm. 16, pp. 153-172.

Parrini, Rodrigo y Alejandro Brito (2012) Crímenes de odio por homofobia. Un concepto en construcción, México: Letra S/Indesol, disponible en: http://www.letraese.org.mx/2013/05/crimenes-deodio-por-homofobia-un-concepto-en-construccion-nuevo-libro-de-letra-s-2/ (visitado el 15 de enero, 2015).

http://www.clam.org.br/uploads/arquivo/Informe $\% 20$ Crimenes $\% 20 \mathrm{de} \% 20$ odio $\% 20 \mathrm{M} \% \mathrm{C} 3$

\%A9xico.pdf (visitado 15 de diciembre, 2014).

Paz, Octavio (1998) El mono gramático, Barcelona: Galaxia Gutenberg.

Pereyra, Guillermo (2012) "México: violencia criminal y 'guerra contra el narcotráfico", en:

Revista Mexicana de Sociología, Vol. 74, núm. 3, julio-septiembre, pp. 429-460.

Peristiany, Jean (1968) El concepto de honor en la sociedad mediterránea, Barcelona: Labor.

Pitt-Rivers, Julian (1979) Antropología del honor o politica de los sexos. Ensayos de antropología mediterránea, Barcelona: Crítica, traducción de Carlos Manzano.

Povinelli, Elizabeth (2011) Economies of Abandonment. Social Belonging and Endurance in Late Liberalism, Durham y Londres: Duke University Press.

Prieur, Annick (2008) La casa de la Mema: travestis, locas y machos, México: Programa Universitario de Estudios sobre Género, Universidad Nacional Autónoma de México.

Programa de las Naciones Unidas para el Desarrollo (2013) Informe Regional de Desarrollo Humano 2013-2014. Seguridad ciudadana con rostro humano: diagnósticos y propuestas para América Latina, Nueva York: PNUD.

Proyecto Mesoamérica (2009a) "Inauguran Carretera El Ceibo-Lagunitas entre México y Guatemala”, octubre, disponible en: http://www.proyectomesoamerica.org/joomla/index.php?option $=$ com content\&view $=$ article $\underline{\text { \&id }=154 \& \text { Itemid }=85}$ (visitado 27 de octubre, 2013)

- (2009b) "Red Internacional de Carreteras Mesoamericanas (RICAM)", disponible en: http://www.proyectomesoamerica.org/joomla/index.php?option $=$ com content\&view $=$ article $\underline{\text { \&id }=179 \& \text { Itemid }=108}$ (visitado 12 de diciembre, 2013) 
Rabinow, Paul; Marcus, George E; Faubion, James D. y Tobías Rees (2008) Desings for an Anthropology of the Contemporary, Durham y Londres: Duke University Press.

Rancière, Jacques (1996) El desacuerdo. Política y filosofía, Nueva Visión: Buenos Aires, traducción de Horacio Pons.

Real Academia de la Lengua (2001) "Comercio", en: Diccionario de la lengua española, 22 edición, disponible en: http://lema.rae.es/drae/?val=comercio (visitado 11 de diciembre, 2014).

Reséndiz, Ernesto (2014) "Cárcel de Belem, cárcel de los deseos: heterotopía de sodomitas, afeminados y hombres con prácticas homoeróticas en las crónicas de Heriberto Frías en 1895”, en: Rodrigo Parrini y Alejandro Brito (coords.) La memoria y el deseo. Estudios gay y queer en México, México: Universidad Nacional Autónoma de México, Programa Universitario de Estudios de Género, pp. 101-118.

Riley, Denisse (2006) "El derecho a estar sola", en: Debate Feminista, año 17, vol. 34, octubre, pp. 3-16.

Rodriguez, Antoine (2012) "Archivar/revelar el cuerpo homosexual en México: las autobiografías de Salvador Novo y Elías Nandino dentro y fuera de contexto", en: Rodrigo Parrini (coord.) Los archivos del cuerpo. ¿Cómo estudiar el cuerpo?, México: Universidad Nacional Autónoma de México, Programa Universitario de Estudios de Género, pp. 147-170.

Rosaldo, Renato (1991) Cultura y verdad. Nueva Propuesta de Análisis Social, México: Centro Nacional de las Artes/Grijalbo.

Rose, Nikolas (2001) 'Politics of Life Itself”, en: Theory, Culture and Society, vol. 18, pp. 1-30.

Rose, Nikolas y Peter Miller (1992) "Political Power beyond the State: Problematics of Government”, en: British Journal of Sociology, vol. 43, núm. 3, junio, pp. 173-205.

Rose, Nikolas; O’Malley, Pat y Mariana Valverde (2006) “Governamentality”, en: Ann. Rev. Law Soc. Sci., vol. 2, pp. 83-104.

Rubin, Gayle (1975) “The Traffic in Women: Notes on the 'political economy' of sex”, en: Rayna Reiter (ed.), Toward an Anthropology of Women, New York: Monthly Review Press, pp. 157210.

Rubio, Miguel Ángel (2008) El Pochó. Análisis de una representación dancístico-teatral asociada al complejo de dramas rituales del tigre-jaguar en el carnaval de Tenosique-Tabasco, Tesis de Doctorado en Ciencias Antropológicas, Universidad Autónoma Metropolitana, Iztapalapa. 
Ruiz, Olivia y Red de la Casa del Migrante-Scalabrini (2001) "Los riesgos de cruzar. La migración centroamericana en la frontera México-Guatemala”, en: Frontera Norte, vol. 13, núm. 25, enero-junio, pp. 7-41.

Salinas, Héctor (2008) Políticas de la disidencia sexual, México: Consejo Nacional para Prevenir la Discriminación.

Santaeulalia, Inés (2013) “Un Estado que ignora dónde están 30.000 ciudadanos no es un Estado”, en: El Paús, 1 de abril de 2013, disponible en: http://internacional.elpais.com/internacional/2013/04/01/actualidad/1364796925 420573.ht $\underline{\mathrm{ml}}$ (visitado el 12 de septiembre, 2013)

Secretaria de Desarrollo Social (2013) "Cédula de información municipal, Tenosique”, Unidad de Microrregiones, Dirección Adjunta de Planeación Microrregional, SEDESOL, disponible en:

http://www.microrregiones.gob.mx/zap/datGenerales.aspx?entra=pdzp\&ent $=27 \&$ mun $=017$ (visitado el 12 de noviembre, 2013).

Secretaría de Salud (2010) Norma Oficial Mexicana NOM-010-SSA2-2010, Para la prevención y el control de la infección por Virus de la Inmunodeficiencia Humana, disponible en: http://www.censida.salud.gob.mx/descargas/drhumanos/NOM-010-SSA2-2010.pdf (visitado 17 de agosto, 2011)

Serres, Michel (2002) Los cinco sentidos. Ciencia, poesía y filosofía del cuerpo, México: Taurus, traducción de María Cecilia Gómez.

Shakespeare, William (2008[1594]) Ricardo III, en: Obras Completas. Dramas históricos, volumen IV, Buenos Aires: Losada, traducción de Cristina Piña, pp. 338-459.

Sloterdijk, Peter (2003a) Esferas I. Burbujas. Microesferología, Madrid: Siruela, traducción de Isidoro Reguera.

- (2003b) Experimentos con uno mismo. Una conversación con Carlos Oliveira, Valencia: Pre-Textos, traducción de Germán Cano.

- (2003c) Crítica de la razón cínica, Madrid: Siruela, traducción de Miguel Ángel Vega.

— (2009a) Esferas III. Espumas. Esferología plural, Madrid: Siruela, traducción de Isidoro Reguera.

- (2009b) El pensador en escena. El materialismo de Nietzsche, Valencia: Pre-Textos, traducción de Germán Cano.

- (2010) En el mundo interior del capital. Para una teoría filosófica de la globalización, Madrid: Siruela, traducción de Isidoro Reguera. 
- (2011) Esferas II. Globos. Macroesferología, Madrid: Siruela, traducción de Isidoro Reguera.

Stevens, Wallace (2012[1954]) Las auroras de otoño y otros poemas, Madrid: Visor, traducción de Jenaro Talens.

- (2012) Has de cambiar tu vida. Sobre antropotécnica, Valencia: Pre-Textos, traducción de Pedro Madrigal.

Soberano, Manuel y José Buendía (2012) “Abandona hospital a enfermos de SIDA en Tenosique", en: Tabasco Hoy, 5 de septiembre de 2012 disponible en: http://tabascohoy.com/2/mobile/nota.php?ID=48632 (visitado el 22 de febrero, 2015).

Strathern, Marilyn (1988) The Gender of the Gift, Berkeley y Los Angeles: University of California Press.

- (2004) Partial Connections, Walnut Creek: Altamira Press.

Taussig, Michael (1980) The Devil and commodity fetishism in South America, Chapel Hill: University of North Carolina Press.

- (1993) Mimesis and Alterity. A particular history of the senses, Londres y Nueva York: Routledge.

- (2010) Desfiguraciones. El secreto público y la labor de lo negativo, Madrid: Fineo, traducción de Marcela Solá.

Thomas, Nicholas (1991) "Against Ethnography", en: Cultural Anthropology, vol. 6, núm. 3, Agosto, 306-322.

Transparencia Mexicana (2014) Índice de Percepción de la Corrupción 2014. Enfoque en México, México: Transparencia Mexicana, disponible http://issuu.com/transparenciamexicana/docs $/$ mexipc2014issu $/ 1$ ? $=0 / 10407301$ (visitado 11 de diciembre, 2014).

Traven, Bruno (2003[1936]) La rebelión de los colgados, México: Selecta, segunda edición, traducción de Esperanza López Mateo.

- (2005[1950]) Macario, México: Selecta, sexta reimpresión, traducción de Esperanza López Mateo.

Tsing, Anne (2000) “The Global Situation”, en: Current Anthropology, vol. 15, num. 3, agosto, pp. 327-360.

- (2001) States of Imagination. Ethnographic Explorations of the Postcolonial State, Durham y Londres: Duke University Press.

- (2005) Friction. An Ethnography of Global Connection, New Jersey: Princeton University Press. 
Tuñon, Esperanza (2006) "Embarazo en adolescentes del sureste de México", en: Papeles de Población, núm. 48, pp. 141-154.

Tuñon, Esperanza y Ranfís Ayús (2003) “Género, sexualidad y fecundidad de los jóvenes del sureste mexicano", en: Mario Bronfman y Catalina Denman (coords.), Salud reproductiva: temas y debates, México: Instituto Nacional de Salud Pública, pp. 83-101.

Tuñón, Esperanza; Ayús, Ramfis y Luis Alberto Montejo (2004) "La sexualidad, un campo de significados. Fuentes de información y educación sexual entre jóvenes de Tabasco", en: Rossana Reguillo, C. Feixa, M. Valdez, C. Gómez-Granell, J.A. Pérez-Islas (coords.), Tiempo de Híbridos, México: Entresiglos/Jóvenes México-Cataluña/ IMJ-Generalitat de Catalunya-Institut d’Infancia i Món Urbà, pp. 55-69.

Ulin, Robert (2004) “Globalization and Alternative Localities”, en: Anthropologica, vol. 46, núm. 2, pp. 153-164.

United Nations Office on Drugs and Crime (2007) Crimen y desarrollo en Centroamérica. Atrapados en la encrucijada, Viena: UNODC, disponible en http://www.unodc.org/pdf/research/Estudio de Centro america 2007.pdf (visitado el 10 de octubre, 2013).

- (2010) Crime and Instability. Case studies of transnational threats, Viena: UNODC, disponible en http://www.unodc.org/documents/frontpage/Crime and instability 2010 final low res.pdf (visitado 5 de febrero, 2013).

Uribe, Patricia; Hernández, Griselda (2000) "Sexo comercial e infecciones de transmisión sexual (ITS) en la ciudad de México”, en: Papeles de Población, enero-marzo, núm. 23, pp. 203219.

Vargas, Susana (2011) "El que ríe al último, ríe mejor: “mujercitos” en la nota roja durante los años setenta en México”, en: Graciela Martínez-Zalce, Will Straw y Susana Vargas Cervantes, (eds.), Aprehendiendo al delincuente: crimen y medios en América del Norte, México: UNAM/CISAN/McGill University, pp. 35-51.

Vázquez, Ignacio (2012) "Quebrantan derechos de sexoservidores en Tenosique, asegura Diputada Local", sin datos.

Virno, Paolo (2011) Ambivalencia de la multitud: entre la innovación y la negatividad, Buenos Aires: Tinta Limón, traducción de Emilio Sadier y Diego Picotto.

Viveiros de Castro, Eduardo (2010) Metafísicas caníbales. Lineas de antropología postestructural, Madrid: Katz, traducción de Stella Mastrangelo. 
Walcott, Dereck (2001) La abundancia, Madrid: Visor, traducción de Jenaro Talens y Vicente Forés.

- (2012) Pleno Verano. Poesía selecta (1948-2004), Madrid: Vaso Roto, traducción de José Luis Rivas.

Wallerstein, Immanuel (1984) El moderno sistema mundial. Volumen 3: La segunda era de gran expansión de la economía-mundo capitalista, 1730-1850, México: Siglo XXI, traducción de Pilar López.

Weber, Max (2012[1922]) Economía y sociedad. Esbozo de sociología comprensiva, México: Fondo de Cultura Económica, decimoctava reimpresión, traducción de José Medina Echeverría, Juan Roura, Eugenio Imaz, Eduardo García Máynez y José Ferrater Mora.

Weider, Jason R. (2009) “Governamentality, Capitalism, and Subjectivity”, en: Global Society, vol. 24, núm. 4, pp. 387-411.

Williams, Raymond (2003) Palabras clave. Un vocabulario de la cultura y la sociedad, Buenos Aires: Nueva Visión, traducción de Horacio Pons.

- (2009[1977]) Marxismo y literatura, Buenos Aires: Las Cuarenta, traducción de Guillermo David.

Withman, Walt (2009[1890]) Hojas de hierba, Buenos Aires: Losada, traducción de Pablo Ingberg.

Wittgenstein, Ludwig (2004[1958]) Investigaciones filosóficas, México y Barcelona: Instituto de Investigaciones Filosóficas de la Universidad Nacional Autónoma de México, Editorial Crítica, traducción de Alfonso García Suárez y Ulises Moulines.

Wolf, Erick (1987) Europa y la gente sin historia, México: Fondo de Cultura Económica, traducción de Agustín Bárcenas.

Wolf, Sonya (2011) "La guerra de México contra el narcotráfico y la Iniciativa Mérida: piedras angulares en la búsqueda de legitimidad”, en: Foro Internacional, vol. LI, núm. 4 (206), octubrediciembre, pp. 669-714.

Žižek, Slavoj (1992) El sublime objeto de la ideología, México: Siglo XXI, traducción de Isabel Vericat.

- (2005) El acoso de las fantasías, México: Siglo XXI, traducción de Clea Braunstein. 